MARCELLO MUNIZ DA SILVA

\title{
ANÁLISE DA ESTRUTURA DE FINANCIAMENTO À INDÚSTRIA NAVAL NO BRASIL
}




\section{MARCELLO MUNIZ DA SILVA}

\section{ANÁLISE DA ESTRUTURA DE FINANCIAMENTO À INDÚSTRIA NAVAL NO BRASIL}

Dissertação apresentada à Escola Politécnica para obtenção do título de Mestre em Engenharia Naval e Oceânica 


\section{MARCELLO MUNIZ DA SILVA}

\section{ANÁLISE DA ESTRUTURA DE FINANCIAMENTO À INDÚSTRIA NAVAL NO BRASIL}

Dissertação apresentada à Escola Politécnica para obtenção do título de Mestre em Engenharia Naval e Oceânica

Área de concentração:

Engenharia Naval e Oceânica

Orientador:

Prof. Dr. Marcelo Ramos Martins 


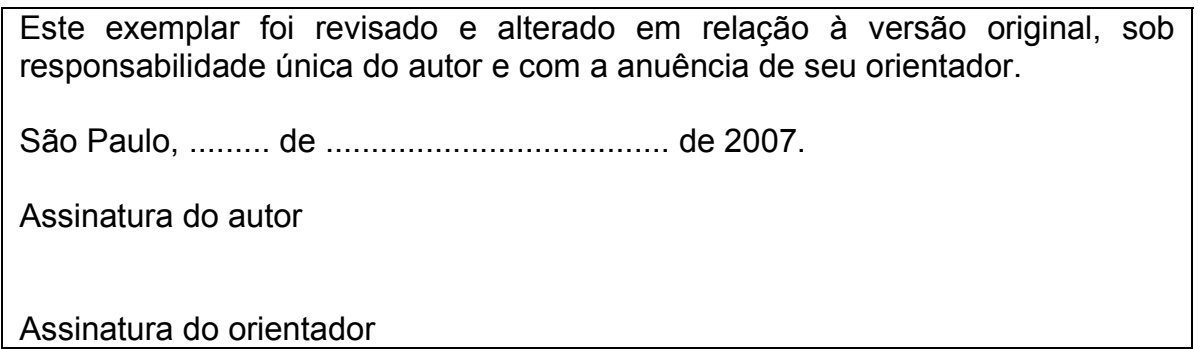

\section{FICHA CATALOGRÁFICA}

Silva, Marcello Muniz da Análise da estrutura de financiamento à indústria naval no Brasil / M.M. da Silva. -- São Paulo, 2007. $346 \mathrm{p}$.

Dissertação (Mestrado) - Escola Politécnica da Universidade de São Paulo. Departamento de Engenharia Naval e Oceânica.

1.Indústria da construção naval - Brasil 2.Financiamento 3.Teoria da complexidade I. Universidade de São Paulo. Escola Politécnica. Departamento de Engenharia Naval e Oceânica Il.t. 


\section{DEDICATÓRIA}

ao meu Pai,

Sr. João Marques da Silva (in memoriam) com quem aprendi coisas incriveis 


\section{AGRADECIMENTOS}

A elaboração desse trabalho contou com o apoio de várias instituições e pessoas. Certamente, sem a contribuição de cada uma dessas, dificilmente esse teria sido concluído. Inicialmente registro os meus mais respeitosos agradecimentos ao meu orientador o Prof. Marcelo Ramos Martins. Ele usou, além de sua experiência, atenção e de seu escasso tempo disponível, muito de sua paciência e dedicação no auxílio ao desenvolvimento do trabalho.

Nesses três anos contei com a colaboração de vários colegas do Departamento de Engenharia Naval da POLI/USP. Um agradecimento especial à colega Lânia Camilo de Oliveira, secretária da pós-graduação do Departamento de Engenharia naval e Oceânica da POLI/USP, e ao Prof. Bernardo L. R. Andrade, que sempre procuraram nos atender com profissionalismo e carinho.

O apoio institucional e o convívio com os colegas do Instituto de Pesquisas Tecnológicas do Estado de São Paulo (IPT) foram, sem dúvida, de grande valia. Ainda no plano institucional, embora não possa citar nomes por sigilo de informações, também quero prestar meus agradecimentos aos profissionais e diretores financeiros das empresas de transporte, e de apoio marítimo e estaleiros que visitei ao longo do desenvolvimento da pesquisa. As informações fornecidas e comentários por eles tecidos foram de grande valor.

Durante a fase exploratória do projeto e em sua fase de execução conheci muitas pessoas e fiz diversos amigos. Estes dedicaram parte do tempo de suas "apertadas agendas" me recebendo e discutindo conceitos e temas ligados ao desenvolvimento da indústria naval e ao financiamento à construção. $O$ profissionalismo dessas pessoas e sua dedicação à indústria e serviços navais me motivaram muito. Assim, presto meus agradecimentos ao pessoal do Departamento de Marinha Mercante (DMM) e Comissão Diretora do Fundo de Marinha Mercante (CDFMM), Banco Nacional de Desenvolvimento Econômico e Social (BNDES), Associação Brasileira das Empresas de Apoio Marítimo (ABEAM), Sindicato Nacional da Indústria de Construção Naval e Offshore (SINAVAL), Petrobras Transporte S/A (Transpetro) e Sindicato Nacional das Empresas de Navegação Marítima (SYNDARMA) - em especial ao colega Cláudio R. F. Décourt. 
Meus agradecimentos aos colegas da COPPE/UFRJ. Em especial aos Profs. Luis Fernando Assis e Floriano Pires Jr., sempre dispostos em contribuir e discutir temas ligados ao mundo naval.

Não poderia deixar de lembrar de meus amigos de longa data que sempre me incentivaram e com os quais tenho uma dívida enorme na realização deste trabalho. São eles os Profs. Milton de Abreu Campanário, Ricardo Leonardo Rovai, Armênio de Souza Rangel e James Manoel Weiss. Estes deram grandes contribuições à pesquisa por meio de suas valiosas críticas e sugestões.

Não poderia esquecer do carinho e incentivos das amigas de trabalho e sempre colaboradoras: Silvia Marques Carneiro Rodrigues e Edna Baptista dos Santos Gubitoso, do IPT. Um abraço especial à colega Estela Fernanda Rodrigues Ferreira, da Nossa caixa Nosso Banco S/A. Além desses, também agradeço a outros colegas com os quais discuti certos temas da dissertação e que muito me ajudaram em momentos que considerei críticos: Tiago Ribeiro Costa, Neiva Cristina Rosa Galoro, Cristiane Punhagui Costa e Roberta Oliveira Costa.

Por fim, meu agradecimento especial em termos da elaboração desse trabalho, fica para o companheiro Vergílio A. Martins, meu amigo, colega de turma e grande incentivador ao longo do curso e da elaboração deste trabalho. 


\section{RESUMO}

Este trabalho discute os microfundamentos do financiamento de projetos orientado à construção naval no Brasil, tendo como base de comparação práticas adotadas em outros países. A experiência brasileira é tratada metodologicamente como um "estudo de caso". Este procedimento se justifica em razão da natureza complexa do problema da pesquisa, importância do contexto na tomada de decisão por parte dos agentes envolvidos (armador, estaleiro, órgãos governamentais, órgãos de financiamento, etc.), escassez de informações estatísticas e escassez de estudos direcionados ao tema. A modelagem proposta abrange dois enfoques complementares. O primeiro toma como base um conjunto de indicadores econômico-financeiros de empresas de armação nacionais e estrangeiras. O objetivo é comparar a estrutura de capital das empresas de navegação nacionais e estrangeiras. Os resultados são confrontados com opiniões de agentes ligados ao setor a fim de verificar se as dificuldades no financiamento possuem relação com as causas explicitadas. Estes foram obtidos a partir de um extenso banco de dados elaborado durante a pesquisa e são analisados á luz de princípios que regem a concessão de financiamentos, incluindo critérios seguidos pelo BNDES no repasse de recursos do Fundo da Marinha Mercante (FMM). As informações geradas são confrontadas com opiniões de diretores financeiros de empresas de armação nacionais, obtidas por meio de entrevistas realizadas ao longo do desenvolvimento do projeto. Essa investigação é complementada pelo posicionamento de especialistas vinculados às associações classistas que atuam ao setor. $\mathrm{O}$ intuito é apontar e discutir a percepção destes atores sobre os obstáculos do financiamento local. O segundo enfoque, ainda baseado nas informações contidas no banco de dados e nas entrevistas realizadas no âmbito da pesquisa, estabelece um modelo, baseado na teoria financeira, destinado a avaliar o nível de atratividade do financiamento setorial. A determinação do modelo tem como ponto de partida a estimação da taxa de retorno setorial por meio da aplicação de técnicas econométricas de cointegração sobre dados de ações de 44 empresas de transporte marítimo e índices de mercado obtidos juntos ao New York Stock Exchange (NYSE). O modelo proposto e executado por meio de simulação computacional é também alimentado por parâmetros das estruturas de financiamento de diversos países e estatísticas que captam os respectivos níveis de risco associados à transferência de recursos. Quando executado, o modelo considera e compara uma operação de financiamento feita por uma empresa de transporte local para a construção de uma embarcação em estaleiro nacional a qual submete a proposta a diferentes linhas de financiamento. $O$ procedimento adotado confronta a estrutura de financiamento brasileira com as praticadas no Japão, Coréia do Sul, Alemanha, Noruega, China e EUA. O grau de atratividade do financiamento local é resumido por meio de índices de atratividade gerados pelo modelo. $O$ estudo termina discutindo os resultados da modelagem e apresentando uma síntese de microfundamentos que orientam o financiamento destinado à construção de embarcações.

Palavras-chave: Indústria da construção naval; Financiamento; Teoria da Complexidade. 


\begin{abstract}
This dissertation presents the micro foundations of the naval construction project finance in Brazil, as it can be compared to practices of other countries. The Brazilian experience is treated methodologically as a "study case". This procedure is justified due not only to the exploratory nature of the research question on a quite complex subject but also to the relevance of the decision making process of major actors involved (shipowner, shipbuilder, regulatory agency, financial agencies, etc.), scarcity of data, information and other previous specific studies. The methodology developed has two complementary perspectives. The first takes as its base a set of economic and financial indicators of Brazilian and foreign merchant marine firms. The indicators were obtained through an extensive data collection undertaken during this research and are analyzed by the same parameters used by the National Economic and Social Development Bank - BNDES in its loan mechanisms to the Marine Merchant Fund FMM. The information is then submitted to an analysis of financial executives of naval construction firms and leaders of entrepreneur's organizations, by means of structured interviews. The objective is to point out and discuss the perception of these important actors on the structural constraints of the Brazilian financial system. The second perspective, based on the data collected and on the interviews realized, establishes a theoretical finance simulation model to measure how attractive are the investments in the naval sector. The model is specified through the estimation of the rate of return in the sector. Cointegration econometric techniques are applied to data of 44 marine transportation firms, utilizing market indicators obtained in the New York Stock Exchange (NYSE). The model is also fed by parameters of several countries' financial structure as well as statistics that capture the risk level in each case. The model considers and compares one project submitted by a single firm to different financial lines. The adopted procedures are able to compare the Brazilian structure of finance to the practices undertaken in Japan, South Korea, Germany, Norway, China and United States. The degree of attraction of the local financial system is summarized by a system of "attraction index" generated by the model. The study ends up with a discussion of the outputs of the model and presents a synthesis of the micro foundations that should subsidy the naval construction industry.
\end{abstract}

Keywords: Industry of Naval Construction; Shipping Finance; Theory of the Complexity 


\section{LISTA DE FIGURAS}

Figura 1 - Os quatro mercados que formam a estrutura de oferta e demanda do transporte marítimo.

Figura 2 - Relação entre os mercados do setor marítimo durante o ciclo marítimo simplificado 56

Figura 3 - Funções oferta e demanda do transporte marítimo no curto prazo. .59

Figura 4 - Funções oferta e demanda do transporte marítimo no longo prazo. .........62

Figura 5 - Cadeia produtiva do mercado de transporte marítimo...............................68

Figura 6 - Forças que dirigem a concorrência na indústria. .....................................70

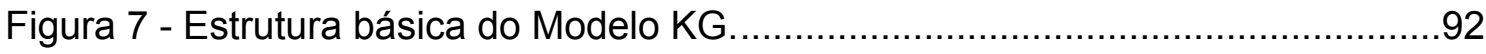

Figura 8 - Perspectiva da dinâmica de um negócio no contexto decisório. ............. 116

Figura 9 - Principais fontes de recursos que podem viabilizar a aquisição de uma embarcação. 118

Figura 10 - Estrutura de gastos de uma empresa de transporte marítimo. 237 


\section{LISTA DE GRÁFICOS}

Gráfico 1 - Volume de transporte marítimo mundial (1950/2006). .........................45

Gráfico 2 - Total da produção mundial de navios (1964-2003) .............................46

Gráfico 3 - Produção mundial de navios por região de origem (1964-2003). ...........48

Gráfico 4 - FMM: Captação e Investimento (Valores em milhões de US\$ de 2002)

Gráfico 5 - FMM: Investimento e retorno (Valores em milhões de US\$ de 2002)... 101

Gráfico 6 - Evolução das cotações das empresas de navegação e do índice Dow

Jones 274

Gráfico 7 - Risco país cotado em termos diários e apurado para o intervalo compreendido entre jan/04 e fev/07

Gráfico 8 - Variação cambial em relação ao US\$ por país selecionado (jan/00 a dez/06) 282

Gráfico 9 - Variação cambial em relação ao $\mathrm{R} \$$ por país selecionado (jan/00 a dez/06) 282

Gráfico 10 - Índice de Atratividade do financiamento naval do Brasil vs. China ..... 288

Gráfico 11 - Índice de Atratividade do financiamento naval do Brasil vs. Coréia do Sul 290

Gráfico 12 - Índice de Atratividade do financiamento naval do Brasil vs. Japão 290

Gráfico 13 - Índice de Atratividade do financiamento naval do Brasil vs. EUA ....... 291 Gráfico 14 - Índice de Atratividade do financiamento naval do Brasil vs. Noruega.... 291

Gráfico 15 - Índice de Atratividade do financiamento naval do Brasil vs. Alemanha... 


\section{LISTA DE QUADROS}

Quadro 1 - Dimensões críticas associadas ao financiamento da construção e

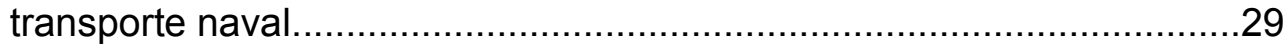

Quadro 2 - Estratégias de pesquisa e sua relação com o tipo de questão, controle e

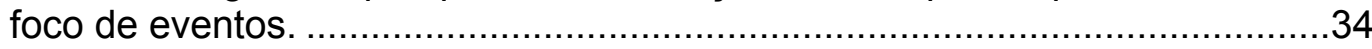

Quadro 3 - Mercados que compõe o mundo marítimo. ........................................52

Quadro 4 - Agentes e papel dos diversos atores na indústria de construção naval. .70

Quadro 5 - Parâmetros da estrutura de financiamento por país selecionado......... 110

Quadro 6 - Mapa de prioridades de políticas públicas por tipo de cadeias............. 128

Quadro 7 - Critérios comuns e políticas usadas pelos bancos locais para assessorar os riscos do shipping finance. ................................................................ 131

Quadro 8 - Exemplo de aplicação de esquema de seguro garantia. ..................... 137

Quadro 9 - Agentes locais do processo de financiamento e seus principais papéis 144

Quadro 10 - Cinco princípios que servem de base de negociação ao financiamento

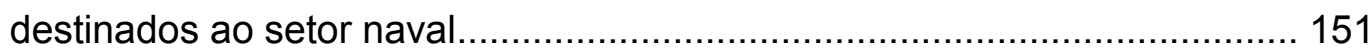

Quadro 11 - Sumário das fontes de riscos específicos das empresas e suas implicações para o setor naval ................................................................. 159

Quadro 12 - Sumário das fontes de risco específicos dos acionistas e suas implicações para o setor naval................................................................ 160

Quadro 13 - Sumário das fontes de risco específicos da empresa dos acionistas e

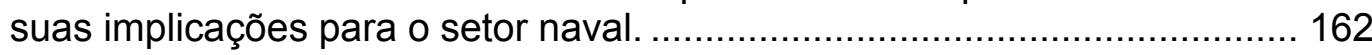

Quadro 14 - Classes, definições e finalidade dos Indicadores de Liquidez (IL)...... 166

Quadro 15 - Classes, definições e finalidade dos Indicadores de Administração de

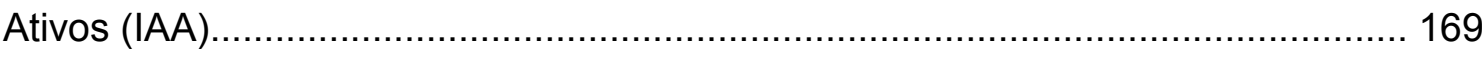

Quadro 16 - Classes, definições e finalidade dos Indicadores de Endividamento (IE).. 171

Quadro 17 - Classes, definições e finalidade dos Indicadores de Rentabilidade (IR) ... 174

Quadro 18 - Indicadores utilizados pelo BNDES na avaliação de propostas do FINEM 177

Quadro 19 - Questões formuladas para abordagem do problema da pesquisa. .... 212

Quadro 20 - Sumário de resultados das entrevistas estabelecidas em torno da questão 1 (formatação e modelagem financeira de projetos). ...................... 215

Quadro 21 - Sumário de resultados das entrevistas estabelecidas em torno da questão 2 (riscos dos empreendimentos). 219 
Quadro 22 - Sumário de resultados das entrevistas estabelecidas em torno da questão 3 (escolha de estaleiro). 224

Quadro 23 - Sumário de resultados das entrevistas estabelecidas em torno da questão 4 (considerações sobre a política de financiamento). ................... 228

Quadro 24 - Representação simplificada do fluxo de caixa de um projeto ............ 239

Quadro 25 - Informações gerais e estatísticas aplicadas no modelo de simulação

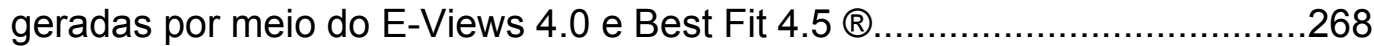




\section{LISTA DE TABELAS}

Tabela 1 - Resultados das estatísticas e teste de diferenças de médias dos Índices de Liquidez (IL) das empresas nacionais e estrangeiras para os anos de 2004 e 2005 . 193

Tabela 2 - Resultados das estatísticas e testes de diferença de médias dos Índices de Administração de Ativos (IAA) para amostras de empresas nacionais e estrangeiras para os anos de 2004 e 2005. 199

Tabela 3 - Resultados das estatísticas e testes de diferença de médias dos Índices de Rentabilidade (IR) para amostras de empresas nacionais e estrangeiras para os anos de 2004 e 2005 203

Tabela 4 - Resultados das estatísticas e testes de diferença de médias dos Índices de Endividamento (IE) para amostras de empresas nacionais e estrangeiras para os anos de 2004 e 2005. 206

Tabela 5 - Resultados das estatísticas de testes para diferença de médias para Índice de Liquidez (IL) das empresas nacionais e estrangeiras segundo metodologia empregada pelos BNDES para os anos de 2004 e 2005. 209

Tabela 6 - Resultados das estatísticas e teste de diferença de médias do Índice de Rentabilidade (IR) para amostras de empresas nacionais e estrangeiras segundo metodologia do BNDES para os anos de 2004 e 2005. 210

Tabela 7 - Resultados das estatísticas e teste de diferença de médias do Índice de Endividamento (IE) para amostras de empresas nacionais e estrangeiras segundo metodologia do BNDES para os anos de 2004 e 2005. 211

Tabela 8 - Teste ADF da cotação das de navegação (Nav) e do índice Dow Jones $(D J)$. 275

Tabela 9 - Teste ADF da cotação das de navegação (Nav) e do índice Dow Jones $(D J)$. 275

Tabela 10 - Unrestricted Cointegration Rank Test. 276

Tabela 11 - Taxa Commercial Interest Reference Rate (CIRR) por país em termos \% e mensais anualizados (jul/02 a dez/06). 


\section{LISTA DE ABREVIATURAS E SIGLAS}

APT - Arbitrage Theory of Capital Asset Pricing (Teoria de Precificação por Arbitragem)

APV - Adjusted Present Value (Valor Presente Ajustado).

AC - Análise de Crédito (Credit Scoring)

AFRMM - Adicional ao Frete para a Renovação da Marinha Mercante

BACEN - Banco Central do Brasil

BNDES - Banco Nacional de Desenvolvimento Econômico e Social

BP - Balanço Patrimonial

CAPM - Capital Asset Pricing Money (Modelo de Precificação de Ativos de Capital)

CDFMM - Comissão Diretora do Fundo da Marinha Mercante

CEPAL - Comissão Econômica para a América Latina e Caribe

CIRR - Comercial Interest Reference Rate (Taxas de Juros Comerciais de

Referência)

CMM - Comissão de Marinha Mercante

CMN - Conselho Monetário Nacional

COPPE - Instituto Alberto Luiz Coimbra de Pós-Graduação e Pesquisa de

Engenharia

CPMF - Contribuição Provisória sobre Movimentação Financeira

CS - Credit Scoring (Classificação de Crédito)

CR - Credit Rating (Classificação de risco)

D-CAPM - Downside Capital Asset Pricing Model

DCP - Dívida de Curto Prazo

DF - Demonstrativos Financeiro

DMM - Departamento de Marinha Mercante

DF - Demonstrativos Financeiros

DFE - Demonstrativo de Fluxo de Caixa

DRE - Demonstrativo de Resultado do Exercício

EAP - Estrutura Analítica do Projeto

EBIT - Earnings Before Interest and Tax (Lucro Antes dos Juros e Impostos)

EBITDA - Earnings Before Interest, Tax, Depreciation and Amortization (Lucro Antes dos Juros, Impostos, Depreciação e Amortização)

EF - Endividamento Financeiro 
EG -Endividamento Geral

EU - União Européia

EUA - Estados Unidos da América

FDC - Fluxo de Caixa

FINEM - Financiamento de Empreendimentos

FMM - Fundo da Marinha Mercante

GAF - Grau de Alavancagem Financeira

GAI - Giro do Ativo Imobilizado

GAT - Giro do Ativo Total

GCR - Giros de Contas a Receber

GRT - Gross Tons (Toneladas Brutas)

IAA - Índices de Administração de Ativos

ICJ - Índice de Cobertura de Juros

ICN - Indústria de Construção Naval

IE - Índices de Endividamento

IEF - Indicadores Econômico-Financeiros

IL - Índices de Liquidez

ILC - Índice de Liquidez Corrente

ILS - Índice de Liquidez Seco

IPEA - Instituto de Pesquisa Econômica Aplicada

IPG - Índice de Poder de Ganho

IR - Índices de Rentabilidade

IRB - Instituto de Resseguros do Brasil

IRE - Índice de Rotação de Estoque

KG - Kommanditgesellschaft (Modelo de Parceria Limitada de Financiamento Naval da Alemanha)

LB - Lucratividade Bruta

LIBOR - London Interbank Offered Rate (Taxa Interbancária de Londres - Reino

Unido)

LL - Lucratividade Líquida

LO - Lucratividade Operacional

LP - Lucratividade Patrimonial

MB - Margem Bruta

MDIC - Ministério do Desenvolvimento da Indústria e Comércio 
MKP - Multiplicador de Capital Próprio

MKPT - Multiplicador de Capital Próprio e de Terceiros

ML - Margem Líquida

MT - Ministério dos Transportes

NYSE - New York Stock Exchange (Bolsa de Valores de Nova York - EUA)

OCDE - Organização para a Cooperação e Desenvolvimento Econômico

PCN - Plano de Emergência de Construção Naval

PM - Plano de Metas

PMR - Prazo Médio de Recebimento

PNB - Produto Nacional Bruto

PTAX - Taxa de câmbio média - cesta de moedas

ROA - Retorno sobre Ativos

ROE - Retorno sobre Patrimônio Líquido

SAC - Sistema de Amortização Constante

SINAVAL - Sindicato Nacional da Indústria da Construção e Reparação Naval e Offshore

SUNAMAM - Superintendência Nacional da Marinha Mercante

SYNDARMA - Sindicato nacional das Empresas de Navegação Marítima

TJLP - Taxa de Juros a Longo Prazo

Ton. - Tonelada

TPB - Toneladas de Porte Bruto

VPL - Valor Presente Líquido

VPL $L_{c}$ - Valor Presente Líquido de Custos

WACC - Weighted Average Cost of Capital (Custo Médio Ponderado do Capital) 


\section{SUMÁRIO}

DEDICATÓRIA

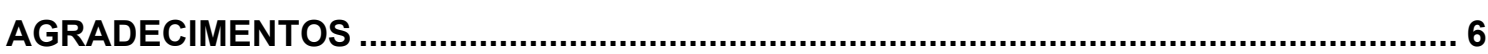

RESUMO

ABSTRACT

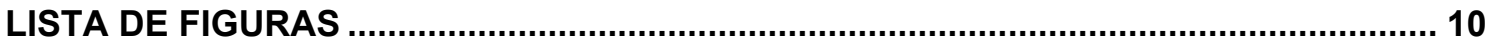

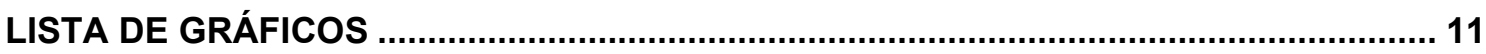

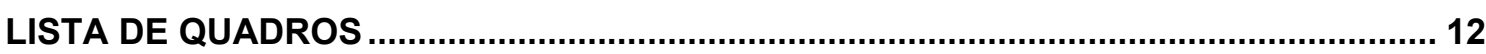

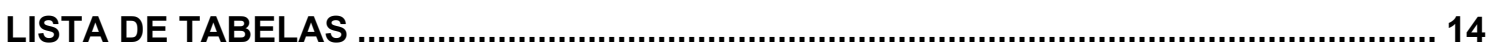

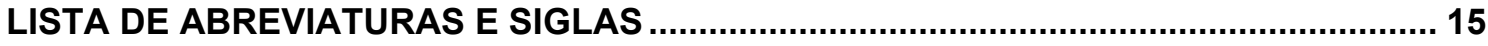

SUMÁRIO

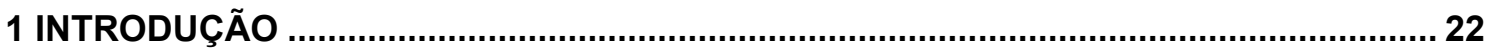

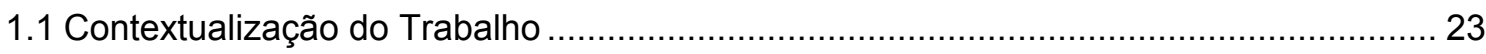

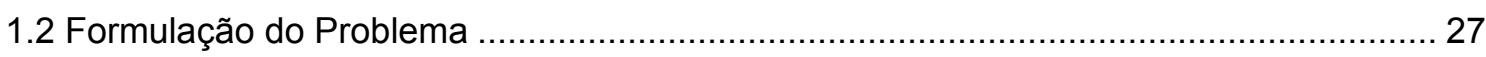

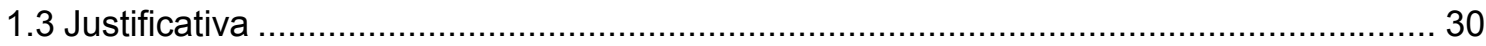

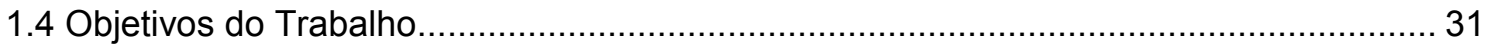

1.5 Questões Propostas e Proposições Assumidas ............................................................ 31

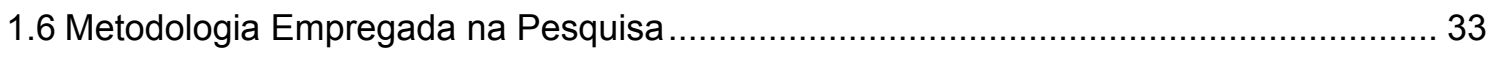

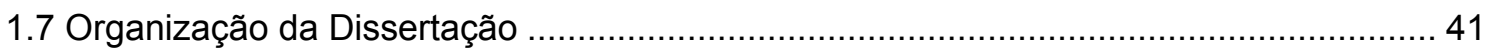

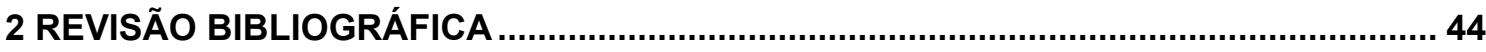

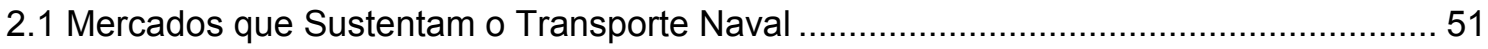

2.2 Mercado de Fretes e Investimento na Construção Naval............................................. 57

2.2.1 Mercado de Fretes no Curto Prazo................................................................... 58

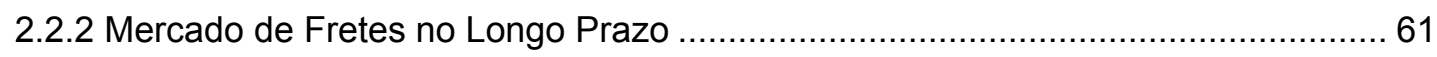

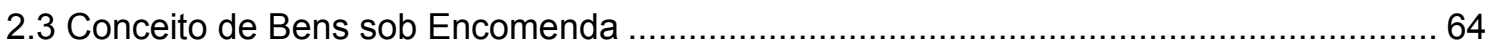

2.4 Cadeia de Valores da Indústria de Construção Naval .................................................... 67

2.5 Sumário das Política de Incentivos, Importância e Parâmetros das Atuais Políticas de Financiamento em Países Selecionados ................................................................... 72

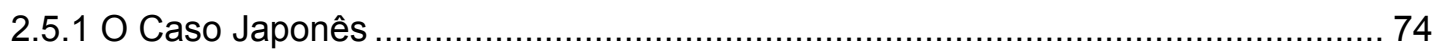

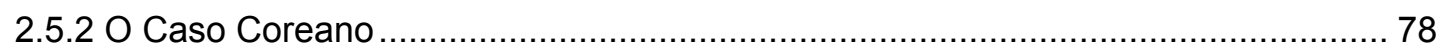

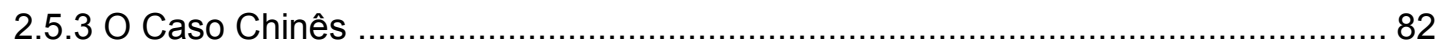

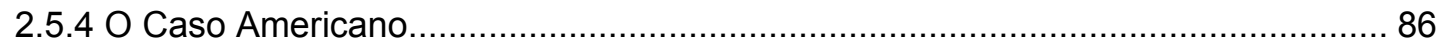

2.5.5 O Caso Alemão

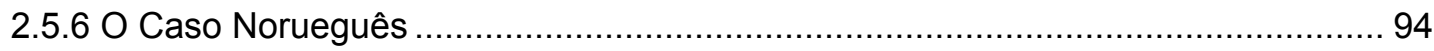

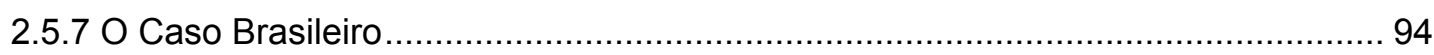

2.6 Características das Estruturas de Financiamento Setorial........................................ 107

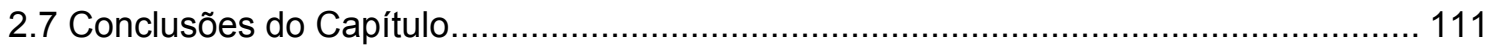




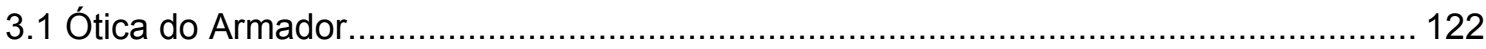

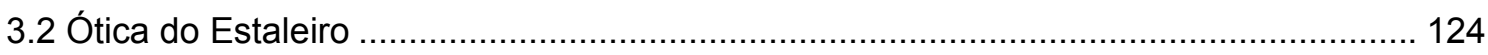

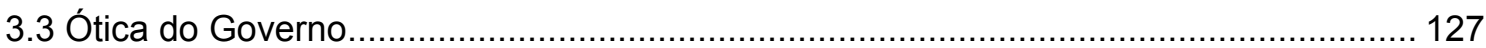

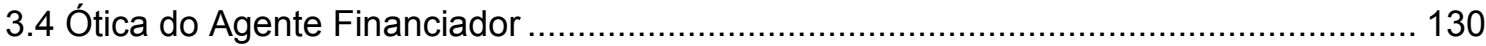

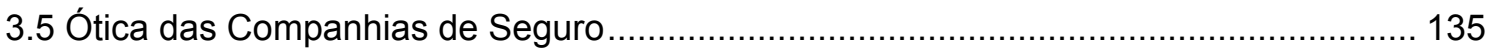

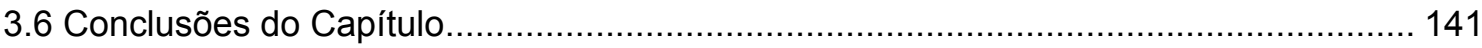

4 MICROFUNDAMENTOS DO PROCESSO DE FINANCIAMENTO SETORIAL............... 146

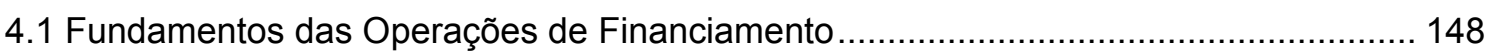

4.2 Tipos de Riscos Envolvidos em Operações de Financiamento...................................... 158

4.3 Avaliação dos Riscos dos Empreendimentos por Meio de Indicadores Econômico-

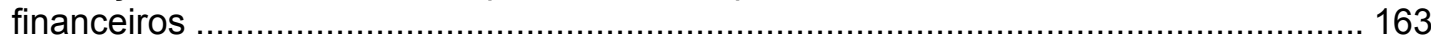

4.3.1 Índices de Solvência ou Liquidez (IL) ........................................................ 165

4.3.2 Índices de Atividade ou Administração de Ativos (IA) ........................................ 167

4.3.3 Índices de Alavancagem Financeira ou Endividamento (IE) ............................... 170

4.3.4 Índices de Rentabilidade ou Retorno sobre Investimento (IR) .......................... 172

4.3.5 Estratégia de Análise de Projetos por Parte do BNDES........................................ 175

4.4 Utilização dos Indicadores Econômico-financeiros na Pesquisa................................ 178

4.5 Avaliação de Indicadores Econômico-financeiros das Empresas de Transporte ........... 184

4.5.1 Informações Gerais dos Balanços das Empresas (BP) ...................................... 185

4.5.2 Informações Gerais dos Demonstrativos de Resultado das Empresas (DRE)..... 187

4.5.3 Informações Gerais dos Demonstrativos de Fluxo de Caixa das Empresas (DFC)

4.5.4 Comparando o grau de Liquidez das Empresas de Transporte Marítimo Nacionais

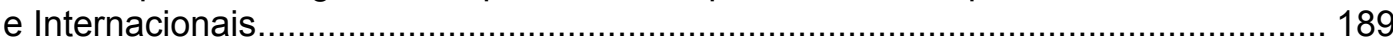

4.5.5 Comparando o Grau Atividade das Empresas de Transporte Marítimo

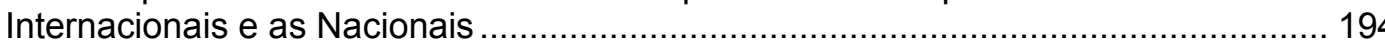

4.5.6 Comparando o Grau Rentabilidade das Empresas de Transporte Marítimo Internacionais e Nacionais.... 201

4.5.7 Comparando o Grau Endividamento das Empresas de Transporte Marítimo

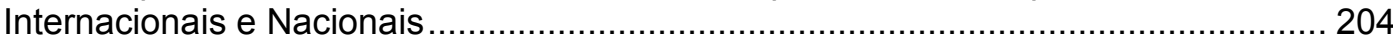

4.5.8 Confronto de Indicadores sob a Ótica da Estratégia do BNDES ........................... 208

4.6 Resultados de Entrevistas e Confronto com Testes de Dados Financeiros................... 212

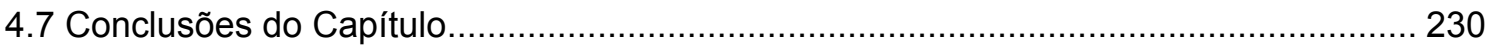

5 COMPARANDO A ESTRUTURA DE FINANCIAMENTO LOCAL COM AS PRÁTICAS

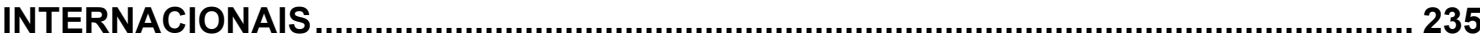

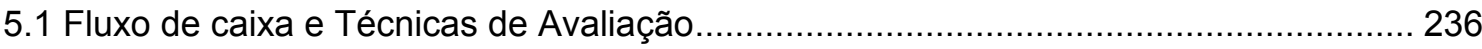

5.2 Cálculo do valor das prestações em Sistema de Amortização - $P M T_{t}$........................ 241

5.3 Métodos Empregados na Obtenção da Taxa de Desconto $-r$.................................. 242 


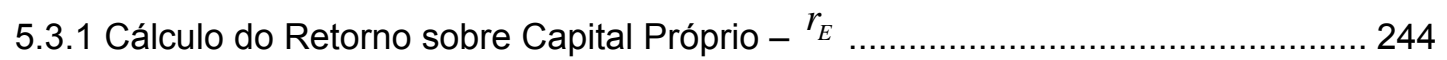

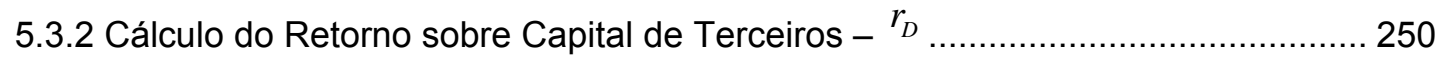

5.3.2.1 Cálculo do Retorno do ativo Livre de Risco e Taxas de Juros Empregadas no

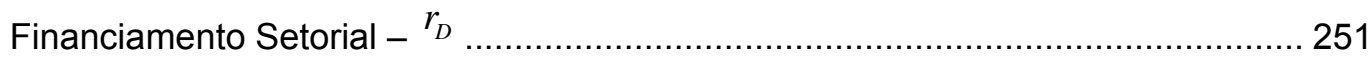

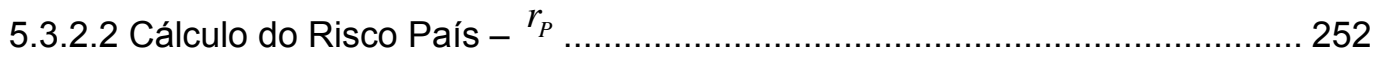

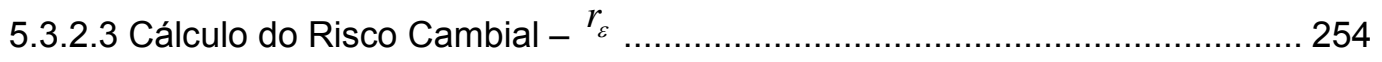

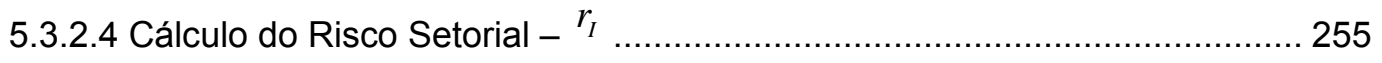

5.3.2.5 Cálculo da Taxa de Retorno sobre Capital de Terceiros no Modelo Proposto $r_{D}^{K}$ 256

5.4 Hipóteses Assumidas e Modelo Matemático Proposto ........................................... 257

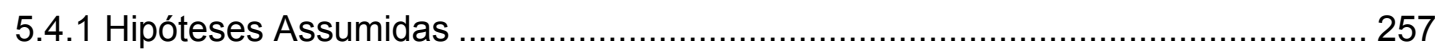

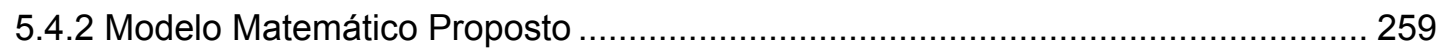

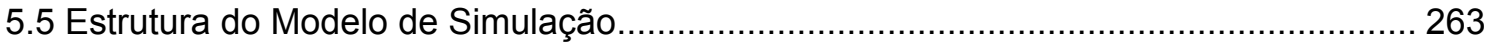

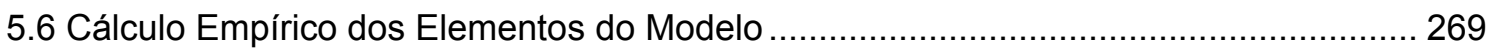

5.6.1 Cálculo Empírico da Taxa de Desconto sobre Capital Próprio - $r_{E} \ldots \ldots \ldots \ldots \ldots \ldots \ldots . . . . . . . .270$

5.6.2 Estimação do Custo de Capital Próprio por meio do beta das Empresas de

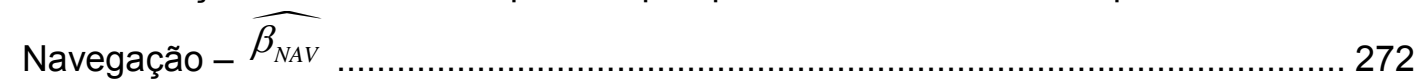

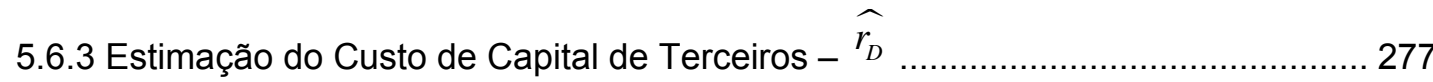

5.6.3.1 Cálculo Empírico da Taxa de Juros Empregada no Financiamento Setorial $\widehat{i_{K}}$ 278

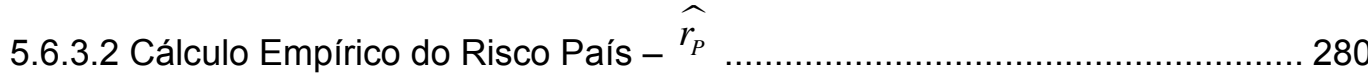

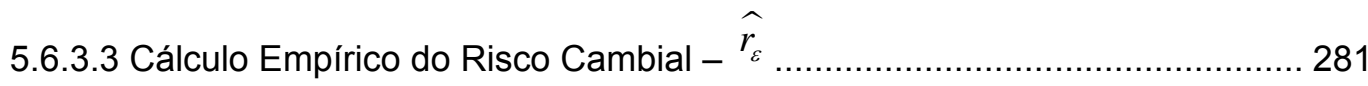

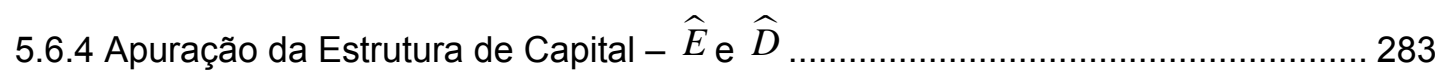

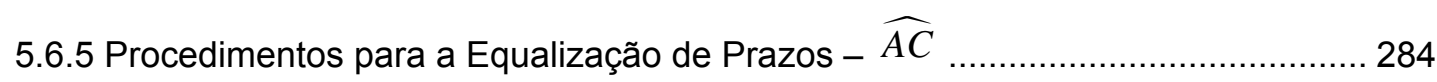

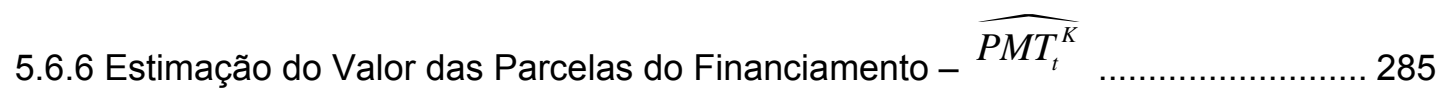

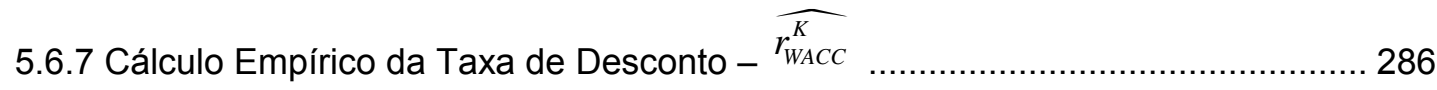

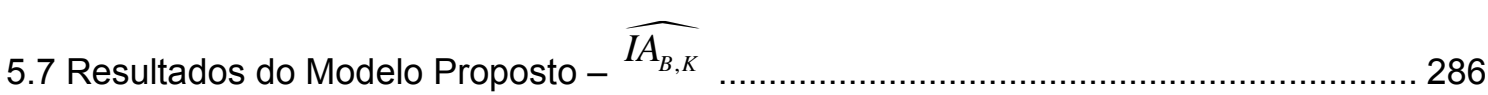

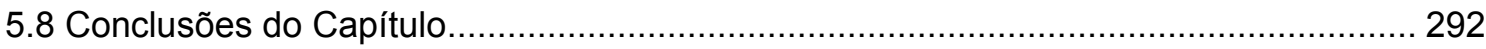

6 CONSIDERAÇÕES FINAIS E IDENTIFICAÇÃO DE NOVAS LINHAS DE PESQUISA. 295

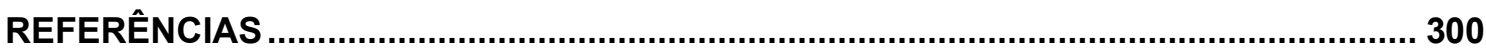


ANEXOS.

ANEXO 1 - QUESTIONÁRIO APLICADO DURANTE A FASE EXPLORATÓRIA DA PESQUISA

ANEXO 2 - PROTOCOLO E QUESTIONÁRIO APLICADOS NA PESQUISA DE CAMPO

ANEXO 3 - RELAÇÃO DE EMPRESAS NACIONAIS CONTATADAS PARA ELABORAÇÃO

DAS ENTREVISTAS 320

ANEXO 4 - E-MAIL E CONTATO DE SOLICITAÇÃO DE ENTREVISTAS ENCAMINHADO ÀS EMPRESAS NACIONAIS 325

ANEXO 5 - RELAÇÃO DE EMPRESAS INTERNACIONAIS 326

ANEXO 6 - DETALHAMENTO DE INFORMAÇÕES PRESENTES NOS DEMONSTRATIVOS CONTÁBEIS DAS EMPRESAS ESTRANGEIRAS 332

ANEXO 7 - RESUMO DA LEGISLAÇÃO QUE REGULAMENTA O REPASSE DE RECURSOS DO FMM 335

ANEXO 8 - SUMÁRIO DAS CARACTERÍSTICAS DAS EMPRESAS NACIONAIS VISITADAS DURANTE PESQUISA DE CAMPO 336

ANEXO 9 - APÊNDICE MATEMÁTICO E DETALHAMENTO DA MODELAGEM 337

ANEXO 10 - CD ROM COM PLANILHAS PARA OBTENÇÃO DO ÍNDICE DE ATRATIVIDADE (IA) 


\section{INTRODUÇÃO}

A indústria de construção naval (ICN) produz um bem de capital de alto valor, fabricado sob encomenda e que apresenta longos ciclos de produção e uso. De acordo com modelos desenvolvidos pela Comissão Econômica para a América Latina (CEPAL), o volume de investimentos e o desempenho dessa indústria estão intrinsecamente relacionados aos movimentos esperados nas taxas de frete. Essas constituem a principal fonte de recursos setorial e uma das principais variáveis de decisão, condicionando as ordens de construção de novas embarcações dos armadores junto aos estaleiros. Uma vez tomada à decisão de investimentos e definidos os parâmetros de preço/custo, qualidade e prazos do projeto, é preciso obter financiamento em condições compatíveis com a escala dos empreendimentos. Em razão do elevado valor das embarcações e baixas margens geradas nos serviços de transporte e apoio marítimo, o financiamento deve prover recursos a custos competitivos, respeitando a programação do projeto de construção, firmado entre armador e estaleiro.

Dada à importância do tema, este trabalho discute os microfundamentos do financiamento de projetos de construção de embarcações. Ao fazer isso procura comparar, sob a ótica das empresas de transporte e apóio marítimo, a estrutura de financiamento setorial existente no Brasil com as praticadas em outros países. Nesse contexto, o estudo discute os aspectos críticos associados à concessão de financiamento, por meio do uso do Fundo da Marinha Mercante (FMM) tal como provido pelo Banco Nacional de Desenvolvimento Econômico e Social (BNDES).

Para tanto, utiliza o método de estudo de caso como meio de avaliar o caso brasileiro. Como será demonstrado adiante, este procedimento metodológico se justifica em razão da natureza do problema da pesquisa, importância do contexto na tomada de decisão por parte dos agentes envolvidos (armador, estaleiro, órgão governamentais, etc.), escassez de estudos direcionados e de informações estatísticas, bem como, complexidade do tema.

O trabalho encontra-se dividido em cinco capítulos, além dessa introdução. O capítulo 2 estabelece a revisão da literatura destacando a importância do financiamento orientado ao setor. Ao fazer isso aborda os seguintes temas: 
mercados do setor naval, funcionamento do mercado de fretes no curto e longo prazo e investimento em construção, caracterização econômica da ICN, cadeia de valores do setor de transporte marítimo, formas de intervenção Estatal e financiamento setorial. O capítulo 3 procura discutir sumariamente o financiamento sob diferentes óticas (armador, estaleiro, governo, agentes financeiros e seguradoras) levando em conta a posição de cada instituição na cadeia de valor setorial. Nesse contexto, sistematiza aspectos financeiros das trocas de ativos de capital estabelecidas em torno da construção de novas embarcações. O capítulo 4 apresenta e discute os tipos de riscos associados aos empreendimentos, sua repercussão no financiamento e formas de medição por meio de indicadores econômico-financeiros. Esses são calculados para um conjunto de empresas nacionais e internacionais que atuam no setor de transporte e apoio marítimo. $O$ objetivo é comparar os indicadores de solvência, gestão, endividamento e rentabilidade das empresas de navegação e apóio a fim de verificar os gaps e implicações de tais índices em relação às práticas internacionais. O capítulo 5 desenvolve e aplica um modelo de simulação baseado na teoria financeira que trata de avaliação de fluxo de caixa. Sua aplicação, apoiada em informações empíricas coletadas junto a diversas fontes de informações econômicas, objetiva comparar o grau de atratividade da linha de financiamento local em relação às práticas internacionais. O capítulo 6 apresenta considerações finais e aponta novas linhas de pesquisa.

As próximas subseções desse capítulo procuram contextualizar o trabalho, apresentar a formulação do problema, a justificativa, seus objetivos, as questões propostas e proposições assumidas e a metodologia empregada no estudo. Ao final do capítulo se discute de maneira mais detalhada a organização da dissertação e o conteúdo de suas partes constituintes.

\subsection{Contextualização do Trabalho}

Segundo a literatura especializada, a ICN pode ser caracterizada como uma indústria global. Em indústrias globalmente competitivas, empresas rivais disputam a liderança mundial competindo entre si para atender a demanda de diferentes países, 
principalmente em mercados nos quais os volumes de negócios são relativamente grandes e onde a atuação competitiva deve se pautar pelo comportamento estratégico (CHO; PORTER, 1986; FADDA, 2006). O mesmo se pode afirmar acerca do segmento de transporte marítimo e de apoio marítimo. Nestes casos, quanto maior o porte de uma empresa maior sua rede de atuação, seu poder de barganha e sua capacidade financeira (PORTER, 1996).

Os maiores estaleiros em operação tendem a concentrar suas atividades em um único país a fim de obter economias de escala, economias de escopo e outras fontes de ganhos econômicos. Por se tratar de um segmento industrial altamente capitalizado, o regime de concorrência global faz com que os estaleiros e armadores competidores se enfrentem em muitos países diferentes, em seus respectivos nichos de mercado (FADDA, 2006).

Dado o volume de capital exigido nos empreendimentos, as condições de financiamento setorial têm grande influência no jogo competitivo. Essa questão é apontada por diversos autores entre eles Alex (2004), Barboza (2004), Cho e Porter (1986), Fadda (2006), Johnson Stokes \& Master (2005), Kendall e Buckley (2005), Khalid (2005), Lacerda (2003), Sloggett (1984), Stopford (2005) entre outros. Apesar disso, ainda foi pouco explorada em termos de seus fundamentos microeconômicos.

A ICN se caracteriza pela produção de um bem de capital de alto valor, produzido sob encomenda, cuja construção dura meses. Por estas razões, estes autores chamam a atenção para a necessidade de aporte de vultosos recursos e quanto à importância de esquemas financeiros como meio de garantir o desenvolvimento sustentável e a competitividade da indústria e do transporte naval. Estes recursos são via de regra, alocados por meio de financiamentos firmados pelas empresas de transporte marítimo e de apoio marítimo junto a instituições financeiras sendo regulados por complexos arranjos contratuais. Contudo, como salienta Kendall e Buckley (2005), em muitos casos estes esquemas são viabilizados por meio de forte intervenção governamental. Sem financiamento adequado e que atenda as demandas setoriais, as empresas que atuam no segmento de transporte marítimo não podem expandir o tamanho de suas frotas e operações, o que pode afetar as perspectivas do negócio como um todo, interferindo no desenvolvimento da indústria naval, na rentabilidade da cadeia de valores setorial e no nível de comércio internacional (BARBOZA, 2004; KHALID, 2005). 
Com o aumento do porte, diversificação de produto e complexidade tecnológica dos navios, os armadores raramente têm condições de financiar a construção com recursos próprios (equity market) (KHALID, 2005; STOPFORD, 2005). Obviamente isso se faz sentir na forma de alocação de capital no setor e em seu impacto sobre a estrutura de custos refletida no time charter diário das embarcações, com efeitos sobre as taxas de retorno das empresas e nos riscos financeiros associados às operações ${ }^{1}$. O resultado dessas influências sobre o custo do capital se adiciona a tendência de aumento de porte das embarcações, demandando esquemas de financiamento mais robustos e compatíveis com as demandas setoriais (BARBOZA, 2004) ${ }^{2}$.

Ao discutir os fatores que afetam o desempenho da cadeia produtiva em termos implícitos e explícitos, Barboza (2004) também chama a atenção para aspectos que tendem a impactar a demanda e custos da indústria. Segundo este autor, as características do produto podem ser relacionadas a três propriedades que variam no tempo (trazendo impactos financeiros): diversificação crescente, incremento na robustez/confiabilidade e rapidez da evolução tecnológica.

O ciclo geral dos negócios associados ao setor de transporte marítimo afeta a avaliação dos ativos das empresas que nele operam (EL CICLO..., 2005). Por esta razão, Alex (2004) salienta que os riscos relacionados ao investimento em construção naval também se refletem na avaliação dos ativos das empresas ligadas ao setor de armação e construção. Fato que interfere diretamente na fixação de garantias contratuais. A rigor, os ciclos de crescimento na ICN sempre caminharam com o volume de comércio internacional. Este, por sua vez, possui alta correlação com o nível de produção industrial e de comércio dos países da Organização para a Cooperação e de Desenvolvimento Econômico - OCDE (EL CICLO ..., 2005).

Segundo Cho e Porter (1986), um contrato de construção naval invariavelmente envolve uma substancial quantia de recursos financeiros. Desta forma, um mercado financeiro bem estabelecido com linhas de financiamento diversificadas, aderentes à realidade setorial e freqüentemente influenciado pelo

\footnotetext{
${ }^{1}$ O time charter corresponde a planilha de custos associadas a operação de uma embarcação. Pode ser traduzida em termos diários. Segundo especialistas consultados, o time charter diário está no cerne das decisões operacionais das empresas de transporte e apoio marítimo.

2 Stopford (2005) sustenta, por exemplo, que a explicação para o contínuo aumento tamanho dos navios se deve a economias de escala. Isso ocorre porque há uma relação entre tamanho e custo: o custo operacional tende a crescer em proporção menor que a redução do custo por tonelada transportada gerando economias de escala.
} 
governo, constitui elemento-chave (não o único) que condiciona a posição competitiva da ICN e dos demais segmentos do mundo naval. A rigor, estes autores relacionam diretamente a vantagem competitiva estática (baseada na dotação de fatores produtivos tais como mão-de-obra especializada, insumos diversos, tecnologia, etc.) e dinâmica (baseada no progresso técnico e especialização produtiva e comercial) da ICN (caracterizada como uma indústria global), à disponibilidade e estrutura das diferentes linhas de financiamento.

Segundo Barboza (2004), o sucesso internacional na produção de um bem de capital, de alto valor unitário e produzido sob encomenda como uma embarcação, depende, cada vez mais, da disponibilidade, qualidade e formatação de linhas de financiamento condizentes com as demandas setoriais. Este autor deixa implícito que estas condições devem ser compatíveis com as demandas setoriais e salienta que tais fatores são críticos no sucesso de um estaleiro e das empresas de transporte e serviços, ultrapassando o tradicional trinômio preço-prazo-qualidade exigido nos empreendimentos.

Considerando o volume de recursos absorvido pelo setor, Khalid (2005, p. 1) destaca que "shipping is an extremely capital intensive industry and the question of financing it has been a key issue to shipping companies intending to establish or expand theirs fleet." E, mais adiante afirma que: "It is an undertaking that features capital intensity, conflicting time horizons between short and long term interests and volatile markets, among other challenges" (KHALID, 2005, p. 1). Nesse contexto, “... the provision of various services such as financing and after sales services is another competitive factor in the shipbuilding market. Financing works like a price reduction and is very important especially in the market for the more expensive complex vessels." (IRENE et al, 2001, p. 7).

O financiamento à ICN implica na avaliação de diversas fontes de risco. Seu tratamento constitui aspecto crítico para credores e companhias de transporte que pretendem estabelecer ou expandir sua frota. Os riscos afetam a dinâmica de transferência de ativos financeiros influenciando os demais mercados que conformam o setor de transporte naval, a saber: mercado de compra e venda de embarcações usadas, mercado de demolição e mercado de fretes, além do próprio mercado de construção de novas embarcações.

Como apontado por Cho e Porter (1986), fatores-país e fatores-firma se complementam oferecendo limites e oportunidades ao desenvolvimento e 
competitividade da ICN radicada em determinado país ${ }^{3}$. Por esta razão, Irene et al (2001) argumentam que "previous studies explained that competitiveness in the shipbuilding industry is determined by market and supply forces and by access to various resources needed by the business to operate effectively. These resources include [acesso ao] capital, human resources, energy and raw materials, equipment, parts and components, supplier capability, technology, and infrastructure." (IRENE et al, 2001, p. 15). Ainda segundo Irene et al (2001), "competitiveness can also be determined by external factors such as external relationships, situation factors, and government policies. External relationships refer to the firm's reputation with its suppliers, distributors, customers and government agencies." (IRENE et al, 2001, p. 15). De fato, o acesso ao capital depende da situação financeira e a reputação das empresas, sendo variáveis extremamente relevantes na transferência de ativos. Estes requisitos são apontados na literatura de finanças e corroborados por meio de entrevistas realizadas ao longo deste estudo (capítulo 4). Não obstante, é de extrema importância à disponibilidade de esquemas especiais de financiamento setorial. Este conforma um dos mais importantes elementos que compõem o chamado fator-país.

Como sugerido acima, a dinâmica de desenvolvimento e posicionamento relativo da indústria naval de um país construtor são condicionados pela estrutura de financiamento setorial. De fato, em muitos países (Coréia do Sul, Alemanha, Noruega, Japão, EUA, etc.) o financiamento é fator crítico de sucesso da ICN. Aspecto que também é enfatizado pelos diversos especialistas consultados.

\subsection{Formulação do Problema}

A partir do que foi exposto acima é possível afirmar que as grandes questões relacionadas à economia marítima (entendida como área da ciência econômica que trata do funcionamento dos mercados de frete, mercado de construção, mercado de compra e venda de embarcações usadas e mercado de demolição de embarcações)

\footnotetext{
${ }^{3}$ Os fatores-país podem ser entendidos como o ambiente geral dos negócios que é função do nível de desenvolvimento e dos rumos da política econômica e industrial. Já os fatores-firma compreendem a estratégia de atuação da firma e a disponibilidade e gestão de ativos tangíveis e intangíveis.
} 
e ao financiamento orientado à construção naval dizem respeito a três dimensões inter-relacionadas apresentadas e discutidas no quadro 1.

Conforme o quadro 1 , os aspectos relacionados a estas três dimensões interferem direta e indiretamente na forma de atuação dos armadores, estaleiros, agentes financeiros, seguradoras e governos, com implicações profundas sobre a alocação de capital no setor. De fato, o quadro sistematiza as dimensões apontadas como relevantes na literatura às suas principais implicações financeiras, econômicas e institucionais. Ao abordar os aspectos relacionados ao financiamento setorial, este estudo trata do funcionamento dos mercados e da caracterização econômica do produto. Contudo, quando pertinentes os temas ligados à caracterização tecnológica da produção serão abordados.

Com efeito, as discussões em torno dessas dimensões, remetem ao problema a ser estudado no âmbito desse projeto de pesquisa: dados os microfundamentos que orientam uma operação de financiamento, como o financiamento setorial é estruturado no Brasil, quais as dificuldades que as empresas apresentam em atender seus requisitos e em que condições é mais atrativo quando comparado às condições de financiamento vigentes em outros países?

Esse problema deriva do fato de que a dinâmica do mercado de transporte e apoio marítimo em sua relação com o ciclo de produção da indústria de construção é complexa e sempre mediada por meio de esquemas de financiamento, cuja viabilidade depende das condições que as empresas apresentam para atender aos diversos requisitos cristalizados na correspondente política de financiamento setorial.

Nesse contexto, o estudo procura explorar tais aspectos, sempre tendo como tema central temas ligados aos microfundamentos do financiamento setorial. Isso é feito em termos de sua complexidade, critérios de tratamento de riscos e demais esquemas inerentes à transferência de ativos. A investigação também se apóia nas percepções dos agentes entrevistados ao longo do desenvolvimento deste estudo. 


\begin{tabular}{|c|c|}
\hline FUNCIONAMENTO DO MERCADO & TEMAS RELEVANTES \\
\hline $\begin{array}{l}\text { Setor marcado pela presença de falhas de mercado } \\
\text { traduzidas em economias de escala no transporte marítimo } \\
\text { e na fabricação de embarcações. } \\
\text { - Presença de externalidades na fabricação e na } \\
\text { oferta de serviços (grande interesse público e implicações } \\
\text { macro e microeconômicas). } \\
\text { - Regido no curto prazo pelas condições de demanda } \\
\text { pois, nesse horizonte de tempo, oferta é rígida já que os } \\
\text { navios levam meses para serem construídos. } \\
\text { - Alta correlação com produção industrial dos países } \\
\text { da OCDE, volume e padrão de comércio internacional. } \\
\text { - Regido no longo prazo pelas expectativas formadas } \\
\text { em torno da taxa de frete que sinalizam a viabilidade de } \\
\text { novos investimentos aos armadores mas que se transferem } \\
\text { por meio da majoração no preço das embarcações usadas } \\
\text { para posterior estímulo na indústria de construção. } \\
\text { - Lucratividade depende da conjugação entre } \\
\text { expansão da oferta (ligada às decisões de investimento } \\
\text { setorial) e nível de procura (resultante da interação entre as } \\
\text { condições de oferta e nível de comércio internacional) - que } \\
\text { não apresentam ligação direta uma vez que é marcada por } \\
\text { gaps temporais. } \\
\text { Dificuldades na avaliação de ativos e necessidade } \\
\text { de identificação de riscos (operacional, financeiro, de taxa, } \\
\text { de evento, de mercado, etc.). }\end{array}$ & 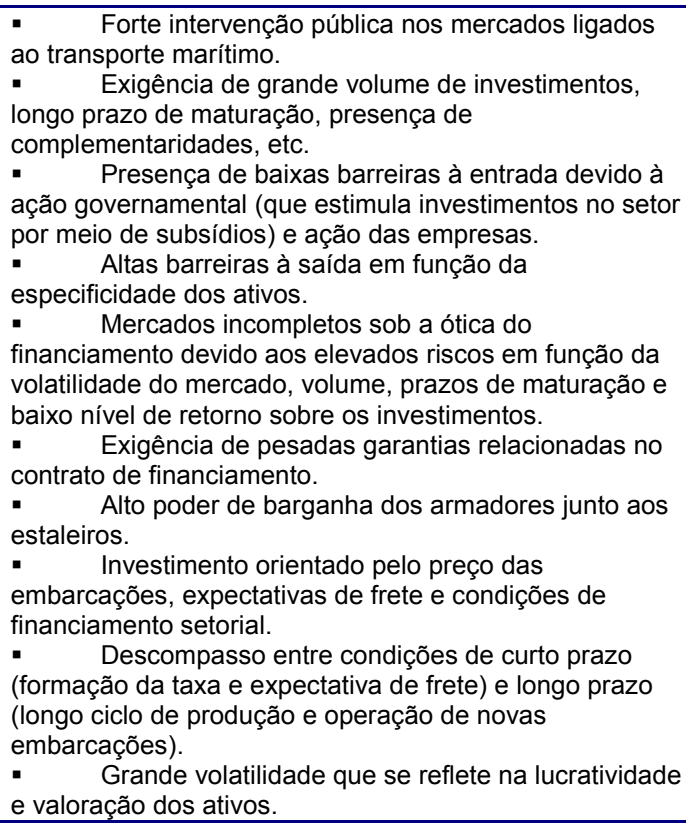 \\
\hline CARACTERIZAÇÃO ECONÔMICA DO PRODUTO & TEMAS RELEVANTES \\
\hline $\begin{array}{l}\text { Bem sob encomenda que apresenta demanda } \\
\text { derivada das expectativas de incremento na demanda de } \\
\text { serviços de transporte. } \\
\text { período de payback. } \\
\text { - Usos especificos quanto ao tipo de embarcação e } \\
\text { rota a ser atendida. } \\
\text { de identificuldação de na avaliação de ativos e necessidade } \\
\text { de evento, de mercado, etc.). }\end{array}$ & 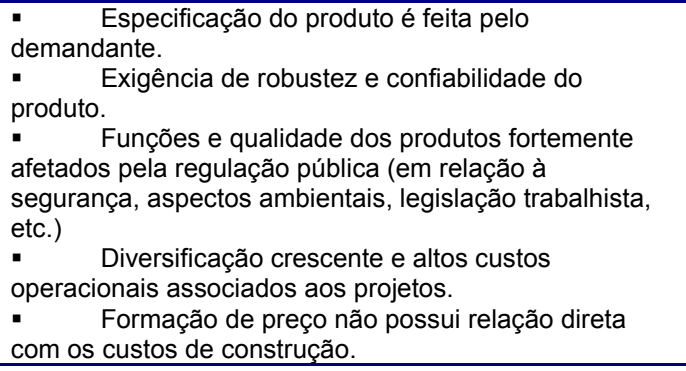 \\
\hline $\begin{array}{c}\text { CARACTERIZAÇÃO DA PRODUÇÃO E } \\
\text { TECNOLOGIA }\end{array}$ & TEMAS RELEVANTES \\
\hline 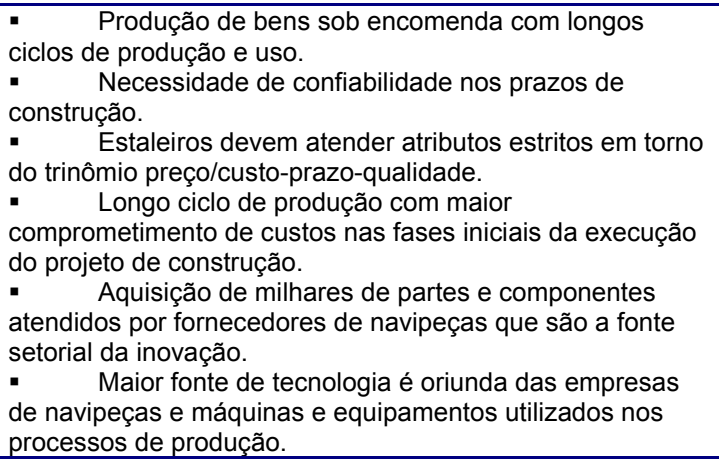 & $\begin{array}{l}\text { Exigência de linhas especiais de financiamento } \\
\text { com vistas a incrementar a capacidade produtiva dos } \\
\text { estaleiros. } \\
\text { devem atender requisitos da programação do projeto em } \\
\text { termos de alocação de recursos ao longo do tempo. } \\
\text { : Capacitação do estaleiro na elaboração do } \\
\text { projeto do navio e na gestão da cadeia de suprimentos é } \\
\text { crítica. } \\
\text { construção e na elaboração do projeto do navio. } \\
\text { : Principal fonte setorial da inovação provém da } \\
\text { indústria de navipeças. } \\
\text { tecnológicas. }\end{array}$ \\
\hline
\end{tabular}

Quadro 1 - Dimensões críticas associadas ao financiamento da construção e transporte naval. Fonte: Elaborado pelo autor. 


\subsection{Justificativa}

Como sugerido acima, dadas às características da construção naval, o financiamento é de estrema relevância. Contudo, embora represente um aspecto dos mais críticos para a dinâmica setorial e seja apontado como o principal fatorpaís, ainda são poucos os estudos tratam de maneira específica questões microeconômicas que afetam a dinâmica da ICN e sua relação com os esquemas de financiamento setorial. De fato, embora alguns autores apontem para a importância do financiamento para o desenvolvimento e posicionamento estratégico da ICN em suas abordagens não são aprofundados os aspectos microeconômicos relacionados à configuração e estruturação das linhas de financiamento. A rigor, poucos estudos focalizam a economia marítima (entendida como área da ciência econômica que trata dos aspectos inerentes aos mercados de frete, mercado de construção, mercado de compra e venda de embarcações usadas e mercado de demolição) e, dentro dela, o shipping finance (entendido como parte da economia marítima que estuda dos esquemas de financiamento setorial).

Os estudos que fazem menção à importância dos esquemas de financiamento setorial abordam com pouca profundidade os microfundamentos do financiamento, apesar de lhes atribuírem um importante papel.

Dadas as características do setor descritas acima, entender esse aspecto é crucial. Sem financiamento adequado que respeite as particularidades setoriais, as empresas que atuam no transporte marítimo não podem expandir o tamanho de sua frota e operações, o que, por sua vez, pode afetar as perspectivas do negócio como um todo interferindo no desempenho e o desenvolvimento da ICN.

Portanto, não é nenhum exagero afirmar que o financiamento é essencial para o sucesso da indústria naval, bem como, para desenvolvimento da indústria e do comércio e, com eles, o crescimento econômico de um país. Em função do exposto, o estudo é pertinente na medida em que propõe uma avaliação crítica acerca da estrutura do shipping finance no Brasil com intuito de explicitar suas características e compará-lo com os esquemas em operação em países que detêm modelos de financiamento orientados ao setor. 


\subsection{Objetivos do Trabalho}

O trabalho procura discutir, a partir da obtenção e análise de indicadores econômico-financeiros e dos parâmetros da estrutura de financiamento de países construtores, as características da atual estrutura de financiamento setorial em vigor no Brasil sob a ótica das empresas de armação. A rigor, o estudo estabelece como objetivo discutir a percepção dos agentes quanto às políticas públicas estabelecidas no exercício da função alocativa orientadas ao setor no que se refere ao financiamento à construção naval e avaliar seu diferencial em relação aos esquemas providos por outros países.

Considerando a questão da pesquisa apresentada na seção 1.2 e o objetivo geral expostos acima, o trabalho tem como objetivos específicos:

- discutir aspectos da estrutura de financiamento adotada no Brasil a fim de avaliar sua adequação no atendimento dos interesses das contrapartes envolvidas na contratação de recursos;

- comparar a estrutura de financiamento à indústria naval brasileira com as práticas adotadas em outros países com intuito de aferir sua atratividade em relação a padrões internacionais.

\subsection{Questões Propostas e Proposições Assumidas}

Feitas considerações acerca do funcionamento do mercado de transporte marítimo, apresentado o problema da pesquisa e os objetivos do trabalho, resta apresentar as duas questões formuladas no estudo.

- questão 1: quais fatores balizam o financiamento orientado à construção naval no Brasil, como esse é atualmente estruturado pelos órgãos governamentais e como é avaliado pelas empresas de transporte e apoio marítimo?

- questão 2: quando avaliado por meio de métodos de simulação, em que medida o modelo de financiamento existente atualmente 
no Brasil é mais atrativo quando comparado a modelos adotados por outros países construtores?

Aderentes aos aspectos associados à dimensão financeira e à caracterização econômica do produto apontadas no quadro 1, a partir da questão 1 foram estabelecidas quatro proposições que se pretende refutar. Relacionados os aspectos econômicos dos empreendimentos ligados ao setor de transporte e apoio marítimo, estas foram agrupadas em torno dos seguintes temas: avaliação econômico-financeira dos empreendimentos e adequação do projeto do produto e do processo, sendo apresentadas a seguir.

- avaliação econômico-financeira dos empreendimentos:

o proposição 1.1: as empresas encontram dificuldades na aprovação do financiamento junto ao Banco Nacional de Desenvolvimento Econômico e Social (BNDES) devido as suas precárias condições econômico-financeiras.

o proposição 1.2: a análise de propostas se baseia em um amplo conhecimento dos agentes quanto aos aspectos do financiamento orientado à construção naval.

o proposição 1.3: as garantias exigidas para obtenção do financiamento representam o principal entrave para a aprovação de propostas junto ao BNDES.

- adequação do projeto do produto e do processo:

o proposição 1.4: os estaleiros nacionais atendem satisfatoriamente ao escopo do produto; contudo, ainda precisam aprimorar os processos planejamento e controle da produção para evitar desvios que comprometam orçamento e prazo de entrega.

A partir da questão 2 foi estabelecida a seguinte proposição:

- proposição 2.1: as condições de financiamento brasileiras são, sob certos limites, competitivas em termos dos parâmetros financeiros 
adotados (taxas praticadas, período de carência, prazos de amortização, etc.), seguindo padrões internacionalmente aceitos.

\subsection{Metodologia Empregada na Pesquisa}

Ao abordar os procedimentos para a elaboração de um projeto de pesquisa, Yin (2005, p. 25), o define como sendo "a seqüência lógica que conecta os dados empíricos às questões iniciais de estudo da pesquisa e, por fim, às suas conclusões". Isso significa que, a elaboração do projeto de pesquisa tem uma influência direta sobre os resultados e validade das conclusões extraídas em um trabalho. O projeto deve servir de guia à investigação e validação de seus resultados. Deve também endereçar a quatro elementos: que questões devem ser estudadas; que dados são relevantes; que dados devem ser coletados; como se devem analisar os resultados (YIN, 2005). A rigor, a formatação do presente projeto do qual deriva este estudo, seguiu estes passos no intuito de atingir os objetivos da pesquisa e garantir a qualidade dos resultados apresentados.

Dada a escassez de estudos e sistematização de informações estatísticas relacionadas ao tema tratado neste estudo, o tratamento das questões envolveu ao levantamento de informações junto a informantes-chaves, realização de entrevistas com atores envolvidos na elaboração do financiamento setorial (armador, estaleiros, órgãos governamentais, etc.) e construção de banco de dados com informações financeiras das empresas de transporte marítimo, as quais normalmente contratam o financiamento para viabilizar a construção de novas embarcações.

Um dos pontos centrais na elaboração de um projeto de pesquisa constitui a definição da estratégia da pesquisa. Segundo Yin (2005) e como indicado no quadro 2, esta atividade depende de três elementos: tipo de questão da pesquisa, controle do pesquisador sobre ventos e foco temporal da investigação.

Ao comparar o método do estudo de caso com outros métodos, Yin (2005), afirma que para se definir o método a ser aplicado é preciso analisar o tipo de questões que são colocadas pela investigação. Yin (2005) também afirma que "o estudo de caso é uma inquirição empírica que investiga um fenômeno contemporâneo dentro de um contexto da vida real, quando a fronteira entre o 
fenômeno e o contexto não é claramente evidente e onde múltiplas fontes de evidência são utilizadas" (YIN, 2005, p. 25). Consoante com o problema da pesquisa, as questões e proposições assumidas no presente estudo, esta abordagem metodológica constitui a estratégia de pesquisa aqui proposta.

\begin{tabular}{|c|c|c|c|}
\hline ESTRATÉGIA & FORMA DA QUESTÃo & CONTROLE EVENTOS & $\begin{array}{c}\text { FOCO EM EVENTOS } \\
\text { CONTEMPORÂNEOS }\end{array}$ \\
\hline Experimento & Como, por que. & Sim & Sim \\
\hline Levantamento & Quem, o quê, onde, quando. & Não & Sim / Não \\
\hline Análise de Arquivo & $\begin{array}{c}\text { Quem, o quê, onde e } \\
\text { quando. }\end{array}$ & Não & Não \\
\hline História & Como, por que. & Não & Sim \\
\hline Estudo de Caso & Como, por que. & Não & \\
\hline
\end{tabular}

Quadro 2 - Estratégias de pesquisa e sua relação com o tipo de questão, controle e foco de eventos

Fonte: Yin (2005, p. 24)

Ao serem empregadas em estratégias de pesquisa que remetem a questões do tipo como e por que, a metodologia de estudo de caso possui características distintas de outras estratégias de pesquisa em termos da definição do problema, delineamento da pesquisa, coleta de dados, análise de dados, composição e apresentação final de resultados (YIN, 2005). A metodologia de estudo de caso corresponde ainda a uma estratégia de pesquisa destinada à investigação de inferências válidas que se encontram fora dos limites do laboratório (YIN, 2005). Esta é recomendada quando o contexto é relevante na obtenção de conhecimentos, em situações em que o pesquisador não tem controle sobre os eventos e onde o número de variáveis sob investigação é maior que o número de pontos de dados em contraste com o método experimental (YIN, 2005). Tal é o caso do problema formulado nesta pesquisa no tratamento das questões propostas e proposições assumidas uma vez que as informações relacionadas aos contratos são protegidas por sigilo legal.

O método de estudo de caso é tido como mais adequado para pesquisas descritivas, exploratórias e explanatórias (YIN, 2005). Este último converge com os 
objetivos do estudo, uma vez que não há muitos dados disponíveis para a avaliação dos microfundamentos do financiamento à construção naval no Brasil, mas há conceitos e modelos presentes na moderna teoria financeira e na literatura que trata de temas ligados ao setor naval. Estes podem ser empregados como ponto de partida no desenvolvimento da modelagem.

Como assevera Yin (2005), estas abordagens igualmente se aplicam ao método histórico e ao método experimental que também objetivam responder a questões desse tipo. Contudo, segundo Yin (2005), o caso do método histórico será recomendado na ciência social quando não houver acesso ou controle do investigador sobre eventos comportamentais. Neste caso, o pesquisador deve lidar com um passado "morto", sem se valer, por exemplo, do relato de pessoas que atuaram ou atuam com aspectos relacionados ao fenômeno estudado. Já na aplicação do método de estudo de casos o pesquisador pode se valer de relatos de acontecimentos e percepções dos agentes envolvidos podendo ainda recorrer a documentos e a artefatos culturais ou físicos como fontes de evidências (YIN, 2005). Como é o caso do escopo da presente pesquisa. A rigor, a preferência pelo uso do método do estudo de caso deve ser dada quando a pesquisa remete ao exame de eventos contemporâneos, em situações onde os comportamentos relevantes não podem ser manipulados, mas em que é possível fazer observações diretas e ou entrevistas sistemáticas acerca de determinado fenômeno (YIN, 2005). Apesar de ter pontos em comum com o método histórico, o estudo de caso se caracteriza pela capacidade de lidar com uma ampla variedade de evidências (documentos, artefatos, entrevistas e observações) que, em conjunto, permitem testar proposições e ou fazer inferências válidas sob determinado fenômeno. Esse método (associado ao emprego de outros métodos qualitativos) é muito útil, no entender de Bonoma (1985), quando um fenômeno é amplo e complexo, onde o corpo de conhecimentos existente não se encontra sistematizado ou não é insuficiente para permitir claramente o teste de proposição sobre questões causais.

Como afirma Bressan (2000), os objetivos do método de estudo de caso são capturar o esquema de referência e a definição da situação junto a indivíduos envolvidos no problema. Essa ação possibilita um exame detalhado do processo sob investigação e contribui para desvendar relações de causalidade.

O método de estudo de caso deve ser empregado quando o propósito é construir uma teoria no sentido de identificar e descrever variáveis-chaves, identificar 
elos entre estas e inferir como estas se relacionam (VOSS; TSIKRITSIS e FROHLICH, 2002). Ante a escassez de estudos orientados ao assunto discutido nesse trabalho o método é tido como adequado.

Ao tratar dos objetivos da coleta de dados, Bonoma (1985) coloca como finalidades do método do estudo de caso não a quantificação ou a enumeração, mas a descrição, classificação (ou desenvolvimento de tipologia), desenvolvimento ou o teste limitado de teoria. Em suma, o objetivo é a compreensão. Novamente, em meio à escassez de estudos acerca dos microfundamentos do financiamento orientado à construção, a abordagem de estudo de caso se justifica. Nesta mesma linha de raciocínio, Yin (2005) apresenta quatro aplicações para o método do estudo de caso: explicar ligações causais nas intervenções na vida real que são muito complexas para serem abordadas por "surveys" ou por estratégias experimentais; descrever o contexto da vida real no qual a intervenção ocorreu; fazer uma avaliação, ainda que de forma descritiva, da intervenção realizada; explorar aquelas situações onde as intervenções avaliadas não possuam resultados claros e específicos. Parte dessas aplicações são adequadas aos objetivos desta pesquisa.

Yin (2005) afirma que método de estudo de caso é aplicado a pesquisas descritivas; contudo, também serve para processar uma análise comparativa; isto é, considerando as especificidades dos respectivos contextos econômico, geográfico, social, político, etc., busca compreender os fatores que afetam o fenômeno a ser estudado e pontos convergentes e divergentes entre casos semelhantes. Assim, o método comparativo consiste em investigar e fazer comparações identificando semelhanças e diferenças. A grande vantagem do estudo de caso é permitir ao pesquisador concentrar-se em um aspecto ou situação específicos e identificar, ou tentar identificar, os diversos processos que interagem no contexto estudado. Esse método é caracterizado por um estudo intensivo que pode avançar na identificação de relações funcionais que de outra forma não seriam descobertas. Novamente há convergência com os objetivos da presente pesquisa ${ }^{4}$.

Em suma, o método de estudo de caso é empregado como instrumento de pesquisa empírica quando deliberadamente se quer lidar com condições contextuais ou quando estas são pertinentes. Tal é o caso da análise do financiamento à construção naval, da forma como abordada no presente estudo.

\footnotetext{
${ }^{4}$ Contudo, como será indicado a seguir, as comparações entre a estrutura de financiamento local e dos países selecionados serão baseadas na formulação de modelo quantitativo.
} 
A aplicação do método de estudo de caso envolve cinco componentes os quais são especialmente importantes e devem ser elaborados com cuidado e rigor: questões de estudo; proposições do estudo; unidade de análise; ligação dos dados à proposição; critérios para a interpretação dos dados (YIN, 2005). Estes elementos, cujos dois primeiros já foram definidos na subseção 1.5 , darão sustentação ao processo de pesquisa e guiarão o investigador em seu trabalho, ajudando-o a se manter no rumo decidido. Consoante com o problema, questões e proposições assumidas, o estudo aqui proposto estabelece como unidade de análise a estrutura de financiamento nacional tal como consubstanciada nos critérios de avaliação de propostas e contratação dos recursos do FMM seguidos pelo Departamento de Marinha Mercante (DMM) e BNDES.

Em seu dimensionamento o método de estudo de caso pode incorporar instrumentos qualitativos e quantitativos, a depender do desenho da pesquisa. Nesse contexto, os métodos quantitativos baseados em experimentos procuram deliberadamente separar um fenômeno de seu contexto para dedicar a atenção apenas a uma ou mais variáveis de interesse. Este enfoque metodológico é empregado quando as respostas às questões são obtidas em situações onde o investigador pode manipular o comportamento das variáveis de forma direta, precisa e sistemática, sendo-lhe possível isolar variáveis (como no caso de experimentos realizados em laboratório). Ao fazer isso, propositalmente se afasta o fenômeno a ser estudado de seu contexto (YIN, 2005).

Com efeito, complementar ao estudo de caso, esse procedimento pode ser empregado nesta pesquisa para efeito de comparação. Assim, ao longo do desenvolvimento da pesquisa, foi obtida uma massa de informações quantitativas (demonstrativos contábeis de empresas nacionais e estrangeiras, dados de cotação de ações de empresas do setor e parâmetros quantitativos das linhas de financiamento nacional e os aplicados em outros países). Essas informações são utilizadas no presente estudo por meio do emprego de ferramentas de cálculo financeiro. A partir desses foi desenvolvido e aplicado um modelo destinado à comparação do financiamento local com práticas internacionais. Este foi aplicado no sentido de contribuir para o teste da proposição associadas às questões formuladas. Em suma, o teste das proposições assumidas nesta pesquisa, notadamente as relacionadas à questão 2, será feito por meio de instrumentos quantitativos. 
Quanto à questão 1, em um primeiro momento as proposições formuladas serão testadas por meio do tratamento de dados financeiros para em seguida serem confrontadas com o conteúdo de entrevistas. Estas se basearam na aplicação de questionários estruturados os quais foram aplicados a diretores financeiros de empresas de transporte e de apoio marítimo. Parte dessas empresas cedeu dados de seus Demonstrativos Contábeis. Esses são utilizados no capítulo $4 .^{5}$

As informações quantitativas foram capturadas a partir de dados da New York Stock Exchange (NYSE). Trata-se de dados de demonstrativos contábeis de 4 empresas que operam no Brasil e de 44 empresas estrangeiras que atuam nos setores de transporte marítimo e apoio marítimo ${ }^{6}$. Essas prestam serviços em diversos países, movimentando ativos da ordem de US\$ 48 bilhões. Também foram obtidas séries históricas da cotação e volume transacionado de ações de 45 dessas empresas. $^{7}$

No tratamento das questões formuladas, estes dados foram utilizados conforme exposto a seguir.

Para dar conta da questão 1 e proposições correspondentes foram adotados os seguintes procedimentos:

- revisão da literatura relacionada aos princípios que regem os microfundamentos das operações de financiamento e de análise de crédito;

- estabelecimento da relação de princípios com as características do financiamento à construção naval e seu desenho no Brasil;

- obtenção, análise e comparação de indicadores econômico-financeiros (IEF) de empresas ligadas ao setor de transporte e apóio marítimo nacionais e estrangeiras;

- apresentação e análise de conteúdo de entrevistas estruturadas feitas com agentes envolvidos nas operações de financiamento (armadores,

\footnotetext{
${ }^{5}$ Os Anexos 3 e 4 apresentam, respectivamente o protocolo da pesquisa e informações sobre as empresas contatadas durante a pesquisa de campo.

${ }^{6}$ Trata-se de amostras não intencionais. Embora centrado em pequena amostra de empresas nacionais foram adotados procedimentos estatísticos amplamente aceitos a fim de gerar estimadores não viesados para os indicadores econômico-financeiros. Os procedimentos são detalhados no capítulo 4.

${ }^{7}$ As informações sumárias sobre as empresas e um detalhamento do banco de dados utilizado na pesquisa encontram-se descritas nos Anexos 4 e 5 . Estes apresentam informações relacionadas as empresas nacionais e internacionais, respectivamente.
} 
estaleiros, órgão governamentais, etc.) com 0 intuito de testar analiticamente as proposições 1.1, 1.2, 1.3 e 1.4;

- confronto de conteúdo das entrevistas com os resultados dos testes feitos a partir de IEF como meio de testar parte das proposições assumidas

Um maior detalhamento de todos os procedimentos metodológicos adotados e avaliação de resultados relacionados à questão 1 são apresentados no capítulo 4 desse trabalho.

Já a questão 2 remete a uma estratégia baseada na elaboração de um modelo de simulação. Segundo Evans e Olson (1998), esta estratégia pode ser definida como o processo de construir um modelo matemático ou lógico de um sistema ou um problema de decisão para, em seguida, experimentá-lo (normalmente tendo o auxílio de um computador) a fim de obter indícios acerca do comportamento do sistema ou problema sob investigação.

De acordo com Evans e Olson (1998, p. 12-13), ao discutir a natureza e os métodos relacionados aos processos de simulação, o procedimento adotado para a realização de uma simulação de Monte Carlo, deve seguir cinco etapas lógicas:

- desenvolvimento de um modelo conceitual do problema sob investigação: esta etapa consiste em entender e definir o problema sob investigação, identificar os objetivos da modelagem, determinar as variáveis de entrada e definir o formato das variáveis de saída;

- construir o modelo de simulação: desenvolver fórmulas ou equações apropriadas, coletar os dados necessários, determinar a distribuição de probabilidades que captam a "incerteza" das variáveis e construir uma forma de obter os resultados da aplicação do modelo;

- verificar e validar o modelo: a verificação consiste em tornar o modelo livre de erros lógicos, certificando-se de que ele seja adequado para a resolução do problema sob investigação; a validação visa garantir que este consista uma representação razoável do problema;

- desenhar experimentos utilizando o modelo: determinar os valores das variáveis sob controle e verificar as questões que podem ser respondidas por meio da aplicação do modelo; 
- executar experimentos e analisar resultados: executar um número razoável de vezes a simulação, obter e analisar os resultados obtidos.

A rigor, o modelo proposto deve ser aderente ao método de estudo de caso, uma vez que se vale do conjunto de informações obtidas no tratamento dado à questão 1 , na revisão da literatura acerca do funcionamento da ICN, emprego de teoria financeira e técnicas econométricas das quais deriva o modelo proposto.

Feitas estas conceituações, o teste de atratividade (relacionado ao tratamento da questão 2 e da proposição correspondente) elaborado no âmbito desta pesquisa se baseia na aplicação de um modelo baseado na moderna teoria financeira e é alimentado a partir do banco de dados obtido ao longo da pesquisa e demais informações obtidas no tratamento da questão 1 e de suas proposições.

A rigor, as comparações entre as condições de financiamento local e estrangeira são feitas com base na estimativa da taxa mínima de atratividade do segmento de transporte e apoio marítimo e sua aplicação sobre o financiamento de uma embarcação. Também leva em consideração fatores como: determinação do valor dos juros e amortização de uma operação de financiamento a partir de parâmetros das linhas de financiamento (taxas de juros, período de carência, prazo de amortização, etc.), spread de juros, grau de alavancagem financeira, técnicas de equalização de prazos das operações, peso da carga tributária, etc., e modelagem de riscos. Em suma, no âmbito do estudo de caso proposto e para dar conta da questão 2, são empregados métodos quantitativos baseados em simulação de Monte Carlo. A construção do modelo proposto será feita por meio dos seguintes procedimentos.

- revisão da literatura sobre técnicas de avaliação de projetos de investimento;

- formulação de modelo matemático baseado na teoria financeira e realização de simulação de operação de financiamento baseada na determinação de indicadores de atratividade;

- cálculo da taxa mínima de atratividade setorial, obtida por meio de técnicas financeiras baseadas na aplicação de modelo de precificação de ativos de capital o que será realizado a partir de informações 
contidas no banco de dados de empresas do setor de transporte marítimo e de apóio marítimo;

- análise de sensibilidade em termos do peso dos componentes do modelo adotado (valor financiado, taxas de juros, período de carência e prazo de amortização, uso de beta desalavancado e aplicação de procedimentos de equalização de prazos das operações, etc.).

- emprego de simulação de Monte Carlo para efeito de análise probabilística dos indicadores de atratividade e comparação da estrutura de financiamento local em relação ao outros países construtores - em conformidade com as etapas sugeridas por Evans e Olson (1998).

O detalhamento de todos os procedimentos empregados na elaboração do modelo de simulação, sua aplicação e a discussão de seus resultados são apresentados no capítulo 5 .

\subsection{Organização da Dissertação}

A presente dissertação se encontra dividida em 5 capítulos, além dessa introdução. O capítulo 2 procura, a partir de uma revisão da literatura, caracterizar o funcionamento da ICN, destacando a importância do financiamento. Esta tarefa abrange a discussão de vários temas o que inclui: caracterizar a estrutura de funcionamento do mercado de transporte marítimo e de seus mercados constituintes (mercado de fretes, mercado de compra e venda de embarcações usadas, mercado de construção de novas embarcações e mercado de demolição de embarcações) (seção 2.1), entendimento do funcionamento do mercado de fretes no curto e longo prazo (seção 2.2), discutir como atuam e se estruturam as forças competitivas que interferem no funcionamento da ICN (seção 2.3) e descrever de maneira sumária os aspectos das estruturas de financiamento setorial providas em alguns países construtores (Japão, Coréia do Sul, China, Alemanha, Noruega, EUA e Brasil) (seções 2.4 e 2.5). O capítulo termina estabelecendo uma síntese quanto aos fundamentos microeconômicos do funcionamento do mercado de construção naval, 
sua relação com os demais mercados do setor naval, enfatizando a importância do financiamento e sua relação com a dinâmica do mercado de construção de embarcações (seção 2.6).

O capítulo 3 procura abordar o problema do financiamento sob diferentes óticas: armador, estaleiro, agente financeiro, seguradoras e governo. Isso será feito sob duas perspectivas intrinsecamente relacionadas: (i) aspectos operacionais do negócio em seu respectivo mercado e (ii) seu rebatimento sobre o caráter financeiro das operações. Esse procedimento é metodologicamente consistente, pois as atividades e inter-relações entre cada um desses mercados possuem um aspecto real e financeiro. O procedimento permite sistematizar as grandes questões operacionais e econômicas associadas ao financiamento.

O capítulo 4 discute alguns dos microfundamentos de operações de financiamento e seu reflexo sobre a ICN. Inicialmente, é definido o conceito de financiamento e os princípios que regem uma análise de crédito (seção 4.1). Em seguida, são discutidos os diversos tipos de risco associados a operações de financiamento (seção 4.2). Nesse contexto, se procura associar tais fatores às especificidades setoriais (seção 4.3). A seção 4.4 estabelece o detalhamento dos procedimentos estatísticos orientados para testar se há diferenças na estrutura de solvência, alavancagem, atividade e rentabilidade das empresas de transporte e apoio marítimo nacionais e estrangeiras. Os resultados dos testes são apresentados e discutidos na seção 4.5. Na seção 4.6, são apresentados os resultados de entrevistas estruturadas, feitas junto a diretores financeiros de empresas de armação e membros de entidades classistas. Os testes das proposições relacionadas à questão 1 são feitos por meio do confronto das opiniões expressadas e resultados dos testes estatísticos. Esses são apresentados nas conclusões do capítulo.

O capítulo 5 descreve os procedimentos adotados na formulação do modelo de atratividade, apresenta e discute os resultados obtidos por meio de sua aplicação. Sua construção tem como ponto de partida a definição de conceitos e apresentação de técnicas de avaliação de fluxo de caixa (seção 5.1), com destaque à determinação do valor presente líquido de custos - calculado a partir de técnicas derivadas de sistemas de amortização (seção 5.2) e da apuração de taxas a serem empregadas em tais operações. A rigor, com base nos conceitos apresentados, o foco da modelagem se orienta à determinação dos métodos de cálculo da taxa de desconto setorial (seção 5.3). Em seguida são apresentados o modelo matemático 
(seção 5.4) e o seu emprego por meio de modelo de simulação (seção 5.5) ambos destinados à avaliação da atratividade da linha de financiamento brasileira em relação a outros países construtores. A aplicação do modelo exigiu o cálculo de diversas taxas e de hipóteses assumidas em torno da introdução dos parâmetros de cada estrutura de financiamento na simulação (seção 5.6). Uma vez definida a forma de entrada das variáveis o modelo foi aplicado. Sua execução se baseou na construção de 6 tabelas que permitiram a aplicação de simulações de Monte Carlo de operações de financiamento a partir de informações empíricas obtidas junto a diversas bases de dados $^{8}$. Os resultados são apresentados a seguir (seção 5.7). O capítulo termina apresentando considerações acerca dos resultados obtidos nas simulações (seção 5.8).

O capítulo 6 apresenta as considerações finais do trabalho, onde se traça uma síntese acerca da importância das linhas de financiamento (considerado fator crítico para o posicionamento e competitividade da indústria naval em cada país) e retoma os principais resultados do estudo de caso em termos qualitativos e quantitativos - tais como abordados nos capítulos 3,4 e 5 .

\footnotetext{
${ }^{8}$ Todos os arquivos que geraram as simulações por meio de planilhas em Excel podem ser obtidas em CD ROM junto a Biblioteca do Departamento de Engenharia Naval da Escola Politécnica (POLI/USP).
} 


\section{REVISÃO BIBLIOGRÁFICA}

O mercado de transporte naval é de grande relevância social e econômica. Estima-se que mais de $90 \%$ da carga transportada mundialmente seja distribuída por meio marítimo, gerando cerca de US\$ 7 bilhões em pagamentos de serviços de frete ao ano (KENDALL; BUCKLEY, 2005; UNITED NATIONS CONFERENCE ON TRADE AND DEVELOPMENT, 2006). Desta maneira, o setor naval é de grande importância quando se avalia o crescente volume de carga transportada, valor dos fretes pagos e volume de ativos alocados no setor.

Segundo Serra (2002), o crescimento do comercio internacional vem superando o crescimento da economia mundial desde os anos 1980 . Estimativas recentes apontam que a taxa de crescimento do comércio é o dobro da taxa de crescimento do produto mundial. Tanto no Brasil como no mundo, a movimentação das mercadorias transacionadas é efetuada de maneira quase absoluta pelo mar, levando em consideração a tonelagem transportada. Os gastos com serviços de frete marítimo representam grande peso no saldo da balança comercial de países como Brasil, ultrapassando a cifra de US\$ 2 bilhões (cerca de $4 \%$ do total do saldo). Esse valor tem crescido com o incremento do volume transportado após a passagem para o regime de câmbio flutuante em janeiro de 1999.

O gráfico 1 permite verificar o expressivo crescimento no volume de carga transportada por meio marítimo. Este só foi interrompido de maneira mais severa durante os dois choques do petróleo (1973 e 1979) e pela recessão mundial verificada no início anos 1980. Este ritmo foi acompanhado por ciclos de crescimento na capacidade de carga da frota mercante mundial. 


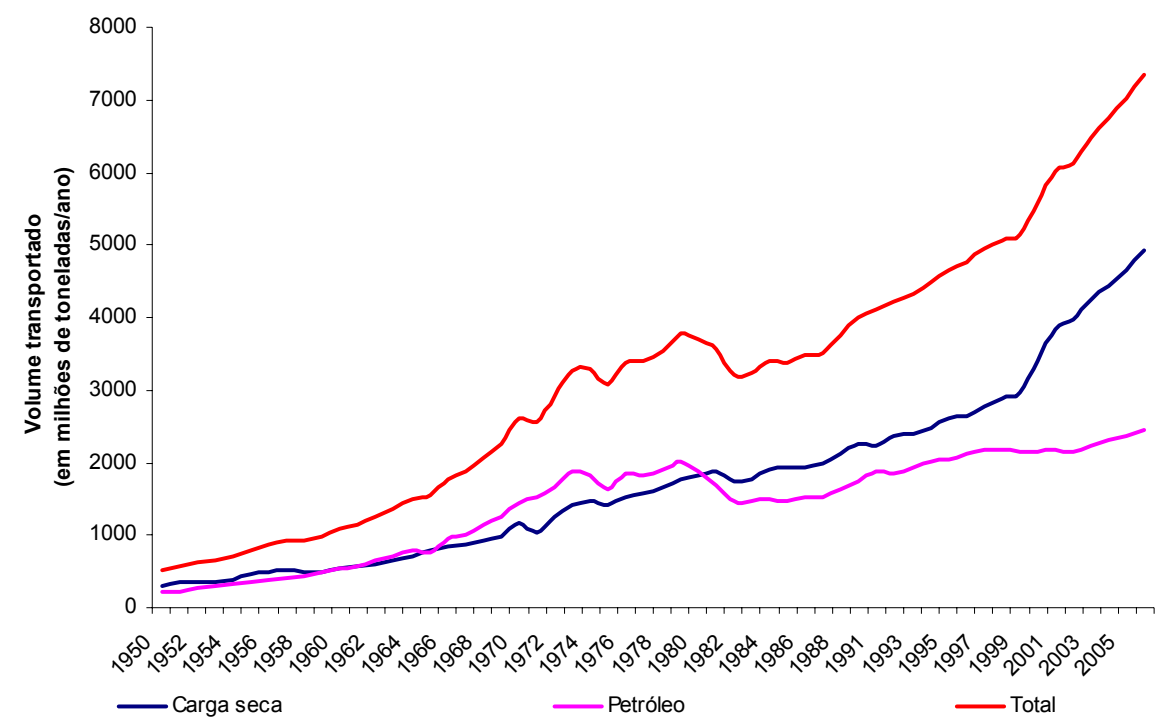

$\left(^{*}\right)$ Nota: Entre 1950 a 1969 OCDE e entre 1970 a 2004 UNCTAD. Valores estimados para os anos de 2005 e 2006.

Gráfico 1 - Volume de transporte marítimo mundial (1950/2006).

Fonte: Elaborado pelo autor

Ao tratar do assunto, Alex (2004) aponta a presença 5 grandes ciclos associados à evolução do comércio, volume de carga e rentabilidade das operações de transporte marítimo: crescimento incremental ao longo da década de 1950; aceleração e euforia com surgimento de "bolha" ao longo dos anos de 1960 e início dos anos 1970; reversão em meio aos impactos das crises do petróleo nos anos 1970; grande recessão verificada nos mercados nos anos de 1980; restabelecimento parcial do equilíbrio nos mercados de construção e frete ao longo dos anos 1990. Os dados apresentados por Alex (2004) permitem constatar a presença de discrepâncias entre a oferta e a demanda por serviços de transporte marítimo em meio ao processo de ajustamento da capacidade de carga e a evolução no volume de comércio. Esse fato corrobora o modelo proposto por El Ciclo... (2005).

Os gráficos 2 e 3 fornecem indícios da elevação da produção mundial de embarcações, respectivamente, em termos globais e por região. De acordo com os dados apresentados, em meados dos anos 1970 se verificou um grande pico na produção mundial de navios cuja tendência foi dominada pela produção do Japão, Europa Ocidental e por novos entrantes no mercado. Entre esses figurou a Coréia do Sul e o Brasil, que chegou a ser um grande construtor mundial de embarcações em meio à implantação de grandes planos de construção capitaneados pelo Estado. 
Chama a atenção o vigor das taxas de crescimento da produção coreana. Sua entrada no mercado ocorreu em meio à crise verificada no setor na década de 1970 . O que explica este fato foi a agressiva estratégia do país baseada em forte intervenção estatal. Já no final do século passado a Coréia ultrapassou o Japão na produção medida em capacidade de carga. Por fim a China vem ganhando destaque na produção mundial desde o final dos anos 1980 e hoje figura entre os maiores produtores mundiais de navios.

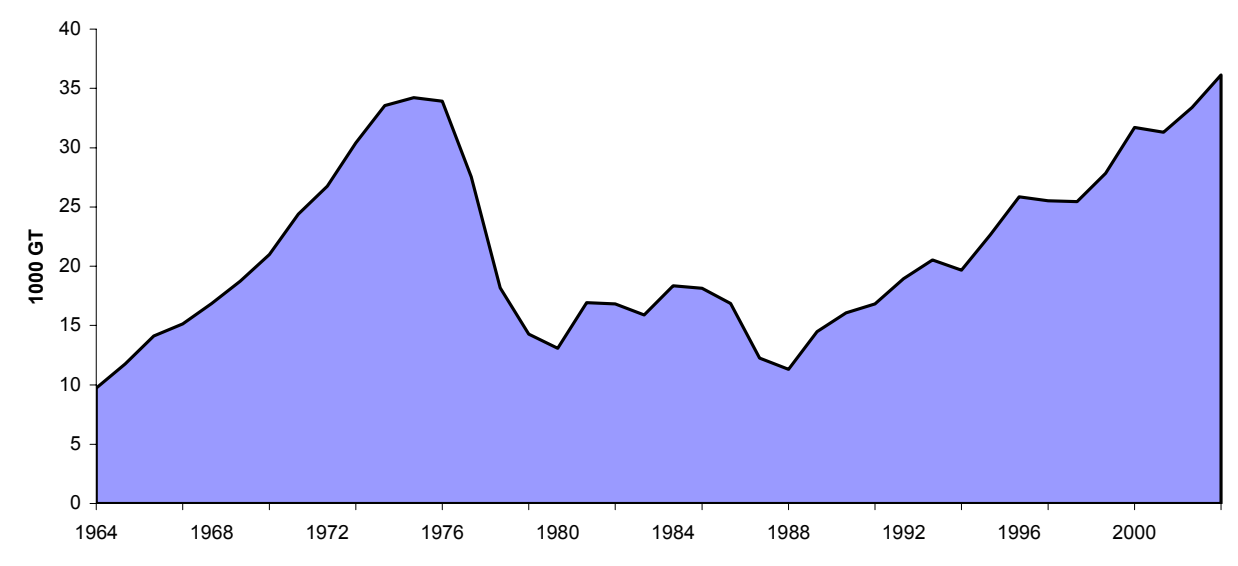

Gráfico 2 - Total da produção mundial de navios (1964-2003) Fonte: Elaborado pelo autor.

Em linhas gerais, a dimensão econômica do transporte naval também se deve ao caráter internacional das atividades a ele ligadas, a tradição histórica desse negócio, às formas de intervenção pública adotadas pelas grandes nações e ao volume de investimentos setoriais (WEISS, 1990). 


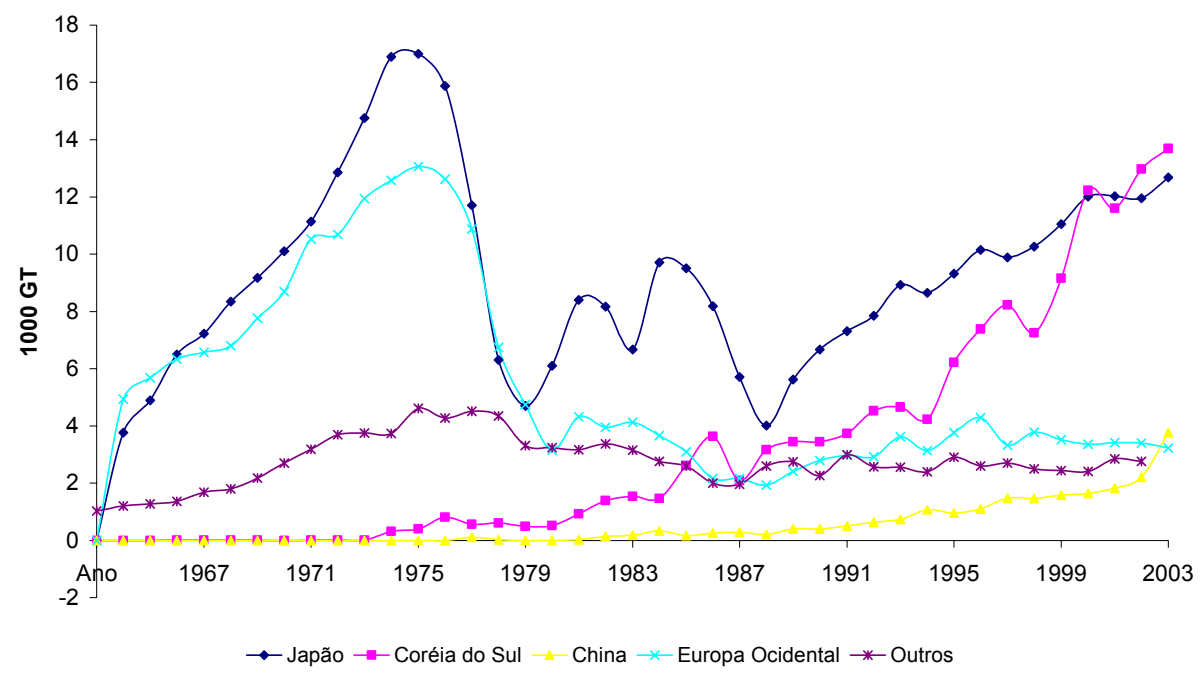

Gráfico 3 - Produção mundial de navios por região de origem (1964-2003) Fonte: Elaborado pelo autor.

Em função da importância do assunto, diversos estudos referenciam o funcionamento do negócio de transporte marítimo. Contudo, como será atestado, grande parte desses estudos analisa, sob diferentes enfoques, aspectos específicos tratando de temas como seu impacto sobre o fluxo de comércio e desenvolvimento econômico, análise do antigo sistema de conferenciais de frete, análise de políticas setoriais, estudos comparados em termos do desenvolvimento da ICN entre os países, estudos de mercados específicos ligados ao transporte marítimo (liner, tramp, etc.), entre outros ${ }^{9}$. Poucos dão conta da questão do financiamento setorial.

Adland, Jia e Strandenes (2006), por exemplo, fazem uma análise do mercado de transporte de cargas secas (dry bulk) a partir do estudo do ciclo de preços de embarcações de segunda mão. King (1999), ao constatar a persistência de manutenção de excesso de capacidade produtiva na ICN mundial no período pós-guerra, discute as práticas e diretrizes das políticas orientadas ao setor. A fazer

\footnotetext{
${ }^{9}$ Para a oferta de transporte oceânico utiliza-se dois tipos básicos de contratos: liner (que atende a serviços regulares) e tramp (feitas por meio de contratos sob medida). A rigor, em um contrato liner a rota, porto de escala e as datas de estadia são fixadas previamente, independente da existência de carga a ser transportada. Este tipo de arranjo é mais adequado para o transporte de carga geral. Já em um contrato tramp a rota e escala são definidas pelo cliente em função de necessidades específicas e o navio fica a disposição das ordens de serviço do contratante - em geral associado ao comércio de commodities.
} 
isso salienta que as políticas de subsídio praticadas pelos países da OCDE, embora importantes para manter o nível de atividade da indústria de construção, geram uma série de distorções como baixa produtividade dos estaleiros em razão das altas barreiras à entrada suportadas pela ação governamental. Tsolakis (2005), por sua vez, aplica métodos econométricos a fim de estudar o mercado de carga seca e suas implicações sobre o investimento setorial. Mayr e McGrath (1997) analisam o papel da tributação na alocação de ativos no mercado tramp. Os trabalhos de Farthing (1993) e Gwilliam (1993) discutem o papel das políticas públicas e outras questões relacionadas à economia marítima.

Também a nível local há uma série de estudos tratando dos mais variados temas. Jason (1988) estuda a participação do Brasil no mercado de fretes marítimos no período de 1969 a 1981. Nesse estudo, descreve a política governamental orientada ao setor no período da análise. Weiss (1990) procura estabelecer uma relação entre os desequilíbrios da ICN brasileira e as políticas econômicas adotadas pelo governo brasileiro nos anos 1980. Este autor constata que havia uma contradição entre a política adotada para o desenvolvimento do setor e o caráter das políticas econômicas aplicadas pelo governo. Assis (1991) traça uma análise acerca do sistema brasileiro de conferências de frete. Já Botelho (1998), tece considerações sobre a ICN considerando variáveis como projeto, localização e mercado. Ao fazer isso, procurou apontar alternativas tecnicamente consistentes para o desenvolvimento do setor no Brasil. Serra (2002) tece um profundo estudo onde procura discutir o desenvolvimento das indústrias de construção naval do Brasil e da Coréia do Sul. Oliva (2004) discute, a partir de um exaustivo inventário, os objetivos das políticas de transporte marítimo e de construção naval no Brasil. Já Pires Junior, Assis e Souza (2005), desenvolvem e aplicam um modelo cuja finalidade é estudar o impacto da estrutura de financiamento setorial brasileira sobre o nível de comércio local.

Estudos recentes abordam temas igualmente críticos. Pires Junior, Assis e Cipriano (2006) analisam, por meio de uma modelagem econométrica, a influência do país de construção no preço dos navios de segunda mão. O estudo demonstra que os preços dos navios usados de origem japonesa são mais elevados. Ao fazer isso procuram demonstrar que esse diferencial reflete um "prêmio de qualidade". Pires Junior e Rezende (2006) propõem e aplicam um modelo que permite obter a distribuição de indicadores de viabilidade de projetos possibilitando avaliar o 
comportamento esperado da rentabilidade de projetos. A fazer isso, não aplicam instrumentos destinados a determinação da taxa de desconto. $\mathrm{Na}$ modelagem assumem que esta é de $7 \%$ a.a.. Weiss (2006) analisa o papel da gestão de suprimentos na indústria de construção naval, procurando apontar os fatores responsáveis pela modernização e reestruturação competitiva da indústria de construção naval no mundo. Cunha e Andrade (2006) discutem o papel do ambiente com a finalidade de propor ações estratégias que capacitem a ICN a competir em uma economia aberta.

Um outro bloco de estudos trata de temas ligados ao "padrão de desenvolvimento" da ICN, entre eles os elaborados por Barboza (2004), Cho e Porter (1986), Fadda (2006), Kendall e Buckley (2005) e Weiss (1990). Tais autores, embora não fixem suas análises na discussão sobre a modelagem do financiamento setorial, denominada shipping finance, destacam sua criticidade quanto ao posicionamento e desenvolvimento da indústria de construção e de transporte naval.

A rigor, a literatura que trata especificamente do tema shipping finance é escassa. Os trabalhos recentes que se dedicam ao assunto foram elaborados por Alex (2004) e Khalid (2005). Alex (2004) aborda a questão sob a ótica do setor bancário e a partir da análise dos grandes ciclos do mercado de fretes. Ao fazer isso aplica o modelo Analytical Hierarchical Process (AHP). Khalid (2005) discute a viabilidade e condições do shipping finance na Malásia. Conforme Pires Junior, Assis e Sousa (2005), outros autores que tratam da questão do financiamento são Branch (1988), Drewry Consultants (1996) e Grammenos (2004).

Poucos livros abordam especificamente o shipping finance, entre eles redigidos por Kendall e Buckley (2005), Sloggett (1984), Stephenson (1995) e Stopford (2005).

No Brasil, essa escassez de literatura em torno do shipping finance também se faz sentir. Contudo, alguns estudos fazem referências ao tema. Lacerda (2003), por exemplo, ao discutir as condições para o crescimento sustentável da construção naval no Brasil, com ênfase na questão do comércio exterior, procura apontar certas falhas na política nacional e discutir os elementos da crise financeira do setor. Já, Lima e Velasco (1998) abordam os principais problemas que afetam a ICN brasileira e as possibilidades para sua superação, incluindo sugestões de reorientação das políticas de financiamento setorial - incluindo estímulos por meio de aporte de recursos orientados ao financiamento à exportação de navios. 
Pasin (2002) traça um diagnóstico do setor naval, investigando as medidas necessárias para o aproveitamento da favorável combinação de aspectos conjunturais e estruturais para o desenvolvimento, visando ao estabelecimento de uma base consistente e duradoura para o desenvolvimento da indústria naval no País. Este autor enfatiza, por meio de uma abordagem microeconômica, que as políticas de financiamento orientadas à construção e capacitação dos estaleiros devem reduzir preços e aumentar o volume de negócios setorial por meio do incremento da escala produtiva e produtividade.

Dadas as características da construção naval, o financiamento é de estrema relevância. Contudo, embora represente um dos aspectos críticos para a dinâmica setorial, são poucos os estudos que tratam de maneira específica de questões microeconômicas que afetam a dinâmica da ICN e sua relação com a política de financiamento setorial. De fato, embora alguns autores atentem para a importância do financiamento, em suas abordagens não são aprofundados os elementos relacionados à configuração e estruturação dessas linhas de financiamento e seu papel no fortalecimento setorial. A rigor, poucos estudos focalizam a economia marítima (entendida como área da ciência econômica que trata do funcionamento dos mercados de frete, mercado de construção, mercado de compra e venda de embarcações e mercado de demolição de embarcações) e, dentro dela, o shipping finance (entendido como parte da economia marítima que estuda dos esquemas de financiamento setorial).

O estudo desse tema e de seus múltiplos aspectos é crucial. Sem financiamento adequado que atenda as particularidades setoriais, as empresas que atuam no transporte marítimo não podem expandir o tamanho de suas frotas e operações, o que, por sua vez, pode afetar suas perspectivas no negócio como um todo, interferindo na dinâmica da ICN. Portanto, não é nenhum exagero afirmar que o financiamento é essencial para o sucesso da ICN, bem como, para o comércio e crescimento econômico de um país, especialmente se o país quiser reduzir o impacto macroeconômico do pagamento de serviços de frete. Dessa forma, é necessário que estudos sobre shipping finance sejam conduzidos contribuindo para o aperfeiçoamento de suas práticas. Para um melhor entendimento do tema, as próximas seções procuram caracterizar os aspectos centrais do funcionamento dos mercados que compõe o mundo marítimo e sua estreita relação com o processo de financiamento. Ao fazer isso adota uma perspectiva microeconômica. 
Esse capítulo se encontra subdividido em sete partes. A próxima seção discute a estrutura do setor de transporte naval destacando a existência e profundo inter-relacionamento de quatro mercados, a saber: mercado de fretes, mercado de compra e venda de embarcações usadas, mercado de construção e mercado de demolição de embarcações. A seguir (seção 2.2), é analisado o funcionamento do mercado de fretes no curto prazo (onde a oferta de serviços de transporte é rígida e a formação da taxa de frete depende da flutuação da demanda pelos serviços de transporte), e no longo prazo (onde as expectativas quanto à taxa de frete orientam as decisões de investimento interferindo no ciclo dos negócios). Feito isso se discute os conceitos de bens sob encomenda (seção 2.3), no qual se insere o segmento de construção de novas embarcações, e se apresenta a cadeia de valores da ICN (seção 2.4). A partir desses elementos se resgata importância do financiamento à construção naval (seção 2.5). A penúltima seção apresenta uma discussão sumária acerca da importância do financiamento em paises selecionados (seção 2.6). Uma síntese do capitulo é apresentada na seção 2.7 .

\subsection{Mercados que Sustentam o Transporte Naval}

A função de um navio é prover serviços de transporte (passageiros ou cargas) ou serviços marítimos específicos a custos unitários reduzidos (WEISS, 1990). Nesse sentido, a fabricação de navios é feita por uma indústria que apresenta demanda derivada ${ }^{10}$, cujos ciclos de produção e uso são longos e dependentes do que ocorre em mercados correlatos (EL CICLO..., 2005). De fato, o nível de atividade no mercado de construção naval está intrinsecamente relacionado ao que acontece no mercado de frete, mercado de compra e venda de embarcações usadas e mercado de demolição de embarcações (STOPFORD, 2005). A rigor, a ICN e seu financiamento são influenciados pelo desempenho desses três grandes mercados, cuja rentabilidade depende, em última instância, dos níveis corrente e esperado dos

\footnotetext{
${ }^{10}$ Além da demanda por serviços de manutenção e reparo, a demanda por serviços de transporte é um dos principais fatores que interfere nos negócios dos estaleiros, afetando o nível operacional por meio da demanda por novas embarcações. Nesse sentido, constitui uma curva de demanda derivada.
} 
fretes, resultantes da dinâmica do comércio mundial (STOPFORD, 2005). A função de cada um desses mercados é descrita no quadro 3.

\begin{tabular}{l} 
mercado de fretes: lócus de "comércio" de serviços de transporte marítimo \\
e fonte primária de recurso setorial; são as empresas do setor, que via de \\
regra obtém financiamento para viabilizar a construção de novas \\
embarcações; o nível de atividade nesse mercado depende das taxas de \\
crescimento do produto e comércio mundiais; a oferta de serviços depende \\
das condições de uso e oferta de novas embarcações se relacionando \\
diretamente com as fontes de financiamento compatíveis com as \\
características desse mercado. \\
\hline mercado de embarcações usadas: lócus de compra e venda de \\
embarcações usadas entre operadores e investidores (assets players) que \\
atuam na oferta de transporte marítimo; com o aquecimento do comércio e \\
impacto sobre o preço dos fretes a operação de embarcações de longo \\
período de uso se torna lucrativas; o resultado é o aumento no preço das \\
embarcações usadas e aquecimento no mercado de construção. \\
\hline mercado de novas construções - mercado onde são firmados os contratos \\
e construção de novas embarcações, dada a natureza do negócio envolve \\
uma série de atores (armadores, estaleiros, agentes financeiros, \\
seguradoras, governo, etc.); as encomendais só se concretizam caso os \\
armadores encarem como perene o aumento dos fretes ou em razão de \\
identificação de oportunidades de venda de serviços sob encomenda. \\
\hline mercado de demolição ou desmanche - lócus de comércio de \\
embarcações que não estão mais em condições econômicas de uso ou \\
embarcações obsoletas que irão gerar caixa a armadores em dificuldades \\
durante os ciclos de queda nas taxas de frete; em contraste ao demais \\
mercados apresentados acima possui caráter anti-cíclico - nos momentos de \\
contração no mercado de fretes o mercado de demolição se aquece e vice- \\
versa.
\end{tabular}

Quadro 3 - Mercados que compõe o mundo marítimo.

Fonte: Elaborado pelo autor.

Um melhor entendimento das inter-relações entre estes mercados fornece subsídios para que se compreenda com mais profundidade as grandes questões relacionadas ao financiamento da ICN sob as óticas do estaleiro, agente financiador, agente de seguro, governo e, sobretudo, do armador - agente que, via de regra, promove o financiamento à construção.

As flutuações esperadas na taxa de frete afetam a ICN de maneira indireta. $\mathrm{O}$ preço do frete oferece sinais e estímulos aos agentes afetando suas decisões de investimento e desinvestimento. A rigor, a expectativa quanto aos movimentos da taxa de frete é a principal força que orienta os quatro mercados apresentados no quadro 3. Esta variável influencia as decisões empresariais, ocasionando mudanças nas condições de oferta dos serviços de transporte, serviços de apoio marítimo e em suas respectivas rentabilidades. Tais oscilações também provocam variações no 
valor dos ativos das companhias. Estas se refletem no preço e lucratividade das embarcações novas e usadas, afetando, por conseguinte, os mercados de construção e de demolição (STOPFORD, 2005).

Conforme a figura 1, estes mercados se encontram intrinsecamente relacionados por meio de fluxos de ativos reais e financeiros. Nela, cada um dos quatro mercados é representado em um quadrante. Os movimentos de entrada e saída de caixa são representados por meio de cada seta representada.

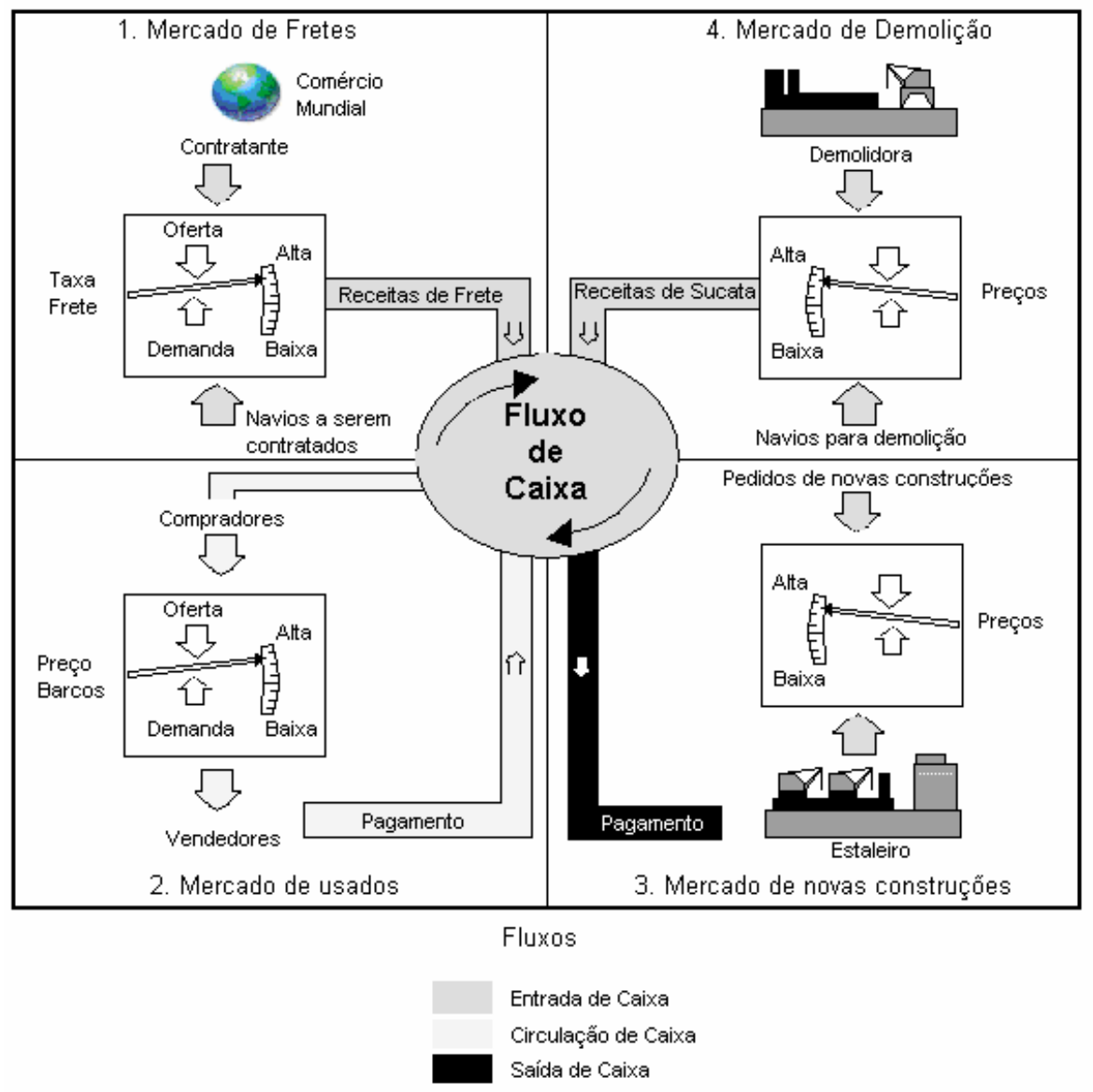

Figura 1 - Os quatro mercados que formam a estrutura de oferta e demanda de transporte marítimo.

Fonte: Stopford (2005, p. 80).

A principal entrada de recursos advém das receitas obtidas no mercado de fretes. Estas aumentam e diminuem de acordo com as oscilações no nível de comércio, oferta e demanda por transporte. 
Outra fonte de entrada de caixa no sistema advém do mercado de demolições de embarcações. As vendas de navios usados, mesmo como sucata, acabam por gerar uma fonte útil de recursos para os armadores em momentos de contração do comércio e conseqüente redução nas taxas de frete. Nesses períodos, as taxas de frete não justificam a utilização de embarcações menos eficientes o que, associado aos níveis de custo de manutenção da frota remanescente, estimula o armador a atracar ou demolir embarcações com maior tempo de uso e ou menos eficientes. Estas operações afetam a estrutura de gastos ou garantem ao armador a obtenção de caixa para manter as operações em momentos de crise aguda, uma vez que grande parcela dos gastos operacionais corresponde a gastos fixos (FADDA, 2006).

Já a compra de uma embarcação usada envolve a transação entre um proprietário e um investidor. Geralmente esse investidor é outro armador (ou se tornará um). Deste modo os recursos do sistema apenas trocam de mãos, não havendo geração de novas fontes de receita e sim circulação de caixa entre os agentes que atuam no mercado de transportes e apoio marítimo. Neste caso, não há mudança na quantidade de ativos disponíveis, tão pouco alterações na capacidade de transporte mundial. Com efeito, não provocam alterações substanciais nos níveis de frete.

No caso de novas construções, o caixa flui no sentido inverso, havendo, inclusive, saída de recursos do sistema. Isso acontece, porque uma parcela dos recursos pagos aos estaleiros para novas construções é apropriada por outras indústrias, como a indústria siderúrgica, indústria de bens de capital, indústria madeireira e todas as outras que ofertam insumos para a construção das embarcações. O pagamento da mão-de-obra também flui para outros setores da economia, fundamentalmente para o mercado de bens de consumo, não retornando ao sistema. Não obstante, os financiamentos que sustentam essas operações geram entradas de caixa no sistema. Contudo devem ser pagos, em última instância, por meio das receitas dos fretes. A imobilização deve gerar excedentes para cobrir tais despesas. Nos ciclos expansivos, novas embarcações aumentam a capacidade de transporte e geram incrementos de caixa e, a depender das condições de comércio, influenciam formação do preço do frete. 
O movimento de caixa entre esses mercados condiciona a rentabilidade das empresas que atuam no setor ${ }^{11}$. Nos ciclos expansivos, os recursos entram no sistema e incentivam os investidores a comprarem novas embarcações. Simultaneamente, há a valorização econômica das embarcações usadas. A rigor, a depender da pressão sobre o mercado de embarcações usadas, o mercado de novas construções também se aquece - principalmente se as expectativas de elevação nos preços dos fretes se mantiverem. Se estas expectativas apontarem uma tendência sustentável de aumento das taxas de fretes o mercado de construções se aquece por meio de novas encomendas.

Este ciclo só deverá se reverter com o início de operação das novas embarcações. Fato que se dará em prazo mais longo, ou então se houver expectativas de desaquecimento no comércio internacional (STOPFORD, 2005).

Como pode ser exemplificado na figura 2, os ciclos de negócios no setor apresentam tendências e implicações de longo prazo. Toda esta dinâmica é influenciada, em última instância, pelas perspectivas de crescimento do comércio mundial e de consumo de energia (muitas vezes afetados por políticas governamentais), que condicionam as expectativas relacionadas às taxas de frete no curto prazo e a oferta de serviços de transporte no longo prazo (STOPFORD, 2005).

Como será enfatizado nas próximas seções, devido às oscilações nas taxas de frete, longo período de reposição do capital e papel das expectativas que orientam as inversões, há certo descompasso no ajustamento de mercado provocando variações na rentabilidade e no valor dos ativos das empresas ligadas ao setor (IRENE et al, 2001; JOHNSON STOKES \& MASTER, 2005; KHALID, 2005). Estes fenômenos impõem severas repercussões na estrutura de financiamento e decisões de investimento setorial (BARBOZA, 2004).

${ }^{11}$ Embora não explicitado, o aporte de recursos por meio de esquemas de financiamento afetam o sistema e constituem um elemento de ajuste intertemporal entre todos estes mercados - daí uma das suas maiores relevâncias. 
Ciclo Maritimo Simplificado

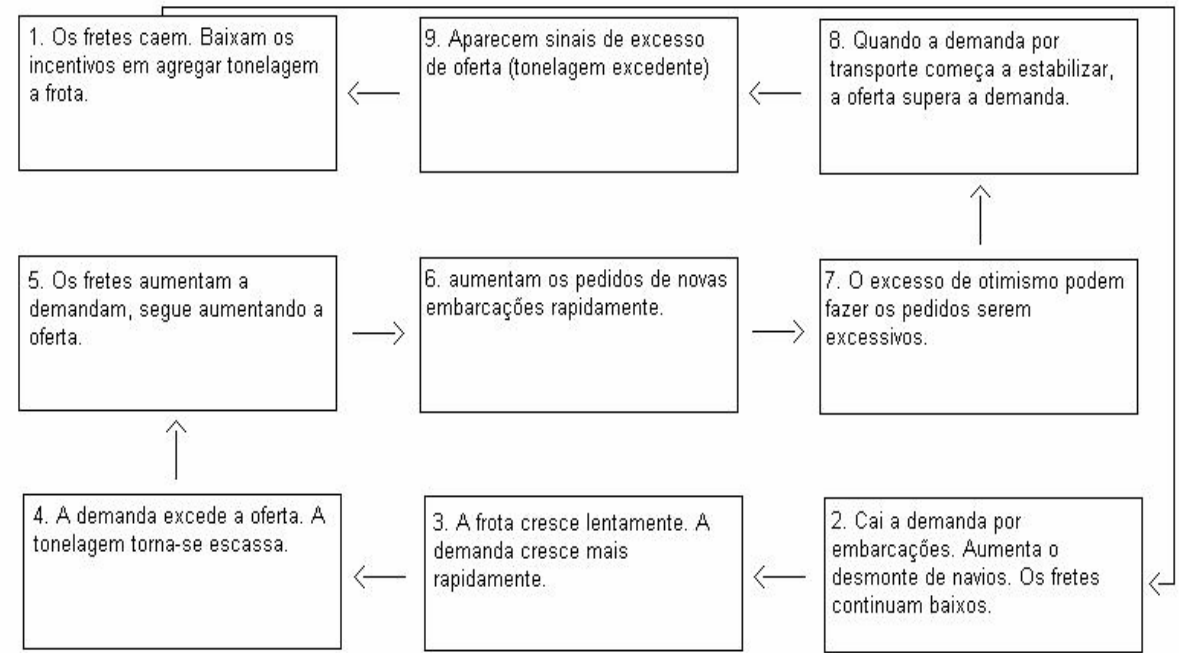

Figura 2 - Relação entre os mercados do setor marítimo durante o ciclo marítimo simplificado.

Fonte: El Ciclo... (2005, p. 1).

Curiosamente os modelos apresentados por Stopford (2005) e El Ciclo... (2005) não introduzem explicitamente o fluxo de caixa proveniente do aporte de financiamento. Com efeito, o fluxo de investimento setorial depende das condições de financiamento as quais respondem pelos níveis presentes e esperados de rentabilidade nos mercados que conformam a oferta de serviços de transporte e apoio marítimo. Devido ao alto valor das embarcações, prazos de maturação das inversões e grande volatilidade verificada nesse mercado (resultado das oscilações no valor dos fretes), novos investimentos exigem grande aporte de financiamento. Grande parte dos recursos para tanto são obtidos fora do sistema. O aporte de financiamento, ao ser alocado no setor viabilizando o reparo e novas construções, gera incrementos no fluxo de pagamento de juros e amortizações que só podem ser suportados por ampliação no fluxo de entradas de caixa no setor. Com efeito, o financiamento promove o ajustamento intertemporal dos mercados.

A oferta desses serviços sofre forte influência do Estado. $O$ transporte marítimo deve atender a regulamentações específicas ligadas à política de transporte, políticas de comércio, preservação ambiental, normas de segurança uni ou multilaterais (KENDALL e BUCKLEY, 2005). Parte dessas normas e 
regulamentos se reflete na elaboração do projeto de construção das embarcações. O Estado também interfere no setor por meio de uma série de instrumentos: subsídios, criação de reservas de mercado na construção e no transporte, benefícios fiscais e proteção da cabotagem, incentivos financeiros à construção e ao transporte, uso do poder de compra, políticas industrial orientada ao setor, entre outros (SERRA, 2002).

Uma vez que o setor é altamente regulado na maioria dos países, em muitas situações, as políticas públicas alocativas orientadas ao setor têm por objetivo suavizar estes ciclos e ou atender as mais diversas finalidades (política energética de petróleo, política de marinha mercante, políticas industriais explícitas e implícitas, política de segurança nacional, políticas ligadas ao emprego setorial, etc.) $\left(\right.$ KENDALL; BUCKLEY, 2005) ${ }^{12}$. Em meio à discussão acerca do papel do Estado, figuram argumentos em torno da defesa da soberania, impacto dos gastos com fretes e afretamentos no Balanço de Pagamentos, necessidade de promover meios ao escoamento da produção doméstica e importância do setor na geração de empregos. Alguns países, além da motivação pela busca de soberania e acesso aos mercados externos, vêem na ICN, uma importante alavanca de seu desenvolvimento industrial e gerador de divisas por meio de incrementos nas exportações desses bens (SERRA, 2002). Tal é o caso da Coréia do Sul e da China.

Os Estados também se fazem presentes no setor, entre outras formas de atuação, pela adoção de mecanismos de reserva de cargas e de regulação do trafego de cabotagem, firmando acordos internacionais bilaterais e multilaterais, além de apoiarem as empresas nacionais oferecendo condições favoráveis de financiamento e subsídios para a aquisição, reparo e operação (SERRA, 2002).

\subsection{Mercado de Fretes e Investimento na Construção Naval}

\footnotetext{
12 Conforme será discutido no capítulo 3, uma das formas de intervenção que o governo exerce na economia se relaciona a função alocativa. Por meio desta o governo induz a alocação de recursos e fatores produtivos em atividades consideradas de grande interesse público ou em setores econômicos que, apesar de sua relevância, apresentam falhas de mercado (monopólios, bens públicos, mercados incompletos, falhas de informação, etc.).
} 
O setor de construção caracteriza-se pela inconsistência em seu nível de atividade, que oscila em razão da flutuação do volume de investimentos (ALEX, 2004; EL CICLO..., 2005; KHALID, 2005). Dada a natureza do empreendimento, cujo ciclo de retorno sobre o investimento possui longa maturidade e é orientado, no curto prazo, pela taxa corrente de frete, e, no longo prazo, pelas expectativas das taxas de frete futuras, o empreendimento deve ser analisado sob duas perspectivas temporais relacionadas. Ambas dizem respeito aos mecanismos que condicionam a formação da taxa de fretes no curto e longo prazo. Um detalhamento desse movimento é apresentado a seguir.

\subsubsection{Mercado de Fretes no Curto Prazo}

No curto prazo, a capacidade de carga da frota mercante mundial é fixa ${ }^{13}$. Assim, os níveis de frete são determinados exclusivamente pela demanda, rígida no curto prazo. Isso significa que nesse horizonte de tempo, a estrutura do mercado do setor de transporte naval pode ser analisada de maneira esquemática por meio da figura 3.

Como em outros mercados, o formato da curva de oferta de uma embarcação deriva de sua curva de custos. A rigor, esta curva pode ser obtida pela derivada da curva de custo total da embarcação. Com efeito, a operação de serviços de transporte marítimo (tramp ou liner) só é viável a partir da contratação de um determinado nível de frete. Conforme a figura (a), a partir desse ponto esta curva possui um longo seguimento horizontal. Fato que caracteriza a presença de economias de escala. A partir de determinado nível de carga, a oferta se torna inelástica em relação ao frete. Isso significa que, dada a capacidade de carga da embarcação, o volume transportado não responde a variações no preço do frete.

\footnotetext{
${ }^{13}$ Nesse horizonte de tempo, a oferta de serviços de transporte é determinada pela capacidade de carga mundial disponível, medida em toneladas de porte bruto - (TPB). Esta entendida como capacidade de carga líquida da embarcação.
} 

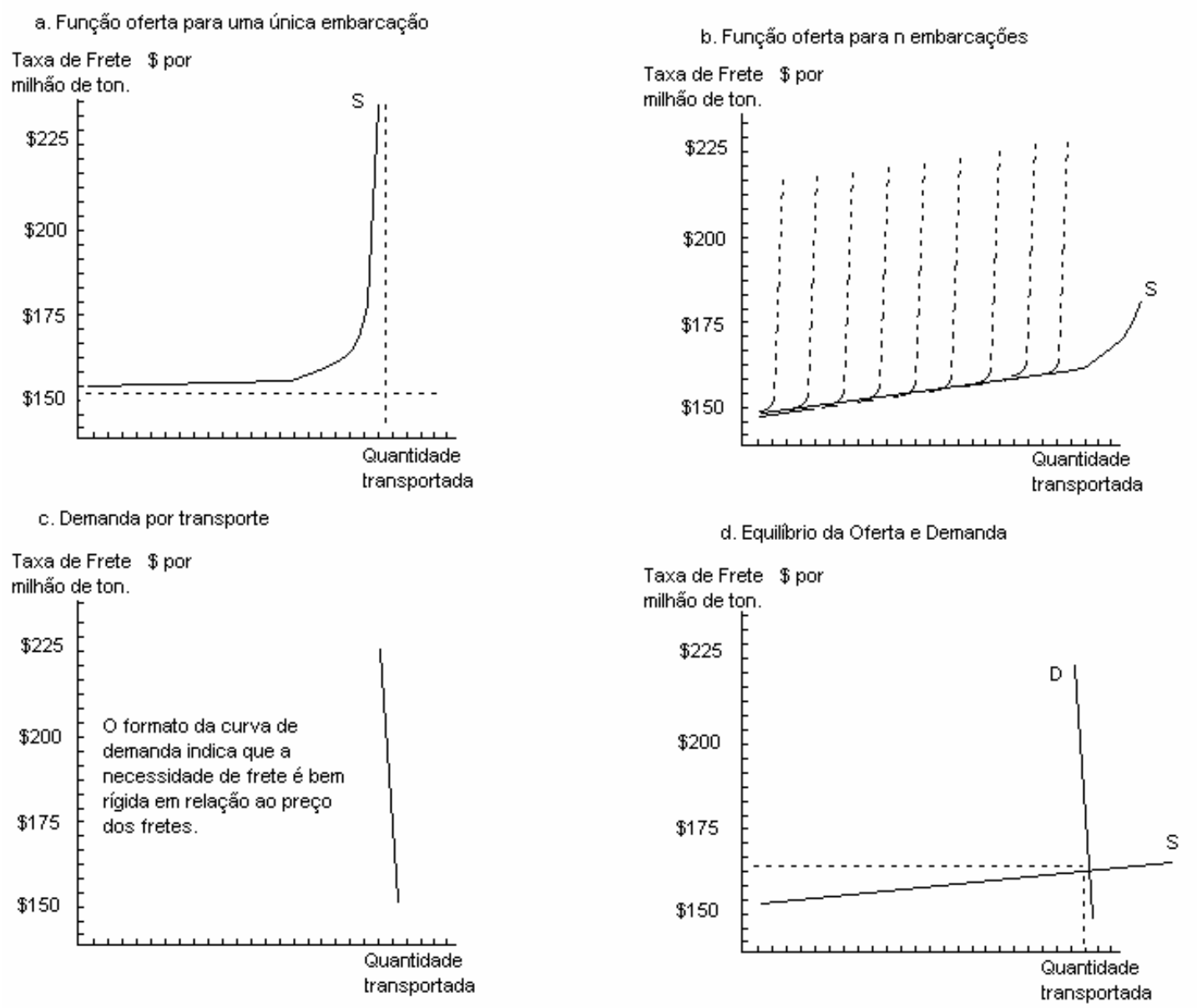

Figura 3 - Funções oferta e demanda do transporte marítimo no curto prazo. Fonte: Stopford (2005, p. 140).

A posição da curva de oferta de uma embarcação individual depende de seu nível de eficiência operacional. Quanto maior esta menor o nível de custos. Geometricamente isso significa que a curva de oferta se encontra próxima do eixo das abscissas, ou seja, sua operação é viável a níveis reduzidos de frete. Isso também é indicado na parte (a) da figura 3.

A curva de oferta de mercado (oferta para $n$ embarcações), por sua vez, é obtida por meio da soma horizontal das curvas de oferta das embarcações alocadas nesse mercado (parte b da figura 3). Como as embarcações que operam em um mesmo segmento de mercado possuem diferentes tempos de uso e, consequentemente, graus diferenciados de eficiência operacional, o valor de frete que as torna economicamente viáveis deve ser distinto. Isso implica que, no espaço 
taxa de frete/tonelagem transportada, é possível dispor as curvas de oferta de cada embarcação em ordem decrescente de eficiência operacional. Desta forma, a curva de oferta de mercado apresenta um seguimento com inclinação levemente positiva a cada nível de frete. Essa inclinação, resultado da soma horizontal das curvas de oferta das embarcações individuais, reflete os diferenciais de eficiência operacional verificado entre estas. A partir de determinado nível de capacidade a curva de oferta de mercado se torna rígida em relação à taxa de frete. Isso explica o seguimento vertical da curva de oferta de mercado. Este é dado pelo nível de frete exigido para a operação da embarcação menos eficiente. Isso pode ser visualizado pela parte (b) da figura 3.

Em contraste, a curva de demanda por transporte possui uma inclinação acentuada caracterizando uma demanda inelástica (parte c da figura 3). No curto prazo, a demanda por transporte marítimo é rígida. Isso acontece porque, neste horizonte de tempo o volume de comércio não é sensível a variações nos níveis de frete. As decisões de produção e consumo já se consubstanciaram em encomendas e contração de transporte de bens intermediários e bens de consumo finais entre empresas de diferentes países. Esta rigidez rebate no mercado de serviços de transporte marítimo por meio dos contratos de frete (liner, tramp, etc. $)^{14}$.

A determinação do ponto de equilíbrio de curto prazo no mercado de fretes é dada pela intersecção das respectivas curvas de oferta e demanda (parte d da figura). Neste ponto é determinado o nível de frete, dado o nível de comércio internacional e capacidade de carga global. Assim, no curto prazo a demanda determina os níveis de frete, uma vez que a oferta de serviços de transporte é dada pela capacidade de carga mundial (medida em toneladas de porte bruto - TPB). Devido à relativa rigidez da oferta, qualquer oscilação na demanda provoca grandes variações na taxa de frete. Este é um dos motivos que explica porque as entradas de caixa no setor, descritas na seção 2.1, apresentam tendências cíclicas.

No curto prazo, certos fatores provocam rigidez no mercado de transporte marítimo. Devido aos elevados custos operacionais, em grande parte compostos de gastos fixos (custos e despesas), em períodos de redução acentuada nas taxas de frete, há estímulo de operar mesmo abaixo da curva de custo médio. Esta decisão constitui um meio de minimizar os prejuízos uma vez que uma parcela dos fixos e

\footnotetext{
${ }^{14}$ Conforme apresentados na nota de rodapé número 9.
} 
variáveis podem ser cobertos. Caso a crise seja persistente e algumas embarcações menos eficientes atinjam níveis de custo médio superiores ao ponto de equilíbrio de mercado, certos armadores serão forçados a abandonar certas rotas ou vender parte delas no mercado de compra e venda de embarcações usadas ou de demolição. Este expediente gera caixa que ajuda a manter as rotas mais atrativas.

Embora o nível de comércio não sofra alterações bruscas no curto e curtíssimo prazo, oscilações no comércio provocadas por fatores conjunturais como variações cambiais, introdução de restrições ao comércio e outros choques advindos do lado da demanda, podem provocar mudanças repentinas na demanda por transporte marítimo. Se permanentes, estes choques podem alterar de maneira perene o equilíbrio de curto prazo.

Contudo, estas não são as grandes fontes de ruptura no equilíbrio estrutural de mercado. A explicação desse fenômeno deve ser buscada nas condições de determinação de frete no horizonte de longo prazo, o que é feito a seguir.

\subsubsection{Mercado de Fretes no Longo Prazo}

No longo prazo, a origem da mudança estrutural surge do lado da oferta por meio de decisões de investimento em novas embarcações. A entrada em operação dessas embarcações afeta de maneira permanente o equilíbrio de curto prazo entre oferta e demanda por serviços de transporte. Como discutido acima, a taxa de investimento depende das expectativas de crescimento do comércio e de sua correspondente influência sobre as taxas de frete. Caso as expectativas dos armadores em torno da taxa de frete justifiquem investimentos na construção de novas embarcações, estas só surtem efeitos com certa defasagem temporal. $O$ mecanismo de ajustamento de longo prazo pode ser descrito com base na figura 4 .

A partir de um dado nível de fretes, apresentado na parte (a) da figura 4, e com base nas expectativas quanto ao comportamento da demanda, os armadores formam suas expectativas acerca das taxas de frete. A curva de demanda esperada com base nessas expectativas é mostrada na parte (c) da figura 4. Esta indica que, para um dado um nível de oferta de serviços de transporte, medidos em TPB, incrementos esperado na demanda, provocam expectativa de aumento nas taxas de 
frete. Este incremento esperado aquece o mercado de embarcações usadas e também provoca ampliação nos pedidos de construção de novas embarcações.
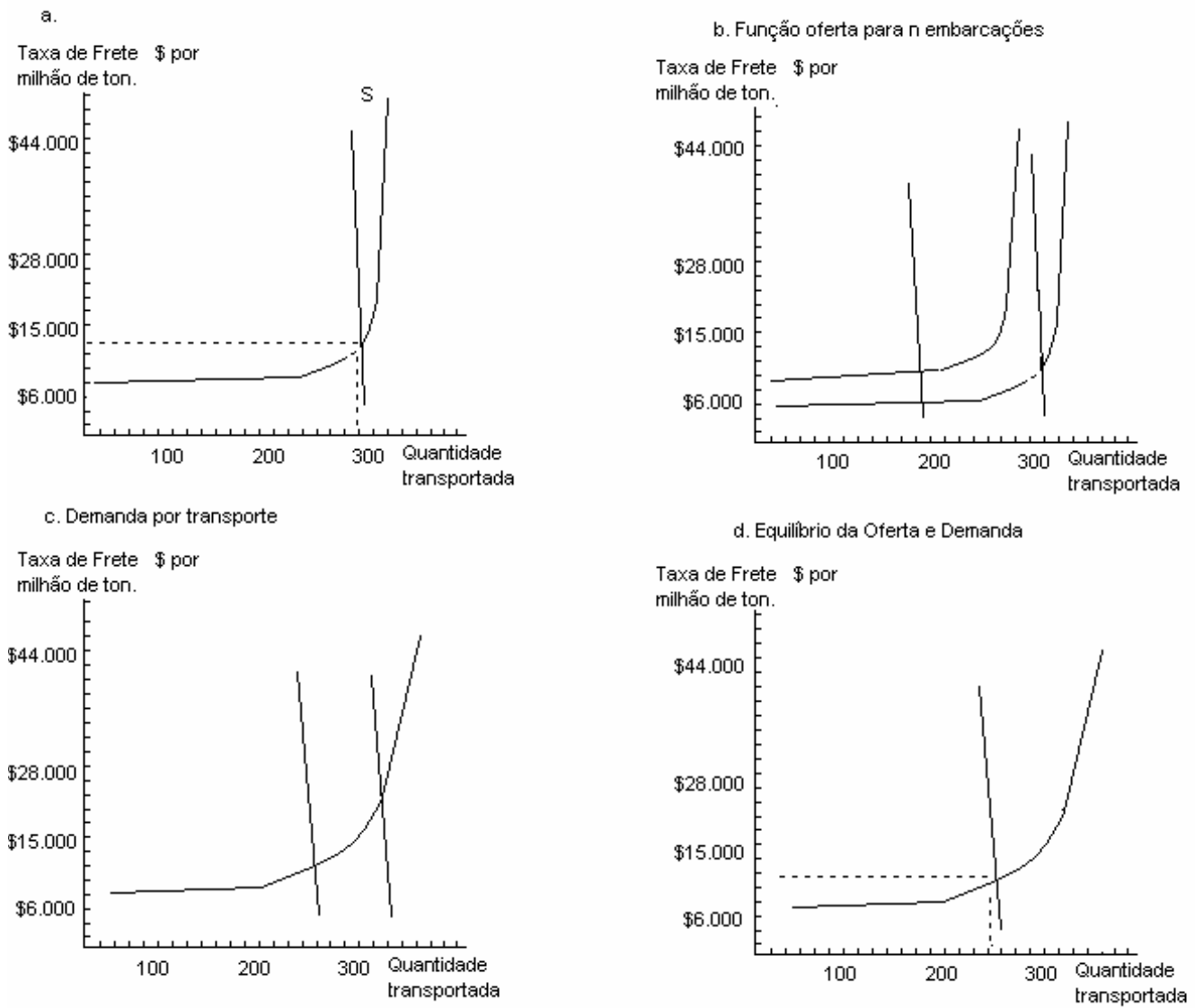

Figura 4 - Funções oferta e demanda do transporte marítimo no longo prazo. Fonte: Adaptado de Stopford (2005, p. 146).

A rigor, a expectativa de incremento na taxa de frete se propaga inicialmente ao mercado de venda e compra de embarcações usadas e mercado de demolição afetando o valor dos ativos desses segmentos, para só então influenciar o mercado de construção de embarcações.

O impacto do incremento da oferta só será efetivo depois de concluído ciclo de produção das embarcações, o que é mostrado na parte (b) da figura 4 por meio do deslocamento da curva de oferta. Quando as novas embarcações começarem a operar, a demanda pode estar acima, abaixo ou em torno do nível esperado em (c). Assim, a rentabilidade dos empreendimentos dependerá do nível de demanda em relação à nova curva de oferta de mercado (parte d da figura 4). 
A priori, não se sabe se as expectativas de aumento de frete gerarão um excesso de capacidade. Tão pouco qual será o novo nível de demanda por serviços de transporte. São estes fatores, associados ao longo ciclo de maturação dos empreendimentos e tempo de vida útil das embarcações que tornam o mercado de serviços de transporte e apoio marítimo altamente voláteis. Essas características se refletem no valor dos ativos das companhias de transporte trazendo sérias implicações econômicas e financeiras aos negócios ligados ao setor.

Barboza (2004), na mesma linha interpretativa de Cho e Porter (1986), sugere que a natureza global dos empreendimentos associada à natureza cíclica dos negócios implicam que os empreendimentos associados ao transporte naval possuem uma natureza "quasi-especulativa" (denotando idéia de equivalência) e ausência ou fraca influência de mecanismos econômicos de curto prazo. Argumentos semelhantes são apresentados por Alex (2004), Kalhid (2005) e Johnson Stokes \& Master (2005).

De fato, a determinação das taxas de frete se dá no curto prazo. Contudo, o equilíbrio depende das decisões de investimento estabelecidas com certa defasagem temporal. Tais decisões se baseiam na formação de expectativas sobre o crescimento do comércio e seu efeito provável sobre as taxas de frete. Isso implica que a capacidade de transporte verificada hoje é resultante de decisões de investimento ocorridas em períodos anteriores. Esse fenômeno deriva do descompasso oriundo do funcionamento do mercado de fretes e do mercado de construção.

Em suma, nos ciclos de expansão da economia mundial ocorre aumento na taxa de frete afetando a taxa de investimento. A expansão de capacidade é feita por meio da provisão de subsídios governamentais e pode gerar excesso de capacidade de carga. Contudo, qualquer retração no mercado de fretes tem potencial de gerar crise no setor. Em meio aos ciclos, a eliminação do excesso de capacidade leva muito tempo. Por outro lado, há outro componente cíclico associado à demanda de navios, cuja vida útil é longa. O período de expansão aumenta o estoque de navios que só serão repostos em intervalos de tempo mais longos. Após certo tempo esses navios tornam-se obsoletos tecnologicamente. Quando vem a expansão tem-se a demanda de reposição e demanda por navios adicionais. Assim, as flutuações se dão em meio ao descasamento entre produção e uso - um navio leva meses para ser construído e possui vida útil longa. 
Este descompasso entre condições de oferta e demanda no curto e longo prazo também é enfatizado por Khalid (2005). Como apontam Kendall e Buckley (2005) e Pasin (2002), tal descompasso constitui uma das razões pelas quais o setor sofre alta suscetibilidade a intervenção governamental, o que inclui a introdução de programas de construção e políticas de financiamento setoriais como meio de garantir menores flutuações na rentabilidade das empresas e maior uso da capacidade operacional de armadores, estaleiros, etc.

Apresentados os mecanismos que regulam a determinação da principal fonte de caixa do setor resta discutir a forma de funcionamento do mercado de construção. Com efeito, o entendimento do problema do financiamento setorial exige ainda o entendimento de dois conceitos fundamentais: bens de encomenda e cadeia de valores setorial. Do ponto de vista desta exposição, antes de apresentar a cadeia de valores da ICN (que será útil para a caracterização da indústria e melhor entendimento das questões relacionadas ao financiamento), convém apresentar o conceito de bens sob encomenda, no qual se classifica a construção de novas embarcações. Posteriormente se discute os elos da cadeia de valores da ICN.

\subsection{Conceito de Bens sob Encomenda}

$\mathrm{Na}$ classificação de estruturas industriais, a ICN se caracteriza como uma indústria de bens de capital produzidos sob encomenda, ou simplesmente bens sob encomenda. Este conceito é de extrema importância para o entendimento da dinâmica de mercado de bens de capital, consequentemente, o padrão de financiamento setorial (VERMULM; ERBER, 2002).

A produção de um bem sob encomenda é desenvolvida para um cliente específico. Assim, cada pedido quase sempre se refere a um bem diferente daquele que foi produzido anteriormente. Esse fenômeno é ainda relevante, embora como apontem Cho e Porter (1986), alguns estaleiros localizados na Coréia do Sul e Japão tenham adquirido habilidades em produzir certos navios de forma análoga à produção seriada. Assim, o construtor espera a manifestação do cliente, o qual formaliza um pedido, acompanhado ou não de um projeto, para em seguida definir os produtos a serem fabricados (VERMULM; ERBER, 2002). Isso se dá porque 
estes bens não podem, ou não devem, a priori, ser produzidos para estoque. Esse fator faz com que as empresas que trabalham com produção sob encomenda tenham grandes dificuldades em seqüenciar a produção, já que é difícil prever "o que", "quando" ou "como" será feita a produção no período seguinte. Na prática, todas estas informações somente ficam definidas com a chegada do pedido. A partir dele, o projeto é modelado, o roteiro de produção é delineado, os materiais e demais itens componentes são encomendados e a produção se inicia (VERMULM; ERBER, 2002).

No ambiente de produção sob encomenda, um bom planejamento e controle da produção possuem enorme importância devido às condições citadas anteriormente (VERMULM; ERBER, 2002). Portanto, torna-se imprescindível para tais empresas a criação ou adoção de ferramentas que sustente a programação das ordens de construção e de recursos de maneira exeqüível e confiável. Estes são elementos vitais para que se atenda de maneira satisfatória prazos e critérios de qualidade de entrega, os quais se refletem sobre os preços praticados.

A existência de um conjunto de fornecedores especializados (ou ofertantes especializados) é um atributo sistêmico de grande importância para a competitividade de indústria que produzem sob encomenda (VERMULM; ERBER, 2002), entre elas os estaleiros. O progresso técnico desse setor industrial é caracterizado pelo learning-by-doing, explicado principalmente pela produção não seriada e pelo uso intensivo de mão-de-obra qualificada. A disponibilidade desta é um atributo importante para o desenvolvimento tecnológico da indústria. Esses fatores estão no cerne da estratégia do Japão e da Coréia.

Os bens sob encomenda são produtos dotados de atributos múltiplos aos quais os demandantes são sensíveis (condições de financiamento e preço, durabilidade, precisão, desempenho, etc.). Como indicado por Weiss (1990), a importância relativa destes atributos por parte dos armadores é muito variável ${ }^{15}$.

Para ser competitiva, toda empresa de bens sob encomenda necessita deter, além de instalações, máquinas e mão-de-obra adequadas, competências específicas em engenharia de projeto e produto, comercialização e serviços de assistência

${ }^{15} \mathrm{Em}$ conseqüência, a heterogeneidade dos produtos é uma das principais características da indústria de bens de capital e também de faz sentir na produção de embarcações. A rigor, a heterogeneidade de usos a que se destinam os bens de capital implica também que coexistam, em um mesmo espaço social, produtos de várias gerações tecnológicas. $\mathrm{Na}$ ICN isso se reflete nas estratégias dos estaleiros como apontado por Cho e Porter (1986). 
técnica pós-venda (VERMULM; ERBER, 2002). Na produção de bens seriados, economias estáticas de escala são muito mais importantes do que na fabricação por encomenda como embarcações.

A rigor, a ICN pode ser caracterizada como uma indústria de montagem processadora de aço, onde as economias dinâmicas, resultado da repetição de experiências de projetar e fabricar bens com características semelhantes, são cruciais. Esse fator também explica o sucesso dos estaleiros japoneses e sul coreanos $^{16}$.

Do ponto de vista jurídico, a fabricação de bens sob encomenda decorre sempre de um contrato de compra e venda entre o adquirente e o fabricante, respectivamente, armador e estaleiro no caso da construção naval. O contrato firmado entre ambos deve refletir um conjunto de obrigações para ambas as partes. Trata-se de contratos elaborados sob-medida.

Quando consideradas as navipeças que compõe o produto, muitas vezes certos atributos (nível de qualidade e confiabilidade de produtos, disponibilidade global de serviços de assistência técnica, etc.) se projetam além do prazo de entrega do bem. A rigor, a confiabilidade do produto se reflete em obrigações de garantia que são objeto das entidades certificadoras, cujo papel último consiste em reduzir os riscos dos empreendimentos.

A competitividade de um estaleiro, uma vez que fabrica bens sob encomenda, depende não apenas da disponibilidade de instalações, máquinas e mão-de-obra. Competências específicas em engenharia de projeto e produto, habilidade na comercialização com a indústria de navipeças e a garantia de disponibilidade de serviços de assistência técnica pós-venda são críticos.

Dada a natureza operacional de uma embarcação oceânica, isso implica que o setor de navipeças também deve possuir ação global. Por outro lado, como a ICN constitui uma indústria de montagem que adquire insumos de indústrias que devem prover serviços de assistência técnica nos principais portos, isso constitui, ao lado das políticas de incentivo governamental, elemento que reduz as barreiras à entrada e o poder de barganha dos estaleiros.

\footnotetext{
16 No caso de bens seriados, as empresas tendem a operar com maquinário especializado e processos relativamente rígidos, enquanto no caso da fabricação de bens sob encomenda a flexibilidade dos equipamentos, da mão-de-obra e das rotinas produtivas é essencial.
} 
Do ponto de vista dos processos de produção, certos ativos e rotinas podem tornar um estaleiro competitivo dentro dos segmentos de mercado em que atua, ou seja, as competências internas têm grande peso no desempenho dessas empresas.

Por fim resta salientar que, na produção de bens seriados, economias estáticas de escala são muito mais importantes do que na fabricação por encomenda, onde as economias dinâmicas, resultado da repetição de experiências de projetar e fabricar bens com características semelhantes, são cruciais. No primeiro caso, as empresas tendem a operar com maquinário especializado e processos relativamente rígidos; no segundo, a flexibilidade na capacidade negociar contratos, de projetar o produto, gerir os processos de montagem, bem como, dos equipamentos, da mão-de-obra e otimizar rotinas produtivas são essenciais (VERMULM; ERBER, 2002).

\subsection{Cadeia de Valores da Indústria de Construção Naval}

Uma vez discutidos elementos fundamentais da estrutura de mercado do transporte marítimo no curto e longo prazo e caracterizada a ICN como uma indústria que produz bens sob encomenda, é preciso resgatar os aspectos que governam a cadeia de valores setorial sob a ótica da ICN. De fato, para um melhor entendimento do mercado de transporte, o posicionamento e contextualização da forma de funcionamento dos negócios ligados à construção naval, também é necessário considerar como se estrutura a cadeia de valores setorial. Ao fazer isso, torna-se possível estabelecer qual o papel de cada um dos atores em sua configuração e discutir o problema do financiamento sob a ótica de estaleiros e armadores em meio à atuação das forças de mercado, o que é feito a seguir.

Como indicado na figura 5 e detalhado no quadro 4, a cadeia de valores da indústria naval é formada por sete elementos. Com base na figura se observa que as empresas de armação estão no centro da tomada de decisão. Essas atuam nesse segmento identificam a demanda de mercado, obtém financiamento para a aquisição de embarcações usadas, construção e reparo de suas frotas. Ao fazer isso promovem a entrada de recursos no setor por meio da contratação de financiamentos. Por meio dessas operações, geralmente subsidiadas pelos 
governos, são integrados os mercados de construção, navipeças e demais mercados que configuram o setor naval. O governo também interfere por meio de incentivos fiscais e financeiros orientados aos estaleiros, empresas de armação e por meio de políticas comerciais. Os incentivos à construção e ao setor de transportes agregam políticas seletivas de natureza alocativa. ${ }^{17}$

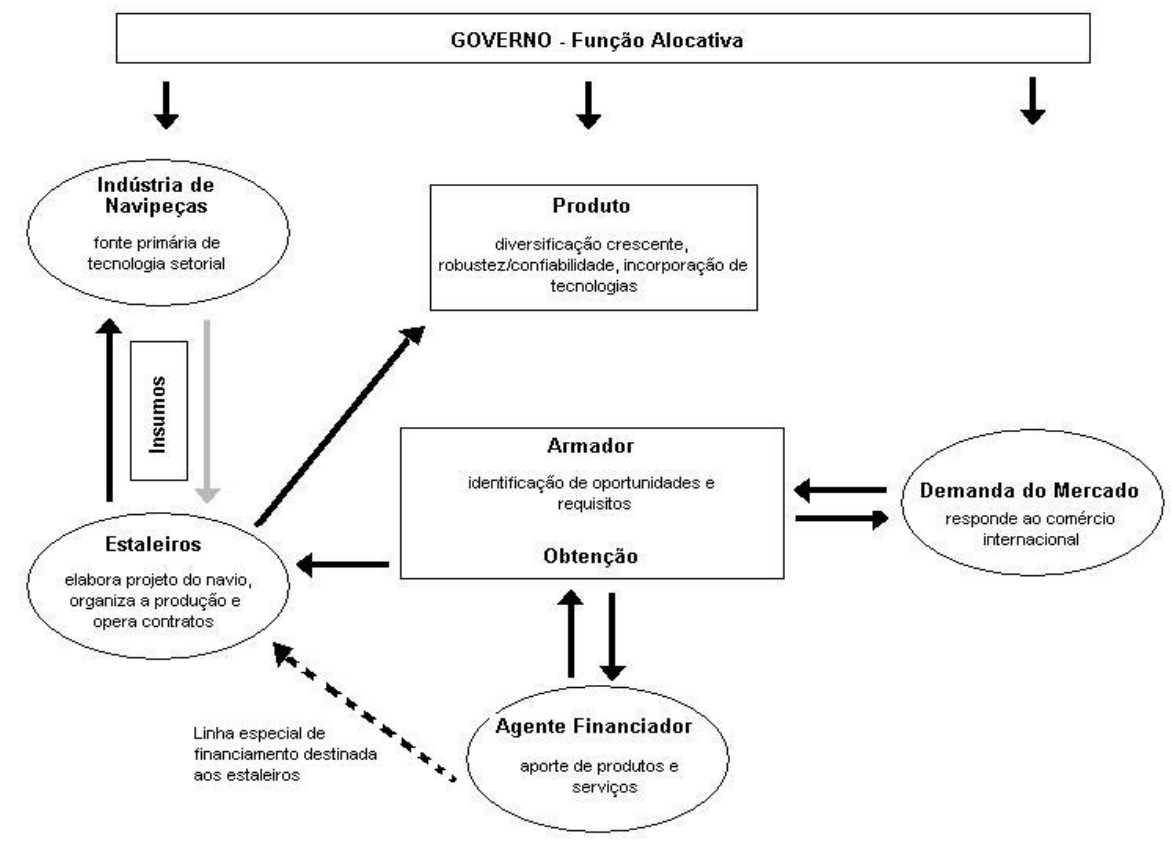

$\left(^{*}\right)$ A seta tracejada indica menor fluxo de recursos de financiamento orientado à construção. Isso se deve ao baixo valor, liquidez e especificidade dos ativos dessas empresas ante aos contratos que operam.

Figura 5 - Cadeia produtiva do mercado de transporte marítimo.(*)

Fonte: adaptado de Barboza (2004, p. 3).

indústria de navipeças: principal fonte de tecnologia no setor, podendo propiciar rápidas entradas e consolidação de produtores no mercado, as evoluções tecnológicas introduzidas pela indústria de navipeças se concentram em certas metas consideradas relevantes pelos armadores: otimização do uso de energia, automação das funções de bordo, nível de conforto, sistemas de comunicação e teletratamento, etc. (BARBOZA, 2004; CHO; PORTER, 1986; WEISS, 1990).

estaleiros: define o projeto naval considerando as tecnologias mais adequadas ao porte, velocidade de serviço, tipo de carga, rotas de operação da embarcação; uma vez fixados estes parâmetros e efetivado o contrato de construção, o estaleiro organiza a produção e gerencia os contratos junto aos fornecedores de navipeças a fim de garantir um fluxo de insumos compatível com a programação do projeto (WEISS, 1990).

\footnotetext{
17 No capítulo 3, a racionalidade da intervenção governamental por meio das funções estabilizadora, distributiva e alocativa será discutida de maneira mais detalhada.
} 


\begin{abstract}
armador: identifica as oportunidades de mercado, estabelecendo o levantamento dos requisitos do produto (STOPFORD, 2006), que, conforme Barboza (2004), exige diversificação crescente, robustez/confiabilidade e incorporação de tecnologias adequadas ao uso.
\end{abstract}

produto: bem produzido sob encomenda que possui alto valor e longos ciclos de produção e uso; marcado pela diversidade crescente, exigência de robustez e que apresenta crescente introdução de novas tecnologias

agente financeiro e seguradoras: provêem aporte de produtos e serviços orientados ao financiamento setorial abrangendo a armação e as indústrias de construção, em ambos os casos com intervenção governamental (BARBOSA, 2005).

demanda do mercado: responde ao comércio internacional que se correlaciona de maneira significativa com do desempenho da produção industrial dos países da OCDE (ALEX, 2004). governo: interfere por meio de mecanismos diretos e indiretos o que se justifica pela presença de falhas de mercado, ao fazer isso exerce função alocativa ${ }^{18}$ (PASIN, 2002).

Quadro 4 - Agentes e papel dos diversos atores na indústria de construção naval Fonte: Baseado em Cho e Porter (1986), Weiss (1990), Alex (2004), Barboza (2004) e Pasin (2002).

Uma indústria pode ser caracterizada como um grupo de empresas que produzem bens ou serviços que são substitutos muito próximos entre si (FERGUSON, 1989) ${ }^{19}$. Segundo Porter (1996), "a essência da formulação de uma estratégia competitiva é relacionar uma companhia ao seu ambiente externo ...[dessa forma] ... o aspecto principal do meio ambiente da empresa é a indústria ou a indústria em que ela compete" (PORTER, 1996, p. 22). Embora forças externas (sociais, políticas, movimentos no produto e na renda, etc.) sejam significativas e afetem o desempenho de todas as indústrias de maneira mais ou menos pronunciada, a atuação da concorrência em uma indústria específica induz a redução da taxa de retorno sobre o capital investido. Segundo Porter (1996), a meta de uma unidade empresarial deve ser encontrar uma posição dentro da indústria de forma que a companhia possa se defender contra tais forças e ou aproveitá-las em seu favor.

Segundo o consagrado modelo proposto por Porter (1996), a concorrência no seio de uma indústria, ao condicionar as taxas de retorno, é orientada por cinco forças: (i) ameaça de novos entrantes, (ii) grau de rivalidade entre as empresas existentes, (iii) ameaça de produtos substitutos, (iv) poder de negociação de fornecedores e (v) poder de negociação de clientes. Isoladas ou em conjunto, estas são cruciais na determinação ou formulação de estratégias empresariais (figura 6).

\footnotetext{
${ }^{18}$ As funções de governo, com destaque à função alocativa que consiste na introdução de esquemas de incentivo à provisão pública ou privada de certos tipos de bens de interesse coletivo, serão discutidas no capítulo 3 .

${ }^{19}$ Por exemplo, a indústria automotiva agrega empresas que produzem automóveis de passeio com características (design, performance, preços, etc.) levemente diferenciadas.
} 


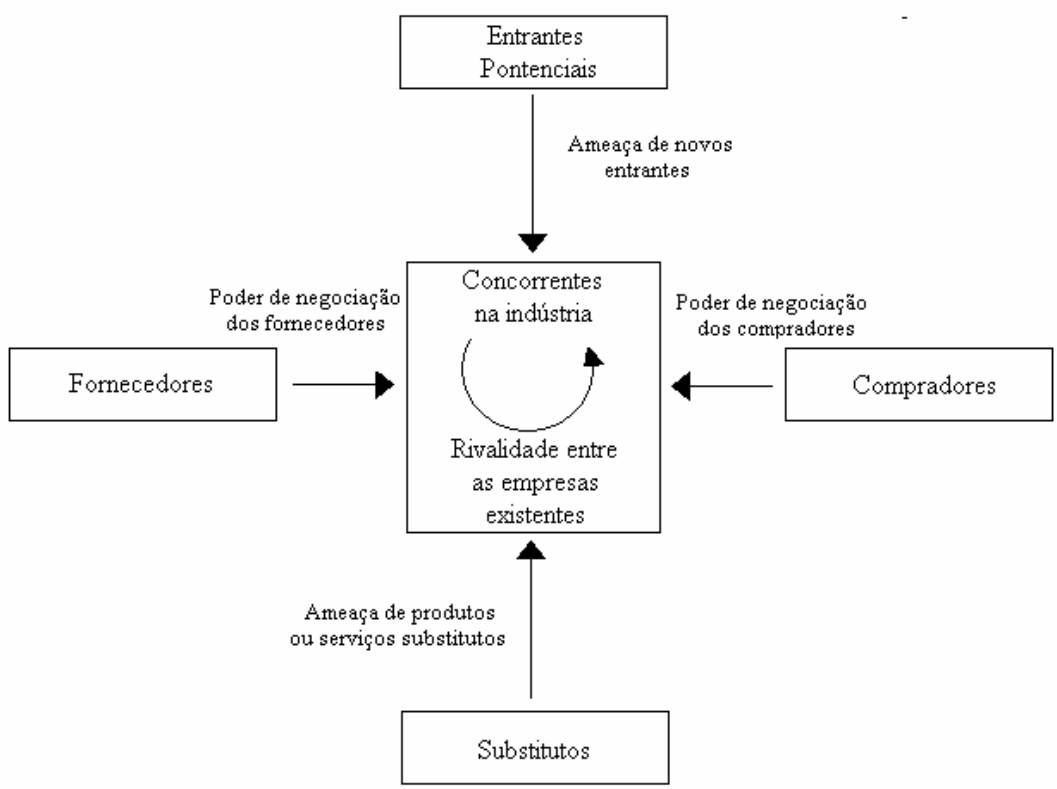

Figura 6 - Forças que dirigem a concorrência na indústria.

Fonte: Porter (1996, p. 23).

As ameaça de novos entrantes é condicionada pelas barreias à entrada cujas fontes fundamentais são: economias de escala, necessidades de capital, diferenciação de produto, custo de mudança e acesso a canais de distribuição. A rivalidade é conseqüência da interação dos seguintes fatores: número de concorrentes; velocidade de crescimento da indústria; peso relativo dos custos fixos na composição de gastos empresariais; baixa diferenciação ou custo de mudança; altos custos para a obtenção de incrementos de produção; concorrentes divergentes cujas assimetrias de estratégias impedem o entendimento acerca do funcionamento da indústria e baixas barreiras à saída. A ameaça de produtos substitutos é condicionada pela oferta de produtos e serviços de outros segmentos industriais que podem competir em um mesmo segmento de mercado ${ }^{20}$. Por fim, um alto poder de poder de negociação de fornecedores e clientes pode afetar a rentabilidade de um empreendimento ${ }^{21}$.

\footnotetext{
${ }^{20}$ A competição entre o transporte rodoviário e o de cabotagem constitui exemplo dessa ameaça.

${ }^{21}$ No primeiro caso, as condições de fixação do preço de um insumo podem afetar demasiadamente os custos de produção e consequentemente a rentabilidade de uma operação. No segundo, o cliente pode impor condições de aquisição (serviços pré o pós venda, por exemplo) que podem afetar a margem do ofertante.
} 
Ao examinar as características técnicas do navio, aspectos do transportes marítimos e da construção naval, Weiss (1990) aplica o modelo proposto por Porter (1996), visando estabelecer os principais direcionadores (drivers) das forças competitivas na indústria naval sob a ótica dos estaleiros. Ao fazer isso, Weiss (1990) tece as seguintes considerações.

1. ameaça dos novos concorrentes: a proteção contra a entrada de novos concorrentes está ligada à existência de barreiras a entrada. No caso do setor naval, a tecnologia não constitui uma barreira severa, pois em grande medida provém dos ofertantes de navipeças e bens de capital. A necessidade de capital não constitui uma barreira à entrada. Isso só se verificaria na ausência de incentivos governamentais. De maneira geral, as barreiras à entrada no setor naval são relativamente reduzidas, fato que explica a ascensão de diversos países como grandes construtores navais ao longo do tempo, como foi o caso da Coréia do Sul, no final da década de 1970, e China, no final do século passado. Ao contrário das barreiras à entrada, as especificidades e baixa liquidez dos ativos criam grandes barreiras à saída, o que pode comprometer a rentabilidade do setor em função do risco adjacente.

2. poder de negociação dos clientes: os clientes do setor naval são em geral as instituições públicas e as empresas privadas de navegação. São os incentivos governamentais que mantém o nível de atividade de grande parte dos estaleiros do mundo. Desde que disponham de serviços financeiros aderentes às demandas setoriais, as empresas de navegação podem adquirir seus navios em qualquer parte do mundo, aos preços que forem mais competitivos. Esse fato torna o poder de negociação dos clientes da ICN muito forte. Desse modo, a fixação de prazos, utilização de determinada matéria prima, componentes, etc., são sujeitos à aprovação dos armadores. Há forte pressão sobre as margens dos estaleiros.

3. poder de negociação dos fornecedores: a construção naval se caracteriza pelo processamento de aço e processos de instalação de equipamentos ao casco. Os fornecedores da ICN naval são em geral as siderúrgicas e o setor de navipeças. Devido à escala de suas operações, o setor de navipeças é altamente oligopolizado. Este setor atua como o 
principal provedor de tecnologia incorporada no navio. Além disso, o setor de navipeças atua no fornecimento de insumos específicos.

4. ameaça de produtos de substituição: não há substitutos perfeitos para o serviço de transporte marítimo. Dentre os meios de transporte para cargas destacam-se o aéreo, o ferroviário e o rodoviário. Desses três, somente o aéreo poderia substituir o transporte de longo curso. No entanto, devido aos custos e à capacidade de transporte, este não se torna substituto viável. Assim, a existência desse segmento deverá permanecer ainda por tempo indeterminado.

5. rivalidade interna: o setor naval vem experimentando intensificação da concorrência, queda de preços e baixa rentabilidade econômica. Com a entrada de novos estaleiros, principalmente na região asiática e a facilidade em construir navios nas diversas partes do mundo, têm aumentado o grau de competição nesse segmento.

\subsection{Sumário das Política de Incentivos, Importância e Parâmetros das Atuais Políticas de Financiamento em Países Selecionados}

Na mesma linha de argumentação estabelecida por Ruth (1991) ao discutir aspectos ligados ao processo de empréstimos de bancos privados, a intervenção do Estado no financiamento naval reflete a racionalidade da política setorial estabelecida. Analogamente aos bancos privados, cada país possui filosofia e estratégias próprias que respaldam a transferência de fundos destinados aos mercados de construção e transporte. Estas estabelecem os parâmetros de incentivos que se refletem na política de financiamento definindo critérios para a contratação de recursos (RUTH, 1991). Assim como a política de empréstimos dos bancos comerciais discutida por Ruth (1991), a política de empréstimo do setor público deve definir a área geográfica na qual o empréstimo pode ser feito, os tipos de empréstimos considerados desejáveis e não desejáveis, o alcance do mercado e várias outras especificações (regras de amortização, períodos de carência, etc.). Este processo é dinâmico e reflete alterações nos padrões de produção e comércio. 
Segundo Herfelt (2000) e Ruth (1991), os empréstimos de longo prazo são comumente empregados para financiar compras de ativos permanentes. Navios são enquadrados nesta categoria porque não são rapidamente consumidos nem depreciados. O empréstimo do montante necessário para viabilizar tais operações envolve o desembolso de grandes somas de recursos em um intervalo de tempo relativamente curto, ao longo do processo de construção. O pagamento do principal e dos juros é feito de maneira discreta, envolvendo períodos mais longos sendo estabelecido por meio da aplicação de sistemas específicos de amortização. Este reembolso à fonte financiadora varia de acordo com o esquema adotado (empréstimo a longo prazo, empréstimo hipotecário e leasing). A forma que condiciona como os recursos são contratados é denominada estrutura de crédito (RUTH, 1991).

No contexto dessas discussões, para a caracterização dos diferentes esquemas de financiamento se adotou o conceito de estrutura de financiamento proposto por Ruth (1991) que se refere ao "...processo por meio do qual as condições de pagamento e valor do empréstimo, seu suporte (se é por meio de garantia real, sem garantia, com garantia não real [...] ) e seu preço são combinados para atingir a finalidade à qual se destina o dinheiro que é tomado como empréstimo." (RUTH, 1991, p. 273) ${ }^{22}$.

Tendo esse conceito como referência, esta seção apresenta uma breve resenha acerca do caráter das atuais políticas de incentivos e das principais linhas de financiamento destinadas à construção naval em certos países (Japão, Coréia do Sul, China, Alemanha, EUA, Noruega e Brasil). Isso é feito a partir da descrição do funcionamento da indústria em sua relação com as políticas de apóio governamental. Esse procedimento foi necessário, uma vez que há grande escassez de informações relacionadas ao tema. Em parte isso se deve ao caráter não recorrente de tais operações e ausência de estudos acadêmicos orientados ao tema. Em razão disso e levando-se em conta o foco da pesquisa, o objetivo central dessa seção é apontar a racionalidade e os parâmetros centrais das respectivas estruturas de financiamento estabelecendo a relação desses fatores com o funcionamento da ICN.

\footnotetext{
${ }^{22}$ Embora extremamente importante para a análise de uma estrutura de financiamento a questão das garantias não é modelada nesse estudo.
} 
Com base nas informações apresentadas nas próximas subseções, uma síntese relacionada à estrutura de financiamento em cada um dos países objeto de investigação é apresentada no quadro 5 da seção 2.6. Desta maneira, as informações apresentadas a seguir dão apenas uma idéia impressionista acerca do assunto. Não obstante os dados apresentados serão empregados nos demais capítulos deste trabalho. Estudos futuros poderão dedicar maior atenção quanto à especificidade de cada caso.

\subsubsection{O Caso Japonês}

Até a década de 1950 a Europa era líder na construção naval. A década de 1960 marca a mudança no eixo da construção naval da Europa para a Ásia. Segundo Ferraz et al (2002) esse movimento resultou da falta de coordenação, eficiência e visão estratégica associada à presença de subsídios que, ao assegurar condições competitivas, distorciam a produtividade dos estaleiros locais.

O Japão possui uma reconhecida tradição em construção naval (BARBOZA, 2004; CAMINHA, 1980). Durante o pós-guerra, esta se refletiu na evolução no número de instalações destinadas à construção cuja média entre 1960 e 1995 foi de aproximadamente 250 milhões $\mathrm{GRT}^{23}$. Até o início da década de 1990, este país detinha a posição de principal construtor naval, sendo seguido e posteriormente ultrapassado pela Coréia do Sul.

Segundo a Empresa Brasileira de Planejamento de Transportes (1999), uma medida de importância estratégica ao setor marítimo é o volume de recursos investidos no setor. Até a década de 1970, “... um terço de todos os empréstimos do Japan Development Bank foi para projetos de transporte marítimo" (EMPRESA BRASILEIRA DE PLANEJAMENTO DE TRANSPORTES, 1999, p. 18). Nesse período "... todos os setores envolvidos com o transporte marítimo e a construção naval foram apoiados e acabaram se estruturando de maneira eficiente" (EMPRESA BRASILEIRA DE PLANEJAMENTO DE TRANSPORTES, 1999, p. 18). Em parte

\footnotetext{
${ }^{23}$ Do inglês: Gross Registred Tons (GRT).
} 
essa priorização reflete uma clara visão quanto a dependência comercial do país e importância estratégica da ICN (CAMINHA, 1980).

Em termos microeconômicos, o objetivo de tais políticas era manter o preço da construção o mais baixo possível - uma vez que a aquisição de navios estrangeiros teria custos elevados, sendo ainda suscetível a flutuações nos níveis de oferta e outras condições associadas à formação do preço das embarcações definidas no mercado internacional. Nesse contexto, "a indústria naval foi selecionada como um dos setores básicos no processo de desenvolvimento industrial" (EMPRESA BRASILEIRA DE PLANEJAMENTO DE TRANSPORTES, 1999, p. 18).

As políticas orientadas ao setor compeliam os armadores a contratar estaleiros locais, em especial por meio de incentivos financeiros. Fatores como comprometimento com o modelo de desenvolvimento, fidelidade dos armadores à indústria local, verticalização entre transporte e construção e baixo custo da mão-deobra, impulsionaram a expansão da ICN japonesa (EMPRESA BRASILEIRA DE PLANEJAMENTO DE TRANSPORTES, 1999).

A estabilidade da demanda doméstica, associada ao baixo custo de construção, maciços investimentos nos estaleiros ao longo dos anos 1960 e 1970 e esforço no sentido de viabilizar um rápido desenvolvimento tecnológico em processo e produtos, também explicam o sucesso do caso japonês. Em meio ao crescimento da capacidade de produção mundial, principalmente após o boom da ICN coreana, houve diminuição do efeito das decisões políticas internas no equilíbrio do mercado de construção (EMPRESA BRASILEIRA DE PLANEJAMENTO DE TRANSPORTES, 1999). A estratégia de penetração coreana que se baseou em baixos preços, provavelmente muitos contratos desse país foram estabelecidos com preços abaixo dos custos de produção, colocou em xeque o predomínio japonês (EMPRESA BRASILEIRA DE PLANEJAMENTO DE TRANSPORTES, 1999).

Em meio à crise verificada no setor ao longo dos anos 1970, o governo coordenou um processo de ajustamento reduzindo o número de grandes estaleiros de 21 para 8 . Isso foi facilitado por meio do processo de fechamento e promoção de fusões e aquisições (EMPRESA BRASILEIRA DE PLANEJAMENTO DE TRANSPORTES, 1999). Posteriormente, em meio ao incremento no custo da mãode-obra e valorização do iene frente ao dólar, a manutenção da competitividade da ICN japonesa só foi possível graças ao aumento na produtividade, que dobrou ao 
longo da década de 1980 (EMPRESA BRASILEIRA DE PLANEJAMENTO DE TRANSPORTES, 1999). Na percepção do governo e “... considerando as características peculiares da indústria naval, as políticas nacionais para o setor deveriam ser decididas observando-se as condições do mercado internacional" (RIZZO, 2003, p. 7).

Uma das principais características das empresas de construção naval japonesas é pertencer a grandes conglomerados que possuem atividades em muitos setores (siderúrgico, comércio exterior, bancário e, em alguns casos, navegação) (EMPRESA BRASILEIRA DE PLANEJAMENTO DE TRANSPORTES, 1999). De acordo com Cho e Porter (1986), a atuação desses conglomerados, operando com elevado grau de rivalidade interna, constitui importante fator no entendimento do sucesso do modelo japonês. Por outro lado, no Japão, as parcerias entre produtores e clientes também foram incentivadas. Estas desenvolveram elos importantes da cadeia de valores, apoiando a integração entre a indústria de navipeças, armadores e estaleiros (CHO; PORTER, 1986). Além de se valer do sistema de incentivos, estímulos orientados a realização de acordos de cooperação técnica e operacional aumentaram a eficiência produtiva dos estaleiros locais (BARBOZA, 2004).

Atualmente, o núcleo central da construção naval japonesa consiste em 19 empresas, que formam o SAJ (Shipbuilding Association of Japan). Entre essas empresas, se pode dizer que 7 são de grande porte e 12 estaleiros de médio porte. Em conjunto respondem por $95 \%$ do total da construção naval no país. Os estaleiros maiores, denominados os "7 Grandes" (Seven Majors), são os seguintes: Mitsubishi Heavy Industries; Ishikawajima Harima Heavy Industries; Hitachi Zosen Coporation; Kawasaki Heavy Industries; Sumitomo Heavy Industries; Mitsui Engineering \& Shipbuilding Co e NKK Co (BARBOZA, 2004).

Segundo Rizzo (2003) e Empresa Brasileira de Planejamento de Transportes (1999), no último decênio do século XX não havia mecanismos de subsídio governamental para a construção naval. Também não eram aplicados incentivos fiscais especiais orientados à ICN. Contudo, o Estado atuava por meio de esquemas de concessão de empréstimos, provisão de garantias e apoio governamental para a reestruturação e modernização das instalações de estaleiros.

O modelo de financiamento é híbrido. Uma parcela dos navios construídos para a exportação é financiada por meio do Exim Bank com aporte de recursos privados. Para o mercado doméstico, uma parte dos financiamentos é concedido 
pelo Japan Development Bank, também em parceria com bancos privados (EMPRESA BRASILEIRA DE PLANEJAMENTO DE TRANSPORTES, 1999; RIZZO, 2003). Atualmente, o financiamento à construção naval é, em grande parte, concedido pelo Maritime Credit Corporation (MCC). Esta instituição financeira é capitalizada pelo governo sendo estabelecida como uma corporação especial em termos de regime jurídico e tributário. A MCC disponibiliza fundos arrecadados pelo programa fiscal do governo japonês acrescidos de outras fontes de fundos públicos. Em razão de grande parte dos recursos serem públicos, a taxa de juros adotada é geralmente menor do que a praticada pelos bancos comerciais. Ao participar do financiamento à construção naval, o governo supervisiona contratos e construções juntamente ao MCC.

No Japão, alguns bancos privados dispõem de linhas de suporte às empresas do setor. O financiamento por meio de leasing também é amplamente utilizado. Em seu conjunto, o aporte de recursos e formas de repasse garante a manutenção de níveis de produção que se reverte em economias de escala e mobilização perene da mão-de-obra resultando em ganhos de aprendizado (CHO; PORTER, 1986). Atualmente, os maiores bancos japoneses especializados em shipping financing são o Sumitomo Mitsui Banking Corp. e o Mizuho and Bank of Tokyo - Mitsubishi.

O governo também oferece seguros de financiamento à exportação e provê garantias contra variações cambiais. Ao que tudo indica, estes esquemas de empréstimos são destinados prioritariamente para a construção de navios cargueiros e embarcações de passageiros.

Em termos estratégicos, de acordo com Barboza (2004) e Ferraz et al (2002), a estratégia competitiva da ICN japonesa está se orientando para a produção de um novo produto destinado ao transporte de contêineres de alta velocidade, grande capacidade de carga e direcionado aos "Hubs Ports". Trata-se do Technosuperliner (TSL). A difusão desse produto e êxito competitivo apresenta desafios. Se por um lado o TSL propicia menor preço no frete; por outro, compreende um produto de custo e preço de aquisição elevado com manutenção mais onerosa que os porta contêineres convencionais.

Segundo Ferraz et al (2002), ante a existência de uma capacidade construtiva superior a oferta, desde 1999 os japoneses estão envolvidos no esforço de intensificar a competitividade de sua ICN. As diretrizes são: intensificar os fundamentos operacionais e promover maior integração de recursos gerenciais. 


\subsubsection{O Caso Coreano}

Segundo Serra (2002), foi no início da década de 1960 que o setor de construção naval passou a ser considerado prioritário no desenvolvimento econômico da Coréia do Sul. Contudo, a ICN coreana começou a se desenvolver e alcançar taxas extremamente elevadas de crescimento somente no início da década de 1970 (EMPRESA BRASILEIRA DE PLANEJAMENTO DE TRANSPORTES, 1999). Embora desde a década de 1950 já houvesse mecanismos de incentivo e subsídios orientados ao setor, somente em meados desse período foram implantadas políticas amplas e sistemáticas de construção naval e transporte marítimo (EMPRESA BRASILEIRA DE PLANEJAMENTO DE TRANSPORTES, 1999).

Com efeito, a história da moderna construção naval coreana pode ser dividida em três períodos: iniciação (anos 1970), desenvolvimento e capacitação (anos 1980) e grande expansão (1990) (SERRA, 2002). Particularmente, o Terceiro Plano Qüinqüenal de Desenvolvimento Econômico (1972-76), teve como um de seus focos a indústria pesada. Nesse ínterim, a ICN coreana expandiu rapidamente sua capacidade produtiva, se consolidando como um setor estratégico (EMPRESA BRASILEIRA DE PLANEJAMENTO DE TRANSPORTES, 1999). As baixas barreiras à entrada, aprofundadas em meio à crise dos anos 1970, explicam o êxito alcançado $\left(\right.$ WEISS, 1990) ${ }^{24}$.

Analogamente ao processo de desenvolvimento dos países de industrialização tardia (late-late-commers), o processo foi orientado por grandes planos de desenvolvimento capitaneados pelo Estado (CAMPANARIO; SILVA, 2004). Nesse contexto, a expansão industrial coreana foi promovida com base em um modelo verticalizado que explorava vínculos intersetoriais (EMPRESA BRASILEIRA DE PLANEJAMENTO DE TRANSPORTES, 1999). Os grandes conglomerados de controle familiar (chaebol) tiveram um papel determinante no desenvolvimento das indústrias pesada e química, bases do processo de

\footnotetext{
${ }^{24}$ A depressão no setor afetou a indústria de navipeças e a indústria de construção facilitando a transferência de tecnologias dos estaleiros japoneses aos estaleiros coreanos.
} 
industrialização do país. Como as principais empresas de transporte pertenciam a conglomerados que também possuíam estaleiros, uma grande parcela das compras era realizada no mercado local (SERRA, 2002). A rigor o volume de recursos canalizados por tais conglomerados explica o desenvolvimento de vários segmentos industriais coreanos, incluindo a indústria de semicondutores.

No início dos anos 1970, além das medidas governamentais de apóio, são enumerados como fatores de sucesso a capacidade gerencial, evolução tecnológica, o baixo custo de mão-de-obra, a posição geográfica, além do aporte de recursos dos chaebols (RIZZO, 2003). Por outro lado, como boa parcela da produção se destinava às exportações, desde sua "gênese" a ICN coreana esteve sujeita as exigências e requisitos de eficiência internacionais, favorecendo o incremento contínuo da competitividade da ICN (SERRA, 2002).

O principal instrumento da política nas fases de iniciação e forte expansão da ICN foi o sistema de financiamento favorecido para a aquisição de navios por armadores nacionais. O sistema era complementado com um conjunto altamente abrangente de medidas de reserva de carga (EMPRESA BRASILEIRA DE PLANEJAMENTO DE TRANSPORTES, 1999). O armador, selecionado pelo governo, tinha acesso a linhas especiais de financiamento que se destinavam a operação de embarcações em um mercado amplamente protegido, sob a condição de construir em estaleiro nacional. O sistema era operado por elevado grau de intervenções, diretas e indiretas, objetivando o desenvolvimento simultâneo da ICN, marinha mercante e das indústrias subsidiárias. A rigor, este sistema "denominado Keihek Zoseon tinha como princípio: a carga do comércio coreano deve ser transportada em navio coreano e navio coreano deve ser construído em estaleiro coreano" segundo Lee (1996 apud EMPRESA BRASILEIRA DE PLANEJAMENTO DE TRANSPORTES, 1999).

Até o lançamento do Keihek Zoseon, em 1975, não havia uma integração direta entre os segmentos de navegação e construção naval na Coréia (SERRA, 2002). A reserva de transporte de minérios, por exemplo, e a obrigatoriedade de construção em estaleiros nacionais constituíram pontos essenciais do modelo. Este também promoveu o desenvolvimento da indústria de máquinas e equipamentos destinados à construção naval. Nesse ínterim, a ICN e indústrias correlatas tiveram sua capacidade instalada amplamente expandida. $O$ feito foi tornar essa indústria competitiva, orientada às exportações de caráter estratégico (SERRA, 2002). 
A maior parte dos recursos que viabilizaram esta rápida expansão eram provenientes do Fundo Nacional de Investimento do governo. Este respondia por aproximadamente $70 \%$ do montante disponível à construção naval. O restante era complementado pelo Banco de Desenvolvimento da Coréia. No período foram alocados cerca de 180 bilhões de won no setor (SERRA, 2002). Além de outras medidas, o Keihek Zoseon oferecia recursos a juros subsidiados à exportação de embarcações. Segundo Serra (2002), o sucesso do programa “... estava no fato de que, em meio a uma política de forte incentivo à exportação, os juros cobrados internamente estavam abaixo das taxas dos bancos comerciais, uma vez que a construção naval era uma das indústrias [consideradas] prioritárias (SERRA, 2002, P. 247)".

Além do sistema de financiamento, os produtores locais gozavam de incentivos fiscais e subsídios diretos (EMPRESA BRASILEIRA DE PLANEJAMENTO DE TRANSPORTES, 1999). A rigor, a criação do Korean Maritime and Port Administration, em 1976, e a promoção de diversos incentivos fiscais e facilidade de empréstimos para a aquisição de navios foram medidas de grande importância para a consolidação da ICN coreana. A navegação costeira absorveu mais da metade dos navios construídos entre 1976 e 1996. Como a orientação geral da economia se voltava para a exportação de manufaturados, sendo subsidiária da importação de petróleo e bens intermediários, as empresas de navegação eram estimuladas a adquirir navios fabricados nos estaleiros locais (SERRA, 2002).

Durante os anos 1980, embora haja indícios que a estratégia de penetração da ICN coreana estivesse baseada no estabelecimento de preços abaixo dos custos de construção, a rápida penetração no mercado somente pôde ser alcançada com consideráveis ganhos de produtividade, elevados níveis de alavancagem financeira e com as implicações que isso representava (EMPRESA BRASILEIRA DE PLANEJAMENTO DE TRANSPORTES, 1999). O grau de endividamento e os problemas que surgiram resultaram na implementação da Lei de Racionalização da Indústria Naval. Esta objetivava: melhorar a produtividade; reforçar a competitividade por meio de mecanismos de regulamentação e controle com vistas a coibir a "expansão imprudente" e prática de dumping e melhorar a estrutura financeira das empresas (EMPRESA BRASILEIRA DE PLANEJAMENTO DE TRANSPORTES, 1999). Assim, analogamente ao que houve no Japão, a ICN coreana passou por um processo de fusões e aquisições regulado pelo Estado. 
Segundo Rizzo (2003), em 1995 o governo coreano anunciou uma nova política de construção destinada a vigorar por 10 anos. O objetivo era reforçar a posição da ICN em torno de sua estratégia de exportações. Os pontos principais das medidas visavam: permitir maior acesso ao mercado local; reduzir os subsídios ao setor fazendo com que o governo atuasse mais no sentido de melhorar o ambiente de negócios do setor, reduzir a regulamentação e ampliar o nível de cooperação internacional. Conforme sugerido pelas informações estatísticas apresentadas na revisão bibliográfica, estas medidas parecem ter surtido o efeito desejado. Já na virada do século XX a Coréia se tornou o maior produtor mundial.

Atualmente, a construção naval na República da Coréia conta com 11 indústrias, reunidas na Associação de Construção Naval da Coréia (Korea Shipbuilders Association). O país atingiu a liderança na produção mundial nos últimos anos e a indústria naval é uma das mais importantes do país. Cerca de $95 \%$ do total da construção estão concentrados nas 4 maiores empresas: Samsung Heavy Industries; Hyundai Heavy Industries; Daewoo Shipbuilding \& Heavy Machinery e Hanjin Heavy Industries (BARBOZA, 2004).

Essas grandes empresas são altamente verticalizadas, tirando proveito de economias de escala, escopo e de rede. A concentração e volume de capital à disposição dos grandes conglomerados coreanos facilitam o investimento em grandes empreendimentos (BARBOZA, 2004). Isso torna possível a prática de operações baseadas em "subsídios cruzados" implicando em ganhos por meio da garantia de continuidade de operações e permanente mobilização de equipes de trabalho. Isso implica na obtenção de economias externas por meio da aceleração dos processos de aprendizado e amplia o poder de barganha das empresas junto aos seus fornecedores.

Em suma, na Coréia do Sul, assim como no Japão, o governo desempenhou forte papel no desenvolvimento da ICN por meio de subsídios diretos e alocação de fundos especiais destinados a promover o setor. Estes proveram recursos para financiamento setorial dando prioridade às exportações de navios.

A rigor, os fortes subsídios existentes na ICN coreana permitiram uma conquista de parcela importante do mercado por meio de construção de navios a baixo custo (IRENE et al, 2001). Assim como no Japão, o diferencial de custos resulta do elevado grau de automação nos processos produtivos. Contudo, a automação das plantas industriais nesses países possui limitações. Segundo 
informações coletadas junto a representantes de estaleiros brasileiros, os estaleiros coreanos podem produzir apenas 7 ou 8 tipos de navios ${ }^{25}$. Grandes alterações em projetos, a depender das exigências do armador, dificilmente podem ser produzidos sem grande absorção de despesas, o que repercute sobre o valor desses contratos. A produção seriada parecer ter subvertido alguns dos aspectos da produção sob encomenda.

Como um dos grandes focos da política setorial (bem como no Japão e na China) se orienta ao incremento do comércio, grande parcela do financiamento à construção naval na Coréia do Sul é feito pelo banco Korea Eximbank, por meio de um programa denominado "Export Loan". Tal programa é dirigido para as exportações coreanas funcionando como provedor de crédito a fim de estimular a exportação de bens de capital, tais como plantas, maquinaria industrial e navios. Desta forma, envolve grande volume de créditos o que, associado às características desses empreendimentos, exige longos prazos de pagamento. Em termos estruturais, essa prática reflete a orientação externa do sistema produtivo coreano e a capacidade financeira dos conglomerados locais.

Do ponto de vista estratégico, o sistema de incentivos em funcionamento no Japão e na Coréia do Sul se combina com outros fatores: escala de operação das empresas, elevados gastos em P\&D, ênfase dada aos aspectos tecnológicos (uso intensivo de inovações na produção e acabamento, aumento nos índices de automação e implantação de modernas técnicas de gestão de produção) (BARBOZA, 2004). Em suma, o sistema de incentivos apresenta repercussões econômicas de longo alcance imprimindo grande dinamismo produtivo e comercial à ICN desses dois grandes players mundiais.

\subsubsection{O Caso Chinês}

Até a década de 1950, a ICN chinesa era incipiente. A escassa produção naval se destinava quase que exclusivamente à navegação fluvial interior. O regime comunista viria a instituir, a partir da década de 1950, a estatização dos estaleiros.

\footnotetext{
${ }^{25}$ No capítulo 4 são apresentados os resultados de entrevistas feitas junto a empresas de armação e estaleiro. Estas se encontram dentro do escopo da metodologia proposta no capítulo 1.
} 
Esta foi acompanhada da implementação de ambicioso plano de construção naval. Em meio ao processo de abertura verificado durante a década de 1970, as encomendas de Hong-Kong viabilizaram a construção de navios graneleiros simples e com baixo conteúdo tecnológico. Em virtude da expansão de encomendas de armadores europeus, atraídos pelos baixos preços praticados, ocorreu um processo de expansão e consolidação da ICN chinesa (BARBOZA, 2004).

A indústria naval chinesa vem apresentado altas taxas de crescimento desde a década de 1980 (CHO; PORTER, 1986). Segundo Ferraz et al (2002) a exportação de navios é uma das principais fontes de receita em moeda forte a China. Contudo, os incrementos da produção têm sido menores do que os verificados na Coréia do Sul ao longo dos anos 1970 (EMPRESA BRASILEIRA DE PLANEJAMENTO DE TRANSPORTES, 1999) ${ }^{26}$. Esta expansão, ocorrida no contexto da estabilidade parcial verificada no mercado de fretes ao longo dos anos 1990 (ALEX, 2004), é acompanhada por uma significativa mudança no destino final das embarcações produzidas na China. A produção (medida em TPB) absorvida pelo mercado externo saltou de 60\%, em 1994, para 80\%, em 1996 (EMPRESA BRASILEIRA DE PLANEJAMENTO DE TRANSPORTES, 1999). Associada ao baixo preço em relação ao mercado internacional, essa dinâmica tem implicado em perdas de fatias de mercados pelos construtores europeus (BARBOZA, 2004). Contudo, estes ainda se mantêm em nichos importantes, como é o caso do segmento de navios de maior conteúdo tecnológico, como os de passageiros (SERRA, 2002).

Vários autores, entre eles Barboza (2004), Cho e Porter (1986) e Fadda (2006), argumentam que a China se consolidará como um dos maiores fabricantes mundiais de navios no século XXI. A evolução dos negócios navais chineses esta associada a uma tendência de ampliação no crescimento da produção, incremento de exportações e aquecimento da oferta local de serviços de transporte. O forte incremento do comércio interno e externo tende a aquecer ainda mais o mercado chinês de construção naval. Associado a estas tendências, grandes empresas navais como a Cosco e a China Shipping têm obtido taxas de retorno crescentes e conseguindo aumentar sua participação nos segmentos em que atuam tornando-se grandes cases de sucesso no mercado naval (ALEX, 2004).

${ }^{26}$ Os principais estaleiros atuando hoje na China são o North Shipbuilding Group e o South Shipbuilding Group (BARBOZA, 2004). 
Apesar dessas previsões otimistas o crescimento da produção chinesa enfrenta grandes desafios. Do ponto de vista estrutural, limitações técnicas e operacionais são apontadas por especialistas. Adicionalmente, o crescimento tem ocorrido em meio à escassez de divisas para suportar a continuidade da expansão. Fato que deve restringir o aumento da produção naval (EMPRESA BRASILEIRA DE PLANEJAMENTO DE TRANSPORTES, 1999).

Outro desafio importante para a ICN chinesa continuar a crescer é seu ingresso na Organização Mundial do Comércio (OMC) e a correspondente necessidade de adequação de suas práticas comerciais às regras institucionais que regulam o comércio internacional. Frequentemente o país é acusado de práticas de dumping social e as pressões OMC devem reverter parcialmente o movimento de expansão do comércio. Tais restrições podem dificultar o acesso aos mercados impedindo que seus estaleiros consigam manter preços competitivos, pois, como aponta o relatório da Empresa Brasileira de Planejamento de Transportes (1999), uma das principais vantagens competitivas da ICN chinesa é o custo de mão-deobra.

Restrições de natureza estrutural também são apontadas. Por exemplo, embora os custos de mão-de-obra sejam extremamente baixos, a pressão para a geração de empregos tende a distorcer os índices de produtividade da ICN chinesa - segundo Barboza (2004) e Ferraz et al (2002), enquanto um estaleiro na China, ocupa de 9.000 a 12.000 trabalhadores, no Japão, um estaleiro com a mesma capacidade produtiva absorve de 900 a 1.500 operários.

Embora grande parcela do setor produtivo chinês esteja gradualmente evoluindo para um padrão orientado pela capacitação em desenvolvimento de produtos e processos, exigências quanto aos padrões de qualidade tendem a pressionar os coeficientes de importação introduzidos nas embarcações (FERRAZ et al, 2002) $)^{27}$. Se quiserem manter os crescentes volumes de exportação de navios no padrão desejado pelos armadores internacionais e locais, os estaleiros chineses devem lidar com a necessidade de importar projetos, grande parcela de peças e equipamentos e, até mesmo, alguns tipos de aço (BARBOZA, 2004; FERRAZ et al, 2002). Tais exigências fragilizam a competitividade da ICN chinesa, pois tendem a se repercutir sobre os custos de produção encarecendo e tornando menos

\footnotetext{
${ }^{27}$ Os coeficientes de importação se referem à participação relativa do valor das importações no valor final de uma embarcação
} 
competitiva a produção para o mercado internacional. A importação de tecnologia também se faz sentir em outras categorias de gastos. Muitas licenças para uso de projetos e processos são desenvolvidas e comercializadas por empresas japonesas (EMPRESA BRASILEIRA DE PLANEJAMENTO DE TRANSPORTES, 1999).

O padrão de crescimento chinês tem sido marcado por desequilíbrios que se difundem a outros mercados. Figurando entre as maiores economias do mundo, as altas taxas de crescimento chinesas têm causado elevações nos preços internacionais dos commodities. O mercado de aço está aquecido e têm reflexos sobre o preço final das embarcações.

$\mathrm{Na}$ China a participação do governo é feita de forma direta por meio da atuação de estaleiros estatais e aporte de recursos financeiros ao setor. Apesar disso, a escassez de recursos governamentais restringe maiores expansões na capacidade produtiva. Uma saída a estas restrições é promoção de uma maior abertura da ICN chinesa ao investimento externo e a obtenção de aporte tecnológico e gerencial que isso venha a representar (EMPRESA BRASILEIRA DE PLANEJAMENTO DE TRANSPORTES, 1999).

Embora se verifiquem condições adversas, a ampliação da participação dos bancos chineses no financiamento à ICN nos últimos anos tem contribuído, ao lado do baixo custo de mão-de-obra, crescente aporte tecnológico e altas taxas de crescimento da economia, para explicar a expansão da produção naval chinesa.

Associado ao crescimento da atividade de construção e transporte naval chineses há os grandes bancos. Estes têm participado ativamente no processo do ship financing (ALEX, 2004). Bancos como o China Eximbank, The Bank of China e o Industrial Commercial Bank of China, estão entre os maiores credores na ICN. Agências de crédito de exportação fornecem outra importante fonte de crédito de capital para o ship financing. Nessa lista se incluem empresas como a China Shipping, em Hong Kong e bancos, como o China Construction Bank, o Shanghai Pudong Development Bank e o Agricultural Bank of China.

O financiamento à ICN também é feito pelo China Eximbank. Este banco possui uma linha especial de crédito denominada "Export Buyer's Credit" que é destinada ao credito de médio e longo prazo. Os empréstimos oferecidos por esta instituição estimulam a exportação de bens de capital, incluindo o financiamento para a exportação dos navios, provisão de serviços e desenvolvimento de projetos chineses. O Export Buyer's Credit financia em até $80 \%$ a construção de um navio 
para exportação. O prazo máximo para o pagamento do empréstimo é de 15 anos. A taxa de juros pode ser fixa, baseada na Commercial Interest Reference Rate (CIRR), conforme anunciada mensalmente pela OCDE, ou uma taxa de juros flutuante, baseada na London Interbank Offered Rate (LIBOR), acrescida de uma taxa de cobertura de crédito. Em alguns casos especiais a taxa de juros pode ser negociada entre o Eximbank e o mutuário.

\subsubsection{O Caso Americano}

Nos EUA, a política de marinha mercante e construção naval sempre foram preponderantemente orientadas pelo Estado (KENDALL; BUCKLEY, 2005). Desde sua fundação, o país possui forte tradição no protecionismo e intervencionismo no setor - sempre dando ênfase à importância da ICN em sua economia. A despeito disso, os mecanismos de incentivo concedidos à ICN americana são contestados, pois não foram capazes de transformar o país em um dos grandes produtores mundiais. Ademais, a produtividade (medida em navios produzidos por carreira) de sua indústria naval é bem inferior à verificada em países como Coréia do Sul, Japão e China.

Segundo Kendall e Buckley (2005) e Empresa Brasileira de Planejamento de Transportes (1999), a política marítima norte americana é sustentada pelo Jones Act (1920) e os dispositivos do Merchant Marine Act (1936). A rigor o Jones Act reserva todo o tráfego de cabotagem aos navios de bandeira americana, construídos e reparados nos EUA, e de propriedade de cidadãos americanos (KENDALL; BUCKLEY, 2005). Por outro lado, até a década de 1990, o Merchant Marine Act constitui "o sistema de proteção e subsídios à operação e à construção de navios mais amplo dentre os adotados em países de economia capitalista" (EMPRESA BRASILEIRA DE PLANEJAMENTO DE TRANSPORTES, 1999, p. 34).

Até o início dos anos 1980, um dos dispositivos centrais do esquema de proteções era o Construction Differential Subsidy (CDS) que consistia na provisão de subsídio à construção como meio de compensar os estaleiros de desvantagens de custo em relação a concorrentes internacionais. Nesse período, quase todos os 
navios contavam com subsídios governamentais. (EMPRESA BRASILEIRA DE PLANEJAMENTO DE TRANSPORTES, 1999).

$\mathrm{Na}$ aquisição de navios nacionais, os armadores locais também contavam com sistema de provisão de garantias oferecido pelo governo. O Title $X I$, oferecido pelo Maritime Administration (MARAD), cobria até $75 \%$ do valor dos financiamentos, que poderiam ser firmados em até 25 anos. O financiamento para o setor de construção naval norte-americano feito por meio do Title XI Program, teve origem em 1936. Uma das principais características do programa era seu sistema de garantias. Por meio dele, o Governo americano oferecia garantias ao financiamento destinado à construção de embarcações em estaleiros americanos.

Em meio à execução de uma política fiscal restritiva praticada durante o governo Reagan, governo americano deixou de prover recursos ao programa fazendo com que os estaleiros americanos praticamente deixassem de produzir navios mercantes. A rigor, o fim da política de subsídios em 1981, o término da Guerra Fria (com a redução do orçamento militar) e a competição com os estaleiros Japoneses e Coreanos fez a produção sofrer severa redução (FERRAZ et al, 2002). Segundo o relatório da Empresa Brasileira de Planejamento de Transportes (1999), entre 1983 e 1992, somente oito navios de grande porte foram construídos em território americano. A operação dos estaleiros se restringiu a oferta de serviços de reparo e construção de navios para uso militar (BARBOZA, 2004). Durante a década de 1980 as reduzidas encomendas da marinha foram responsáveis por grande parcela dos níveis de ocupação dos principais estaleiros. Entre 1980 e 1991 estas registraram uma média de 18 navios contratados por ano (EMPRESA BRASILEIRA DE PLANEJAMENTO DE TRANSPORTES, 1999).

Ante ao fim da Guerra Fria no início da década de 1990, passou a haver a necessidade de uma reorientação da produção para o setor mercante. Em meio à expressiva expansão e ganhos de produtividade dos estaleiros asiáticos, o setor passou a atuar em situação extremamente desfavorável (EMPRESA BRASILEIRA DE PLANEJAMENTO DE TRANSPORTES, 1999). A produtividade da ICN americana é baixa quando comparada a estes países. No início da década de 1990, estimava-se que a produtividade da mão-de-obra alcançava apenas $40 \%$ da produtividade da ICN japonesa (EMPRESA BRASILEIRA DE PLANEJAMENTO DE TRANSPORTES, 1999). 
Em meio à crise da ICN americana, uma série de subsídios foram reeditados. Simultaneamente seria publicada legislação exigindo a substituição da frota de petroleiros de caso simples para casco duplo. Graças à provisão de subsídios os estaleiros americanos conseguiram contratar as encomendas (FERRAZ et al, 2002).

Em 1994 o governo americano reativou o Title XI. Nesse ínterim, as regras foram alteradas permitindo a construção de navios para armadores estrangeiros e empréstimos orientados para a modernização de estaleiros. Por outro lado, tem se ampliado, nas contratações por meio do Title Act, a não inclusão do Jones Act nos acordos (EMPRESA BRASILEIRA DE PLANEJAMENTO DE TRANSPORTES, 1999). Isso indica uma clara flexibilização na política orientada ao setor.

Em linhas gerais a finalidade do Title Act é promover o crescimento e a modernização da frota naval mercante dos estaleiros dos EUA. O programa permite aos proprietários de embarcações e de estaleiros obter o financiamento de longo prazo, em condições atrativas aderentes as características dos empreendimentos. Atualmente, as embarcações elegíveis para o auxílio do programa incluem geralmente embarcações mercantes. Quanto à tecnologia elegível, inclui-se geralmente emprego de técnicas e processos que comprovadamente resultem em maior produtividade e qualidade dos estaleiros.

O aporte de recursos se beneficia da maturidade e liquidez do mercado mobiliário americano. Os fundos para o programa são obtidos por meio de fontes diversas como bancos, fundos de pensão, companhias de seguro de vida, subscrição de títulos e aportes governamentais.

A atual política orientada ao setor é orquestrada pelo Maritime Administration (MARAD) e se baseia no apoio ao setor por meio de políticas protecionistas e grandes aportes financeiro. A rigor, a política naval e de marinha mercante americana ainda figuram entre as mais protecionistas do mundo (KENDALL; BUCKLEY, 2005). Um dos focos do financiamento é o estímulo à introdução de modernas tecnologias de construção de navios. O programa é administrado pela Secretaria de Transportes (Secretary of Transportation), que atua por meio da Administração Marítima (Maritime Administrator). A política naval se combina à política de marinha mercante como meio de gerar estímulos à produção local.

Do ponto de vista operacional, o financiamento, garantido pelo governo, é baseado em estimativas de custo das embarcações ou no aporte de tecnologias empregadas, acompanhados pela Secretaria de Transportes. O custo real de uma 
embarcação inclui geralmente aqueles artigos que normalmente são capitalizados como custos sob práticas usuais da contabilidade, tais como o custo da construção da embarcação, associado ao período da construção e a taxa de garantia.

O Programa Title financia até $87,5 \%$ da construção, com prazo de até 25 anos para amortização do financiamento. O débito é geralmente quitado por meio de pagamentos semestrais do valor do contrato, acrescido de uma taxa acumulada de juros.

O financiamento utiliza taxas de juros fixas ou flutuantes, mas que são atrativas ao financiamento. A taxa de garantia é estabelecida entre do $0,5 \%$ e $1 \%$ da obrigação, no ato de fechamento no contrato. A taxa de juros é determinada pelo setor privado, que geralmente utiliza como medida as obrigações do Tesouro Americano para a sua determinação. O MARAD deve determinar se as taxas são aceitáveis.

Em 1981, existiam 22 grandes estaleiros, nos Estados Unidos, construindo navios de grande porte para o governo norte-americano e para a marinha mercante. Atualmente operam apenas seis: Avondale Industries, New Orleans, LA; Bath Iron Works, Bath, ME (controlado pela General Dynamics); Electric Boat, Groton, CT (controlado pela General Dynamics); Ingalls Shipbuilding, Pascagoula, MS (Litton Industries); National Steel \& Shipbuilding Co. (NASSCO), San Diego, CA (controlado pela General Dynamics) e Newport News Shipbuilding, Newport News, VA. Assim como no Japão e Coréia do Sul, o mercado de construção naval passou por um processo de reestruturação orientado pelo Estado. Este teve como base o fim de subsídios providos pelo Marad. Com isso o número de grandes estaleiros se reduziu para apenas seis. Estes são denominados "Big Six”. A partir de 1990 houve reedição com ampliação dos subsídios governamentais (BARBOZA, 2004).

Os fatores apontados como essenciais à vantagem competitiva da ICN americana são o custo da mão-de-obra (menor que os verificados no Japão e Alemanha) e a existência de uma sólida base tecnológica para o desenvolvimento de projetos e processos. Contudo, reformas rápidas e profundas nos mecanismos de incentivos encontram resistência ante a cultura dos estaleiros e práticas consolidadas de gestão da produção (EMPRESA BRASILEIRA DE PLANEJAMENTO DE TRANSPORTES, 1999). 


\subsubsection{O Caso Alemão}

A Alemanha vem se destacando ao longo dos últimos anos como um dos maiores produtores navais no mercado europeu e mundial. Os esforços no sentido de prover contínuos ganhos de produtividade, a presença de uma indústria de serviços de apóio ampla e eficiente e a concentração verificada ao longo dos últimos anos no mercado de construção estão no cerne deste desempenho. Essas condições, associadas fundamentalmente ao apoio político e financeiro dos governos central e local, explicam o desempenho favorável verificado pela ICN alemã em meio a crise do setor nos anos 1980 (EMPRESA BRASILEIRA DE PLANEJAMENTO DE TRANSPORTES, 1999).

Se até os anos 80 a competitividade da ICN alemã se baseada em políticas de subsídio (sobre pretexto de compensar as vantagens competitivas dos países asiáticos), atualmente a política de incentivos fiscais constitui um dos aspectos centrais do modelo (EMPRESA BRASILEIRA DE PLANEJAMENTO DE TRANSPORTES, 1999). Estas práticas vão de encontro aos esforços empreendidos pelo governo com objetivos de eliminar os subsídios à produção implementados na Europa a partir de 2000 (FERRAZ et al, 2002). O sistema se baseia na concessão de isenções fiscais extremamente significativas orientadas aos investimentos em carteira feitos em navios de bandeira alemã (EMPRESA BRASILEIRA DE PLANEJAMENTO DE TRANSPORTES, 1999; NORTON ROSE, 2005).

Na década de 1990, a possibilidade de obter isenções tributárias previstas no regime fiscal aumentou a atratividade dos investimentos orientados no setor. Investidores que obtinham grandes rendimentos tributáveis passaram a aderir ao promissor mercado de fundos de investimentos que se desenvolveu a partir do modelo denominado Kommanditgesellschaft ou KG (figura 7) (NORTON ROSE, 2005). Nesse contexto, os fundos de investimento em navios tornaram-se produtos que oferecem um campo atrativo, envolvendo o desejo de cada investidor em auferir benefícios fiscais. Em meio à crescente popularidade do "Modelo KG", o investimento no setor de transporte marítimo se difundiu. Dados apresentados por Norton Rose (2005) indicam o crescimento no volume total de fundos investidos no setor. Entre 1993 e 2003, o volume total de fundos aumentou aproximadamente $700 \%$ (de $€ 1,5$ bilhão para algo em torno de $€ 7,0$ bilhões). Ao viabilizar os 
negócios, o crescente influxo de investimentos possibilita, além de benefícios tributários, "divisão dos riscos empresariais" entre as participações e ofertantes de capital próprio (NORTON ROSE, 2005).

A adoção de um esquema de tributação sobre tonelagem gerou incentivos adicionais aos investidores uma vez que a participação das exportações no produto alemão é da ordem de $50 \%$ do PNB (Produto Nacional Bruto) ${ }^{28}$. A generalização de negócios orientados à exportação estimulou o volume de recursos canalizados para tais fundos. O modelo KG assegura que as políticas governamentais possam oferecer vantagens a conglomerados de mesmo controle acionário, sob a forma de redução de imposto de renda incidentes sobre resultado das operações - o qual compõe o time charter das embarcações. Do ponto de vista estrutural, as expectativas de benefícios favorecem a criação de grandes conglomerados capazes de competir com a indústria americana e asiática.

A estrutura de financiamento de navios "KG" não é nova, mas recentemente tem recebido maior atenção na indústria naval e dos armadores alemães. O sucesso do modelo atraiu um grande número de armadores e instituições financeiras. A estrutura básica do modelo KG é relativamente simples (figura 7). O KG funciona como uma sociedade limitada de obrigações cujos recursos são providos por investidores privados que atuam como sócios limitados (NORTON ROSE, 2005). Os recursos do KG são canalizados para a aquisição de embarcações. Estas são afretadas por um determinado período de anos. O preço de compra do navio é financiado em parte pelos investidores privados e em parte por um empréstimo bancário. O valor das participações geralmente figura entre 35-50\% e 65-50\% para investimento privado e empréstimo bancário, respectivamente, sendo segurado pela hipoteca do navio. O período de arrendamento depende do porte e do tipo do navio. Por exemplo, porta contêineres (pequenos) possuem um período de arrendamento que varia entre três e cinco anos enquanto que para navios maiores, especializados em algum tipo de serviço, o período de arrendamento sobe para dez ou mais anos (NORTON ROSE, 2005).

\footnotetext{
${ }^{28}$ O Produto Nacional Bruto mede a totalidade de bens e serviços gerados pelos fatores de produção possuídos por um país.
} 


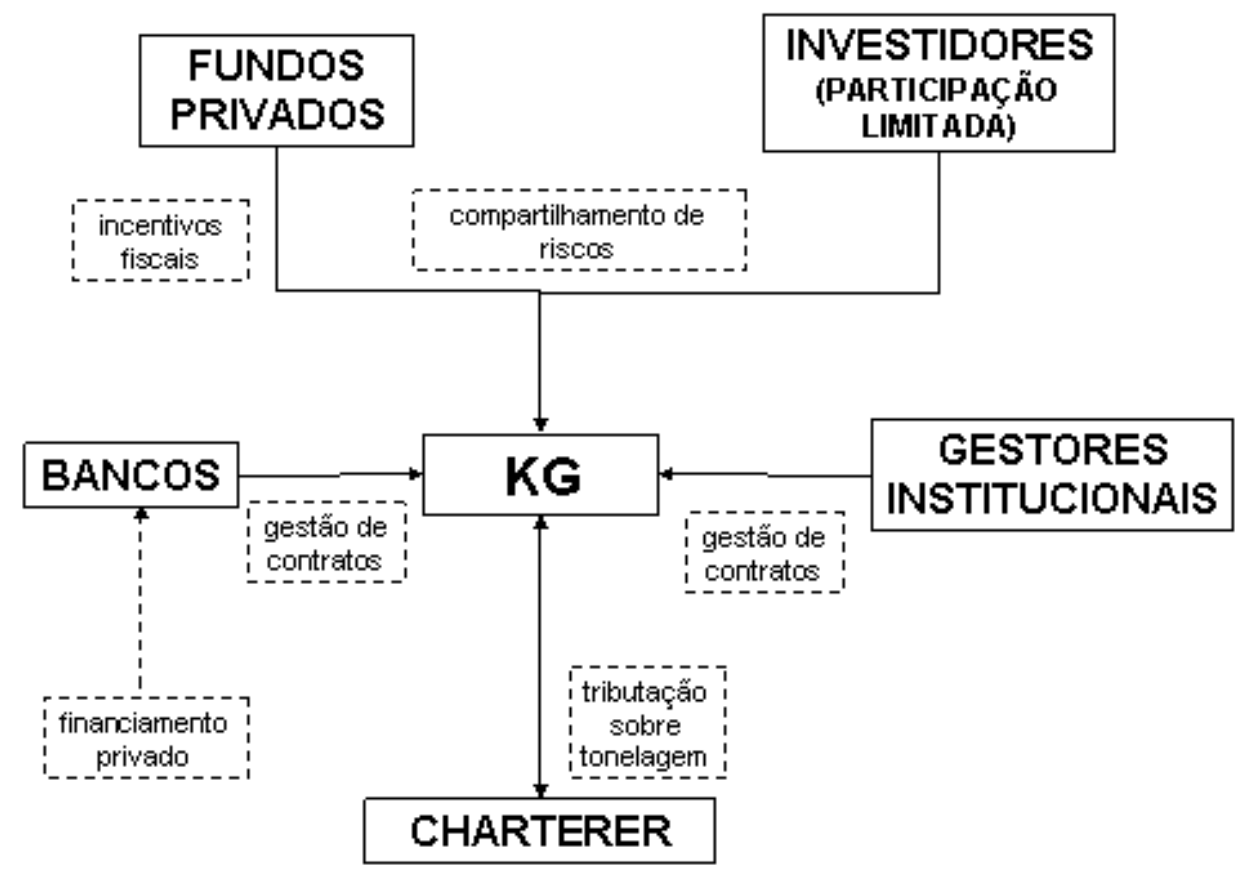

Figura 7 - Estrutura básica do modelo KG. Fonte: Adaptado de Norton Rose (2005, p. 2).

A principal razão para os investidores aderirem o modelo $K G$ diz respeito aos benefícios que são obtidos pelo sistema de tributação alemã sobre a tonelagem do navio. O sistema de tributação incide sobre os investidores individuais a partir de uma faixa de tributação. De acordo com o sistema de tributação sobre a tonelagem do navio, o imposto sobre o rendimento não é cobrado com base no resultado operacional. Ao contrário disso, são estimados lucros fixos com base no volume de carga líquida do navio. Esta estimativa de lucro, que também cobre qualquer lucro adicional obtido com a venda de um navio, resulta em uma insignificante taxa de imposto sobre os lucros realmente obtidos nas operações (NORTON ROSE, 2005).

Atualmente a maioria das estruturas KG combina benefícios fiscais com a aplicação do imposto sobre a tonelagem. O modelo é híbrido e prevê flexibilidade aos investidores. Estes utilizam os benefícios fiscais da depreciação e de outras despesas nos primeiros anos de operação a fim de reduzir o rendimento tributável. Só depois optam por adotar o regime de tributação sobre tonelagem (NORTON ROSE, 2005). 
O sistema de tributação sobre a tonelagem foi corrigido recentemente e mudou a forma de concessão dos benefícios fiscais obtidos com o uso do modelo KG. Essa mudança marcou a passagem de um modelo combinado que desapareceu em $1^{\circ}$. de Janeiro de 2007. Dessa data em diante, o modelo KG passou a permitir apenas ao proprietário do navio optar pelo tratamento da tributação sobre a tonelagem ao adquiri-lo, ou depois de dez anos após a compra do navio; mas não poderá mais optar pelo beneficio desse imposto durante esses 10 anos (NORTON ROSE, 2005).

O modelo KG permite aos proprietários de navios oportunidades de arrendamento de médios e longos prazos, sob menores taxas de juros. A maioria dos investidores do modelo KG procura assegurar retornos em longo prazo e garantir uma margem de lucros no curto prazo. Proprietários de navios também podem revendê-los para o KG, obtendo parte do valor de mercado para aquisição de um navio novo. Um outro benéfico da estrutura $K G$ é que o navio não constará no Balanço Contábil da empresa naval, ficando restrito ao fundo (NORTON ROSE, 2005).

O mercado KG também propicia oportunidades para as instituições financeiras internacionais. A atual natureza do mercado é de tal forma estruturada que, à medida que os navios vão ficando maiores, requerem também maiores investimentos para o seu financiamento. No passado, vários empréstimos para os modelos KG eram fornecidos por instituições financeiras alemãs, em uma base bilateral. É provável que a geração de novos navios requeira maiores volumes de capital internacional. A crescente popularidade e o uso de novas estruturas financeiras trarão grandes oportunidades para as instituições financeiras internacionais.

A rigor o modelo KG provoca incremento no volume de fundos investidos no setor, contudo os bancos privados ainda possuem um importante papel (NORTON ROSE, 2005). O principal banco participante no mercado de financiamento de navios da Alemanha é o German Banks, que concede financiamento de longo prazo e em grandes volumes para o setor. Especialistas estimam que o volume mundial de capital total disponível para financiamento no setor de transporte é de US\$180 bilhões. O German Banks, disponibiliza aproximadamente $50 \%$ dessa quantia. A maior parte desse financiamento é processada em Hamburgo, na forma de empréstimos de longo prazo ou na forma de project finance. Esta é a razão porque 
Hamburgo, ao lado de Londres, é denominada a "capital global" do shipping financing.

\subsubsection{O Caso Norueguês}

Ao longo do desenvolvimento desse projeto foram escassas as informações obtidas quanto ao financiamento norueguês. O fato de figurar entre os países sob investigação se deve a disponibilidade dos parâmetros de sua atual estrutura de financiamento. Com efeito, as informações apresentadas no quadro 5 ao final desse capítulo serão empregadas na modelagem formulada no capítulo 5.

O financiamento de navios na Noruega é feito pelo Eksportfinans ASA - a agência norueguesa de crédito orientado à exportação. Este fornece crédito para a exportação de navios às empresas norueguesas e também a interessados que atuam em outros países. A rigor os esquemas de financiamento abrangem apoio à indústria de bens de capital e de serviços. Contudo, o financiamento ao setor marítimo é uma das maiores áreas de atividade da agência.

Eksportfinans oferece financiamento de projetos de navios de acordo com os esquemas de financiamento internacionais, regulados pela OCDE e pela União Européia (EU). Além disso, os financiamentos são oferecidos dentro do padrão do mercado internacional. Os principais termos e condições de financiamento da Eksportfinans são: financiamento máximo de até 80\%; taxa de juros de acordo com as condições da Commercial Interest Reference Rate CIRR; prazo de amortização de até 12 anos.

\subsubsection{O Caso Brasileiro}

No Brasil a principal forma de financiamento para a indústria naval advém do Fundo da Marinha Mercante (FMM). Segundo Pires Junior, Assis e Souza (2005), o sistema brasileiro de financiamento setorial possui características únicas. Os fundos constituídos para financiar a construção e aquisição de embarcações provêem da 
tributação incidente sobre as tarifas de frete recolhidas pelo governo junto aos armadores. Esta é denominada Adicional ao Frete para a Renovação da Marinha Mercante (AFRMM). Segundo Ferraz et al (2002) a política de promoção, ao atender a ICN e marinha mercante, se caracterizou pelo fato dos incentivos serem concedidos aos armadores para contratarem navios junto a estaleiros nacionais em uma economia fechada. Contudo, este autor sustenta que nunca esta esteve associada a requisitos de eficiência na utilização dos recursos.

Para entender a atual estrutura de financiamento setorial brasileira é necessário remontar a origem do FMM.

A concepção do sistema de financiamento é contemporânea ao Plano de Metas - 1956-61 (EMPRESA BRASILEIRA DE PLANEJAMENTO DE TRANSPORTES, 1999). Até este período a capacidade das instalações locais estava orientada, em sua maior parte, a realização de reparos - embora alguns estaleiros já tivessem realizado construções de rebocadores e embarcações de pequeno porte. A partir dessa época foram lançadas as bases do grande boom do setor. A rigor o Plano de Metas se baseava na criação e estruturação de, ao menos, três grandes fundos de investimento - entre eles o FMM. A iniciativa de criação do FMM se alinhava com a orientação da política governamental nacionaldesenvolvimentista que objetivava a consolidação da indústria de bens de capital e infra-estrutura no país (EMPRESA BRASILEIRA DE PLANEJAMENTO DE TRANSPORTES, 1999).

Tal como concebido o FMM seria sustentado inicialmente pelo AFRMM, criado em 1958. Este adicional, obtido por meio de uma sobretaxa incidente sobre os fretes das importações, deveria ter existência efêmera. Conforme arquitetado, registrado em documentos governamentais e com base em simulações feitas pelos técnicos do governo na época, era previsto que a partir de certo momento o pagamento das amortizações e rentabilidade gerada nas operações de financiamento auto-sustentassem a existência do FMM. A partir desse momento o AFRMM deveria ser extinto, segundo Brasil (1958 apud EMPRESA BRASILEIRA DE PLANEJAMENTO DE TRANSPORTES, 1999, p. 44).

O modelo começou a "operar" em 1959, mas só surtiu seus efeitos no início dos anos 1970 com a entrega das primeiras embarcações financiadas pelo FMM.

A lógica de criação do FMM esteve vinculada e orientada para a consolidação de uma ICN no Brasil. Portanto, é a partir da década de 1950 que o governo 
estabelece políticas efetivas destinadas ao estabelecimento da construção e transporte naval no Brasil (EMPRESA BRASILEIRA DE PLANEJAMENTO DE TRANSPORTES, 1999). Segundo o relatório da Empresa Brasileira de Planejamento de Transportes (GEIPOT) "uma característica importante de todos os modelos adotados tem sido a integração dos dois setores [construção e marinha mercante], não apenas em termos dos mecanismos de regulação, mas também dos próprios órgãos setoriais de governo" (EMPRESA BRASILEIRA DE PLANEJAMENTO DE TRANSPORTES, 1999, p. 44).

A implantação do Plano de Metas (PM) foi apoiada pela criação dos chamados Grupos Executivos que foram organizados em paralelo com a estrutura dos ministérios. Estes se encarregavam pela administração dos programas governamentais e, por vezes, da própria formulação de políticas setoriais (EMPRESA BRASILEIRA DE PLANEJAMENTO DE TRANSPORTES, 1999). Por meio da meta 28, estabelecida no PM, foi criado o Grupo Executivo da Indústria de Construção Naval (GEICON). Suas atribuições eram centralizar o estudo, a proposição e o estabelecimento de normas e critérios na execução da política orientada ao setor, bem como aprovar e propor medidas orientadas a realização de projetos em estaleiros nacionais, em conformidade com as metas estabelecidas pelo governo (EMPRESA BRASILEIRA DE PLANEJAMENTO DE TRANSPORTES, 1999).

Segundo a Empresa Brasileira de Planejamento de Transportes, "desde sua criação o FMM constituiu-se na principal fonte de financiamento aos armadores para a aquisição de navios no Brasil e no exterior" (EMPRESA BRASILEIRA DE PLANEJAMENTO DE TRANSPORTES, 1999, p. 48). O órgão regulamentador do setor e responsável pela aplicação dos recursos era a Comissão de Marinha Mercante (CMM). Criada em 1941 a CMM era a entidade responsável pela administração do FMM e pela execução financeira dos contratos. Na prática os navios eram encomendados pela CMM junto aos estaleiros nacionais e posteriormente repassados aos armadores.

Estas iniciativas foram bem sucedidas, mas sofreram reversão em meio à recessão verificada no início dos anos 1960 em razão das políticas econômicas de combate a inflação e reformas estruturais da economia. Nesse contexto, a atuação da CMM foi reestruturada em 1967. Em meio a estes acontecimentos, em 1969 a CMM transforma-se na Superintendência Nacional da Marinha Mercante 
(SUNAMAM) cujas principais atribuições seriam: planejamento da frota, regulação setorial e representação do governo nas antigas conferências de frete. A SUNAMAM concentrava uma série de atividade devendo legislar, formular e executar políticas para o setor de marinha mercante, agindo como banco, intermediário e supervisor de construção, podendo inclusive, contratar empréstimos interna e externamente. Com o tempo, a centralização de tantas atribuições se mostraria ineficaz.

No período compreendido entre 1969 e 1980, a indústria de construção naval e marinha mercante viveram uma fase de consolidação e forte expansão (EMPRESA BRASILEIRA DE PLANEJAMENTO DE TRANSPORTES, 1999). Esta foi suportada pela atuação da SUNAMAM, pela legislação protecionista (característica do processo de industrialização baseado na substituição de importações) e pelos grandes planos nacionais de construção naval.

O primeiro deles foi o Plano de Emergência de Construção naval (1969-70). Já durante a década de 1970 a política setorial esteve pautada nos Planos de Construção Naval (1970-79). O I PCN (1970-74) aumentou de maneira expressiva a capacidade de transporte da marinha mercante medida em TBP. Com os choques do petróleo nos anos de 1973 e 1979 e a recessão mundial que se seguiu no início da década de 1980, a ICN local sofreu pesado revés (WEISS, 1990). A crise culminou no fracasso do II PCN (1975-79), pois muitos armadores passaram a cancelar os pedidos e ou atrasar pagamentos o que comprometia os níveis de estoque de recursos alocados no FMM.

Uma vez que parte dos recursos alocados no I e II PNC foi obtido junto a fontes externas, o FMM sofreu pesado impacto. Esses efeitos foram reforçados pelo desincentivo que marcava o comportamento dos armadores. A rigor uma das críticas ao II PNC era o comprometimento de recursos em projetos de longo prazo que rapidamente se mostravam obsoletos em meio à mudança estrutural pela qual passava o setor a nível internacional. Parte dos armadores alegava que os projetos eram obsoletos (ante as restrições de consumo de energia e difusão de novas regulamentações) e ou que atrasavam demais (EMPRESA BRASILEIRA DE PLANEJAMENTO DE TRANSPORTES, 1999). Essas práticas colocaram em cheque o modelo. O desequilíbrio desencadeado pela crise associado, a elevação das taxas internacionais de juros e a recessão mundial do início dos anos 1980, fez a SUNAMAM mergulhar em uma crise que culminou em escândalo, pois se alegava que certo armadores seriam favorecidos nas operações. Na prática, como a garantia 
oferecida consistia na primeira hipoteca do navio e como o início do pagamento dos financiamentos deveria ser feito após a entrega das embarcações, muitos armadores optavam pela execução das garantias. Como estas constituíam a própria embarcação financiada todo o risco era transferido para a SUNAMAM.

O escândalo da SUNAMAN, associado ao incremento de seus passivos em dólar, em meio à elevação dos juros no mercado financeiro internacional, colocou em xeque as justificativas de manutenção de uma política para a marinha mercante nos moldes em que se alicerçava (baseada em instrumentos de reserva de mercado) e contribuiu para mudanças significativas na regulação setorial. A principal delas foi à alteração no regime de registros que efetivou a perda de reserva de mercado com grandes implicações para armadores e, sobretudo, para os estaleiros.

Segundo Ferraz et al (2002), em meados dos anos 1980 se observa um processo gradual de mudanças institucionais, incluindo a desregulamentação e fim de reservas de mercado e subsídios aos estaleiros.

Com o "escândalo da SUNAMAM" o governo criaria, em 1983 o Comissão Diretora do Fundo da Marinha Mercante (CDFMM). Este estabeleceria nova sistemática de financiamento. A partir de então o FMM passou a ser operado pelo BNDES em consonância com as diretrizes estabelecidas pelo CDFMM. Os prazos de financiamento seriam de três anos e as amortizações deveriam ser pagas seis meses antes de entrega do navio - a partir do $24^{\circ}$ mês contado a partir da assinatura do contrato.

Inicialmente, o FMM era operado de forma que a estrutura de financiamento garantisse que o preço pago pelo armador ficasse em torno dos preços praticados no exterior - o que, a partir da reserva de mercado, estimularia a ICN nacional por meio do incremento das encomendas junto aos estaleiros nacionais. Isso dependeria das estimativas de preços praticados no exterior - sofrendo, portanto influência dos baixos preços praticados no Japão e Coréia do Sul. O modelo operava por meio de um mecanismo de preço prêmio que cobria a diferença entre uma estimativa de preço praticado no exterior e o preço final de entrega da embarcação produzida pelo estaleiro local.

$\mathrm{Na}$ prática, o preço prêmio constituía um subsídio a fundo perdido para viabilizar a construção naval em estaleiros locais e em condições de preço compatíveis com os praticados internacionalmente. O mecanismo objetivava compensar, por meio da redução do custo de capital, os diferenciais de 
produtividade entre os estaleiros locais e internacionais. As questões críticas relacionadas a este mecanismo se associam aos seguintes aspectos: (1) a determinação do valor do preço prêmio não era fixada a priori; (2) sua forma de determinação não era estabelecida de maneira clara. Na prática o preço prêmio sempre ficava muito acima das estimativas iniciais.

Em suma, o esquema de subsídio patrocinado com o FMM possuía certas deficiências. A principal delas é que não havia limites para a fixação do preço prêmio. Os recursos do fundo cobririam integralmente a diferença entre o valor absorvido durante a construção e o preço de contrato a fim de estabelecer equivalência entre o preço praticado no mercado interno e externo.

Em muitas situações o fundo cobria valores muito acima dos preços praticados internacionalmente. Para Ferraz et al (2002), “... possivelmente sempre existiu combinação de interesses na formação de preços para o mercado interno" (FERRAZ et al, 2002, p. 34). Segundo este autor "bastava o armador e o estaleiro acertarem entre si uma sobrevalorização no preço do navio" (FERRAZ et al, 2002, p. 34). Os indícios que sustenta tais argumentos são a grande assimetria de preços das encomendas voltadas para o mercado interno e externo. Contudo, não se pode deixar de considerar que o preço final cobrado do estaleiro também sofreria reflexos de problemas na gestão de projetos que se traduziam em atrasos, desvios de custos e conseqüente estouro orçamentário - e não somente diferenciais provocados por deficiências produtivas dos estaleiros e ou conluio entre as contrapartes. Nessas condições, o modelo não introduzia critérios que induzissem a eficiência produtiva por meio do modelo de financiamento setorial.

Do ponto de vista da captação e aplicação dos recursos do FMM as informações apresentadas a seguir são ilustrativas. O gráfico 4 indica 0 descompasso existente entre o investimento e a capitação para o período de 1967/1999. Como é possível observar, até 1973 o volume de investimento foi superior a capitação. A partir desse ano e até 1979, houve um forte crescimento induzido da indústria de construção naval brasileira, fato que se reflete no fluxo de investimentos e no volume de captação de recursos - embora este movimento sofra inflexão a partir de 1975, resultado dos efeitos do primeiro choque do petróleo. 


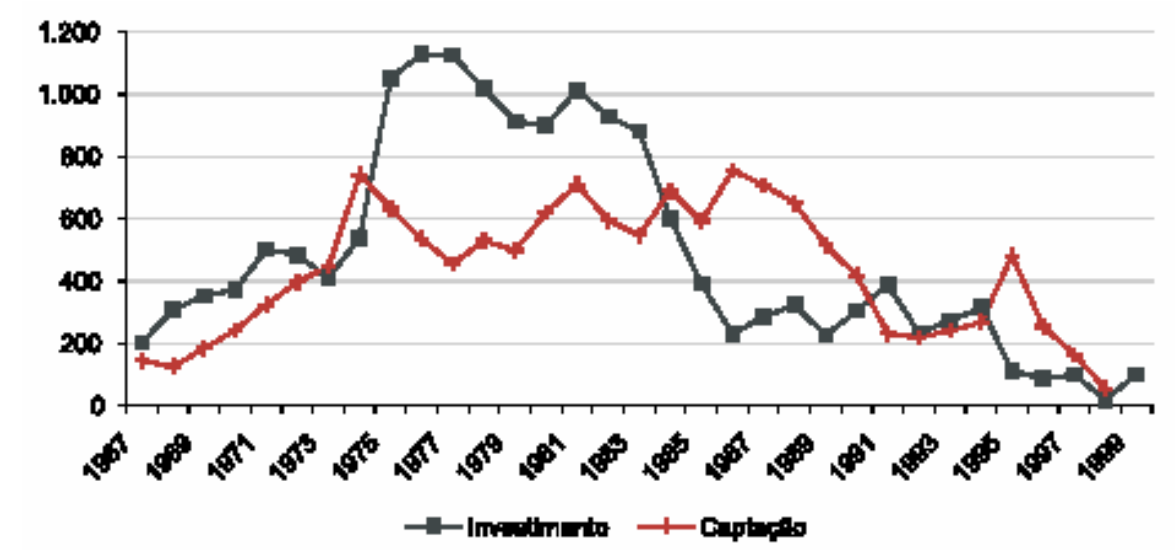

Gráfico 4 - FMM: Captação e Investimento (Valores em milhões de US\$ de 2002) Fonte: Lacerda (2003).

A partir dai o volume de investimento passa a cair sistematicamente, com inflexão acentuada em 1983. A partir de 1985, o volume de capitação torna-se maior que o de investimentos. Fato que se repete no período de 1985 a 1999.

Com base nessas informações é possível destacar dois grandes aspectos relacionados ao esquema de incentivos. Inicialmente, cabe ressaltar que a política de incentivos traduzida pelos programas simultâneos de construção naval e de substituição de importações de navipeças promoveu o crescimento setorial, porém resultou em ônus traduzido pelo elevado preço dos bens finais e nos preços dos fretes - fato que se agrava devido à fragilidade da estrutura de financiamento. Além disso, devido à ruptura do modelo, houve queda no nível de investimento/capitação que também acarretou ônus, pois implicava em custos de oportunidade traduzidos pelo descompasso entre o total de recursos investido e capitado. Essas informações evidenciam a importância e a necessidade de compatibilizar efetivamente os fluxos de investimento setorial e de capitação de recursos.

O gráfico 5 apresenta as séries de investimento e retorno para o período de 1967 a 2000. O investimento corresponde ao total dos desembolsos do FMM para a indústria e o retorno traduz os pagamentos de amortizações e juros dos empréstimos realizados. Entre 1967 e 2000, foram investidos, por meio do FMM, cerca de US\$ 16 bilhões. Nesse período, o retorno do investimento, em termos de amortizações e pagamentos de juros, foi de apenas US\$ 4,3 bilhões. 


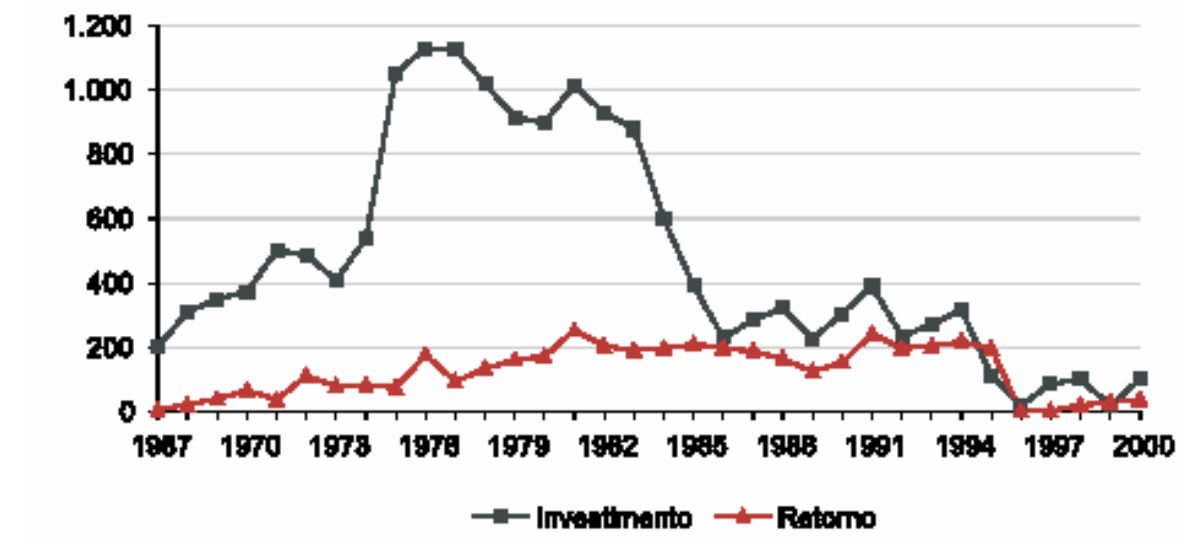

Gráfico 5 - FMM: Investimento e retorno (Valores em milhões de US\$ de 2002) Fonte: Lacerda (2003)

A partir de 1975, os investimentos do FMM, que estavam em torno de US\$ 500 milhões anuais, passam para ordem de US\$ 1 bilhão, o que é mantido até 1982. Desse ano em diante, os investimentos diminuem sistematicamente, reduzindo-se para o patamar de US\$300 milhões anuais e voltando a diminuir, em 1995, para US\$ 100 milhões anuais. Em 1999, os investimentos atingem o seu ponto mínimo, US\$ 19 milhões. Certamente, este efeito resultou da desregulamentação do setor iniciada no final dos anos 1980. Esta foi marcada pela paulatina redução dos subsídios governamentais que gozava o setor.

O retorno sobre os investimentos cresceu progressivamente até alcançar a cifra de US\$ 254 milhões em 1981, permanecendo em torno de US\$ 190 milhões até 1995. Em 1997, o retorno diminuiu substancialmente, atingindo US\$2,6 milhões. Durante todo o período, a rentabilidade do FMM foi negativa em 73,4\%, sendo que os anos de 1995 e 1998 foram os únicos em que o retorno foi maior do que o investimento (LACERDA, 2003). Em parte isso pode ser explicado pelos efeitos da política econômica e da recessão verificada nos anos 80. Estas que reduziram sensivelmente a demanda por serviços de transporte gerando sérias dificuldades a ICN, tal como apontado por Weiss (1990).

A indústria de construção de navios de grande porte (acima de 1.000 TPB) foi praticamente desativada na década de 1970 - trazendo a conseqüente desativação da indústria de navipeças. A sobrevivência de poucas empresas especializadas fez com que o recurso à importação atendesse a construção de navios e plataformas offshore. Assim, a indústria naval ficou em compasso de espera após a crise do 
petróleo dos anos 1970. O choque desencadeou novos paradigmas de transporte naval e seria afetado pelas descobertas de jazidas em águas profundas e pela demanda de equipamentos para extração, operação e transporte de petróleo. No contexto, ocorreu a internacionalização na indústria de armação e construção naval.

Em suma, a estrutura de financiamento setorial se ressentiu, a partir da década de 1980, da queda no volume de investimentos, ineficiências na alocação dos recursos (capitados junto a fontes internas e externas) e perda de rentabilidade dos ativos (traduzida pela redução do montante de juros e amortizações pagos) a despeito de ter colocado o país entre os maiores produtores mundiais.

Atualmente, todos os parâmetros relacionados às linhas de financiamento para a construção de novas embarcações se encontram relacionados na legislação e dispositivos que regulamentam a contratação do FMM apresentados no ANEXO 6. Quanto a esse ponto houve dois grandes cortes. Até recentemente eram os armadores que se comprometiam com a instituição financeira por meio do contrato de financiamento. Quando o projeto por algum motivo não cumpria seus parâmetros (preço, prazo, qualidade) era o armador que tinha que arcar, via de regra, com os prejuízos e pior, caso a embarcação não fosse entregue este teria que arcar também com o ônus financeiros. A lógica adjacente ao modelo é que o armador teria estímulo de acompanhar a construção da embarcação junto ao estaleiro a fim de evitar atrasos e mal uso de recursos. Com o fim do mecanismo de preço prêmio a capacidade de prover garantias tornou-se crítica.

Devido a uma série de problemas, a situação mudou. Os armadores passaram a não querem mais assumir o ônus da contratação do financiamento. Assim, havia pressões para que os financiamentos passassem a serem contratados pelos estaleiros. Ao submeter uma ordem de compra a um estaleiro, este seria chamado a viabilizar o financiamento junto às instituições bancárias que o operam, ou seja, os bancos federais. O banco ao analisar o binômio risco/retorno dispõe de informações sobre contratos executados pelo estaleiro. Devido à escassa capacidade dessas empresas em oferecer garantias e como grande parte dessas possui um histórico de não ser capaz de respeitar o binômio preço-prazo as propostas muitas vezes eram rejeitadas durante o processo de avaliação de crédito.

Na prática, hoje o uso do FMM se dá por meio de uma triangulação: (1) parte dos recursos deve financiar o estaleiro garantindo um fluxo de caixa para atender o projeto o qual é feito com base em estimativa no demonstrativo de usos e fontes - a 
adequação de instalações a fim de atender o contrato deve também ser incorporada nas contas; (2) parte financia o armador que, paga o estaleiro na entrega do navio e, finalmente, (3) com o caixa gerado pelas operações de transporte ou apoio marítimo o armador realiza o pagamento de juros e amortizações fazendo com que os recursos alocados retornem ao FMM.

Do ponto de vista operacional quatro etapas lógicas são críticas no processo de concessão de financiamento à construção naval no Brasil:

(1) verificação da prioridade do projeto: o DMM, órgão vinculado ao Ministério dos Transportes (MT), recebe e avalia o projeto sob o ponto de vista técnico. Nesse contexto, verifica aspectos do projeto do produto e o plano de contas apresentados por meio do Demonstrativo de Usos e Fontes (DUF) e Modelo OS5 (formulário que estabelece o padrão para formatação de gastos de um projeto de construção naval). Nessa etapa também é fixado um valor de referência para concessão do financiamento. Em reunião dos órgãos colegiados que conformam o Comissão Diretora do Fundo da Marinha Mercante (CDFMM) o parecer é analisado ${ }^{29}$. O objetivo é estabelecer se o projeto vai de encontro às políticas estabelecidas para o setor. Concedida ou não a prioridade esta é formalizada através de resolução do CDFMM. Caso favorável, o parecer acompanha um valor de referência para a concessão do financiamento. análise da empresa e imersão do projeto na empresa: tendo parecer favorável ao projeto, a documentação é encaminhada para o BNDES ou um dos Bancos Federais autorizados a operar o FMM (Banco do estado da Amazônia, Banco do Nordeste, Banco do Brasil, etc.). Estes vão iniciar o processo de Consulta Prévia como meio de analisar as condições econômico-financeiras da empresa e o enquadramento do projeto no âmbito das operações dessa. O objetivo é estabelecer uma classificação preliminar de riscos verificando por meio de procedimentos de análise de

\footnotetext{
${ }^{29}$ A CDFMM, coordenada pelo Ministério dos Transportes, por meio do Departamento do Fundo de Marinha Mercante, conta com a participação de representantes dos Ministérios da Fazenda, Planejamento, Orçamento e Gestão, Desenvolvimento, Indústria e Comércio Exterior, além de membros do BNDES. O Grupo tem por objetivo assessorar o ministro dos Transportes na gestão dos recursos do FMM. Criado em 1958, o FMM é administrado pelo Ministério dos Transportes e tem uma arrecadação anual de cerca de $\mathrm{R} \$ 650$ milhões. A principal fonte de recursos é o Adicional ao Frete para Renovação da Marinha Mercante - AFRMM, contribuição cobrada de cada navio que atraca nos portos brasileiros.
} 
crédito (credit scoring e credit rating). Essa avaliação se estabelece a partir de uma série de documentos e dados que acompanham as propostas (dados do grupo/empresa, mercado e projeto). No processo se atesta se a proposta atende aos requisitos mínimos para ter direito de obter recursos do FMM. A metodologia empregada na elaboração de propostas é a mesma utilizada no Roteiro de Informações para Enquadramento do Financiamento de Empreendimentos (FINEM).

(3) estudo de viabilidade econômico-financeira: o banco submete o projeto a um estudo de viabilidade como critério de aprovação. A formatação do projeto deve atender o Roteiro de Informações para Análise de Projetos cristalizado no Financiamento de Empreendimentos (FINEM). A partir de dados contidos no modelo OS5 (que estabelece o padrão para formatação de gastos de um projeto de construção naval a ser submetido ao BNDES) e com base em dados históricos presentes em Banco de Dados do BNDES o valor final do contrato de financiamento é fixado. Este tem como base o valor de referência contido no parecer do Comissão Diretora do Fundo da Marinha Mercante (CDFMM).

(4) fixação de condições contratuais: com base em todas essas análises e documentação são definidos os termos do financiamento. Este envolve o valor do contrato, taxas e prazos de carência e amortização correspondentes. Também são estabelecidas as garantias exigidas para a efetivação do contrato. Aqui se encontra um dos grandes desafios à efetivação do contrato. Os critérios de análise de crédito não são divulgados. Por se tratar de contratos "feitos sob medida", a concessão do financiamento irá depender da discussão de aspectos técnicos e econômicos estabelecidos durante as negociações firmadas entre as contrapartes envolvidas.

Segundo a Portaria MT $\mathrm{n}^{\circ}$ 090/2005 ${ }^{30}$ do Ministério dos Transportes, atualmente os pedidos de concessão de prioridade (atestando que o projeto atende as diretrizes da política setorial de transportes) necessários para obtenção de

${ }^{30}$ Como pode ser verificado no Anexo 7, a Portaria MT n 090/2005 aprova os procedimentos e regras para a liberação de recursos financeiros do FMM que estabelece normas para a apresentação e análise dos pedidos de concessão e de cancelamento de prioridade. 
financiamento a projetos com a utilização de recursos do FMM, são avaliados mediante os seguintes critérios e informações:

- projeto de empresa brasileira de navegação, para construção de embarcação em estaleiro brasileiro; ou jumborização, conversão, modernização ou reparação de embarcação própria, inclusive para a aquisição e instalação de equipamentos necessários, quando realizadas por estaleiro brasileiro;

- participação da bandeira brasileira no mercado onde a embarcação será empregada;

- política industrial e geração de empregos;

- perda de divisas com pagamentos de fretes e afretamentos ao exterior;

- características do mercado de enquadramento;

- incorporação de melhoria no processo produtivo do país;

- atividade considerada prioritária e de relevante interesse social;

- histórico cadastral do postulante perante o FMM; e

- capacidade econômica, financeira e operacional do estaleiro construtor.

O não atendimento desses critérios pode restringir as operações de financiamento. Em todo o caso, muitos dos critérios conduzem a análises que podem induzir a vieses de seleção (política de geração de emprego, melhoria de processo produtivo, relevância social, etc.) uma vez que são de difícil avaliação. Nesse contexto, além de informações cadastrais são exigidos:

- caracterização da empresa postulante e descrição dos elementos fundamentais do projeto;

- quadro de usos e fontes (este constitui um instrumento destinado a acompanhar a apropriação de gastos do projeto e as respectivas fontes de recursos destinados a financiá-lo);

- especificação técnica resumida e arranjo geral da embarcação, no nível de projeto de contrato;

- pré-contrato assinado entre a empresa postulante do financiamento e o estaleiro construtor ou, no caso do estaleiro ser o postulante, entre este e a empresa que o contratou. 
Acoplado ao mecanismo de reserva de mercado (no âmbito do financiamento), os dispositivos possuem uma filosofia. Esta visa assegurar, por meio das condições de financiamento, o desenvolvimento dos negócios ligados ao setor. Isso deve ser garantido pelas condições de financiamento que, ao afetar o custo do capital das operações, deve prover certa isonomia de preço dos navios contratados com os padrões internacionais. ${ }^{31}$ Segundo esta concepção, os diferenciais nos custos e nas condições de financiamento devem contribuir para que isso seja atingido. Contudo, os principais desafios se encontram relacionados à fixação do valor financiado e à questão das garantias. Esta deriva da análise de aspectos relacionados à capacidade e estrutura financeiras das contrapartes envolvidas e na avaliação de riscos dos empreendimentos (condições financeiras, programação dos projetos, capacitação do estaleiro e problemas estruturais do mercado de construção naval). Em linhas gerais não há grandes óbices ao esquema de financiamento operado pelo BNDES que dão condições de prazo e carência superiores que a média mundial (quadro 5). Esta instituição provê os recursos do FMM e cabe a um conjunto de instituições viabilizá-lo.

O principal aperfeiçoamento no sistema de financiamento poderia derivar do estabelecimento e ou aperfeiçoamento de esquemas de provisão de garantias e ou do estabelecimento de esquemas securitização das operações de financiamento. De fato, um incentivo imprescindível à cadeia produtiva da indústria naval seria o estabelecimento de mecanismos de seguro de crédito. Proposta, concedida dentro da Lei 10.893/2004, visava dar garantias ao BNDES na concessão de financiamentos para construção de navios. O dispositivo previa a destinação de recursos do FMM como subsídios ao prêmio (valor pago a uma seguradora para que ela assuma o risco) de seguros para os financiamentos pedidos pelos empresários. Contudo, o texto não foi aprovado pelo Ministério da Casa Civil.

A rigor, o seguro de crédito poderia eliminar falhas no mercado segurador, uma vez que os modelos existentes no mercado não atendiam às necessidades de todos os segmentos envolvidos. As seguradoras em operação no Brasil não possuem experiência na contratação de seguro garantia ao setor naval e, diante de

\footnotetext{
${ }^{31}$ Membros de entidades classistas entrevistados afirmam que os armadores têm como foco o gasto diário com o pagamento de juros e amortizações. Como será indicado, o prazo mais dilatado do financiamento local implica em menor volume de despesas financeiras.
} 
poucos estaleiros existentes no mercado, não tinha como diluir os riscos (estes são elevados pois o patrimônio dos estaleiros é, em geral, inferior ao valor dos financiamentos pedidos). De acordo com a proposta original, as seguradoras deveriam assumir apenas um percentual de risco do projeto. Estimativas apontam que este deve ficar em torno de $30 \%$ do valor do contrato. Tal reserva poderia ser utilizada caso algum estaleiro entrasse em dificuldades financeiras durante a execução do contrato. Como garantia adicional, os estaleiros poderiam contratar auditores independentes para acompanhar 0 andamento das obras. Nas negociações, a equipe envolvida na proposta, deixou para o governo federal a decisão do percentual do prêmio que será subsidiado pelo FMM.

Mais recentemente, o Governo Federal tem sinalizado com a redução da taxa de juros para financiamentos quanto ao aporte do FMM para a construção de navios. Segundo fontes oficiais do Ministério dos Transportes (MT), já foi acertado junto ao Tesouro Nacional a redução da taxa de juros, dentro das regras ou políticas de financiamento geridas pelo BNDES. A taxa de financiamento dos contratos, que hoje varia entre $4 \%$ e $6 \%$ ao ano, deve ficar entre $3 \%$ e $5 \%$ ao ano, com prazo variável entre 18 e 20 anos.

\subsection{Características das Estruturas de Financiamento Setorial}

A apresentação sumária dos casos internacionais enfatizou aspectos do funcionamento da ICN em alguns países e apresentou a origem dos recursos dando destaque a racionalidade que orienta as políticas de financiamento. Estas se revertem na definição dos parâmetros atualmente empregados no financiamento à ICN. Estas informações estão no cerne da modelagem e simulação que serão desenvolvidas no capítulo 5.

Conforme o quadro 5 , os grandes países construtores possuem distintos parâmetros relacionados à estruturação de financiamentos. Neste quadro se encontra relacionada a síntese da estrutura de financiamento por país selecionado. O tratamento dos elementos quantitativos aqui apresentados serão utilizados no capítulo 5. O mesmo vale para as notações empregadas. 
Estes são orientados em torno de baixas taxas de juros, longos períodos de carência e amortização, entre outros. Associados a estes sistemas se encontra uma série de subsídios que não serão objeto dessa investigação. Apesar disso, o quadro apresenta uma série de notas explicativas associadas às informações apresentadas - sobretudo no que diz respeito à questão das garantias.

A rigor, o setor sofre pesados incentivos, mas as empresas que nele atuam também se beneficiam da maturidade do mercado financeiro de apoio governamental provido por seus países de origem. Países com sólidos fundamentos macroeconômicos possuem maior estabilidade nas condições de financiamento e crédito, no nível de atividade e no fluxo de comércio. Dessa forma, o lado monetário da economia (que responde pelos mecanismos de regulação dos níveis gerais de preço e juros, por exemplo) se desenvolve e se estrutura de forma mais equilibrada. O efeito é garantir uma provisão mais eficiente de mecanismos de financiamento de longo prazo, os quais praticamente inexistem no Brasil. Seja como for, a maior estabilidade e solidez possibilitam a existência de um mercado de capitais mais diversificado, com maior disponibilidade e melhores mecanismos de financiamento de longo prazo ${ }^{32}$.

Embora as informações contidas no quadro 5 não apresentem maiores detalhes acerca da estrutura de financiamento dos respectivos países, dada a disponibilidade e dispersão de fontes de informação, a partir de sua análise se pode observar que uma parcela dos recursos canalizados para financiamento do setor se originam de fundos públicos, com destaque aos fundos oriundos das Eximbanks. Esse fato denota que as políticas orientadas à exportação desse tipo de bem de capital são consideradas prioritárias. Tal orientação contribui para manter determinado nível de operações da indústria naval o que tende a incrementar o nível de produtividade, introdução de novos processos produtivos, assegurar uma taxa maior de emprego e divisas externas geradas pelo setor. Também contribui para tornar os preços mais competitivos e aderentes a padrões internacionais.

\footnotetext{
${ }^{32}$ Essas discussões serão retomadas no capítulo 3.
} 


\begin{tabular}{|c|c|c|c|c|c|c|c|c|}
\hline $\begin{array}{c}\text { PAÍs }(K) \\
\text { (1) }\end{array}$ & $\begin{array}{l}\text { ORIGEM DOS } \\
\text { RECURSOS }\end{array}$ & $\begin{array}{l}\text { SUBSÍDIOS } \\
\text { (2) }\end{array}$ & $\begin{array}{l}\text { TAXA DE JUROS DE } \\
\text { REFERÊNCIA }\left(i_{K}\right)\end{array}$ & \begin{tabular}{|c|} 
PERÍODO \\
DE \\
CARÊNCIA \\
$\left(z_{K}\right)$ \\
\end{tabular} & $\begin{array}{c}\% \% \\
\text { FINANCIAMENTO } \\
\theta^{K} \text { - onde } \\
D^{K}=\theta^{K} \bar{P} \\
\end{array}$ & $\begin{array}{c}\text { PRAZO DE } \\
\text { AMORTIZAÇÃo } \\
\left(n_{K}\right)\end{array}$ & $\begin{array}{c}\text { REGRAS DE AMORTIZAÇÃO } \\
\text { - DETERMINAÇÃO DE } \\
P M T_{t}^{K}\end{array}$ & $\begin{array}{l}\text { TERMOS DE } \\
\text { GARANTIA (3) }\end{array}$ \\
\hline $\begin{array}{l}\text { Alemanha } \\
\text { (ALE) }\end{array}$ & $\begin{array}{l}\text { Für de Kreditanstalt } \\
\text { financiando pelo } \\
\text { Wiederaufbau, KfW }\end{array}$ & $\begin{array}{l}\text { Implícito no } \\
\text { sistema de } \\
\text { financiamento e } \\
\text { demais políticas. }\end{array}$ & $\begin{array}{l}\text { CIRR na data de } \\
\text { fechamento do } \\
\text { contrato da moeda de } \\
\text { referência (US\$ ou } \\
\text { euro) (4) } \\
\end{array}$ & $\begin{array}{l}0,5 \text { anos } \\
\text { (seis meses) }\end{array}$ & De 80 a $90 \%$ (5) & $\begin{array}{l}\text { De } 12 \text { a } 17 \text { anos } \\
\text { (5) }\end{array}$ & \begin{tabular}{|l|} 
Sistema de Amortização \\
Constante (SAC) capitalizado \\
em bases semestrais
\end{tabular} & $\mathrm{Nd}$ \\
\hline $\begin{array}{l}\text { Brasil } \\
\text { (B) }\end{array}$ & $\begin{array}{l}\text { BNDES: FMM, } \\
\text { constituído atualmente } \\
\text { de recursos } \\
\text { arrecadados através do } \\
\text { tributo AFRMM } \\
\end{array}$ & Idem. & $\begin{array}{l}2,5 \text { a } 5 \% \text { a.a. }+ \\
\text { variação da TJPL ou } \\
\text { cesta de moedas - } \\
\text { notação } i_{B}\end{array}$ & $\begin{array}{l}\text { até } 4 \text { anos - } \\
\text { notação } Z_{B} \\
\text { no caso } \\
\text { brasileiro }\end{array}$ & até $90 \%$ & $\begin{array}{l}\text { até } 20 \text { anos - } \\
\text { notação } n_{B} \text { no } \\
\text { caso brasileiro }\end{array}$ & $\begin{array}{l}\text { SAC capitalizado em bases } \\
\text { trimestrais }\end{array}$ & \begin{tabular}{|l|}
$130 \%$ do valor \\
fixado no \\
contrato
\end{tabular} \\
\hline $\begin{array}{l}\text { China } \\
\text { (CHI) }\end{array}$ & China Eximbank & Idem & $\begin{array}{l}\text { Fixa, baseada na } \\
\text { CIRR, ou variável, se } \\
\text { baseada na LIBOR, } \\
\text { acrescida de uma taxa } \\
\text { de cobertura (6) } \\
\end{array}$ & $\begin{array}{l}\text { de } 5 \text { até } 7 \\
\text { anos }\end{array}$ & até $80 \%$ (7) & até 15 anos & $\begin{array}{l}\text { SAC. capitalizado em bases } \\
\text { semestrais. }\end{array}$ & $\mathrm{Nd}$ \\
\hline $\begin{array}{l}\text { Coréia do } \\
\text { Sul } \\
\text { (COR) }\end{array}$ & Korea EximBank & Idem & \begin{tabular}{|l|} 
Fixa, baseada na CIRR \\
ou LIBOR + taxa de \\
cobertura
\end{tabular} & até 5 anos & até 90\% (8) & até 12 anos & SAC. pagas anualmente & $\begin{array}{l}\text { Cobra garantia de } \\
\text { reembolso (9) }\end{array}$ \\
\hline $\begin{array}{l}\text { Estádios } \\
\text { Unidos da } \\
\text { América } \\
\text { (EUA) }\end{array}$ & $\begin{array}{l}\text { Marad:seus fundos são } \\
\text { obtidos no setor } \\
\text { privado, por meio de } \\
\text { bancos, fundos de } \\
\text { pensão, companhias } \\
\text { de seguro e emissão de } \\
\text { títulos públicos }\end{array}$ & Idem. & \begin{tabular}{|l|} 
Determinada no \\
mercado privado, \\
tendo como referência \\
os custos dos papéis \\
emitidos pelo Tesouro \\
dos EUA
\end{tabular} & até 5 anos & de 75 a $87,5 \%$ & até 25 anos & $\begin{array}{l}\text { SAC. capitalizado em bases } \\
\text { semestrais }\end{array}$ & $\mathrm{Nd}$ \\
\hline
\end{tabular}

\section{Notas}

(1) O sobrescrito K denota o país. No caso brasileiro o sobrescrito empregado é B; (2) Conforme entrevistas realizadas ao longo do desenvolvimento desse trabalho cujo conteúdo é tratado no capítulo 4 , a própria estrutura de financiamento constitui um mecanismo de subsídio ao setor ao tornar mais barato o acesso ao capital. A real medida do subsídio deve considerar uma análise de custo e benefício social das políticas. Em entrevistas feitas junto a informantes-chaves a medição de tais variáveis é extremamente complexa. Tais discussões, embora extremamente importantes, fogem ao escopo do presente estudo. Para os demais países tais informações não foram recuperadas. Contudo isso não impediu a utilização das demais informações apresentadas no quadro para a aplicação do modelo proposto no capítulo 5. 
CONTINUAÇÃO

\begin{tabular}{|c|c|c|c|c|c|c|c|c|}
\hline & & & & & & & & \\
\hline $\begin{array}{l}\text { PAÍS } \\
(K)\end{array}$ & ORIGEM RECURSOS & SUBSÍDIOS (2) & $\begin{array}{l}\text { TAXA DE } \\
\text { JUROS } \\
\left(i_{K}\right)\end{array}$ & $\begin{array}{l}\text { CARÊNCIA } \\
\qquad\left(z_{K}\right)\end{array}$ & $\begin{array}{l}\text { \% FINANCIAMENTO - } \\
\theta^{K} \text { onde }\left(D^{K}=\theta^{K} \bar{P}\right)\end{array}$ & $\begin{array}{l}\text { PRAZO DE } \\
\text { AMORTIZAÇÃo } \\
\qquad\left(n_{K}\right)\end{array}$ & $\begin{array}{c}\text { REGRAS DE } \\
\text { AMORTIZAÇÃ̃O - } \\
\text { DETERMINAÇÃO DE } \\
P M T_{t}^{K}\end{array}$ & $\begin{array}{l}\text { TERMOS DE } \\
\text { GARANTIA (2) }\end{array}$ \\
\hline $\begin{array}{l}\text { Japão } \\
\text { (JAP) }\end{array}$ & $\begin{array}{l}\text { Exportação: Eximbank } \\
\text { Mercado doméstico: Banco de } \\
\text { Desenvolvimento do Japão, em } \\
\text { conjunto com bancos privados } \\
\text { conjunto com bancos privados }\end{array}$ & Idem & 3,5 a.a. & 6 anos * & até $85 \%$ * & 14 anos * & SAC semestral * & $\mathrm{Nd}$ \\
\hline $\begin{array}{l}\text { Noruega } \\
\text { (NOR) }\end{array}$ & $\begin{array}{l}\text { Eksportfinans, fundos } \\
\text { constituídos por } 15 \% \text { do } \\
\text { governo e } 85 \% \text { dos bancos } \\
\text { noruegueses }\end{array}$ & $\begin{array}{l}\text { Subsídios diretos para a } \\
\text { construção de } \\
\text { embarcações em } 9 \% \text { para } \\
\text { contratos acima de } 10 \\
\text { milhões de euros e em } \\
\text { 4,5\% para os contratos } \\
\text { abaixo desse valor }\end{array}$ & $\begin{array}{l}\text { Fixa, se } \\
\text { solicitada, } \\
\text { baseada } \\
\text { na CIRR }\end{array}$ & 4 anos & $\begin{array}{l}\text { Eksportfinans: Até } 100 \% \\
\text { para navios com garantia } \\
\text { bancária. Com a garantia } \\
\text { do Giek, o valor } \\
\text { financiado cai para } 80 \%\end{array}$ & 12 anos & $\begin{array}{l}\text { O banco garantidor do } \\
\text { empréstimo é flexível, } \\
\text { portanto só é sujeito à } \\
\text { especificação fixada pelo } \\
\text { fiador. }\end{array}$ & $\begin{array}{l}\text { Garantias de } \\
\text { exportação: Gieks, } \\
\text { em termos } \\
\text { comerciais. Giek } \\
\text { oferece garantias de } \\
80 \text { a } 90 \% \text { do valor } \\
\text { do contrato }\end{array}$ \\
\hline
\end{tabular}

\section{Notas}

(3) Segundo Ruth (1991), a garantia não constitui o objetivo do contrato. Ela representa uma segurança em razão de precariedades do postulante explicitadas durante a avaliação de crédito. Em função dos riscos associados ao empreendimento (idiossincrático, de liquidez ou de mercado, etc.), volume de capital exigido, longos prazos de maturação, período de payback, etc., os contratos de financiamento de construção de embarcações novas, ou mesmo aquisição de embarcações usadas, exigem esquemas de financiamento que envolvam várias instituições, entre elas companhias de seguro. A avaliação de seguros, a depender de sua finalidade, pressupõe uma análise criteriosa dos riscos. Esta avaliação deve relacionar a probabilidade de ocorrência de determinados eventos específicos e associá-los com o correspondente grau de severidade.

Segundo a literatura, a estrutura das garantias pode ser de vários tipos, tais como caução, penhor, valor mobiliários posto à disposição de garantia de pagamento (collateral), etc. (JOHNSON STOKES \& MASTER, 2005; KHALID, 2005, RUTH, 1991). Uma das principais análises feitas pelos bancos é referente ao valor mobiliário posto à disposição como garantia de pagamento - muitas vezes de difícil avaliação. Devido à flutuação no preço dos ativos em meio ao ciclo naval, para que seja efetivado um contrato é preciso avaliar os riscos dos haveres da empresa naval. Estas análises fogem ao escopo do presente estudo; (4) Cobra taxa de compromisso de 0,375\% a.a.; (5) O tipo de

financiamento e amortização dependem do rating e qualidade do plano de negócios do armador/fretador; (6) Levando em conta as taxas fixadas pela OECD; (7) Mais um sinal de $20 \%$ do valor do contrato; (8) Durante o período de construção, financia até $90 \%$, acrescido de até $20 \%$ de sinal do preço do contrato. Após a entrega, concede empréstimo de exportação para o estaleiro contratante e um financiamento para o tomador estrangeiro de no máximo 80\%.; (9) Aplicação de "garantia de reembolso" que consiste em aplicar uma taxa baseada no rating do estaleiro. Se este for ruim, pede-se uma carta de garantia de outros bancos comerciais ou uma apólice de seguro de garantia para a efetivação do contrato. ( $\left.{ }^{*}\right)$. Aferido com base nos parâmetros de seus concorrentes diretos, China e Coréia do Sul. Isso foi feito pois, até o fechamento deste estudo não foi possível capturar estes parâmetros.

Quadro 5 - Parâmetros da estrutura de financiamento por país selecionado.

Fonte: Elaborado pelo autor. 
Por fim, vale salientar que a grande diferenciação dos esquemas de financiamento está ligada a magnitude das taxas de juros praticadas, períodos de carência e prazos definidos para a amortização do principal. Como será indicado na modelagem, esses diferenciais podem implicar em substanciais diferenças no custo de capital fato que se reflete nos custos das operações. Por exemplo, os EUA possuem maior prazo de amortização e período de carência quando comparado aos demais países. Já a Alemanha possui uma taxa fixa mínima de $2 \%$ a.a. e uma das melhores condições de prazo. A aplicação de ferramentas de cálculo financeiro por meio do modelo proposto no capítulo 5 irá indicar que estas diferenças tornam relativa a atratividade da linha de financiamento brasileira em relação aos demais países construtores apresentados no quadro.

\subsection{Conclusões do Capítulo}

Este capítulo procurou caracterizar o funcionamento da ICN relacionando-o a questão do financiamento. Ao fazer isso tratou dos seguintes temas: (i) funcionamento dos mercados de frete, construção, compra e venda de embarcações usadas e demolição; (ii) funcionamento do mercado de fretes no curto e longo prazo e suas relações com padrão de investimento na ICN; (iii) classificação econômica da ICN; (iv) funcionamento da cadeia de valores da ICN; (v) descrição sumária das cinco forças competitivas no mercado de construção; (vi) orientação e parâmetros da provisão de financiamento setorial em diferentes países construtores (Japão, China, Coréia do Sul, Alemanha, Noruega, EUA e Brasil).

Essas discussões são pertinentes uma vez que a política e a prática de financiamento orientada ao setor envolvem o entendimento de especificidades setoriais. Como sustenta a teoria financeira, a transferência de ativos de capital deve se basear no entendimento acerca das características do mercado, empresa e projeto. Ao abordar aspectos associados ao funcionamento dos mercados, esse capítulo se insere no contexto dessas discussões. Essas serão retomadas e aprofundadas nos capítulos subseqüentes. 
A ICN pode ser classificada como indústria global cujas vantagens competitivas estão associadas ao comportamento estratégico das empresas. As principais forças econômicas que orientam a indústria são as barreiras á entrada (escala operacional mínima, grande aporte de recursos, etc.), as barreiras á saída (em razão das especificidades, valor e liquidez dos ativos) e intervenções governamentais (orientadas por intervenções de caráter alocativo destinadas a contornar falhas de mercado). A interação dessas forças afeta a estrutura de custos, valoração e liquidez dos ativos e processos de formação de preços de produtos e serviços dos estaleiros. Parte desses argumentos podem ser aplicados aos segmentos de transporte e apoio marítimo.

Os estaleiros devem estar aptos a projetar produtos sob encomenda, atendendo as especificidades dos pedidos dos armadores. Isso exige capacitação em projetos e processos de gestão os quais devem garantir a aderência aos padrões internacionalmente aceitos em termos de preço/custo, prazo de entrega, qualidade, etc.. Portanto, a eficiência da indústria é função de economias de escala e ganhos de experiência, resultado da repetição das experiências de projetar e fabricar bens com características semelhantes. Falhas na gestão das operações podem ocasionar desvios em prazos e orçamentos trazendo severas repercussões sobre a viabilidade dos empreendimentos. Adicionalmente, a reputação constitui um dos componentes essenciais ao sucesso dos empreendimentos.

As encomendas á ICN respondem à demanda derivada de reposição (associadas ao envelhecimento das frotas, sinistros e reparos) e expansão (associadas a abertura de novos mercados, crescimento do produto mundial e comércio e mudanças nos padrões de comércio) das frotas. Estas ocorrem em meio aos ciclos verificados no mercado de fretes.

A rigor, o mercado de construção é orientado por fraca relação preço/custo e acirrada competição em meio aos ciclos de expansão e contração no mercado de transportes. Em razão de seus custos e despesas fixas, as empresas encontram dificuldades para se manter operando ao longo dos ciclos de contração; já nos períodos de expansão a situação de reverte apenas parcialmente, uma vez que os estaleiros rivais disputam avidamente as carteiras de investimento. A intensa competição pressiona as margens para baixo implicando em riscos operacionais e financeiros. Em meio aos ciclos, fatores como reputação, qualidade, respeito á programação, aderência das condições do contrato a padrões internacionais, prazos 
e custos do financiamento, capacidade financeira, qualidade do management, entre outros, são essenciais no sucesso da indústria.

Como sugerido, o processo de financiamento exige que se entenda como se articulam os mercados associados ao setor naval, especialmente o mercado de fretes em sua estreita relação com o mercado de construção naval. O equilíbrio de curto prazo entre a demanda e oferta por serviços de transporte (medidos TPB ou TEU's) e as condições de uso das embarcações da frota mundial determinam a rentabilidade dos ativos, dado o nível presente e esperado dos fretes.

A receita de fretes constitui a fonte primária de geração de caixa setorial, cuja dinâmica afeta os mercados de compra e venda de embarcações usadas, demolição e construção. Elevação ou expectativas de incremento perene nessa variável se repercutem no equilíbrio desses mercados. Em períodos em que as expectativas de longo prazo são otimistas os preços das embarcações usadas se elevam. Nesse contexto, o financiamento se torna viável e surge como elemento que, ao viabilizar a construção de novas embarcações, restabelece o equilíbrio entre oferta e demanda. Caso as expectativas sejam demasiadamente otimistas o incremento no volume de inversões pode gerar um excesso de oferta a médio e longo prazo, trazendo repercussões sobre a rentabilidade futura dos ativos sob controle das empresas. Isso ocorre porque, ante a expansão da oferta, qualquer reversão brusca no valor dos fretes pode comprometer a rentabilidade das operações. Esses eventos acarretam sérias dificuldades operacionais e financeiras aos armadores e estaleiros. Tais desequilíbrios podem perdurar por muito tempo, dado o longo período de vida útil das embarcações. Em suma, há uma fraca relação entre os mecanismos que regem as condições de curto e longo prazo e a ICN e transporte operam em meio a gaps de intertemporais entre oferta e demanda.

Em razão de sua baixa capacidade de prover garantias, são as empresas de transporte e apoio marítimo que normalmente viabilizam o financiamento orientado à construção. Fatores como especificidades e baixa liquidez e de ativos, fraca reação preço/custo e baixa rentabilidade sobre o capital restringem a capacidade de financiamento dos estaleiros. Portanto, a questão do financiamento e suas implicações econômicas e financeiras devem priorizar essa perspectiva.

A revisão da literatura acerca do desenvolvimento da indústria de certos países construtores permite inferir que, historicamente a intervenção pública no setor de transporte e construção naval se deu por meio de diversos mecanismos: clara 
visão quanto a importância no desenvolvimento e comprometimento com metas; vinculação entre marinha mercante e ICN por meio de mecanismos de reserva de mercado; incentivos à criação de vínculos inter-setoriais e presença de grandes conglomerados rivais; crescente aporte de tecnologias e incentivo a constituição de parcerias; forte orientação externa. Contudo, uma das principais formas de intervenção estatal se deu por meio da provisão de fundos de investimentos públicos, contratados sob condições favoráveis. Além de prover diversos mecanismos de incentivo (uso de poder de compra, regulamentação do longo curso e cabotagem, etc.), o Estado interfere no setor por meio do financiamento cuja contratação se dá por meio de juros subsidiados, longos períodos de carência e prazos de amortização.

Em função das características apontadas o financiamento privado orientado ao setor é escasso e implica em forte intervenção governamental. A rigor, nesse aspecto há uma aderência ao que os economistas denominam de mercado incompleto. A intervenção pública, ao procurar reduzir o custo de capital e dilatar os prazos das operações, interfere nos processos de formação do valor final dos contratos firmados entre armadores, estaleiros e demais contrapartes envolvidas na contratação. O objetivo das políticas é estimular as inversões em transporte e construção garantindo certo nível de atividade e competitividade nos serviços de transporte e apoio. Nesse sentido, objetiva gerar e otimizar economias externas.

Dada a escassez de estudos orientados ao tema, até onde foi possível constatar os esquemas de financiamento em vigor ainda são fortemente subsidiados. Isso é garantido por meio da fixação de baixas taxas de juros, longos períodos de carência, participação do financiamento no volume total de investimentos e prazos de amortizações dilatados. Uma característica que se destaca é a orientação externa do financiamento. Isso se traduz em termos de estímulos à produção e exportação de navios por meio da atuação dos Eximbanks. As exportações garantem ganhos à escala e aderência aos parâmetros que orientam a demanda internacional.

O financiamento orientado à construção praticado no Brasil possui prazos vantajosos e taxas de juros competitivas. A rigor, a estratégia nacional visa prover vantagens competitivas por meio da redução do custo de capital. Contudo, como será indicado adiante nesse estudo, estas vantagens não são absolutas e nem sempre se revertem em benefícios às empresas de armação. Essas discussões 
serão retomadas com mais profundidade adiante. Com efeito, o capítulo 3 procura discutir o financiamento a partir de diferentes óticas (armador, estaleiro, agente financeiro, seguradoras e governo). O capítulo 4 aborda os princípios que regem uma estrutura de financiamento e sua modelagem. Já o capítulo 5 formula e aplica um modelo que objetiva avaliar o grau de atratividade da estrutura de financiamento local em relação a esquemas providos em outros países construtores. 


\section{FINANCIAMENTO SOB DIFERENTES PERSPECTIVAS}

Segundo Helfert (2000), qualquer negócio pode ser descrito como um sistema de relações financeiras e movimento de caixa associados a decisões administrativas $^{33}$. Nesse contexto podem ser estabelecidas três avaliações conceituais. A primeira se traduz na representação do sistema empresarial ou caracterização do modelo do negócio. Conforme a figura 8 , esse pode ser representado por relações dinâmicas em três áreas da administração: decisões de investimento, decisões de financiamento e decisões operacionais. Uma outra dimensão indica, sob uma perspectiva abrangente, a natureza e o significado das informações financeiras traduzidas em Demonstrações Contábeis. A terceira dimensão envolve a interpretação do desempenho do sistema empresarial.

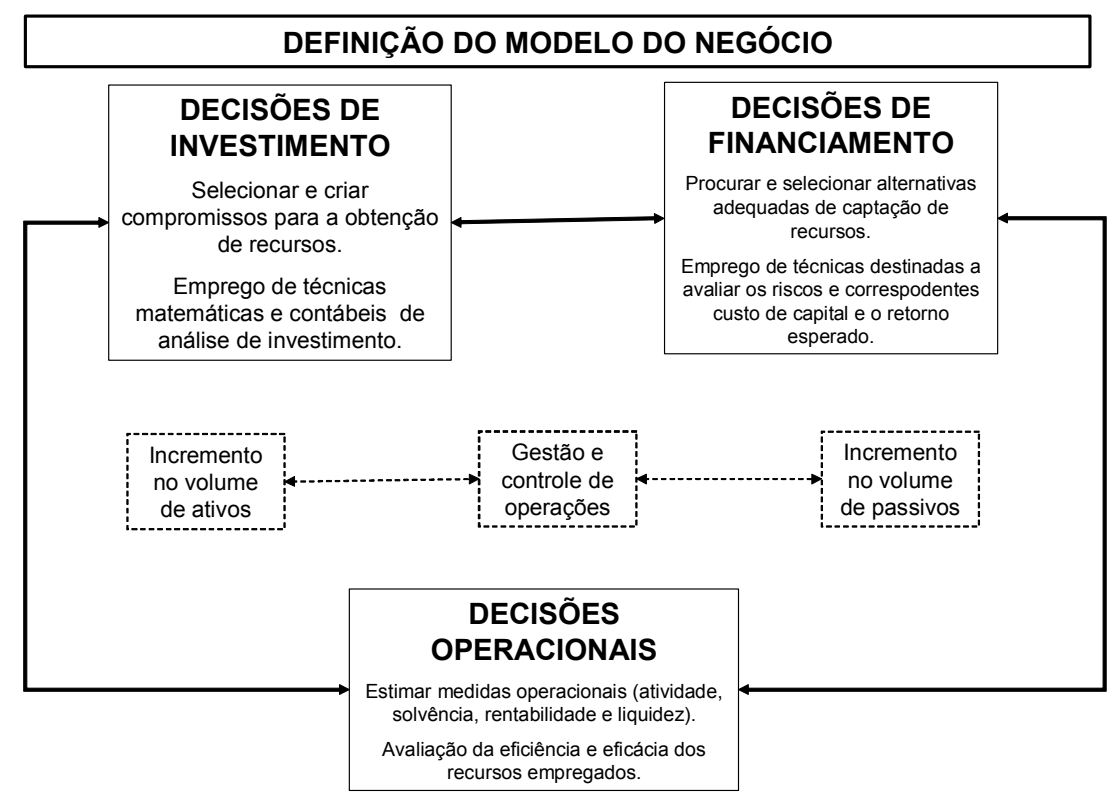

Figura 8 - Perspectivas da dinâmica de um negócio e contexto decisório. Fonte: Adaptado de Helfert (2000).

Em termos gerais, o sucesso de uma operação, do desempenho e da viabilidade de um negócio a longo prazo depende de uma seqüência contínua de

${ }^{33} \mathrm{O}$ Anexo 1 apresenta os fundamentos que justificam o funcionamento do sistema financeiro e sua importância quanto ao processo de desenvolvimento econômico e setorial. 
decisões individuais e coletivas. A maioria dessas envolve processos do dia-a-dia e mostram seus efeitos em curto intervalo de tempo. Outras decisões são essenciais e se encontram tipicamente relacionadas às iniciativas de investimento. Seja como for, o efeito combinado dessas decisões influencia o desempenho e o valor do negócio (HELFERT, 2000).

Segundo Sloggett (1984), uma companhia de transporte ou de apoio marítimo que deseja expandir sua frota reagindo às expectativas de mercado, tem que considerar os aspectos associados às alternativas de financiamento à sua disposição (equity market, empréstimo bancário, mercado de títulos, aporte de recursos de fundos de pensão e ou linhas governamentais de financiamento, etc.) e as exigências correspondentes. Ao sumarizar a origem dos recursos que podem viabilizar o financiamento para a aquisição de embarcações novas ou usadas em economias desenvolvidas, Stopford (2005) sugere a representação indicada na figura $9^{34}$.

Com efeito, em países onde o mercado financeiro é relativamente desenvolvido, há um conjunto amplo de alternativas disponíveis. Nesses países os sistemas de poupança e crédito são mais eficientes atendendo de forma mais efetiva a demandas específicas do sistema produtivo. A rigor, em tais economias os mecanismos de transferência de recursos dos poupadores aos investidores possuem custos mais reduzidos. Assim, a alocação privada de capital conta com maior nível de diversificação e escala - fatos que se revertem em maior dinamismo e menor custo associados às trocas de ativos financeiros. O volume dessas operações amplia a especialização das instituições gerando economias. A diversificação e recorrência das transações geram ganhos de aprendizado o que torna mais eficiente o uso de ferramentas destinadas a verificar ex ante e controlar ex post o financiamento empresarial (sua estrutura de capital, lucratividade atual e projetada, etc.) e qualidade dos projetos (SLOGGETT, 1984).

\footnotetext{
${ }^{34}$ Estas fontes de recursos incrementam o fluxo de caixa setorial, tal como representado na figura 1 da seção 2.1 .
} 


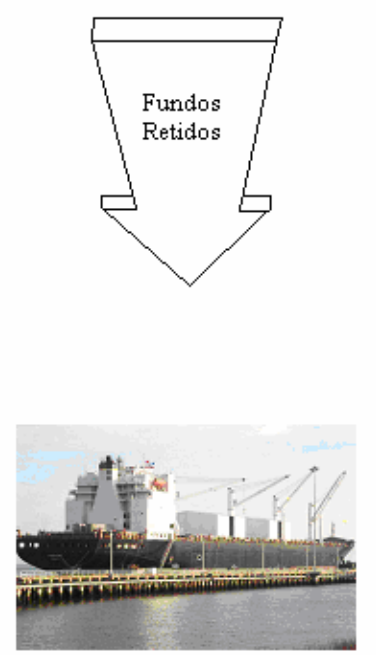

A ser financiado

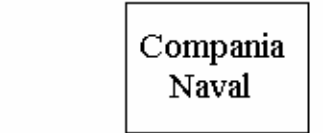

* Fluxo de Recursos

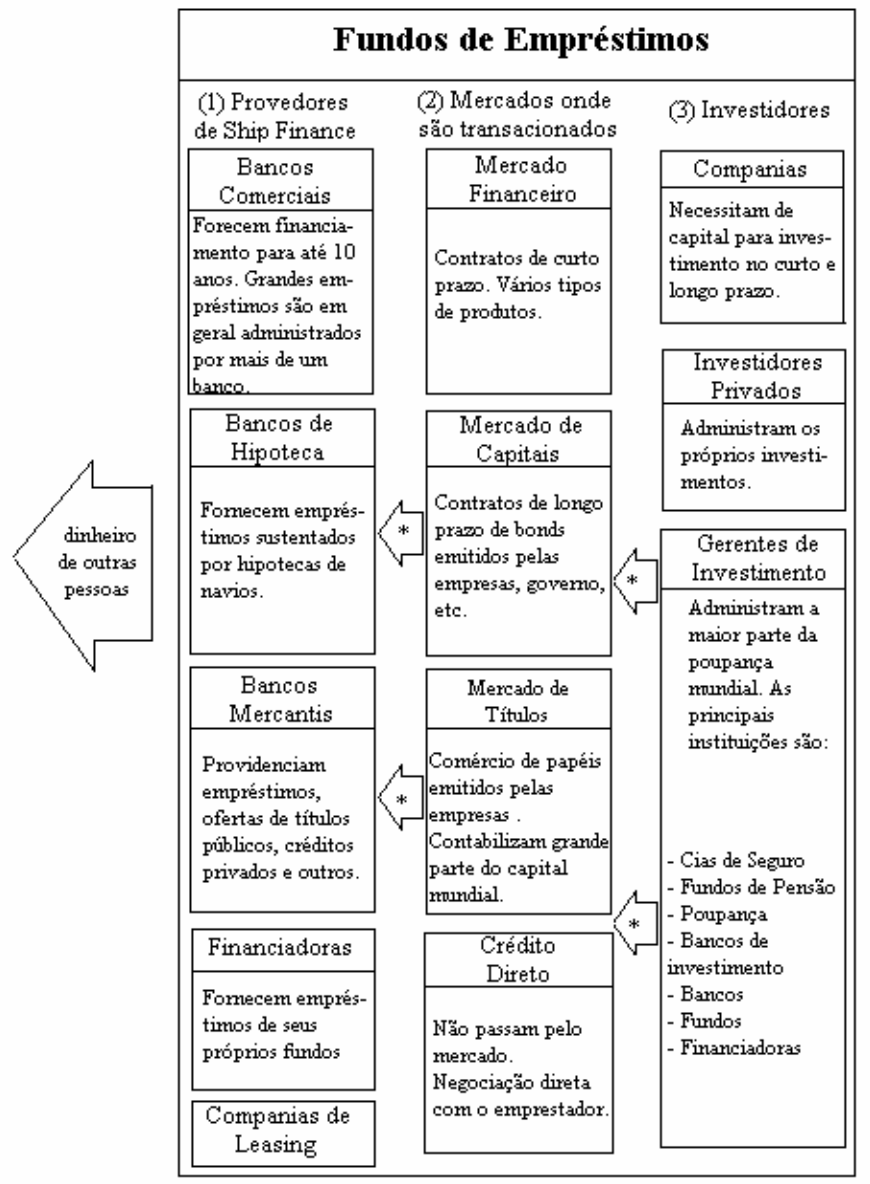

$\left(^{*}\right)$ Em contraste com financiamentos providos por meio de fundos públicos, os bancos privados estabelecem prazos de amortização mais restritivos.

Figura 9 - Principais fontes de recursos que podem viabilizar a aquisição de uma embarcação . Fonte: Stopford (2005, p. 145).

Diferentemente de outros países construtores, no Brasil praticamente inexiste um esquema de financiamento privado destinado ao setor. Por esta razão, o modelo de financiamento é fundamentado na provisão pública. Como discutido na seção 2.6, os recursos destinados ao financiamento setorial são obtidos por meio de um adicional ao frete (AFRMM) os quais, juntamente com o pagamento de juros e amortizações e aportes governamentais, formam o Fundo da Marinha Mercante (FMM).

Segundo Pires Junior, Assis e Souza (2005), o Brasil é o único país que provê recursos por meio desse instrumento. Em parte isso resulta do modesto grau de desenvolvimento, maturidade e características do Sistema Financeiro Nacional 
(SFN). Este é marcado por relativa concentração e baixo volume de ativos transacionados além de operar sob política fiscal restritiva e política monetária fundamentada em juros reais elevados. Outras condições estruturais explicam a concepção do modelo de financiamento nacional. No Brasil, o volume de poupança privada, pública e externa representa baixo percentual do Produto Interno Bruto (PIB) quando comparada a outros países ${ }^{35}$. Isso restringe o volume de recursos orientados ao investimento produtivo. Dai surge a necessidade de provisão pública no atendimento de setores econômicos menos propensos a atuação de instituições financeiras privadas. Tal é o caso do financiamento à ICN.

Em termos internacionais, o financiamento orientado ao setor naval é altamente especializado (SLOGGETT, 1984). Há vários segmentos de financiamento: construção naval, aquisição e reparo de embarcações usadas, financiamentos hipotecários (estabelecidos por meio de garantias registradas em hipotecas), financiamento mobiliário (por meio da emissão de ações), sistemas de securitização (financiamento por meio de fundos públicos e privados) e outros serviços. O termo shipping finance é normalmente usado para designar o conjunto desses serviços financeiros (KENDALL; BUCKLEY, 2005; LIMA; VELASCO, 1998). Esta diversidade também é explicitada na Figura 9. Os investidores alocam seus fundos em diferentes mercados e uma fração destes é orientada ao setor naval.

Segundo Zan e Jian (2004), há duas definições de shipping finance. Uma delas enfatiza o financiamento de capital feito por meio do mercado de títulos. Neste sistema a transferência de capital é estabelecida a partir de emissão de ações cujo preço reflete as expectativas de retorno sobre o valor dos ativos das empresas. A outra leva em conta o processo de transformar poupanças em investimentos por meio do funcionamento da atuação de bancos comerciais, bancos mercantis, bancos de hipoteca, financiadoras e companhias de leasing. Ao tratar do assunto, o shipping finance constitui uma das áreas de estudo da economia marítima (entendida como

\footnotetext{
${ }^{35}$ Assim como o consumo agregado, o nível de poupança privada é função da renda disponível. Historicamente, no Brasil o consumo agregado gravita em torno de $65 \%$ do PIB. A ampliação da carga tributária verificada nos últimos anos tem pressionado os níveis de poupança agregada. Por outro lado, o setor público é um grande devedor provocando o chamado efeito esvaziamento. Neste sentido, ao financiar suas dívidas por meio de práticas de elevadas taxas de juros ele provoca encarecimento dos fundos emprestáveis. Nos últimos anos, os níveis de poupança externa têm se recuperado em razão da ampliação no saldo comercial. Contudo, a disponibilidade de fundos para financiar os investimentos produtivos ainda é escassa. Em países como Japão e China, por exemplo, os níveis de poupança são da ordem de $1 / 3$ do PIB, enquanto no Brasil mal chega a $1 / 5$. A disputa por estes recursos é acirrada, pois é com base nesses fundos que a carteira de projetos da economia ou seu volume de investimentos deve ser financiado.
} 
área da ciência econômica que trata dos aspectos inerentes aos mercados de frete, mercado de construção, mercado de compra e venda de embarcações e mercado de demolição).

O shipping finance apresenta duas características importantes: emprego do dólar americano, que é a moeda de referência utilizada em quase todas as transações (uma vez que os serviços de frete são tradicionalmente cotados nesta moeda), e o predomínio da legislação inglesa nos contratos (KENDALL; BUCKLEY, 2005; LIMA; VESLACO, 1998). A primeira característica implica em atenção ao risco da variação do preço do dólar, que é regido por movimentos no comércio e no mercado monetário. A segunda se deve à tradição. Historicamente a legislação inglesa evoluiu com a marinha mercante. Além disso, Londres constitui, até o presente, o maior centro de negócios da economia naval abrigando, inclusive, a Baltic Shipping Exchange que representa a "bolsa global de valores" de fretes (LIMA; VESLACO, 1998).

No atendimento do setor, a maior parcela de recursos para novos investimentos se origina no mercado bancário, influenciada pela ação de bancos estatais. Esta modalidade de transferência de ativos é capital-intensiva e envolve altos níveis de risco. Estas instituições devem ser cuidadosas a fim de garantir rentabilidade compatível com o nível de riscos das operações do setor (KHALID, 2005).

No processo decisório são examinadas as condições de crédito tais como a razão social, histórico de crédito e capacidade de geração de caixa. Também são identificadas as fontes, probabilidades e severidade dos riscos envolvidos (RUTH, 1991). Muitos dos esquemas demandam o estabelecimento de garantias o que torna o financiamento mais complexo em razão dos intrincados procedimentos de avaliação de ativos das empresas ligadas ao setor. Em muitos casos, a capacidade das empresas em atender as exigências contratuais constitui o principal entrave à efetivação das operações (STOPFORD, 2005; ZAN; JIAN, 2004). De fato, os esquemas de financiamento orientados à construção de embarcações são de elevada complexidade e, dado o volume de capital, prazo das operações e riscos inerentes, sempre envolvem salvaguardas múltiplas para evitar perdas para as instituições envolvidas nas operações (armador, instituição financeira, etc.) (LIMA; VELASCO, 1998). A rigor, essa complexidade se reflete no contrato de financiamento que constitui o elo fundamental entre o agente financeiro, armador, 
estaleiro e seguradoras, sofrendo ainda forte influência governamental (KHALID, 2005).

Muitas vezes é difícil encontrar um arranjo que atenda simultaneamente aos interesses das contrapartes envolvidas. Isso reflete os diferentes pontos de vista e interesses envolvidos em cada operação (KHALID, 2005). Por exemplo, nas negociações, os armadores são orientados pelos seguintes fatores: contribuição patrimonial mínima, responsabilidade mínima caso o empreendimento fracasse, maiores períodos de carência, prazos de amortização e etc. Já os agentes financeiros esperam incorrer em menor contribuição em termos do valor total do projeto, menores prazos de carência e de amortização, maior retorno sobre o capital emprestado, maior cobertura de risco por meio do estabelecimento de garantias e etc. (KHALID, 2005). De fato, como indica de maneira explícita Khalid (2005) e de maneira implícita Alex (2004), Sloggett (1984) e Stopford (2005), o financiamento ao setor de transporte naval pode e deve ser avaliado sob diferentes óticas nem sempre convergentes.

Este capítulo, ao discutir aspectos do financiamento sob diferentes óticas, aborda duas perspectivas, intrinsecamente relacionadas. Estas dizem respeito (i) aos aspectos operacionais do negócio em seu respectivo mercado e ao (ii) rebatimento desses sobre o caráter das operações de financiamento - a exemplo do que se procurou fazer nas seções 2.5 e 2.6 do capítulo 2 onde se enfatizou aspectos relacionados ao financiamento em diferentes países. Conforme aponta Helfert (2000) esse procedimento é metodologicamente consistente, pois as atividades e inter-relações entre cada um desses atores possuem um aspecto real e financeiro - fato que foi explicitado de maneira preliminar no capítulo 2 e apresentado de maneira explícita na figura 8. Esses aspectos sofrem diferentes influências, a depender do lugar que cada ator ocupa na cadeia de valores setorial. A rigor, esta posição condiciona as transações de ativos reais (traduzido pela troca de bens e serviços e formação de ativos reais) e financeiros (traduzido pela transferência de ativos financeiros e formação de passivos ou obrigações sobre ativos), tal qual apontado por Barboza (2004) e Stopford (2005), respectivamente ${ }^{36}$.

\footnotetext{
${ }^{36}$ As relações entre as funções do sistema financeiro e o desenvolvimento setorial são apresentadas de maneira sumária no Anexo 1.
} 


\section{1 Ótica do Armador}

Os armadores orientados por expectativas de incremento no preço do frete ou ao identificar novas oportunidades de mercado desenvolvem novos projetos de construção de nova(s) embarcação(s) junto ao(s) estaleiro(s) (ALEX, 2004; EL CICLO..., 2005; STOPFORD, 2005) ${ }^{37}$. O valor do contrato deve ser fixado com base na especificação do produto a ser entregue ${ }^{38}$. Este é função do tipo de embarcação e mercado que irá atender. Ambos definem os critérios de desempenho da embarcação (velocidade, gasto combustível, critérios, especificações ambientais e etc.), bem como capacidade de transporte medida em volume (ou em TPB), tipo de carga, rotas de atuação, entre outros (WEISS, 1990) ${ }^{39}$. Os parâmetros do produto e do projeto de construção devem ser fixados respeitando o trinômio: preço/custo, qualidade do produto e prazo de entrega (BARBOZA, 2004).

Traduzidos nas propostas, estes elementos apresentam implicações econômicas e financeiras sobre armador, estaleiro e agente financeiro uma vez que se refletem no caráter das negociações em torno do alto valor das operações e demais parâmetros associados à contratação de recursos (período de carência, prazo de amortização, taxas aplicadas, período de payback, etc.).

Em geral, cada proposta deve acompanhar um pré-contrato firmado com o estaleiro. Essa é outra característica de contratação de bens sob encomenda. No pré-contrato as contrapartes estabelecem especificações do produto a ser entregue, o valor acordado, o correspondente cronograma de desembolso de recursos, o prazo de entrega e as condições de pagamento. Em suma, os contratos devem ser feitos sob medida. O estaleiro de escolha do armador (eleito com base em uma série de atributos técnicos e econômicos) deve ser relacionado na proposta. Isso também é necessário uma vez que durante a análise de crédito deve ser avaliada a

\footnotetext{
${ }^{37}$ As figuras 1 e 5 apresentadas nas seções 2.1 e 2.4, respectivamente, ajudam a entender alguns dos argumentos apresentados nesta seção.

${ }^{38}$ A avaliação e precisão nas estimativas de preço do contrato de construção obtido junto ao estaleiro têm como base a especificações de escopo do produto, e do projeto da construção. A rigor, as estimativas de receitas, associadas às estimativas de frete e volume de carga transportada e absorção de recursos a elas associadas, se encontram vinculadas ao ciclo do projeto e ciclo operacional. Estas estimativas permitem montagem de planilhas com informações financeiras (Demonstrativos de Usos e Fontes, Demonstrativo de Resultado do Exercício, Projeções de Balanço, etc.) que servem de base para a tomada de decisão do armador e posteriormente do agente financeiro.

39 Do ponto de vista operacional, há um trade off entre porte da embarcação e as condições de gestão e instalações portuárias. Como demonstra Weiss (1990), quanto maior a capacidade de carga menor o custo fixo médio. Contudo, é maior o tempo permanência no porto e custo de descarga.
} 
capacitação operacional e financeira do construtor no atendimento do escopo do produto e do projeto. Além da capacidade de pagamento, os riscos dos empreendimentos são influenciados pela incerteza quanto ao cumprimento da programação do projeto, e possibilidade de não conclusão da construção. Estes elementos dizem respeito ao "risco estaleiro" ou risco operacional.

Dentre os riscos ligados ao armador se encontram: (1) os riscos relacionados ao não cumprimento dos parâmetros do contrato por parte do estaleiro, os quais podem comprometer prazos, custos, qualidade do projeto e efetividade de entrega do bem final (KHALID, 2005; STOPFORD, 2005) e (2) os riscos associados a desvios nas estimativas de frete e despesas relacionadas ao ciclo de operação da embarcação. Tais elementos afetam o retorno esperado e, conseqüentemente, as condições de financiamento do projeto (ALEX, 2004; KHALID, 2005; STOPFORD, $2005)^{40}$.

A rigor, o primeiro fator diz respeito ao risco operacional (ou idiossincrático). Este possui relação direta com a capacidade operacional e qualidade de gestão do projeto de construção sob responsabilidade do estaleiro. Atrasos no cronograma, desvios e ou flutuações em torno das estimativas de custos podem acarretar ônus adicionais às contrapartes. No limite, podem tornar impeditiva a conclusão do projeto. Para contornar estes riscos, freqüentemente, os armadores têm que destacar equipes cuja finalidade é acompanhar a execução do projeto de construção. Esta necessidade encarece as operações; por outro lado, tende a contribuir para a redução do grau de exposição ao "risco estaleiro". A rigor, o risco operacional se desdobra em duas classes de risco. Em caso de atrasos significativos o armador fica sem o produto durante determinado período de tempo e portando não pode auferir receitas com as quais poderá saudar obrigações contratuais (ALEX, 2004). Estas obrigações têm prioridade sobre o fluxo de caixa e estão associadas ao "risco de prazo", influenciado pelos riscos de evento, câmbio, etc. $^{41}$

Em caso de não entrega, uma vez que é o armador que normalmente firma o contrato e oferece garantias ao financiamento, este se vê obrigado a cobri-las

\footnotetext{
${ }^{40}$ A apresentação e discussão mais sistematizada acerca dos riscos envolvidos nas operações e suas formas de medição será estabelecida no capítulo 4.

${ }^{41}$ Parte desses riscos serão melhor conceituados e mensurado no capítulo 4.
} 
integralmente. Ou seja, corre o risco de ficar sem o produto e tem, por força do contrato, de arcar com obrigação da dívida. Trata-se do "risco de entrega".

O segundo fator se relaciona mais diretamente ao risco de mercado e ao risco de liquidez. O risco de mercado reflete as condições esperadas de geração de fluxo de caixa por parte do armador. Já o risco de liquidez se relaciona à impossibilidade de vender ou liquidar um ativo sem grandes perdas de valor. Ambos, ao afetarem a capacidade financeira da empresa, trazem severas implicações sobre as condições de financiamento e fixação dos termos de garantia.

Os custos e prazos estabelecidos são decisivos para a contratação do financiamento. Por esta razão os armadores tendem a exigir taxas de juros competitivas que, sob a perspectiva do agente financeiro, são função do prazo, riscos envolvidos e da credibilidade das contrapartes envolvidas. De maneira geral, os armadores esperam que os esquemas de financiamento ofereçam empréstimos a taxas de juros subsidiadas e prazos mais dilatados em comparação com outros setores de capital-intensivo, tais como a aviação, bens de capital e infra-estrutura (KHALID, 2005).

Outro ponto importante considerado pelo armador é a velocidade de aprovação do crédito. Muitas vezes a avaliação por parte dos bancos pode levar muito tempo. Em parte isso resulta da falta de conhecimento acerca do funcionamento do setor naval e de dificuldades que as companhias marítimas encontram para atender as exigências da contratação (JOHNSON STOKES \& MASTER, 2005).

Os aspectos explicitados conduzem a impasses nas negociações. O mais crítico se relaciona à fixação das garantias (KHALID, 2005). Seja como for, o conjunto desses fatores faz com que muitos dos projetos não sejam aprovados ou o sejam sob condições proibitivas. O conjunto desses elementos acarreta impactos severos sobre os custos financeiros e rentabilidade esperada dos empreendimentos com reflexos sobre o dinamismo da ICN, haja vista o forte inter-relacionamento entre estes mercados.

\section{2 Ótica do Estaleiro}


O valor dos ativos dos estaleiros possui baixo valor e liquidez o que torna proibitiva a contratação - dado o valor dos contratos de construção que operam. Isso é ainda mais crítico quando se considera que um mesmo estaleiro pode estar envolvido na construção de várias embarcações simultaneamente. Por esta razão é raro que o financiamento seja celebrado por estas empresas. Além disso, a especificidade de seus ativos é restritiva em termos de cobertura dos riscos. Isso se traduz no valor das garantias exigidas pela instituição financeira.

Uma vez que os estaleiros raramente financiam a construção, sob sua ótica o financiamento pode ser analisado sob duas perspectivas: (1) disponibilidade de linhas de crédito para a inversão em equipamento e capacitação produtiva e (2) forma de aporte de recursos financeiros destinados a atender as exigências relacionadas à execução de um determinado projeto. Ambas trazem repercussões sobre os custos e riscos dos empreendimentos.

A primeira perspectiva implica na necessidade de oferta de linhas especiais de financiamento orientadas à capitalização das empresas. De fato, em muitas situações, dadas as especificidades técnicas de cada pedido de construção, há a necessidade de aporte de capital junto ao estaleiro a fim de que este possa dispor de ativos destinados a atender as demandas de determinado projeto. A segunda imprime a exigência de esquemas de repasse de capital compatíveis com a absorção de recursos do projeto durante a sua fase de execução ou, dito de outra forma, exige que se garanta compatibilidade entre o cronograma físico e cronograma financeiro. Ainda em termos dessa perspectiva, existe a necessidade de financiamento de capital de giro para cobrir os custos absorvidos pelo estaleiro ao longo do ciclo de construção. A literatura sustenta que é de responsabilidade exclusiva do estaleiro a obtenção de capital de giro para financiar a realização da obra, estando implícito que quaisquer dificuldades na sua obtenção não poderão afetar o ritmo de construção das obras, sob risco de perdas ao armador (KHALID, 2005).

Do ponto de vista estratégico, como demonstram Weiss (1990) e Barboza (2004), há um forte poder de barganha do armador em relação ao estaleiro o que tende a pressionar as margens nos períodos de expansão e contração do ciclo naval. Isso tem implicações na capacidade que os estaleiros possuem de se autofinanciarem. Por outro lado, considerando que a ICN é uma indústria global ( $\mathrm{CHO}$; PORTER, 1986), o estaleiro deve possuir capacidade técnica e condições de custo 
compatíveis com os padrões internacionais. De fato, a depender do tipo de embarcação, se pode afirmar que os armadores escolhem determinado estaleiro com base em sua reputação em torno de sua capacitação técnica, no histórico de confiabilidade produtiva, pontualidade na entrega de encomendas e valor estabelecido na proposta sob encomenda (JOHNSON STOKES \& MASTER, 2005).

Ao lado da capitalização do estaleiro estes elementos constituem précondição para que possam atender de maneira efetiva o trinômio preço-prazoqualidade. Do ponto de vista operacional, a construção de uma embarcação exige, além de numerosa mão-de-obra qualificada, instalações adequadas e a aquisição de diversos componentes (máquinas, equipamentos, etc.) adquiridos sob encomenda junto aos fabricantes de bens de capital e fornecedores de navipeças (WEISS, 1990). Também exige uma eficiente gestão da cadeia de suprimentos e programação da produção. Sob a ótica gerencial, um estaleiro é um "operador de contratos". Uma de suas principais atividades é, além de elaborar projeto do casco e da estrutura da embarcação, garantir que as máquinas e equipamentos estejam disponíveis em momento oportuno para serem instaladas na embarcação - o que deve ser garantido por uma adequada programação da construção (WEISS, 1990).

Assim, a habilidade operacional e de gestão da cadeia de suprimentos estão no cerne da competitividade entre estaleiros rivais (CHO; PORTER, 1986; FADDA, 2006; WEISS, 1990). Isso também demanda grande habilidade na negociação com os fornecedores de navipeças. Como demonstra Weiss (1990), o poder de barganha do estaleiro junto aos fabricantes de navipeças também é limitado, constituindo outra fonte de pressão sobre suas margens. Fato que também restringe capacidade financeira dessas empresas.

Dado o alto valor de alguns dos equipamentos encomendados, os fabricantes de navipeças só estarão dispostos a iniciar a construção e liberar as encomendas quando uma parte substantiva ou a totalidade de seu pagamento estiver coberta. Empiricamente, as fases iniciais de execução do projeto só podem ser efetivadas quando parcela substancial de recursos (insumos diversos como aço, mão-de-obra, etc.) que irá viabilizar a construção do navio, estiver à disposição do estaleiro. A cobertura de seu valor varia de acordo com o tipo e preço da máquina ou equipamento que é, em geral, construído sob encomenda.

Em suma, fatores como a capitalização, reputação, habilidade na programação e gestão da cadeia de suprimentos por parte dos estaleiros são 
críticos. Atrasos na entrega de insumos e equipamentos e escassez de recursos para atender as exigências do empreendimento inviabilizam ou ampliam os prazos e custos reduzindo sua rentabilidade.

\section{3 Ótica do Governo}

A intervenção governamental nos mercados se justifica quando ocorrem as chamadas falhas de mercado - traduzidas em monopólios, bens públicos, economias de escala de longo alcance, falhas de informação, abuso de poder econômico, mercados incompletos, presença de externalidades, etc. (GIAMBIAGI; ALÉM, 2001; STIGLITZ 1986). Nesses casos a intervenção governamental pode ser praticada por meio de diversos mecanismos. Estas práticas se consubstanciam em leis, normas, regras e instituições as quais refletem aspectos históricos e sociais que respondem, em maior ou menor grau, pelo grau de desenvolvimento das forças produtivas - tal qual descrito por autores como Marx (1982) e Schumpeter (1988). Mais recentemente, destacam-se os trabalhos de North (1990) e Williamson (1975) que enfatizam o impacto dos custos de transação sobre a atividade econômica (CAMPANARIO; SILVA, 2004). Estes custos surgem quando a obtenção e o uso da informação acarretam custos aos agentes podendo ocasionar perdas ou a ação de agentes oportunistas. Entre os problemas relacionados à presença de custos de transação se encontram o risco moral e seleção adversa.

O risco moral ocorre quando a empresa encobre informações, não conhecidas, sobre ineficiências produtivas internas. Trata-se de mal uso de recursos internos à organização como excesso de pessoal, elevados custos indiretos, excessos de investimentos em ativos, etc. A seleção adversa surge quando o agente utiliza informação especializada como forma de tomar uma ação que, embora não eficiente do ponto de vista alocativo, Ihe trás benefícios privados, em detrimento dos mecanismos de ação propostos pelo governo para salvaguardar os interesses coletivos. Trata-se de alocar fatores em proporções ineficientes do ponto de vista econômico como forma de obter ganhos ${ }^{42}$. Muitas vezes o comportamento de

\footnotetext{
42 Para maiores informações sobre o problema do risco moral e seleção adversa ver Laffont e Tirole (1993) e Araújo (2003).
} 
armadores e estaleiros é marcado por esses problemas que se repercutem no financiamento. Em entrevistas realizadas junto a informantes-chaves contatou-se que muitas propostas apresentam excesso de custos apropriados pelo estaleiro (mão-de-obra, custos indiretos, etc.) ${ }^{43}$. Essa prática inflaciona o valor dos contratos. Por outro lado, falhas no sistema de incentivos induzem a um excesso de alavancagem financeira por parte das empresas de transporte. Essas questões serão retomadas nos capítulos 4 e 5 .

As intervenções do Estado abrangem três funções básicas: alocativa, distributiva e estabilizadora (GIAMBIAGI; ALÉM, 2001; MUSGRAVE; MUSGRAVE, 1989; STIGLITZ 1986) ${ }^{44}$. A função alocativa está intrinsecamente relacionada à formulação de políticas industriais ativas.

Fazendo menção a este assunto, Lacerda (2003) aponta que o setor de transporte marítimo é marcado pela presença de falhas de mercado que se manifestam na forma de economias de escala, mercados incompletos, informação assimétrica, externalidades e oferta bens públicos. Ainda segundo este autor, a presença dessas falhas, enseja o desenho e justificam a introdução de mecanismos de natureza alocativa. Portanto, a lógica de desenho desses mecanismos é orientada pela função alocativa (LACERDA, 2003). Esta trata da forma como os fatores produtivos (capital, mão-de-obra e insumos diversos) são direcionados pelo Estado entre as várias alternativas de uso econômico, a fim de produzir um conjunto de bens e serviços de interesse coletivo. Para tanto, o governo utiliza alguns instrumentos como impostos, subsídios e transferências governamentais para oferecer serviços de consumo de alto interesse social, tal como serviços de transporte.

\footnotetext{
${ }^{43}$ Os resultados dessas entrevistas serão apresentados no capítulo 4.

${ }^{44}$ A função estabilizadora interfere nos níveis de emprego, renda, estabilidade de preços, juros, câmbio e crescimento. Ela se justifica porque nem sempre os mecanismos de mercado são capazes de assegurar o nível ótimo de emprego, com estabilidade de preços e níveis de crescimento sustentáveis e desejáveis do ponto de vista social. Esta função interfere diretamente na política monetária, cambial e tributária, condicionando o desenho do desempenho macroeconômico. Essas três funções constituem diretrizes gerais que justificam a atuação do governo. Porter (1998) argumenta, ainda, que as políticas governamentais também devem possuir certas diretrizes e orientações estratégicas, entre elas uma regulamentação eficiente e a promoção da inovação tecnológica - esta diretamente relacionada com as funções alocativa e distributiva. A função distributiva procura criar mecanismos de inclusão social desejados pela sociedade. Neste particular, merece destaque distribuição dos bens públicos. A oferta e distribuição desses bens não são obtidas de forma satisfatória pelos mecanismos de mercado. O governo deve então determinar o tipo, a quantidade e calcular o nível de contribuição de cada cidadão para viabilizar a existência do "mercado" para esses bens ou serviços, como é o caso das telecomunicações.
} 
Como sugere Lacerda (2003), a montagem de tais esquemas está geralmente associada aos governos. De fato, o papel da ação governamental orientada ao setor naval, por meio da função alocativa e dos esquemas de financiamento, é crucial quando analisada sob a perspectiva de posicionamento e desenvolvimento da indústria naval. Fato que também é ressaltado por Kendall e Buckley (2005) e outros estudiosos do tema.

Historicamente, e em todos os países construtores, o Estado tem presença significativa na construção e transporte naval. De fato, as atividades relacionadas à construção e operação de navios sofrem influência de uma série de mecanismos de incentivo e regulação abrangendo: subsídios; criação de reservas de mercado; benefícios fiscais e proteção da cabotagem; incentivos financeiros; normas e regulação de segurança no trabalho; normas e regulação de segurança ambiental (KENDALL; BUCKLEY, 2005; SERRA, 2002).

Entre as principais práticas de incentivos e regulação observados no mundo naval, destacam-se a existência de subsídios orientados à operação e construção naval, estímulo ao investimento em transporte e apoio marítimo, reserva de mercado para a navegação de cabotagem, concessão de benefícios fiscais e de outros mecanismos de proteção às indústrias locais (KENDALL; BUCKLEY, 2005). Estudos feitos por Ferraz et al (2002) indicam a natureza do foco das políticas públicas orientadas à ICN no Brasil. Um resumo de resultados quanto à participação do Estado em alguns setores econômicos pode ser observado no quadro 6.

\begin{tabular}{|c|c|c|c|c|c|c|}
\hline & \multicolumn{3}{|c|}{ Política Comercial } & \multicolumn{2}{|c|}{ Política Industrial } & \multirow{2}{*}{$\begin{array}{c}\text { Capital } \\
\text { Estrangeiro } \\
\left(^{*}\right)\end{array}$} \\
\hline & Acesso & Defesa & Promoção & Modernização & Reestruturação & \\
\hline \multicolumn{7}{|l|}{ Bens de capital } \\
\hline \multicolumn{7}{|l|}{ Naval } \\
\hline \multicolumn{7}{|l|}{ Petroquímica } \\
\hline \multicolumn{7}{|l|}{ Plásticos } \\
\hline \multicolumn{7}{|c|}{ Têxtil/confecções } \\
\hline Legenda: & & Relevante & & $\begin{array}{c}\text { Muito } \\
\text { relevante }\end{array}$ & & Prioritário \\
\hline
\end{tabular}

Quadro 6 - Mapa de prioridades das políticas públicas por tipo de cadeias produtivas. Fonte: Ferraz et al (2002, p. 23).

Segundo Ferraz et al (2002), no Brasil as empresas desses segmentos formam cadeias menos competitivas e deficitárias em termos de comércio. Neste caso, as prioridades das políticas públicas deveriam ser dirigidas para a promoção 
da competitividade por meio do estímulo ao investimento em novas tecnologias e reestruturação patrimonial, entre outras. Como explicitado, em termos de seu raio de ação as atuais políticas ao setor naval orientam suas prioridades à defesa, reestruturação e modernização e aporte de capital financeiro. Os instrumentos associados a estas diretrizes se vinculam a mecanismos aderentes aos planos da política comercial, política industrial e de incentivo ao investimento privado e formação de parcerias com empresas estrangeiras, respectivamente.

\section{4 Ótica do Agente Financiador}

Conforme sustenta Ruth (1991), o empréstimo a pessoas jurídicas envolve uma série de procedimentos: formulação de entrevistas e análise do perfil de crédito, análise de demonstrações contábeis, definição da estrutura do empréstimo, documentação, acompanhamento, etc. (RUTH, 1991). Neste processo, o agente financeiro deve proceder a avaliação dos riscos o que inclui a análise do histórico das instituições envolvidas na operação ${ }^{45}$. Esses procedimentos são conhecidos como análise de crédito e de riscos (credit scoring e cretid rating). O objetivo fundamental do tomador (obter o empréstimo com o mínimo de retardo e de explicações) não corresponde ao mesmo objetivo do agente financeiro (obter o máximo de documentos e informações acerca do empreendimento).

Segundo Zan e Jian (2004) e Stopford (2005), há muitas formas de financiar a construção naval. Estas formas dão tratamento distinto a questões como custos de capital de capital, prazos das operações, modos de pagamento, garantias exigidas, entre outras condições. Conforme sustenta Ruth (1991), estas refletem distintas políticas de financiamento as quais rebatem sobre a estrutura do financiamento, sendo entendida: como determinação das condições de prazo (carência e amortização), taxas praticadas, etc., a partir da definição da política de financiamento.

\footnotetext{
${ }^{45}$ Como será indicado adiante, no Brasil uma série de avaliações são feitas a partir da proposta e sob diferentes óticas. Esta deve ser submetida ao Departamento de Marinha Mercante (DMM) que emite parecer técnico e encaminha ao Conselho da Marinha Mercante (CMM). Este órgão avalia o alinhamento do projeto a política de transporte nacional. A partir daí, a proposta é encaminhada ao agente financeiro (no caso o BNDES) o qual procede o estudo de viabilidade econômico e financeiro.
} 
As negociações em torno de operações orientadas à construção naval são complexas. Além da avaliação das condições de crédito, estudo da estrutura de capital e verificação da qualidade do management (das empresas de navegação e estaleiros), fatores externos influenciarão as decisões. Estes podem ser representados por fenômenos que causam flutuações nas taxas de frete (STOPFORD, 2005), intervenção pública por meio da política econômica (STIGLITZ, 1986), aspectos relacionados a regulação de mercados (ARAÚJO, 2003), alterações no padrão de comércio (KRUGMAN; OBSTFELD, 2001), flutuações no preço dos ativos, mudanças nas condições financiamento internacional, variação cambial (GITMAN, 2000), entre outros.

Com base na definição prévia de um conjunto de procedimentos previamente elaborados, o agente financiador decide se deve ou não financiar o projeto. Os critérios genéricos mais desejados pelo agente financeiro na concessão de financiamento são obter o maior retorno sobre o capital emprestado, garantindo o menor risco de recuperação do principal e menor prazo na alocação do capital (resgate e retorno sobre o principal). A rigor, os objetivos perseguidos pelas instituições financeiras são: a captação recursos a baixos custos; a maximização de retornos; a minimização de riscos de cada operação (RUTH, 1991). Contudo, isso não constitui tarefa simples.

Ao avaliar um projeto, a instituição financeira deve modelar os riscos envolvidos. Os riscos de mercado e financeiro são apontados pelas instituições financeiras como críticos na concessão de financiamento ao setor de transporte naval e derivam da volatilidade do mercado, mudanças inesperadas no padrão de comércio, natureza cíclica da valoração de embarcações novas e usadas e incerteza quanto ao valor residual dos navios exigidos como garantias ao financiamento (KHALID, 2005). Todos esses fatores acarretam imprevisibilidade na capacidade financeira, valoração de ativos das empresas navais e quanto a sua rentabilidade esperada. Como sugerido na seção 2.2, isso tem profunda relação com o funcionamento do mercado de fretes.

Os agentes financeiros devem ser muito criteriosos ao analisar a proposta sob o ponto de vista técnico e econômico-financeiro. Sob o primeiro ponto de vista são avaliados o histórico do armador (composição de seus ativos, rentabilidade, liquidez e de capacidade de provisão das garantias exigidas) e do estaleiro (cumprimento de prazos e orçamento de projetos). Sob o segundo financeiro é avaliada a viabilidade 
econômica e financeira do projeto. Em todo o caso, o agente financeiro deve proceder a uma avaliação sistemática e mais robusta possível de cada proposta.

A falta de conhecimento das instituições financeiras acerca da sistemática de funcionamento do setor de transporte naval e de seus mercados é apontada por Khalid (2005) como um dos entraves para a concessão de financiamentos tornandoas um negócio incerto e de alto risco. Conforme Khalid (2005), as questões que interferem na liberação de financiamento estão relacionadas ao histórico e credibilidade dos clientes, perfil do ativo a ser financiado (embarcação) e experiência passada adquirida pelo agente neste tipo de operação.

Ainda segundo Khalid (2005), os principais fatores envolvendo o financiamento o setor naval podem ser agrupados em três classes: segurança, condições de financiamento e riscos associados às operações.

Em termos da segurança há grande dispêndio de recursos associados à necessidade de desenvolver modelagem dos riscos que dê conta das especificidades ligadas aos negócios do setor - o que consiste em modelar os mecanismos de funcionamento do mercado de fretes. A questão da segurança se desdobra em aspectos relacionados à definição de garantias. Nesses termos se trata de prover mecanismos que garantam ao financiador tomar posse, realizar a venda, penhoras, etc., do navio ou outros ativos, caso o tomador do financiamento não cumpra as especificações previstas em contrato.

Os agentes financeiros podem exigir também participação em ativos, garantias pessoais, introduzir complexos esquemas de seguros envolvendo outras instituições, etc. ${ }^{46}$. Segundo Ruth (1991), as garantias não devem constituir a finalidade do contrato, mas prover uma segurança adicional quanto ao cumprimento das obrigações nele estabelecidas.

As condições de financiamento variam entre as companhias e entre os países. É comum os bancos formarem um benchmarking das diversas companhias existentes. A grande disponibilidade de informações relacionadas ao cadastro de clientes permite aos bancos saberem mais a respeito de cada companhia, tornando as condições de empréstimo específicas para cada uma delas.

Há também os riscos operacionais que emergem da própria estrutura do negócio e do projeto. Segundo Khalid (2005), o financiamento de navios envolve os

\footnotetext{
${ }^{46}$ Este última questão será abordada na próxima seção.
} 
riscos de liquidez, risco da operação, risco de creditício, risco de estratégia, risco de regulação e risco de mercado. A grande questão associada aos riscos se relaciona à experiência do agente financiador. A este respeito, Khalid (2005) apresenta um quadro sinóptico quanto aos critérios comuns e políticas usadas pelos bancos para dar conta dos riscos em operações de financiamento ligadas ao setor naval. Estas informações são apresentadas no quadro 7.

\begin{tabular}{|c|c|}
\hline Critérios associados ao tratamento de riscos & Políticas relacionadas \\
\hline Caução (ou penhor) ${ }^{(2)}$ & $\begin{array}{l}\text { Submissão de um bem em garantia ao } \\
\text { cumprimento de uma obrigação. No caso pode } \\
\text { estar associado a empréstimo cuja garantia } \\
\text { são navios. O financiamento se dá de acordo } \\
\text { com valor estimado de cada ativo. }\end{array}$ \\
\hline Hipoteca $\left(^{*}\right)$ & $\begin{array}{l}\text { Onerarão de um bem em garantia acerca do } \\
\text { cumprimento de obrigação. }\end{array}$ \\
\hline Alienação fiduciária $\left(^{*}\right)$ & $\begin{array}{l}\text { Transmissão de direitos de propriedade de um } \\
\text { bem ao credor para estabelecer a garantia de } \\
\text { uma obrigação. }\end{array}$ \\
\hline Contrato (termo de comprometimento) & $\begin{array}{l}\text { Enfatiza a classificação por caução (ou } \\
\text { penhor). }\end{array}$ \\
\hline Seguro & $P \& I^{(*)} ; H \& M^{(2 *)}$ \\
\hline Bandeira & $\begin{array}{l}\text { Associado a garantia por meio de } \\
\text { embarcações com bandeira de conveniência } \\
\text { aceitável. está associada a reputação da frota } \\
\text { e estrutura legal aceitável. }\end{array}$ \\
\hline Idade da embarcação & $\begin{array}{l}\text { Limita o prazo de financiamento pela idade da } \\
\text { embarcação. }\end{array}$ \\
\hline Avaliação & $\begin{array}{l}\text { Feita por especialistas, utiliza técnicas } \\
\text { destinadas a aferir o valor patrimonial das } \\
\text { empresas envolvidas nos empreendimentos. }\end{array}$ \\
\hline Reputação do cliente & $\begin{array}{l}\text { Boa administração, sólidos rendimentos, } \\
\text { relatórios acessíveis, contratos de longo prazo } \\
\text { assegurados, boa estratégia de negócios. }\end{array}$ \\
\hline Outras qualidades desejáveis. & $\begin{array}{l}\text { Baixa idade média da frota, relatórios e } \\
\text { Demonstrações Contábeis auditadas e } \\
\text { confiáveis e com flexibilidade aceitável. }\end{array}$ \\
\hline
\end{tabular}

\section{Notas}

$\left(^{*}\right)$ Valor mobiliário posto à disposição do credor como garantia paralela de pagamento de dívida.

$\left.{ }^{* \star}\right)$ P\&I - Proteção e indenização. Geralmente requeridos por quem fornece empréstimo e estabelecidos por meio de contrato por escrito. Seguros P\&I geralmente são emitidos e colocados no mercado na forma de títulos mobiliários sob a proteção dos clubes de P\&I. Estes cobrem eventos associados à propriedades de bens e direitos associados ao funcionamento do mercado de transportes (i.e., a carga). Cobrem perdas de receitas, indenizações associadas a questões ambientais, guerras, passivos trabalhistas, etc..

$\left.{ }^{* * *}\right) \mathrm{H} \& \mathrm{M}$ - Casco e maquinaria, cobrindo principalmente bens tangíveis como o casco do navio, maquinaria e outros equipamentos. Esses riscos são colocados diretamente por emissões de títulos no mercado de seguros e oferecidos por grandes empresas locais tais como Takaful Malaysia, MNI, Jerneh e Assurance. Entretanto, como sua capacidade para colocar os títulos H\&M é limitada, eles sempre fazem um resseguro de cobertura com as empresas de seguros internacionais que atuam no mercado londrino.

Quadro 7: Critérios comuns e políticas usadas pelos bancos locais para assessorar os riscos do shipping finance

Fonte: Adaptado de Khalid (2005, p. 47). 
Do ponto de vista das atividades do agente financeiro, os custos do financiamento da construção naval não refletem exclusivamente o custo de capital e de intermediação financeira. Este também se associa diretamente a complexidade dos processos de avaliação e tratamento dos riscos dos empreendimentos por parte dessas instituições (KHALID, 2005).

Os fatores descritos têm profundas implicações quanto às práticas de financiamento e forma de atuação dos bancos. A rigor, o conjunto e peso de cada um desses fatores acarreta imprevisibilidade no fluxo de ganhos setorial, no valor residual dos ativos das empresas navais, no desempenho de armadores e dos estaleiros e nos demais parâmetros do negócio de transporte marítimo (KHALID, 2005).

A exemplo das falhas de mercado existentes no mercado de transporte marítimo, também ocorrem falhas no mercado de financiamento orientado setor. $A$ principal delas é a existência de mercados incompletos. Isso ocorre devido ao volume de investimentos exigidos e se associa a alta volatilidade do negócio e exigência de longos prazos de maturação das inversões o que implica, por exemplo, em altos custos das operações e a provisão de pesadas garantias conduzindo a severos impasses em torno das negociações das contrapartes.

As empresas desejam que os bancos forneçam maior apóio à construção por meio de melhores condições de financiamento, taxas de juros mais competitivas e que aumentem seu conhecimento sobre o setor marítimo a fim de melhorar a análise de riscos (KHALID, 2005). Os bancos são sensíveis aos riscos envolvidos nas operações e reconhecem sua falta de conhecimento sobre economia marítima. Como aponta Khalid (2005), perdas passadas em operações orientadas ao setor ${ }^{47}$, as precárias condições financeiras dos interessados e o fraco volume de crédito disponível para empréstimo restringem a oferta de crédito para o setor.

A experiência de empréstimos passados é crítica. Informações sobre as experiências passadas e histórico de empréstimos dos armadores são vitais para a tomada de decisão. Com estas informações em mãos, os bancos são capazes de avaliar os retornos apropriados exigidos para cada nível de risco, estabelecer classificação de credito e perfis de risco que envolvam a estruturação dos contratos

\footnotetext{
${ }^{47}$ A formação de expectativas, ainda sob o espectro das crises provocadas pelas recessões de 1974 e 1985 que afetaram profundamente o setor, ainda provocam temores de perdas por parte dos bancos que operam linhas de financiamento orientadas ao setor (ALEX, 2004).
} 
(KHALID, 2005). Os bancos presentes em um país normalmente preferem financiar armadores e construtores locais (KHALID, 2005).

Por isso os bancos são mais cautelosos em transacionar com o setor (ALEX, 2004; KHALID, 2005). Em razão de problemas no financiamento, os bancos se tornaram mais cuidadosos na análise de capacidade de cumprimento das obrigações de seus clientes e mais diligentes em administrar o nível de risco de cada contrato (KHALID, 2005). O que também foi enfatizado por técnicos do BNDES nas entrevistas realizadas no âmbito do projeto ${ }^{48}$.

Os bancos envolvidos na atividade destacam os altos riscos envolvidos nos empréstimos, as rígidas obrigações regulatórias, que variam de país para país (embora haja certa convergência em torno dos aspectos ambientais), e sua falta de conhecimento sobre economia marítima (ALEX, 2004; KENDALL; BUCKLEY, 2005; STOPFORD, 2005).

Os bancos apontam ainda a escassa liquidez, que implica em baixo volume de recursos destinados para efetivar empréstimos, como os principais fatores que restringem a oferta de crédito para o setor (ALEX, 2004; KHALID, 2005). Isso restringe a oferta de crédito resultando em maiores dificuldades na obtenção de empréstimos ao setor (KHALID, 2005).

\section{5 Ótica das Companhias de Seguro ${ }^{49}$}

Em função dos riscos associados ao empreendimento (idiossincrático ou operacional, de liquidez, de mercado, etc.), volume de capital exigido, longos prazos de maturação, período de payback, etc., os contratos de financiamento de construção de embarcações novas, ou mesmo aquisição de embarcações usadas, exigem esquemas de financiamento que envolvam várias instituições, entre elas companhias de seguro.

\footnotetext{
${ }^{48}$ Como o BNDES opera o FMM, única forma de provisão de recursos financeiros ao setor existente no país, ele possui critérios estabelecidos, acesso ao histórico de crédito das empresas e expertise para avaliar propostas sob a ótica financeira.

${ }^{49}$ Esta seção foi redigida com base no Relatório do Grupo de Trabalho do Seguro Garantia (2004) e com base em entrevistas realizadas junto a informantes-chaves.
} 
A avaliação de seguros, a depender de sua finalidade, pressupõe uma análise criteriosa dos riscos. Esta avaliação deve relacionar a probabilidade de ocorrência de determinados eventos específicos com o correspondente grau de severidade.

No mercado existem empresas que são propensas ao risco, de modo que a operação de seu negócio envolve a aceitação de riscos mediante uma remuneração adequada. O seguro é um contrato pelo qual uma das partes se obriga, mediante cobrança de prêmio, a indenizar a outra parte pela ocorrência de determinados eventos ou prejuízos eventuais.

No contrato de seguro o contratante repassa então parte do seu risco às seguradoras pagando uma taxa (denominada prêmio) sobre a importância segurada e assim tem garantido certos direitos na eventualidade de sinistros. Estes devem ser definidos previamente no contrato de seguro. O prêmio, por sua vez, é calculado a partir da ponderação das perdas monetárias prováveis pelas suas probabilidades, levando também em consideração fatores específicos da operação tais como natureza do bem segurado, histórico da empresa, características do setor, etc.

Existem diversas modalidades de seguro no mercado, criadas com o objetivo de atender as especificidades das demandas de cada setor/bem a ser segurado. No caso da construção naval, tem sido usual aplicar práticas já consagradas, como a utilização do Seguro do Construtor, o conhecido Builder's Risk. Seu objetivo é assegurar a entrega do bem cobrindo acidentes e ou danos materiais que possam vir a ocorrer durante a construção.

As discussões em torno do seguro de crédito exigem estudos acerca de cálculo atuarial que respaldam a estruturação dos contratos de seguros. Os esquemas de seguro de crédito destinados à construção naval em processo de discussão recente são inspirados nos modelos de seguro empregados na construção civil, cujos projetos e operações possuem características em comum com a construção naval. Estas características em comum se traduzem na magnitude de recursos a serem alocados nos contratos de financiamento e em certa similaridade em termos de prazo e riscos envolvidos em cada operação.

O Seguro Garantia - Modalidade Executante Construtor é um tipo especial de seguro em que o contratante paga um prêmio com o objetivo de garantir que, no caso de um sinistro, a seguradora utilizará o valor acordado de cobertura para finalizar a construção do bem segurado. 
No caso de um seguro garantia para um prédio, por exemplo, a construtora contrata uma empresa de seguros e, caso haja algum problema durante a obra (dificuldades financeiras da construtora, atrasos excessivos ou outros sinistros acordados por contrato) a seguradora assume a construção, contratando outra empresa para finalizar o prédio e cobrindo as despesas adicionais. No caso da aplicação desta modalidade de seguro à construção naval haverá necessidade de adequação, principalmente porque, diferentemente da construção de obras civis como um todo, a construção de embarcações se dará obrigatoriamente nas dependências do estaleiro do construtor. Portanto, diferentemente do seguro tradicional, esta modalidade específica do seguro garantia prevê a finalização do bem pela seguradora. Esta atua como uma espécie de "sócia" garantidora da operação/construção, ou ressarcimento ao contratante dos prejuízos decorrentes do sinistro até o valor fixado na apólice.

A grande vantagem deste tipo de seguro é, portanto, assegurar o término da construção do bem, fornecendo garantias aos compradores e financiadores do projeto. Estas garantias de entrega devem se reverter em melhores condições de financiamento.

Entretanto, nesta operação, há um claro exemplo do que é chamado de "problema de assimetria de informação": o contratante detém toda a expertise, conhece os riscos reais e acompanha todas as fases do processo, enquanto o mesmo não ocorre com a Seguradora, "sócia" do projeto. Na verdade ocorre o problema do risco moral tal qual definido na seção 3.3. Assim, para que esta aceite participar da operação garantindo a finalização da construção do bem, são exigidas ações que auxiliem na mitigação dos riscos decorrentes desta assimetria de informação.

A identidade a seguir expressa os elementos de uma operação típica, onde $\mathrm{P}^{*}$ representa o valor total estimado do projeto, base de cálculo primária de contrato padrão de seguro:

$$
P^{*}=P+\Delta P
$$

$P^{*}$ é composto por duas parcelas. O termo $P$ representa o valor do contrato determinado a partir das negociações firmadas entre armador e estaleiro, de acordo 
com o orçamento do empreendimento. A rigor este valor afere estimativa do orçamento do empreendimento. Já $\Delta P$ corresponde a um adicional estimado para cobrir desvios sobre o valor $P$. Sua apuração está relacionada a uma estimativa técnica própria feita pela seguradora para o contrato do seguro. Em geral na construção civil, o valor de $\Delta P$ é um percentual em torno de $30 \%$ sobre o valor $P$. Na estruturação de um esquema de seguro, o dilema está relacionado a que valor deve ser segurado, $P$ ou $P+\Delta P$, e a metodologia empregada para se determinar a magnitude de $\Delta P$.

As instituições financeiras dão destaque ao valor do principal $(P)$. Do ponto de vista destas há dois tipos de risco a serem considerados risco de perda do principal $(P)$ e risco de retorno sobre o capital empregado na operação. Este valor se encontra embutido em $P$. Em caso de falência do contratante ou moratória devido a problemas no projeto, os bancos se concentram em recuperar o valor $P$ (este tema não será objeto de discussões nesse trabalho).

A lógica que respalda o trabalho das seguradoras em esquemas de seguro garantia dão maior atenção na determinação do valor de $\Delta P$. A questão que se coloca sob este enfoque é qual o valor máximo de recursos adicionais, em condições normais de execução do projeto, que se deve disponibilizar para que o produto do projeto, objeto do contrato, seja efetivamente entregue caso haja desvios?

Essa divergência de enfoques está no cerne da discussão dos esquemas de seguro de crédito dificultando os avanços. O banco quer garantir que o valor $P$ seja recuperado; a lógica de trabalho da seguradora na modalidade de seguro garantia é definir o montante de recursos para que o projeto seja concluído e o produto entregue. Na prática consiste em definir o limite de segurança, ou seja, o valor de $\Delta P$. Na determinação desse valor é utilizado um ranking de risco de crédito cujos parâmetros universais são estimados pelo IRB (Instituto de Resseguros do Brasil).

O exemplo numérico apresentado no quadro 8 ajuda a ilustrar os procedimentos. 


\begin{tabular}{|c|c|c|}
\hline Classe de risco (1) & Alíquota base (2) & Valor (em milhões de US\$) (3) \\
\hline A & $1,0 \%$ & 0,2 \\
\hline$B$ & $2,5 \%$ & 0,4 \\
\hline C & $3,0 \%$ & 0,5 \\
\hline$D$ & $3,5 \%$ & 0,6 \\
\hline
\end{tabular}

(1) A classe de risco segue um padrão estabelecido pelo IRB Brasil Resseguros S.A.

(2) Alíquota a ser cobrada em uma operação de seguro é definida a partir de avaliações técnicas e com base na classe de risco na qual a empresa opera. Essas classificações de risco são estabelecidas por auditores independentes por meio de mecanismos de credit scoring e credit rating. No caso desse exemplo se utilizou valores fictícios.

(3) O valor segurado varia a depender da percepção de risco associada ao empreendimento.

Empreendimentos com pior perfil de risco devem receber um maior volume de recursos em caso de desvios.

Quadro 8 - Exemplo de aplicação de esquema de seguro garantia.

Fonte: Elaborado pelo autor.

Para um valor orçado de US\$ 50 milhões, inicialmente é calculado o valor $\Delta P$. Este valor deriva das estimativas de gastos associados ao projeto de construção.

A partir da especificidade do projeto é atribuído o nível de risco da operação. Isto é feito com base em uma escala de riscos que vai de A à D. A cada classe de risco é atribuída uma alíquota que serve de base para o cálculo do prêmio a ser pago pelo contratante. A incidência dessa alíquota sobre $P$ retorna o valor do prêmio a ser pago pela seguradora $\Delta P$.

Para que tal esquema seja aplicado no financiamento na construção naval, algumas questões se colocam: como será determinado o valor $\Delta P$ ?; em qual classe de risco deve ser enquadrado o empreendimento?; uma vez que os riscos são elevados e se refletem na classificação de risco e prêmio pago para a seguradora, como o governo pode atuar para viabilizar o esquema?

Estudos indicam que, dadas as características dos projetos de construção de embarcações, histórico setorial e das empresas ligadas ao setor (armadores e estaleiros) quando analisadas individualmente, a determinação do valor $\Delta P$ deve ser fixada com base em coeficiente superior a 30\%. Pela mesma razão, é de se esperar que a maioria das instituições sejam enquadradas na classe de risco D. Neste caso, o governo deveria se limitar a cobrir uma parcela do valor do prêmio de forma que o empreendimento possa ser enquadrado (em termos de valor de prêmio a ser pago) em classe superior - digamos C ou B? Ocorre que há resistências em relação à alocação de uma parte dos recursos do FMM para cobrir tal valor. Este impasse fez com que a criação do Fundo Garantidor (FIGIN) fosse vetado pelo Presidente. 
O ponto crucial relacionado à questão das garantias é que, em razão dos mecanismos de formação do valor dos contratos no mercado local de construção e nível de eficiência operacional dos estaleiros, estas são majoradas. Entrevistas realizadas com diversos agentes ligados ao setor naval, indicam que os valores dos contratos locais são mais elevados do que os praticados em nível internacional ${ }^{50}$. Estudos realizados também indicam haver prática de sobre-preço no mercado doméstico (PIRES JUNIOR; ASSIS; SERRA, 2002). Este pode ser explicado por diferenciais de produtividade e escala operacional, forma de gestão da cadeia de suprimentos, etc., mas também pode ser induzido pelas barreiras impostas pelo modelo local de financiamento. Este, por razões ligadas à produção sob encomenda: não estabelece qual deve ser diferencial máximo entre o valor dos contratos; não introduz critérios de eficiência nas operações; impede o uso dos recursos do FMM para a aquisição de embarcações fabricadas no exterior com uso da conta vinculada (exceto sob condições especiais), etc. Assim, se o preço $P^{*}$ de uma embarcação no mercado internacional for de US\$ 50 milhões, p. ex., o valor do contrato no mercado interno será acrescido de um $\theta$, que procura captar o sobre-preço. O valor das garantias então será obtido como:

$$
P^{* *}=P^{*}(1+\theta)
$$

Assim, o problema do sobre-preço se relaciona á questão das garantias. Caso o preço do navio no mercado internacional se reduza para $P$, seu proprietário terá um ativo contratado por $P^{* *}$, cujo valor é $P<P^{*}<P^{* *}$. Contudo, terá ainda terá que honrar garantias sobre o valor de $P^{* *}$ detendo um ativo que vale apenas $P$ e cujo valor inicial corresponde a $P^{*}$. Essa amplificação do risco cria um impasse no financiamento constituindo um dos maiores entraves à contratação. No caso brasileiro, o valor máximo financiado é de $90 \%$ do total da proposta e as garantias cobradas são da ordem de $130 \%$. Isso faz com que a garantia exigida em contrato que assuma $90 \%$ do valor do empreendimento assuma a magnitude de $117 \%$ do valor do ativo. Este fato amplifica o nível de risco das operações.

Um outro aspecto importante a ser considerado na criação de linhas de seguro se encontra associado ao tamanho do mercado. Em contratos de seguro

\footnotetext{
${ }^{50}$ Tais entrevistas foram realizadas ao longo de desenvolvimento desse projeto e são apresentadas no capítulo 4.
} 
normais (de construção civil, por exemplo) o número de carteiras de seguros dilui o risco da seguradora, pois nesses mercados, além do risco ser individualmente menor, o número de contratos segurados dilui o risco da carteira segurada. Isso não ocorre em contratos de seguro orientados à construção naval dada a reduzida escala dos negócios.

\subsection{Conclusões do Capítulo}

Este capítulo abordou sumariamente a questão do financiamento a partir de diferentes óticas, a saber: armador, estaleiro, governo, agente financeiro e seguradora. Ao fazer isso discutiu aspectos estratégicos e operacionais que regem a atuação em cada segmento enfatizando objetivos e fontes de divergências que influenciam as decisões em torno dessas operações. Nesse contexto, foram explicitadas como estas questões interferem na definição dos parâmetros associados à transferência de ativos e os riscos associados. Esse entendimento é particularmente importante, pois embora respeitando políticas de financiamento diferenciadas, os contratos firmados entre as contrapartes são feitos sob medida e envolvem riscos específicos que afetam de maneira diferenciada cada agente.

Dadas às características do mercado de construção naval, tempo de vida útil da embarcação e período de payback dos empreendimentos, os contratos de financiamento exigem longos períodos de maturação cujo retorno é incerto. Em suma: o investimento setorial é orientado ao longo prazo. Esse fator enseja a necessidade de prazos dilatados bem como a definição de salvaguardas múltiplas para contornar os riscos de cada operação. A base de negociação é estabelecida por meio de mecanismos de classificação de crédito de riscos (credit scoring e credit rating). As características econômicas explicitadas no capítulo 2 justificam o exercício da função alocativa por parte do Estado na provisão de financiamento como meio de promover o nível de atividade e competitividade da ICN e dos transportes.

O valor de um contrato depende da especificidade do pedido. Esse é função do tipo de navio e rota a ser atendida. Os estaleiros devem possuir habilidades no planejamento e gestão de operações. Parte das expectativas dos armadores e 
agente financeiro em relação à construção naval se relaciona ao risco operacional do armador e risco estaleiro. Percepções quanto a flutuações nas receitas de frete, atrasos no cronograma de construção, desvios e flutuações em torno das estimativas de custos, etc., podem acarretar dificultar as negociações. A capacidade de geração de receitas por parte do armador e a reputação do estaleiro são criticas. Esses fatores se refletem da estrutura e custos dos contratos. No limite, podem tornar impeditiva a contração.

Caso o financiamento à construção seja contratado pelo armador, o risco de não entrega do navio é fatal, pois este corre o risco de ficar sem o produto (perdendo a janela de oportunidades vislumbrada no planejamento) e ter de arcar com obrigação da dívida (contraída junto ao agente financeiro). Por essas razões os riscos de mercado e de liquidez também devem ser cuidadosamente avaliados. Esses fatores refletem expectativas quanto à capacidade de geração de caixa dos ativos para saldar obrigações (operacionais, financeiras, etc.) e quanto ao valor esperado dos direitos colocados como garantias (collateral). Pequenos diferenciais nas taxas ou prazos podem tornar impeditiva a contratação - dado seus efeitos no valor das prestações e consequentemente sobre o time charter diário dos empreendimentos.

Sob a ótica do armador, o foco do financiamento se baseia em taxas reduzidas, menor valor de participação, maior período de carência, prazos dilatados e menor volume de documentação. Isso contrasta com o foco do agente financeiro. Em ambos os casos, o foco de baseia em expectativas orientadas para um relacionamento focado em produtos e serviços sob medida. A velocidade na aprovação constitui outra fonte de divergências. Muitas vezes as avaliações são muito morosas, ampliando os custos financeiros e riscos do empreendimento.

Os estaleiros raramente financiam a construção naval, pois nem sempre possuem condições para atender as garantias exigidas em tais contratos. A rigor, isso se deve à fraca relação preço/custo e baixo valor e liquidez dos ativos que operam. Não obstante, essas empresas necessitam recursos destinados à aquisição de equipamentos e capital de giro para viabilizar a produção. Em meio a competição global verificada nessa indústria e dado seu reduzido poder de barganha ante a fornecedores e clientes, as margens nesse segmento são muito reduzidas o que restringe a capacidade de auto-financiamento e de endividamento dessas empresas. Excelência na elaboração e execução de projetos e na gestão da cadeia de 
suprimentos são elementos críticos avaliados pelos armadores e agentes financeiros. Novamente mecanismos de credit scoring são vitais nas avaliações. Como os contratos são feitos sob medida, sua atuação (presente a passada) influencia as decisões de financiamento. Isso remete ao conceito de credit rating.

Ao longo de sua execução, um projeto de construção pode atrasar em razão de erros de programação, insuficiência de recursos financeiros para atender as necessidades de caixa, ou por outros motivos (risco de evento, poder aquisitivo, cambio, etc.). Seja qual for a expectativa quanto a ocorrência desses eventos, esses podem ser severos, afetando as condições de custo e prazos das operações de financiamento. Esses fatores exigem eficiência no planejamento e aplicação efetiva de mecanismos de controle pelas contrapartes - o que é estabelecido pela identificação de micro-eventos que possam afetar a qualidade dos projetos.

Em função da capacidade das empresas em tomar empréstimos e riscos inerentes às operações, os bancos são cuidadosos na análise de capacidade de cumprimento das obrigações e diligentes em administrar o nível de risco de cada contrato. Com base em mecanismos de análise de crédito (credit scoring, credit rating, etc.), as instituições financeiras devem ser capazes de avaliar com algum grau de certeza os retornos apropriados exigidos para cada nível de risco. Isso também envolve o uso de informações para determinar as garantias contratuais de cada operação. Nesse caso, o emprego de mecanismos acurados de avaliação é fundamental. Eficiência e eficácia na avaliação de riscos operacionais, segurança e experiência são essenciais no sucesso da contratação.

O seguro de crédito constitui uma das modalidades de seguro que podem auxiliar na contratação. O foco é garantir o pagamento do principal e juros das operações mediante o pagamento de um prêmio. Esse é definido a partir da avaliação qualitativa e quantitativa dos riscos. Em função de suas similaridades, certos esquemas de securitização são semelhantes aos empregados na construção civil. Caso se verifique desvios durante fase de execução (dificuldades financeiras da construtora, atrasos excessivos ou outros sinistros previstos em contrato) a seguradora deve assumir a construção, contratando outra empresa para finalizá-la. O contrato deve prever a cobertura das despesas adicionais. Na aplicação dessa modalidade de seguro a seguradora deve atuar como "sócia" garantidora da operação/construção, provendo o ressarcimento de prejuízos decorrentes de sinistros previstos até o valor fixado na apólice. O principal desafio nesses arranjos 
consiste em identificar as fontes de risco e avalia-los como meio de determinar o valor da apólice de seguros e estabelecer a classificação de risco das empresas a fim de tornar factível a contratação do seguro.

No Brasil, os papéis e as instituições envolvidas nos esquemas de financiamento são sumarizados no quadro 9. Cada agente possui papeis e procedimentos bem definidos.

\begin{tabular}{|l|} 
Armador \\
\hline - Solicita do FMM prioridade para o financiamento pré e/ou pós- \\
entrega \\
\hline - Submete o projeto ao BNDES ou a outro agente oficial \\
credenciado \\
\hline - Contrata o Estaleiro \\
\hline - Atua como fiscalizador \\
\hline Estaleiro (se for o responsável para obter o financiamento \\
para a construção) \\
\hline - Solicita do FMM prioridade para o financiamento pré-entrega \\
\hline - Submete o projeto ao BNDES ou outro agente oficial \\
credenciado e apresenta o seguro garantia \\
\hline - Executa a obra \\
\hline Comissão Diretora do Fundo da Marinha Mercante - CDFMM \\
\hline - Define a prioridade dos pedidos de financiamento apresentados \\
ao Departamento do Fundo da Marinha Mercante - DFMM \\
\hline - Encaminha ao Agente Financeiro os projetos que receberam \\
prioridades \\
\hline - Acompanha a execução do projeto \\
\hline BNDES ou Outro Agente Oficial Credenciado \\
\hline - Analisa riscos (operacional, financeiro, de mercado, etc.) \\
\hline - Estabelece e contrata as garantias \\
\hline - Concede o financiamento e libera os recursos de acordo com a \\
programação do projeto e avaliação de documentos \\
\hline - Acompanha a execução do projeto \\
\hline Seguradora (modalidades seguro de crédito e garantia) (*) \\
\hline - Identifica e analisa riscos \\
\hline - Emite apólice de seguro garantindo o cumprimento do contrato \\
\hline - Participa da gestão e do controle da construção \\
\hline - Assume obrigações pactuadas até o limite do capital segurado \\
\hline - Emite apólice para os riscos de acidente na obra \\
\hline - Ressegura o risco \\
\hline- Agentes locais do processo de financiamento e seus principais
\end{tabular}

Quadro 9 - Agentes locais do processo de financiamento e seus principais papéis. ${ }^{*}$ ) Até o termino desse estudo seguro garantia não havia sido aprovado pela Casa Civil. Fonte: Elaborado com base em documentos cedidos durante as rodadas de entrevistas realizadas ao longo do desenvolvimento do estudo.

Estabelecidas essas discussões, o próximo capítulo conceitua de maneira mais acurada os diversos tipos de riscos das operações de transferência de ativos de capital. Ao fazer isso procura quantificá-los empiricamente por meio de 
indicadores econômico-financeiros de empresas em operação. Os resultados são analisados e discutidos a partir de entrevistas realizadas durante a elaboração do projeto. 


\section{MICROFUNDAMENTOS DO PROCESSO DE FINANCIAMENTO SETORIAL}

Um projeto pode ser definido como um conjunto de informações (internas e externas à empresa) coletadas, processadas e analisadas para a tomada de decisões de investimento (WOILER; MATIAS, 1996). Nesse sentido, pode ser entendido como um modelo que procura simular, ao incorporar informações qualitativas e quantitativas, as decisões de investimento e suas implicações operacionais e financeiras sobre as contrapartes nele envolvidas.

De maneira abrangente, o financiamento de projetos envolve três elementos: práticas administrativas (iniciação, planejamento, execução, controle e finalização) (KERZNER, 2002); obtenção e análise de indicadores econômico-financeiros, calculados a partir dos Demonstrativos Contábeis da(s) empresa(s) envolvida(s) no negócio; (DAMODARAN, 2003); obtenção e avaliações de fluxo de caixa e de informações associadas ao empreendimento por meio do emprego de técnicas de engenharia econômica (GITMAN, 2000). Esses elementos devem envolver o tratamento dos riscos correspondentes (operacional, financeiros, etc. $)^{51}$.

A finalidade de um investimento é incrementar o valor, atendendo ou superando as expectativas de retorno dos investidores. $\mathrm{Na}$ modelagem de um projeto, o processo de determinação do fluxo de caixa articula um conjunto de dados e estimativas associados a receitas e gastos a fim de evidenciar seu retorno provável (MOTTA; CALÔBA, 2002). Os procedimentos se originam de projeções diversas, envolvendo ainda premissas e restrições (KERZNER, 2002). A partir do conjunto dessas informações se processa a análise matemática e análise contábil do retorno sobre investimentos (HERFELT, 2000; KASSAI, 2000).

Em termos da análise contábil, o tratamento sistemático de informações da empresa resulta a classificação de crédito (credit scoring), perfis de riscos de propostas (credit rating), fixação de parâmetros orientados para a tomada de decisão de financiamento e determinação de condições contratuais de transferência de ativos. As decisões envolvem também o entendimento do ciclo operacional e de

\footnotetext{
${ }^{51}$ Os indicadores econômico-financeiros serão apresentados a seguir.
} 
caixa do negócio (HELFERT, 2000; RUTH, 1991). Esses abordados de forma preliminar no capítulo 2.

Já a análise matemática do retorno sobre investimento, pode ser caracterizada como um conjunto de procedimentos orientados para a tomada de decisão, tendo como base a obtenção e avaliação/processamento das estimativas de fluxo de caixa (FDC) do empreendimento (COPELAND; KOLLER; MURRIN, 2002; KASSAI, 2000) ${ }^{52}$.

Este capítulo apresenta e discute os principais elementos associados à análise de crédito e estruturação de financiamentos. Ao fazer isso procura relacionálos aos esquemas de financiamento orientado ao setor de transporte marítimo e contratação da construção naval. Isso é feito por meio da revisão da literatura em temas que tratam da análise contábil do retorno sobre investimentos, associada ao credit scoring e credit rating. Aspectos relacionados a análise matemática do retorno sobre investimentos serão abordados mais adiante, no capítulo 5.

Com efeito, a seção 4.1 dá conta dos aspectos relacionados às operações de financiamento. Ao fazer isso discute os princípios que sustentam uma análise de crédito e sua relação com o processo de financiamento setorial. Ao final desta seção, são sintetizados cinco fundamentos relacionados à análise de propostas (análise de indicadores econômico-financeiros e definição do perfil de crédito; estudo de projeções relacionadas ao empreendimento; avaliação do aporte de recursos; fixação do perfil das obrigações; estabelecimento de cláusulas contratuais e condicionantes dos níveis desejados de garantias). A seção 4.2 detalha os diversos tipos de riscos envolvidos nos negócios, riscos estes associados à alocação de ativos de capital (risco operacional, risco financeiro, risco de mercado, risco de taxa, risco cambial, etc.). A finalidade é estabelecer a relação desses conceitos com as especificidades setoriais (tal como esboçado de maneira preliminar no capítulo 3). A seção 4.3 apresenta a forma de quantificação desses riscos por meio da utilização de indicadores econômico-financeiros, incluindo os que são empregados pelo BNDES em seus processos de avaliação de crédito. A seção 4.4 estabelece a aplicação dos indicadores econômico-financeiros no estudo. São apresentados e discutidos os indicadores econômico-financeiros das empresas de armação para os

52 Dadas às características econômicas dos empreendimentos e escassez de conhecimento das atividades que envolvem o mundo marítimo, estes procedimentos são ainda mais críticos para a tomada de decisão (KHALID, 2005). 
anos de 2003, 2004 e 2005 e 2006 (seção 4.5). A construção desses indicadores foi feita a partir do banco de dados de 48 empresas de armação internacionais e 4 empresas nacionais, obtidas de uma amostra não intencional de empresas. O foco das análises se concentrou nos exercícios de 2004 e 2005 e tem como ponto de partida análises agregadas quanto à composição de ativos, passivos, receitas, gastos, caixa, etc.. A apresentação de resultados deriva da implementação de procedimentos estatísticos cuja finalidade foi eliminar outliers. Os dados remanescentes foram tratados a partir da aplicação de testes estatísticos (teste $\mathrm{F}$ e teste $t$ de Student) a fim de verificar se existem diferenças nas médias dos diversos indicadores. Uma vez elaborados os testes estatísticos esses são empregadas no processo de avaliação das opiniões de especialistas entrevistados (seção 4.6). O objetivo foi estabelecer comparações das diversas classes de indicadores obtidos a fim de verificar se há discrepâncias na estrutura de capital das empresas nacionais vis-à-vis as empresas internacionais ${ }^{53}$. O capítulo termina estabelecendo considerações acerca das informações apresentadas (seção 4.7). Nesse contexto, discute a capacidade que as empresas de transporte marítimo locais possuem nas negociações em torno do financiamento à construção de embarcações.

\subsection{Fundamentos das Operações de Financiamento}

Abstraindo aspectos relacionados às práticas administrativas de um projeto, tal como apresentado por Kerzner (2002) e sistematizado no PMBoK @ (2004), uma análise financeira destinada a concessão de crédito conjuga técnicas de estudo de viabilidade e processos de análise retrospectiva e análise prospectiva de indicadores econômico-financeiros. Nesse contexto, os agentes financeiros estabelecem e aplicam critérios próprios destinados ao tratamento sistemático e conjuntos das informações econômicas e financeiras associadas a cada empreendimento (RUTH, 1991).

Em linhas gerais, uma operação de financiamento envolve a expectativa de recebimento (ou pagamento) de determinada quantia de dinheiro por determinado

\footnotetext{
${ }^{53}$ Para melhor compreender os resultados das entrevistas feitas ao longo do projeto (seção 4.6), vale considerar as discussões acerca do financiamento setorial conforme discutida no capítulo 3.
} 
período de tempo (COPELAND, KOLLER; MURRIN, 2002). O processo de captação de recursos (funding) e sua contratação têm como base a obtenção e análises de indicadores econômico-financeiros que, ao refletir os riscos de transferência de ativos, se repercutem na estrutura de financiamento (GITMAN, 2000; ROSS; WESTERFIELD; JAFFE, 2002). Para minimizar os riscos de perdas as instituições financeiras devem fazer uma rigorosa análise de crédito. Nesse contexto, cinco critérios são tradicionalmente utilizados: caráter, capacidade, capital, collateral, conglomerado (RUTH, 1991). Estes constituem os cinco C's preconizados por Weston e Brigham (2000) e são sumarizados por Ruth (1991). ${ }^{54}$

Nesta mesma linha analítica Johnson Stokes \& Master (2005), ao discutir o financiamento orientado ao setor naval, aponta cinco fatores relevantes nas negociações em torno das operações de financiamento. Apresentados no quadro 10, estes se encontram diretamente relacionados aos cinco C's.

54 Mais recentemente se fala em 6's, esse último corresponde as condições micro e macroeconômicas que afetam o desempenho de mercado de setores econômicos e empresas. 


\begin{tabular}{|c|c|}
\hline \multirow[t]{4}{*}{ (1) caráter } & $\begin{array}{l}\text { é imprescindível verificar se as empresas envolvidas nas propostas (armador e } \\
\text { estaleiro) possuem boa reputação; isso é feito por meio de mecanismos de credit } \\
\text { scoring }\end{array}$ \\
\hline & $\begin{array}{l}\text { se o banco realiza negócios com empresas de baixa integridade, compromisso e } \\
\text { profissionalismo, comprovada aderência a estratégia corporativa, cedo ou } \\
\text { tarde, esses fatores irão provocar viés de risco, expondo o banco a perdas } \\
\text { financeiras (recuperação e remuneração do capital) }\end{array}$ \\
\hline & para dar conta disso, cada banco possui critérios próprios para avaliar seus clientes \\
\hline & $\begin{array}{l}\text { as variáveis associadas ao caráter são difíceis de medir mas, como o mercado } \\
\text { naval é muito concentrado, o histórico das operações pretéritas em torno de } \\
\text { variáveis qualitativas associadas a análise de variáveis quantitativas auxilia na } \\
\text { tomada de decisão }{ }^{\left({ }^{*}\right)}\end{array}$ \\
\hline \multirow[t]{7}{*}{$\begin{array}{l}\text { (2) } \\
\text { capacidade }\end{array}$} & $\begin{array}{l}\text { é necessário estimar e avaliar a segurança das operações em termos da } \\
\text { capacidade de gestão dos projetos de construção e quanto as perspectivas de } \\
\text { geração de fluxo de caixa de cada projeto ao longo do ciclo operacional }\end{array}$ \\
\hline & $\begin{array}{l}\text { uma vez entregue o navio, mesmo que seu lucro seja relativamente pequeno, o } \\
\text { fluxo de caixa esperado deve ser contínuo e suficiente para pagar a divida bancária } \\
\text { e suportar as despesas operacionais }\end{array}$ \\
\hline & $\begin{array}{l}\text { obviamente, as variáveis que afetam o fluxo de caixa desses empreendimentos } \\
\text { dependerão do tipo de mercado no qual a embarcação ira operar }\end{array}$ \\
\hline & $\begin{array}{l}\text { o lucro esperado deve gerar um valor residual da embarcação após expirar o } \\
\text { contrato de afretamento }\end{array}$ \\
\hline & $\begin{array}{l}\text { fragilidade de um contrato de afretamento pode ser avaliada no longo prazo em } \\
\text { termos das flutuações esperadas nas receitas de frete, custos, preço do dólar, etc. }\end{array}$ \\
\hline & $\begin{array}{l}\text { a inflação de despesas operacionais, flutuação das taxas de juros e nas taxas de } \\
\text { financiamento bancário podem tornar baixa expectativa de fluxo de caixa caso as } \\
\text { taxas de juros do contrato sejam pós-fixadas }\end{array}$ \\
\hline & $\begin{array}{l}\text { o financiador tem que "vislumbrar" todo o ambiente econômico dentro do horizonte } \\
\text { projetado para o financiamento }\end{array}$ \\
\hline \multirow[t]{4}{*}{ (3) capital } & $\begin{array}{l}\text { a condição financeira da empresa ligada a setor de transporte naval não é fácil para } \\
\text { identificar a partir de seus demonstrativos contábeis }{ }^{55} \text { - ativos intangíveis como } \\
\text { relacionamento com fornecedores, capital humano, etc., são extremamente } \\
\text { relevantes em se tratando da produção e operação de bens sob encomenda }\end{array}$ \\
\hline & $\begin{array}{l}\text { um entendimento sobre as operações da empresa é condição indispensável para a } \\
\text { decisão do banco em conceder ou não o crédito }\end{array}$ \\
\hline & $\begin{array}{l}\text { para facilitar essa analise, um banco normalmente vai requerer demonstrações } \\
\text { financeiras (financial statements) dos três anos prévios para obter e analisar seus } \\
\text { indicadores econômicos e financeiros; projeções também são requeridas }\end{array}$ \\
\hline & $\begin{array}{l}\text { contudo essas análises são ainda incompletas e a experiência e conhecimentos } \\
\text { focados no setor ainda são essenciais para o sucesso de um financiamento }\end{array}$ \\
\hline
\end{tabular}

Continua

\footnotetext{
${ }^{55}$ Vale ressaltar que o presente capítulo apresenta as fórmulas de cálculo de tais indicadores dentro de seus respectivos grupos.
} 


\begin{tabular}{|c|c|}
\hline \multirow[t]{4}{*}{$\begin{array}{l}\text { (4) } \\
\text { conglomerado }\end{array}$} & $\begin{array}{l}\text { devido às incertezas econômicas, os armadores desejam empréstimos com o } \\
\text { maior prazo que puderam, com a menor quantia de ações ou investimento de } \\
\text { capital }\end{array}$ \\
\hline & $\begin{array}{l}\text { isso coloca o armador e o banco em lados opostos - particularmente no caso } \\
\text { de empréstimos longos e com grande participação }\end{array}$ \\
\hline & $\begin{array}{l}\text { os bancos buscam reduzir a sua exposição restringindo o volume de aporte } \\
\text { de capital }\end{array}$ \\
\hline & $\begin{array}{l}\text { um outro principio que é prudente do banco adotar é aquele em que os } \\
\text { bancos só deveriam conceder empréstimos para os projetos em que os } \\
\text { armadores já tenham feito um significante investimento de capital (que } \\
\text { também esteja disponível antes da concessão do empréstimo bancário) e no } \\
\text { qual o armador esteja preparado para perder caso o empréstimo não seja } \\
\text { pago }\end{array}$ \\
\hline \multirow[t]{3}{*}{ (5) collateral } & $\begin{array}{l}\text { estas podem ser de vários tipos, tais como caução, penhor, valor mobiliários } \\
\text { posto à disposição de garantia de pagamento (collateral), entre outros }\end{array}$ \\
\hline & $\begin{array}{l}\text { uma das principais análises feitas pelos bancos é referente ao valor mobiliário } \\
\text { posto à disposição como garantia de pagamento }\end{array}$ \\
\hline & $\begin{array}{l}\text { o banco deve avaliar os riscos dos haveres da empresa naval, como um } \\
\text { exercício separado dos prospectos de troca da embarcação ou os riscos } \\
\text { operacionais (embora algumas omissões tendam a ocorrer pois deseja operar } \\
\text { ou vender a embarcação para recuperar seu dinheiro). }\end{array}$ \\
\hline
\end{tabular}

NOTAS

$\left(^{*}\right)$ As considerações acerca do caráter estritamente financeiro desses princípios foram feitas com base em Gitman (2000), Ross, Westerfield e Jaffe (2002) e Weston e Brigham (2000).

$\left({ }^{* *}\right)$ A comunidade naval é pequena no sentido em que a maior parte dos decision makers nela empregada (sejam armadores, administradores, emissores de títulos, corretores, reparadores, advogados) se conhecem. A reputação de um armador pode ser obtida a partir de uma investigação discreta no mercado. Um banco seria imprudente se não fizesse uma investigação das operações do armador antes de se comprometer com qualquer tipo de negócio de empréstimos.

Quadro 10 - Cinco princípios que servem de base de negociação ao financiamento destinados ao setor naval ${ }^{(*)}$

Fonte: Elaborado pelo autor.

Conforme o quadro 10, o caráter é medido em termos da reputação da empresa que, segundo Irene et al (2001), “...is an important factor considering that planning, production and financing of a new shipbuilding is a complex task. Shipowners usually prefer shipbuilders who have achieved good track record in terms of delivery period, meeting deadlines, and quality" (IRENE et al, 2001, p. 13). Obviamente, certas exigências são estabelecidas e igualmente esperadas quanto a atuação dos armadores em sua relação com agentes financeiros ${ }^{56}$.

${ }^{56}$ Durante entrevistas realizadas e descritas adiante neste capítulo, muitas as decisões são tomadas com base em levantamentos informais junto a comunidade ligada ao setor. Essas informações dão maior respaldo às decisões mesmo após a análise exaustiva de demonstrativos financeiros e atendimento se certas exigências previstas em contratos. Obviamente isso evidencia o emprego do conceito de caráter e a forma como ele pode ser avaliado pelos agentes. 
A expectativa de cumprimento do prazo previsto de construção repercute sobre a viabilidade do financiamento e custo de capital. De fato, "delivery period and timeliness are also important factors because shorter delivery periods and timely delivery can reduce the exposure of shipping companies to investment risks resulting from changes in interest rates, foreign exchange rates, and shipping demand." (IRENE et al, 2001, p. 14).

Como o prazo de construção é longo e exige grande volume de recursos, linhas adequadas de financiamento são vitais, inclusive quando analisadas sob a ótica da competitividade da indústria ${ }^{57}$. Contudo, a competitividade depende da combinação de um conjunto mais amplo de fatores: "competitiveness in the shipbuilding industry has been defined in terms of price, quality, product innovation, delivery period, timeliness (ability to meet deadlines), flexibility, reputation, financing services, and customer service (IRENE et al, 2001, p. 13)."

Segundo a literatura relacionada ao tema, certas ferramentas visam garantir que se atenda, de forma exeqüível e confiável, os critérios de qualidade do projeto. Estes se traduzem no cumprimento de seu escopo, prazo e custo, definidos no plano de cada projeto (KERZNER, 2002). Expectativas de atrasos ocasionados por falhas na programação podem implicam em incerteza quanto ao cumprimento do orçamento e prazos. Nesse contexto, expectativas desfavoráveis, captadas pela experiência histórica, são incorporadas aos riscos por meio da classificação de rating das empresas. Essas percepções ocasionam maior incerteza quanto as margens implicado em ônus financeiro para estaleiros e armadores. Fato que pode implicar no ao financiamento ou elevação nas taxas de juros com redução da capacidade de remunerar o capital absorvido pelos empreendimentos.

Outra característica importante que afeta os negócios ligados ao setor é o volume capital exigido nos contratos. Navios são caros para construir e operar, o que significa que assistência financeira é necessária para estaleiros e armadores (KHALID, 2005; STOPFORD, 2005). Como em outras indústrias produtoras de bens sob encomenda, os interesses das partes envolvidas nos negócios nem sempre são convergentes. Conflitos em torno de taxas de remuneração sobre as inversões, riscos e prazos restringem a troca de ativos e o volume de operações.

\footnotetext{
57 Em termos da indústria naval esse aspecto é apontado por diversos autores, entre eles, Barboza (2004), Fadda (2006) e Cho e Porter (1986)
} 
Conforme Johnson Stokes \& Master (2005), relacionadas ao conceito de caráter, certas questões são relevantes: as empresas envolvidas em um empreendimento possuem boa reputação ${ }^{58}$; o banco estabelece critérios suficientes para avaliar seus clientes? esses são atendidos? Já Ruth (1991) sugere que o caráter se relaciona na determinação quanto ao cumprimento de obrigações referentes ao empréstimo - o que remete à qualidade do management empresarial. Clientes, fornecedores, credores e outras instituições podem fornecer boas indicações a respeito do caráter de uma empresa.

Segundo Copeland, Koller e Murrin (2002) e Ruth (1991), os financiamentos devem ser pagos com caixa gerado durante o ciclo operacional de um negócio. Portanto, a habilidade em gerar caixa suficiente para fazer jus às obrigações assumidas é o que se denomina capacidade. Ainda segundo a literatura especializada, a capacidade de tomar empréstimo por parte das empresas interfere é crítica o mercado de bens sob encomenda. De fato, no mundo dos bens sob encomenda (onde o financiamento se associa a uma demanda derivada), além da capacidade de cumprimento das especificações técnicas do produto e dos parâmetros de programação fixados em uma proposta, informações sobre as experiências passadas em torno de cumprimento de orçamento e prazo dos contratos têm grande peso nas análises, interferindo diretamente nas decisões de financiamento. Novamente a análise do histórico de empréstimos e atendimento das obrigações contratuais são críticos. Com estas informações em mãos, os agentes financeiros avaliam os retornos apropriados relacionando-os à cada nível de risco. Ao associar caráter e capacidade, estas organizações conduzem a classificação de crédito e perfis de risco durante o processo de avaliação de propostas (KHALID, 2005).

Como em outras operações de financiamento, o porte da empresa e capacidade de oferecer garantias é vital para a efetivação de contratos. Grandes armadores e estaleiros não enfrentam muitas dificuldades para obter financiamento, dadas suas capacidade de atender as garantias de crédito (KHALID, 2005). Muitas pequenas e médias empresas navais não obtêm as mesmas facilidades (KHALID,

\footnotetext{
${ }^{58}$ A comunidade naval é pequena no sentido em que a maior parte dos dirigentes e tomadores de decisão que atuam no setor (sejam armadores, administradores, emissores de títulos, corretores, reparadores, advogados) se conhecem. A reputação de um armador pode ser obtida por uma investigação discreta no mercado. Um banco seria imprudente se não fizesse uma investigação das operações do armador antes de se comprometer com qualquer tipo de negócio de empréstimos.
} 
2005). Clientes com sólida reputação merecem melhores termos de empréstimos do que os novos clientes (JOHNSON STOKES \& MASTER, 2005). Empresas capitalizadas que estejam aptas a injetar grande porcentagem de recursos próprios (atendendo as garantias estabelecidas pelo financiador) gozam de melhores termos de transferência de fundos próprios em contraste com empresas que não possuem base financeira consolidada (JOHNSON STOKES \& MASTER, 2005). Na prática, os bancos tendem a conceder empréstimos preferencialmente para clientes de maior solidez, para proteger seus ativos e garantir maior taxa de retorno, dado um mesmo nível de riscos. Sem o suporte dos bancos, as empresas navais de menor porte encontram dificuldades para expandir seus negócios e, por conseguinte, melhorar a sua capacidade de obter crédito (KHALID, 2005). Em torno desses aspectos analíticos, Ruth (1991) aponta a ênfase das instituições financeiras em torno da capacidade: conhecer qual a fonte específica do pagamento da obrigação, inferir sobre fontes secundárias se a fonte específica falhar, saber se há garantidores e seu tipo de relação com o empreendimento e conhecer a capacidade financeira dos garantidores.

Como o volume de capital exigido nos empreendimentos navais é de grande monta, expectativas ou aporte efetivo de capital próprio por parte das empresas envolvidas são vistos como um indicador do comprometimento em relação ao empreendimento $^{59}$. Empresas ligadas por meio de conglomerados e grandes empresas também possuem maior capacidade financeira para alocar recursos próprios em projetos de investimento. Isso tende a criar expectativas favoráveis quanto a efetividade dos empreendimentos. Por isso os bancos privilegiam propostas nas quais os envolvidos já alocaram ou se comprometem contratualmente a alocar uma boa parcela do capital exigido pelo empreendimento. Esse expediente amplia a percepção de confiança nas operações (JOHNSON STOKES \& MASTER, 2005). Tais fatores têm relação direta com os conceitos de conglomerado e capital. A rigor, o capital se refere à magnitude de fundos disponíveis para a operação de uma empresa. Nesse contexto, o montante de capital patrimonial, de terceiros e

\footnotetext{
${ }^{59}$ As práticas bancárias internacionais normalmente estabelecem que contratantes-compradores se responsabilizem integralmente pelos $20 \%$ ou $30 \%$ iniciais do contrato de construção por meio de emprego de capitais próprios. Disso resulta que os créditos bancários são utilizados para cobrir o saldo adicional. Isso enseja maior segurança nas operações - há somente um caso tornado público de financiamento de $100 \%$ (ALEX, 2004).
} 
indícios acerca do grau de eficiência com que estes são geridos são vitais às análises (RUTH, 1991).

Em muitas situações, a real condição financeira da empresa naval não é de simples identificação, a partir de seus Demonstrativos Contábeis. A disponibilidade de ativos intangíveis como relacionamento com clientes e fornecedores, capital humano, etc., são relevantes e não são explicitados em tais documentos ${ }^{60}$. Portanto, um bom entendimento sobre as operações da empresa e seu posicionamento no mercado também são condições indispensáveis, condicionado a decisão da concessão de crédito (KHALID, 2005) $)^{61}$. Para proceder a análise de crédito o banco normalmente vai requerer demonstrações financeiras (financial statements) dos três anos prévios a fim de obter, analisar e comparar seus indicadores econômicofinanceiros com o de outras empresas do mesmo segmento (RUTH, 1991; WESTON; BRIGHAM, 2000). Adicionalmente, exigem consistentes projeções de receitas e custos associadas ao projeto e ao empreendimento como um todo (MOTTA; CALÔBA, 2002; WOILER; MATIAS, 1996). Dada a sua natureza, tais análises são ainda incompletas. Por esta razão a experiência e conhecimento focado no setor são essenciais aos bancos (KHALID, 2005).

Mesmo que as projeções sugiram que o lucro durante a operação do navio (objeto do contrato) seja relativamente adequado surgem duas questões: o fluxo de caixa projetado é contínuo e suficiente para pagar as obrigações financeiras e suportar as despesas operacionais? os ativos deixam valor residual em caso de execução de garantias? (KHALID, 2005). A rigor, o fluxo de caixa projetado dependerá do tipo de mercado no qual a embarcação irá operar e do status da contratação dos serviços. Por exemplo, a fragilidade de um contrato de afretamento no longo prazo deriva de suas receitas fixas antes as flutuações no preço do dólar e nos custos e despesas operacionais. Assim, a inflação nessas categorias de gastos poderia tornar incerta uma dada expectativa de fluxo de caixa. Por isso, tais contratos devem possuir cláusulas que indexem seu valor às flutuações nas despesas operacionais.

Os conceitos de conglomerado e capital conduzem a um princípio segundo o qual só se deve conceder empréstimos para os projetos em que os armadores já

${ }^{60}$ Outros fatores ligados a gestão dos ativos das empresas do setor serão tratados mais adiante neste capítulo.

${ }^{61}$ Como será indicado adiante, esse aspecto foi apontado pelos entrevistados ao longo da pesquisa. 
tenham feito um significante investimento de capital (preferencialmente antes da concessão do empréstimo bancário) e no qual o armador esteja preparado para arcar com despesas adicionais caso haja atrasos e aumento nos custos (KHALID, 2005) decorrentes, inclusive, de atrasos na construção (STOPFORD, 2005).

Em função das características apontadas, o financiamento naval envolve sofisticados mecanismos de avaliação e de fixação de garantias sobre as dívidas (ALEX, 2004; KHALID, 2005) os quais são função das altas somas envolvidas, prazos e níveis de riscos das operações (JOHNSON STOKES \& MASTER, 2005). Uma das formas de contornar estes desafios é por meio do estabelecimento de cláusulas que garantam o direito do financiador tomar posse do navio ou de outros ativos da empresa que efetiva o contrato de financiamento, em caso do não cumprimento de suas cláusulas (KHALID, 2005) ${ }^{62}$.

Segundo Ruth (1991), a garantia exigida visa "compensar fraquezas" em relação aos demais fundamentos da análise de crédito (caráter, capital, etc.). Neste sentido, funciona como um mecanismo por meio do qual as instituições financeiras se resguardam contra os riscos potenciais do empréstimo à uma empresa de determinado segmento. Com efeito, "a finalidade da garantia é dar ao credor meios pelos quais poderá recorrer caso o caixa para pagamento não se materialize no decorrer do ciclo operacional normal da empresa (RUTH, 1991, p. 119)". Como aponta Ruth (1991), a garantia em si não efetua o pagamento da obrigação e não justifica por si só a concessão de financiamento. Também por estas razões as garantias exigidas são, em muitas situações, elevadas.

Ao se concentrar nos procedimentos de avaliação de garantias, Ruth (1991) estabelece que se deve conhecer onde está localizada a garantia, se esta possui liquidez, sua forma de avaliação e sua expectativa de valor futuro, etc. Segundo Ruth (1991), a garantia nunca deve ser considerada como a fonte de pagamento de empréstimos. Estes temas remetem a especificidade econômica dos empreendimentos ligados ao mundo naval, tal qual explicitado no capítulo 2 deste trabalho.

\footnotetext{
${ }^{62}$ Se os esquemas tradicionais de financiamento dão grande peso à recuperação do principal da dívida como fator-chave nas negociações de propostas; modernamente os esquemas de garantias visam oferecer confiança quanto a entrega do bem final - a exemplo da formatação e implementação do seguro garantia no Brasil inspiradas nos contratos de financiamento à construção civil. Esse tema foi discutido em maiores detalhes no capítulo 2.
} 
Segundo a literatura a estrutura das garantias pode ser de vários tipos, tais como caução, penhor, valor mobiliários posto à disposição de garantia de pagamento (collateral), etc. (JOHNSON STOKES \& MASTER, 2005; KHALID, 2005; RUTH, 1991). Uma das principais análises feitas pelos bancos se refere ao valor mobiliário posto à disposição como garantia de pagamento. Devido a flutuação no preço dos ativos em meio ao ciclo naval, para que seja efetivado um contrato é preciso avaliar os riscos dos haveres da empresa naval (KHALID, 2005). Isso imprime a necessidade de estabelecer estudos orientados a avaliação dos ativos das empresas envolvidas nos contratos. Esses ativos são, em muitas vezes situações, de difícil avaliação (TOBIAS; PASIN, [200-]).

A partir da leitura sistemática do quadro 10 e das considerações estabelecidas acima é possível afirmar que os fundamentos de uma operação de financiamento dependem dos fatores explicitados a seguir.

A análise de indicadores econômicos e financeiros visa medir a condição financeira dos atores envolvidos na operação, o que é possível por meio dos indicadores obtidos a partir de Demonstrativos Contábeis das empresas. Como apontam Tobias e Pasin (200-), sempre que possível tais avaliações devem ser complementadas por outras análises que captem a eficiência dos ativos intangíveis (carteira de clientes, competência técnica e operacional, gestão da cadeia de suprimentos, etc.), nem sempre possíveis ou simples de mensurar.

Também é preciso considerar a qualidade das projeções a fim de avaliar ex ante as propostas (identificando os riscos potenciais do empreendimento) e acompanhá-las ex post em torno da aderência do orçamento e prazo de execução do projeto com os planos estabelecidos. Isso é feito a fim de evitar desvios e permite propor medidas corretivas com objetivo de garantir maior eficiência na alocação e uso de recursos ao projeto. Além disso, é necessário proceder a avaliação da estrutura e aporte de recursos envolvidos nas operações a fim de verificar as condições das empresas em alocar parcelas de capital próprio no total do investimento (capital) previsto nas projeções.

Outra tarefa importante é estabelecer o perfil das obrigações o que consiste em construir um perfil dessas em torno escopo do empreendimento e do caráter do cliente. Isso deve ser feito de forma a relacioná-los ao tipo de obrigações, objeto da proposta, tendo como base os níveis de retorno e riscos envolvidos. Todos estes elementos são necessários no estabelecimento de cláusulas relacionadas 
ao nível de segurança das operações. Esta atividade consiste na introdução de cláusulas de garantias como meio de assegurar a recuperação do principal (caução, penhor, valor mobiliário posto à disposição do credor como garantia paralela de pagamento de dívida).

\subsection{Tipos de Riscos Envolvidos em Operações de Financiamento}

As perspectivas acima descritas possuem relação direta com os riscos financeiros. Como aponta Gitman (2000, p. 184), "o risco financeiro constitui a possibilidade de perda financeira; ativos considerados mais arriscados são os que oferecem maiores possibilidades de perdas financeiras". Sob esta perspectiva é que a análise de financiamento é praticada. Tendo em vista essa definição, Gitman (2000), Ross, Westerfield e Jaffe (2002) e Damodaran (2004), apontam nove fontes comuns de risco financeiros. Estas podem ser agrupadas em três grandes grupos: riscos específicos da empresa, riscos específicos dos acionistas e riscos da empresa e acionistas. Os quadros 11, 12 e 13 apresentados a seguir sumarizam cada uma dessas fontes de riscos ${ }^{63}$. Neles se procurou relacionar as implicações para o setor naval por meio do relacionamento dos conceitos com o que a literatura estabelece sobre shipping finance. Ressalte-se que o conjunto dessas fontes de risco é, em maior ou menor grau, objeto de grande atenção na avaliação de propostas.

63 Outras fontes de risco muito comuns e que afetam setores que apresentam alto grau de intervenção pública e de progresso técnico são o risco regulatório e risco tecnológico, respectivamente. 


\section{1. riscos específicos da empresa}

1.1 risco operacional - possibilidade da empresa não ser capaz de arcar com os custos operacionais cujo nível é determinado pela estrutura e estabilidade das receitas e custos (custos variáveis) e despesas operacionais.

implicações para o setor - navios demoram para serem construídos e possuem longa vida útil o que implica em severos riscos operacionais em função da ocorrências não esperadas de flutuações nas receitas, flutuações nas despesas e custos, afetando o resultado operacional de estaleiros e armadores - Barboza (2004), Weiss (1990).

1.2 risco financeiro - possibilidade de a empresa não ser capaz de saudar suas obrigações financeiras cujo nível é determinado pela previsibilidade dos fluxos de caixa operacionais da empresa e seu nível de obrigações financeiras.

implicações para o setor - como muitos dos ativos são específicos, há grande rigidez nos dispêndios operacionais vis-à-vis as receitas, assim o nível de lucro operacional pode flutuar implicando em condições adversas de capacidade de pagamento das obrigações financeiras - Stopford (2005).

Quadro 11 - Sumário das fontes de riscos específicos das empresas e suas implicações para o setor naval

Fonte: Elaborado pelo autor.

Os conceitos apresentados nesses quadros vão de encontro aos quatro grandes tipos de risco associados às operações de financiamento setorial. Tal como apontado por Alex (2004), ao analisar o shipping finance sob a perspectiva dos bancos, se deve estimar o risco de crédito, risco do negócio, risco de mercado e risco operaciona ${ }^{64}$. Estes se relacionam à natureza intrínseca e extrínseca das operações ligadas ao setor e têm implicações diretas sobre as garantias (collateral) exigidas pelo agente financeiro.

${ }^{64}$ Ao discutir os tipos de risco associados aos empreendimentos sob a ótica do agente financeiro, Alex (2004) procura relacionar uma série de fatores de risco que repercutem sobre o financiamento setorial. Ao fazer isso destaca essas quatro fontes de risco. 


\section{2. riscos específicos dos acionistas}

2.1 risco de taxa de juros - possibilidade de variação nas taxas de juros as quais possuem relação inversa com o valor dos ativos

implicações para o setor - e. g., quando um contrato de financiamento é firmado a taxa de juros é estabelecida em função dos níveis de risco envolvidos em cada empreendimento dada a política de financiamento, desta forma, flutuações nas taxas de juros implicam em redistribuição de rendas não esperadas entre agente financeiro e tomador do financiamento ${ }^{65}$. No Brasil, as taxas de juros para o financiamento setorial são pré-fixadas, o que limita o risco de taxa. Contudo, pequenos diferenciais nas taxas praticadas nas operações de financiamento de empresas que concorrem no mesmo nicho de mercado podem significar a vida ou a morte uma vez que se repercutem sobre o nível do time charter diário.

2.2 risco de liquidez - possibilidade de que o ativo não possa ser liquidado a preço razoável cuja magnitude é afetada pelo porte e número de vezes em que este ativo pode ser negociado

implicações para o setor - ativos ligados ao setor (armação, construção, etc.) possuem baixa liquidez em função de sua especificidade, isso gera implicações diretas a depender do processo de avaliação do ativo medido por meio do valor de liquidação ou valor de uso trazendo impactos severos sobre a análise de riscos de cada empreendimento - Barboza (2004).

2.3 risco de mercado - o valor de um ativo responde pela dinâmica de mercados que não possui relação direta com o mercado do ativo em si (demanda derivada). Assim, quanto mais sensível é a variação do preço do ativo, em razão da flutuação em mercados correlatos, maior seu risco

implicações para o setor - a demanda pelos ativos de capital do setor é derivada da dinâmica do comércio internacional de bens finais e intermediários (demanda derivada), flutuações nos níveis de comércio desses bens afetam profundamente a rentabilidade esperada do setor pois afetam diretamente 0 mercado de fretes e os demais mercados navais - Stopford (2005).

Quadro 12 - Sumário das fontes de risco específicos dos acionistas e suas implicações para o setor naval

Fonte: Elaborado pelo autor.

Segundo Alex (2004), o risco de crédito capta a possibilidade de perda quando uma das contrapartes se torna inapta a cumprir plenamente obrigações contratuais. Já o risco do negócio advém de fatores que alteram as variáveis do projeto em seu ambiente de mercado, destruindo a sua viabilidade. Este risco inclui elementos quantificáveis (incluindo flutuações no ciclo dos negócios e ou na demanda) e não quantificáveis (estes envolvem, por exemplo, mudanças no comportamento estratégico de um competidor, choque tecnológico ou mudança no marco regulatório) (CHO; PORTER, 1986).

\footnotetext{
${ }^{65}$ Como as taxas de juros dos contratos de financiamento setorial são pré-fixadas, caso as taxas de juros de mercado sofram aumentos inesperados o tomador obtém ganhos inesperados.
} 
Alex (2004) sustenta que o risco de mercado emerge de fatores como variação nas taxas de juros, no câmbio e ou no valor dos ativos associados ao empreendimento. Este tipo risco, que reflete expectativas futuras, também deve ser objeto de cuidadosa análise. Uma vez que o setor naval é cíclico os bancos são extremamente cautelosos em sua avaliação (JOHNSON STOKES \& MASTER, 2005; KHALID, 2005).

Do ponto de vista do empreendimento, Alex (2004) argumenta que o risco operacional se associa às operações do agente financeiro e abarca o risco de perda relacionado a uma catástrofe imprevisível provocada por uma falha técnica ou ação humana - incluindo fraude, desvios na gestão e ou erros de processos. Alex (2004) sustenta ainda que, sob a ótica dos bancos, o risco operacional é muito distinto do risco do negócio em termos de sua identificação e gestão. A rigor, estas instituições dependem do desenvolvimento contínuo de recursos humanos, da expertise acumulada por seus executivos e de pesados investimentos em sistemas de informação a fim de evitar erros estratégicos. Esses fatores encarecem o custo de suas operações. Este risco, também associado à possibilidade de falhas ou deficiências nos sistemas de informação ou controle interno, pode resultar em perdas não esperadas. 


\section{3. riscos para empresas e acionistas}

3.1 risco de evento - possibilidade de que um evento totalmente inesperado exerça influência sobre o valor da empresa ou sobre o valor de um ativo específico

implicações para o setor - guerras, embargos econômicos, fatores climáticos, etc., implicam em choques inesperados sobre os níveis de comércio global ou regional afetando lucros e margens - Stopford (2005), Alex (2004), Khalid (2005).

3.2 risco de câmbio - exposição do valor do ativo a variações futuras nas taxas de câmbio podem acarretar efeitos adversos sobre o fluxo de caixa

implicações para o setor - como apontam Stopford (2005), Kendall e Buckley (2005); Lima e Veslaco (1998) a rentabilidade do setor sofre grande influência do valor do dólar uma vez que esta moeda constitui a referência utilizada em quase todas as transações do setor (os serviços de frete são tradicionalmente cotados nesta moeda).

3.3 risco de poder aquisitivo - possibilidade de que variações sistemáticas nos níveis gerais de preços (inflação ou deflação) afetem desfavoravelmente o fluxo de caixa em função de variações relativas no valor das receitas e custos

implicações para o setor - aqui alguns exemplos podem ser apontados, contratos de fretes longos podem trazer perdas inesperadas caso haja variações positivas nos preços desses (KHALID, 2005); perdas de poder aquisitivos ou inflação de custos trazem implicações adversas sobre o lucro das empresas ligadas ao setor (GITMAN, 2000), o comportamento do setor é cíclico de forma que alterações nos ciclos de produção e preços condicionam a rentabilidade dos ativos.

3.4 risco de tributação e regulatório - possibilidade que mudanças inesperadas na legislação tributária venham a ocorrer

implicações para o setor - como o setor é altamente regulado e grande parte das operações respeita a um intricado número de normas e regulamentos, fatores adversos associados ao risco regulatório e tributário podem ocasionar perdas aos agentes envolvidos nas operações.

Quadro 13 - Sumário das fontes de risco específicos da empresa dos acionistas e suas implicações para o setor naval.

Fonte: Elaborado pelo autor.

Considerando o conceito de financiamento apresentado no início da seção 4.2, a formatação e aprovação de um contrato tratam, além da análise dos riscos apresentados, dependem da avaliação da garantia sobre o valor da dívida. Esta garantia implica no direito do financiador tomar posse de ativos do tomador do financiamento em caso de não cumprimento das obrigações contratuais (KHALID, 2005).

Por fim, vale ressaltar que, em função da experiência passada e considerando que o funcionamento da economia marítima é complexo, apresentando flutuações cíclicas, os bancos que operam linhas de financiamento orientadas ao setor são sempre muito cautelosos na avaliação de propostas (KHALID, 2005). 
A próxima seção apresenta algumas formas empregadas na medição dos diversos tipos de riscos expostos acima.

\subsection{Avaliação dos Riscos dos Empreendimentos por Meio de Indicadores Econômico-financeiros}

A depender das expectativas dos agentes, um projeto pode ser considerado viável, mas as condições financeiras das empresas nele envolvidas podem restringir a captação de recursos necessários para viabilizá-lo. Por esta razão, as condições financeiras das contrapartes envolvidas nas operações (p. ex., armador e estaleiro) precisam ser captadas a partir de indicadores econômico-financeiros. Uma vez obtidos, esses devem ser analisados (em termos absolutos e relativos) e comparados com os índices das demais empresas que atuam no mesmo segmento de mercado (WESTON; BRIGHAM, 2000). A rigor, o conjunto dessas informações é avaliado por meio de algum tipo de critério estabelecido na política de financiamento da instituição financeira. A saída desse processo é a determinação do nível de risco do empréstimo e fixação das correspondentes condições de financiamento (prazos, taxas de juros, garantias exigidas, etc.) (RUTH, 1991). Estes parâmetros constituem a base das negociações.

Esta seção apresenta ferramentas tradicionalmente utilizadas na avaliação retrospectiva e prospectiva das condições financeiras de uma empresa. Estas constituem uma das principais bases de uma transação financeira. Com efeito, as instituições financeiras quando decidem conceder ou não financiamento a um projeto devem proceder a análise do retorno e dos riscos associados a cada operação (RUTH, 1991; KHALID, 2005). Ao fazerem isso trabalham com ao menos quatro tipos de informações: (i) informações relacionadas ao projeto, (ii) projeções de mercado, (iii) avaliação econômico-financeira da empresa (retrospectiva e prospectiva) e (iv) tratamento de aspectos jurídicos ${ }^{66}$.

\footnotetext{
${ }^{66}$ Este trabalho não se propõe a discutir os temas relacionados as projeções de mercado e ou os aspectos jurídicos, dado o escopo da pesquisa e escassez de informações relacionadas a estes temas. Com efeito, pretende abordar tais temas apenas quando remeterem diretamente a elementos eminentemente econômicos e financeiros associadas ao problema e questões explicitadas na pesquisa.
} 
Muitos dos riscos discutidos no item anterior podem ser capitados por meio de indicadores econômico-financeiros obtidos a partir de demonstrações financeiras (Balanço Patrimonial, Demonstrativo de Resultado e Demonstrativo de Fluxo de Caixa). Segundo Ruth (1991) e Damodaran (2004), o uso desses indicadores dão sustentação empírica aos princípios relacionados à concessão de crédito por parte das instituições financeiras. Além disso, constituem uma forma de reorganizar as informações contidas em tais demonstrativos relacionando-as aos aspectos do desempenho financeiro de uma empresa (GITMAN, 2000; ROSS; WESTERFIELD; JAFFE, 2002). Do ponto de vista do investidor, a prospecção do desempenho futuro constitui a base das Demonstrações Financeiras (HERFELT, 2000). Elas ajudam a prever os lucros e dividendos constituindo a base de negociação em muitas operações (WESTON; BRIGHAM, 2000).

Embora úteis na avaliação de crédito, se deve ressaltar que tais indicadores não são capazes de dar respostas precisas a todas estas questões. No entanto, os interessados (acionistas, credores, etc.) sempre os avaliam como meio de ter uma idéia do desempenho da empresa e da sua capacidade para cumprimento de suas obrigações (ROSS; WESTERFIELD; JAFFE, 2002).

Embora não abranjam diretamente todos os conceitos de riscos apresentados na seção 4.2 (dada a carência de informações e dificuldade de medições), a discussão relacionada aos riscos remete ao cálculo de diversas classes de índices financeiros obtidos a partir das informações presentes nos demonstrativos contábeis (WESTON; BRIGHAM, 2000). Com efeito, a análise desses indicadores é importante para os acionistas, credores e gestores das empresas permitindo-Ihes avaliar o nível de retorno e risco corrente e futuro da empresa (GITMAN, 2000). Os credores, por exemplo, querem saber se a empresa apresenta liquidez suficiente para saldar as obrigações de longo prazo traduzidas em amortizações e juros. Sua análise pode ser efetuada a partir de uma leitura pura e simples das demonstrações contábeis, complementadas com análises com base em percentuais, como análise horizontal, análise vertical e ou análise ponderada (KASSAI, 2000) ${ }^{67}$.

\footnotetext{
${ }^{67}$ Duas análise podem ser estabelecidas a partir dos Demonstrativos Contábeis (DC): analise vertical e horizontal. A primeira considera a evolução de uma única conta presente no DC ao longo do tempo; a segunda relaciona duas contas em um mesmo momento. A análise por meio de indicadores econômico-financeiros faz parte da análise vertical pois relaciona uma ou mais contas em um mesmo instante no tempo. pode ser feita
} 
Estes indicadores podem ser classificados em diferentes grupos a partir dos quais se pode tecer comentários acerca da saúde financeira de uma empresa e até mesmo estabelecer comparações entre esta e empresas do mesmo ou de outros setores de atividade (ROSS; WESTERFIELD; JAFFE, 2002). Entre os principais figuram: índices de solvência ou liquidez; índices de alavancagem financeira ou endividamento; índices de atividade ou administração de ativos; índices de rentabilidade ou retorno sobre investimento e índices de valor ${ }^{68}$. Basicamente os índices de liquidez, atividade e endividamento medem os riscos globais do empreendimento e serão empregados nesse trabalho. Já os índices de rentabilidade, medem a capacidade de geração de valor para o acionista (GITMAN, 2000). Vale ressaltar que a "aceitação" da magnitude de cada um dos índices depende do setor de atividade no qual a empresa atua (RUTH, 1991), o que é discutido a seguir.

\subsection{1 Índices de Solvência ou Liquidez (IL)}

Os índices de solvência medem a capacidade de uma empresa de saldar suas obrigações de curto e de curtíssimo prazo; ou seja, indicam a capacidade de pagamento de suas contas repetitivas. Freqüentemente esta classe de índice se encontra associada às exigências de capital de giro (razão entre ativos e passivos circulantes e variações nas demais contas do ativo e passivo que geram mudanças nos níveis de caixa) (ROSS; WESTERFIELD; JAFFE, 2002).

A fonte principal de pagamento dessas dívidas de curto prazo é o ativo circulante $(A C)$ - embora as empresas possam se desfazer de ativos imobilizados $(A l)$ ou outros ativos fixos $(A F)$ como meio de fazer frente a dificuldades de caixa. As informações obtidas em sua apuração provêem do Balanço Patrimonial. Contudo, a origem dos movimentos na liquidez também pode ser capitada por meio do Demonstrativo de Fluxo de Caixa. Uma operação de financiamento ou a venda de um ativo pode ampliar o volume de caixa. Por outro lado, o pagamento de juros ou a aquisição de um ativo pode diminuir o nível de caixa de uma empresa.

\footnotetext{
${ }^{68}$ Os índices de valor não serão abordados neste trabalho.
} 
Conforme o quadro 14, duas formas de medir a solvência são largamente utilizadas. O índice de liquidez corrente (ILC) é obtido por meio da razão entre ativo $(A C)$ e passivo circulantes (PC). Caso tenha problemas de saldar as dívidas de curto prazo a empresa poderá passar por sérios problemas sendo obrigada a renegociá-las ou obter crédito bancário adicional - em condições nem sempre favoráveis. Neste caso, o passivo circulante pode crescer ainda mais rápido que o ativo circulante conduzindo a graves problemas de solvência no futuro (GITMAN, 2000). Um baixo ILC representa o primeiro sinal de problemas financeiros. Da mesma maneira com que devem ser lidas as demais classes de índices apresentadas a seguir, estes devem ser avaliados sob uma perspectiva histórica e comparado aos níveis verificados em outras empresas do setor (ROSS; WESTERFIELD; JAFFE, 2002).

O índice de liquidez seco (ILS) é calculado por meio da razão entre a diferença entre o ativo circulante total e os estoques (Est) e o passivo circulante. Considera-se que os ativos prontamente disponíveis são rapidamente conversíveis em caixas sem grandes perdas de valor; o que não é o caso dos estoques. Portanto, este indicador mede a capacidade da empresa de saldar suas dívidas de curto e curtíssimo prazo sem abrir mão de seus estoques.

\begin{tabular}{|l|l|l|l|l|l|}
\hline \multicolumn{1}{|c|}{$\begin{array}{c}\text { Classe de } \\
\text { Índice }\end{array}$} & \multicolumn{1}{|c|}{ Definições } & $\begin{array}{c}\text { Notação } \\
\text { Matemática }\end{array}$ & \multicolumn{1}{c|}{ O que mede? } & $\begin{array}{l}\text { Quem se interessa } \\
\text { mais diretamente? }\end{array}$ & $\begin{array}{l}\text { Informação } \\
\text { utilizada }\end{array}$ \\
\hline $\begin{array}{l}\text { Índice de } \\
\text { Liquidez } \\
\text { Corrente (ILC) }\end{array}$ & $\begin{array}{l}\text { Ativo } \\
\text { Circulante/ } \\
\text { Passivo } \\
\text { Circulante }\end{array}$ & $I L C=\frac{A C}{P C}$ & $\begin{array}{l}\text { Capacidade de pagamento } \\
\text { de contas, necessidade de } \\
\text { empréstimos para financiar } \\
\text { Capital de Giro. }\end{array}$ & $\begin{array}{l}\text { Financiadores de } \\
\text { curto prazo } \\
\text { (fornecedores, mão- } \\
\text { de-obra, credores, } \\
\text { etc.). }\end{array}$ & $\begin{array}{l}\text { Ativo } \\
\text { Circulante e } \\
\text { Passivo } \\
\text { Circulante }\end{array}$ \\
\hline $\begin{array}{l}\text { Índice de } \\
\text { Liquidez Seco } \\
\text { (ILS) }\end{array}$ & $\begin{array}{l}\text { (Ativo } \\
\text { Circulante - } \\
\text { Estoque Total)/ } \\
\text { Passivo } \\
\text { Circulante }\end{array}$ & $I L S=\frac{A C-E s t}{P C}$ & $\begin{array}{l}\text { Estoques são menos } \\
\text { líquidos que demais ativos. } \\
\text { O ILS mede a solvência } \\
\text { imediata do Passivo } \\
\text { Circulante. }\end{array}$ & $\begin{array}{l}\text { Financiadores de } \\
\text { curto prazo } \\
\text { (fornecedores, mão- } \\
\text { de-obra, etc.). }\end{array}$ & $\begin{array}{l}\text { Ativo } \\
\text { Circulante, } \\
\text { Passivo } \\
\text { Circulante e } \\
\text { Estoque }\end{array}$ \\
\hline
\end{tabular}

Quadro 14 - Classes, definições e finalidade dos Indicadores de Liquidez (IL).

Fonte: Elaborado pelo autor.

Em suma, o índice de liquidez corrente (ILC) mede a disponibilidade de recursos e a capacidade de pagamento de contas das empresas. Dá uma idéia a cerca da necessidade de empréstimos para financiamento de capital de giro. Já o índice de liquidez seco (ILS) deduz do ativo líquido a conta estoques, pois da classe 
de ativos circulantes, são os ativos de menor liquidez perdendo grande parte de valor em caso de sua liquidação (ROSS; WESTERFIELD; JAFFE, 2002).

Os índices de solvência ou de liquidez se relacionam diretamente com a maioria das fontes de riscos descritas na seção 3.2 (operacional, financeiro, de mercado, de liquidez, cambial e de poder aquisitivo). Quanto maior a previsibilidade das receitas e dos custos correntes, maior o grau de aceitação de índices de liquidez relativamente baixos (GITMAN, 2000).

A depender do segmento de atuação da empresa (transporte marítimo ou apoio marítimo) as receitas podem sofrer bruscas alterações em razão do tipo de contrato e das condições do mercado (liner ou tramp) ${ }^{69}$. Empresas do setor de apoio marítimo, por exemplo, atuam ofertando serviços padronizados a diversas empresas. Muitas vezes estabelecem contratos de longo prazo com seus clientes nos quais estipulam cláusulas que as protegem de variações nos custos de operação por meio de mecanismos de indexação de preços. O mesmo não se dá em outros segmentos.

\subsection{2 Índices de Atividade ou Administração de Ativos (IA)}

O nível de investimento em ativos está relacionado a vários fatores: setor de atividade, sazonalidade, características do ciclo operacional, volume de capital alocado (dada a estratégia adotada pela empresa), etc. Portanto, refletem peculiaridades setoriais e as decisões dos gestores. Como pode ser observado no quadro 15, os índices de atividade são construídos para medir a eficácia com que os ativos de uma empresa são empregados e a velocidade com que as várias contas são convertidas em receitas operacionais (GITMAN, 2000).

Um dos indicadores mais empregados para medir a eficiência na gestão de ativos é o índice de giro total de ativos (GAT). Este é obtido por meio da razão entre a receita operacional e o ativo total. Se este índice for elevado, quando comparado a empresas do mesmo setor, há indícios que a empresa gerencia bem seus ativos. Caso contrário, ela deve avaliar a magnitude desses e ou aumentar seu esforço na obtenção de receitas. A interpretação desse indicador deve ser

\footnotetext{
${ }^{69}$ Definidos na nota de rodapé 14 do capítulo 2.
} 
ponderada pela idade dos ativos que ela dispõe. Ativos mais antigos possuem valor de livro mais baixo do que os ativos mais novos, distorcendo sua interpretação. Dado o nível de receitas, o processo de acumulação de capital de cada empresa também interfere na magnitude do GAT. (ROSS; WESTERFIELD; JAFFE, 2002). O índice de poder de ganho (IPG) mede a relação entre o lucro líquido e o total de ativos. Serve como medida da eficiência global na alocação de ativos por parte da empresa.

Outro importante indicador do grau de eficiência com que uma empresa gere seus ativos é o índice de giro do ativo imobilizado (GAI). Este é obtido por meio da razão entre a receita operacional bruta e o ativo imobilizado. A partir do saldo médio de contas a receber (SMR) é possível obter o giro de contas a receber (GCR). Este apura quantas vezes a receita operacional é maior que o volume de vendas entre dois exercícios. Já o prazo médio de recebimento (PMR) é a razão entre o volume de contas a receber as vendas médias diárias. Em suma, o GCR e o PMR medem a eficiência com a qual a empresa gere seus investimentos em contas a receber refletindo a política de crédito junto a seus clientes. Há outros tipos de índices de atividade, entre eles o índice de índice de rotação estoque (IRE) que mede a eficiência na gestão de estoques. 


\begin{tabular}{|c|c|c|c|c|c|}
\hline $\begin{array}{l}\text { Classe de } \\
\text { Índice }\end{array}$ & Definições & $\begin{array}{c}\text { Notação } \\
\text { Matemática }\end{array}$ & O que mede? & $\begin{array}{l}\text { Quem se interessa } \\
\text { mais diretamente? }\end{array}$ & $\begin{array}{l}\text { Informação } \\
\text { utilizada }\end{array}$ \\
\hline $\begin{array}{l}\text { Índice de } \\
\text { Poder de } \\
\text { Ganho (IPG) }\end{array}$ & $\begin{array}{l}\text { Lucro líquido/ } \\
\text { Ativo Total }\end{array}$ & $I P G=\frac{L L}{A T}$ & $\begin{array}{l}\text { Capacidade dos ativos em } \\
\text { gerar renda operacional } \\
\text { antes da dedução dos } \\
\text { impostos e despesas } \\
\text { financeiras. } \\
\end{array}$ & $\begin{array}{l}\text { Financiadores de curto e } \\
\text { longo prazo (Credores, } \\
\text { Gestores e Acionistas) }\end{array}$ & $\begin{array}{l}\text { Lucro líquido e } \\
\text { Ativo Total }\end{array}$ \\
\hline $\begin{array}{l}\text { Giro de } \\
\text { Ativos (GAT) }\end{array}$ & $\begin{array}{l}\text { Receita } \\
\text { Operacional/ } \\
\text { Ativo Total }\end{array}$ & $G A T=\frac{R O}{A T}$ & $\begin{array}{l}\text { Eficiência global com que os } \\
\text { ativos da empresa são } \\
\text { administrados para gerar } \\
\text { vendas. }\end{array}$ & $\begin{array}{l}\text { Financiadores de curto e } \\
\text { longo prazo (Gestores, } \\
\text { Acionistas e Credores) }\end{array}$ & $\begin{array}{l}\text { Receita } \\
\text { Operacional } \\
\text { Bruta e } \\
\text { Ativo Total } \\
\end{array}$ \\
\hline $\begin{array}{l}\text { Giro Ativo } \\
\text { Imobilizado } \\
\text { (GAI) }\end{array}$ & $\begin{array}{l}\text { Receita } \\
\text { Operacional/ } \\
\text { Ativo } \\
\text { Imobilizado }\end{array}$ & $G A I=\frac{R O}{A I}$ & $\begin{array}{l}\text { Eficiência com que uma } \\
\text { empresa utiliza suas } \\
\text { máquinas, instalações e } \\
\text { equipamentos. }\end{array}$ & $\begin{array}{l}\text { Financiadores de curto e } \\
\text { longo prazo (Gestores, } \\
\text { Acionistas e Credores) }\end{array}$ & $\begin{array}{l}\text { Receita } \\
\text { operacional } \\
\text { Bruta e } \\
\text { Ativo } \\
\text { Imobilizado } \\
\end{array}$ \\
\hline $\begin{array}{l}\text { Saldo Médio } \\
\text { Contas a } \\
\text { Receber } \\
\text { (SCR) }\end{array}$ & $\begin{array}{l}\text { Contas a } \\
\text { Receber } \\
(\mathrm{CR}) \text { (média) }\end{array}$ & $S C R=\frac{C R_{t}-C R_{t-1}}{2}$ & $\begin{array}{l}\text { Política de financiamento da } \\
\text { organização junto aos seus } \\
\text { clientes }\end{array}$ & $\begin{array}{l}\text { Financiadores de curto } \\
\text { prazo (Gestores e } \\
\text { Acionistas) }\end{array}$ & $\begin{array}{l}\text { Contas a } \\
\text { receber }\end{array}$ \\
\hline $\begin{array}{l}\text { Giro Contas a } \\
\text { Receber } \\
\text { (GCR) }\end{array}$ & $\begin{array}{l}\text { Receita } \\
\text { Operacional/ } \\
\text { Saldo Médio } \\
\text { Recebimento }\end{array}$ & $G C R=\frac{R O}{S C R}$ & $\begin{array}{l}\text { Eficiência com que a } \\
\text { empresa opera sua política } \\
\text { de financiamento junto a } \\
\text { clientes. }\end{array}$ & $\begin{array}{l}\text { Gestores, Acionistas e } \\
\text { Credores }\end{array}$ & $\begin{array}{l}\text { Receita } \\
\text { operacional e } \\
\text { Saldo médio } \\
\text { Recebimento }\end{array}$ \\
\hline $\begin{array}{l}\text { Índice de } \\
\text { Rotação de } \\
\text { Estoques } \\
\text { (IRE) }\end{array}$ & $\begin{array}{l}\text { Receita } \\
\text { Operacional/ } \\
\text { Estoque }\end{array}$ & $I R E=\frac{R O}{E s t}$ & $\begin{array}{l}\text { Eficiência na administração } \\
\text { de estoques e sua } \\
\text { rotatividade. }\end{array}$ & Gestores e Acionistas & $\begin{array}{l}\text { Receita } \\
\text { Operacional } \\
\text { Bruta e } \\
\text { Estoques }\end{array}$ \\
\hline $\begin{array}{l}\text { Prazo Médio } \\
\text { de } \\
\text { Recebimento } \\
\text { (PMR) }\end{array}$ & $\begin{array}{l}\text { Contas a } \\
\text { Receber/ } \\
\text { Vendas } \\
\text { diárias }\end{array}$ & $P M R=\frac{C R}{(V / 360)}$ & $\begin{array}{l}\text { Avalia as políticas de crédito } \\
\text { e cobrança. }\end{array}$ & Gestores e Acionistas & $\begin{array}{l}\text { Contas a } \\
\text { receber e } \\
\text { Vendas diárias }\end{array}$ \\
\hline
\end{tabular}

Quadro 15 - Classes, definições e finalidade dos Indicadores de Administração de Ativos (IAA). Fonte: Elaborado pelo autor.

Esta classe de índices econômico-financeiros também possui relação com os riscos operacional, financeiro, de mercado e de poder aquisitivo apresentados na seção 3.2, sendo afetados pela variação no nível de receitas de vendas e volume de estoques. Assim, estão associados à política de administração de ativos da empresa (composição de contas a receber, magnitude e tipos de ativo imobilizados, etc.). Como aponta Stopford (2005), há um trade off entre a idade das embarcações e os custos operacionais e nível de despesas financeiras. Particularmente, as estratégias de investimento de cada empresa afetam consideravelmente a magnitude dos índices de poder de ganho e de gestão de ativos totais e imobilizados.

Por fim, espera-se que os índices associados ao giro de ativos e de rotação de estoques apresentem níveis irrisórios nas operações de transporte e apoio 
marítimo. No primeiro caso, isto se deve ao alto valor dos ativos em relação ao volume de receitas geradas. No segundo, ao pertencerem ao segmento de serviços, o nível de estoque nesse setor é baixo quando comparado ao valor dos ativos. Por fim, o volume de capital alocado depende da estratégia da companhia em termos da idade das embarcações.

\subsection{3 Índices de Alavancagem Financeira ou Endividamento (IE)}

A capacidade de investimento aumenta o potencial de retorno de um empreendimento e sua correspondente capacidade de endividamento uma vez que ampliam o volume de ativos e capacidade de geração de receitas (ROSS; WESTERFIELD; JAFFE, 2002). A composição de recursos destinada a financiar o empreendimento deve ser planejada com objetivo de maximizar o valor do empreendimento. Em geral, o uso elevado de capital de terceiros indica uma situação financeira precária, a depender do setor de atividade.

O analista financeiro se preocupa mais com as dívidas de longo prazo, uma vez que estas comprometem a capacidade da empresa ao longo de muitos períodos (ROSS; WESTERFIELD; JAFFE, 2002). Quanto maior a utilização de recursos de terceiros maior seu nível de alavancagem financeira, ou seja, ocorre a ampliação conjunta dos níveis de risco e do retorno (GITMAN, 2000).

Conforme o quadro 16, o grau de alavancagem financeira pode ser medido por meio de vários índices. O nível desses indicadores dá uma noção acerca da "probabilidade" de não pagamento das dívidas contraídas. Quanto mais endividada uma empresa estiver, maior o peso da dívida onerosa e a possibilidade de não cumprimento de suas obrigações contratuais. Diferentemente do pagamento de dividendos, que dependem da política de redistribuição do lucro líquido da empresa. Dívidas geram obrigações jurídicas e seu não pagamento pode levar a sanções por parte dos credores e até a liquidação da empresa (DAMODARAN, 2004; GITMAN, 2000).

O índice de endividamento geral (IEG) é obtido por meio da razão entre o total das dívidas (Passivo Circulante e Exigíveis a Longo Prazo - ELP) e total dos ativos. Quanto maior seu valor maior a participação de capital de terceiros no 
financiamento das operações corporativas. Outros índices bastante empregados são o multiplicador de capital próprio e de terceiros (MKPT) e o multiplicador de capital próprio (MKP). Estes informam sobre a proteção dos credores contra insolvência e a capacidade de obtenção de financiamento adicional - tendo em vista o aproveitamento de oportunidades de investimento entendidas como potencialmente atraentes.

$O$ índice de cobertura de juros (ICJ) mede a capacidade da empresa de efetuar pagamentos de juros previstos em contratos. Ele é obtido por meio da razão entre o lucro antes de impostos e juros $\left(\mathrm{EBIT}^{70}\right)$ e o valor dos juros $(\mathrm{J})$. Vale destacar que o valor EBIT corresponde ao resultado operacional apresentado no Demonstrativo de Resultados.

\begin{tabular}{|c|c|c|c|c|c|}
\hline Classe de Índice & Definições & Notação Matemática & O que mede? & $\begin{array}{l}\text { Quem se interessa } \\
\text { mais diretamente? }\end{array}$ & $\begin{array}{l}\text { Informação } \\
\text { utilizada }\end{array}$ \\
\hline $\begin{array}{l}\text { Índice de } \\
\text { Endividamento } \\
\text { Geral (IEG) }\end{array}$ & $\begin{array}{l}\text { (Passivo } \\
\text { Circulante }+ \\
\text { Exigível a } \\
\text { Longo Prazo)/ } \\
\text { Ativo Total }\end{array}$ & $I E G=\frac{(P C+E L P)}{A T}$ & $\begin{array}{l}\text { Avalia o grau de } \\
\text { alavancagem ou } \\
\text { percentagem de } \\
\text { recursos fornecidos } \\
\text { pelos credores. }\end{array}$ & $\begin{array}{l}\text { Credores. Quanto } \\
\text { menor este índice } \\
\text { menor o risco de } \\
\text { perda em caso de } \\
\text { liquidação. }\end{array}$ & $\begin{array}{l}\text { Passivo } \\
\text { Circulante e } \\
\text { Exigível a } \\
\text { Longo Prazo } \\
\text { Ativo Total }\end{array}$ \\
\hline $\begin{array}{l}\text { Multiplicador do } \\
\text { Capital Próprio } \\
\text { (MKP) }\end{array}$ & $\begin{array}{l}\text { Ativo Total/ } \\
\text { Patrimônio } \\
\text { Líquido }\end{array}$ & $M K P=\frac{A T}{P L}$ & $\begin{array}{l}\text { Grau de cobertura } \\
\text { dos ativos em termos } \\
\text { dos recursos } \\
\text { aportados pelos } \\
\text { acionistas. }\end{array}$ & $\begin{array}{l}\text { Acionistas e Credores. } \\
\text { Quanto maior este } \\
\text { índice maior o uso de } \\
\text { capital de terceiros. }\end{array}$ & $\begin{array}{l}\text { Ativo Total e } \\
\text { Patrimônio } \\
\text { Líquido }\end{array}$ \\
\hline $\begin{array}{l}\text { Multiplicador do } \\
\text { Capital Próprio e } \\
\text { de Terceiros } \\
\text { (MKPT) }\end{array}$ & $\begin{array}{l}\text { Dívida Total/ } \\
\text { Patrimônio } \\
\text { Líquido }\end{array}$ & $M K P T=\frac{(P C+E L P)}{P L}$ & $\begin{array}{l}\text { Grau de cobertura de } \\
\text { obrigações sobre } \\
\text { recursos próprios. }\end{array}$ & $\begin{array}{l}\text { Acionistas. Quanto } \\
\text { maior este índice } \\
\text { maior a exposição ao } \\
\text { risco de terceiros. }\end{array}$ & \begin{tabular}{|l} 
Passivo \\
Circulante, \\
Exigível a \\
Longo Prazo \\
e \\
Patrimônio \\
Líquido \\
\end{tabular} \\
\hline $\begin{array}{l}\text { Índice de } \\
\text { Cobertura de } \\
\text { Juros (ICJ) }\end{array}$ & $\begin{array}{l}\text { EBIT/ } \\
\text { Juros }\end{array}$ & $I C J=\frac{E B I T}{J}$ & $\begin{array}{l}\text { Mede a capacidade } \\
\text { de atender ao } \\
\text { pagamento de juros. } \\
\text { Extensão do grau de } \\
\text { redução de lucro } \\
\text { para atender } \\
\text { serviços da dívida. }\end{array}$ & $\begin{array}{l}\text { Credores, Acionistas. } \\
\text { Mede a capacidade } \\
\text { de geração de lucro } \\
\text { suficiente para } \\
\text { pagamento de juros } \\
\text { previstos em } \\
\text { contratos. }\end{array}$ & $\begin{array}{l}\text { Lucro antes } \\
\text { de Impostos e } \\
\text { Juros e } \\
\text { Pagamento } \\
\text { de Juros }\end{array}$ \\
\hline
\end{tabular}

Quadro 16 - Classes, definições e finalidade dos Indicadores de Endividamento (IE). Fonte: Elaborado pelo autor.

${ }^{70}$ Do inglês: Earning Before Interest and Tax (EBIT). Constitui o resultado antes das deduções de Juros e Impostos e mede a capacidade absoluta de saldar estas obrigações garantindo um excedente ao acionista.

${ }^{71}$ Idem nota anterior. 
Considerando o valor dos ativos (financiados com capital próprio e de terceiros), os índices de alavancagem ou endividamento são afetados pelo estoque da dívida, fluxo de pagamento de amortizações e pelo nível de taxas de juros. Esses possuem relação direta com o risco de taxa de juros e cambial (a depender do contrato de financiamento) e com o risco de tributação (em razão da possibilidade de se afetar o lucro tributável).

Como o setor naval é intensivo em capital, se espera que os índices de endividamento das empresas ligadas ao setor sejam elevados quando comparado a outros setores da economia. Contudo, como o cálculo do ativo imobilizado é feito a partir do valor do livro pode haver distorções na interpretação no ICJ. Apesar disso, para intervalos curtos de tempo estes constituem uma boa ferramenta analítica uma vez que o setor possui baixa velocidade no incremento de investimentos e no correspondente incremento do endividamento.

\subsection{4 Índices de Rentabilidade ou Retorno sobre Investimento (IR)}

Segundo Gitman (2000) e Ross, Westerfield e Jaffe (2002) e, no mercado internacional, as taxas de juros sobre as dívidas são pós-fixadas, um dos atributos de mais difícil "visualização" e medição em uma empresa é a sua taxa de rentabilidade. Os indicadores consideram um dos conceitos de lucro (contábil, operacional, bruto, etc.) obtidos a partir do Demonstrativo de Resultados e o dividem por um indicador de alocação de capital (ativo total, imobilizado, etc.) presente no Balanço Patrimonial (KASSAI, 2000). A depender da metodologia adotada, a rentabilidade de uma empresa reflete sua capacidade de auto-financiamento, as políticas de distribuição de dividendos e sua capacidade de gerar receitas.

Os principais índices de rentabilidade são apresentados no quadro 17. A margem de lucro bruta $(\mathrm{MB})$ é calculada a partir da razão entre o lucro bruto e receita operacional. Já a margem de lucro líquida (ML) é calculada a partir da razão entre o lucro líquido e receita operacional. Ambos medem a capacidade de uma empresa vender um produto ou prestar um serviço a baixo custo e ou preço elevado. As margens não são medidas diretas da rentabilidade sobre ativos por que se baseiam na receita operacional e não no investimento efetuado pela empresa. 
Empresas comerciais tendem a ter margens mais estreitas e as empresas prestadoras de serviços tendem a apresentar margens mais elevadas.

O retorno sobre o patrimônio líquido (ROE) mede a razão entre o lucro líquido para os acionistas e o capital dos acionistas (patrimônio líquido). Empresas tradicionais que operam em mercados altamente competitivos possuem baixo ROE.

Já o retorno sobre ativos totais (ROA) mede a eficiência no uso dos ativos por parte da empresa. Trata-se de uma das medidas mais comuns de desempenho gerencial e é obtido por meio da razão entre o lucro líquido e o ativo total. Quanto mais capitalizada a empresa menor o ROA. Este indicador de rentabilidade pode ser desdobrado dando uma idéia de ligação com os demais indicadores financeiros. A relação mais famosa é conhecida como sistema DuPont de controle financeiro (ROSS; WESTERFIELD; JAFFE, 2002). Este realça o fato de que o ROA pode ser expresso em termos da margem de lucro liquido e giro dos ativos.

Conforme o quadro 17, é possível encontrar das relações entre o ROA e o ROE. Isso é feito multiplicando o ROA pela relação entre o ativo total e o patrimônio líquido dos acionistas. Este índice, ao decompor a eficiência operacional de uma empresa, reflete o que deve ser associado como margem de ganho, giro de ativos e contribuição incremental dos recursos de parceiros.

Outro coeficiente associado ao ROA é o grau de alavancagem financeira (GAF). Este é obtido por meio da razão entre o ROE e o ROA. Este mede o grau com que a empresa consegue alavancar sua rentabilidade a partir do uso de capital de terceiros. 


\begin{tabular}{|c|c|c|c|c|c|}
\hline $\begin{array}{l}\text { Classe de } \\
\text { Índice }\end{array}$ & Definições & Notação Matemática & O que mede? & $\begin{array}{c}\text { Quem se } \\
\text { interessa } \\
\text { mais } \\
\text { diretamente } \\
? \\
\end{array}$ & $\begin{array}{l}\text { Informação } \\
\text { utilizada }\end{array}$ \\
\hline $\begin{array}{l}\text { Margem Bruta } \\
\text { (MB) }\end{array}$ & $\begin{array}{l}\text { Lucro Bruto/ } \\
\text { Receita Bruta }\end{array}$ & $M B=\frac{L B}{R O}$ & $\begin{array}{l}\text { Parcela sobre as } \\
\text { vendas que resta para } \\
\text { cobrir demais } \\
\text { despesas. }\end{array}$ & $\begin{array}{l}\text { Gestores, } \\
\text { Acionistas e } \\
\text { Credores }\end{array}$ & $\begin{array}{l}\text { Lucro Bruto e } \\
\text { Receita Bruta } \\
\text { Total }\end{array}$ \\
\hline $\begin{array}{l}\text { Margem Líquida } \\
\text { (ML) }\end{array}$ & $\begin{array}{l}\text { Lucro Líquido/ } \\
\text { Vendas }\end{array}$ & $M L=\frac{L L}{R O}$ & $\begin{array}{l}\text { Mede a renda por } \\
\text { unidade monetária de } \\
\text { vendas após dedução } \\
\text { de todos custos e } \\
\text { despesas (incluindo } \\
\text { gastos com juros). }\end{array}$ & $\begin{array}{l}\text { Acionistas, } \\
\text { Gestores }\end{array}$ & $\begin{array}{l}\text { Lucro Líquido e } \\
\text { Receita Bruta } \\
\text { Total }\end{array}$ \\
\hline $\begin{array}{l}\text { Retorno sobre } \\
\text { Patrimônio } \\
\text { Líquido (ROE) }\end{array}$ & $\begin{array}{l}\text { Lucro Líquido/ } \\
\text { Patrimônio } \\
\text { Líquido }\end{array}$ & $R O E=\frac{L L}{P L}$ & $\begin{array}{l}\text { Retorno obtido com o } \\
\text { capital provido pelos } \\
\text { acionistas. }\end{array}$ & Acionistas & $\begin{array}{l}\text { Lucro Líquido e } \\
\text { Patrimônio Líquido }\end{array}$ \\
\hline $\begin{array}{l}\text { Decomposição } \\
\text { ROE }\end{array}$ & $\begin{array}{l}\text { Margem Líquida x } \\
\text { Giro Ativos x } \\
\text { Multiplicador do } \\
\text { Capital Próprio } \\
\text { (Alavancagem) } \\
\end{array}$ & $R O E=\left(\frac{L L}{V}\right)\left(\frac{V}{A T}\right)\left(\frac{A T}{P L}\right)$ & $\begin{array}{l}\text { Componentes que } \\
\text { contribuem para a } \\
\text { geração de valor ao } \\
\text { acionista }\end{array}$ & $\begin{array}{l}\text { Acionistas e } \\
\text { Credores }\end{array}$ & $\begin{array}{l}\text { Lucro Líquido, } \\
\text { Ativo Total, } \\
\text { Receita Bruta } \\
\text { Total e Patrimônio } \\
\text { Líquido } \\
\end{array}$ \\
\hline $\begin{array}{l}\text { Retorno sobre } \\
\text { Ativos Totais } \\
\text { (ROA) }\end{array}$ & $\begin{array}{l}\text { Lucro Líquido/ } \\
\text { Ativo Total }\end{array}$ & $R O A=\frac{L L}{A T}$ & $\begin{array}{l}\text { Eficiência operacional } \\
\text { em gerar lucros a partir } \\
\text { dos ativos após os } \\
\text { efeitos dos } \\
\text { financiamentos }\end{array}$ & $\begin{array}{l}\text { Acionistas, } \\
\text { Gestores e } \\
\text { Credores }\end{array}$ & $\begin{array}{l}\text { Lucro Líquido e } \\
\text { Ativo Total }\end{array}$ \\
\hline $\begin{array}{l}\text { Decomposição } \\
\text { ROA }\end{array}$ & $\begin{array}{l}\text { (Lucro Líquido/ } \\
\text { Vendas) X } \\
\text { (Vendas/ Ativo } \\
\text { Total) }\end{array}$ & $R O A=\frac{L L}{V} \frac{V}{A T}$ & $\begin{array}{l}\text { Eficiência operacional } \\
\text { em gerar lucros a partir } \\
\text { dos ativos após o } \\
\text { efeitos dos } \\
\text { financiamentos } \\
\end{array}$ & $\begin{array}{l}\text { Acionistas, } \\
\text { Gestores e } \\
\text { Credores }\end{array}$ & $\begin{array}{l}\text { EBIT, } \\
\text { Ativo Total } \\
\text { (Total ativos } \\
\text { Impostos /EBIT) }\end{array}$ \\
\hline $\begin{array}{l}\text { Grau de } \\
\text { Alavancagem } \\
\text { Financeira } \\
\text { (GAF) }\end{array}$ & $\begin{array}{l}\text { Razão ROE/ } \\
\text { ROA- }\end{array}$ & $G A F=\frac{R O E}{R O A}$ & $\begin{array}{l}\text { Grau com que a } \\
\text { empresa consegue } \\
\text { alavancar o retorno do } \\
\text { acionista com emprego } \\
\text { de capital de terceiros. }\end{array}$ & Acionistas & $\begin{array}{l}\text { ROE e } \\
\text { ROA- }\end{array}$ \\
\hline
\end{tabular}

Quadro 17 - Classes, definições e finalidade dos Indicadores de Rentabilidade (IR) (*).

$\left({ }^{*}\right)$ A rentabilidade é particularmente importante pois permite avaliar a capacidade de pagamento de dividendos, auto-financiamento e processos de valoração de ativos das empresas.

Fonte: Elaborado pelo autor.

Os índices de rentabilidade possuem relação direta com a gestão de ativos das empresas, sua política de investimento/desinvestimento e forma de financiamento de seus ativos. Particularmente, o ROE sofre de três deficiências: não leva em conta a perspectiva histórica, oferecendo uma visão de médio prazo; leva em conta o valor de livro do Patrimônio Líquido, que pode ser muito diferente do valor de mercado, e tem pouco a dizer acerca do risco do negócio associado ao nível de endividamento da companhia.

Embora o ROA não apresente esta última deficiência (uma vez que toma o valor total do ativo que em muitas situações é financiado por recursos de terceiros), 
sofre influência da estratégia de investimento da empresa. Desta forma, o ROA pode ser muito distorcido pelo nível de endividamento e, portanto, deve ser olhado com cuidado na comparação de dois negócios diferentes.

\subsubsection{Estratégia de Análise de Projetos por Parte do BNDES ${ }^{72}$}

$\mathrm{Na}$ linha proposta por Johnson Stokes \& Master (2005) seis elementos, relacionados aos conceitos apresentados acima, norteiam um pacote de financiamento para a construção de novas embarcações: contrato de empréstimo/financiamento (loan agreement), hipoteca marítima (uso da hipoteca da embarcação como garantia de financiamento), assinatura de contrato de construção naval, tarifa de restituição de fiança, fiança/garantia (guarantee) e hipoteca de ações.

O contrato de financiamento deve descrever o armador, o montante de financiamento, o estaleiro, os prazos de construção e condições de seu progresso (cronograma físico e financeiro), os prazos de pagamento, o nível das taxas e a sua periodicidade. Em termos da contratação e do acompanhamento, uma série de cláusulas, conhecidas como cláusulas "boiler-plate", são inseridas para obrigar o armador a fornecer cópias dos relatórios financeiros, declaração de impostos pagos, etc. Geralmente, são exigidos documentos de propriedade para assegurar o pagamento da dívida. Os prazos e as condições do financiamento são geralmente estabelecidos em forma de parcelas pré-determinadas, liberadas de acordo com o estágio da construção da embarcação.

Conforme explicitado no Capítulo II da Portaria MT n 090/2005 ${ }^{73}$ são exigidas, no mínimo, informações relativas ao pré-contrato assinado entre a empresa postulante do financiamento e o estaleiro construtor ou, no caso do estaleiro ser o postulante, entre este e a empresa que o contratou. Assim, a

\footnotetext{
${ }^{72}$ A seção 2.5 .7 apresentou os processos associados a concessão de financiamento pelo DMM, CDFMM e BNDES - incluindo a concessão de recursos do FMM. Esta seção detalha os indicadores utilizadas para a avaliação dos riscos dos empreendimentos.

73 Uma breve resenha da legislação que regulamenta o financiamento por meio do FMM é apresentada no ANEXO 7, o que inclui esta Portaria.
} 
avaliação de riscos do armador, bem como do estaleiro vinculado no contrato, é parte integrante da avaliação da proposta.

Em função da exposição aos riscos descritos acima, as operações de financiamento providas pelo BNDES utilizam certos indicadores econômicofinanceiros e técnicas de análise matemática a fim de obter estimativas confiáveis de risco e retorno. Estes indicadores, apresentadas a seguir, são complementadas por análises de mercado por meio de técnicas de projeção que utilizam bancos de informações estatísticas. Os processos contam com a experiência de técnicos especializados em estudos setoriais e atuação de equipes dedicadas.

De acordo com técnicos e documentos disponibilizados pelo BNDES os critérios utilizados para a avaliação de propostas são os critérios comuns ou tradicionais empregados na avaliação de investimentos. Estes são descritos nos documentos Roteiro de Informações para a Análise de Projeto e Roteiro de Informações para Enquadramento os quais regulam o Financiamento de Empreendimentos (FINEM) do BNDES e, particularmente, a forma de acesso aos recursos do $\mathrm{FMM}^{74}$. As informações exigidas abrangem os seguintes aspectos: grupo/empresa, projeto, mercado, aspectos econômico-financeiros e aspectos jurídicos relacionados a cada proposta encaminhada ${ }^{75}$. Tais abordagem são aderentes aos aspectos apontado por Johnson Stokes \& Master (2005) e ao conceito de 5C's apresentadas na seção 4.1.

Além de informações cadastrais, o BNDES exige dados acerca do setor de atuação da empresa, evolução da produção e faturamento dos principais produtos da empresa, descrição da capacitação tecnológica e descrição dos principais aspectos organizacionais. Estas informações devem ser acompanhadas dos Demonstrativos Contábeis dos três últimos anos (RODRIGUES; MENDES, 2004). Alguns dos indicadores utilizados nas avaliações do BNDES no âmbito do FINEM, aderentes aos indicadores econômico-financeiros apresentados acima, são sistematizados no quadro 18.

\footnotetext{
${ }^{74}$ Estes documentos podem ser encontrados no site do BNDES (www.bndes.gov.br).

${ }^{75}$ Estes e outros critérios estão presentes nos documentos, disponíveis no site do BNDES, os quais estabelecem critérios para o FINEM: Roteiro de Informações para Análise de Projetos e Roteiro de Informações para Enquadramento.
} 


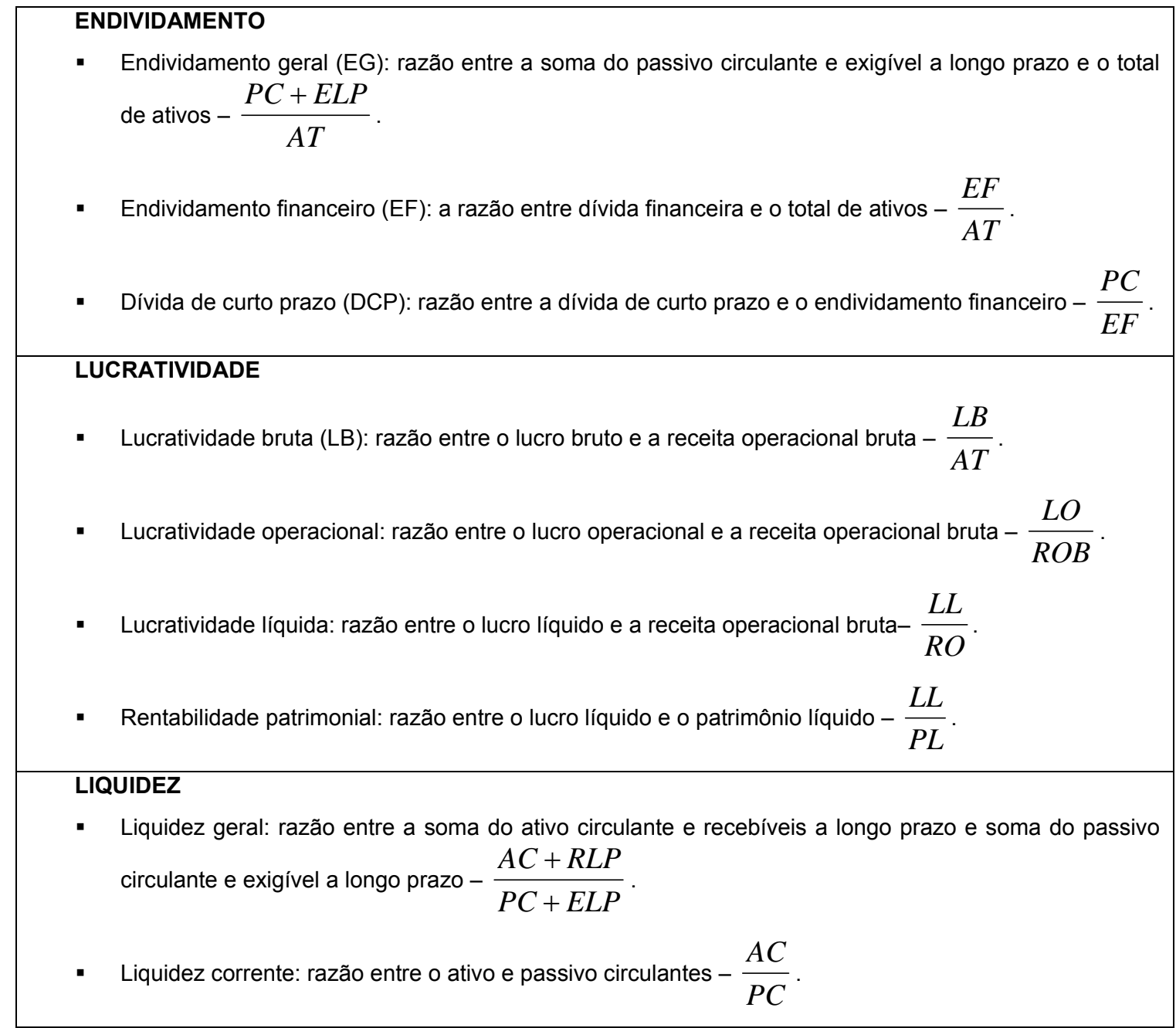

Quadro 18 - Indicadores utilizados pelo BNDES na avaliação de propostas do FINEM Fonte: Banco Nacional de Desenvolvimento Econômico e Social (2006).

Informações de natureza qualitativa fornecidas pelo proponente visam complementar o processo de tomada de decisão, entre elas: descrição da estratégia de investimento (expansão, diversificação, etc.); descrição da finalidade do projeto e de seus parâmetros (prazo de implantação e de operação); informações sobre origem e evolução do faturamento; padrão de concorrência e posicionamento da empresa; descrição dos principais fatores de competitividade. Certos temas são críticos: quais fatores mais interferem na obtenção de receitas? Quais são os principais fatores que afetam os custos?

Apesar de exigir dados dos Demonstrativos Contábeis das empresas e de solicitar as projeções dos mesmos, os bancos geralmente não divulgam os critérios 
de ponderação por meios dos quais são efetivamente avaliadas as propostas e por meio dos quais são estabelecidos os parâmetros da negociação. O mesmo se aplica ao BNDES. É sabido que a análise dos indicadores é feita de forma ponderada remetendo a tomada de decisão (RUTH, 1991).

As comparações e análises empíricas dos indicadores econômico-financeiros estabelecidas a partir de dados de amostras de empresas nacionais e internacionais estabelecidas a seguir se fundamentam e partem de considerações dos conceitos apresentados nas seções 4.3.1, 4.3.2, 4.3.3, 4.3.4 e quadro 17 Nesse contexto, certos procedimentos estatísticos são adotados a fim de garantir maior consistência e acuracidade nos resultados ${ }^{76}$.

\subsection{Utilização dos Indicadores Econômico-financeiros na Pesquisa}

Sumarizando as discussões estabelecidas em torno dos princípios que regem um financiamento e riscos envolvidos, é possível afirmar que, mesmo que seja viável do ponto de vista técnico ${ }^{77}$, um projeto de construção naval pode não obter financiamento de fontes bancárias em função de pelo menos quatro razões:

R.1 histórico das empresas e projetos financiados: dada a vinculação entre as contrapartes envolvidas no setor de bens sob encomenda, os contratos são feitos sob medida e muitas propostas deixam de ser efetivadas devido das dificuldades que armadores e estaleiros enfrentaram no passado em atender as condições de financiamento exigidas - histórico de atrasos e ou estouro orçamentário implicam em maior percepção de risco o que inclui aspectos relacionados ao conceito de caráter e capacidade com efeitos sobre o rating das empresas;

\footnotetext{
${ }^{76}$ Informações relacionadas as empresas presentes nas amostras são detalhadas no: Anexo 3, que apresenta o protocolo de pesquisa aplicada nas empresas nacionais; Anexo 4, que apresenta informações associadas as empresas estrangeiras e as empresas nacionais que contribuíram com dados para a obtenção de uma parcela dos indicadores apresentados nesta seção.

${ }^{77}$ Entende-se por "viável do ponto de vista técnico" como considerado eficiente quando analisado à luz de padrões adequados de engenharia do projeto. - Viável tecnicamente não tem nada a ver com eficiência e sim com ser possível, ou não, sua construção.
} 


\section{R.2 análise retrospectiva e prospectiva de indicadores econômico-} financeiros: as condições financeiras das empresas envolvidas nas propostas, devem ser avaliadas por meio dos indicadores de endividamento, administração de ativos e liquidez obtidos a partir de suas Demonstrações Contábeis, estes podem indicar elevado grau de risco - esse tipo de análise remete aos conceitos de conglomerado, capital, etc., e sua relação com os riscos operacionais, financeiros, etc., apresentados na seção 4.1;

R.3 exigência de garantias: em muitas situações, dada a avaliação de riscos de cada proposta, as garantias exigidas muitas vezes são de tal ordem que os agentes não possuem condições ou não estão dispostos a cobri-las integralmente, desta forma, tais condições inviabilizam as negociações e a efetivação do contrato de financiamento.

R.4 atendimento de demais exigências previstas na legislação: regularidade fiscal, não cumprimento de exigências legais (falta de documentação, laudos, atestados, registros, etc.).

Estas questões remetem à primeira questão do estudo e às proposições a ela associadas. Com feito, esta parte do estudo focaliza diretamente a segunda razão (R.2). Ao fazer isso explora o aspecto retrospectivo ${ }^{78}$. Isso se justifica uma vez que ao longo do desenvolvimento do estudo não foi possível obter dados de projetos específicos nem indícios quantitativos relacionados à R.1. Pelo mesmo motivo, as questões R.3 e R.4 serão abordadas de marginalmente nesse estudo.

Assim para que seja possível testar a capacidade financeira das empresas locais, vis-à-vis as práticas internacionais, serão utilizados dois procedimentos. Esses são condizentes com o emprego da metodologia de estudo de caso, definida no capítulo 1 do presente estudo. O primeiro procedimento será feito por meio de análises quantitativas a partir da obtenção e comparação estatística de indicadores econômico-financeiros das empresas locais e estrangeiras, obtidos a partir de uma parcela do banco de dados gerado para o estudo. Para tanto, os procedimentos metodológicos adotados foram os seguintes.

Foram obtidas as cinco classes de indicadores econômico-financeiros tais como apresentados nas seções 4.3.1, 4.3.2, 4.3.3, 4.3.4 e 4.3.5. Para tanto, um

${ }^{78}$ Contudo, não irá estabelecer análises prospectivas. 
primeiro procedimento estatístico adotado consistiu em eliminar os outliers verificados nas amostras de indicadores das empresas internacionais. Isso foi feito excluindo valores abaixo e acima de um desvio padrão em torno da média de cada série de indicadores. Esse procedimento visou concentrar cada IEF em torno de seu valor médio eliminando oscilações resultantes de variações não recorrentes nos ativos e passivos das empresas internacionais. Em cada caso o valor dos ativos das empresas que geraram as estatísticas esteve acima de $90 \%$ do valor total de ativos da amostra. Isso indica a compatibilidade do procedimento com os objetivos dos testes.

A literatura sugere que a comparação dos indicadores financeiros seja estabelecida a partir do valor médio verificado em um dado segmento econômico. Assim, tal procedimento foi particularmente importante, pois ao concentrar a magnitude dos índices em torno da média, visou eliminar distorções causadas por valores extremos muito acima ou abaixo da média ${ }^{79}$. A partir dos dados remanescentes aplicou-se testes de diferença de médias. O objetivo foi comparar estes índices com os verificados para uma amostra de empresas nacionais. Este procedimento caracteriza um teste de hipótese para a diferença de médias e pode ser definido como:

$$
\begin{aligned}
& H_{0}: \mu_{1, i}=\mu_{2, i} \\
& H_{1}: \mu_{1, i} \neq \mu_{2, i}
\end{aligned}
$$

A rigor, se procura testar a hipótese nula $\left(\mathrm{H}_{0}\right)$ : o valor médio do indicador $i$ difere de maneira significativa entre as duas amostras?. Ou seja, o teste visa estabelecer se há diferença na média de cada indicador econômico-financeiro a partir dos dados de uma amostra de empresas de transporte internacionais $\left(\mu_{1, i}\right)$ e nacionais $\left(\mu_{2, i}\right)$.

\footnotetext{
${ }^{79}$ Por exemplo, por meio da análise do banco de dados obtido para a pesquisa se constatou que a venda de ativos imobilizados, feitas nos anos considerados, provocaram distorções nos indicadores de liquidez corrente (ILC) e seco (ILS). O procedimento garantiu que tais informações não distorcessem os resultados dos testes tais como apresentados nessa seção.
} 
Com efeito, supondo duas populações, para cada amostra de tamanho $n_{1}$ pode ser calculada a média amostral $\bar{X}_{1, i}$. A rigor, esta possui distribuição amostral dada pela média $\mu_{\bar{X} 1, i}$ e pelo desvio padrão $\sigma_{\bar{X} 1, i}$. $\bigcirc$ mesmo se aplica para outra amostra. Segundo Griffiths, Hill e Judge (1993) e Bussab e Morettin (2002), considerando todas as combinações possíveis das amostras das duas populações, é possível obter a distribuição amostral da diferença $\bar{X}_{1, i}-\bar{X}_{2, i}$, cuja média e desvio padrão são dados respectivamente por $\mu_{X 1, i-X 2, i}=\mu_{X 1, i}-\mu_{X 2, i} \quad \mathrm{e}$ $\sigma_{X 1, i-X 2, i}=\sqrt{\sigma_{X 1, i}^{2}+\sigma_{X 2, i}^{2}}$.

Desde que as amostras escolhidas não estejam relacionadas uma da outra de qualquer forma, as amostras são consideradas independentes (BUSSAB; MORETTIN, 2002) $)^{80}$. Se as variâncias são diferentes e desconhecidas, como no caso dos indicadores econômico-financeiros da população de empresas de navegação nacionais e internacionais, as estatísticas utilizadas na aplicação de cada teste devem ser feitas a partir de cada variável padronizada. Nesta situação, o teste de diferença de médias deve ser definido como ${ }^{81}$ :

$$
-t_{\alpha=0,1 / 2} \leq \frac{\mu_{X 1, i}-\mu_{X 2, i}}{\sqrt{\frac{\sigma_{X 1, i}^{2}}{n_{1}}+\frac{\sigma_{X 2, i}^{2}}{n_{2}}}} \leq+t_{\alpha=0,1 / 2} .
$$

Contudo, testes $F$ realizados a partir dos dados amostrais indicaram não haver diferenças significativas entre as variâncias da esmagadora maioria dos indicadores. Neste caso, o teste a ser aplicado deve ser o teste $t$ de Student. Este

\footnotetext{
${ }^{80}$ Essa hipótese é plausível, pois o nível de liquidez ou endividamento de uma empresa local não deve apresentar correlação com os mesmos índices das empresas estrangeiras. Isso só se verificaria se as empresas fossem ligadas juridicamente, o que não é o caso das amostras obtidas.

${ }^{81}$ A partir dos dados das amostrais é possível obter estatísticas (que são parâmetros associados a amostra) as quais podem ser comparas com as verificadas em distribuições conhecidas. Com base no valor padronizado de tais estatísticas e dos correspondentes valores presentes em tais tabelas é possível fazer afirmações acerca da probabilidade ou chance de um dado valor estar acima ou abaixo de determinado nível. O processo de padronização é empregado para que as estatísticas amostrais tornem-se comparáveis a uma distribuição conhecida (normal, T de Student, F, etc.). Ao utilizar as estatísticas de cada amostra, utilizar o número de graus de liberdade $\left(n_{1}+n_{2}-2\right)$ e assumindo um valor crítico para alfa (no caso 10\%), o teste retorna com que confiança se espera que não haja diferenças nas médias (hipótese nula $\mathrm{H}_{0}$ ).
} 
permite realizar testes de diferenças de média iguais e desconhecidas de um mesmo parâmetro de duas amostras, sendo definido como:

$$
-t_{\alpha=0,1 / 2} \leq \frac{\mu_{X 1, i}-\mu_{X 2, i}}{\sigma_{X i}^{2} \sqrt{\frac{1}{n_{1}}+\frac{1}{n_{2}}}} \leq+t_{\alpha=0,1 / 2}
$$

Neste caso, a variância deve ser calculada levando em conta a variância de cada amostra e seu tamanho sendo definida como: $\sigma_{X i}^{2}=\frac{\left(n_{1}-1\right) \sigma_{X 1, i}^{2}+\left(n_{2}-1\right) \sigma_{X 2, i}^{2}}{n_{1}+n_{2}-2}$. Caso sejam diferentes se deve adotar a expressão correspondente para cálculo de variâncias diferentes e desconhecidas apresentado anteriormente.

Em ambas as metodologias, em um teste bicaucal se deve verificar se, dado o números de graus de liberdade $\left(g l=n_{1}+n_{2}-2\right)$, a estatística T se encontra dentro da região crítica definida por $\left(-t_{C} \leq T \leq+t_{C}\right)$. Caso isso ocorra não se pode rejeitar a hipótese nula $\left(H_{0}\right)$ : as médias das populações são diferem e vice-versa. ${ }^{82}$

Aplicados os correspondentes testes, constata-se se há indícios de diferença estatística entre os valores médios dos indicadores das empresas nacionais vis-à-vis aos correspondentes indicadores econômico-financeiros das empresas internacionais de transporte marítimo. Os resultados de cada teste são apresentados em tabelas que contêm as seguintes informações: tamanho amostral, amplitude (valores mínimos e máximos de cada indicador), desvio padrão e coeficiente de variação ${ }^{83}$ de cada amostra (razão entre o desvio padrão e média amostral). Para as amostras de empresas internacionais também são apresentados os coeficientes de

\footnotetext{
${ }^{82}$ Segundo Bussab e Morettin (2002), o procedimento para uso do teste de hipótese abrange cinco passos: fixar a hipótese $H_{0}$ que se pretende testar; definir qual estatística é o melhor estimador para ser usado em cada teste; fixar a probabilidade $\alpha$ de cometer o chamado erro do tipo 1 (aceitar $H_{0}$ sendo ele falso); usar as informações amostrais para obter a estatística $T$ que definirá a decisão; confrontar a estatística obtida para a amostra $(T)$ com a região crítica, caso $\left(-t_{C} \leq T \leq+t_{C}\right)$ se verifique, não se pode rejeitar a hipótese nula $H_{0}$.

${ }^{83} \mathrm{O}$ coeficiente de variação é calculado por meio da razão entre o desvio padrão e a média.
} 
skweness e kurtosis. ${ }^{84}$ Por fim, são apresentados os resultados do testes $\mathrm{t}$ de Student (bicaudal), tendo como base o número de graus de liberdade e o intervalo de confiança, correspondente (GRIFFITHS; HALL; JUDGE, 1993). Nesse caso, caso a estatística obtida por meio do teste esteja fora do intervalo de confiança definido para o teste, rejeita-se a hipótese nula $\mathrm{H}_{0}$. Neste caso, há evidências de que a média dos indicadores difere entre as duas populações.

Para garantir uma maior consistência dos resultados, dado que o número de observações nas empresas nacionais é $n_{1} \leq 4$, dois métodos adicionais foram implementados ${ }^{85}$. O primeiro desses consistiu em expandir a amostra de indicadores das empresas nacionais. Isso foi feito a partir do valor médio e de desvio padrão de cada indicador com o uso do software BestFit $₫$. O procedimento visou garantir que, quando expandida, a amostra de indicadores das empresas nacionais apresentasse $n_{1}=n_{2} \leq 48$, ou seja, convergisse para o tamanho da amostra de empresas internacionais. Caso houvesse divergência nos resultados verificados com a aplicação desses dois métodos, um segundo método estatístico foi adotado. Este consistiu em selecionar aleatoriamente os valores dos indicadores de um dado número de empresas internacionais. Este número deveria ser compatível com o tamanho da amostra de indicadores disponíveis na amostra de empresas nacionais, $4 \geq n_{1}=n_{2}$. A rigor, este consistiu o critério final de "desempate" cuja finalidade última foi atestar o nível de significância da diferença de médias de cada indicador.

Uma vez obtidas as estatísticas estas foram utilizadas na avaliação das entrevistas apresentadas na seção 4.6. A rigor, uma avaliação mais detalhada das informações apresentadas esteve baseada na análise do conteúdo de entrevistas feitas junto a diretores financeiros das empresas, membros da academia e de outras instituições ligadas ao setor, visitados durante a elaboração do projeto. Esse procedimento foi adotado como forma dar um embasamento mais consistente às opiniões expressas pelos agentes que atuam no setor. Vale destacar que as entrevistas foram feitas antes da obtenção das estatísticas. Desta forma, o confronto objetivou estabelecer se as opiniões dos entrevistados convergem com os resultados dos testes efetuados.

\footnotetext{
84 Isso foi feito porque o tamanho da amostra das empresas internacionais permitia a obtenção dessas estatísticas. O que não foi o caso para as empresas nacionais.

${ }^{85}$ Como será explicitado, foi feito um esforço no sentido de ampliar o volume dessas informações mas não se obteve êxito.
} 
Em suma, foram calculadas a partir de dados obtidos junto a uma amostra não intencional de 48 empresas estrangeiras e de 4 empresas nacionais as seguintes classes de indicadores: indicadores de solvência, indicadores de administração de ativos, indicadores de endividamento, indicadores de retorno sobre investimento e as classes de indicadores utilizadas pelo BNDES na análise de projetos. Em seguida foram utilizados procedimentos para verificar se há ou não diferença nas médias em tais indicadores entre a amostra de empresas estrangeiras a amostra de empresas nacionais. A análise dos resultados das entrevistas foi feita com base nos resultados quantitativos avaliando a validade das percepções expressas quanto às dificuldades que os agentes alegam existir na contratação de financiamento setorial. O resultado desses procedimentos foi utilizado para testar as proposições relacionadas a questão 1 apresentada no capítulo 1.

As próximas seções apresentam os resultados do emprego dos procedimentos descritos. Antes, cabe destacar que embora centrado em pequena amostra foram adotados procedimentos estatísticos clássicos a fim de garantir a eficiência dos estimadores. Todos os testes são corrigidos pelo número de graus de liberdade. Adicionalmente, para uma amostra de 39 grandes empresas foram obtidos dados de 4 ou aproximadamente $10 \%$.

\subsection{Avaliação de Indicadores Econômico-financeiros das Empresas de Transporte}

A construção e avaliação dos indicadores econômico-financeiros das empresas do setor estabelecidas nesse estudo se baseiam no tratamento de informações presentes nos Demonstrativos Contábeis de 48 empresas de navegação estrangeiras e 4 empresas nacionais. Estes dados foram consolidados por meio do software Microsoft Access a fim de garantir a sua consistência e facilitar a obtenção dos indicadores ${ }^{86}$. O banco de dados possui informações de Demonstrativos Contábeis das empresas, distribuídas em 8203 registros. Estes

${ }^{86}$ Gostaria de agradecer a Cristiane Punhagui Costa que ajudou a construir o banco de dados a partir das informações que obtidas junto a New York Stoke Exchange (NYSE). Certamente, sem o seu valoroso auxílio e dedicação eu teria gastado muito mais tempo e paciência na consolidação do conjunto das informações. 
abrangem dados do Balanço Patrimonial, Demonstrativo de Resultados e Demonstrativo do Fluxo de Caixa referentes aos anos de 2003, 2004 e 2005 de empresas estrangeiras e aos anos de 2004 e 2005 para as empresas nacionais.

A amostra foi não intencional. Em termos das empresas internacionais, recuperaram-se os dados disponíveis na New York Stock Exchange (NYSE) conforme ANEXO 5 e de parte das empresas de transporte consideradas TOP $10^{87}$. Já a obtenção de dados contábeis das empresas nacionais esteve baseada em solicitação direta feita por meio eletrônico e contatos telefônicos junto a 39 empresas de transporte e durante as visitas feitas ao longo da pesquisa. Nesse ínterim, se obteve dados de apenas 4 empresas. Maiores detalhes acerca dos dados são descritos a seguir.

\subsubsection{Informações Gerais dos Balanços das Empresas (BP)}

Inicialmente se deve destacar que os ativos das empresas estrangeiras totalizavam mais de US\$ 48 bilhões de dólares em 2005. Este montante se encontrava pulverizado de maneira relativamente uniforme entre as 48 empresas. Conforme o ANEXO 5, estas empresas atuam nas mais diversas regiões do planeta oferecendo serviços de transporte marítimo.

O volume de ativos destas empresas é extremamente elevado, haja vista que compreende o valor de livro dos ativos e que as embarcações possuem longo período de vida útil. Espera-se que o período de vida útil das embarcações dessas empresas esteja em torno da média mundial - que era de 16 anos em 2005. Uma vez que os valores de livro não sofrem correções, o valor dos ativos se encontra sub-avaliado.

Do total dos ativos dessas empresas, cerca de US\$ 32 bilhões estavam na forma de ativos imobilizados, US\$ 4,4 bilhões na forma de investimentos de longo prazo (ativos em carteira) e US\$ 281 milhões na forma de ativo diferido de longo prazo (imobilização de recursos em novos projetos). Consideradas as características do setor apresentadas no capítulo 2, os ativos de longo prazo se concentram em

\footnotetext{
87 Além das empresas apresentadas no anexo 5, foram obtidos dados adicionais das seguintes empresas: Maersk, Evergreen, Hanjin e NYK Line. Estas figuram entre as TOP10 em carga geral.
} 
capital imobilizado de baixa liquidez e difícil avaliação. O mesmo se pode dizer a partir dos registros das empresas nacionais.

Os ativos das quatro empresas nacionais no ano de 2005 somaram cerca de US\$ 1,0 milhão. Desse total de ativos, cerca de US\$ 0,6 milhão estavam na forma de ativo imobilizado, US\$ 0,16 milhões na forma de investimentos de longo prazo e US\$ 0,34 milhão na forma de ativo diferido de longo prazo.

O ativo circulante das empresas estrangeiras totalizava US $\$ 7,4$ bilhões em 2005 e se encontra mais pulverizado em torno de suas contas constituintes quando comparado ao ativo de longo prazo. No entanto, destaca-se o valor das contas a receber cujo valor era de US\$ 2,2 bilhões em 2005, ou seja, $29 \%$ do valor do ativo circulante das empresas - o que reflete a política de crédito de tais empresas junto a seus clientes.

Os ativos circulantes das empresas nacionais totalizaram cerca de US\$300 milhões, enquanto que o valor das contas a receber ficou em torno de US\$15 milhões, o que equivale a apenas $5 \%$ do ativo circulante das empresas, ao contrário do que se observa nas empresas estrangeiras.

O passivo exigível a longo prazo das empresas estrangeiras totalizou US\$ 23 bilhões. O volume de contas a pagar foi de US\$ 2 bilhões em 2005 - próximo do nível verificado em contas a receber. Já o patrimônio líquido dos acionistas das empresas que fazem parte do banco de dados totalizou US\$ 22 bilhões no mesmo período o que, juntamente com outros recursos providos pelos acionistas (US\$2,2), totaliza $50 \%$ do volume de ativos. Isso indica que grande parte do capital alocado no setor é provida por meio do aporte de recursos seus proprietários. Os ganhos retidos foram expressivos e da ordem de US\$ 8,9 bilhões. Há indícios de que muitas das empresas possuem condições de aportar capital próprio em novos empreendimentos e, dado o valor e composição de seus ativos, possuem elevada capacidade de prover garantias aos credores (ANEXO 5).

O mesmo se pode dizer a partir dos registros das empresas nacionais. $O$ passivo exigível a longo prazo em 2005 totalizou cerca de US\$ 0,5 milhão, enquanto que o volume de contas a pagar foi de US\$ 0,8 milhão, montante bem menor do que o de contas a receber. O patrimônio líquido dos acionistas das empresas nacionais totalizou cerca de US\$ 400 milhões em 2005, nível bem abaixo, proporcionalmente, das empresas estrangeiras, mas que totaliza $60 \%$ do valor dos ativos. 


\subsubsection{Informações Gerais dos Demonstrativos de Resultado das Empresas (DRE)}

Em 2005, a receita bruta gerada pelas empresas estrangeiras foi superior a US $\$ 17$ bilhões absorvendo custos da ordem, de US $\$ 9,2$ bilhões. Isso resultou em um lucro bruto da ordem de US\$ 8,3 bilhões. O volume total de despesas operacionais, de vendas e administrativas das empresas foi da ordem de US\$2 bilhões no mesmo ano. As demais despesas operacionais de vendas e administrativas absorveram cerca de US $\$ 1,7$ bilhão e o volume de despesas não recorrentes (dispêndios com manutenção, por exemplo) foi da ordem de US\$ 439 milhões. Ou seja, o setor absorveu pesadas despesas (cerca de US\$3,8 bilhões no ano de 2005)

O mesmo se pode dizer a partir dos registros das empresas nacionais. Nesse caso, a receita bruta gerada pelas empresas totalizou cerca de US\$330 milhões, enquanto que seus custos ficaram em US\$200 milhões. Esses custos são proporcionalmente superiores aos custos das empresas estrangeiras, em relação as suas respectivas receitas brutas. O lucro bruto das empresas nacionais foi de cerca de US\$ 80 milhões. Já o volume das despesas operacionais, de vendas e administrativas, foram da ordem de US\$ 7,2 milhões. As empresas nacionais também absorveram pesadas despesas no ano de 2005 (cerca de US\$260 milhões).

O lucro líquido auferido pela empresas estrangeiras foi da ordem de US $\$ 4,5$ bilhões no ano de 2005 , o que totaliza uma taxa de retorno em torno de $10 \%$ sobre os ativos e $20 \%$ sobre o patrimônio líquido dos acionistas. O lucro depois dos impostos totalizou aproximadamente US\$ 4,3 bilhões, ou seja, o setor recolhe apenas US\$ 0,2 bilhão em impostos o que dá indícios acerca dos incentivos tributários concedidos ao setor de transporte marítimo - mesmo se considerarmos a bandeira de conveniência das embarcações (ANEXO 5).

Já lucro líquido auferido pelas empresas nacionais foi na ordem de US\$75 milhões no ano de 2005 , o que totaliza uma taxa de retorno entorno de $7 \%$ sobre os ativos e em torno de $20 \%$ sobre o patrimônio líquido. O lucro antes dos impostos totalizou cerca de US\$ 115 milhões; entretanto, o setor recolheu pesados tributos (o 
imposto sobre o frete), o que totalizou aproximadamente US\$ 43 milhões. Dado que ressalta a pesada carga tributária brasileira no setor.

Em nível internacional a conta total líquido de outras receitas/despesas operacionais da amostra de empresas internacionais foi de US\$ 542 milhões. Isso indica que o setor descapitalizou parcialmente no ano de 2005. A despeito disso e com base nas informações contidas no banco de dados, se aferiu que o volume de ativos sofreu incrementos contínuos ao longo do período compreendido entre 2003 e 2005. O movimento positivo em outras fontes de despesa indica o sucateamento ou transferência de ativos das companhias.

Outra informação que chama a atenção é o incipiente valor nos gastos com pesquisa e desenvolvimento (P\&D). Por ser um receptor de progresso técnico, o setor investe muito pouco nessas atividades.

As 48 empresas estrangeiras analisadas pagaram mais de US $\$ 1,3$ bilhão com juros em 2005 (29\% sobre o lucro bruto e cerca de 30\% sobre o lucro líquido), quase a metade de suas despesas operacionais. Isso mostra, a despeito do alto peso dos recursos dos acionistas no total de ativos, o peso das despesas financeiras sobre o segmento de transporte.

O mesmo se pode dizer a partir dos registros das empresas nacionais. No ano de 2005, essas empresas pagaram mais de US\$ 34 milhões em juros (em torno de $22 \%$ sobre o lucro bruto e em torno de $23 \%$ sobre o lucro líquido), o que também caracteriza quase a metade das suas despesas operacionais. Fato indica, o peso das despesas financeiras sobre o segmento de transportes.

\subsubsection{Informações Gerais dos Demonstrativos de Fluxo de Caixa das Empresas (DFC)}

O fluxo de caixa proveniente das atividades operacionais do conjunto das empresas estrangeiras totalizou US\$ 5,4 bilhões em 2005 que foi gerado a partir de uma receita líquida de US \$ 4,6 bilhões, portanto variações em outras contas do ativo e do passivo cobriram explicam esta diferença. Neste mesmo ano, US\$ 2,3 bilhões foram redistribuídos na forma de dividendos. Mesmo assim, US $\$ 6,3$ bilhões foram utilizados na realização de novos investimentos. 
O influxo de caixa proveniente de operações de financiamento foi da ordem de US\$ 1 bilhão. O aporte de recursos ao caixa dessas empresas por meio da variação do volume de empréstimos líquidos (diferença entre o pagamento e recebimento de empréstimos e financiamentos) chama a atenção e foi de US $\$ 1,2$, US $\$ 1,1$ e US $\$ 2,4$ bilhões nos anos de 2003, 2004 e 2005, respectivamente. Esses recursos incrementaram a alocação de capital em ativos. Este movimento pode ser capitado pelos recursos alocados em investimentos contabilizados como crescente dispêndio de capital de US\$2,2, US\$3,6 e US\$ 8,8 nos anos de 2003, 2004 e 2005, respectivamente.

O volume depreciado foi da ordem de US\$ 2 bilhões, cerca de $4,2 \%$ dos ativos. Este valor é relativamente baixo o que constitui indício de que uma parcela considerável do valor do imobilizado já foi amortizada corroborando a hipótese de que o valor do total dos ativos registrados em livro se encontra sub-avaliado.

Estes movimentos foram acompanhados por uma variação contabilizada no balanço de apenas US\$282 milhões no passivo e de apenas US\$ 41 milhões na alínea contas a receber. A partir da análise das informações contidas no banco de dados, estas parecem ter um comportamento oscilante em contas a receber cuja variação é baixa o que indica certa inelasticidade (rigidez) no curto prazo. Esse comportamento é oriundo das condições de mercado e da rigidez na capacidade de transporte em TPB.

Até o término dessa pesquisa não foi possível obter dados do Demonstrativo de Fluxo de Caixa das empresas nacionais.

Antes de iniciar a próxima seção valem algumas ressalvas. Em razão de dispor de Demonstrativos Contábeis das empresas nacionais apenas para os anos de 2004 e 2005, as discussões subseqüentes estarão restritas a esses dois anos. O mesmo se dará para as demais classes de indicadores econômico-financeiros. Apesar disso serão feitos comentários sumários acerca da evolução dos índices entre os anos de 2003 e 2005 para as empresas das quais se dispunha de dados.

\subsubsection{Comparando o grau de Liquidez das Empresas de Transporte Marítimo Nacionais e Internacionais}


Entre os anos de 2004 e 2005, as empresas estrangeiras apresentaram ILC médio de 1,7, ou seja, o valor dos ativos circulantes das empresas pode cobrir menos de duas vezes as dívidas de curto e curtíssimo prazo ${ }^{88}$. Como aponta Gitman (2000), é recomendável que este valor se encontre acima de 2. Devido à rigidez e peso das despesas das empresas e seu caráter perene, qualquer perda de receita ou dificuldade de pagamento de despesas correntes têm potencial de provocar severos desequilíbrios no cumprimento de obrigações de curto e curtíssimo prazo fato que se associa diretamente com o risco de mercado e operacional dessas empresas. Como o peso dos custos e despesas operacionais são altos e inelásticos, é por esta razão que, durante o ciclo recessivo, muitas empresas decidem atracar ou vender navios mais antigos e obsoletos, fato que é discutido por Stopford (2005).

O baixo grau e relativa rigidez na liquidez imprimem elevado risco operacional, também se refletindo no risco financeiro, uma vez que a periodicidade de pagamento de juros e amortizações apresenta prazo de vencimento inferior a um ano. Pequenas oscilações no preço do dólar também afetam de maneira pronunciada a capacidade das empresas de honrar suas dívidas de curto prazo, uma vez que tais compromissos possuem valor fixo e que grande parte dos custos operacionais estão vinculados ao preço dessa moeda. O efeito líquido da desvalorização do dólar em relação maioria das moedas $(R \mathbb{Q}$, $€ \$$, etc.) deve ter gerado benefícios financeiros não previstos. Certamente, este efeito alavancou os ganhos de liquidez ocorridos entre 2004 e 2005.

Para o conjunto dessas empresas, o índice de liquidez seco (ILS) foi ligeiramente inferior ao índice de liquidez corrente (média de 1,6 para o período). Neste segmento de serviços, os níveis de estoques são extremamente reduzidos, muitas vezes restrito a gastos com combustíveis, lubrificantes e certas peças sobressalentes. Portanto, diferentemente de outros setores de serviços e vendas a varejo, que podem se valer da venda dos estoques por meio de "ofertas" e "promoções" a fim de levantar recursos em momentos de escassez nos níveis de caixa, as empresas do setor não podem adotar esse expediente. Este aspecto também é discutido por Stopford (2005). O crédito de capital de giro ou a venda de ativos imobilizados (no mercado de compra e venda de embarcações usadas ou de demolição) constituem medidas para contornar problemas de liquidez - fato que vai

${ }_{88}^{8}$ Dados apresentados por Gitman (2000) e Roos, Westerfield e Jaffe (2002) indicam que para o setor comercial este nível se encontra acima de 3,7. 
se refletir nos índices de administração de ativos e no fluxo de caixa não operacional das empresas. Este expediente é evidenciado quando se observa os movimentos de liquidez do conjunto das 48 empresas internacionais investigadas (ANEXO 5). Para uma reduzida parcela dessas empresas, elevados níveis de liquidez são acompanhados de variação positiva na conta Fluxo de Caixa de Investimentos ${ }^{89}$.

Os níveis dos indicadores de liquidez das empresas nacionais, representados por uma amostra não intencional de 4 empresas visitadas durante a elaboração desse trabalho, são sensivelmente maiores (apresentando níveis médios de 2,2 e 1,2 nos conceitos corrente e seco no período analisado). A rigor, esses resultados sofrem forte efeito dos altos níveis de liquidez de uma das empresas presentes na amostra que foi de 4,6 e 4,7 no período analisado. Essas informações oferecem indícios acerca da relativa fragilidade das empresas locais em cumprirem suas obrigações de curto e curtíssimo prazo. Pequenas flutuações no nível de receitas ou custos podem provocar dificuldades financeiras ao conjunto das empresas do setor.

Antes de apresentar os resultados dos testes aplicados vale tecer algumas considerações acerca da distribuição empírica do ILC e ILS dos dados amostrais das empresas estrangeiras. O procedimento, para eliminar o efeito de outilers sobre a média dos índices, manteve um grupo de empresas que responderam por mais de $92 \%$ do valor total dos ativos das empresas presentes na amostra ${ }^{90}$. Em termos da aderência ao formato da curva normal, as distribuições empíricas desses dados possuem elevados níveis de assimetria à direita - fato que é medido pelo coeficiente de skewness das distribuições $\left(\alpha_{3}>0\right)$. Isso denota a tendência do setor em apresentar alta freqüência em torno de baixos níveis de liquidez (calda positiva longa). Isso era esperado com base na caracterização do setor feita ao longo da revisão da literatura. Além disso, o coeficiente de kurtosis das distribuições apresenta valores sensivelmente altos $\left(\alpha_{4} \geq 3\right)$. Isso indica que a maior parte dos valores se encontra concentrado em torno da média, mas que apresentam um intervalo de variação pronunciado.

\footnotetext{
${ }^{89}$ Como explicitado na seção 4.4 , estas grandes variações positivas não foram consideradas nos teste subseqüentes. O mesmo se deu em torno de grandes variações negativa. Isso foi possível graças a aplicação de critérios para eliminação de outliers, por meio do emprego dos procedimentos estatísticos adotados.

${ }^{90}$ Doravante, estas informações serão apresentadas nas notas associadas a cada tabela.
} 
Feitas estas considerações iniciais, a Tabela 1 apresenta os resultados dos testes de diferenças de média dos indicadores de liquidez (IL) para empresas que atuam nos segmento de transporte e apoio marítimo no Brasil e no exterior. 
Tabela 1 - Resultados das estatísticas e teste de diferenças de médias dos Índices de Liquidez (IL) das empresas nacionais e estrangeiras para os anos de 2004 e 2005.

\begin{tabular}{|c|c|c|c|c|c|}
\hline & \multirow{2}{*}{ ESTATÍSTICAS } & \multicolumn{2}{|c|}{ ILC } & \multicolumn{2}{|c|}{ ILS } \\
\hline & & 2004 & 2005 & 2004 & 2005 \\
\hline \multirow{5}{*}{$\begin{array}{l}\frac{0}{\Sigma} \\
z \\
\frac{O}{U} \\
\Sigma\end{array}$} & n1 & 3 & 4 & 2 & 3 \\
\hline & Amplitude amostral & $(1,14 ; 4,25)$ & $(1,09 ; 4,69)$ & $(0,81 ; 4,20)$ & $(0,56 ; 2,58)$ \\
\hline & Média (BRA) & 2,09 & 2,33 & 0,92 & 1,47 \\
\hline & Desv Pad. (BRA) & 1,88 & 1,84 & 0,16 & 1,24 \\
\hline & Coef. Variação (*) & 0,90 & 0,79 & 0,17 & 0,84 \\
\hline \multirow{7}{*}{ 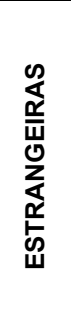 } & n2 (**) & 31 & 39 & 30 & 39 \\
\hline & Amplitude amostral & $(0,31 ; 4,20)$ & $(0,14,4,40)$ & $(0,11 ; 4,20)$ & $(0,13 ; 5,16)$ \\
\hline & Média (INT) & 1,87 & 1,58 & 1,73 & 1,59 \\
\hline & Desv Pad. (INT) & 1,05 & 0,97 & 1,09 & 1,15 \\
\hline & Coef. Variação & 0,56 & 0,62 & 0,63 & 0,72 \\
\hline & Skewness normal: $\alpha_{3}=0$ & 0,66 & 1,45 & 0,56 & 1,57 \\
\hline & Kurtosis normal $\alpha_{4}=3$ & 2,35 & 4,67 & 2,26 & 4,84 \\
\hline \multirow{2}{*}{ 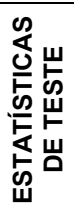 } & $\begin{array}{l}\text { Estatística } \mathbf{T} \\
\text { Estatística de Teste Bicaudal } \\
\left( \pm t_{C}\right)\left(^{(* *}\right)\end{array}$ & $\begin{array}{l}-0,318 \\
\pm 1,697\end{array}$ & $\begin{array}{l}-1,359 \\
\pm 1,684\end{array}$ & $\begin{array}{r}1,028 \\
\pm 1,697\end{array}$ & $\begin{array}{r}0,172 \\
\pm 1,684\end{array}$ \\
\hline & \begin{tabular}{|l|} 
Intervalo de Confiança para \\
Diferença de Médias (90\%)
\end{tabular} & $(-1,37 ; 0,93)$ & $(-1,69 ; 0,18)$ & $(-0,52 ; 2,14)$ & $(-1,04 ; 1,21)$ \\
\hline
\end{tabular}

$\left({ }^{\star}\right)$ Definido como a razão entre o desvio padrão e a média, permite comparar a magnitude da variação em termos de cada amostra.

$\left({ }^{* *}\right)$ Conforme descrito na seção 4.4 , os valores calculados para os dados válidos foram feitos após emprego de procedimento destinado a eliminação de outliers. Das 48 empresas internacionais, restou um número que responde por mais de $92 \%$ e $90 \%$ do valor dos ativos, em cada caso.

$\left({ }^{* * *}\right)$ Tal como definido na seção 4.4, caso o valor da estatística T esteja fora do intervalo formado pelo módulo de tC rejeita-se a hipótese nula $(\mathrm{H} 0)$. Neste caso, há evidências de que a médias dos indicadores não sejam significativamente diferentes.

Fonte: Elaborado pelo autor.

Conforme apresentado, os dados obtidos a partir dos testes de diferenças de média para os períodos considerados sugerem que não se pode rejeitar a hipótese nula $H_{0}$. Nesse caso não se pode afirmar que existam diferenças significativas nos níveis médios de liquidez seca e corrente entre o grupo de empresas de transporte e apoio marítimo nacionais e estrangeiras. Do ponto de vista estatístico, isso se evidencia na medida em que o valor de cada uma das estatísticas $T$, associadas ao teste de diferença de média se encontram dentro do intervalo de confiança definido, em cada caso, por $\left(-t_{C} \leq T \leq-t_{C}\right)$. Os testes $F$ também apontaram não haver diferenças significativas na dispersão em torno da média para a amostra de 
empresas $^{91}$. Considerando que os ILC e ILS se concentram em torno do valor médio, os dados apresentados permitem inferir que há indícios que o nível médio de liquidez das empresas locais se encontra dentro do intervalo de confiança de $90 \%$ para a média internacional. Adicionalmente, os coeficientes de variação verificados para essas amostras das empresas nacionais se encontram muito próximos do verificado para as empresas internacionais. Isso acontece embora a variância para a pequena amostra de empresas nacionais seja maior.

Os testes adicionais de expansão amostral das empresas nacionais e de seleção aleatória dos índices de empresas internacionais apontam na mesma direção. No primeiro caso, mesmo assumindo a distorção que um maior desvio padrão verificado na amostra das empresas nacionais possa provocar o teste foi não significativo, ou seja, não se pode afirmar que existam diferenças nas médias dos indicadores de liquidez das empresas nacionais e internacionais. No segundo caso, os testes refletiram uma maior assimetria à direita verificada nos dados das empresas estrangeiras. Nesse contexto e sob a ótica das empresas de armação, o grau de exposição aos os riscos operacional, financeiro, de mercado, cambial e de evento são muito semelhantes aos verificados no resto do mundo.

Isso denota que o nível médio de liquidez a disposição das empresas (o qual pode ser utilizado para saldar suas obrigações de curto e curtíssimo prazo) são muito semelhantes. Neste sentido o grau de exposição ao risco (operacional, financeiro, de mercado e cambial) de investidores e credores que operam no setor é muito similar.

\subsubsection{Comparando o Grau Atividade das Empresas de Transporte Marítimo Internacionais e as Nacionais}

Considerando as informações válidas para os anos de 2004 e 2005, os dados das empresas nacionais e internacionais indicam que o setor é marcado por modestos níveis de gestão de ativos segundo diferentes conceitos (IPG, GAT e GAI). Essa característica setorial reflete o grande peso do valor dos ativos empregados vis-à-vis o volume de lucros e receitas operacionais geradas pelo setor

\footnotetext{
91 Os resultados de tais testes não são apresentados nas tabelas.
} 
em cada período - fato que conforma a estrutura dessa classe de índices econômico-financeiros. A despeito disso, os ativos empregados geram receitas e absorvem custos e despesas por longos períodos de tempo - contrastando com outros segmentos econômicos do setor de serviços.

Como a amostra das empresas internacionais é grande e agrega empresas de diferentes anos de existência (ANEXO 5) com ativos de idades diferenciadas, o valor de livro (book value $)^{92}$ dos ativos associado a sua vida útil não deve distorcer de maneira pronunciada os resultados dos testes, uma vez que capta o valor médio desses ativos. Adicionalmente, se espera que se verifique certa convergência em torno da idade média dos ativos (embarcações). Essa tendência de concentração em torno do valor médio deve contribuir para reduzir eventuais distorções ${ }^{93}$.

Antes de discutir as estatísticas convém salientar que a aplicação dos testes $F$ indica que não se pode afirmar que haja diferenças significativas nas variâncias das estatísticas. Isso constitui um dos primeiros indícios de relativa homogeneidade em torno da eficiência na gestão de ativos para estas amostras de empresas.

Uma primeira forma de discutir esse aspecto dos negócios ligados ao setor é por meio do IPG. De fato, este índice esteve abaixo de um dígito para todos os anos de 2004 e 2005, apresentando baixo valor médio, mais precisamente 0,07 e 0,08 para o grupo de empresas nacionais e estrangeiras durante o período sob investigação. Contudo, o desvio padrão verificado para cada grupo de empresas é relativamente elevado $(0,05$ para as empresas nacionais contra 0,04 para as estrangeiras). Isso provavelmente capta o diferencial no valor de livro dos ativos, mas também sofre efeitos dos diferenciais de lucro líquido das empresas. A rigor, esse aspecto se transfere para a magnitude dos coeficientes de variação que foi maior no caso brasileiro. As empresas nacionais apresentaram níveis de IPG ligeiramente maiores e mais dispersos em torno do valor médio, refletindo os diferenciais no resultado medido por meio do lucro líquido.

O grau de assimetria e de kurtosis verificados a partir dos dados das empresas internacionais foram modestos. Isso resulta em uma distribuição

\footnotetext{
92 O valor de livro (book value) corresponde ao valor histórico dos ativos registrados no Balanço Patrimonial de cada empresa.

93 A rigor, não foi possível obter dados relacionados à idade média da frota de cada uma das empresas. Contudo, como os testes estão centrados no valor médio se espera que haja uma convergência em torno do valor de registro dos ativos expressos nos Balanços Patrimoniais (BP) em cada amostra de empresas.
} 
relativamente uniforme em torno do valor médio e uma menor amplitude relativa nesse índice.

Ao medir a eficiência com a qual os ativos de uma empresa são empregados, o índice de giro de ativos (GAT) também apresentou valores médios relativamente baixos para o período (0,6 para as empresas nacionais contra 0,4 para as estrangeiras). Isso se explica uma vez que o volume de receitas operacionais em cada ciclo é baixo quando comparado ao volume de ativos empregado. Segundo Ross, Westerfield e Jaffe (2002), em muitas situações um GAT baixo indica que as empresas estão usando seus ativos no limite da capacidade devendo aumentar o volume de receitas ou se desfazer de alguns de seus ativos. Nem uma dessas medidas é fácil de implementar no setor de transporte marítimo, dada a indivisibilidade dos ativos e baixa elasticidade da demanda pelos serviços (capítulo 2).

Uma grande parcela das empresas estrangeiras apresenta GAT inferior a 0,5. Isso reflete uma tendência de baixo giro dos ativos das companhias. Observa-se também grande dispersão no GAT e que este sofreu pequena flutuação ao longo do período considerado. Já as empresas nacionais apresentaram valor médio ligeiramente superior. Comparando as estatísticas do GAT, é possível verificar que as empresas nacionais apresentaram valor médio ligeiramente superior, maior dispersão e coeficientes de variação muito semelhante, compensados pelos diferenciais verificados nos valores médios.

Já o giro de ativo imobilizado (GAl) apresenta níveis médios muito próximos do GAT (médias de 0,7 e 0,6 para a amostra das empresas nacionais e estrangeiras ao entre os anos de 2004 e 2005). Isso ocorre em função do grande peso que os ativos imobilizados apresentam no volume total de ativos das empresas do setor. Contudo a dispersão é significativamente maior quando comparada com a verificada no IGA. Estas mesmas características se verificam nos dados das empresas nacionais. Adicionalmente, o grau de assimetria e de kurtosis, para a amostra das empresas estrangeiras, é bem maior que o verificado para o GAT. Como apontado por Stopford (2005), este fato certamente reflete as diferentes políticas de inversão das companhias e acesso ao financiamento. A despeito disso o grau de assimetria das distribuições não é muito dispare em relação ao GAT quando medido pelo skewness das distribuições. 
Já o giro de contas a receber $(G C R)$ apresenta grande dispersão entre as empresas e grande coeficiente de variação $(0,9$ para nacionais e 1,1 para estrangeiras). A depender do desvio médio de cada empresa, isso reforça o temor em torno do baixo valor no ILC. A rigor, o grau de associação linear entre as contas a receber e o prazo médio de recebimento é baixo. Isso indica que o GCR depende da política de contas a receber das empresas junto aos seus fornecedores. O PMR também apresenta grande dispersão, mas em compensação, possui valores médios reduzidos para o período (médias de 19 e 30 dias para empresas nacionais e estrangeiras, respectivamente, durante o período).

Por fim, o índice de recuperação de estoque (IRE) apresentou valores médios de 92 (nacionais) e 73 (estrangeiras) para o período com maior coeficiente de variação sendo verificado para as empresas nacionais. Isso indica que, embora não se verifique diferenças nas médias, as empresas locais apresentam maior dispersão na gestão desse tipo de ativo. Isso indica que as empresas locais apresentam menor volume de estoques em relação as receitas. Certamente, este resultado se encontra associado as diferenças nas escalas operacionais das empresas de cada amostra.

Os dados das empresas internacionais permitem constatar que há ligeira assimetria à direita em todos os índices apurados. Já o coeficiente de kurtosis é ligeiramente diferente quando comparado à distribuição normal. Essa informação reflete os diferentes níveis de eficiência na forma como os ativos são empregados.

A tabela 2 apresenta os valores dos indicadores de atividade (IAA) para as empresas presentes na amostra. Com base nessas informações é possível tecer as seguintes considerações acerca dos níveis verificados dos indicadores de atividade.

Os dados apresentados sugerem que ao menos para GAI, GCR e IRE, não se pode rejeitar a hipótese nula $H_{0}$. Assim, não de afirmar que existam diferenças significativas entre as médias verificadas nessas categorias de indicadores para grupo de empresas de transporte e apoio marítimo: ou seja, há indícios que o nível desses se encontra dentro do intervalo de confiança de $90 \%$ para a média internacional. Do ponto de vista estatístico, isso se evidencia na medida em que o valor de cada uma das estatísticas $\mathrm{T}$, associadas ao teste de diferença de média se encontram dentro do intervalo de confiança definido, em cada caso, por $\left(-t_{C} ;+t_{C}\right)$. Assim, o uso de ativos imobilizados como total das receitas são semelhantes em termos proporcionais. Adicionalmente, a política de gestão de financiamento junto a 
clientes e a política de administração de estoques são similares e possuem níveis semelhantes de eficiência, certamente refletindo o padrão internacional dessas operações. 
Tabela 2 - Resultados das estatísticas e testes de diferença de médias dos Índices de Administração de Ativos (IAA) para amostras de empresas nacionais e estrangeiras para os anos de 2004 e 2005.

\begin{tabular}{|c|c|c|c|c|c|c|c|c|c|c|c|c|}
\hline \multirow{2}{*}{\multicolumn{2}{|c|}{ ESTATÍSTICAS (*) }} & \multicolumn{2}{|c|}{ IPG } & \multicolumn{2}{|c|}{ GAT } & \multicolumn{2}{|c|}{ GAI } & \multirow{2}{*}{$\begin{array}{l}\text { GCR } \\
2005\end{array}$} & \multicolumn{2}{|c|}{ IRE } & \multicolumn{2}{|c|}{ PMR } \\
\hline & & 2004 & 2005 & 2004 & 2005 & 2004 & 2005 & & 2004 & 2005 & 2004 & 2005 \\
\hline \multirow{5}{*}{$\begin{array}{l}\frac{0}{\mathbf{S}} \\
\mathbf{Z} \\
\frac{0}{U} \\
\mathbf{Z}\end{array}$} & n1 & 3 & 4 & 3 & 4 & 2 & 3 & 3 & 2 & 3 & 3 & 4 \\
\hline & Amplitude & $\begin{array}{c}(0,05 ; \\
0,19)\end{array}$ & $(0,02 ; 0,10)$ & $\begin{array}{c}(0,47 \\
1,25)\end{array}$ & $\begin{array}{l}(0,09 ; \\
0,96)\end{array}$ & $\begin{array}{c}(0,62 ; \\
1,52)\end{array}$ & $(0,01 ; 086)$ & $(0,01 ; 1,02)$ & $\begin{array}{l}(30,8 ; \\
92,3)\end{array}$ & $\begin{array}{l}(33,4 ; \\
295,7)\end{array}$ & $\begin{array}{l}(8,98 \\
33,81)\end{array}$ & $\begin{array}{l}6,24 ; \\
34,55)\end{array}$ \\
\hline & Média (BRA) & 0,10 & 0,05 & 0,80 & 0,47 & 1,07 & 0,45 & 0,62 & 61,53 & 122,22 & 18,66 & 18,79 \\
\hline & Desv Pad. (BRA) & 0,07 & 0,04 & 0,40 & 0,36 & 0,64 & 0,43 & 0,55 & 43,47 & 150,25 & 13,28 & 12,46 \\
\hline & Coef. Variação $\left.{ }^{* *}\right)$ & 0,71 & 0,86 & 0,50 & 0,76 & 0,60 & 0,95 & 0,87 & 0,71 & 1,23 & 0,71 & 0,66 \\
\hline \multirow{7}{*}{ 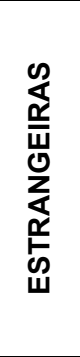 } & n2 & 26 & 29 & 33 & 32 & 28 & 42 & 29 & 20 & 29 & 17 & 28 \\
\hline & Amplitude & $\begin{array}{l}(0,01 ; \\
0,18)\end{array}$ & $(0,04 ; 0,14)$ & $\begin{array}{c}(0,01 ; \\
1,02)\end{array}$ & $\begin{array}{l}(0,12 ; \\
0,72)\end{array}$ & $\begin{array}{c}(0,13 ; \\
1,68) \\
\end{array}$ & $(0,01 ; 1,85)$ & $(0,01 ; 1,79)$ & $\begin{array}{l}(0,12 ; \\
123,4) \\
\end{array}$ & $\begin{array}{l}(1,93 ; \\
552,9)\end{array}$ & $\begin{array}{l}(12,4 \\
46,02)\end{array}$ & $\begin{array}{l}(7,37 ; \\
58,3)\end{array}$ \\
\hline & Média (INT) & 0,09 & 0,08 & 0,43 & 0,32 & 0,68 & 0,58 & 0,46 & 47,53 & 98,38 & 31,37 & 29,64 \\
\hline & Desv Pad. (INT) & 0,06 & 0,03 & 0,25 & 0,13 & 0,40 & 0,49 & 0,50 & 36,78 & 26,98 & 9,66 & 14,78 \\
\hline & Coef. Variação & 0,63 & 0,38 & 0,58 & 0,41 & 0,59 & 0,84 & 1,10 & 0,77 & 0,27 & 0,31 & 0,50 \\
\hline & Skweness normal: $\alpha_{3}=0$ & $-0,08$ & 0,42 & 0,66 & 1,16 & 0,87 & 1,17 & 1,27 & 0,57 & 2,65 & $-0,36$ & 0,18 \\
\hline & Kurtosis normal $\alpha_{4}=3$ & 1,44 & 1,87 & 2,71 & 4,45 & 2,75 & 3,36 & 3,57 & 2,18 & 9,24 & 2,22 & 2,04 \\
\hline \multirow{3}{*}{ 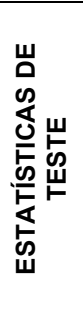 } & Estatística $\mathrm{T}\left({ }^{* * *}\right)$ & $-0,41$ & 1,763 & $-2,352$ & $-1,788$ & $-1,321$ & 0,437 & $-0,541$ & $-0,508$ & $-0,294$ & 2,004 & 1,394 \\
\hline & $\begin{array}{l}\text { Estatística de Teste } \\
\text { Bicaudal Estatística de } \\
\text { Teste Bicaudal }\left( \pm t_{C}\right) \\
\left({ }^{* * * *}\right)\end{array}$ & $\pm 1,708$ & $\pm 1,708$ & $\pm 1,690$ & $\pm 1,690$ & $\pm 1,701$ & $\pm 1,697$ & $\pm 1,697$ & $\pm 1,725$ & $\pm 1,697$ & $\pm 1,734$ & $\pm 1,697$ \\
\hline & $\begin{array}{l}\text { Intervalo de Confiança } \\
\text { para Diferença de Médias } \\
(90 \%)\end{array}$ & $\begin{array}{c}(-0,07 \\
0,05)\end{array}$ & $(0,01 ; 0,06)$ & $\begin{array}{l}(-0,64 ;- \\
0,11)\end{array}$ & $\begin{array}{l}(-0,30 ;- \\
0,01)\end{array}$ & $\begin{array}{c}(-0,91 \\
0,11)\end{array}$ & $(-0,36 ; 0,62)$ & $(-0,69 ; 0,35)$ & $\begin{array}{l}(-61,5 \\
33,51)\end{array}$ & $\begin{array}{c}(-161,36 \\
113,7)\end{array}$ & $\begin{array}{l}(1,71 ; \\
23,7)\end{array}$ & $\begin{array}{l}(-2,36 \\
24,01)\end{array}$ \\
\hline
\end{tabular}

$\left({ }^{*}\right)$ Conforme descrito, os valores calculados para os dados válidos foram feitos após emprego de procedimento destinado a eliminação de outliers. Das 48 empresas internacionais restou um número que respondem por mais de $70 \%, 75 \%, 79 \%, 69 \%$ e $60 \%$ para IPG, GAT, GCR, IRE e PMR em termos dos ativos da amostra, respectivamente.

$\left.{ }^{* *}\right)$ Definido como o desvio padrão sobre a média, permite comparar a magnitude da variação em termos de cada amostra.

$\left({ }^{* * *}\right)$ Os testes adicionais apresentaram os mesmos resultados do teste T original.

$\left.{ }^{* * * *}\right)$ Tal como definido na seção 4.4 , caso o valor da estatística T esteja fora do intervalo formado pelo módulo de tC rejeita-se a hipótese nula (H0). Neste caso, há evidências de que a médias dos indicadores não sejam significativamente diferentes.

Fonte: Elaborado pelo autor. 
Contudo o PMR, ao menos para o ano de 2004, o teste de diferença de média apresentou diferença significativa. Neste caso, as empresas internacionais apresentaram políticas de crédito e cobrança mais frouxas quando comparadas as nacionais. A despeito disso, em se tratando de setor de serviços, os prazos médios de recebimentos são muito próximos, o mesmo ocorrendo com o volume de contas a receber. Nesse contexto e sob a ótica das empresas de armação, o grau de exposição aos os riscos operacional, financeiro, de mercado, cambial e de evento são muito semelhantes ao verificado no resto do mundo.

Os testes indicaram que GAT é significativamente diferente para as amostras de empresas. Assim, não se pode aceitar a hipótese nula $H_{0}$ Nesses casos, os valores das estatísticas de teste apresentaram valores $\left(-t_{C}>-2,352\right)$ e $\left(-t_{C}>-\right.$ 1,788). Como os valores dos testes apurados são negativos, há indícios que as empresas nacionais operam com maior eficiência global seus ativos obtendo, em termos relativos, maior volume de receitas por meio da venda de serviços. A rigor, os resultados refletem elevados níveis de GAT de uma das empresas nacionais presentes na amostra. Caso os dados dessa empresa fossem excluídos dos testes, não seria observada significância em torno do GAT, ou seja, as estatísticas de teste ficariam dentro do intervalo $\left(-t_{C} ;+t_{C}\right)$. Por outro lado este efeito pode estar associado a maior idade relativa dos ativos das empresas nacionais.

Os testes também apontam certa dubiedade em relação à gestão de ativos quando avaliada sob o conceito de IPG. Como o volume de ativos administrados pelas empresas internacionais é significativamente maior que o administrado pelas empresas nacionais, a eficiência com que os montantes de capital são administrados difere de maneira substancial. A eficiência na gestão é crítica, haja vista que a característica fundamental do setor é a grande participação no ativo imobilizado no total de ativos e baixa lucratividade. Ao medir a capacidade dos ativos em gerar lucro, o teste do IPG foi afetado por dois movimentos: redução na média de retorno de uma das empresas nacionais em 2005 e redução da dispersão do índice para a amostra de empresas internacionais. Isso pode ser verificado por meio da variação do coeficiente de variação entre os dois anos. Como há uma relativa rigidez na taxa de crescimento dos ativos das empresas vis-à-vis a geração de lucros, este resultado só pôde se verificar ante a variações pronunciadas nos resultados. 


\subsubsection{Comparando o Grau Rentabilidade das Empresas de Transporte Marítimo Internacionais e Nacionais}

Embora apresente altas dispersões e coeficientes de variação, o nível de rentabilidade das empresas estrangeiras é ligeiramente maior que o verificado nas empresas nacionais quando medido por meio do conceito de margem bruta (MB). A rigor, a média nesse índice entre 2004 e 2005 foi de 0,25 e 0,58 para a amostra de empresas nacionais e internacionais, respectivamente. Estas diferenças não se verificam quando a rentabilidade é mensurada por meio do conceito de ML, ROE e ROA. A rigor, a média da margem líquida não foi tão diferenciada apresentando valores de 0,20 e 0,23 . Considerando o período de 2004 e 2005, o valor médio do ROE e do ROA foram de 0,18 e 0,21 e de 0,07 e 0,08, respectivamente, para as empresas nacionais e estrangeiras. Nos dois casos, embora a média seja semelhante para as amostras de empresas, a explicação deve ser buscada na eficiência e rentabilidade das vendas vis-à-vis a eficiência no uso dos ativos ${ }^{94}$. A média das margens e giro para as empresas internacionais foi de 0,27 e 0,49 entre os anos de 2004 e 2005. Já os correspondentes valores para as empresas nacionais foram de 0,18 e 0,66 . O giro de ativos maior obtido pelas empresas nacionais compensa o diferencial de margem. Por fim, o grau médio de alavancagem das empresas internacionais foi de 2,5 enquanto as nacionais apresentaram índice de 2,4. Novamente os resultados se mostram consistentes.

Em termos relativos o ROE e o ROA parecem dar indícios de que a rentabilidade empresarial média das empresas nacionais e das estrangeiras, em termos da estrutura patrimonial, possui certas semelhanças. Embora esses dois índices demandem análises para intervalos mais longos de tempo sua estrutura não muda de maneira tão brusca como se espera que ocorra na MB e ML. Assim, constitui uma boa estratégia para a comparação da rentabilidade sobre patrimônio e

\footnotetext{
${ }^{94}$ Conforme o quadro 17, o ROE e o ROA podem ser decompostos por meio das respectivas expressões: $\quad R O E=\left(\frac{L L}{V}\right)\left(\frac{V}{A T}\right)\left(\frac{A T}{P L}\right)$ e $R O A=\left(\frac{L L}{V}\right)\left(\frac{V}{A T}\right)$. Os termos associados ao ROE são margem, giro e alavancagem, respectivamente. Os termos associados ao ROA são margem e giro, respectivamente.
} 
total de ativos deste setor, denotando o risco em relação à pressão para distribuição de dividendos vis-à-vis o pagamento de dívida onerosa.

Outro fato curioso é que o GAF das empresas é muito semelhante em termos das médias, desvios e, consequentemente, coeficientes de variação apurados. Ou seja, como este constitui uma razão entre a rentabilidade dos ativos e rentabilidade do capital próprio dos ativos, a relação entre o total de ativos e o patrimônio líquido é muito semelhante. Os coeficientes de assimetria da MB é deslocado à esquerda e o inverso se dá com a ML para a amostra de empresas estrangeiras. O coeficiente de kurtosis indica que as curvas são levemente achatadas exceto em termos da GAF.

A tabela 3 apresenta os resultados dos testes estatísticos. 


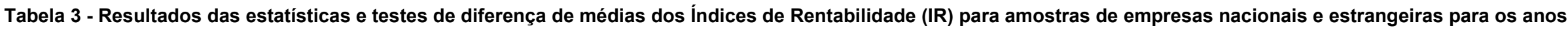

\begin{tabular}{|c|c|c|c|c|c|c|c|c|c|c|c|}
\hline \multirow{2}{*}{\multicolumn{2}{|c|}{ ESTATÍSTICAS (*) }} & \multicolumn{2}{|c|}{ MB } & \multicolumn{2}{|c|}{ ML } & \multicolumn{2}{|c|}{ ROE } & \multicolumn{2}{|c|}{ ROA } & \multicolumn{2}{|c|}{ GAF } \\
\hline & & 2004 & 2005 & 2004 & 2005 & 2004 & 2005 & 2004 & 2005 & 2004 & 2005 \\
\hline \multirow{5}{*}{$\begin{array}{l}\frac{n}{K} \\
Z \\
\frac{0}{U} \\
\frac{U}{Z}\end{array}$} & n1 & 3 & 4 & 3 & 4 & 3 & 4 & 3 & 4 & 3 & 4 \\
\hline & Amplitude & $(0,16 ; 0,30)$ & $(0,08 ; 058)$ & $(0,06 ; 0,27)$ & $(0,05 ; 0,80)$ & $(0,09 ; 0,51)$ & $(0,02 ; 0,32)$ & $(0,05 ; 0,19)$ & $(0,01 ; 0,10)$ & $(1,97 ; 2,72)$ & $(1,70 ; 3,11)$ \\
\hline & Média (BRA) & 0,23 & 0,28 & 0,14 & 0,27 & 0,23 & 0,13 & 0,10 & 0,05 & 2,36 & 2,43 \\
\hline & Desv Pad. (BRA) & 0,07 & 0,21 & 0,11 & 0,36 & 0,19 & 0,14 & 0,07 & 0,04 & 0,34 & 0,62 \\
\hline & Coef. Variação $\left(^{*}\right)$ & 0,30 & 0,77 & 0,77 & 1,33 & 0,81 & 1,07 & 0,71 & 0,86 & 0,14 & 0,26 \\
\hline \multirow{7}{*}{ 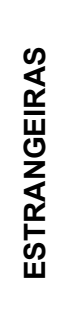 } & n2 $(* *)$ & 21 & 30 & 27 & 27 & 29 & 46 & 26 & 26 & 26 & 38 \\
\hline & Amplitude & $(0,28 ; 0,78)$ & $(0,35 ; 0,78)$ & $(0,01 ; 0,53)$ & $(0,10 ; 0,44)$ & $(0,10 ; 0,42)$ & $(0,01 ; 1,02)$ & $(0,01 ; 0,18)$ & $(0,04 ; 0,13)$ & $(1,60 ; 3,27)$ & $(1,34 ; 3,80)$ \\
\hline & Média (INT) & 0,56 & 0,60 & 0,20 & 0,27 & 0,22 & 0,20 & 0,09 & 0,08 & 2,24 & 2,27 \\
\hline & Desv Pad. (INT) & 0,16 & 0,13 & 0,18 & 0,11 & 0,18 & 0,20 & 0,06 & 0,03 & 0,48 & 0,66 \\
\hline & Coef. Variação & 0,29 & 0,22 & 0,90 & 0,40 & 0,83 & 1,00 & 0,63 & 0,34 & 0,22 & 0,29 \\
\hline & Skewness normal: $\alpha_{3}=0$ & $-0,19$ & $-0,60$ & 0,52 & 0,04 & 0,21 & 0,29 & 0,05 & 0,52 & 0,56 & 0,29 \\
\hline & Kurtosis normal $\alpha_{4}=3$ & 1,67 & 2,14 & 1,77 & 1,64 & 1,60 & 8,81 & 1,44 & 2,34 & 2,45 & 2,82 \\
\hline \multirow{3}{*}{ 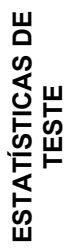 } & Estatística T $\left({ }^{\star * *}\right)$ & 3,342 & 4,360 & 0,494 & $-0,028$ & $-0,139$ & 0,696 & $-0,412$ & 1,561 & $-0,426$ & $-0,451$ \\
\hline & $\begin{array}{l}\text { Estatística de Teste } \\
\text { Bicaudal Estatística de } \\
\text { Teste Bicaudal }\left( \pm t_{C}\right)^{(* * *)}\end{array}$ & $\pm 1,717$ & $\pm 1,697$ & $\pm 1,701$ & $\pm 1,699$ & $\pm 1,697$ & $\pm 1,676$ & $\pm 1,703$ & $\pm 1,701$ & $\pm 1,701$ & $\pm 1,684$ \\
\hline & $\begin{array}{l}\text { Intervalo de Confiança para } \\
\text { Diferença de Médias (90\%) }\end{array}$ & $(0,16 ; 0,5)$ & $(0,11 ; 0,45)$ & $\begin{array}{c}(-0,13 \\
0,23)\end{array}$ & $\begin{array}{c}(-0,14 \\
0,14)\end{array}$ & $\begin{array}{c}(-0,20 \\
0,17)\end{array}$ & $\begin{array}{c}(-0,10 \\
0,25)\end{array}$ & $\begin{array}{c}(-0,07 \\
0,05)\end{array}$ & $\begin{array}{c}(-0,01 \\
0,05)\end{array}$ & $\begin{array}{c}(-0,61 \\
0,37)\end{array}$ & $\begin{array}{c}(-0,74 \\
0,43)\end{array}$ \\
\hline
\end{tabular}

$\left({ }^{*}\right)$ Definido como o desvio padrão sobre a média, permite comparar a magnitude da variação em termos de cada amostra.

$\left.{ }^{* *}\right)$ Conforme descrito, os valores calculados para os dados válidos foram feitos após emprego de procedimento destinado a eliminação de outliers. Das 48 empresas restou um número que respondem por mais de $72 \%, 70 \%, 80 \%, 65 \%$ e $73 \%$ para MB, ML, ROE, ROA e GAF dos ativos da amostra, respectivamente.

$\left({ }^{* * *}\right)$ Os testes adicionais apresentaram os mesmos resultados do teste T original.

$\left.{ }^{(* \star \star}\right)$ Tal como definido na seção 4.4 , caso o valor da estatística T esteja fora do intervalo formado pelo módulo de tC rejeita-se a hipótese nula (H0). Neste caso, há evidências de que a médias dos indicadores não sejam significativamente diferentes.

Fonte: Elaborado pelo autor. 
Os dados apresentados sugerem que, de maneira geral, não se pode afirmar que exista diferenças significativas nos níveis de rentabilidade quando avaliados por meio dos conceitos de ML, ROE, ROA e GAF para o grupo de empresas de transporte e apoio marítimo: ou seja, há indícios que o nível desses se encontra dentro do intervalo de confiança de $90 \%$ da média internacional.

Os testes feitos a partir da expansão das amostras das empresas nacionais e seleção aleatória na amostra de empresas internacionais também remetem as mesmas conclusões.

Como discutido acima e como será indicado no capítulo 5, esses dados indicam que as taxas de rentabilidade setorial estão em conformidade com o padrão internacional refletindo as características de empresas que atuam sob regime global de competição. Nesse sentido a capacidade de retenção de lucros e de distribuição de dividendos se encontra dentro do padrão internacional.

\subsubsection{Comparando o Grau Endividamento das Empresas de Transporte Marítimo Internacionais e Nacionais}

Em linhas gerais, o valor médio dos índices de endividamento para a amostra de empresas nacionais e estrangeiras é semelhante (tabela 4). Contudo, os níveis verificados no endividamento da mostra de empresas locais é sensivelmente menor, também apresentando coeficientes de variação mais reduzidos. Dessa classe de indicadores o que apresenta diferença mais pronunciada é o multiplicador de capital próprio e de terceiros (MKPT). Embora baseados em amostras de tamanhos diferentes, a média para todo o período considerado foi de 1,5 e 1,2 para as empresas nacionais e estrangeiras, respectivamente. A diferença no volume de endividamento médio em relação ao patrimônio líquido (MKP) é relativamente menor na estrutura de ativos das empresas nacionais em relação as internacionais apresentando médias de 2,5 e de 2,3, respectivamente.

O multiplicador do capital próprio (MKP) relaciona o total dos ativos e o patrimônio líquido dos acionistas. A grande maioria das empresas apresenta um MKP superior a 2. Esse dado também reflete o peso do capital de terceiros nos empreendimentos. Assim, grande parte dos ativos das empresas é financiada por 
meio de recursos de terceiros. Essa característica reflete as políticas de financiamento público as quais provocam alto nível de alavancagem financeira nas empresas do setor de transporte. Indícios a este respeito foram apresentados na seção 2.

A maior parte das empresas ligadas ao setor de transporte marítimo apresenta um índice geral de endividamento (IGE), medido como a razão entre o total do passivo exigível a longo prazo e o total de ativos, acima de 0,5. Este nível de endividamento é característico em setores intensivos em capital.

O índice de cobertura de juros (ICJ), medido como a razão entre o EBIT e os gastos com juros, possui maior dispersão entre a classe de índices de liquidez. Neste caso e como sugere a literatura, pequenos diferenciais de prazo e taxas devem explicar esta maior dispersão. Ao refletir a capacidade de pagamento de juros das empresas, também indicam as respectivas estratégias operacionais. Estas são funções do trade off entre financiar embarcações novas, assumindo maior nível de despesa com juros, ou optar por maior número de embarcações usadas, suportando maiores despesas de manutenção. Essas informações também refletem a política operacional das empresas. Como aponta Stopford (2005), empresas que possuem maior número de embarcações novas têm um peso maior nas despesas de juros vis-à-vis as empresas que possuem um número maior de embarcações usadas.

Um aspecto importante a ser enfatizado é que o nível médio de cobertura de juros é maior para as empresas nacionais e que a distribuição do ICJ não apresenta grande assimetria em torno da média (baixos coeficientes de skewness). Já no caso das empresas nacionais se verifica grande dispersão em torno da média quando se observa o coeficiente de variação (desvio padrão sobre a média). 
Tabela 4 - Resultados das estatísticas e testes de diferença de médias dos Índices de Endividamento (IE) para amostras de empresas nacionais e estrangeiras para os anos de 2004 e 2005.

\begin{tabular}{|c|c|c|c|c|c|c|c|c|c|}
\hline \multirow{2}{*}{\multicolumn{2}{|c|}{ ESTATÍSTICAS (*) }} & \multicolumn{2}{|c|}{ IEG } & \multicolumn{2}{|c|}{ MKP } & \multicolumn{2}{|c|}{ MKPT } & \multicolumn{2}{|c|}{ ICJ } \\
\hline & & 2004 & 2005 & 2004 & 2005 & 2004 & 2005 & 2004 & 2005 \\
\hline \multirow{5}{*}{$\begin{array}{l}\frac{\infty}{4} \\
\mathbf{Z} \\
\text { O } \\
\mathbf{U} \\
\mathbf{Z}\end{array}$} & n1 & 3 & 4 & 3 & 4 & 3 & 4 & 2 & 3 \\
\hline & Amplitude & $(0,49 ; 0,61)$ & $(0,44 ; 0,68)$ & $(1,97,2,72)$ & $(1,79 ; 3,11)$ & $(0,97 ; 1,64)$ & $(0,79 ; 2,11)$ & $(0,01 ; 2,61)$ & $(0,01 ; 1,49)$ \\
\hline & Média (BRA) & 0,57 & 0,58 & 2,41 & 2,54 & 1,38 & 1,53 & 1,30 & 0,51 \\
\hline & Desv Pad. (BRA) & 0,06 & 0,11 & 0,39 & 0,66 & 0,36 & 0,66 & 1,84 & 0,85 \\
\hline & Coef. Variação (**) & 0,11 & 0,20 & 0,16 & 0,26 & 0,26 & 0,43 & 1,09 & 2,81 \\
\hline \multirow{7}{*}{ 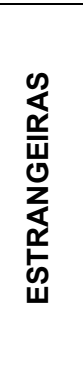 } & n2 & 27 & 32 & 31 & 41 & 31 & 42 & 17 & 23 \\
\hline & Amplitude & $(0,37 ; 0,79)$ & $(0,35 ; 0,73)$ & $(1,01 ; 5,23)$ & $(1,05 ; 4,26)$ & $(0,01 ; 4,24)$ & $(0,05 ; 3,26)$ & $(1,66 ; 9,24)$ & $(2,03 ; 7,29)$ \\
\hline & Média (INT) & 0,55 & 0,54 & 2,37 & 2,24 & 1,23 & 1,15 & 5,23 & 4,72 \\
\hline & Desv Pad. (INT) & 0,11 & 0,10 & 0,94 & 0,77 & 0,93 & 0,76 & 2,71 & 2,70 \\
\hline & Coef. Variação & 0,19 & 0,18 & 0,40 & 0,34 & 0,75 & 0,66 & 0,52 & 0,57 \\
\hline & Skewness normal: $\alpha_{3}=0$ & 0,06 & 0,08 & 1,36 & 0,79 & 1,55 & 0,92 & $-0,05$ & $-0,08$ \\
\hline & Kurtosis normal $\alpha_{4}=3$ & 2,40 & 2,17 & 5,00 & 3,02 & 6,13 & 3,50 & 1,53 & 1,88 \\
\hline \multirow{3}{*}{ 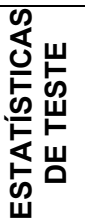 } & Estatística T $\left({ }^{* * *}\right)$ & $-0,291$ & $-0,819$ & $-0,068$ & $-0,744$ & $-0,276$ & $-0,977$ & 2,35 & 2,65 \\
\hline & $\begin{array}{l}\text { Estatística de Teste Bicaudal }\left( \pm t_{C}\right) \\
\left({ }^{* \star \star *}\right)\end{array}$ & $\pm 1,699$ & $\pm 1,690$ & $\pm 1,697$ & $\pm 1,684$ & $\pm 1,697$ & $\pm 1,684$ & $\pm 1,74$ & $\pm 1,71$ \\
\hline & $\begin{array}{l}\text { Intervalo de Confiança Diferença } \\
\text { de Média }(90 \%)\end{array}$ & $(-0,11 ; 0,08)$ & $(-0,13 ; 0,05)$ & $(-0,98 ; 0,90)$ & $(-0,97 ; 0,37)$ & $(-1,08 ; 0,78)$ & $(-1,04 ; 0,28)$ & $(1,02 ; 6,84)$ & $(1,49 ; 6,45)$ \\
\hline
\end{tabular}

$\left(^{\star}\right)$ Conforme descrito, os valores calculados para os dados válidos foram feitos após emprego de procedimento destinado a eliminação de outliers. Das 48 empresas restou um número que responderam por mais de $70 \%, 75 \%, 85 \%$ e $70 \%$ para o IGE, MKP, MKPT e ICJ para o valor dos ativos da amostra, respectivamente.

$\left(^{* \star}\right)$ Definido como o desvio padrão sobre a média, permite comparar a magnitude da variação em termos de cada amostra.

$(* * *)$ Os testes adicionais apresentaram os mesmos resultados do teste T original.

$\left.{ }^{* * * \star}\right)$ Tal como definido na seção 4.4 , caso o valor da estatística T esteja fora do intervalo formado pelo módulo de tC rejeita-se a hipótese nula (H0). Neste caso, há

evidências de que a médias dos indicadores não sejam significativamente diferentes.

Fonte: Elaborado pelo autor. 
Adicionalmente, o peso da dívida onerosa também reflete a razão entre o total de ativos imobilizado e os gastos com juros. O grau de associação linear das empresas internacionais entre o dispêndio com juros e o total de ativo imobilizado é positivo e da ordem de 0,61, 0,75, 0,74 para os anos de 2003, 2004, e 2005, respectivamente. Os dados presentes no Demonstrativo de Resultado do Exercício das empresas das empresas indicam que quanto maior o nível de gastos com juros, menor o valor das despesas operacionais não recorrentes (compostas por gastos com manutenção). O que corrobora a existência de trade off apontada na seção 4.3.2. ${ }^{95}$

A Tabela 4 apresenta os testes de diferença de média para os indicadores de endividamento (IE) para uma amostra de empresas estrangeiras e nacionais. Conforme explicitados os dados apresentados sugerem que não se pode rejeitar a hipótese nula $H_{0}$. De maneira geral, não se pode afirmar que exista diferenças significativas nos níveis de alavancagem financeira para o grupo de empresas de transporte e apoio marítimo: ou seja, há indícios que o nível desses índices se encontra dentro do intervalo de confiança de $90 \%$ quando confrontados com a média internacional. Os testes feitos a partir da expansão das amostras das empresas nacionais e seleção aleatória na amostra de empresas internacionais também remetem às mesmas conclusões.

Contudo, o nível de cobertura de juros das empresas varia significativamente. A rigor, a amostra de empresas internacionais possui maior nível médio no ICJ quando comparadas a amostra de empresas nacionais.

Em suma, não se verifica diferença na estrutura de endividamento das empresas nacionais e internacionais, indicando semelhanças no grau de proteção dos credores contra insolvência. Certamente este resultado reflete as políticas de incentivo em torno de estímulo ao financiamento setorial. Contudo, o maior volume dos ativos das empresas internacionais deve facilitar o acesso ao financiamento pois, implica em maior folga financeira em torno dos conceitos de capacidade, capital e collateral.

${ }^{95}$ Segundo esta tese o peso do custo de capital e despesas operacionais e de reparo estão intimamente relacionados e refletem uma relação inversa: quanto maior o gasto em capital menor as despesas operacionais e de reparo e vice-versa. 


\subsubsection{Confronto de Indicadores sob a Ótica da Estratégia do BNDES}

As seções anteriores, ao empregar métodos de análise de demonstrações financeiras sugeridos pela literatura, ofereceram indícios segundo os quais a estrutura de capital das empresas nacionais é muito semelhante. Para tanto, testou as diferenças de média dos níveis de solvência, atividade, rentabilidade e endividamento.

As informações apresentadas nesta seção estão baseadas na elaboração de um exercício. Esse consiste em aplicar a metodologia empregada pelo BNDES no FINEM, tal como apresentada na seção 4.3.5, sobre os dados dos Demonstrativos Contábeis da amostra de empresas nacionais e internacionais. Como nas últimas seções, o intuito foi verificar se há diferenças significavas entre as médias amostrais dos indicadores. Caso não se verifique diferenças significativas nesses índices quando aplicados os critérios previstos no FINEM, não se pode sustentar que o setor apresente risco demasiado sob o ponto de vista de seu funcionamento. Isso pode ser verdade em relação a outros setores que estabelecem relação com o BNDES. Caso os resultados não sejam significativos, a percepção de risco deveria se orientar a uma análise mais detida da estrutura de capital das empresas do setor em relação as empresas internacionais.

Com efeito, as tabelas 5, 6 e 7 apresentam as estatísticas e os testes de diferenças de médias obtidos a partir dos indicadores econômico-financeiros adotados pelo BNDES na avaliação de projetos de investimento. Como nos demais casos, foram aplicados testes F, utilizados para verificar se havia diferenças significativas nas variâncias das duas amostras. Estes não apresentaram resultados significativos.

Os testes $t$ de Student indicam que não se pode rejeitar a hipótese nula, ou seja, os níveis médios de liquidez das empresas nacionais e estrangeiras verificados são semelhantes. A rigor, o índice de liquidez geral (ILG) apresenta níveis muito próximos, o mesmo se dando com o grau de liquidez corrente (ILC). Novamente chama a atenção o grau de assimetria e de kurtosis das distribuições verificado para a amostra das empresas estrangeiras. 
Tabela 5 - Resultados das estatísticas de testes para diferença de médias para Índice de Liquidez (IL) das empresas nacionais e estrangeiras segundo metodologia empregada pelos BNDES para os anos de 2004 e 2005.

\begin{tabular}{|c|c|c|c|c|c|}
\hline & \multirow{3}{*}{ ESTATÍSTICAS } & \multicolumn{4}{|c|}{ Índices de Liquidez BNDES } \\
\hline & & \multicolumn{2}{|c|}{ Liquidez Corrente (LC) } & \multicolumn{2}{|c|}{ Liquidez Geral (LG) } \\
\hline & & 2004 & 2005 & 2004 & 2005 \\
\hline \multirow{5}{*}{$\begin{array}{l}\frac{0}{4} \\
Z \\
\text { O } \\
\\
Z\end{array}$} & $n 1$ & 3 & 4 & 2 & 3 \\
\hline & Amplitude & $(1,14 ; 4,25)$ & $(1,09 ; 4,69)$ & $(0,36 ; 0,64)$ & $(0,56 ; 2,88)$ \\
\hline & Média (BRA) & 2,09 & 2,33 & 0,50 & 0,41 \\
\hline & Desv Pad. (BRA) & 1,88 & 1,84 & 0,20 & 0,17 \\
\hline & Coef. Variação (*) & 0,90 & 0,79 & 0,39 & 0,41 \\
\hline \multirow{7}{*}{ 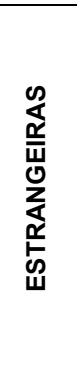 } & $\mathrm{n} 2\left({ }^{* *}\right)$ & 31 & 39 & 24 & 29 \\
\hline & Amplitude & $(0,31 ; 4,20)$ & $(0,14,4,40)$ & $(0,36 ; 0,71)$ & $(0,29 ; 0,68)$ \\
\hline & Média (INT) & 1,87 & 1,58 & 0,52 & 0,55 \\
\hline & Desv Pad. (INT) & 1,05 & 0,97 & 0,11 & 0,20 \\
\hline & Coef. Variação & 0,56 & 0,62 & 0,21 & 0,36 \\
\hline & $\begin{array}{l}\text { Skewness normal: } \\
\alpha_{3}=0\end{array}$ & 0,66 & 1,45 & 0,18 & 0,32 \\
\hline & Kurtosis normal $\alpha_{4}=3$ & 2,35 & 4,67 & 1,84 & 2,17 \\
\hline \multirow{3}{*}{ 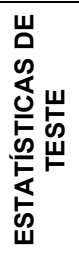 } & Estatística T & $-0,318$ & $-1,359$ & 0,248 & 1,45 \\
\hline & $\begin{array}{l}\text { Estatística de Teste } \\
\text { Bicaudal }\left( \pm t_{C}\right)^{\left({ }^{* * *}\right)}\end{array}$ & $\pm 1,697$ & $\pm 1,684$ & $\pm 1,711$ & $\pm 1,697$ \\
\hline & $\begin{array}{l}\text { Intervalo de Confiança } \\
\text { para Diferença de } \\
\text { Médias }(90 \%)\end{array}$ & $(-1,36 ; 0,93)$ & $(-1,69 ; 0,18)$ & $(-0,12 ; 0,16)$ & $(-0,02 ; 0,30)$ \\
\hline
\end{tabular}

${ }^{*}$ ) Definido como o desvio padrão sobre a média, permite comparar a magnitude da variação em termos de cada amostra.

$\left.{ }^{(* *}\right)$ Conforme descrito, os valores calculados para os dados válidos foram feitos após emprego de procedimento destinado a eliminação de outliers.

$\left.{ }^{(* *}\right)$ Tal como definido na seção 4.4, caso o valor da estatística T esteja fora do intervalo formado pelo módulo de tC rejeita-se a hipótese nula $(\mathrm{H} 0)$. Neste caso, há evidências de que a médias dos indicadores não sejam significativamente diferentes.

Fonte: Elaborado pelo autor.

Adicionalmente, os testes em torno dos indicadores de lucratividade sugerem que: considerando a LB não se pode aceitar a hipótese nula $H_{0}$, tal como formulado o teste, as empresas internacionais LB superior as nacionais; a LO apresenta efeito dúbio, contudo este fato reflete o espetacular desempenho de uma das empresas nacionais, quando esta é retirada da amostra os resultados são não significativos; não se pode rejeitar a hipótese nula $H_{0}$ a partir da análise das estatísticas da LP. 
Tabela 6 - Resultados das estatísticas e teste de diferença de médias do Índice de Rentabilidade (IR) para amostras de empresas nacionais e estrangeiras segundo metodologia do BNDES para os anos de 2004 e 2005.

\begin{tabular}{|c|c|c|c|c|c|c|c|c|c|}
\hline & \multirow{2}{*}{ ESTATÍSTICAS (*) } & \multicolumn{2}{|c|}{ Lucratividade Bruta (LB) } & \multicolumn{2}{|c|}{ Lucratividade Operacional (LO) } & \multicolumn{2}{|c|}{ Lucratividade Líquida (LL) } & \multicolumn{2}{|c|}{ Lucratividade Patrimonial (LP) } \\
\hline & & 2004 & 2005 & 2004 & 2005 & 2004 & 2005 & 2004 & 2005 \\
\hline \multirow{5}{*}{$\begin{array}{l}\frac{0}{K} \\
z \\
\frac{0}{U} \\
\frac{1}{z}\end{array}$} & n1 & 3 & 4 & 2 & 3 & 3 & 4 & 3 & 4 \\
\hline & Amplitude & $(0,16 ; 0,31)$ & $(0,08 ; 0,63)$ & $(0,23 ; 0,24)$ & $(0,14 ; 1,16)$ & $(0,06 ; 0,28)$ & $(0,06 ; 0,25)$ & $(0,09 ; 0,51)$ & $(0,02 ; 0,32)$ \\
\hline & Média (BRA) & 0,25 & 0,30 & 0,23 & 0,50 & 0,13 & 0,24 & 0,23 & 0,13 \\
\hline & Desv Pad. (BRA) & 0,08 & 0,23 & 0,01 & 0,58 & 0,10 & 0,36 & 0,19 & 0,14 \\
\hline & Coef. Variação (*) & 0,31 & 0,78 & 0,03 & 1,16 & 0,78 & 1,49 & 0,81 & 1,07 \\
\hline \multirow{7}{*}{ 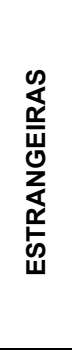 } & n2 (**) & 20 & 29 & 25 & 19 & 22 & 34 & 27 & 40 \\
\hline & Amplitude & $(0,28 ; 0,78)$ & $(0,35 ; 078)$ & $(0,01 ; 0,52)$ & $(0,12 ; 0,37)$ & $(0.03 ; 0,49)$ & $(0,01 ; 0,40)$ & $(0,01 ; 0,42)$ & $(0,02 ; 0 ; 40)$ \\
\hline & Média (INT) & 0,55 & 0,60 & 0,17 & 0,22 & 0,20 & 0,19 & 0,20 & 0,17 \\
\hline & Desv Pad. (INT) & 0,16 & 0,13 & 0,17 & 0,08 & 0,17 & 0,13 & 0,13 & 0,10 \\
\hline & Coef. Variação & 0,30 & 0,22 & 1,01 & 0,37 & 0,82 & 0,69 & 0,64 & 0,63 \\
\hline & Skewness normal: $\alpha_{3}=0$ & $-0,11$ & $-0,55$ & 0,78 & 0,01 & 0,48 & 0,33 & 0,17 & 0,35 \\
\hline & Kurtosis normal $\alpha_{4}=3$ & 1,67 & 2,08 & 2,81 & 1,81 & 1,64 & 1,88 & 1,54 & 2,27 \\
\hline \multirow{3}{*}{ 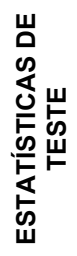 } & Estatística T $\left(^{* * *}\right)$ & 3,135 & 3,928 & $-0,570$ & $-2,226$ & 0,707 & $-0,664$ & $-0,370$ & 0,634 \\
\hline & $\begin{array}{l}\text { Estatística de Teste } \\
\text { Bicaudal }\left( \pm t_{C}\right)\left(^{(* * *)}\right. \\
\end{array}$ & $\pm 1,721$ & $\pm 1,697$ & $\pm 1,708$ & $\pm 1,729$ & $\pm 1,714$ & $\pm 1,690$ & $\pm 1,701$ & $\pm 1,684$ \\
\hline & $\begin{array}{l}\text { Intervalo de Confiança } \\
\text { para Diferença de Médias } \\
(90 \%)\end{array}$ & $(0,14 ; 0,47)$ & $(0,17 ; 0,43)$ & $(-0,27 ; 0,14)$ & $(-0,49 ;-0,06)$ & $(-0,10 ; 0,24)$ & $(-0,20 ; 0,09)$ & $(-0,17 ; 0,11)$ & $(-0,06 ; 0,13)$ \\
\hline
\end{tabular}

$\left(^{*}\right)$ Definido como o desvio padrão sobre a média, permite comparar a magnitude da variação em termos de cada amostra.

$\left({ }^{* *}\right)$ Conforme descrito, os valores calculados para os dados válidos foram feitos após emprego de procedimento destinado a eliminação de outliers.

$\left({ }^{\star * \star}\right)$ Os testes adicionais apresentaram os mesmos resultados do teste $\mathrm{T}$ original.

${ }^{* * \star \star}$ ) Tal como definido na seção 4.4, caso o valor da estatística T esteja fora do intervalo formado pelo módulo de tC rejeita-se a hipótese nula (H0). Neste caso, há evidências de que a médias dos indicadores não sejam significativamente diferentes.

Fonte: Elaborado pelo autor. 
Em relação ao grau de endividamento, os testes dão indícios que não há diferença na estrutura de endividamento das empresas nacionais e internacionais em relação a EG e EF. Como não se pode rejeitar a hipótese nula $\left(\mathrm{H}_{0}\right)$, o nível de proteção dos credores contra insolvência é semelhante. Contudo, não se pode aceitar a hipótese nula $\left(\mathrm{H}_{0}\right)$. Nesse caso, as empresas internacionais apresentam maior nível de dívida de endividamento financeiro dimensionada pelo conceito de passivo circulante. Há indícios que volume de juros pagos em relação as demais dívidas de curto prazo (inferiores a um ano) é menor que o que incide sobre as empresas nacionais.

Tabela 7 - Resultados das estatísticas e teste de diferença de médias do Índice de Endividamento (IE) para amostras de empresas nacionais e estrangeiras segundo metodologia do BNDES para os anos de 2004 e 2005.

\begin{tabular}{|c|c|c|c|c|c|c|c|}
\hline & \multirow[t]{2}{*}{ ESTATÍSTICAS } & \multicolumn{2}{|c|}{$\begin{array}{c}\text { Endividamento } \\
\text { Geral (EG) }\end{array}$} & \multicolumn{2}{|c|}{$\begin{array}{l}\text { Endividamento } \\
\text { Financeiro (EF) }\end{array}$} & \multicolumn{2}{|c|}{$\begin{array}{l}\text { Dívida de Curto } \\
\text { Prazo (DCP) }\end{array}$} \\
\hline & & 2004 & 2005 & 2004 & 2005 & 2004 & 2005 \\
\hline \multirow{5}{*}{$\begin{array}{l}\frac{0}{1} \\
z \\
0 \\
0 \\
z \\
z\end{array}$} & n1 & 3 & 4 & 3 & 4 & 3 & 4 \\
\hline & Amplitude & $\begin{array}{l}0,49 \\
0,61) \\
\end{array}$ & $\begin{array}{l}0,44 ; \\
0,68) \\
\end{array}$ & $\begin{array}{l}0,01 ; \\
0,03)\end{array}$ & $\begin{array}{l}0,01 ; \\
0,02)\end{array}$ & $\begin{array}{l}4,21 \\
14,8) \\
\end{array}$ & $\begin{array}{l}8,83, \\
24,3) \\
\end{array}$ \\
\hline & Média (BRA) & 0,57 & 0,58 & 0,02 & 0,01 & 7,99 & 11,99 \\
\hline & Desv Pad. (BRA) & 0,06 & 0,11 & 0,01 & 0,01 & 5,96 & 8,54 \\
\hline & Coef. Variação $\left(^{*}\right)$ & 0,11 & 0,20 & 0,36 & 0,66 & 0,75 & 0,71 \\
\hline \multirow{7}{*}{ 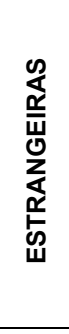 } & $\mathrm{n} 2(* *)$ & 26 & 38 & 24 & 32 & 11 & 24 \\
\hline & Amplitude & $\begin{array}{l}(0,37 \\
0,69) \\
\end{array}$ & $\begin{array}{l}(0,35 \\
0,86) \\
\end{array}$ & $\begin{array}{l}(0,01 \\
0,04) \\
\end{array}$ & $\begin{array}{l}(0,01 ; \\
0,05)\end{array}$ & $\begin{array}{l}(1,87 \\
5,44)\end{array}$ & $\begin{array}{l}(1,67 ; \\
10,1) \\
\end{array}$ \\
\hline & Média (INT) & 0,54 & 0,58 & 0,02 & 0,02 & 3,01 & 4,77 \\
\hline & Desv Pad. (INT) & 0,10 & 0,14 & 0,01 & 0,01 & 1,03 & 2,59 \\
\hline & Coef. Variação & 0,18 & 0,23 & 0,36 & 0,43 & 0,34 & 0,54 \\
\hline & Skewness & 0,06 & 0,01 & $-0,11$ & $-0,03$ & & \\
\hline & Kurtosis & 2,4 & 2,16 & 1,79 & 2,20 & & \\
\hline \multirow{3}{*}{ 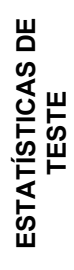 } & Estatística T $\left({ }^{\star \star *}\right)$ & $-0,436$ & $-0,017$ & 0,553 & 1,812 & $-2,937$ & $-3,53$ \\
\hline & $\begin{array}{l}\text { Estatística de Teste } \\
\text { Bicaudal }\left( \pm t_{C}\right)\left(^{(\star \star \star *}\right)\end{array}$ & $\pm 1,703$ & $\pm 1,684$ & $\pm 1,708$ & $\pm 1,690$ & $\pm 1,782$ & $\pm 1,71$ \\
\hline & $\begin{array}{l}\text { Intervalo de Confiança } \\
\text { para Diferença de } \\
\text { Médias }(90 \%)\end{array}$ & $\begin{array}{c}(-0,12 \\
0,07)\end{array}$ & $\begin{array}{c}(-0,12 \\
0,12)\end{array}$ & $\begin{array}{c}(-0,01 \\
0,01)\end{array}$ & $\begin{array}{l}(0,00 \\
0,02)\end{array}$ & $\begin{array}{c}(-8,01,- \\
1,96)\end{array}$ & $\begin{array}{l}(-10,7 ;- \\
3,72)\end{array}$ \\
\hline
\end{tabular}

${ }^{*}$ ) Definido como o desvio padrão sobre a média, permite comparar a magnitude da variação em termos de cada amostra.

$\left.{ }^{(* *}\right)$ Conforme descrito, os valores calculados para os dados válidos foram feitos após emprego de procedimento destinado a eliminação de outliers.

$\left.{ }^{* * *}\right)$ Os testes adicionais apresentaram os mesmos resultados do teste T original.

${ }^{* * * \star}$ ) Tal como definido na seção 4.4 , caso o valor da estatística T esteja fora do intervalo formado pelo módulo de tC rejeita-se a hipótese nula $(\mathrm{H} 0)$. Neste caso, há evidências de que a médias dos indicadores não sejam significativamente diferentes.

Fonte: Elaborado pelo autor. 


\subsection{Resultados de Entrevistas e Confronto com Testes de Dados Financeiros}

Esta seção apresenta os resultados de entrevistas realizadas durante a pesquisa. O intuito foi levantar a percepção dos agentes quanto a adequação da estrutura do financiamento nacional em torno das demandas setoriais. $O$ questionário aplicado durante as entrevistas esteve baseado no desenvolvimento de um protocolo de pesquisa (ANEXO 2) inspirado na metodologia de estudo de caso e foi construído a partir de procedimentos sugeridos por Yin (2005). A rigor, foi estruturado a partir dos seguintes elementos: envio de carta de apresentação, aplicação de questões da pesquisa (conforme apresentadas no quadro 19) elaboradas a partir da revisão do referencial teórico, das evidências consideradas, proposições assumidas, sumário do escopo das entrevistas exploratórias, descrição dos procedimentos de coleta de dados, formulação de plano de análise (conforme apresentado na seção 4.4) e planejamento da estruturação final do relatório ${ }^{96}$.

Q1 - FORMATAÇÃO DO PROJETO E EXPOSIÇÃO A LINHAS DE FINANCIAMENTO: como tem início a formatação de propostas, como ela é modelada em torno de seus componentes e quais técnicas são empregadas em sua avaliação?

Q2 - RISCOS DOS EMPREENDIMENTOS: sob a ótica do financiamento, quais os principais riscos dos empreendimentos e como são abordados?

Q3 - CRITÉRIOS SEGUIDOS NA ESCOLHA ESTALEIRO: preço, qualidade, prazo de entrega, reputação, etc., são apontados como critérios críticos na escolha de um estaleiro. Quais critérios a sua empresa utiliza nesta decisão?

Q4 - PONTOS FORTES, PONTOS FRACOS E SUGESTÕES: em sua opinião, quais os pontos fortes e fracos do modelo de financiamento local? Como o modelo poderia ser aperfeiçoado?

Quadro 19 - Questões formuladas para abordagem do problema da pesquisa.

Fonte: Elaborado pelo autor.

Ao todo, foram realizadas 3 (três) rodadas de entrevistas com diretores financeiros de empresas ligadas ao segmento de transporte marítimo, apoio marítimo e membros de entidades classistas ligadas ao setor.. O processo de escolha das empresas foi inicialmente feito com base na obtenção de contatos com informantes-chaves. A carta de apresentação da pesquisa foi enviada a 39 empresas, destas quatro empresas foram visitadas. Esse índice resultou de

\footnotetext{
${ }^{96}$ A rigor, o protocolo dessa parte da pesquisa é apresentado no ANEXO 3.
} 
incompatibilidade de agendas, não atendimento de solicitação com a alegação de sigilo e não atendimento da solicitação. Este reduzido número também é conseqüência da indisponibilidade de recursos por parte do pesquisador. Posteriormente, estes informantes-chaves passaram a fornecer uma rede de contatos. No total foram entrevistadas 24 pessoas ligadas ao setor - em sua maioria diretores de entidades classistas e diretores financeiros de empresas de armação. Esses são informantes importantes, pois são estas empresas que, via de regra, contratam o financiamento.

A primeira rodada de entrevistas, ainda sob uma perspectiva exploratória, foi realiza no Rio de Janeiro entre os dias 06/Junho e 09/Junho de 2006, junto a diretores financeiros de empresas e entidades ligadas ao setor. A segunda rodada foi realizada entre os dias 27/Novembro e 01/Dezembro de 2006, durante a realização do XXI Congresso Nacional de Transportes Marítimos, Construção naval e Offshore e EXPONAL 2006, promovidos pela Sociedade Brasileira de Indústria Naval (SOBENA). Esta rodada de entrevistas se baseou na aplicação de questionário apresentado no quadro 18. A terceira rodada de entrevistas, também baseada no questionário e na revisão do conteúdo das entrevistas feitas nas rodadas anteriores, foi realizada entre os dias 05/02 e 09/02 de 2007 e se baseou em visitas a empresas e entidades ligadas ao setor naval.

Em meio à elaboração das entrevistas junto aos diretores financeiros das empresas ${ }^{97}$, também foram entrevistados informantes-chaves junto ao Sindicato Nacional das Empresas de Navegação Marítima (SYNDARMA), Departamento de Marinha Mercante (DMM), Banco Nacional de Desenvolvimento Econômico e Social (BNDES), Associação Brasileira das Empresas de Apoio Marítimo (ABEAM), Sindicato Nacional da Indústria de Construção Naval e Offshore (SINAVAL), pesquisadores do Instituto de Pesquisas Tecnológicas do Estado de São Paulo (IPT), acadêmicos da Escola Politécnica da USP (POLI/USP) e da COPPE da Universidade Federal do Rio de Janeiro (COPPE/UFRJ).

As informações coletadas durantes estas entrevistas foram transcritas e analisadas em torno de seus pontos de convergência e divergência. $O$ método utilizado a fim de julgar a validade das proposições assumidas foi validade dos constructo (múltiplas fontes de evidência e seu encadeamento). Tais procedimentos

\footnotetext{
${ }^{97}$ Por compromisso assumido para a elaboração das entrevistas, não é possível citar as fontes de informação.
} 
são recomendados por Yin (2005) sendo adequados para o teste de proposições. Adicionalmente, foi eleito um método adicional: teste de confiabilidade. Este se baseou na elaboração de um protocolo, cujos elementos são apresentados no ANEXO 3, e no desenvolvimento de um banco de dados do estudo, tal qual recomendado por Yin (2005).

Feita a descrição dos procedimentos, passa-se à transcrição sumária de resultados.

As empresas de transporte e apóio marítimo atuam por meio de contratos taylor made (elaborados sob medida) e ou por meio de contratos de curto prazo. A carteira e os tipos dos contratos operados afetam a confiança do agente financeiro quanto à capacidade financeira da empresa. O primeiro tipo implica em forte redução do risco operacional e financeiro, pois permite que se estabeleça projeções de receita mais acuradas. Nesses contratos de longo prazo, os armadores procuram vincular as flutuações de custos junto ao contratante como meio de reduzir flutuações no EBITDA e EBIT ${ }^{98}$. O segundo arranjo contratual se baseia na experiência dos gestores respaldando contratos de prazos mais curtos. Estes implicam em maior flexibilidade e maior nível de riscos. Nesse regime, grandes empresas contratantes buscam maior flexibilidade operacional. Com efeito, a maior parte dos entrevistados alega que procura atuar de forma semelhante às empresas de apóio marítimo, ou seja, estabelecendo contratos perenes, fato que fortalece a posição financeira ajudando nas negociações de financiamentos junto ao BNDES.

A síntese com os resultados das entrevistas em torno da questão 1 (formatação, modelagem e avaliação) é apresentada no quadro 20. Dois aspectos chamam a atenção: certa falta de conhecimento em torno dos critérios de avaliação e emprego de metodologias tradicionais baseadas na avaliação de fluxo de caixa.

\footnotetext{
98 Do ingles, Earnings Before Interest, Taxes, Depreciation and Amortization (EBITDA) e Earnings Before Interest, Taxes (EBIT).
} 


\begin{tabular}{|c|c|c|c|}
\hline SETOR & $\begin{array}{l}\text { INSTITUICAÁOI } \\
\text { NÚMERO DE } \\
\text { ENTREVISTADOS }\end{array}$ & CARGO & FORMATAÇÃO, MODELAGEM E AVALIAÇÃO (*) \\
\hline \multirow{4}{*}{$\begin{array}{l}\text { ÓRGÃO DO } \\
\text { GOVERNO }\end{array}$} & BNDES/1 & $\begin{array}{l}\text { Gerente de Infra- } \\
\text { estrutura }\end{array}$ & $\begin{array}{l}\text { não possuo informações acerca do referencial teórico que orienta a arquitetura do financiamento atual; esse é baseado em critérios "tradicionais"; } \\
\text { a sistemática não diverge de outras análises realizadas pelo BNDES; o esquema atende a requisitos previstos na legislação que regulamentam a } \\
\text { contratação FMM; ao receber a documentação do DMM/CDFMM, as análises são baseadas no FINEM e roteiros de enquadramento e de análise } \\
\text { de projetos desenvolvidos pelo BNDES; todas as informações encontram-se no site do BNDES; as avaliações são estabelecidas a partir do } \\
\text { emprego de banco de dados, estudos do BNDES, expertise e na avaliação econômico-financeira estabelecida pela instituição. }\end{array}$ \\
\hline & $\mathrm{DMM} / 2$ & $\begin{array}{l}\text { Coordenador } \\
\text { Geral de } \\
\text { Projetos } \\
\text { Técnico } \\
\text { responsável pelo } \\
\text { parecer }\end{array}$ & $\begin{array}{l}\text { estabelecemos a análise técnica do empreendimento; redigimos parecer e fixamos o preço de referência para as propostas; a base da avaliação } \\
\text { envolve o Modelo OS5; esse apresenta a estrutura de gastos do empreendimento dado o tipo de navio; o financiamento é estabelecido por meio } \\
\text { de um processo de "engenharia reversa"; desde sua gênese em 1958; esse visa equiparar preço do contrato com padrões internacionais; isso é } \\
\text { feito por meio da redução do custo de capital e dilatamento de prazos (carência e amortização); empresas com solidez operacional e financeiras } \\
\text { que atendam aos requisitos são escassas; maior competição deve se verificar em função das encomendas da Transpetro. }\end{array}$ \\
\hline & $\begin{array}{l}\text { BANCO DO } \\
\text { BRASIL/1 }\end{array}$ & $\begin{array}{l}\text { Gerente de } \\
\text { Operações }\end{array}$ & $\begin{array}{l}\text { os processos de contratação seguem trâmites previstos na legislação; avaliações econômico-financeiras atendem a protocolos de análise de } \\
\text { projetos empregados em outras operações do banco; várias questões dificultam essas operações - incluindo o processo de avaliação de riscos } \\
\text { corporativos medidos na análise de crédito; poucas empresas atendem aos requisitos das análises; isso se reflete no spread e garantias. }\end{array}$ \\
\hline & BACEN/1 & $\begin{array}{l}\text { Analista de } \\
\text { Negócios }\end{array}$ & $\begin{array}{l}\text { muitos aspectos são regulados por normas e portarias específicas; a definição da TJLP e os processos de avaliação de riscos são } \\
\text { regulamentados pelo BACEN; a Resolução BACEN 3.262/2005 dispõe sobre a contratação dos recursos do Fundo da Marinha Mercante - FMM. }\end{array}$ \\
\hline \multirow[t]{2}{*}{$\begin{array}{l}\text { ENTIDADE DE } \\
\text { CLASSE }\end{array}$} & SYNDARMA/1 & $\begin{array}{l}\text { Vice- Presidente } \\
\text { Executivo }\end{array}$ & $\begin{array}{l}\text { o FMM era operado a fim de que a estrutura de financiamento garantisse que o preço pago pelo armador ficasse em torno dos praticados no } \\
\text { exterior; desconheço os aspectos mais específicos do financiamento e sua origem remonta o Plano de Metas; em termos, gerais são adotados } \\
\text { critérios tradicionais na avaliação; as empresas "transporte" avaliam o impacto do financiamento sobre o time charter diário; a estruturação de } \\
\text { propostas utiliza o modelo OS5 que serve de base à formatação do projeto; há viés de benefícios aos estaleiros devido à barreiras na } \\
\text { contratação e importações. }\end{array}$ \\
\hline & ABEAM/1 & Presidente & $\begin{array}{l}\text { modelagem baseada em técnicas tradicionais de análise de viabilidade de projetos; um dos focos centrais é a qualidade dos indicadores (ROI, } \\
\text { ROE, ROA, etc.); falta transparência em torno do processo de avaliação; um aspecto central é a percepção do investidor e a pressão para a } \\
\text { distribuição de dividendos que restringem o financiamento e capacidade de auto-investimento das empresas. }\end{array}$ \\
\hline \multirow{6}{*}{$\begin{array}{l}\text { SEGMENTO } \\
\text { PRIVADO }\end{array}$} & $\begin{array}{l}\text { EMPRESA DE } \\
\text { NAVEGAÇÃO/1 }\end{array}$ & $\begin{array}{l}\text { Diretor } \\
\text { Financeiro }\end{array}$ & $\begin{array}{l}\text { os critérios adotados constituem técnicas baseadas em projeções de caixa e análise financeiras; a modelagem é estabelecida a partir de diversas } \\
\text { projeções; essas incluem o impacto sobre indicadores obtidos a partir de Demonstrações Financeiras das empresas envolvidas. }\end{array}$ \\
\hline & $\begin{array}{l}\text { EMPRESA DE } \\
\text { NAVEGAÇÃO/1 }\end{array}$ & $\begin{array}{l}\text { Diretor } \\
\text { Financeiro }\end{array}$ & $\begin{array}{l}\text { são adotadas metodologias convencionais de análise de viabilidade econômica e financeira; a elaboração das propostas e pedidos de } \\
\text { financiamento é feita por uma equipe dedicada de especialistas contratados por nossa empresa; isso implica em custos adicionais que se } \\
\text { repercutem na viabilidade das operações mas funcionam como meios de minimizar os riscos. }\end{array}$ \\
\hline & $\begin{array}{l}\text { EMPRESA DE } \\
\text { NAVEGAÇÃO/1 }\end{array}$ & $\begin{array}{l}\text { Diretor } \\
\text { Financeiro }\end{array}$ & $\begin{array}{l}\text { sob o ponto de vista financeiro são estabelecidas análises tradicionais no estudo de viabilidade e formatação de projetos; um aspecto central é o } \\
\text { planejamento de recursos e os controles e acompanhamentos da fase de execução do projeto. }\end{array}$ \\
\hline & $\begin{array}{l}\text { EMPRESA DE } \\
\text { NAVEGAÇÃO/1 }\end{array}$ & $\begin{array}{l}\text { Diretor } \\
\text { Financeiro }\end{array}$ & $\begin{array}{l}\text { o setor de construção naval no Brasil constitui uma "espécie de cartel"; a modelagem depende das condições de mercado e dos avanços em } \\
\text { torno das negociações entre as contrapartes; em geral, os critérios adotados não diferem de análises de retorno sobre investimentos; existe certa } \\
\text { falta de transparência nos critérios adotados nas avaliações por parte do BNDES; isso se reflete nos diferenciais de taxas praticadas. }\end{array}$ \\
\hline & $\begin{array}{l}\text { APOIO } \\
\text { MARÍTIMO/1 }\end{array}$ & $\begin{array}{l}\text { Diretor } \\
\text { Financeiro }\end{array}$ & $\begin{array}{l}\text { há um grande desconhecimento por parte de técnicos e investidores em torno de assuntos relacionados aos aspectos financeiros e econômicos } \\
\text { relacionados ao setor; em geral o envio de propostas segue o padrão estabelecido nos roteiros do BNDES; primamos pela qualidade das } \\
\text { projeções e definição de mecanismos de controle de projetos; isso envolve profissionais da empresa e contratação de consultorias com impactos } \\
\text { no custo final dos empreendimentos ao longo de seu planejamento, execução e controle. }\end{array}$ \\
\hline & ESTALEIRO/2 & $\begin{array}{l}\text { Diretor } \\
\text { Financeiro } \\
\text { Diretor de } \\
\text { Produção }\end{array}$ & $\begin{array}{l}\text { os cursos de engenharia dão pouca ênfase aos aspectos financeiros das operações; atualmente um de nós faz mestrado na área; na prática a } \\
\text { modelagem depende do tipo de projeto e avanços nas negociações das contrapartes; a produção sob encomenda implica que um projeto nunca } \\
\text { é igual ao outro; os avanços em torno das negociações deveriam absorver essa percepção. }\end{array}$ \\
\hline
\end{tabular}


CONTINUAÇÃO

\begin{tabular}{|c|c|c|c|}
\hline SETOR & $\begin{array}{l}\text { INSTITUICCÁO/ NÚMERO } \\
\text { DE ENTREVISTADOS }\end{array}$ & CARGO & FORMATAÇÃO, MODELAGEM E AVALIAÇÃO (*) \\
\hline \multirow{8}{*}{ ACADEMIA } & POLI/USP/1 & $\begin{array}{l}\text { Professor Engenharia } \\
\text { Naval e Oceânica }\end{array}$ & $\begin{array}{l}\text { a modelagem segue prazos dilatados (carência e amortização) com taxas pré-fixadas; um aspecto central, além de um bom projeto, é a } \\
\text { velocidade na aprovação e critérios que regem o aporte de recursos ao longo da execução do projeto; há um total desconhecimento } \\
\text { científico em torno dessa questão; tal conhecimento é essencial para o desenvolvimento da ICN. }\end{array}$ \\
\hline & POLI/USP/1 & $\begin{array}{l}\text { Professor Engenharia } \\
\text { Naval e Oceânica }\end{array}$ & $\begin{array}{l}\text { os armadores têm que encaminhar um projeto com um nível de detalhamento compatível com o empreendimento; este deve especificar, } \\
\text { em detalhes, os atributos relacionados ao uso, performance e equipamentos associados a operação das embarcações; esses elementos } \\
\text { estão na base da modelagem econômico-financeira e das negociações. }\end{array}$ \\
\hline & COPPE/UFRJ/1 & $\begin{array}{l}\text { Professor Engenharia } \\
\text { Naval e Oceânica }\end{array}$ & $\begin{array}{l}\text { a modelagem e encaminhamento das propostas seguem o modelo OS5; esse gera uma série de distorçães, pois induz a majoração dos } \\
\text { custos apropriados pelo estaleiro e alavancagem das empresas de navegação; as ferramentas se baseiam em processos de avaliação } \\
\text { difundidos e não diferem de metodologias de amplo emprego; contudo, a avaliação de riscos está no cerne da contratação de recursos. }\end{array}$ \\
\hline & COPPE/UFRJ/1 & $\begin{array}{l}\text { Professor Engenharia } \\
\text { Naval e Oceânica }\end{array}$ & $\begin{array}{l}\text { estudos realizados pelo GEIPOT discutem os aspectos centrais da Política de Marinha Mercante e a Política de Indústria Naval, apontando } \\
\text { alguns dos aspectos do financiamento; o modelo OS5 serve de base para a elaboração da proposta e a viabilidade vai depender do } \\
\text { mercado de atuação; os estudos de viabilidade compreendem análise de custo/benefício e processos de avaliação de riscos. }\end{array}$ \\
\hline & COPPE/UFRJ/1 & $\begin{array}{l}\text { Professor Engenharia } \\
\text { Naval e Oceânica }\end{array}$ & $\begin{array}{l}\text { não há duvidas que o financiamento constitui um processo central na viabilidade da ICN; ao que parece os critérios de modelagem nessa } \\
\text { área são tradicionais baseados em VPL e TIR; contudo um bom planejamento é essencial para obter a aprovação. }\end{array}$ \\
\hline & FEA/USP/1 & $\begin{array}{l}\text { Professor Economia e } \\
\text { Finanças }\end{array}$ & $\begin{array}{l}\text { os financiamentos são realizados a partir de análises tradicionais em torno do fluxo de caixa esperado cuja estimação constitui o principal } \\
\text { desafio; os processos de avaliação se baseiam em projeções e um dos pontos centrais é a definição da taxa de desconto empregada; os } \\
\text { modelos de avaliação de FDC se inspiram em ferramentas de finanças (WACC, CAPM, etc.) }\end{array}$ \\
\hline & FEA/USP/1 & $\begin{array}{l}\text { Professor de } \\
\text { Administração }\end{array}$ & $\begin{array}{l}\text { projetos de investimento de longo prazo como os orientados à ICN envolvem esquemas de provisão governamental; os procedimentos } \\
\text { envolvem o estabelecimento de linha de corte para o projeto; isso exige mecanismos de estimativas e avaliações de FDC eficientes. }\end{array}$ \\
\hline & FEA/USP/1 & $\begin{array}{l}\text { Professor Economia e } \\
\text { Finanças }\end{array}$ & $\begin{array}{l}\text { os contratos firmados por empresas do setor de apoio marítimo apresentam demanda garantida; a elevação e contínua necessidade pelo } \\
\text { petróleo e seus derivados garantem demanda a esse seguimento e têm melhorado a rentabilidade das operações; os contratos seguem a } \\
\text { Lei } 8666 \text {, que regulamenta a legislação e, devido a preceito legal, podem ser firmados por prazos de até } 3 \text { anos. }\end{array}$ \\
\hline \multirow{2}{*}{ OUTROS } & $\begin{array}{l}\text { CONSULTORIA } \\
\text { EMPRESARIAL/1 }\end{array}$ & $\begin{array}{l}\text { Consultor - Área } \\
\text { Financeira }\end{array}$ & $\begin{array}{l}\text { todos os parâmetros relacionados às linhas de financiamento para a construção de novas embarcações se encontram relacionados na } \\
\text { legislação e dispositivos que regulamentam a contratação; muitas vezes esses envolvem critérios tradicionais; devido aos prazos e volume } \\
\text { de recursos envolvidos esquemas de Project Finance são mais adequados pois contribuem para aumentar as responsabilidades das } \\
\text { contrapartes e diluir os riscos das operações; muitos avanços poderiam advir a partir desse enfoque. }\end{array}$ \\
\hline & $\begin{array}{l}\text { CONSULTORIA } \\
\text { EMPRESARIAL/1 }\end{array}$ & $\begin{array}{l}\text { Consultor - Área } \\
\text { Financeira }\end{array}$ & $\begin{array}{l}\text { na modelagem prevalece a lógica baseada no binômio risco-retorno dentro do estudo de viabilidade econômico-financeira; nesse ponto, as } \\
\text { propostas de construção enfrentam um grande desafio; os bancos tomam decisões baseados mecanismos de credit scoring e credit rating } \\
\text { dos solicitantes; a maioria dos estaleiros e armadores possui um histórico temerário no cumprimento de contratos, daí a importância da } \\
\text { qualidade do projeto e aporte de capital pelas contrapartes - esse funciona como uma trava de riscos. }\end{array}$ \\
\hline
\end{tabular}

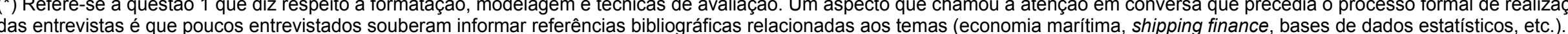

\section{Quadro 20 - Sumário de resultados das entrevistas estabelecidas em torno da questão 1 (formatação e modelagem de projetos).}

Fonte: Elaborado pelo autor. 
Os entrevistados apontaram a existência de uma série de riscos operacionais associados a novos empreendimentos, muitos desses podem ser previstos e mitigados, porém outros não (greves, guerras, entre outros riscos de evento). Em todo caso, os contratos de financiamento são sempre de longo prazo e seus operadores possuem esta percepção. Quanto ao cumprimento de orçamento e prazos, os representantes das empresas de armação dizem não verificar grandes desvios. Contudo, desvios de prazo sempre ocorrem e é natural que ocorram nesse setor. O que não pode acontecer são desvios muito pronunciados, como no passado recente. Não há grandes desvios caso o projeto seja bem elaborado. Isso ajuda a evitar problemas reduzindo riscos operacionais. Contudo contratos nunca são completos. Por isso os técnicos do BNDES são criteriosos em suas projeções e análises.

As empresas têm que estar preparadas para implementar ações estratégicas que se revertam em investimentos de grande montante e prazo. Contudo, certos acionistas têm pouca sensibilidade em torno dessas questões. Sem fluxo de investimentos projetados as empresas tendem a sucumbir. Por esta razão a política de investimento e o acesso ao financiamento são essenciais, mas muitas vezes é difícil explicar isso aos acionistas - principalmente quando possuem idade mais avançada e preferem realizar retornos por meio de uma política agressiva de distribuição de dividendos, fato que atrapalha o financiamento e se reflete nas negociações. Via de regra, as propostas e os pedidos de financiamento são executados por equipes dedicadas do quadro funcional das empresas.

Os estaleiros locais possuem excelência na fabricação de navios, mas deixam a desejar na gestão de operações, apontam os entrevistados. O histórico de atrasos e desvios orçamentários atrapalha as negociações. Por esta razão, a maior parte das empresas procura prever os riscos operacionais durante a elaboração do projeto. Estes são tratados por meio de cláusulas presentes nos contratos firmados entre as contrapartes. Contudo, observou-se que as empresas possuem baixo nível de maturidade na aplicação de ferramentas de análise de riscos, uma vez que as técnicas de formatação e análise de projetos são tradicionais. Grande ênfase é dada em relação aos riscos operacionais relacionados à fase de execução do projeto. Quando da efetivação da contratação, as empresas arcam com os custos fixos a fim de monitorar e acompanhar o andamento das obras objetivando a mitigação de 
riscos. Isso é importante, pois é preciso se precaver para evitar desvios pronunciados. Em geral técnica adotada no controle do processo construtivo é a Estrutura Analítica de Projeto (EAP) que compreende o monitoramento de micro eventos ao longo da execução do projeto, com efeitos sobre o custo de capital. Nesse contexto, é crucial identificar os principais pontos de risco e sua severidade a fim de estabelecer pontos de controle. Segundo os entrevistados este processo funciona como uma trava de riscos das operações. Caso os desvios sejam pronunciados e o casco já tenha sido lançado da carreira é possível romper o contrato e procurar outro estaleiro a fim de terminar a construção. Os entrevistados alegam que atuação de equipes dedicadas, embora incrementem os custos fixos, ajuda a mitigar os riscos mas não apaga o histórico de desvios. O bom pré-contrato entre cliente e estaleiro deve possuir salvaguardas múltiplas e prover meios de superar as fontes de desvios. A performance dependerá do acompanhamento realizado e os técnicos do BNDES são muito sensíveis quanto a estes aspectos, durante as negociações.

Segundo os entrevistados, os riscos de mercado devido os riscos de variação de preços de certos insumos podem ser contornados por meio da antecipação de compras de certos insumos (aço, maquinaria, etc.). Os entrevistados destacaram que a identificação e negociação em torno da determinação e forma de apuração dos custos indiretos de construção é crítica, pois esta pode distorcer os custos e conseqüentemente o valor do contrato. Por outro lado, há sempre o risco de se utilizar moeda única, como previsto no modelo OS5, ao invés de cesta de moedas ${ }^{99}$. Esta prática reflete a absorção das diversas categorias de gastos construtivos, mas não dá conta de outras como a mão-de-obra que deve ser paga em $\mathrm{R} \$$. Desvios pronunciados em custos apropriados são confrontados com a média histórica como meio de tornar mais real o valor do financiamento. A síntese com os resultados das entrevistas em torno da questão 2 (riscos dos empreendimentos) é apresentada no quadro 21.

\footnotetext{
99 O modelo OS5, adotado em 1983 e em vigor até o presente, é uma referência que deve ser utilizada pelas empresas para lançar os gastos associados a proposta de construção, reparo, junborização, etc. de embarcação. Estas informações organizadas em tal modelo são utilizadas na avaliação técnica e financeira das propostas pelo DMM e BNDES, respectivamente.
} 


\begin{tabular}{|c|c|c|c|}
\hline \multirow[b]{2}{*}{ SETOR } & & & \multirow{2}{*}{ RISCOS DOS EMPREENDIMENTOS (*) } \\
\hline & $\begin{array}{l}\text { INSTITUIÇÃO/NÚMER } \\
\text { O ENTREVISTADOS }\end{array}$ & CARGO & \\
\hline \multirow{4}{*}{$\begin{array}{l}\text { ÓRGÃO LIGADO } \\
\text { AO GOVERNO }\end{array}$} & BNDES/1 & $\begin{array}{l}\text { Gerente de Infra- } \\
\text { estrutura }\end{array}$ & $\begin{array}{l}\text { o grau de alavancagem financeira das empresas que atuam no setor, medido pela relação debit/equity, ou outros indicadores econômico- } \\
\text { financeiros, é muito precário; isso implica em dificuldades à concessão de financiamento em razão ao grau aceitável de exposição ao risco; } \\
\text { outra questão remete à classificação de risco das empresas; o setor é o que apresenta maior histórico de problemas quanto ao } \\
\text { financiamento; isso não se pode apagar, no pais, se verifica grande dispersão em termos de qualidade na gestão; isso inclui dispersão na } \\
\text { sistematização e controle contábil; seguimos normas, o spread é fixado com base em legislação própria do BACEN e CMN. }\end{array}$ \\
\hline & DMM/2 & $\begin{array}{l}\text { Coordenador Geral de } \\
\text { Projetos } \\
\text { Técnico responsável } \\
\text { pelo parecer }\end{array}$ & $\begin{array}{l}\text { o BNDES ao analisar o binômio risco/retorno dispõe de informação dos contratos executados por diversos estaleiros; como grande parte } \\
\text { desses não foi capaz historicamente em atender binômio orçamento-prazo as propostas muitas vezes sofrem restrições; nesse ponto a } \\
\text { questão das garantias é secundária; se houver um estaleiro que comprove o estrito cumprimento a programaçãoo e orçamento esse } \\
\text { certamente terá acesso facilitado à linha de financiamento; poucos estaleiros possuem condiçôes de atender aos requisitos exigidos. }\end{array}$ \\
\hline & BANCO DO BRASIL/1 & Gerente de Operações & $\begin{array}{l}\text { os riscos das operações são captados por meio do spread; esse é sensível a uma série de variáveis, sobretudo qualidade de crédito do } \\
\text { emissor, condições de mercado, volume e liquidez da emissão ou empréstimo, prazo, etc.; normas do BACEN regulam a fixação do spread. }\end{array}$ \\
\hline & BACEN/1 & Analista de Negócios & $\begin{array}{l}\text { os processos de contratação são orientados pela Resolução 3.262/2005 que estabelecer que as condições financeiras aplicáveis às } \\
\text { operações realizadas com recursos do Fundo da Marinha Mercante - FMM; os critérios para fixação de juros serão estabelecidos pelo } \\
\text { agente financeiro conforme sua política de crédito e elementos mitigadores de custos e riscos, observadas as condições previstas na } \\
\text { Resolução. }\end{array}$ \\
\hline \multirow[b]{2}{*}{$\begin{array}{l}\text { ENTIDADE DE } \\
\text { CLASSE }\end{array}$} & SYNDARMA/1 & $\begin{array}{l}\text { Vice- Presidente } \\
\text { Executivo e }\end{array}$ & $\begin{array}{l}\text { o principal risco está associado ao caráter cíclico das operações; o time charter diário é fundamental; o valor do bem financiado é muito } \\
\text { superior aos ativos dos estaleiros - o que é ainda mais crítico quando se considera que um mesmo estaleiro pode ter ordem de construção } \\
\text { de mais de uma embarcação; em funçâa dessas características se encontra um grande obstáculo oo financiamento da construção naval. }\end{array}$ \\
\hline & ABEAM/1 & Presidente & $\begin{array}{l}\text { o sistema de financiamento penaliza quem possui maior necessidade de obter crédito; as empresas de transporte ou apoio marítimo ligadas } \\
\text { a grupos econômicos enfrentam menor dificuldade na obtenção do financiament; as empresas estrangeiras possuem melhores condiçōes } \\
\text { de obter crédito e obtém com relativa facilidade carta de crédito junto bancos internacionais; essas empresas possuem grande capacidade } \\
\text { financeira e obtêm melhores condiç̃ose em termos de prazos, taxas e possuem condiçoes de obter carta fiança ou termos de garantia em } \\
\text { melhores termos (prazo, valor, etc.) de bancos classificados como internacional AAA; quem mais precisa enfrenta dificuldades no } \\
\text { financiamento devido a percepção de riscos. }\end{array}$ \\
\hline \multirow{4}{*}{$\begin{array}{l}\text { SEGMENTO } \\
\text { EMPRESARIAL }\end{array}$} & $\begin{array}{l}\text { EMPRESA DE } \\
\text { NAVEGAÇÃO/1 }\end{array}$ & Diretor Financeiro & $\begin{array}{l}\text { uma série de riscos está associada aos empreendimentos; muitos desses podem ser previstos e mitigados outros não (greves, guerras, } \\
\text { etc.); parte deles tem relação com os riscos operacionais (na fase de execuçãá do projeto) e outros referenciam os riscos de mercado } \\
\text { (riscos de variação de preços de insumos); a identificaçãa e negociação em torno da determinação e forma de apuração dos custos } \\
\text { indiretos é crítica pois podem distorcer os custos e conseqüentemente o valor do contrato; há sempre o risco de se utilizar moeda única ao } \\
\text { invés de cesta de moedas que refletiriam melhor a absorção das diversas categorias de gastos; há também o risco do sobre-preço e das } \\
\text { taxas que se refletem no time charter e na determinação do valor das garantias, respectivamente. }\end{array}$ \\
\hline & $\begin{array}{l}\text { EMPRESA DE } \\
\text { NAVEGAÇÃO/1 }\end{array}$ & Diretor Financeiro & $\begin{array}{l}\text { Sob a ótica financeira as variáveis mais relevantes são o grau de alavancagem financeira, qualidade do management; a taxa de juros final, } \\
\text { cobrada nos contratos de financiamento, depende da estrutura financeira da companhia e é crítica pois acaba influenciando a } \\
\text { competitividade dos negócios; uma prioridade é a elaboraçãao de projeções financeiras de qualidade feitas por técnicos dedicados; é preciso } \\
\text { se precaver para evitar desvios e cumprir orçamentos e prazos cujos impactos são severos; o controle é um aspecto essencial. }\end{array}$ \\
\hline & $\begin{array}{l}\text { EMPRESA DE } \\
\text { NAVEGAÇÃO/1 }\end{array}$ & Diretor Financeiro & $\begin{array}{l}\text { a experiência histórica mal sucedida ou negativa se encontra no cerne da discussão acerca dos riscos; no passado a Petrobrás assumia a } \\
\text { responsabilidade de financiar a construção; atrasos e desvios no orçamento eram freqüentes ocasionando grandes perdas; houve caso em } \\
\text { que uma embarcação demorou } 7 \text { anos para ser entregue; isso implica em forte atenção na contratação no que se refere aos riscos. }\end{array}$ \\
\hline & $\begin{array}{l}\text { EMPRESA DE } \\
\text { NAVEGAÇÃO/1 }\end{array}$ & Diretor Financeiro & $\begin{array}{l}\text { as características da embarcação são definidas pelo armador; o armador envia cotação preliminar; propostas são submetidas aos estaleiros } \\
\text { e poucos encaminham projetos; o DMMM avalia propostas com base em dados da Clarkson; a regra é verificar se há desvios nas estimativas } \\
\text { de orçamento; fortes desvios amplificam os custos e os riscos das operaçôes. }\end{array}$ \\
\hline
\end{tabular}




\begin{tabular}{|c|c|c|c|}
\hline & & & \\
\hline SETOR & $\begin{array}{l}\text { INSTITUIÇÃO/NÚMER } \\
\text { O ENTREVISTADOS }\end{array}$ & CARGO & RISCOS DOS EMPREENDIMENTOS $\left({ }^{*}\right)$ \\
\hline \multirow[b]{2}{*}{$\begin{array}{l}\text { SEGMENTO } \\
\text { EMPRESARI } \\
\quad \text { AL }\end{array}$} & APOIO MARÍTIMO/1 & Diretor Financeiro & $\begin{array}{l}\text { a identificação e negociação em torno da determinação e forma de apuração dos custos indiretos é crítica; sua avaliação pode distorcer os } \\
\text { custos e conseqüentemente o valor do contrato e pior, afetar nas negociações em torno das garantias; há o risco do sobre-preço e das } \\
\text { taxas que se refletem no time charter e na determinação do valor das garantias. }\end{array}$ \\
\hline & ESTALEIRO/2 & $\begin{array}{l}\text { Diretor Financeiro } \\
\text { e } \\
\text { Diretor de Produção }\end{array}$ & $\begin{array}{l}\text { a análise de riscos associada a fixação de garantias é feita com base em atributos técnicos que não encontram referência e sustentação se } \\
\text { observarmos os eventos relacionados ao processo de construção; como se pode dar garantia em termos do valor total do contrato se em } \\
\text { cada período da construção há um limitado nível de riscos?; qual o risco de cortar o aço?; o lançamento é um dos pontos críticos da etapa } \\
\text { de construção e não há histórico de eventos desastrosos nessa etapa, contudo os analistas de risco dão grande peso a este evento o que } \\
\text { majora o valor das garantias; na prática há uma majoração dos riscos operacionais incompatível com a realidade da produção; seja como } \\
\text { for, nossos engenheiros (e os engenheiros que militam no setor) trabalham com limites de segurança muito rigorosos o que restringe a } \\
\text { possibilidade de sinistros. }\end{array}$ \\
\hline \multirow{7}{*}{ ACADEMIA } & POLI/USP/1 & $\begin{array}{l}\text { Professor Engenharia } \\
\text { Naval e Oceânica }\end{array}$ & $\begin{array}{l}\text { como o risco do sistema é elevado, encarecendo ainda mais o valor dos contratos, ele é repassado pelo BNDES por meio de elevado nível } \\
\text { de spread (o qual é aplicado ao sobre-preço); o banco se vê obrigado a cobrar pesados spreads uma vez que, em última instancia é o } \\
\text { provedor do FMM, sendo responsável em repor os recursos ao FMM; dessa forma, o modelo amplifica os riscos inflando o valor final dos } \\
\text { contratos, aumentando o custo de capital, o valor das garantias e, em conseqüência, os riscos dos empreendimentos }\end{array}$ \\
\hline & POLI/USP/1 & $\begin{array}{l}\text { Professor Engenharia } \\
\text { Naval e Oceânica }\end{array}$ & $\begin{array}{l}\text { historicamente, uma série de distorções podem ser verificadas na estrutura de financiamento setorial; parte delas foi explorada em estudos } \\
\text { feitos pelo GEITOP no início da década de 1990; talvez a principal fonte de distorções seja o excesso de risco que emana do modelo de } \\
\text { financiamento (risco armador, estaleiro, alavancagem, etc.). }\end{array}$ \\
\hline & COPPE/UFRJ/1 & $\begin{array}{l}\text { Professor Engenharia } \\
\text { Naval e Oceânica }\end{array}$ & $\begin{array}{l}\text { inicialmente há uma indução para a prática de sobre-preço que se repercute sobre os riscos de tomar recursos do FMM; devido a falhas do } \\
\text { modelo, muitas vezes os preços são fixados sem relação direta com os custos de produção das embarcações; esse risco tem origem no } \\
\text { modelo OS5 que induz a majoração artificial de custos indiretos, custos de mão-de-obra e taxa de lucro; além disso todos os custos, } \\
\text { incluindo overheads, são fixados em dólar com base em certos custos diretos (fixados como percentual dos custos diretos como o custo do } \\
\text { custo como aço, p. ex.) o que provoca graves distorções na fixação nos valores dos contratos; muitos dos itens de custos presentes na OS5 } \\
\text { não tem clara relação com os custos diretos. }\end{array}$ \\
\hline & COPPE/UFRJ/1 & $\begin{array}{l}\text { Professor Engenharia } \\
\text { Naval e Oceânica }\end{array}$ & $\begin{array}{l}\text { o modelo de financiamento á construção naval possuía e ainda possui uma série de distorções; uma delas se relacionava as regras de } \\
\text { repasse do prêmio que, por não possuir percentual previamente estipulado, funcionava como uma espécie de subsídio a fundo perdido } \\
\text { repassado sempre que houvesse desvios entre no valor do contrato e os custos de construção; isso gerava uma série de ineficiências - que } \\
\text { certamente perduram até hoje; a prática de sobre-preços também representava e certamente representa outra grande distorção do modelo; } \\
\text { historicamente os preços são sistematicamente mais caros implicando em incrementos nos riscos. }\end{array}$ \\
\hline & COPPE/UFRJ/1 & $\begin{array}{l}\text { Professor Engenharia } \\
\text { Naval e Oceânica }\end{array}$ & $\begin{array}{l}\text { os principais problemas são a situação financeira das empresas e questões relacionadas à gestão na construção; no que tange a gestão do } \\
\text { processo de construção, os estaleiros estão capacitados para a construção dentro dos padrões de desempenho internacionais; contudo, } \\
\text { ainda carecem de mecanismos eficientes e eficazes de controle de operações. }\end{array}$ \\
\hline & FEA/USP/1 & $\begin{array}{l}\text { Professor Economia e } \\
\text { Finanças }\end{array}$ & $\begin{array}{l}\text { o funcionamento do setor se assemelha ao funcionamento da economia cafeeira no início do século passado; a demanda por novas } \\
\text { construções para reposição e expansão normalmente ocorre em momentos em que o frete está aquecido; quando as novas embarcações } \\
\text { são entregues nada garante que o frete se mantenha; caso haja reversão pronunciada nos fretes há uma "quebradeira geral"; esse } \\
\text { desequilíbrio tende a perdurar devido ao período de vida útil das embarcações; nesse contexto, há forte risco que afeta armadores, } \\
\text { estaleiros e bancos. }\end{array}$ \\
\hline & FEA/USP/1 & $\begin{array}{l}\text { Professor de } \\
\text { Administração }\end{array}$ & $\begin{array}{l}\text { as principais fontes de risco dizem respeito ao risco operacional e financeiro as empresas que atuam no setor; contudo; duas principais } \\
\text { fontes de risco são pouco estudadas: velocidade na aprovação de financiamento e cumprimento do cronograma de desembolsos; a } \\
\text { experiência indica que a demora nos processos de avaliação e contratação amplificam os riscos dos empreendimentos; por outro lado, } \\
\text { contingenciamento e atrasos nos desembolsos podem ampliar os riscos de forma crítica. }\end{array}$ \\
\hline
\end{tabular}




\begin{tabular}{|c|c|c|c|}
\hline & & & CONTINUAÇÃO \\
\hline SETOR & $\begin{array}{c}\text { INSTITUIÇÃO/NÚMER } \\
\text { O ENTREVISTADOS }\end{array}$ & CARGO & RISCOS DOS EMPREENDIMENTOS $\left(^{*}\right)$ \\
\hline ACADEMIA & FEA/USP/1 & $\begin{array}{l}\text { Professor Economia e } \\
\text { Finanças }\end{array}$ & $\begin{array}{l}\text { o grande problema do setor tem a ver com os conceitos de seleção adversa e risco moral tratados pela Economia Institucional; o primeiro } \\
\text { conceito sustenta que devido as assimetrias de informação os estaleiros podem majorar o valor dos contratos; o segundo implica que certas } \\
\text { informações não são de conhecimento comum podendo beneficiar uma das contrapartes. }\end{array}$ \\
\hline \multirow{2}{*}{ OUTROS } & $\begin{array}{l}\text { CONSULTORIA } \\
\text { EMPRESARIAL/1 }\end{array}$ & $\begin{array}{l}\text { Consultor - Área } \\
\text { Financeira }\end{array}$ & $\begin{array}{l}\text { empreendimentos que envolvem longos períodos de maturação ou payback são particularmente arriscados; os longos ciclos de construção } \\
\text { e uso implicam em maior atenção com os riscos operacionais de estaleiros e armadores; os bancos são muito cautelosos pois além dos } \\
\text { riscos o custo de oportunidade dessas operações é muito alto; embora a economia esteja estabilizada; o mercado financeiro nacional ainda } \\
\text { não está maduro o suficiente para prover esse tipo de financiamento; daí a necessidade de intervenção governamental na oferta de fundos. }\end{array}$ \\
\hline & $\begin{array}{l}\text { CONSULTORIA } \\
\text { EMPRESARIAL/1 }\end{array}$ & $\begin{array}{l}\text { Consultor - Área } \\
\text { Financeira }\end{array}$ & $\begin{array}{l}\text { nesse tipo de operação é preciso se precaver para evitar desvios e cumprir orçamentos e prazos; a técnica de controle de processo } \\
\text { utilizada é o EAP que compreende o monitoramento de micro eventos ao longo da execução do projeto; essas operações têm efeitos sobre } \\
\text { o custo de capital; nesse contexto, é preciso identificar os principais pontos de risco e sua severidade; o controle de risco por processos } \\
\text { funciona como uma trava de riscos das operações. }\end{array}$ \\
\hline
\end{tabular}

$\left(^{*}\right)$ Refere-se a questão 2 que diz respeito aos riscos dos empreendimentos.

Quadro 21 - Sumário de resultados das entrevistas estabelecidas em torno da questão 2 (riscos dos empreendimentos).

Fonte: Elaborado pelo autor. 
Sob a ótica estritamente financeira, as variáveis mais relevantes nas avaliações são o grau de alavancagem financeira, qualidade do management, a política de distribuição de dividendos e a capacidade de prover garantias - a depender da combinação desses elementos há sérias dificuldades na concessão do financiamento. A taxa de juros final, cobrada nos contratos de financiamento, depende da estrutura financeira da empresa, sendo crítica na lucratividade e viabilidade dos negócios.

Segundo os técnicos do BNDES consultados, o nível de alavancagem financeira tem grande implicação no financiamento e se repercutem sobre as garantias exigidas pelo BNDES. A discussão em torno dos limites de endividamento (relação debit/equity) sempre causa restrições. Em certa medida, o modelo de financiamento local penaliza empresas que mais demandam do FMM, pois afeta os indicadores de endividamento, afetando parcialmente os índices de lucratividade e liquidez. Um aspecto crucial está ligado ao grau de alavancagem financeira das empresas, induzido pelo uso dos recursos da conta vinculada. Contudo, quanto mais financiamentos uma empresa tenha em carteira mais difíceis são as negociações entre armador e agente financeiro. Segundo os entrevistados, o grau de endividamento, associado aos riscos de liquidez, de poder aquisitivo e de câmbio tornam as avaliações prospectivas mais complexas e tendem a elevar o valor dos juros e das garantias, colocando sérios entraves às contratações.

Em linhas gerais, os entrevistados, incluindo técnicos do BNDES, sustentam que não são feitas avaliações financeiras muito complexas. As projeções, baseadas em certas bases de dados do setor, visam estabelecer o break even point ${ }^{100}$ da proposta e a capacidade financeira das empresas. Uma prioridade apontada pelas empresas é a elaboração de projeções financeiras de qualidade feitas por técnicos dedicados. Estas são confrontadas pela análise retrospectiva e prospectiva do BNDES. De toda a forma, empresas ligadas a conglomerados possuem maior capacidade financeira para prover as garantias exigidas - o que representa um ponto crítico na negociação com o BNDES.

\footnotetext{
100 Nível de operação que garante receita suficiente para cobrir apenas custos e despesas. A partir desse ponto ocorre a geração de lucros; abaixo desse as receitas não são capazes de cobrir os custos fixos e o nível de custos variáveis.
} 
Em função dos riscos associados ao empreendimento (operacional, de liquidez ou de mercado, etc.), do volume de capital exigido, dos longos prazos de maturação, do período de payback ou prazo médio de recuperação do capital investido, etc., os contratos de financiamento de construção de embarcações novas, ou mesmo aquisição de embarcações usadas, exigem esquemas de financiamento que envolvem várias instituições, entre elas companhias de seguro. A avaliação de seguros, a depender de sua finalidade, pressupõe uma análise criteriosa dos riscos. Esta avaliação deve relacionar a probabilidade de ocorrência de determinados eventos específicos e associá-los com o correspondente grau de severidade. Os estaleiros afirmam que há excesso de zelo em relação a certos eventos e questionam: qual o risco associado ao corte do aço? Alguma vez houve acidente no lançamento do casco na carreira? Embora constituam eventos críticos não há histórico de problemas nesses eventos. Contudo as seguradoras dão grande peso a estes eventos e o que falta é um maior conhecimento do funcionamento da ICN.

A maior parte dos entrevistados afirmou que a escolha do estaleiro se baseia em um mix de critérios, muitos deles intangíveis. Integridade, condições financeiras, confiabilidade, caráter, comprometimento são fatores fundamentais e que afetam a tomada de decisões. O caráter depende de vários fatores (incluindo o histórico de operações da empresa) os quais podem afetar um vasto conjunto de variáveis minimizando o sobre-preço, gerando uma expectativa favorável quanto ao cumprimento do cronograma e aderência ao demonstrativo de usos e fontes dos projetos. Assim, a credibilidade do estaleiro é crítica na decisão do armador e do agente financeiro. Técnicos da DMM também afirmam que estes critérios são vitais na elaboração dos pareceres. Pré-contratos firmados entre empresas de bom histórico têm mais chance de obter financiamento.

A síntese com os resultados das entrevistas em torno da questão 3 (seleção de estaleiro) é apresentada no quadro 22. 


\begin{tabular}{|c|c|c|c|}
\hline SETOR & $\begin{array}{l}\text { INSTITUIÇÃO } \\
\text { INÚMERO DE } \\
\text { ENTREVISTADOS }\end{array}$ & CARGO & SELEÇÃO DO ESTALEIRO (*) \\
\hline \multirow{4}{*}{$\begin{array}{l}\text { ÓRGÃO LIGADO } \\
\text { AO GOVERNO }\end{array}$} & BNDES/1 & Gerente de Infra-estrutura & $\begin{array}{l}\text { como se trata de operações feitas sob medida que exigem um pré-contrato entre armador e estaleiro, avaliamos o histórico de crédito e } \\
\text { condições financeiras das empresas envolvidas; há certa precariedade na gestão financeira de grande parte das empresas ligadas ao } \\
\text { setor pois não possuem sistemática de registros contábeis - exceto os estritamente exigidos pela legislação. }\end{array}$ \\
\hline & $\mathrm{DMM} / 2$ & $\begin{array}{l}\text { Coordenador Geral de } \\
\text { Projetos e Técnico } \\
\text { responsável pelo parecer }\end{array}$ & $\begin{array}{l}\text { a seleção do estaleiro é feita com base em critérios técnicos pelo armador que deve vincular esse na proposta; ao submeter uma ordem } \\
\text { de compra a um estaleiro este é chamado a viabilizar o financiamento junto às instituições bancárias que o operam (e.g. Bancos } \\
\text { Federais); os armadores não querem mais assumir o ônus da contratação do financiamento pois temem desvios, atrasos e a } \\
\text { possibilidade de não entrega; os estaleiros atendem a padrões internacionais em torno da qualidade do produto. }\end{array}$ \\
\hline & $\begin{array}{l}\text { BANCO DO } \\
\text { BRASIL/1 }\end{array}$ & Gerente de Operações & $\begin{array}{l}\text { essa escolha constitui um elementos crítico pois as avaliações são estabelecidas a partir do histórico de crédito e capacitação das } \\
\text { contrapartes envolvidas na contratação. }\end{array}$ \\
\hline & BACEN/1 & Analista de Negócios & Não se aplica. \\
\hline \multirow{2}{*}{$\begin{array}{l}\text { ENTIDADE DE } \\
\quad \text { CLASSE }\end{array}$} & SYNDARMA/1 & Vice- Presidente Executivo & $\begin{array}{l}\text { as elevadas barreiras à entrada geraram severas distorções no mercado de construção; aqui ao invés de o armador escolher o estaleiro } \\
\text { é o estaleiro que escolhe o armador; várias evidências podem ser apontadas em torno desse aspecto; em muitas situações ao fazer um } \\
\text { pedido o armador recebe um "papel com o preço" e não uma propostas mais detalhada. }\end{array}$ \\
\hline & ABEAM/1 & Presidente & $\begin{array}{l}\text { os problemas com os estaleiros são uma constante; durante o período de alta inflação era comum o uso de recursos no mercado } \\
\text { financeiro e a rolagem de obrigações pretéritas; a cobertura de gastos de um projeto pretérito eram feitas por meio de recursos de um } \\
\text { projeto mais recente e assim os negócios iam sendo gerenciados; por esta razão os atores são muito cuidadosos na contratação. }\end{array}$ \\
\hline \multirow{5}{*}{$\begin{array}{l}\text { SEGMENTO } \\
\text { EMPRESARIAL }\end{array}$} & $\begin{array}{l}\text { EMPRESA DE } \\
\text { NAVEGAÇÃO/1 }\end{array}$ & Diretor Financeiro & $\begin{array}{l}\text { a escolha do estaleiro se baseia em um mix de critérios (caráter, integridade, condições financeiras, etc.); confiabilidade, capacidade, } \\
\text { comprometimento, etc., são fatores fundamentais e que afetam a tomada de decisões; o caráter depende de vários fatores que podem } \\
\text { afetar um vasto conjunto de variáveis impedindo o sobre-preço, garantindo o cumprimento do cronograma e aderência ao demonstrativo } \\
\text { de usos e fontes dos projetos; assim, a credibilidade do estaleiro é crítica na decisão. }\end{array}$ \\
\hline & $\begin{array}{l}\text { EMPRESA DE } \\
\text { NAVEGAÇÃO/1 }\end{array}$ & Diretor Financeiro & $\begin{array}{l}\text { a proposta é encaminhada para estaleiros respeitando critérios de caráter, reputação e confiabilidade no atendimento dos requisitos do } \\
\text { produto e do projeto (prazo, valor orçado, etc.); esses são os ingredientes fundamentais que orientam a seleção. }\end{array}$ \\
\hline & $\begin{array}{l}\text { EMPRESA DE } \\
\text { NAVEGAÇÃO/1 }\end{array}$ & Diretor Financeiro & $\begin{array}{l}\text { os principais problemas associados a escolha do estaleiro não dizem respeito a capacidade para atender ao escopo do produto; a } \\
\text { situação financeira das empresas e problemas de gestão na construção são questionáveis; no que tange a gestão do processo de } \\
\text { construção, os estaleiros estão capacitados para a construção de produtos dentro dos padrões de desempenho internacionais; contudo, } \\
\text { ainda carecem de mecanismos eficientes na área de gestão da produção, gestão de suprimentos, etc. }\end{array}$ \\
\hline & $\begin{array}{l}\text { EMPRESA DE } \\
\text { NAVEGAÇÃO/1 }\end{array}$ & Diretor Financeiro & $\begin{array}{l}\text { a determinação do valor dos contratos nem sempre reflete os custos efetivos de produção e muitas vezes é elaborada com base em } \\
\text { mecanismos de equalização do custo de capital ou consiste em ajustamento feito em função da capacidade de pagamento do armador; } \\
\text { esses fatores destorcem o valor final dos contratos; como o fluxo de caixa incorpora essas distorções, a vantagem do financiamento é } \\
\text { absorvida pelo estaleiro }\end{array}$ \\
\hline & $\begin{array}{l}\text { APOIO } \\
\text { MARITIMO/1 }\end{array}$ & Diretor Financeiro & $\begin{array}{l}\text { em razão do histórico de desvios o setor está se verticalizando, muitos operadores de transporte estão adquirindo ou tentando adquirir } \\
\text { estaleiros; os estaleiros constituem processadores de aço e esta estratégia reflete um procedimento de travamento de risco refletindo } \\
\text { também as condições excepcionais verificadas no mercado; o preço das embarcações se encontra aquecido, incluindo as usadas. }\end{array}$ \\
\hline
\end{tabular}

CONTINUA 
CONTINUAÇÃO

\begin{tabular}{|c|c|c|c|}
\hline SETOR & $\begin{array}{l}\text { INSTITUIÇÃO } \\
\text { INÚMERO DE } \\
\text { ENTREVISTADOS }\end{array}$ & CARGO & SELEÇÃO DO ESTALEIRO (*) \\
\hline $\begin{array}{l}\text { SEGMENTO } \\
\text { EMPRESARIAL }\end{array}$ & ESTALEIRO/2 & $\begin{array}{l}\text { Diretor Financeiro } \\
\text { e } \\
\text { Diretor de Produção }\end{array}$ & $\begin{array}{l}\text { os armadores têm que encaminhar um projeto com um nível de detalhamento compatível com o empreendimento especificando em } \\
\text { detalhes os atributos relacionados ao uso, performance e equipamentos associados a operação das embarcações; então a pergunta que } \\
\text { se deve fazer é "qual empresa está preparada para produzir navios"?; as empresas que produzem para o mercado offshore não se } \\
\text { enquadram nessa classificação; poucas empresas atuam como no setor de construção atuam efetivamente como estaleiros no sentido } \\
\text { de produzir sob encomenda; os estaleiros coreanos e japoneses, por exemplo, possuem verdadeiras linhas de produção altamente } \\
\text { mecanizadas e especializadas; na prática tais linhas de produção têm capacidade de produzir apenas } 7 \text { ou } 8 \text { tipos de embarcações; } \\
\text { caso haja a demanda por um tipo de embarcação que esteja fora desse espectro a produção não será feita sem grandes custos de } \\
\text { adequação na linha; a definição do preço em estaleiros que produzem sob encomenda dependerá das especificações da embarcação } \\
\text { estabelecidas pelo armador; assim o preço possui uma relação bem determinada em termos dos atributos do produto e do projeto sendo } \\
\text { únicos; além disso, a especificidade do produto a ser produzido força que algumas operações sejam estabelecidas entre o demandante } \\
\text { e uns poucos estaleiros; por esta razão não se pode falar em preço da embarcação; o que se pode afirmar é que deve haver uma } \\
\text { sinergia entre as contrapartes em se tratando do tipo de troca (troca idiossincrática) }\end{array}$ \\
\hline \multirow{5}{*}{ ACADEMIA } & POLI/USP/1 & $\begin{array}{l}\text { Professor } \\
\text { Engenharia Naval }\end{array}$ & $\begin{array}{l}\text { os processos de seleção se baseiam na lógica que orienta a contratação sob encomenda; varia a depender do tipo de embarcação, } \\
\text { disponibilidade de carreira e outras condições operacionais e administrativas. }\end{array}$ \\
\hline & POLI/USP/1 & $\begin{array}{l}\text { Professor } \\
\text { Engenharia Naval }\end{array}$ & $\begin{array}{l}\text { não existe atitude dos armadores no sentido de privilegiar estaleiros nacionais; não se verifica patriotismo da parte desses; as ações são } \\
\text { baseadas no senso de oportunidade de negócios tanto na encomenda de navios e escolha do estaleiro; no financiamento subseqüente } \\
\text { para sua aquisição e escolha da bandeira sob a qual irão operar (bandeira de conveniência, bandeira nacional, segundo registro } \\
\text { nacional etc.) essa prática também se verifica. }\end{array}$ \\
\hline & COPPE/UFRJ/1 & $\begin{array}{l}\text { Professor } \\
\text { Engenharia Naval }\end{array}$ & $\begin{array}{l}\text { os critérios de escolha, além do caráter e confiabilidade, estão baseados no valor final do contrato e prazo de entrega; essas condições } \\
\text { são, ao lado do financiamento, críticas na tomada de decisões; mecanismos de financiamento e incentivos à exportação são necessários } \\
\text { para manter o nível de atividade e gerar economias à ICN. }\end{array}$ \\
\hline & COPPE/UFRJ/1 & $\begin{array}{l}\text { Professor } \\
\text { Engenharia Naval }\end{array}$ & $\begin{array}{l}\text { a seleção é estabelecida com base em atributos técnicos e operacionais; a política de financiamento não introduz critérios de eficiência } \\
\text { produtiva; o subsídio por meio da conta vinculada é discriminatório e as regras adotadas distorcem o acesso aos recursos. }\end{array}$ \\
\hline & COPPE/UFRJ/1 & $\begin{array}{l}\text { Professor } \\
\text { Engenharia Naval }\end{array}$ & $\begin{array}{l}\text { na verdade não há um único critério que orienta a escolha; diversas fatores condicionam e orientam o processo; no momento se verifica } \\
\text { certa concentração de financiamento em um dos estaleiros em operação no Brasil; confiabilidade, qualidade e atendimento à } \\
\text { programação e qualidade do management têm orientado a escolha. }\end{array}$ \\
\hline
\end{tabular}

$\left(^{*}\right)$ Refere-se a questão 3 que diz respeito aos aspectos que orientam a escolha do estaleiro.

Quadro 22 - Sumário de resultados das entrevistas estabelecidas em torno da questão 3 (processo de escolha do estaleiro).

Fonte: Elaborado pelo autor. 
Segundo os entrevistados os preços praticados internamente são muito elevados devido às barreiras à importação e exigências estabelecidas no financiamento, tendo impacto severo sobre encargos financeiros e garantias uma vez que se refletem nas práticas produtivas locais e na formação dos valores dos contratos. Contudo, em certas situações o sobre preço resulta da baixa produtividade e escala das operações. Em parte, isso se deve às barreiras para a entrada e às regras de acesso aos recursos do FMM - os recursos só são liberados para a construção em estaleiro nacional restringindo a competição. Embora isso ocorra, há relativa concorrência entre os estaleiros a qual impede preços abusivos. Conforme um dos entrevistados "alguém está sempre disposto a ocupar a carreira, mas se as negociações não avançarem sempre é possível arranjar outro estaleiro"

$\mathrm{Na}$ opinião da maior parte dos entrevistados não há grandes problemas no modelo de financiamento setorial. A rigor, trata-se de uma das estruturas de financiamento setorial mais vantajosa do mundo: as taxas são as mais baixas e préfixadas e os períodos de carência e prazo de amortização figuram entre os mais longos. Segundo a maior parte dos entrevistados, elementos exógenos estão no cerne dos problemas com o modelo de financiamento e implicam em práticas de sobre-preço e absorção das vantagens providas pela linha de financiamento pelos estaleiros $^{101}$. O que também é corroborado por membros das entidades classistas consultados. O excesso de regulamentações e de tributação também gera distorções uma vez que encarecem demasiadamente a importação de embarcações, fragilizando a negociação entre armador e estaleiro. Estas normas, não são ligadas diretamente ao modelo de financiamento setorial e originam uma série de distorções sobre o preço praticado e as garantias. As maiores dificuldades apontadas são a morosidade, excesso e requintes das leis, quantidade de documentos exigidos (excesso de cadastros, certidões, etc.). Segundo alguns dos entrevistados todas essas exigências se refletem no prazo de obtenção do financiamento. Há caso em que a assinatura do contrato demorou cerca de 1,5 ano o que prejudicou muito a qualidade das projeções, tornando mais arriscado o empreendimento. Alguns armadores iniciam as obras por meio de aporte de capital próprio e posteriormente

\footnotetext{
${ }^{101}$ A rigor, devido as barreiras à entrada obrigatoriedade de contratação de estaleiro nacional para uso dos recursos do FMM, muitos armadores alegam que o sobre-preço não resulta exclusivamente de diferenciais na estrutura de custos. Por meio da inflação dos custos apropriados (custos de mãode-obra, despesas operacionais etc.), uma parcela dos pagamentos é apropriada sem ônus pelos estaleiros.
} 
solicitam ressarcimento dos valores aplicados junto ao BNDES. Isso também amplifica o nível de riscos dos empreendimentos. Os entrevistados alegam que por se tratar de órgãos oficiais "não se pode pressionar muito" e que "se fosse agente privado, atuando em concorrência com outros atores, as condições de financiamento certamente seriam melhores". Infelizmente estes reconhecem que tal concorrência é impraticável devido ao prazo, escala e riscos envolvidos nas operações.

Uma crítica apontada é que o financiamento se destina aos armadores e, em muitas situações, os estaleiros é que obtém vantagens financeiras: "temos que nos contentar com um second best traduzido em preços maiores que os praticados no mercado internacional mas abaixo de um limite superior estabelecido por meio de 'mecanismos de equalização do custo de capital' ou fixado exclusivamente em termos da capacidade de pagamento das empresas". Por fim alega-se que o BNDES não paga funding (juros sobre a captação de recursos) pela captação de recursos, assim não deveria cobrar tais taxas. Por outro lado, o limite de financiamento possui duas restrições: sendo de até $90 \%$ do valor do contrato vai contra acordo da Basiléia Il que estabelece que operações de financiamento devam se restringir a $50 \%$ do valor dos ativos. Isso coloca restrições ao modelo, pois o volume de financiamento exigido impede a concorrência de novos entrantes.

A síntese com os resultados das entrevistas em torno da questão 4 (considerações acerca da política de financiamento local) é apresentada no quadro 23. 


\begin{tabular}{|c|c|c|c|}
\hline SETOR & $\begin{array}{l}\text { INSTITUIÇÃOINÚM } \\
\text { ERO DE } \\
\text { ENTREVISTADOS }\end{array}$ & CARGO & CONSIDERAÇÕES (*) \\
\hline \multirow{4}{*}{$\begin{array}{l}\text { ÓRGÃO } \\
\text { LIGADO AO } \\
\text { GOVERNO }\end{array}$} & BNDES/1 & $\begin{array}{l}\text { Gerente de Infra- } \\
\text { estrutura }\end{array}$ & $\begin{array}{l}\text { a provisão de financiamento por meio do FMM é regulamentada; as análises das propostas são feitas a partir de bancos de dados e contam } \\
\text { com o expertise dos técnicos da instituição; não há grandes problemas com a contratação desde que (i) a avaliação econômica e financeira } \\
\text { por meio de técnicas de análise de crédito e (ii) as projeções de mercado e de gastos do projeto sejam coerentes. }\end{array}$ \\
\hline & $\mathrm{DMM} / 2$ & $\begin{array}{l}\text { Coordenador Geral } \\
\text { de Projetos } \\
\text { Técnico } \\
\text { responsável pelo } \\
\text { parecer }\end{array}$ & $\begin{array}{l}\text { não há grandes problemas com o esquema de financiamento operado pelo BNDES; essa instituição provê os recursos do FMM e cabe a um } \\
\text { conjunto de instituições viabilizá-lo; o problema do repasse não é fundamental; o grande problema é a falta de competição na oferta; o } \\
\text { mercado de construção naval apresentaria ganhos caso houvesse maior competição na oferta }\end{array}$ \\
\hline & $\begin{array}{l}\text { BANCO DO } \\
\text { BRASIL/1 }\end{array}$ & $\begin{array}{l}\text { Gerente de } \\
\text { Operações }\end{array}$ & $\begin{array}{l}\text { recentemente participei de uma contratação que envolveu muito tempo e não avançou; isso se deu em parte pelas dificuldades das } \\
\text { empresas envolvidas em torno da análise de crédito. }\end{array}$ \\
\hline & BACEN/1 & $\begin{array}{l}\text { Analista de } \\
\text { Negócios }\end{array}$ & $\begin{array}{l}\text { o modelo de financiamento é bem especificado em torno de seus parâmetros; os processos de avaliação são complexos, envolvem várias } \\
\text { instituições e rodadas de negociação; dessa forma levam tempo. }\end{array}$ \\
\hline \multirow{2}{*}{$\begin{array}{l}\text { ENTIDADE DE } \\
\text { CLASSE }\end{array}$} & SYNDARMA/1 & $\begin{array}{l}\text { Vice- Presidente } \\
\text { Executivo e }\end{array}$ & $\begin{array}{l}\text { o principal meio de aperfeiçoar o modelo de financiamento setorial é por meio de mecanismos que contornem os problemas das garantias - } \\
\text { resultantes do risco operacional dos empreendimentos; certamente grandes avanços podem ser obtidos com a introdução do seguro de } \\
\text { garantia ou a introdução de outros mecanismos de securitização; poderia ser viabilizado um mecanismo que pudesse prover um subsídio } \\
\text { sendo transferido ao prêmio de seguro a fim de viabilizá-lo por meio do uso de recursos do FMM. }\end{array}$ \\
\hline & ABEAM/1 & Presidente & $\begin{array}{l}\text { a burocracia atrapalha perdemos muito tempo na coleta de documentos e certidões que têm validade de poucos dias ou semanas; com a } \\
\text { maior abertura e possibilidade dos bancos operarem recursos do FMM poderia haver ganhos; em muitas situações os órgão públicos não } \\
\text { possuem condições de efetuar tais operações pois falta pessoal qualificado; vai levar tempo até que os demais bancos passem a operar de } \\
\text { maneira satisfatória as linhas de crédito do BNDES. }\end{array}$ \\
\hline \multirow{4}{*}{$\begin{array}{l}\text { SEGUIMENTO } \\
\text { EMPRESARIAL }\end{array}$} & $\begin{array}{l}\text { EMPRESA DE } \\
\text { NAVEGAÇÃOI } \\
1\end{array}$ & Diretor Financeiro & $\begin{array}{l}\text { não há grandes problemas no modelo de financiamento setorial; a rigor, é a estrutura de financiamento mais vantajosa do mundo (as taxas } \\
\text { são as mais baixas e pré-fixadas, os períodos de carência e prazo de amortização são os mais longos); elementos exógenos estão no cerne } \\
\text { dos problemas com o modelo de financiamento e implicam em práticas de sobre-preço e absorção das vantagens providas pela linha de } \\
\text { financiamento pelos estaleiros; certas regulamentações que encarecem demasiadamente a importação de embarcaçoses, entre outros } \\
\text { fatores (cobrança de ICMS, IPT, etc.), fragilizam a negociação entre armador e estaleiro pois distorcem o processo de formação de preços. }\end{array}$ \\
\hline & $\begin{array}{l}\text { EMPRESA DE } \\
\text { NAVEGAÇÃOI } \\
1\end{array}$ & Diretor Financeiro & $\begin{array}{l}\text { há muita morosidade em razão do excesso de deliberações em órgãos diferentes (análise do projeto DMM, análise do agente financeiro } \\
\text { BNDES, reuniões de conselho de crédito, etc.); o governo deveria se esforçar para agilizar dinâmica do fluxo de papeis, promover a } \\
\text { simplificação na contratação e empregar mecanismos que permitam a análise conjunta de propostas a fim de agilizar a contratação; por } \\
\text { outro lado deveria criar mecanismos para aumentar a competição e competitividade dos estaleiros nacionais, minimizar o spread cobrado } \\
\text { nas operações para que juros não sejam tão elevados inviabilizando os negócios. }\end{array}$ \\
\hline & $\begin{array}{l}\text { EMPRESA DE } \\
\text { NAVEGAÇÃOl } \\
1\end{array}$ & Diretor Financeiro & $\begin{array}{l}\text { o modelo ficou no meio do caminho no sentido de promover os negócios do setor; a prática de sobre-preço existe e constitui um problema } \\
\text { estrutural; as escalas de operação são baixas, a mão-de-obra é desmobilizada, a tecnologia é arcaica e a gestão da produção e dos } \\
\text { suprimentos é rudimentar; além disso, a estrutura financeira é precária o que reflete a gestão dos ativos das companhias. }\end{array}$ \\
\hline & $\begin{array}{l}\text { EMPRESA DE } \\
\text { NAVEGAÇÃOI } \\
1\end{array}$ & Diretor Financeiro & $\begin{array}{l}\text { os benefícios da política de financiamento setorial não se convertem em vantagens efetivas; isso fica evidente quando se analisa a carteira } \\
\text { da Transpetro e mesmo as práticas de atendimento de propostas feitas pelos estaleiros - alguns mandam um projeto elaborado atendendo } \\
\text { as solicitações efetuadas, outros encaminham uma folha com preço; há certo paradoxo pois, ao contrário do que deveria ocorrer, o estaleiro } \\
\text { escolhe o armador e não o contrário; os custo de importação é muito elevado, o financiamento externo é difícil de obter e uso do FMM para } \\
\text { aquisição de embarcação no exterior só se dá em casos excepcionais; isso implica em elevação dos preços praticados no mercado interno }\end{array}$ \\
\hline
\end{tabular}




\begin{tabular}{|c|c|c|c|}
\hline & & & TINUA \\
\hline SETOR & $\begin{array}{l}\text { INSTITUIÇÁOINÚME } \\
\text { RO DE } \\
\text { ENTREVISTADOS }\end{array}$ & CARGO & CONSIDERAÇÕES (*) \\
\hline \multirow{2}{*}{$\begin{array}{l}\text { SEGUIMENT } \\
\text { O } \\
\text { EMPRESARI } \\
\quad \text { AL }\end{array}$} & $\begin{array}{l}\text { APOIO } \\
\text { MARITIMO/1 }\end{array}$ & Diretor Financeiro & $\begin{array}{l}\text { o maior entrave as negociações é o tratamento dados aos riscos por parte do agente financeiro; prevalece certa desconfiança no tratamento } \\
\text { do financiamento ao setor; em parte isso deriva do desconhecimento que os operadores das linhas de financiamento possuem acerca do } \\
\text { funcionamento do setor; em parte isso deriva do lugar comum segundo o qual as empresas não cumprem seus compromissos; isso não } \\
\text { corresponde a realidade. }\end{array}$ \\
\hline & ESTALEIRO/2 & $\begin{array}{l}\text { Diretor Financeiro } \\
\text { Diretor de } \\
\text { Produção }\end{array}$ & $\begin{array}{l}\text { os estaleiros possuem uma capacidade limitada de financiamento da construção em razão da composição de seus ativos; não se pode } \\
\text { financiar um valor que representa mais de } 3 / 4 \text { do valor do ativo dessas empresas; por outro lado o tratamento dados aos riscos, da forma que } \\
\text { vêm sendo conduzido, é muito inadequado; a análise de riscos associada a fixação de garantias é feita com base em atributos técnicos que } \\
\text { não encontram referência e sustentação se observarmos os micro eventos relacionados ao processo de construção. }\end{array}$ \\
\hline \multirow{8}{*}{ ACADEMIA } & POLI/USP/1 & $\begin{array}{l}\text { Professor } \\
\text { Engenharia Naval }\end{array}$ & $\begin{array}{l}\text { as garantias constituem um dos principais entraves nas negociações; o modelo poderia ser aperfeiçoado por meio da introdução de } \\
\text { instrumentos de seguro ao financiamento; há um grupo de estudos empenhado em montar e apresentar um esquema junto ao governo; no } \\
\text { entanto, isso exige um consenso acerca de qual órgão vai bancar os custos finais e controlar as operações. }\end{array}$ \\
\hline & POLI/USP/1 & $\begin{array}{l}\text { Professor } \\
\text { Engenharia Naval }\end{array}$ & $\begin{array}{l}\text { o sistema de financiamento provido pelo governo é antigo e passou por várias revisões desde sua gênese em } 1958 \text { com a criação do FMM; } \\
\text { um dos grandes impasses está associado ao sobre-preço e aos esquemas de subsídio por meio do financiamento; na opinião da maior parte } \\
\text { das pessoas que estudam o tema, o governo deveria criar mecanismos para aumentar a eficiência operacional e produtiva dos estaleiros que } \\
\text { operam no país. }\end{array}$ \\
\hline & COPPE/UFRJ/1 & $\begin{array}{l}\text { Professor } \\
\text { Engenharia Naval }\end{array}$ & $\begin{array}{l}\text { há uma estreita relação entre a produtividade das carreiras, investimento no setor de construção e dinâmica da demanda por novas } \\
\text { construçães; há muito espaço para a expansão pois o mercado atualmente se encontra aquecido; tudo vai depender de como o setor vai } \\
\text { aproveitar esse boom; a contração de financiamento depende das condições que as empresas possuem; }\end{array}$ \\
\hline & COPPE/UFRJ/1 & $\begin{array}{l}\text { Professor } \\
\text { Engenharia Naval }\end{array}$ & $\begin{array}{l}\text { o modelo deveria se assumir a existência de certo diferencial de preço (calculado em termos percentuais) a fim de estipular um teto para a } \\
\text { cobertura em torno do preço praticado no exterior; isso que induziria a maior eficiência no mercado de construção. }\end{array}$ \\
\hline & COPPE/UFRJ/1 & $\begin{array}{l}\text { Professor } \\
\text { Engenharia Naval }\end{array}$ & $\begin{array}{l}\text { como já mencionei, um dos grandes problemas está relacionado as condições de produção dos estaleiros; não há grandes investimentos nos } \\
\text { estaleiros há anos; as encomendas da Transpetro representam um novo marco; contudo, tudo vai depender das carteiras de investimento } \\
\text { previstas para os próximos anos; sem investimento nos estaleiros e sustentabilidade na demanda fica difícil a equação fechar; a política de } \\
\text { financiamento deve atrelar normas de eficiência na produção }\end{array}$ \\
\hline & FEA/USP/1 & $\begin{array}{l}\text { Professor } \\
\text { Economia e } \\
\text { Finanças }\end{array}$ & $\begin{array}{l}\text { grandes volumes de investimento, longos prazos de maturação, baixa rentabilidade, incertezas e outros fatores tornam os investimentos no } \\
\text { setor de transporte marítimo e aquaviário altamente arriscados; o sistema de financiamento orientado ao setor tem que levar em conta esses } \\
\text { fatores; em parte a provisão de recursos por meio do sistema FMM/BNDES atende a esses requisitos mas necessita ajustes operacionais. }\end{array}$ \\
\hline & FEA/USP/1 & $\begin{array}{l}\text { Professor de } \\
\text { Administração }\end{array}$ & $\begin{array}{l}\text { o modelo de financiamento penaliza quem mais produz pois, devido ao incremento de financiamento do valor em carteira se reflete nos } \\
\text { riscos das operações; um mecanismo que abrisse a possibilidade de importação de navios em melhores condições abriria a possibilidade de } \\
\text { melhorar as condições de contratação; os mecanismos de avaliação de propostas são feito com base em critérios tradicionais pelo BNDES. }\end{array}$ \\
\hline & FEA/USP/1 & $\begin{array}{l}\text { Professor } \\
\text { Economia e } \\
\text { Finanças }\end{array}$ & $\begin{array}{l}\text { estudos e pareceres nos quais participei mostram que é difícil calcular o resultado líquido da política de subsídios setorial; outro problema é a } \\
\text { apropriação de resultados - em muitos casos os estaleiros se apropriam dos ganhos que deveriam ser revertidos para os armadores; se o } \\
\text { esquema de financiamento visa incentivar o setor por meio da redução do custo de capital isso deveria se refletir no valor das prestações o } \\
\text { que não ocorre na prática; em suma, a questão do subsídio deve ser considerada nas discussões - mesmo que de maneira preliminar }\end{array}$ \\
\hline \multirow{2}{*}{ OUTROS } & $\begin{array}{l}\text { CONSULTORIA } \\
\text { EMPRESARIALI } \\
1\end{array}$ & $\begin{array}{l}\text { Consultor - Área } \\
\text { Financeira }\end{array}$ & $\begin{array}{l}\text { o mercado financeiro local está aquecido pois há grande disponibilidade de fundos de investimento no mercado internacional; mecanismos } \\
\text { de incentivo fiscal poderiam ser acoplados a estrutura de financiamento como na Alemanha; isso canalizaria fundos para aplicação nos } \\
\text { setores de construção e transporte naval; oportunidades existem em razão do sucateamento do modal de transportes terrestres }\end{array}$ \\
\hline & $\begin{array}{l}\text { CONSULTORIA } \\
\text { EMPRESARIALI } \\
1\end{array}$ & $\begin{array}{l}\text { Consultor - Área } \\
\text { Financeira }\end{array}$ & $\begin{array}{l}\text { os bancos ainda são lentos nos processos de avaliação - o que em parte se justifica pela periodicidade de operações e insipiente } \\
\text { aprendizado com essa linha de financiamento; o resultado é certa letargia nas operações; talvez o principal aperfeiçoamento no sistema } \\
\text { derive do estabelecimento de modelos de seguro de crédito. }\end{array}$ \\
\hline
\end{tabular}

$\left.{ }^{*}\right)$ Refere-se a questão 4 que diz respeito considerações acerca da política de financiamento local.

Quadro 23 - Sumário de resultados das entrevistas estabelecidas em torno da questão 4 (considerações sobre financiamento).

Fonte: Elaborado pelo autor. 


\subsection{Conclusões do Capítulo}

Este capítulo discutiu processos envolvidos em operações de financiamento. Nesse contexto, apresentou conceitos e discutiu os princípios empregados na avaliação de financiamentos e sua relação com o setor marítimo. Tendo como foco a análise contábil do retorno sobre investimentos a qual permite a análise de crédito (credit scoring e credit rating), quatro classes de indicadores econômico-financeiros foram apresentados (solvência, atividade, rentabilidade e alavancagem). Utilizados em análises retrospectivas e ou prospectivas, esses são obtidos a partir dos Demonstrativos Contábeis.

Ao considerar quatro elementos relacionados à concessão ou obtenção de financiamento (registro histórico de operações e projetos; análises de indicadores econômico-financeiros; exigência de garantias; atendimento de trâmites legais que regulamentam a transferência de ativos ao setor) e considerando que não se dispôs de informações para realizar cada uma das abordagens, o capítulo se concentrou na análise retrospectiva de indicadores econômico-financeiros. O processo envolveu a criação de um banco de dados que agregou dados dos Demonstrativos Contábeis de uma amostra não intencional de empresas de transporte nacionais e internacionais (ANEXOS 3 e 4). O objetivo foi testar de há diferenças quanto ao grau de exposição ao risco por meio de tais indicadores. Nesse contexto, se procurou estabelecer comparações quantitativas em torno de análises de Demonstrações Contábeis a fim de avaliar em que medida estas impõem limites a aprovação de financiamentos às empresas locais. Os procedimentos dizem respeito a questão $1 \mathrm{e}$ proposições 1.1, 1.2, 1.3 e 1.4, apresentadas no capítulo 1. A rigor, duas estratégias metodológicas complementares, condizentes com o plano metodológico geral do estudo, foram adotadas a fim de testar as proposições assumidas. A primeira, de natureza quantitativa consistiu em realizar testes de diferenças de médias para indicadores econômico-financeiros. Foram utilizados dados financeiros de 48 empresas internacionais e de 4 empresas nacionais. Todos os procedimentos estatísticos adotados foram descritos na seção. 4.4.

Uma segunda abordagem, de natureza qualitativa e alinhada as questões do estudo e as proposições, foi estabelecida de forma independente da elaboração dos procedimentos estatísticos. Este exercício consistiu na elaboração de entrevistas 
estruturadas em torno de temas associados ao financiamento (formatação de projetos, riscos dos empreendimentos, escolha do estaleiro e pontos fortes e fracos percebidos quanto à estrutura de financiamento à construção naval) junto a operadores que atuam no setor. ${ }^{102}$

Considerando o primeiro procedimento, não se pôde afirmar que o nível médio de liquidez das empresas nacionais difere significativamente do verificado em nível internacional. De maneira geral, a liquidez das empresas nacionais e estrangeiras é baixa. Dadas às flutuações nas receitas, oriundas do ciclo de preço dos fretes, e rigidez relativa nos custos, o financiamento é susceptível a riscos operacional e financeiro.

As empresas do setor de transporte apresentam baixos níveis de ganho sobre ativos. Trata-se de uma característica estrutural dos setores de transporte e apoio marítimo. Isso reflete o alto grau de imobilização e de participação do capital de terceiros no total de ativos vis-à-vis o volume de receitas e custos absorvidos pelas operações. Os ativos empregados pelas empresas de transporte apresentam longos ciclos de uso, capazes de cobrir os investimentos realizados. Contudo, como o pagamento de juros e amortizações possuem prazos de vencimento inferiores a um ano, flutuações de curto prazo nas receitas e rentabilidade de ativos podem comprometer sua solvência no longo prazo. Os testes realizados indicam que não se verifica diferenças pronunciadas na eficiência no uso de ativos.

O setor é marcado por baixa lucratividade. A rentabilidade das empresas apresentou diferença significativa em torno do conceito de MB. Esse resultado certamente reflete as diferenças na escala operacional, oriundas das grandes diferenças no volume absoluto de capital alocado pelas empresas estrangeiras e esfera de atuação global. Contudo a ML, ROE, ROA e o GAF não apresentam diferenças significativas. Esses resultados estão associados aos níveis de margem, giro e alavancagem das empresas em cada caso. A rigor, as empresas nacionais possuem margens menores que são compensadas por um maior giro de ativos. Já o nível de alavancagem é muito semelhante. Assim, há indícios segundo os quais a capacidade relativa de auto-financiamento e de distribuição de dividendos não difere, em média, da vigente em nível internacional. A necessidade de financiamento é crítica, mas a capacidade de prover garantias difere substancialmente dado o

\footnotetext{
${ }^{102}$ Esses procedimentos são descritos de maneira mais detalhada nos ANEXOS 1 e 2.
} 
volume de ativos operados pelas empresas nacionais em relação as internacionais. Isso remete aos conceitos de capital e conglomerado discutidos em sua relação com o setor.

Quando os testes de diferença de média dos indicadores são aplicados sobre as estratégias do BNDES também não foram observadas diferenças significativas nas médias dos indicadores - exceto nos conceitos de LB, LO e DCP. Assumindo que uma empresa internacional pudesse solicitar financiamento junto ao BNDES, os resultados relativos às análises de crédito em torno dos índices seriam semelhantes - embora os valores absolutos o EBITDA, o EBIT e capacidade de prover garantias sejam diferenciadas.

Embora centrados em pequena amostra de empresas nacionais esses resultados são particularmente importantes. Em contraste com a análise dos testes apresentados, um dos argumentos sustentados pelos técnicos é que as avaliações das empresas colocam óbices à concessão de financiamento e que o grau de alavancagem das empresas é muito alto. Contudo, como demonstrado este não difere significativamente do padrão observado na amostra de empresas estrangeiras. A rigor, foram apresentados indícios que estrutura de capital das empresas nacionais se encontra dentro dos padrões internacionalmente existentes.

Uma vez que esses fenômenos se verificam e tendo em vista as informações apresentadas, as proposições 1.1 (as empresas encontram dificuldades na aprovação do financiamento junto ao BNDES devido as suas precárias condições econômico-financeiras) e 1.2 (a análise de propostas se baseia em um amplo conhecimento do agente BNDES acerca da forma de funcionamento do setor naval) não se sustentam, devendo ser rejeitadas. Ante a estas constatações, as razões para o "mau" funcionamento do mercado de financiamento orientado ao setor devem ser buscadas em outras causas. Essas constatações remeteram à análise qualitativa por meio da análise das explanações das entrevistas.

Segundo os entrevistados e considerando a avaliação de propostas e fixação de garantias de financiamento, o rating de risco das empresas coloca óbices na concessão do financiamento pelo BNDES ${ }^{103}$. Segundo o BNDES o setor é o que apresenta maiores problemas; já os armadores e estaleiros argumentam que, mesmo ante a crise do setor no início dos anos 1990, as empresas sempre

\footnotetext{
${ }^{103}$ Este resulta do histórico de atrasos e da estrutura financeira das empresas - muito embora nem uma empresa tenha deixado de realizar o pagamento integral de suas obrigações.
} 
cumpriram suas obrigações. Como os contratos são feitos sob medida, vinculando armadores e estaleiros, o histórico de atrasos e desvios nos prazos e orçamentos de projetos de construção repercutem severamente sobre as avaliações contemporâneas. O nível de rating capta esse fator.

Embora haja divergências quanto à apropriação real dos benefícios da política local de financiamento, a maior parte dos entrevistados destacou que a estrutura de financiamento provida pelo BNDES é adequada, em termos das taxas, prazos, etc. As análises são bem fundamentadas em torno de projeções. A rigor, a maior crítica estabelecida indica que fatores exógenos tais como excesso de documentos (certidões, registros, etc.), requintes de leis, morosidade, dificuldades de acesso aos recursos do FMM e restrições da política de importação de navios com uso dos recursos do FMM (exceto em casos excepcionais), dificultam a expansão das operações locais e destorcem os processos de formação do preço dos contratos.

As barreiras à entrada são apontadas como uma das principais causas. A rigor, estas afetam o processo de formação de preços e custos no mercado de construção, restringindo as contratações. Segundo os entrevistados o sobre-preço deriva da majoração de custos apropriados pelos estaleiros (custos de mão-de-obra, custos indiretos, despesas administrativas, etc.). Devido a dificuldade de sua medição esses podem ser majorados, inflacionado o valor do contrato. Por fim, a prática de sobre-preço implica em dificuldades traduzidas pela majoração no valor das garantias - dada às dificuldades que as empresas locais têm para atendê-las.

Curiosamente, os principais riscos apontados pelos entrevistados quanto à contratação de construção não são de natureza financeira, nem técnica e sim operacional. O destaque é dado ao risco estaleiro. Isso remete a aceitação da proposição 1.4 (os estaleiros nacionais atendem satisfatoriamente ao escopo do produto; contudo, ainda precisam aprimorar os processos produtivos e de gestão da produção para evitar desvios que comprometam o orçamento). Na verdade, o risco operacional se relaciona ao grau de eficiência na gestão de projetos por parte dos estaleiros. A tônica se dá em torno da efetiva implementação de mecanismos de controle de micro eventos. Fato que foi enfatizado durante as entrevistas até por representantes da academia. A perspectiva de atrasos no processo construtivo está associada a uma maior percepção de risco em torno dos prazos e orçamentos. Esses fatores são apontados como causa de dificuldades para a viabilização de empreendimentos. Embora impliquem em aumento no custo de capital, na prática 
essas ocorrências são mitigadas pela atuação de equipes dedicadas no planejamento e acompanhamento dos projetos. Ante a esses entraves muitas empresas de apoio têm, inclusive, adquirido estaleiros. Por outro lado, muitos entrevistados alegaram que as empresas do setor jamais deixaram de cumprir suas obrigações financeiras junto aos órgãos competentes. Assim, a alegação que o nível de risco das empresas é extremamente elevado deve ser reconsiderada. Isso contrasta com os testes em torno do grau de rentabilidade e endividamento realizado.

Quanto a proposição 1.3 há certo consenso em seu entorno. A maior parte dos entrevistados afirma que as garantias exigidas para obtenção do financiamento representam um dos principais entraves à aprovação de propostas junto ao BNDES. De fato, a maioria das empresas alega não ter condições nem interesse em atender a tais exigências para a efetivação dos contratos. Dado o volume de ativos que possuem, as empresas internacionais apresentam melhores condições de atender as exigências de collateral e capital. Outro empecilho apontado é o nível de rating de risco atribuído às empresas.

Feitas estas considerações, o próximo capitulo aborda os aspectos matemáticos do retorno sobre investimento. Nesse contexto, estabelece um modelo a partir do qual são realizadas simulações a fim de verificar o nível de atratividade da estrutura de financiamento local em relação a outras estruturas providas por um grupo de países construtores. 


\section{COMPARANDO A ESTRUTURA DE FINANCIAMENTO LOCAL COM AS PRÁTICAS INTERNACIONAIS}

Entendido como o tratamento sistemático de informações (internas e externas à empresa), a análise de viabilidade de um projeto é feita com base em projeções de caixa, cujos diversos componentes e implicações financeiras devem ser apropriadamente dimensionados. A partir dessas estimativas é feita a análise contábil e a análise matemática do retorno sobre investimento (KASSAI, 2000). A análise contábil, retrospectiva e prospectiva, é elaborada a partir de indicadores econômico-financeiros e dos dados do projeto. Estes assuntos foram apresentados e discutidos no capítulo 4. Naquela parte do trabalho foram feitos testes estatísticos a fim de verificar se havia diferenças significativas em quatro de classes indicadores econômico-financeiros (incluindo os empregados pelo BNDES na avaliação de projetos) entre uma amostra de empresas de navegação nacionais e internacionais.

As técnicas matemáticas de avaliação de projetos ou a análise matemática do retorno sobre investimentos são objeto de discussões e tratamento nesse capítulo. Como discutido no capitulo 1, o objetivo é avaliar o grau de atratividade da estrutura de financiamento nacional em relação às práticas adotadas em outros países construtores (Japão, Coréia do Sul, China, Alemanha, Noruega e EUA).

A rigor, os procedimentos aqui apresentados fazem parte do que se denomina orçamento de capital (DAMODARAN, 2004; ROSS; WESTERFIELD; JAFFE, 2002). Este exige que seja apurada, além do dimensionamento do investimento e dos retornos esperados, a taxa de desconto $(r)$ a ser empregada na avaliação do fluxo de caixa do empreendimento. Tal taxa deve refletir o custo de oportunidade e níveis de riscos associados ao emprego de todas as fontes de capital que irão financiar o empreendimento (COPELAND; KOLLER; MURRIN, 2002; DAMODARAN, 2004).

O capítulo se encontra dividido em sete seções, além dessa introdução. A seção 5.1 apresenta as principais técnicas destinadas à avaliação do fluxo de caixa de projetos de investimento, com destaque ao valor presente líquido de custos. As seções 5.2 e 5.3 apresentam métodos no cálculo do valor de prestações de financiamentos e apuração da taxa de taxa de desconto, respectivamente. Nesse contexto, os diversos fatores de risco (risco país, risco cambial, risco setorial, etc.) são incorporados na modelagem. Como será explicitado, para apurar a taxa de 
desconto do fluxo de caixa é preciso calcular o valor do $\beta$ das empresas. Este deve refletir o risco sistemático ou não diversificável do investimento no setor. Contudo, antes da apresentação do modelo de apuração da taxa de desconto e considerando as restrições e premissas assumidas, a seção 5.3 discute os procedimentos adotados para a realização do cálculo empírico do $\beta$ das empresas de navegação. O modelo de simulação proposto e banco de dados utilizado em sua implementação são apresentados nas seções 5.4 e 5.5, respectivamente. A seção 5.6 trata do cálculo empírico das variáveis do modelo. Os resultados obtidos são apresentados na seção 5.7. Finalmente, a seção 5.8 apresenta as conclusões do capítulo.

Cabe salientar que na aplicação do modelo e execução das simulações foram feitos a partir da construção de 6 planilhas (ANEXO 10) sendo empregados os softwares Microsoft Excel, Microsoft Access, E-Views 4.0, Best Fit $4.5 \AA$ e Crystal Ball ${ }^{\circledR} 7.1$ na automatização dos procedimentos empregados.

\subsection{Fluxo de caixa e Técnicas de Avaliação}

Os principais métodos quantitativos empregados na avaliação de investimentos, tanto do ponto de vista conceitual, quanto do ponto de vista prático, se baseiam em projeções de fluxo de caixa, cujo dimensionamento é um dos aspectos mais importantes da avaliação (COPELAND; KOLLER; MURRIN, 2002; DAMODARAN, 2004; SHARPE; ALEXANDER; BAILEY, 1999). Devido a sua complexidade e características, isso é particularmente importante em projetos ligados ao mercado de transporte marítimo, tal como sugerido por Alex (2004), Khalid (2005), Stopford (2005) e Sloggett (1984), quando discutem a importância do fluxo de caixa e os princípios das operações financeiras orientados ao setor.

A correta avaliação do fluxo de caixa é crucial pelo fato de que o caixa é o meio utilizado para o pagamento de todos os tipos de obrigações fixas e variáveis (salários, fornecedores, dividendos, juros e amortizações, etc.) (COPELAND; KOLLER; MURRIN, 2002). Não obstante, como aponta Damodaran (2004), o processo de avaliação nunca é preciso, sendo sempre acompanhado por algum grau de subjetividade, uma vez que estão sujeitos a hipóteses e premissas 
assumidas pelo investidor, além de depender da disponibilidade e do tratamento de dados. Tais processos exigem a alocação de recursos e escolha entre diferentes métodos de estimação de gastos e seu seqüenciamento ${ }^{104}$. Tendo como unidade de análise o projeto, parte desses elementos é discutido por Kerzner (2002).

A figura 10 descreve os principais custos e despesas dos empreendimentos ligados ao transporte marítimo. A partir de diversas deduções previstas sobre a receita é apurado o fluxo de caixa disponível aos ofertantes de capital. Com efeito, a magnitude dos empréstimos, o nível de pagamento juros e estratégia operacional afetam o fluxo de caixa residual (STOPFORD, 2005). Após a incidência dos impostos, o resultado é distribuído na forma de dividendos aos acionistas.

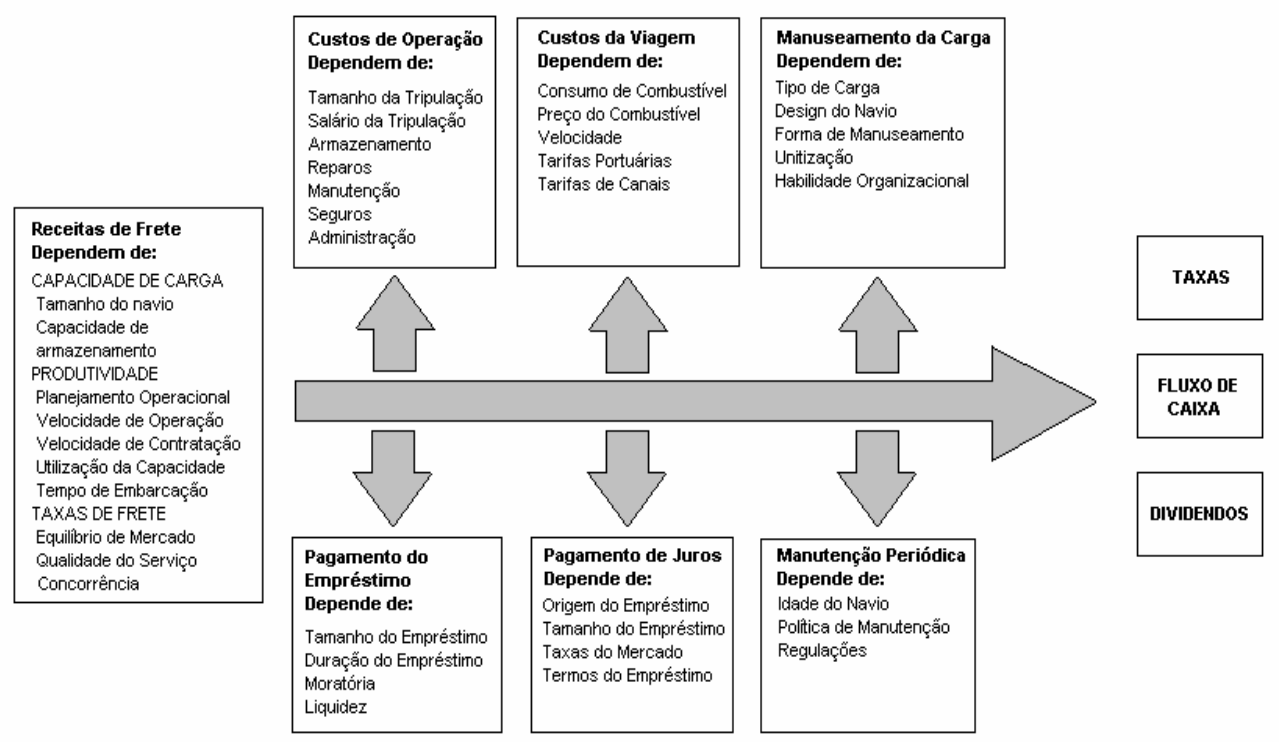

Figura 10 - Estrutura de gastos de uma empresa de transporte marítimo Fonte: Stopford (2005, p. 140).

\footnotetext{
${ }^{104}$ Há várias formas de se obter projeções de fluxo de caixa (técnicas de regressão e sistemas de equações simultâneas, econometria de séries temporais, técnica Delphi, domínio de estimativas topdown ou de estimativas botton-up, estas últimas aderentes ao domínio das disciplinas de Gerenciamento de Projetos). Como será explicitado, tais processos não são objeto desse trabalho, exceto a projeção das despesas financeiras em torno da determinação das parcelas de juros e amortizações cuja a avaliação constitui o cerne do presente capítulo.
} 
Quando alternativas de investimento são avaliadas, os agentes envolvidos têm interesse no excedente que elas poderão gerar sobre os gastos, o que conduz ao conceito de retorno. Como não se pode ter certeza do que vai acontecer no futuro, o cálculo do retorno se relaciona ao conceito de risco (GITMAN, 2000) ${ }^{105}$. Normalmente este reflete a possibilidade de perdas financeiras. Isso é apenas parcialmente correto, pois ignora a oportunidade de ganho acima do esperado, que normalmente acompanha a possibilidade de perda. Uma definição mais abrangente colocaria que risco está associado à incerteza (BLANARU; TELES, 2006). Essa tem relação direta com o processo de avaliação de determinada decisão de investimento e deve ser incorporada à taxa de retorno que irá remunerar as fontes de financiamento de um empreendimento (DAMODARAN, 2004). Na prática, a incerteza varia de acordo com uma série de fatores, setor da economia, país em que o investimento é realizado, nível de concorrência e de desenvolvimento do mercado, condições financeiras da empresa, grau de alavancagem financeira (COPELAND; KOLLER; MURRIN, 2002) ${ }^{106}$. Parte desses temas foi abordado no capítulo 4.

Tecnicamente os métodos de análise de investimento podem ser agrupados e discutidos em três contextos: certeza (em formulações como VPL, TIR, payback, etc.), risco (envolve métodos probabilísticos de simulação e árvore de decisão), incerteza (análise de sensibilidade, análise de cenários, entre outros), técnicas utilizadas em situação de risco e incerteza (método de opções e opções reais) (EVANGELISTA, 2006). Estas abordagens sugerem que parte das ferramentas destinadas à avaliação de projetos fixa seu foco na análise de riscos e benefícios das decisões. Neste estudo serão abordados métodos no contexto de certeza e risco. Esses serão aplicados, respectivamente, na formulação e na aplicação do modelo de simulação, ambos desenvolvidos para avaliar o nível de atratividade da estrutura local em relação à adotada em outros países construtores.

Conforme define Copeland, Koller e Murrin (2002), o fluxo de caixa livre representa o fluxo de caixa disponível aos investidores, fornecedores de capital de terceiros (ou credores) e de capital próprio, depois de saldadas as demais obrigações. Uma representação do fluxo de caixa é apresentada no quadro 24.

\footnotetext{
105 Isso é particularmente importante nos negócios associados ao investimento no setor naval os quais envolvem longos ciclos de produção e uso como discutido no capítulo 2 desse trabalho.

${ }^{106} \mathrm{O}$ termo alavancagem financeira se refere à capacidade de uma empresa tomar recursos a custos fixos de forma a maximizar os lucros dos proprietários. Altos níveis de alavancagem se associam a maiores custos e maior nível de riscos financeiros afetando as decisões dos investidores.
} 
Como pode ser observado, o fluxo de caixa deriva do Demonstrativo de Resultados do Exercício (DRE) sistematiza as fontes de receitas e gastos contra receitas, incluindo despesas com juros. A partir do lucro líquido oriundo do DRE são imputadas as demais entradas e saídas de caixa, incluindo a depreciação (que não constitui propriamente um desembolso de caixa) e amortização de débito. O modelo, amplamente empregado na modelagem de projetos, permite a avaliação do fluxo de caixa esperado. De acordo com esta representação, as despesas com juros e amortização afetam a magnitude do fluxo de caixa em cada momento no tempo. Taxas de juros maiores e prazos de amortização menores reduzem a disponibilidade de caixa disponível e vice-versa.

\begin{tabular}{|l|c|l|}
\hline A & \multicolumn{2}{|l|}{ Demonstrativo de Resultado (DRE) } \\
\hline 1.1 & $(+)$ & Receita Bruta \\
\hline 1.2 & $(-)$ & Impostos sobre receitas \\
\hline 1.3 & $=$ & Receita Líquida \\
\hline 1.4 & $(-)$ & Custos dos Produtos/Serviços Vendidos \\
\hline 1.5 & $=$ & Lucro Operacional Bruto (EBITDA) \\
\hline 1.6 & $(-)$ & Outras despesas e receitas \\
\hline 1.7 & $(-)$ & Amortização de despesas pré-operacionais \\
\hline 1.8 & $(-)$ & Depreciação \\
\hline 1.9 & $=$ & Lucro antes do IR (EBIT) \\
\hline 1.10 & $(-)$ & Juros \\
\hline 1.11 & $(-)$ & Imposto de Renda (IR) \\
\hline 1.12 & $=$ & Lucro após IR \\
\hline
\end{tabular}

\begin{tabular}{|l|c|l|}
\hline B & \multicolumn{2}{|l|}{ Fluxo de Caixa (FDC) } \\
\hline 2 & $=$ & Entradas/Disponibilidades \\
\hline 2.1 & $(+)$ & Lucro após IR (1.12) \\
\hline 2.2 & $(+)$ & Empréstimos \\
\hline 2.3 & $(+)$ & Amortização de Despesas Pré-operacionais \\
\hline 2.4 & $(+)$ & Depreciação \\
\hline 2.5 & $(+)$ & Valor residual do Investimento \\
\hline 2.6 & $(+)$ & Valor do Capital de Giro aportado \\
\hline 3 & $=$ & Saídas/Exigibilidades \\
\hline 3.1 & $(-)$ & Investimento \\
\hline 3.2 & $(-)$ & Amortização de débito \\
\hline 3.3 & $(-)$ & Valor do Capital de Giro \\
\hline 3.4 & $(-)$ & Reposição de Investimento \\
\hline 3.5 & $=$ & Fluxo de Caixa (FDC) residual \\
\hline
\end{tabular}

Quadro 24 - Representação simplificada do fluxo de caixa de um projeto (*). 
${ }^{*}$ ) A rigor, como pode ser observado no quadro, o fluxo de caixa final ou residual é oriundo de todas atividades operacionais, de investimento e de financiamento corporativo que provocam variação na disponibilidade imediata de caixa.

Fonte: Adaptado de Motta e Calôba (2002, p. 192).

É importante enfatizar que, associado à fase conceitual do projeto (KERZNER, 2002), o estudo de viabilidade se baseia em um conjunto de variáveis aleatórias pois, na maioria dos casos não se sabe ao certo o valor das receitas e gastos que o projeto irá absorver. O mesmo se dá com as contas 1.10 (pagamento de juros) e 3.2 (amortização de débito). Ao submeter uma proposta de financiamento a um banco o pleiteante não sabe ao certo as condições de prazo e de juros estabelecidas. A fixação destas depende do processo de avaliação feito pelo banco a partir de informações providas pela empresa (tais como demonstrativos contábeis, dados do projeto) e análise de mercado. Essas interferem no processo de avaliação e tendem a afetar o resultado de caixa do empreendimento.

Tendo esse referencial em perspectiva, a maior parte dos indicadores de tomada de decisão permite considerar se um projeto é viável, ou não, tendo como critério o valor presente do fluxo de caixa residual $(V P)$. Uma vez obtido o fluxo de caixa (a partir de uma série de estimativas), este indicador é calculado por meio da aplicação de uma taxa de retorno $(r)$ sobre cada parcela do fluxo de caixa $\left(P M T_{t}\right)$. Tal taxa deve refletir, de maneira apropriada, as expectativas de riscos e retorno do empreendimento (DAMODARAN, 2004). Portanto, é a partir da síntese de projeções de fluxo de caixa e da determinação de $r$ que são gerados os diversos indicadores empregados na avaliação de projetos ${ }^{107}$.

Embora os conceitos e técnicas em que se baseiam os modelos de avaliação sejam diferentes, grande parte deles trabalha com ao menos três variáveis essenciais: fluxo de caixa, risco e tempo (COPELAND; KOLLER; MURRIN, 2002). Uma das ferramentas mais utilizadas na avaliação de investimentos é o valor presente líquido (VPL). Este é calculado por meio da seguinte expressão:

\footnotetext{
${ }^{107}$ Como será indicado a seguir, por meio do tratamento do fluxo de caixa e determinação de uma taxa de desconto adequada que pondere o custo de capital próprio, o custo de capital de terceiros e o grau de alavancagem financeira, é possível obter vários indicadores de tomada de decisão tais como VPL, VPL de custos, TIR, TIRM, IL, TR, VAUE, períodos de payback, entre outros.
} 


$$
V P L=\sum_{t=0}^{n} \frac{P M T_{t}}{(1+r)^{t}}
$$

Sob esse critério um projeto é preferível a outro alternativo quando, equivalente em termos do prazo e dada a taxa de desconto $r$, apresentar maior $V P L$. Outra ferramenta comumente empregada é o VPL de custos (KASSAI, 2000). Seu uso é adotado quando a tomada de decisão se baseia exclusivamente na avaliação do fluxo de despesas entre diferentes alternativas. Dessa forma o VPL pode ser reescrito como:

$$
V P L_{C}=\sum_{t=0}^{n} \frac{P M T_{t}}{(1+r)^{t}}
$$

Sob este critério o projeto mais atrativo é o que apresentar menor $V P L_{C}$.

Como salienta Ehrlich e Moraes (2005) e Damodaran (2004) ao discutir algumas características dos processos de tomada de decisão baseados no valor, apenas as diferenças entre as alternativas de investimento são relevantes e devem ser objeto no processo de avaliação.

Para efeito das discussões subseqüentes, dois processos são fundamentais na avaliação e serão abordados na especificação do modelo por meio do qual se presente avaliar o grau de atratividade da estrutura de financiamento local em relação às práticas internacionais: determinação do fluxo $P M T_{t}$ e da taxa de desconto, $r$, a partir das quais se obtém o $V P L_{C}$ de um projeto. Nesse contexto, o $P M T_{t}$ se restringe à determinação das despesas financeiras calculadas com base nas informações apresentadas no quadro 5 do capítulo 2. Todos os passos metodológicos adotados são apresentados nas próximas seções.

\subsection{Cálculo do valor das prestações em Sistema de Amortização - $P M T_{t}$}


O cálculo do valor de $P M T_{t}$ é feito por meio do emprego de sistemas de amortizações. Estes constituem planos ou regras segundo os quais o valor total e o serviço da dívida de um financiamento são pagos por meio de amortizações e juros periódicos. Segundo o quadro 5, apresentado no capítulo 2, o sistema de amortização amplamente empregado nos países sob investigação é o Sistema de Amortização Constante (SAC). Sob este modelo o valor de cada parcela de amortização é apurado da seguinte forma: $A^{K}=\frac{D^{K}}{n_{K}}$. Onde $D^{K}$ representa o montante financiado e $n_{K}$ o prazo ou número de pagamentos da operação. Assim, o emprego do SAC retorna valores constantes de amortização. Sob este sistema saldo devedor $\left(S D_{t}\right)$ em cada momento $t$ pode ser calculado da seguinte forma: $S D_{t}=A^{K}\left(n_{K}-t\right)$. Já o valor dos juros $\left(J_{t}\right)$ em cada instante $t$ pode ser obtido por meio da seguinte expressão: $J_{t}=r_{D} S D_{t-1}=r_{D} A^{K}\left(n_{K}-t+1\right)$. Desta forma, sob o SAC o valor das prestações é definido como $P M T_{t}=A^{K}+J_{t}$. Quando comparado a outros sistemas de amortização (Francês, Americano, etc.) o SAC retorna menor valor de juros. Apresentando ainda as seguintes características: redução linear no valor das prestações, nos juros e no saldo devedor.

\subsection{Métodos Empregados na Obtenção da Taxa de Desconto - $r$}

Os escassos estudos que tratam do tema do financiamento ao setor naval ou de sua avaliação não fazem menção à forma como é apurada a taxa de desconto aplicada como instrumento na determinação do valor dos ativos e projetos ${ }^{108}$. Este fato certamente reflete a dificuldade na obtenção de informações de natureza financeira relacionadas ao setor.

Conforme a literatura especializada, a taxa de desconto $r$ deve ser definida a priori pelo investidor com base no custo de oportunidade e benefícios de uso de cada uma das fontes de capital (DAMODARAN, 2004; GITMAN, 2000; KASSAI,

\footnotetext{
${ }^{108}$ Ver, por exemplo, as discussões feitas por Stopford (2005) e Sloggett (1984) quando discutem o emprego de critérios de avaliação de investimentos no setor e mais recentemente o trabalho de Pires Junior e Rezende (2006).
} 
2000; ROSS; WESTERFIELD; JAFFE, 2002; WESTON; BRIGHAM, 2000). Esta taxa é denominada taxa mínima de atratividade (TMA).

Na prática, caso a empresa possua capital em excesso, ela pode distribuí-los imediatamente aos seus acionistas sob a forma de pagamento de dividendos, aplicar em ativos financeiros e ou investi-lo em um novo projeto, para posteriormente distribuir os fluxos excedentes gerados na forma de dividendos. O procedimento a ser adotado irá depender da rentabilidade esperada de cada alternativa. Caso os acionistas possam reinvestir seus dividendos em um ativo financeiro que apresente o mesmo nível de risco do projeto, estes desejariam aplicar em um ativo de maior retorno. Assim, um projeto só será realizado se o retorno esperado for superior ao de um ativo financeiro com risco comparável. Portanto, a princípio a TMA deve ser igual ou maior que a taxa de retorno de um ativo financeiro que apresente risco e prazo semelhantes (ROSS; WESTERFIELD; JAFFE, 2002, p. 382).

Quando a empresa utiliza outras fontes de capital para se financiar, como é o caso das empresas de transporte marítimo (conforme discutido no capítulo 4), é preciso considerar, além do custo do capital próprio $r_{E}$, o custo capital de terceiros $r_{D}$ na determinação da taxa de desconto $r$. Nesta situação, custo do capital empregado deve ser apurado como uma média ponderada de suas fontes de financiamento (COPELAND; KOLLER; MURRIN, 2002; DAMODARAN, 2004). Neste caso, se deve deduzir os impostos incidentes $(T)$, uma vez que a remuneração do capital de terceiros é contabilizada como despesa a qual reduz o lucro tributável, gerando benefícios à empresa (quadro 8) ${ }^{109}$.

Segundo Gitman (2000) e Weston e Brigham (2000), quando a empresa utiliza capital próprio $(E)$ e de terceiros $(D)$ a apuração do valor presente de seu fluxo de caixa livre deve ser elaborada por meio do custo médio ponderado do capital (WACC) $)^{110}$. A rigor, o WACC "é a taxa de desconto, ou valor do dinheiro no tempo, usada para converter o fluxo de caixa futuro em valor presente para os investidores." (DAMODARAN, 2004, p. 205). Este representa o custo futuro médio esperado dos fundos alocados no empreendimento no longo prazo. A rigor, "o enfoque do WACC parte da idéia de que projetos de empresas alavancadas são

\footnotetext{
${ }^{109}$ De acordo com a primeira proposição de Modigliani e Miller (1958) (proposição I MM), na ausência de falhas de informação e de impostos a composição do capital não afeta o valor da empresa.

${ }^{110}$ Do ingles, Weight Average Cost of Capital (WACC).
} 
financiados simultaneamente com capital de terceiros e capital próprio" (ROSS; WESTERFIELD; JAFFE, 2002, p. 382). Nessas condições, o $V P L_{C}$ deve ser dimensionado por meio da seguinte expressão:

$$
V P L_{C}=\sum_{t=0}^{n} \frac{P M T_{t}}{\left(1+r_{\text {WACC }}\right)^{t}} .
$$

Portanto, para obter $\circ V P L_{C}$ das despesas financeiras de um empreendimento ou outros indicadores de viabilidade que utilizam o conceito de valor presente (VP) (payback descontado, índice de lucratividade, etc.), é necessário estimar, além dos valores do fluxo de caixa $P M T_{t}$, a taxa de desconto $r_{\text {WACC }}$, o que, de acordo com Copeland, Koller e Murrin (2002) e Damodaran (2004) deve ser feito por meio da seguinte expressão:

$$
r_{\text {WACC }}=r_{E}\left(\frac{E}{E+D}\right)+r_{D}(1-T)\left(\frac{D}{E+D}\right)
$$

Ou seja, o retorno exigido $\left(r_{\text {WACC }}\right)$ dependerá da estrutura de capital do empreendimento $(E+D)$, da taxa de impostos $(T)$ e dos níveis de remuneração exigidos pelo capital próprio $\left(r_{E}\right)$ e de terceiros $\left(r_{D}\right)$ (DAMODARAN, 2004).

Os métodos empregados para obter cada um desses componentes necessários para a determinação de $V P L_{C}$ e construção do modelo proposto neste capítulo são abordados a seguir.

\subsubsection{Cálculo do Retorno sobre Capital Próprio $-r_{E}$}

O custo de capital próprio $\left(r_{E}\right)$ é mensurado de maneira relativamente complexa (DAMODARAN, 2004). Por esta razão, é possível afirmar que se trata de 
um assunto de grande polêmica nos meios acadêmicos, governamentais e empresariais. Como afirma Catapan (2001), há certa falta de consenso acerca dos critérios e premissas para sua obtenção. A rigor, a determinação de $r_{E}$ envolve o cálculo do beta do ativo, $\beta_{i}$. Este fator capta a sensibilidade do retorno de um ativo em relação aos movimentos do mercado e reflete dois tipos de risco: risco de negócio e risco financeiro ${ }^{111}$. O primeiro diz respeito ao grau de incerteza da projeção de retorno sobre o respectivo ativo e não pode ser eliminado por meio da diversificação (GITMAN, 2000). Constitui, portanto, o risco sistemático ou não diversificável de um ativo. O segundo reflete o risco adicional devido ao emprego do capital de terceiros no financiamento do projeto e ou da empresa e corresponde ao incremento de risco provocado pelo grau de alavancagem financeira (DAMODARAN, 2004; ROSS; WESTERFIELD; JAFFE, 2002).

Com efeito, a literatura aponta vários métodos para o cálculo do custo de oportunidade do capital próprio, entre eles a Teoria de Precificação por Arbitragem $\mathrm{APT}^{112}$, o Valor Presente Ajustado - APV ${ }^{113}$, o modelo de precificação de ativos de capital - $\mathrm{CAPM}^{114}$ e o modelo downside de precificação de ativos de capital - D$\mathrm{CAPM}^{115}$. Estes são apresentados de maneira sumária a seguir

O método APT, desenvolvido por Ross em meados da década de 1970, parte do princípio que o retorno de um ativo é gerado por fatores setoriais e de mercado (ROSS, 1976). Essa abordagem considera que o retorno possui duas parcelas, $r_{N} \mathrm{e}$ $U$. Estas constituem, respectivamente, o retorno normal ou esperado previsto pelos investidores e uma parcela inesperada, decorrente de novas informações que podem afetar a rentabilidade esperada do investimento. Formalmente:

$$
r_{A P T}=r_{N}+U
$$

${ }^{111} \mathrm{O}$ risco do negócio se refere aos riscos operacionais, de mercado, de evento, cambial, etc., conforme apresentados no capítulo 4. Como indicado nessa seção, por convenção e dado o enfoque apresentado a seguir, se considera em separado essas fontes de risco do risco financeiro.

${ }_{112}$ Do ingles, Arbitrage Theory of Capital Asset Pricing (APT).

113 Do ingles, Adjusted Present Value (APV).

114 Do ingles, Capital Asset Price Model (CAPM).

115 Do inglês, Downside Capital Asset Pricing Model (D-CAPM). 
Tal como concebido, o APT explicita que a parcela inesperada do retorno $(U)$ deve ser o foco da análise, pois representa o verdadeiro risco de qualquer investimento (ROSS; WESTERFIELD; JAFFE, 2002). Na prática este modelo é traduzido em termos fatoriais cujos fatores adotados (índice de produção industrial, taxa de juros, risco de inadimplência, inflação esperada de curto e longo prazo, etc.) constituem os elementos que normalmente descrevem o processo de geração da taxa de retorno do ativo (DAMODARAN, 2004). Contudo, seu emprego exige que se leve em conta a influência de muitos fatores gerais e setoriais antes de fazer com que o risco não sistemático (ou diversificável) de um ativo passe a apresentar correlação nula com os riscos não sistemáticos associados aos demais elementos inseridos no modelo (ROSS; WESTERFIELD; JAFFE, 2002) ${ }^{116}$. Por outro lado, o uso do APT exige um maior volume de informações estatísticas nem sempre disponíveis, a depender do setor a ser considerado (GITMAN, 2000). Tal é o caso da disponibilidade de informações relacionadas ao setor naval no Brasil.

O modelo APV também data da década de 1970 e foi desenvolvido por Stewart Myres (apud ROSS; WESTERFIELD; JAFFE, 2002). O modelo, ao refletir as proposições de Modigliani-Miller (1958), parte do princípio de que a modelagem do retorno dos ativos deve considerar não apenas o retorno esperado pelas atividades normais da empresa, mas também o efeito fiscal gerado pelo uso do capital de terceiros $^{117}$. Tal modelo tem como característica central o fato de considerar no cálculo do valor presente (VPL) um fluxo de caixa esperado $(R t)$, na hipótese que a empresa não possua dívidas. Cada parcela desses deve ser acrescida de um adicional que reflita os benefícios fiscais. Dessa maneira, a taxa de desconto $\left(r_{A P V}\right)$ deve ser apurada considerando a hipótese da empresa sem dívidas. Sobre o valor do VPL assim obtido se adiciona o valor presente do efeito fiscal $\left(V P L_{T}\right)$. Assim sendo, a equação que resume o modelo APV pode ser expressa por:

$$
A P V=V P L_{N}+V P L_{T}
$$

\footnotetext{
${ }^{116}$ Isso significa que todas as demais fontes de risco que não afetam o negócio de maneira específica devem ser isolados.

117 Segundo Damodaran (2004), Modigliani e Miller (1958) demonstraram que, em um mundo livre de impostos, o valor de uma empresa independe de sua estrutura de capital. Neste caso, um investidor obteria a mesma taxa de retorno esperada, independente da estrutura de capital da empresa. Este resultado foi obtido de maneira indireta no capítulo 4. Não há indícios que as taxas de rentabilidade quando mediadas por meio do ROE e do ROA difiram significativamente - mesmo considerando que as empresas apresentem escalas diferentes de operação e difiram individualmente quanto o grau de alavancagem.
} 
Em contraste ao APV e ao ATP, que demandam grande disponibilidade de dados, estudos desenvolvidos independentemente por Lintner (1965), Markowitz (1952), Mossin (1966), Sharpe (1964) e Tobin (1958) resultaram no modelo mais usado no meio acadêmico e empresarial para cálculo do retorno sobre ativos financeiros: o CAPM (PAIVA, 2005).

A taxa de retorno obtida por meio desse modelo serve como elemento para 0 cálculo da taxa de retorno de empreendimentos em ativos reais $\left(r_{\text {WACC }}\right)$, uma vez que ao refletir toda a informação disponível no mercado, capta o risco sistemático (ou não diversificável) de se transferir recursos financeiros a uma dada companhia (DAMODARAN, 2004; GITMAN, 2000, ROSS; WESTERFIELD; JAFFE, 2002; WESTON, BRIGHAM, 2000).

Segundo Sharpe, Alexander e Bailey (1999), sua simplicidade teórica e prática explicam seu sucesso e difusão. O modelo presume que o retorno dos ativos financeiros pode ser previsto por meio de uma relação linear aplicada sobre prêmio de risco. Tal como formalizado a seguir, esse reflete a diferença entre o retorno do ativo de mercado $\left(r_{M}\right)$ e ativo livre de risco $\left(r_{F}\right)$. Em suma, o CAPM capta o prêmio de risco exigido pelo mercado para o carregamento de um título. Uma das hipóteses fundamentais dessa abordagem é que os mercados são perfeitos de forma que os agentes não cometem erros sistemáticos. Assim, o retorno no esperado ajusta de maneira eficiente o preço dos ativos quando trazidos a valor presente.

Como os demais modelos apresentados acima, o CAPM deriva de estudos microeconômicos e constitui um modelo de equilíbrio que possibilita o cálculo do retorno dos ativos por meio do $\beta_{i}$. O modelo se apóia nos seguintes pressupostos: atomismo (grande número de investidores que não conseguem, por meio de sua ação individual, influenciar o preço dos ativos por meio de suas operações); captação e risco (todos os investidores podem emprestar e tomar empresado a taxa livre de risco); divisibilidade (os ativos são infinitamente divisíveis); inexistência de friç̧ões de mercado (não há custos de transação e nem impostos sobre os ganhos); eficiência informacional (a informação é gratuita, instantânea e idêntica para todos os investidores); homogeneidade de expectativas (as expectativas dos investidores são homogêneas). 
Estas hipóteses podem ser criticadas devido a sua falta de realismo. Contudo, segundo Sharpe, Alexander e Bailey (1999, apud PAIVA, 2005), o cerne do modelo não consiste em afirmar que tais hipóteses não são realistas; o que vale é a aceitabilidade de suas implicações. Ademais, estes postulados implicam nas condições de equilíbrio e formam a maior parte da doutrina financeira clássica especialmente se for levado em conta a escassez de modelos alternativos e sua dificuldade de implementação. As hipóteses relacionadas ao CAPM, embora possam ser contestadas, contribuíram para seu desenvolvimento e da teoria em finanças ${ }^{118}$. Em razão disso, o foco das questões mudou para: o que aconteceria com os preços das ações se todos os investidores investissem de maneira similar? (SHARPE; ALEXANDER; BAILEY, 1999). Em tal situação o mercado atingiria o que se chamou de equilíbrio entre os pontos de risco e retorno.

O cálculo do custo de capital próprio $\left(r_{E}\right)$ feito por meio do CAPM indica haver uma relação positiva entre o retorno de um ativo $i$ e seu risco, sendo calculado por meio do seguinte modelo:

$$
r_{i}=r_{F}+\beta_{i}\left(r_{M}-r_{F}\right)
$$

Assim especificado, o $\beta_{i}$ mede o prêmio de risco do ativo $i$. Este é definido como risco sistemático (ou não diversificável) cuja magnitude pode ser calculada por meio da seguinte expressão:

$$
\beta_{i}=\alpha_{i}+\left(\frac{\sum\left(r_{i}-\overline{r_{i}}\right)\left(r_{M}-\overline{r_{M}}\right)}{\sigma_{F}^{2}}\right) r_{F}+e_{j}
$$

\footnotetext{
${ }^{118}$ Assim como os princípios do atomismo, da transitividade, ausência de custo de transação, etc., contribuíram para o desenvolvimento da teoria do consumidor e da firma na moderna teoria microeconômica.
} 
Sob esta concepção, o $\beta_{i}$ é obtido por meio de regressão linear ${ }^{119}$. Contudo, como será indicado na parte empírica deste estudo, este modelo estatístico conduz a problemas de estimação sendo necessário o emprego de técnicas econométricas de séries temporais (time series).

Por fim, o modelo D-CAPM é uma generalização do CAPM aplicado quanto o retorno das ações é assimétrico. Este problema pode ser identificado quando se calculada a diferença estatística entre a média e a mediana dos retornos das ações em mercados emergentes (PAIVA, 2005). Neste caso, ao invés de se utilizar a covariância entre o $r_{i}$ e $r_{M}$ e o desvio padrão de $r_{F}$ para o cálculo do $\beta_{i}$ se utiliza os conceitos de semi-covariância e o semi-desvio. Este procedimento, sugerido por Estrada (2000), também é empregado como meio de corrigir distorções provocadas pela baixa liquidez e alta volatilidade que se refletem na assimetria de retornos, característicos em mercados emergentes (PAIVA, 2005).

Face ao exposto, se pode afirmar que a diferença fundamental entre o CAPM e o APT é que este pressupõe que os retornos dos ativos são decorrentes de uma série de fatores setoriais e de mercado. A rigor, o APT supõe que os retornos das ações são gerados por modelos fatoriais (ROSS; WESTERFIELD; JAFFE, 2002). Nesse sentido, o CAPM seria um caso particular do APT que considera como único fator o termo $\left(r_{M}+r_{F}\right)$ na determinação $\beta_{i}$.

Por outro lado e de acordo com Copeland, Koller e Murrin (2002) e Damodaran (2004), um aumento na alavancagem financeira de uma empresa faz com que seu $\beta_{i}$ aumente e vice-versa. Maior nível alavancagem financeira implica em maior $\beta_{i}$. Assim, é necessário que os $\beta_{i}$ 's de diferentes empresas sejam ajustados para que possam ser comparáveis entre si. Dai o emprego do modelo APV e sua relação com o CAPM. Para calcular o beta desalavancado $\left(\beta_{i}^{*}\right)$, utiliza-se a seguinte expressão:

$$
\beta_{i}^{*}=\beta_{i}\left[1+(1-T)\left(\frac{D}{E}\right)\right]
$$

\footnotetext{
${ }^{119}$ A magnitude do $\beta_{i}$ se altera ao longo do tempo e em razão de três fatores: natureza cíclica das receitas, grau de alavancagem operacional, os quais dependem da estrutura de custos fixos e variáveis, e grau de alavancagem financeira (ROSS; WESTERFIELD; JAFFE, 2002).
} 
O $\beta_{i}^{*}$ têm implicações em diversos casos. É empregado quando a empresa é muito alavancada, quando o grau de alavancagem financeira aumenta com a ampliação de financiamentos em carteira, etc. Tal é o caso do setor naval.

Adicionalmente, Damodaran (2004) salienta que além do nível de alavancagem financeira, o nível do $\beta_{i}$ também varia de acordo com a sensibilidade da demanda pelos produtos e serviços da empresa e com a alavancagem operacional. Empresas altamente alavancadas cujos produtos apresentam demanda cíclica ou elástica têm $\beta$ maior. Por outro lado, quanto maior a proporção de custos fixos nos custos totais, maior o $\beta_{i}$. Em face às discussões feitas nos capítulos 1 e 2 , observa-se grande convergência do CAPM e APV com a estrutura de capital das empresas de transporte marítimo.

Na prática, o uso do WACC, obtido a partir do cálculo do $\beta_{i}$, deve ser ajustado com objetivo de captar outras fontes de risco que possam interferir nas transações de ativos entre agentes que atuam em diferentes mercados de capitais. Estes temas e sua modelagem são discutidos nas próximas seções.

\subsubsection{Cálculo do Retorno sobre Capital de Terceiros $-r_{D}$}

Segundo Catapan (2001), defini-se custo de capital de terceiros $\left(r_{D}\right)$ como sendo a taxa de retorno que os credores impõem para realizar empréstimos à empresa demandante de tais recursos. Em parte a definição dessa taxa se relaciona aos procedimentos de análise dos riscos conforme apresentados no capítulo 4. Como os critérios de ponderação das instituições financeiras não são divulgados publicamente, estudos empíricos adotam expedientes relacionados ao conceito de custo de oportunidade ${ }^{120}$.

${ }^{120}$ Isso foi evidenciado ao longo das rodadas de entrevistas. Os agentes chegam a indagar, mesmo considerando o efeito que o endividamento adicional apresenta sobre os riscos operacionais e financeiros, por que financiamentos para uma mesma empresa apresentam condições de juros tão 
A literatura sugere que a apuração da taxa a ser aplicada sobre o capital de terceiros depende da taxa de retorno do ativo livre de risco $\left(r_{F}\right)$ e de um adicional definido como prêmio de risco $\left(r_{M}-r_{F}\right)$. Este deve refletir os riscos associados ao empréstimo de capital em um empreendimento específico. A rigor, deve referenciar a lucratividade esperada de um ativo livre de risco com mesma maturidade e o prêmio de risco sobre a operação de financiamento - uma vez que quem dispõe desse recurso poderia empregá-lo entre fins alternativos. Como será indicado nas próximas subseções, além deste fator, o custo de capital de terceiros $\left(r_{D}\right)$ deve agregar o retorno do ativo livre de risco $\left(r_{F}\right)$, o prêmio de risco país $\left(r_{P}\right)$, o prêmio de risco cambial $\left(r_{\varepsilon}\right)$ e, em muitos casos, um prêmio de risco setorial $\left(r_{I}\right)$ (ROSS; WESTERFIELD; JAFFE, 2002).

$$
r_{D}=r_{F}+r_{P}+r_{\varepsilon}+r_{I}
$$

Esta expressão retorna o custo do capital de terceiro $\left(r_{D}\right)$ em termos nominais. Para ser apurada em termos reais é necessário deflacioná-la a fim de que reflita o custo real da aplicação. Então, a taxa real é obtida por meio da expressão:

$$
r_{D}^{R}=\left(\frac{1+r_{D}}{1+\pi}\right)-1
$$

\subsubsection{Cálculo do Retorno do ativo Livre de Risco e Taxas de Juros Empregadas no Financiamento Setorial $-r_{D}$}

Em operações financeiras realizadas por bancos privados o retorno do ativo livre de riscos, tal como o US Treasury 10 nos EUA, serve de piso para o

diferenciadas. Nesse contexto, reclamam da falta de transparência em relação aos critérios de avaliação adotados. 
estabelecimento da taxa a ser aplicada em um contrato de transferência de ativos financeiros. No Brasil, por exemplo, a taxa de referência utilizada pelo mercado é a taxa Over Selic. Esta constitui a taxa básica de juros a partir da qual as demais taxas de juros praticadas no mercado gravitam. Esta taxa remunera os títulos da dívida pública e tem relação com a condução da política monetária.

No caso do financiamento setorial as taxas são subsidiadas e refletem as opções que norteiam a estrutura do financiamento em cada caso. Como apresentado no quadro 5, cada país possui uma taxa de referência que serve para balizar as operações de financiamento orientadas ao setor naval. No caso do Brasil, por exemplo, a taxa de referência se encontra entre 2,5 e 5\% a.a., acrescida da TJPL ou variação do US\$, por meio da Ptax. Assim, o processo de modelagem levará em conta não a taxa do ativo livre de risco, mas as taxas subsidiadas tal como expressas no quadro 5.

Quando ativos financeiros são transacionados em diferentes mercados se deve atribuir um ganho adicional associado ao risco país o qual é apresentado a seguir.

\subsubsection{Cálculo do Risco País - $r_{P}$}

Quando são efetuadas operações de transferência de ativos financeiros entre agentes radicados em diferentes países, é preciso incorporar no $r_{D}$ um prêmio de risco adicional que se reflete na magnitude do $r_{\text {WACC }}$. Assim dimensionado, $r_{D}$ captura o chamado risco país o qual procura captar o grau de desconfiança do mercado quanto ao não cumprimento de contratos e ou dificuldades no reembolso de valores transferidos nessas transações. Ao considerar fatores associados ao risco país $\left(r_{P}\right)$, o retorno exigido deve então ser reescrito como:

$$
r_{D}^{*}=r_{F}+r_{P}
$$


Com efeito, esta remuneração adicional sobre o retorno do ativo livre de risco deve ser dimensionada. O risco país se origina da falta de perfeita mobilidade de capitais. A literatura especializada diferencia o risco país do risco soberano (SHARPE; ALEXANDER; BAILEY, 1999).

O risco país $\left(r_{P}\right)$ é o risco adicional que um projeto carrega por ser desenvolvido em determinado país, em comparação a ser desenvolvido em uma economia mais estável e com maior solidez institucional. Em geral, o $r_{P}$ se encontra relacionado à possibilidade de instabilidade política, institucional e de condução da política monetária e fiscal de uma nação. Isso remete ao conceito de risco soberano $\left(r_{s}\right)$. Este pode ser modelado a partir da diferença entre a rentabilidade dos títulos públicos emitidos e negociados no exterior (C-Bond ou Global Bond) e dos títulos livres de risco, como os bônus do tesouro americano (US Treasury). Tal diferença reflete o prêmio de risco soberano $\left(r_{s}\right)$.

$$
r_{S}=r_{C-B O N D}-r_{U S-T R E A S U R Y}
$$

Com efeito, o risco país agrega risco soberano $\left(r_{S}\right)$ e o risco de crédito $\left(r_{C}\right)$. Para que seja possível obter este, de $r_{S}$ se deve subtrair o $r_{C}^{K}$. Esse último compreende o que as empresas dos EUA com mesma classificação de crédito (ou que atuam no mesmo setor econômico) pagam acima do bônus do tesouro dos EUA. O resultado é o prêmio de risco do país $\left(r_{P}\right)$.

$$
r_{P}=r_{S}-r_{C}^{K}
$$

Onde $r_{S}$ é o risco soberano, definido acima. Já $r_{C}^{K}$ constitui o fator que capta o risco de crédito definido como o spread de risco que as empresas com mesma classificação de risco estão pagando sobre a taxa livre de risco traduzida pelo US Treasury. Formalmente o risco de crédito é obtido por meio da seguinte expressão: 


$$
r_{C}^{K}=r_{U S-T R E A S U R Y}+\frac{\sum \theta}{n}
$$

Onde o $r_{C}^{K}$ constitui a soma entre do $r_{F}$ e uma média ponderada do risco de crédito das empresas do setor. Com efeito, sobre as taxas de juros aplicadas nas transferências de ativos de capital, feitas por meio de financiamento externo, também devem considerar outras fontes de risco. Nessas operações, a variação no preço relativo da moeda também implica em fonte adicional de risco. A rigor, os investidores também exigem um prêmio de risco que capta a expectativa de variação cambial. A modelagem de tratamento dessa fonte de risco é discutida a seguir.

\subsubsection{Cálculo do Risco Cambial $-r_{\varepsilon}$}

Durante a década de 1990, com a implementação do Plano Real, o país teve o câmbio controlado. O Plano Real de estabilização viabilizou a reforma patrimonial pública e privada e conduziu ao incremento do volume de investimento externo direto no país por meio da abertura comercial e financeira. Com a posterior passagem para o regime de câmbio flutuante, em 15 de janeiro de 1999, passou a ser importante a introdução do prêmio de risco cambial como meio de proteger os investidores estrangeiros de eventuais perdas em razão da flutuação do preço da moeda local em relação a outras moedas. Em geral, este risco é medido em termos da flutuação do preço da moeda local em relação ao preço do US\$.

O equilíbrio no mercado monetário implica que caso haja diferenciais pronunciados nas taxas de juros entre dois países haverá um movimento de capital do país de menor taxa para o país de maior taxa. $O$ resultado é o estabelecimento do equilíbrio entre as respectivas taxas a taxa de juros. Nesse movimento, a taxa de juros externa deve refletir a taxa de juros interna, a expectativa de desvalorização cambial e o prêmio de risco do país (KRUGMAN; OBSTFELD, 2001). Formalmente: 


$$
r_{X}=r_{M}+(F-S)+r_{P}
$$

O termo $(F-S)$ constitui o chamado forward premium, observável no mercado futuro do dólar e pode ser decomposto em duas parcelas: $(F-S)=E\left(S_{T}-S_{t}\right)+r_{\varepsilon}$. Onde $S_{T}$ é a taxa de câmbio do dólar a vista futuro, $S_{t}$ é a taxa do dólar cotada no presente e $r_{\varepsilon}$ é o risco cambial objeto de análise. A partir da equação anterior, também pode ser calculado o prêmio de risco país. Apesar de esse modelo gerar resultados com elevado grau de correlação com o modelo apresentado na seção anterior, pode haver sérias divergência em razão de incompatibilidades de prazo, efeito tributário e influência das expectativas dos agentes quanto ao risco país. Por esta razão este é adotado exclusivamente para o cálculo do risco cambial. Acionalmente e conforme apresentado a seguir, o risco setorial também deve ser captado na modelagem.

\subsubsection{Cálculo do Risco Setorial $-r_{I}$}

Na seção 5.2.3 definiu-se o risco de crédito como sendo o que as empresas dos EUA com mesma classificação de crédito pagam acima do bônus do tesouro dos EUA. A despeito dessa definição o $r_{I}$ também pode ser apurado por meio dos indicadores econômico-financeiros. Para tanto, deve ser estabelecida uma estrutura de ponderação que agregue os diversos indicadores (KASSAI, 2000). Esta deve retornar uma estimativa $r_{I}$ para o setor e para cada empresa em particular. Como a estrutura de ponderação dessas instituições não é divulgada, tais métodos não serão empregados no presente estudo. Essa decisão também se apóia na constatação de que a transferência de ativos orientados a certos setores econômicos conta com subsídios públicos interferindo no equilíbrio de mercado e nas taxas aplicadas nas operações. Tal é o caso do setor naval. 


\subsubsection{Cálculo da Taxa de Retorno sobre Capital de Terceiros no Modelo Proposto $-r_{D}^{K}$}

A taxa de desconto exigida para o emprego de capital de terceiros captado junto a um país $K$ reflete, a depender do caso, a taxa de juros prevista na estrutura de financiamento $i_{K}$, o risco cambial e o risco país. Admitindo-se que a embarcação será financiada por armador local e construída em estaleiro nacional, podendo este submeter sua proposta as diferentes estruturas de financiamento (quadro 5), a taxa de juros empregada no modelo pode ser definida como:

$$
r_{D}=\left\{\begin{array}{cc}
r_{D}^{B}=f\left(i_{B}, i_{j}\right) & \text { no caso do Brasil } \\
r_{D}^{K}=g\left(i_{K}, r_{P}^{B}, r_{\varepsilon}^{B . K}\right) & \text { no caso do país K }
\end{array}\right.
$$

Ante ao exposto, a taxa $i_{j}$ a qual determina a magnitude de $r_{D}^{B}$, deve referenciar a TJLP ou variação da Ptax. Adicionalmente, admitindo-se que o armador possa submeter sua proposta a diferentes estruturas de financiamento, respeitando as respectivas condições de cada uma conforme apresentadas no quadro 5 , os riscos país $r_{P}^{B}$ e cambial $r_{\varepsilon}^{B, K}$ referenciam as únicas fontes de risco associadas à transferência de ativos do país $K$ ao país $B$, devendo ser apropriadamente dimensionados. Nesse sentido, se assume que dada a estrutura de financiamento de cada país $K$ (Japão, China, etc.), o diferencial associado ao custo de capital de terceiros deverá refletir, além da taxa de juros empregada nas operações $i_{K}$ conforme apresentadas no quadro 5, apenas o risco cambial e o risco país.

Por fim, como será demonstrado a seguir, para cada país $K$ como os valores de $r_{D}^{K}$ irão diferir em razão de $i_{K}$ e $r_{\varepsilon}^{B, K}$. Dessa forma, o termo $r_{\text {WACC }}$ também será diferenciado em cada caso, refletindo ainda as proporções $E / E+D$ e $D / E+D$. Como $r_{D}^{K}$ é aplicado na determinação do valor das prestações, o mesmo efeito ocorre em 
torno do valor das $P M T_{t}$ devido à relação desse fator com o processo de formação do juro embutido no valor de cada parcela.

\subsection{Hipóteses Assumidas e Modelo Matemático Proposto}

\subsubsection{Hipóteses Assumidas}

O modelo proposto a seguir possui três componentes fundamentais: determinação do $P M T_{t}$ por meio do aproveitamento das informações apresentadas no quadro 5; estimação e uso da taxa empregada no financiamento em nível local $\left(r_{D}^{B}\right)$ e internacional $\left(r_{D}^{K}\right)$ (idem); estimação e uso da taxa $r_{E}$ para as empresas de transporte marítimo. Como explicitado acima o cálculo dessas últimas são particularmente importantes uma vez que se relacionam a determinação do valor das prestações em cada país afetado ainda a retorno $\left(r_{\text {WACC }}\right)$, obtido por meio do emprego do WACC. O ANEXO 9 contém todas as fórmulas empregadas na determinação do fluxo final de despesas financeiras, incluindo a determinação dos saldos devedores sobre juros e amortizações (essas formulações são utilizadas nas tabelas do ANEXO 10 que geram o índice de atratividade).

Para efeito da aplicação do modelo proposto, e dados os objetivos de seu emprego, se admite seis hipóteses de trabalho:

- $\mathrm{H} 0$ - a taxa de retorno sobre o capital próprio ${ }^{r_{E}}$ reflete a remuneração das empresas de navegação internacionais podendo ser aferida por meio do CAPM - esta hipótese, denominada shadow price, foi assumida pos não se obteve dados para estimar as taxas de retorno das empresas locais, por se tratar de setor que atua em competição global e devido as similaridades da estrutura de capital das empresas;

- H1 - a embarcação será financiada por armador local e construída em estaleiro nacional, nesse caso as receitas e demais categorias de 
gastos podem ser abstraídas também o prazo de construção e processo de alocação do capital pode ser considerado exógeno;

- $\mathrm{H} 2$ - o armador pode submeter sua proposta a diferentes estruturas de financiamento, respeitando as respectivas condições de cada uma conforme apresentadas no quadro 5;

- H3 - admite-se que apenas duas fontes de capital possam financiar o empreendimento: capital próprio $(E)$ e de terceiros (D), por meio do financiamento;

- H5 - o custo do capital de terceiros reflete a taxa de juros empregada em cada estrutura de financiamento, conforme o quadro 5 , bem como o risco país e o cambial;

- H6 - a taxa de desconto sofre efeitos dos diferencias de custo sobre o capital de terceiros.

Essas hipóteses são particularmente importantes no modelo. Em suma, a modelagem doravante aplicada parte dos seguintes pressupostos: considera uma operação de financiamento de embarcação feita por uma empresa de transporte ou apoio marítimo brasileira, a ser construída em estaleiro nacional e que submete o projeto a diferentes linhas de financiamento. Em cada caso, o indicador $I A_{B, K}$, definido a seguir, informará qual a condição mais vantajosa por meio do $V P L_{C}$.

Dessas hipóteses resulta que, excetuando-se as despesas financeiras, os demais dados (fluxo de receitas, custos operacionais e demais despesas) não são relevantes para as análises subseqüentes, podendo ser abstraídos do modelo. A adoção desse procedimento, além de fixar exclusivamente nas diferenças oriundas do diferencial de custo financeiro $\left(P M T_{t}^{K}\right)$, quando aplicados os diferentes parâmetros apresentados no quadro 5 e as variáveis $r_{D}^{K}, r_{P}$ e $r_{\varepsilon}$, afasta o grau de subjetividade e contorna a escassez de informações necessárias para a estimação de receitas e demais itens de gasto associados a um projeto. Com efeito, permite dar maior ênfase no diferencial de custos de capital quando adotados os parâmetros da diferentes estruturas de financiamento. Com avanços das pesquisas nesta área, outros estudos podem incorporar estes elementos adensando a modelagem e tornando mais realista a aplicação do modelo. 
Com efeito, o valor esperado de cada fluxo de despesas financeiras no instante $t$ será doravante denotando por $\mathrm{PMT}_{t}^{K}$. Conforme indicado a seguir, dado o valor da embarcação a ser financiada $P$, os valores de $P M T_{t}^{K}$ podem ser obtidos por meio do emprego dos diferentes parâmetros apresentados no quadro 5 , com destaque às taxas $r_{D}^{K}$ e $r_{D}^{B}$. Uma vez obtidos esses valores, aplica-se o conceito de $V P L_{C}^{K}$ por meio do emprego das taxas $r_{\text {WACC }}$. Por fim, com base no $V P L_{C}$ de cada país $\left(B\right.$ e $K$ ) se obtém o índice $I A_{B, K}$, apresentado a seguir.

\subsubsection{Modelo Matemático Proposto}

Ante ao exposto, os procedimentos aqui adotados se baseiam nos seguintes instrumentos: modelo de precificação de ativos de capital (CAPM), emprego do custo médio ponderado de capital (WACC), emprego de sistemas de amortização, processo de equalização de prazo de operações por meio do modelo de atividade cessante $(A C)$ e seu uso na apuração valor presente líquido de custos $V P L_{C}^{K}$ das prestações de financiamento. Conforme explicitado nessa seção, esses elementos serão utilizados para obtenção do valor presente líquido das despesas financeiras $\left(V P L_{C}^{K}\right)$ quando adotados os parâmetros da estruturar de financiamento de cada país K (Japão, Coréia do Sul, Alemanha, Noruega, China e EUA) ou brasileiro (B).

Conforme apresentado na seção 5.2, o valor de cada prestação, ao incorporar amortização e juro $\left(P M T_{t}^{K}=A^{K}+J_{t}^{K}\right)$, pode ser obtido por meio do Sistema de Amortização Constante (SAC), amplamente empregado nas operações de financiamento setorial e cuja determinação depende dos seguintes componentes.

O valor do projeto de construção do navio a ser financiado, doravante denotado por $P$. Este é formado exogenamente, no processo de negociações entre armador e estaleiro, e a partir da definição das condições apresentadas no quadro 5.

Sob o SAC, adaptado a presente modelagem e dado o prazo de carência $\left(z_{K}\right)$, previsto nas operações de financiamento, o valor da amortização $\left(A^{K}\right)$ é formado por dois componentes. Uma parcela depende do valor financiado 
$\left(D^{K}=\theta^{K} P\right)$, este restrito pelo percentual de participação previsto na estrutura de financiamento do país $K\left(\theta^{K}\right)$. A outra parcela se associa ao estoque dos juros acumulados durante $o$ período de carência $\left[\sum_{j=0}^{a_{z_{K}}} P_{j}\left(1+r_{D}^{K}\right)^{j}-\sum_{j=0}^{z_{K}} P_{j}\right]$. Nessas operações, durante o período $z_{K}$ são formados e acumulados juros sobre o valor de cada parcela de desembolso, $P_{j}$ (onde $\left.j=1,2, \ldots, z_{K}\right)^{121}$. O termo $\alpha$ corrige o período de carência de acordo com o prazo de capitalização e periodicidade da taxa de juros (quadro 5).

Esse dois elementos que compõe $P M T_{t}$ devem ser dimensionados pelo prazo de amortização $n_{K}$ estabelecido nas negociações. Desta forma, o valor da amortização pode ser calculado por meio da seguinte expressão: $A_{D}^{K}=\frac{D_{k}}{\alpha n_{K}}=\frac{\sum_{j} P_{j}}{\alpha n_{K}}$, onde $n_{K}$ denota o prazo total da operação o termo $P_{j}$ correspondem aos recursos aportados no projeto pela instituição financeira no instante $j=1,2, \cdots, z_{K}$, segundo a programação estabelecida no projeto. Com efeito, $D^{K}=\sum_{j=o}^{2 \alpha} P_{j}=\theta^{K} P^{K}$. No caso o prazo de construção, definido exogenamente, foi fixado em 2 anos.

De maneira análoga, o valor das parcelas de juro em cada instante $t$ também é derivada por meio de dois componentes. O primeiro deve ser apurado por meio da incidência da taxa de juros $r_{D}^{K}$ sobre o saldo devedor relacionado ao principal da dívida $\left(D^{K}\right)$. Tal taxa constitui o custo de capital de terceiros. A outra parcela reflete a incidência dessa mesma taxa sobre o total dos juros acumulados durante o período de carência, $z_{K}$. De maneira simplificada, o valor total dos juros no instante $t$ pode ser escrito como $J_{t}=\frac{r_{D}^{K}}{\alpha n_{K}}\left[\sum_{j=0}^{2 \alpha} P_{j}\left(1+r_{D}\right)^{\alpha z_{K}-j}\left(\alpha n_{K}+\alpha z_{K}-t\right)\right]$ - relembrando que o pagamento de $\operatorname{PMT}_{t}^{K}$ se inicia após o término do período de carência $\left(z_{K}\right)$ no qual se forma o juro sobre o saldo devedor $\left[\sum_{j=0}^{\alpha_{2}} P_{j}\left(1+r_{D}^{K}\right)^{j}-\sum_{j=0}^{z_{K}} P_{j}\right]$, o qual é obtido por

${ }^{121}$ Como será indicado, no processo de simulação se assumiu que o prazo de construção é de no mínimo 2 anos ou quatro semestres. 
meio da incidência da taxa de juros $r_{D}^{K}$ sobre cada parcela de desembolso $P_{j}$ prevista na programação do projeto.

Assim, o fluxo de caixa relevante na modelagem subseqüente é $P M T_{t}^{K}=A^{K}+J_{t}^{K}$, onde o sobrescrito indica que o valor da prestação no instante $t$ foi obtido por meio do emprego dos parâmetros de financiamento do país $K$, conforme apresentados no quadro 5 (seção 2.7). O mesmo procedimento deve ser adotado para a apuração do valor das prestações nacionais.

Nesse contexto, o processo de avaliação leva em conta (abstraindo a avaliação dos indicadores econômico-financeiros discutidos no capítulo 4) a determinação do montante a ser financiado $D_{K}$, a taxa de juros $r_{D}^{K}$, o período de carência $z_{K}$ e do prazo $n_{K}$. Estes elementos se encontram no cerne do processo de verificação da atratividade da estrutura de financiamento do país $B$ em relação ao país $K$.

Como demonstrado nas seções anteriores, a taxa $r_{D}^{K}$ não se confunde com a taxa de desconto $r$ empregada na avaliação do fluxo de caixa; não obstante ela é empregada na apuração do valor dos juros e amortizações embutidos na formação de cada parcela $P M T_{t}^{K}$ e no calculo da taxa de desconto, $r_{\text {WACC }}$.

Quando há diferenciais no prazo total do financiamento, $\overline{n_{K}}=\left(n_{K}+z_{K}\right) \leq \overline{n_{K}}=\left(n_{B}+z_{B}\right)$, o $V P L_{C}$ de cada alternativa não pode ser comparado diretamente. Para que isso seja possível estes devem ser corrigidos por meio de um critério de equalização prazos. Como o que se objetiva é construir um indicador destinado a comparar a atratividade da exposição de um projeto a diferentes linhas de financiamento adotou-se o modelo conhecido como atividade cessante $(A C)$. Assim, quando $\overline{n_{K}}=\left(n_{K}+z_{K}\right) \leq \overline{n_{K}}=\left(n_{B}+z_{B}\right)$ o valor de cada parcela $P M T_{t}^{K}$ deve ser ajustado no tempo conforme discutido a seguir.

Considerando duas alternativas de financiamento mutuamente excludentes, sob este critério os termos $P M T_{t}$ da alternativa de menor prazo total $\bar{n}_{K}=\left(n_{K}+z_{K}\right)$ devem ser levados a valor futuro por meio do correspondente fator de valor futuro $\left(1+r_{\text {WACC }}\right)^{t}$ - onde $\left(t=1,2, \ldots, n_{K}\right)$. A partir da soma do valor futuro das prestações até o instante $n_{K}$, se aplica $\left(1+r_{W A C C}^{K}\right)^{\left(\bar{n}_{B}-\bar{n}_{K}\right)}$. Em seguida, se traz o resultado obtido a 
valor presente pelo fator de valor atual $1 /\left(1+r_{\text {WACC }}\right)^{\left(\overline{\bar{z}}_{B}+\bar{n}_{B}\right)}$. Este procedimento, ao garantir a equalização de prazos das diferentes alternativas, possibilita a comparação direta entre os valores presente $\left(V P L_{C}^{K}\right)$ dos diferentes fluxos de pagamentos $\left(P M T_{t}^{K}\right)$ no instante 0 .

A taxa aplicada sobre o valor de cada parcela deve ser $r_{W A C C}^{K}$ uma vez que ela se relaciona com o processo de avaliação do fluxo de caixa representado pelos custos da operação de financiamento $\left(r_{D}^{K}\right)$. A taxa $r_{D}^{K}$ só é empregada isoladamente no dimensionamento do valor dos juros relacionados ao saldo devedor e reflete o retorno exigido pelo capital de terceiros. O mesmo se aplica a taxa $r_{D}^{B}$.

Assim, dados dois diferentes modelos de financiamento, a determinação do $V P L_{C}^{K}$ de financiamento à construção naval do país $K$ pode ser feita por meio da seguinte desigualdade:

$$
V P L_{C}^{K}=\left\{\begin{array}{cl}
A C \sum_{t=\alpha z_{K}}^{\alpha n_{K}} P M T_{t}^{K}\left(1+r_{W A C C}^{K}\right)^{\alpha \overline{n_{K}}-t} & \text { se } \overline{\mathrm{n}_{B}}=\mathrm{z}_{B}+n_{B} \geq \overline{\mathrm{n}_{K}}=z_{K}+n_{K} \\
\sum_{t=0}^{\alpha n_{K}} \frac{P M T_{t}^{K}}{\left(1+r_{W A C C}^{K}\right)^{t+\alpha z_{K}}} & \text { se } \overline{n_{B}}=z_{B}+n_{B}<\overline{n_{K}}=z_{K}+n_{K}
\end{array}\right.
$$

Onde: $\quad \mathrm{PMT}_{t}^{K}, \quad A C=\left[\frac{\left(1+r_{\text {WACC }}^{K}\right)^{\left[\left(z_{B}+n_{B}\right)-\left(z_{K}+n_{K}\right)\right] \alpha}}{\left(1+r_{W A C C}^{K}\right)^{\left(z_{B}+n_{B}\right) \alpha}}\right], \quad z_{K}+n_{K}, \quad z_{B}+n_{B}, \quad$ e $\quad r_{W A C C}^{K}$ representam, respectivamente, o valor da prestação no instante $t$, obtido por meio do método SAC, comumente empregado no financiamento setorial; o fator de equalização de prazos $A C_{z_{i_{i}} n_{i} \geq z_{j+} n_{j}}$ apresentado acima; os prazos de carência e amortização do país $K$ e $B$ (Brasil), e a taxa mínima de atratividade, apurada por meio do custo médio ponderado do capital (WACC) por meio do emprego do CAPM. Por fim, o termo $\alpha$ ajusta os prazos, apurados anualmente, ao período de 
capitalização de cada sistema de financiamento conforme apresentados no quadro 5. O mesmo se aplica em relação à apuração do $V P L_{C}^{B}$.

Assim, para efeito de comparação das diferentes estruturas de financiamento e dada a interpretação de $V P L_{C}$ vista acima, o indicador de atratividade do financiamento brasileiro $(B), \quad V P L_{C}^{B}$, em relação ao $V P L_{C}^{K}$ do país $K$ e objeto das simulações apresentadas adiante, pode ser escrito por meio da seguinte desigualdade:

$$
I A_{B, K}=\left\{\begin{array}{cc}
0 \leq \frac{V P L_{C}^{B}}{V P L_{C}^{K}} \leq 1 & \text { se o modelo de financiamento local for mais atrativo que o do país } \mathrm{K} \\
\frac{V P L_{C}^{B}}{V P L_{C}^{K}}>1 & \text { caso contrário }
\end{array}\right.
$$

A desigualdade será utilizada no emprego das simulações ${ }^{122}$. Como se trata de índice de custos, caso $0 \leq I A_{B, K} \leq 1$, o custo do financiamento local é menor que o do apurado por meio do financiamento junto ao país $\mathrm{K}$ e vice-versa.

Antes de apresentar como foram implementadas as simulações, resta registrar que o modelo proposto foi apresentado, verificado e validado durante a segunda e terceira rodada de entrevistas. Adicionalmente, foi apresentado a especialistas da Universidade Federal do Rio de Janeiro (COPPE/UFRJ) e professores da Faculdade de Economia, Administração e Contabilidade da Universidade de São Paulo (FEA/USP). Esse reconheceram sua relevância na abordagem no tratamento da questão 2 formulada nesse estudo (ANEXO 11).

\subsection{Estrutura do Modelo de Simulação}

A formulação do modelo de simulação se fez necessária uma vez que não foi possível obter dados de projetos realizados com objetivo de analisar e comparar o

\footnotetext{
${ }^{122}$ As derivadas parciais de cada função são apresentadas no ANEXO 7.
} 
diferencial das estruturas de financiamento em vigor nos diferentes países (Japão, Coréia do Sul, China, Alemanha, Noruega e EUA) com a atualmente praticada no Brasil pelo BNDES.

Ao utilizar o modelo proposto, a fim de testar em que condições o financiamento local é mais atrativo quando comparado a esquemas existentes em outros países por meio do índice $I A_{B, K}$, foram realizados experimentos baseados em simulações de Monte Carlo. A rigor, essa consiste em um processo de elaboração de um sistema hipotético e a condução de experimentos com a finalidade de verificar seu comportamento. Desta maneira uma simulação consiste em uma técnica de solução de um problema feita a partir da formulação e análise de um modelo que descreve o comportamento de um sistema usando um computador.

Um "bom" modelo é aquele que permite atingir aos objetivos da simulação com o mínimo de custo. Segundo Evans e Olson (1998), um bom modelo deve possuir duas características: (i) é válido - no sentido de representar satisfatoriamente a realidade; (ii) é simples - no sentido de incluir somente os elementos que influenciam no problema a ser solucionado.

Três categorias de simulação computacional: simulação de Monte Carlo, simulação contínua e simulação de eventos discretos. A simulação de Monte Carlo é aquela onde um problema, notadamente não probabilístico, é solucionado por um modelo estocástico. Nessa abordagem, inexiste a representação do tempo. Tanto a simulação contínua (equações diferenciais) como a simulação de eventos discretos, levam em conta o tempo.

O método de simulação de Monte Carlo tem por base a geração de números aleatórios, de acordo com parâmetros definidos para as variáveis que compõem o modelo a ser utilizado. A simulação de Monte Carlo é basicamente um experimento amostral, cuja proposta é estimar a distribuição de uma variável de saída que depende de diversas variáveis probabilísticas de entrada (EVANS; OLSON, 1998, p. 6). Segundo Evans e Olson (2002), uma simulação pode ser definida como o processo de construir um modelo matemático ou lógico de um sistema ou um problema de decisão para, em seguida, experimentá-lo (normalmente com auxílio computacional) a fim de obter insights acerca de seu comportamento.

De acordo com Evans e Olson (2002), ao discutir a natureza e os métodos relacionados aos processos de simulação, o procedimento adotado deve seguir 
cinco etapas lógicas: desenvolvimento do modelo conceitual, construção do modelo, verificação e validação, desenho de experimentos e execução e análise.

A aplicação do modelo se baseou na construção de 6 pares de planilhas ${ }^{123}$ destinadas em cada caso a:

- receber as informações relacionadas à estrutura de financiamento de cada país, $K$ e $B$, conforme o quadro 5 (prazos, participações, etc.);

- receber o valor dos correspondentes componentes necessários (taxa de retorno sobre capital próprio e de terceiros e seus diversos componentes) para calcular os valores de amortização (esta decomposta em amortização sobre o valor do financiamento e do montante de juros apurados até o final período de carência);

- receber o valor dos correspondentes componentes necessários para o cálculo do valor dos juros em cada período de tempo (este composto pelo juro apurado sobre o saldo devedor e sobre o montante dos juros acumulados durante o período de carência);

- calcular, em cada momento, o valor das prestações $P M T_{t}$, garantido que, durante o processo de simulação esses se ajustassem automaticamente a variações no período de carência e no prazo de amortização em cada rodada das simulações;

- realizar o processo de equalização de prazos para tornar os valores presentes comparáveis em termos do maior prazo total;

- efetuar o cálculo dos termos $V P L_{C}^{K}$ e $V P L_{C}^{B}$ retornando o valor de $I A_{B, K}$ para cada par de países $K$ e $B$;

- retornar seis gráficos com os resultados das simulações executadas;

- retornar as estatísticas associadas às seis simulações executadas.

Para tanto, macros especiais foram desenvolvidas a fim de garantir a validade do modelo (EVANS; OLSON, 2002), garantir o processo de ajustamento de prazos e

\footnotetext{
${ }^{123}$ Para efeito da execução das simulações, essas relacionam dados dos seguintes países: Brasil e Japão; Brasil e Coréia do Sul; Brasil e China; Brasil e EUA; Brasil e Alemanha; Brasil e Noruega. Todas disponíveis em CD ROM junto a Biblioteca do Departamento de Engenharia Naval e Oceânica da Escola Politécnica da Universidade de São Paulo (POLI/USP).
} 
executar o modelo de atividade cessante (AC). Feita a verificação (EVANS; OLSON, 2002) das planilhas, o experimento desenhado visou a geração de $I A_{B, K}$ (índice de atratividade do financiamento brasileiro em relação ao país $\mathrm{K}$ ).

Todos os arquivos que geraram as simulações por meio de planilhas em Excel podem ser consultados em CD ROM disponível junto a Biblioteca do Departamento de Engenharia Naval e Oceânica da Escola Politécnica (POLI/USP).

Conforme detalhado na seção 5.6, o processo de simulação incorpora como termos aleatórios os diversos componentes da estrutura de financiamento para cada país $\left(D^{K}, n_{K}, z_{K}\right.$, etc.) e os fatores de risco presentes em $r_{D}^{K}\left(i_{K}, r_{P}\right.$ e $\left.r_{\varepsilon}\right)$ e em $r_{W A C C}\left(r_{D}^{K}\right.$ e $\left.r_{E}\right)$. Assim, ao ser executado torna aleatória as parcelas $P M T_{t}$ e assim os valores de $V P L_{C}^{K}, V P L_{C}^{B}$ na formação da distribuição de $I A_{B, K}$.

Com efeito, um sumário das equações fundamentais do modelo e das variáveis de entrada é apresentado no quadro 25. Este resume os dados de entrada do modelo em torno dos seguintes componentes: equações empregadas, variáveis ou parâmetros do modelo, descrição sumária dos parâmetros ou variáveis, fonte secundária de dados, período de apuração e formato empírico das distribuições das variáveis ${ }^{124}$.

A interpretação do modelo está associada ao número de ocorrências e freqüências associadas a $\left(0 \leq I A_{B, K} \leq 1\right)$ para cada par de simulação entre $B$ e $K$ (onde K representa Japão, China, Coréia do Sul, Alemanha, Noruega e EUA). Caso o número de ocorrências abaixo de 1,0 seja maior que 0,5 a estrutura brasileira será considerada mais atrativa. Os procedimentos devem permitir ainda a verificação da contribuição de cada componente na variação no índice de atratividade. Nesse caso, estes podem estar associados aos parâmetros da própria estrutura de financiamento (diferenciais de prazo, etc.) ou dos fatores de risco embutidos na taxa de desconto (ANEXO 10).

O processo de simulação a partir das 6 planilhas foi feito por meio do emprego do software Crystal Ball @ 7.1. Neste caso, certas células deveriam conter as variáveis aleatórias que iriam alimentar o modelo.

${ }^{124}$ Este procedimento foi possível graças ao emprego do software BestFit $4.5{ }^{\circledR}$. 
Feita esta exposição sumária dos aspectos operacionais, a parte final dessa seção trata do cálculo empírico das variáveis aleatórias que alimentam o modelo proposto. As informações que irão alimentar o modelo proposto, foram obtidas junto a New York Stock Exchange (NYSE) e outras fontes de informação (OCDE, Unctad, BACEN, etc.). A rigor, as simulações foram elaboradas a partir de dados de 44 empresas de transporte marítimo e de outras estatísticas econômicas e financeiras ${ }^{125}$. Conforme apresentado no capítulo 4 , atuando em escala global, estas empresas administraram ativos da ordem de US\$ 48 bilhões em 2005 e refletem os movimentos do mercado de transporte naval, política de investimento e rentabilidade setorial.

${ }^{125}$ Das 48 empresas abordadas no capítulo 4, foi possível obter dados relacionados a operações em mercado aberto de apenas 44. Essas informações são apresentadas de maneira sumária nessa seção. 


\begin{tabular}{|c|c|c|c|c|c|}
\hline $\begin{array}{l}\text { EQUAÇÃO/PARÂMETRO } \\
\text { EMPREGADO }\end{array}$ & $\begin{array}{l}\text { VARIÁVEIS OU } \\
\text { PARÂMETROS DO } \\
\text { MODELO }\end{array}$ & DESCRIÇÃO SUMÁRIA DOS PARÂMETROS OU VARIÁVEIS & $\begin{array}{c}\text { FONTE PRIMÁRIA } \\
\text { DE DADOS }\end{array}$ & $\begin{array}{l}\text { PERÍODO DE } \\
\text { APURAÇÃO }\end{array}$ & FORMATO DA DISTRIBUIÇÃO \\
\hline \multirow{3}{*}{$\begin{array}{c}\text { Taxa de retorno sobre o capital } \\
\text { próprio da carteira das empresas } \\
\text { de } \\
\text { Navegação }(N a v) \\
r_{E}=r_{F}+\beta_{N A V}\left(r_{M}-r_{F}\right)\end{array}$} & $r_{F}$ & Taxa de retorno do ativo livre de risco (US Treasury de 10 anos). & NYSE & $2002 / 2006$ & Não se aplica \\
\hline & $r_{M}$ & Taxa de retorno do ativo de mercado (Dow Jones). & NYSE & $2002 / 2006$ & Não se aplica \\
\hline & $\beta_{N A V}$ & Beta da carteira das empresas de navegação (Nav). & $\begin{array}{l}\text { Estimado com } \\
\text { dados NYSE }\end{array}$ & $2002 / 2006$ & Não se aplica \\
\hline \multirow{2}{*}{$\begin{array}{c}\text { Taxa de juros do credor nacional } \\
\text { (BNDES) } \\
r_{D}^{B}=f\left(i_{B}, i_{j}\right)\end{array}$} & $i_{B}$ & Taxa de juros financiamento setorial brasileira. & Quadro 1 & $2002 / 2006$ & Uniforme contínua $\left({ }^{*}\right)$ \\
\hline & $i_{j}$ & Câmbio R\$/US\$ - para Brasil foi tomada a taxa Ptax e a TJLP. & BACEN/OCDE & $2002 / 2006$ & Disponível em CD ROM $\left({ }^{* *}\right)$ \\
\hline \multirow{2}{*}{$\begin{array}{l}\text { Taxa juros ou retorno exigido pelo } \\
\text { credor estrangeiro }\end{array}$} & $i^{K}$ & Atual taxa de juros financiamento setorial do país $K$. & Quadro 1 & NA & Uniforme contínua $\left({ }^{*}\right)$ \\
\hline & $r_{e}^{K}$ & Câmbio $\$ / U S \$$ país $K$ em relação a R $\$ / U S \$$ & OCDE & $2002 / 2006$ & Disponível em CD ROM $\left({ }^{* *}\right)$ \\
\hline $\begin{array}{c}r_{D}^{K}=g\left(i_{K}, r_{e}^{B, K}, r_{P}^{B}\right) \\
\text { (conforme teoria que trata da } \\
\text { transferência de ativos financeiros } \\
\text { entre diferentes países) }\end{array}$ & $r_{P}$ & Taxa que capta o risco soberano definido por $r_{S}=r_{C-B O N D}-r_{U S-T 10}$ & NYSE & $2002 / 2006$ & Disponível em CD ROM $\left(^{* *}\right)$ \\
\hline VALOR DA EMBARCAÇÃO & $P$ & Valor a ser financiado fixado na simulação em US\$ 100.000. & $\begin{array}{l}\text { Valor definido } \\
\text { exogenamente }\end{array}$ & NA & Uniforme contínua $\left({ }^{*}\right)$ \\
\hline \multirow[t]{2}{*}{$\begin{array}{l}\text { ESTRUTURA DE CAPITAL } D_{j} \\
\qquad(j=B, K)\end{array}$} & $D_{j}$ & Valor a ser financiado dentro do intervalo definido como $\left(0,5 \overline{P_{B}} ; \theta^{K} \overline{P_{B}}\right)$. & Quadro 1 & NA & Uniforme contínua $\left({ }^{*}\right)$ \\
\hline & $E_{j}$ & Capital próprio definido no intervalo $\left(1-0,5 \overline{P_{B}} ; 1-\theta_{j} \overline{P_{B}}\right)$. & NA & NA & Uniforme contínua (*) \\
\hline ESTRUTURA DE IMPOSTOS & $(1-T)$ & Alíquota local do imposto sobre resultado (IR + CSSL). & Empresas do setor & NA & NA \\
\hline PRAZO DE CONSTRUÇÃO & NA & $\begin{array}{l}\text { Dois anos em todas as simulações com processo de formação de juros } \\
\text { dado pela taxa } r_{D} \text { e prazo de carência } z_{K} \text { de cada país. }\end{array}$ & NA & NA & NA \\
\hline \multirow{3}{*}{$\begin{array}{l}\text { PERIOODO DE CARÊNCIA E } \\
\text { PRAZOS DE AMORTIZAÇÃO }\end{array}$} & $n_{B}$ & Simula a partir de 8 anos e tem como limite superior o prazo de $B$. & Quadro 1 & NA & Uniforme discreta $\left({ }^{*}\right)$ \\
\hline & $n_{K}$ & Simula a partir de 8 anos e tem como limite superior o prazo de $K$. & Quadro 1 & NA & Uniforme discreta $\left(^{*}\right)$ \\
\hline & $Z_{K}, Z_{B}$ & $\begin{array}{l}\text { Período de carência da operação de cada país. Varia de } 2 \text { anos até o } \\
\text { limite superior de prazo de carência de cada país } K \text {. }\end{array}$ & Quadro 1 & NA & Uniforme discreta $\left({ }^{*}\right)$ \\
\hline
\end{tabular}

Quadro 25 - Informações gerais e estatísticas aplicadas no modelo de simulação geradas por meio do E-Views 4.0 e Best Fit 4.5 ®.

\section{Notas:}

$\left({ }^{*}\right)$ Formato da distribuição determinado pelos autor conforme hipóteses definidas na seção 5.6 e ANEXO 10.

$\left({ }^{* *}\right)$ Formato da distribuição e demais medidas calculadas com auxílio do software BestFit 4.5 囚, após tratamento preliminar das séries. Ver ANEXO 10.

Fonte: Elaborado pelo autor. 
A fim de calcular a taxa de retorno sobre capital próprio $r_{E}$ por meio do CAPM, foram capturadas e consolidadas informações referentes ao preço máximo, preço mínimo, preço de fechamento, preço ajustado e volume transacionado associados às cotações de ações de 44 empresas estrangeiras que compõe a industries shipping ${ }^{126}$. A amostra é constituída por empresas que atuam no setor de transporte marítimo em diversas regiões do globo e nos mais diferentes segmentos desse mercado ${ }^{127}$.

Também foram capturados e sistematizados dados dos índices de mercado (Dow Jones, S\&P 500, Nasdaq Transportation e NYSE) e de ativos considerados livres de risco (US Treasury de 10 e 30 anos). Esses dados, abrangendo o período de 1984 a 2006, totalizaram mais de 600 mil registros. A partir do tratamento dessas informações por meio do software Microsoft Access (utilizado para consolidar os registros em torno dos prazos), foi possível obter as informações que serão empregadas para a geração de uma proxy da taxa de retorno sobre o capital próprio e de terceiros (este relacionado com o processo de financiamento de empreendimentos das empresas do setor de transporte marítimo) e os demais parâmetros necessários para alimentar o modelo proposto. Esses apresentados nas próximas seções.

Estabelecidas estas considerações, a próxima seção apresenta a forma empírica de apuração de cada um dos componentes que alimentam o modelo de simulação.

\subsection{Cálculo Empírico dos Elementos do Modelo}

As próximas seções discutem os procedimentos empregados no cálculo empírico das variáveis que irão alimenta o modelo de simulação apresentado acima (taxa de retorno sobre capital próprio e taxa de retorno sobre capital de terceiros, taxa de desconto aplicada sobre o fluxo de despesas financeiras, participação do financiamento no empreendimento, período de carência, prazos de amortização, etc., para cada país).

\footnotetext{
${ }^{126}$ Preço de fechamento ajustado pelos dividendos e pelo desmembramento das ações.

127 O ANEXO 6 apresenta um breve sumário com as características das empresas presentes nessa amostra.
} 


\subsubsection{Cálculo Empírico da Taxa de Desconto sobre Capital Próprio - $r_{E}$}

Nesse e em outros estudos, o cálculo empírico do $\beta_{i}$ envolve a adoção de algumas premissas e discussão de certas restrições. Aqui estas dão conta do modo de operação do setor de transporte marítimo e disponibilidade de dados estatísticos a ele relacionadas, respectivamente. Em se tratando de setor que atua em competição global, a taxa de retorno que regula operações financeiras das empresas de navegação locais, obtida por meio do WACC, deve constituir um múltiplo da taxa de média de retorno do setor a nível internacional, ajustada pelo risco país, risco cambial, e outras fontes de risco discutidas nas seções anteriores. Isso é perfeitamente plausível uma vez que a rentabilidade das empresas depende das políticas de preço adotadas em nível global e que é possível apurar as fontes de risco adicionais por meio de modelagem. Com o fim das Conferências de Frete o setor tornou-se mais competitivo. Como se verifica com os estaleiros, as empresas de transporte atuam em competição global e possuem pouco poder de barganha em torno da determinação do nível dos fretes. Por outro lado, tal procedimento se faz necessário uma vez que as empresas nacionais que atuam no setor de transporte e apoio marítimo não possuem ativos negociados no mercado mobiliário local, o que impede o cálculo empírico do $\beta_{i}$ e conseqüentemente do WACC.

Quando a empresa não possui o capital aberto, a literatura sugere que se utilize o $\beta_{i}$ de empresas comparáveis como aproximação (DAMODARAN, 2004; GITMAN, 2000). Quando tais dados não estão disponíveis, é preciso assumir que os diversos mercados funcionam de modo perfeito. Isso implica que a remuneração das empresas do mesmo setor deve apresentar, em média, remuneração semelhante, quando ajustada pelo nível de riscos. (GITMAN, 2000). Além do mais, como recomendado na literatura (GITMAN, 2000; ROSS; WESTERFIELD; JAFFE, 2002) e levando em conta as diversas particularidades setoriais (longos ciclos de produção e uso, forte intervenção governamental, etc.) apresentadas nos capítulos anteriores, a estimação do $\beta_{i}$ a partir da cotação de ações de empresas que atuam em setores semelhantes não refletiria de maneira consistente com binômio risco/retorno setorial. 
Ademais, é baixo volume de transações realizadas diariamente no mercado mobiliário local o qual também concentra seu volume de operações em poucos papéis, conduzindo a problemas de estimação do CAPM (PAIVA, 2005) e adoção desse expediente.

Em contraste além de transacionarem papéis de diversas empresas do setor, os grandes mercados mobiliários são mais eficientes, pois o número de participantes, volume e diversidade de papéis negociados diariamente são expressivos. Isso faz com que o mercado reflita toda a informação disponível acerca da dinâmica setorial e sua relação com a dinâmica dos demais mercados. Tais características de ajustam aos pressupostos da modelagem de equilíbrio entre risco e retorno dos ativos. Além disso, não há no Brasil uma taxa livre de risco adequada para a estimação do modelo ${ }^{128}$. Este fato é enfatizado por diversos autores, entre eles Estrada (2000) e Paiva (2005)

Em razão das restrições e hipóteses assumidas, uma forma alternativa de obter o $\beta_{i}$ é tomar as informações de empresas do setor de transporte marítimo que possuam ações cotadas em mercados relevantes de alta liquidez. Tal é o caso da New York Stocke Exchange (NYSE). Uma vez obtido este $\beta_{i}$ do setor de transportes, este deve ser ajustando por meio do spread de risco o que é feito por meio dos procedimentos apresentados nas seções anteriores.

Em setores altamente concentrados, capitalizados e que atuam em competição global essa hipótese perfeitamente é plausível. Segundo Damodaran (2004), mercados relevantes funcionam de forma eficiente, atendendo os postulados de eficiência de mercado que fundamentam os modelos de precificação de ativos. Neles os títulos estão em equilíbrio o que significa que seus preços são "justos", ao refletir toda a informação disponível, sendo os retornos esperados são iguais aos retornos exigidos. Nesse contexto, os preços reagem instantaneamente a novas informações: a qualquer momento os preços dos ativos refletem toda a informação publicamente disponível sobre as empresas e seus títulos. Com efeito, caso haja desequilíbrios nesses mercados estes serão corrigidos instantaneamente por meio de operações de arbitragem. Ou seja, o capital flui à busca de retornos extraordinários, restabelecendo o real valor dos ativos entre os diversos mercados e

\footnotetext{
128 Isso tem relação com a determinação do duration (medida de sensibilidade do preço do ativo em relação à variação na taxa de juros) do ativo.
} 
papéis. Neste caso, o movimento de capital, ao refletir toda a informação disponível, permite que as empresas sejam financiadas em função de seu real valor e níveis de riscos. Isso também explica o movimento de capital entre diferentes mercados. Feitas estas ressalvas, os procedimentos empíricos para alimentar o modelo proposto são apresentados nas próximas seções.

\subsubsection{Estimação do Custo de Capital Próprio por meio do beta das Empresas de Navegação - $\widehat{\beta_{N A V}}$}

O cálculo da taxa de desconto $r_{E}$ é feito por meio do emprego do modelo CAPM. Este foi apurado com base nos dados das empresas de armação negociadas na NYSE uma vez que as empresas locais não possuem papéis negociados em mercado local. Cogitou-se tomar papéis de empresas com características semelhantes, mas em se tratando de setor que atua em competição global, optou-se por tomar dados de cotações empresas que possuem ações negociadas na Bolsa de Valores de Nova York (NYSE).

A composição da carteira das empresas de navegação foi construída a partir de dados que abrangem o período compreendido entre 2002 a 2006 . Na prática, foi utilizado o preço médio de fechamento dos papéis ponderado pelo valor transacionado das 44 principais companhias de navegação. O tamanho da amostra correspondente é de 1251 observações. O método de estimação empregado foi o vetor de cointegração pela metodologia formulada do Johansen e Juselius (1990), conforme será discutindo a seguir.

Para que o beta das empresas de navegação $\left(\beta_{N A V}\right)$ seja estimado por meio do CAPM foi necessário tomar, além dos dados da cotação das ações das empresas, séries correspondentes do ativo de mercado (Nasdaq Transportation) e do ativo livre de risco (US Treasury 10). Este índice é recomendado por Copeland, Koller e Murrin (2002), pois reflete o fluxo de caixa das empresas e o movimento do preço dos demais ativos negociados. Assim foram obtidas as estimativas $\widehat{r_{M}}$ e $\widehat{r_{F}}$ para os anos de 2005 a 2006. 
Os procedimentos para obter $\widehat{\beta_{N A V}}$ se basearam no emprego de técnicas de séries temporais (time series). Isso se deu porque o modelo de regressão assume que há uma relação de um único sentido entre a taxa de retorno do ativo $r_{i}$ e o prêmio de risco $\left(r_{M}-r_{F}\right)$, o que não se verifica para efeito de cálculo do CAPM, uma vez que a cotação do ativo de mercado é uma média ponderada das cotações das ações nele negociadas o que conduz a sérios problemas de cointegração. Por esta razão a aplicação de métodos de regressão linear implicou em sérios problemas na estimação do $\beta_{i}$ setorial. Em termos empíricos e em se tratando de séries temporais, há algum grau de cointegração entre $r_{i}$ e $\left(r_{M}-r_{F}\right)$ Isso é evidenciado por meio do gráfico 6 , onde os movimentos de uma média ponderada das cotações de 44 empresas que atuam no setor, acompanham, com algum grau de defasagem, o movimento do mercado acionário medido pelo índice Dow Jones.

Em decorrência disso o procedimento estatístico adotado foi a estimação do vetor de cointegração baseado na metodologia proposta por Johansen e Juselius (1990). Esta assume que se existe equilíbrio de longo prazo entre o valor da carteira das empresas de navegação (Nav) e o índice Dow Jones (Dj) este pode ser captado por meio do vetor de cointegração entre as mesmas. Isso quer dizer que há uma relação estável entre estas variáveis no longo prazo. 


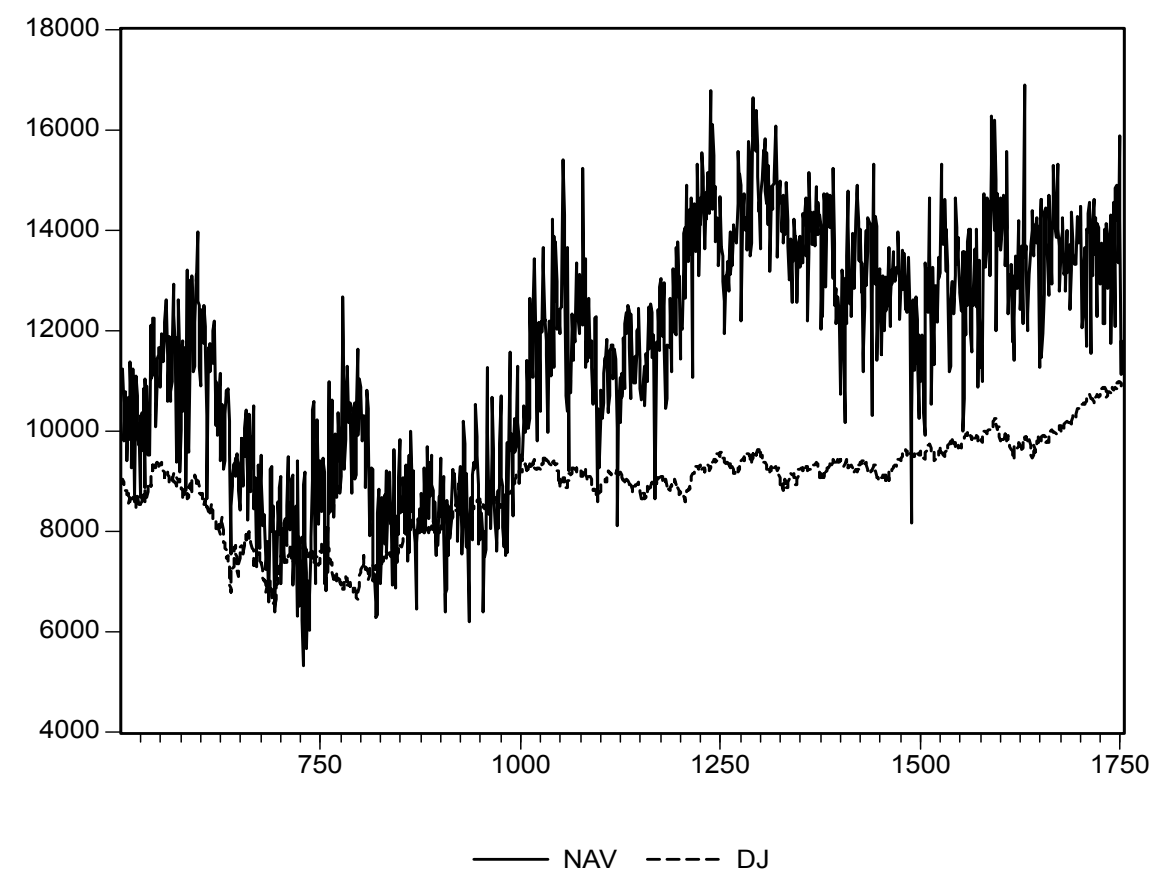

Gráfico 6 - Evolução das cotações das empresas de navegação e do índice Dow Jones Fonte: Elaborado pelo autor

Segundo esta metodologia, a existência de um vetor de cointegração depende do grau de integração entre as variáveis, ou seja, é necessário que as mesmas se tornem estacionárias com o mesmo grau de diferenciação. Em termos estatísticos, a verificação desse pressuposto é feita por meio do teste de raiz unitária aplicado as variáveis. Nesses termos, duas séries possuem o mesmo grau de integração $[l, 1]$, ou seja, tornam-se estacionárias na primeira diferença medida estatisticamente segundo os testes ADF. $O$ resultado dos testes é apresentado na tabela 8. 
Tabela 8 - Teste ADF da cotação das de navegação (Nav) e do índice Dow Jones (DJ).

\begin{tabular}{|c|c|c|c|c|c|}
\hline Índice & Tipo & Teste & $\begin{array}{c}\text { Estatística de } \\
\text { teste }\end{array}$ & $\begin{array}{c}\text { Nível de } \\
\text { significância }\end{array}$ & T crítico \\
\hline \multirow{4}{*}{$D J$} & \multirow{2}{*}{ Nível } & \multirow{2}{*}{$\begin{array}{l}\text { ADF Test } \\
\text { statistic }\end{array}$} & \multirow{2}{*}{-0.657636} & $1 \%$ Critical Value ${ }^{*}$ & -3.4384 \\
\hline & & & & $5 \%$ Critical Value & -2.8643 \\
\hline & \multirow{2}{*}{$1^{a}$ diferença } & \multirow{2}{*}{$\begin{array}{l}\text { ADF Test } \\
\text { statistic }\end{array}$} & \multirow{2}{*}{-16.31818} & $1 \%$ Critical Value ${ }^{*}$ & -3.4384 \\
\hline & & & & $5 \%$ Critical Value & -2.8643 \\
\hline \multirow{4}{*}{ Nav } & \multirow{2}{*}{ Nível } & \multirow{2}{*}{$\begin{array}{l}\text { ADF Test } \\
\text { statistic }\end{array}$} & \multirow{2}{*}{-3.424301} & $1 \%$ Critical Value ${ }^{*}$ & -3.4384 \\
\hline & & & & $5 \%$ Critical Value & -2.8643 \\
\hline & \multirow{2}{*}{$1^{a}$ diferença } & \multirow{2}{*}{$\begin{array}{l}\text { ADF Test } \\
\text { statistic }\end{array}$} & \multirow{2}{*}{-23.72607} & $1 \%$ Critical Value ${ }^{*}$ & -3.4384 \\
\hline & & & & $5 \%$ Critical Value & -2.8643 \\
\hline
\end{tabular}

Nota: *MacKinnon critical values for rejection of hypothesis of a unit root.

Fonte: Elaborado pelo autor.

De acordo com a tabela, o modelo VAR (Vetores Auto-regressivos) nas duas variáveis indica que, de acordo com o critério de Schwars, se deve adotar 3 defasagens no modelo de cointegração. O modelo de cointegração, adotando-se 3 defasagens, indica a possibilidade da existência de inúmeros vetores de cointegração entre as variáveis de acordo com o teste de rank e o teste máximo eigen-value para um nível de significância de 5\%, conforme a tabela 9.

Tabela 9 - Teste ADF da cotação das de navegação (Nav) e do índice Dow Jones (DJ).

\begin{tabular}{l|c|c|c|c|c}
\hline \multicolumn{1}{c|}{ Data Trend: } & None & None & Linear & Linear & Quadratic \\
\hline \multicolumn{1}{c|}{ Rank or No. of CEs } & $\begin{array}{c}\text { No Intercept } \\
\text { No Trend }\end{array}$ & $\begin{array}{c}\text { Intercept } \\
\text { No Trend }\end{array}$ & $\begin{array}{c}\text { Intercept } \\
\text { No Trend }\end{array}$ & $\begin{array}{c}\text { Intercept } \\
\text { Trend }\end{array}$ & $\begin{array}{c}\text { Intercept } \\
\text { Trend }\end{array}$ \\
\hline Selected (5\% level) Number of Cointegrating Relations by Model (columns) \\
\hline Trace & 1 & 1 & 1 & 1 & 2 \\
\hline Max-Eig & 1 & 1 & 1 & 1 & 2 \\
\hline
\end{tabular}

Fonte: Elaborado pelo autor.

Ainda de acordo com o critério de Schwars, foi adotado o modelo sem constante no vetor de cointegração. Conforme a tabela 10, os testes de rank e de máximo eigen value mostram a existência de um vetor de cointegração a $5 \%$ e $1 \%$. 
Tabela 10 - Unrestricted Cointegration Rank Test.

\begin{tabular}{c|c|c|c|c}
\hline $\begin{array}{c}\text { Hypothesized } \\
\text { No. of CE(s) }\end{array}$ & Eigenvalue & $\begin{array}{c}\text { Trace } \\
\text { Statistic }{ }^{* *}\end{array}$ & $\begin{array}{c}\mathbf{5} \text { Percent } \\
\text { Critical Value }\end{array}$ & $\begin{array}{c}\text { 1 Percent } \\
\text { Critical Value }\end{array}$ \\
\hline None $\left(^{* *}\right)$ & 0.025489 & 32.80019 & 12.53 & 16.31 \\
\hline At most 1 & 0.000379 & 0.474560 & 3.84 & 6.51 \\
\hline
\end{tabular}

$\left({ }^{*}\right)$ Trace test indicates 1 cointegrating equation(s) at both $5 \%$ and $1 \%$ levels.

$\left({ }^{* *}\right)$ Denotes rejection of the hypothesis at the $5 \%(1 \%)$ level.

Fonte: Elaborado pelo autor.

Portanto, a partir dos procedimentos a aplicados se obteve $\widehat{\beta_{N A V}}=1,30685$. Esta magnitude confirma as observações preliminares segundo as quais a carteira de ações das empresas de navegação (Nav) possui elevado risco, ao refletirem as características do setor. O termo $r_{F}$ foi estimado pelo retorno dos UST-10 para o ano de 2006 com dados diários. Seu retorno médio anual foi de $4,79 \%$ e o desvio padrão de $0,24 \%$. Já $r_{M}$ foi estimado tomando-se a variação do $D J$ para o ano de 2006. Nesse período, seu retorno foi de $15,2 \%$ a.a.. Portanto, o retorno anual esperado da carteira de ações das companhias de navegação (Nav), admitida a hipótese $\mathrm{HO}$, pode ser escrito como:

$$
\widehat{r_{E}}=4,793644+1,30685(15,16874-4,793644)
$$

Isso totaliza $18,3 \%$ a.a. em US\$ o que, segundo sondagens feitas ao longo das entrevistas realizadas, foi considerado razoável e verificado no setor. Com efeito, esta será a taxa de retorno sobre o capital de próprio a ser empregada nas simulações. Contudo esta taxa não deve ser confundida com a taxa de desconto final. A rigor, esta deve ser ponderada por meio do WACC.

Com efeito, assumindo a hipótese H0 (taxa de retorno sobre o capital próprio $r_{E}$ reflete a remuneração das empresas de navegação internacionais podendo ser aferida por meio do CAPM) e H1 (a embarcação será financiada por armador local e construída em estaleiro nacional) e admitindo que a taxa de rentabilidade sobre capital próprio das empresas nacionais e internacionais sejam as mesmas, em 
média (conforme sugerido no capítulo 4), a taxa $\widehat{r_{E}}=18,3 \%$ a.a. foi empregada em todas as simulações executadas. Conforme o modelo WACC, esta taxa deve ser ponderada pela participação do capital próprio $E /(E+D)$. Uma vez que se assume que $E=\left(1-D^{K}\right)$, o grau de participação do financiamento no empreendimento $D^{K}=\theta^{K} P$ afeta os resultados das simulações em torno da contribuição do retorno sobre capital próprio. A partir desse valor foi apurado o beta desalavancado que conforma cada taxa de desconto $r_{\text {WACC }}^{K}$ aferida pelo uso da estrutura de financiamento de cada país.

\subsubsection{Estimação do Custo de Capital de Terceiros $-\widehat{r_{D}}$}

O custo de capital de terceiros $r_{D}^{K}$, a depender da estrutura de financiamento de cada país, foi estimado a partir soma de três componentes: taxa de juros aplicada na correspondente estrutura de financiamento, risco país e risco cambial. Este procedimento Damodaran (2004) e Ross, Westerfield e Jaffe (2002). A rigor estas taxas são definidas por $\ln \left(1+\widehat{r_{D}^{K}}\right)=\ln \left(1+\widehat{i_{K}}+\widehat{r_{P}^{B}}+\widehat{r_{\varepsilon}^{B, K}}\right)$, no caso do país $K$, ou $\ln \left(1+\widehat{r_{D}^{B}}\right)=\ln \left(1+\widehat{i_{B}}+\widehat{i_{j}}\right)$ no caso do Brasil. Com efeito, as próximas seções apresentam as estatísticas associadas a cada um desses elementos para os sete países que são objeto da modelagem. Convém lembrar que esses valores foram obtidos a partir das distribuições da CIRR, LIBOR, C-BOND, US Treasury, TJLP, Ptax, etc., e respectivas taxas de câmbio em relação ao dólar americano em cada caso. Além disso, o processo de simulação foi alimentado pelas respectivas médias, variâncias e respeitou o formato de cada distribuição tal qual calculado com auxílio do software BestFit 4.5 ®. 


\subsubsection{Cálculo Empírico da Taxa de Juros Empregada no Financiamento Setorial $-\widehat{i_{K}}$}

Como explicitado no quadro 5 e na seção 5.2.2.1, as taxas de juros aplicadas ao setor são subsidiadas e refletem as opções que norteiam racionalidade da estrutura do financiamento em cada caso. Como apresentado no quadro 5, cada país possui uma taxa de referência, que serve para balizar as operações de financiamento orientadas ao setor naval.

Assim, conforme o quadro 5, a taxa de juros praticada na Alemanha é a Commercial Interest Rate Reference (CIRR) da data fechamento contrato da moeda de referência (US\$ ou euro). No caso do Brasil a taxa básica é fixada entre 2,5 a 5\% a.a., acrescida de variação da Taxa de Juros de Longo Prazo (TJPL) ou cotação da Ptax. No caso da China a taxa é fixa, baseada na CIRR ou variável, baseada na LIBOR, acrescida de uma taxa de cobertura. Na Coréia do Sul a taxa empregada nas operações é fixa, baseada na CIRR ou LIBOR também acrescida de taxa de cobertura. Nos EUA a taxa para financiamento setorial é determinada no mercado de capitais, tendo como referência os custos dos papéis emitidos pelo Tesouro norte-americano. Até onde foi possível constatar a taxa de juros praticada no Japão era de 3,5\% a.a. Finalmente, as taxas praticadas na Noruega são fixas, se solicitada, ou baseadas na CIRR.

Em cada caso foram obtidas as séries de tais taxas (Ptax, TJLP, CIRR, LIBOR, etc.). O procedimento adotado foi estimar cada taxa $r_{D}^{K}$ a partir dos demais componentes que envolvem a transferência de ativos entre agentes radicados em diferentes países (variação cambial de cada moeda em relação ao US\$, cotação do C-Bond, do US Treasury, etc.) apresentados acima para emprego nas simulações.

Em linhas gerais a provisão de financiamento ao setor é feita por meio da CIRR ou da LIBOR (quadro 5). Como pode ser observado na tabela 11, a CIRR apresentou uma tendência de queda em todos os países considerados no estudo. Este mesmo movimento também foi verificado nas taxas de juros de longo prazo praticadas nesses países. Com efeito, o custo de capital para financiamento de longo prazo tem apresentado uma tendência de queda nos países construtores sob investigação. Estes efeitos têm implicações sobre os resultados da aplicação do modelo tal qual aqui formulado. 
Tabela 11 - Taxa Commercial Interest Reference Rate (CIRR) por país em termos \% e mensais anualizados (jul/02 a dez/06). (*)

\begin{tabular}{|c|c|c|c|c|c|c|c|}
\hline & $\operatorname{CIRR}\left({ }^{* *}\right)$ & JAP-YEN & COR-WON & EUA - US\$ & ALE-EURO & NOR-KR & BRA- REAL \\
\hline \multirow{4}{*}{2002} & Med (S2) & 1,75 & 7,37 & 5,12 & 5,55 & 7,76 & 9,92 \\
\hline & Desv Pad (S2) & 0,12 & 0,38 & 0,57 & 0,36 & 0,59 & 0,20 \\
\hline & Var (S2) & 0,02 & 0,15 & 0,33 & 0,13 & 0,35 & 0,04 \\
\hline & Coef Var (S2) & 8,04 & 2,61 & 1,74 & 2,74 & 1,70 & 4,90 \\
\hline \multirow{8}{*}{2003} & Med (S1) & 1,49 & 6,30 & 4,52 & 4,85 & 6,24 & 11,17 \\
\hline & Desv Pad (S1) & 0,06 & 0,35 & 0,12 & 0,23 & 0,41 & 0,75 \\
\hline & $\operatorname{Var}(\mathrm{S} 1)$ & 0,00 & 0,12 & 0,01 & 0,05 & 0,17 & 0,57 \\
\hline & Coef Var (S1) & 17,79 & 2,89 & 8,29 & 4,37 & 2,42 & 1,33 \\
\hline & Med (S2) & 1,70 & 5,74 & 4,47 & 4,63 & 5,30 & 11,67 \\
\hline & Desv Pad (S2) & 0,33 & 0,22 & 0,44 & 0,24 & 0,18 & 0,52 \\
\hline & $\operatorname{Var}(\mathrm{S} 2)$ & 0,11 & 0,05 & 0,19 & 0,06 & 0,03 & 0,27 \\
\hline & Coef Var (S2) & 3,07 & 4,53 & 2,30 & 4,16 & 5,54 & 1,94 \\
\hline \multirow{8}{*}{2004} & Med (S1) & 1,95 & 6,06 & 4,67 & 4,82 & 4,77 & 10,08 \\
\hline & Desv Pad (S1) & 0,08 & 0,14 & 0,21 & 0,18 & 0,44 & 0,47 \\
\hline & $\operatorname{Var}(\mathrm{S} 1)$ & 0,01 & 0,02 & 0,04 & 0,03 & 0,19 & 0,22 \\
\hline & Coef Var (S1) & 12,17 & 7,19 & 4,78 & 5,68 & 2,27 & 2,15 \\
\hline & Med (S2) & 2,15 & 5,21 & 5,03 & 4,82 & 4,70 & 9,75 \\
\hline & Desv Pad (S2) & 0,14 & 0,46 & 0,27 & 0,17 & 0,27 & 0,00 \\
\hline & $\operatorname{Var}(\mathrm{S} 2)$ & 0,02 & 0,21 & 0,07 & 0,03 & 0,07 & 0,00 \\
\hline & Coef Var (S2) & 7,19 & 2,19 & 3,72 & 5,81 & 3,73 & - \\
\hline \multirow{8}{*}{2005} & Med (S1) & 1,93 & 4,95 & 5,04 & 4,31 & 4,28 & 9,75 \\
\hline & Desv Pad (S1) & 0,06 & 0,43 & 0,17 & 0,10 & 0,11 & 0,00 \\
\hline & $\operatorname{Var}(\mathrm{S} 1)$ & 0,00 & 0,18 & 0,03 & 0,01 & 0,01 & 0,00 \\
\hline & Coef Var (S1) & 17,08 & 2,35 & 5,85 & 9,85 & 9,47 & - \\
\hline & Med (S2) & 1,91 & 5,47 & 5,08 & 3,95 & 4,17 & 9,75 \\
\hline & Desv Pad (S2) & 0,16 & 0,47 & 0,18 & 0,09 & 0,20 & 0,00 \\
\hline & $\operatorname{Var}(\mathrm{S} 2)$ & 0,02 & 0,22 & 0,03 & 0,01 & 0,04 & 0,00 \\
\hline & Coef Var (S2) & 6,37 & 2,14 & 5,45 & 11,42 & 5,02 & - \\
\hline \multirow{8}{*}{2006} & Med (S1) & 2,34 & 6,22 & 5,58 & 4,41 & 4,64 & 8,84 \\
\hline & Desv Pad (S1) & 0,21 & 0,14 & 0,21 & 0,24 & 0,19 & 0,61 \\
\hline & $\operatorname{Var}(\mathrm{S} 1)$ & 0,04 & 0,02 & 0,05 & 0,06 & 0,04 & 0,37 \\
\hline & Coef Var (S1) & 4,87 & 7,31 & 4,66 & 4,12 & 5,25 & 1,64 \\
\hline & Med (S2) & 2,57 & 5,87 & 5,89 & 4,80 & 5,05 & 7,39 \\
\hline & Desv Pad (S2) & 0,12 & 0,14 & 0,18 & 0,08 & 0,10 & 0,49 \\
\hline & Var (S2) & 0,01 & 0,02 & 0,03 & 0,01 & 0,01 & 0,24 \\
\hline & Coef Var (S2) & 8,23 & 7,08 & 5,44 & 11,84 & 10,32 & 2,04 \\
\hline
\end{tabular}

( $^{*}$ Como aqui apresentado CIRR compreende uma taxa média das taxas de longo prazo para operações com maturidade superior a 8,5 anos.

$\left.{ }^{(* *}\right)$ Médias, desvios padrão e coeficiente de variação em bases semestrais (S1 e S2) apuradas a partir da taxa mensal anualizada.

Fonte: Café Money (2007) 


\subsubsection{Cálculo Empírico do Risco País - $\widehat{r_{P}}$}

Admitida a $\mathbf{H 2}$ apresentada na seção 5.4 (o armador local pode submeter sua proposta a diferentes estruturas de financiamento, respeitando as respectivas condições de cada uma conforme apresentadas no quadro 1), a literatura aponta que o $\widehat{r_{P}}$ deve ser incorporado à modelagem. Uma vez que não se dispôs de dados relacionados a $\widehat{r_{C}^{K}}$, este foi estimado a partir do retorno do $C-B O N D$, lançado em 1997, e do US Treasury $10-\widehat{r}_{S}=\hat{r}_{C-B O N D}-\hat{r}_{U S-T R E A S U R Y}$. Por meio da análise do gráfico 7 é possível observar que houve forte queda do risco país ao longo do período compreendido entre 2004 e 2007, quando apurado em bases point (0,01\%). Neste sentido, nos últimos períodos há uma forte diminuição do peso do risco país nas operações de transferência de ativos de outros países ao Brasil. Contudo, a experiência histórica tem mostrado que este índice é marcado por alta volatilidade a exemplo do que ocorreu no em meio ao processo de sucessão eleitoral do governo FHC.

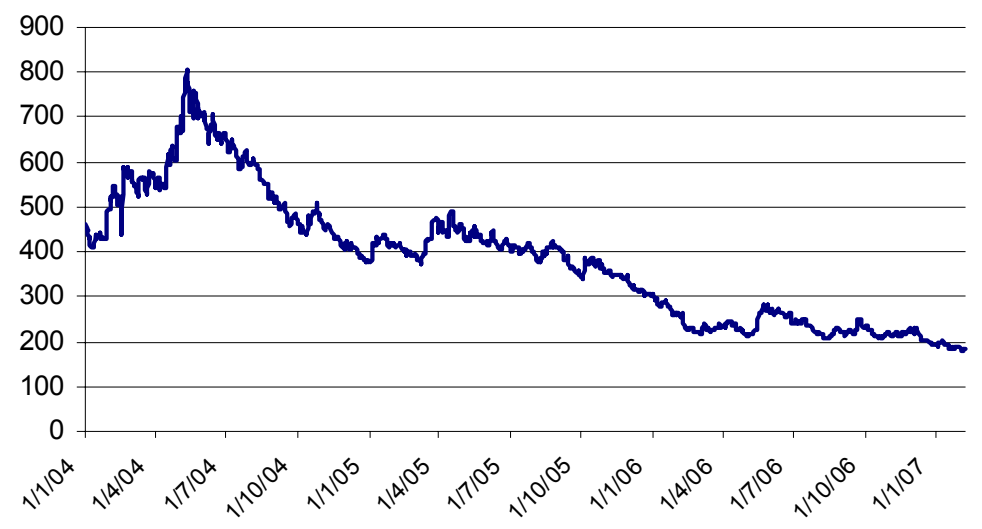

Gráfico 7 - Risco país cotado em termos diários e apurado para o intervalo compreendido entre jan/04 e fev/07 (*).

$\left(^{\star}\right)$ Refere-se a diferença entre a cotação do C-Bond e do US Treasury de 10 anos medido em bases point $(0,1 \%)$.

Fonte: Elaborado pelo autor. 


\subsubsection{Cálculo Empírico do Risco Cambial $-\widehat{r}_{\varepsilon}$}

Na seção 5.3.2.3, foi discutido que o cálculo do risco cambial deve refletir a expectativa de desvalorização cambial. Ocorre que até o fechamento desse trabalho não foi possível obter tais taxas. Desta forma se utilizou a variação histórica do câmbio como proxy dessa variável.

No caso, o $r_{\varepsilon}$ reflete a variação média da taxa de câmbio do país $K$ em relação ao US\$. No caso brasileiro a Ptax capta esta variação. A perspectiva de desvalorização induz a um aumento no risco da operação. Este efeito é reforçado caso se espere que a moeda do país de origem do recurso se valorize em relação ao US\$. Neste caso, a perda do poder de compra do US\$ faz com que cada parcela de $P M T_{C}$ represente menor volume de recurso em moeda local. Os juros praticados podem não compensar este movimento no câmbio ampliando o risco das operações. A variação relativa entre as moedas é apresentada no gráfico 8.

É possível verificar que as moedas dos países apresentados sofreram uma desvalorização mais acentuada em relação ao real durante o período. Esse efeito amplifica o nível de riscos associados à transferência de ativos entre estes países.

A rigor, a desvalorização relativa das moedas afeta a rentabilidade da transferência de ativos de capital. Como apresentado no gráfico 8, nos últimos anos as moedas dos países construtores considerados nesse estudo vêm se apreciando ante ao US\$. Para que haja redução nos riscos, a apreciação do $\mathrm{R} \$$ deve mais que compensar a apreciação da moeda do país financiador. Nesses termos, $\frac{\Delta K \$}{\Delta R \$}$ capta este tipo de risco devendo ser acrescida à taxa de remuneração $r_{D}^{K} \cdot{ }^{129}$ Esta variação

\footnotetext{
${ }^{129}$ A rigor esta variação foi calculada por meio da seguinte razão $\frac{\Delta K \$}{\Delta U S \$} / \frac{\Delta R \$}{\Delta U S \$}$. A apreciação do R\$
} em relação ao US\$ deve mais que compensar a apreciação de $\mathrm{K}$ \$ em relação ao US\$. Dados 
relativa implica em efeitos diferenciados na transferência de ativos financeiros entre os diversos países (gráfico 9).
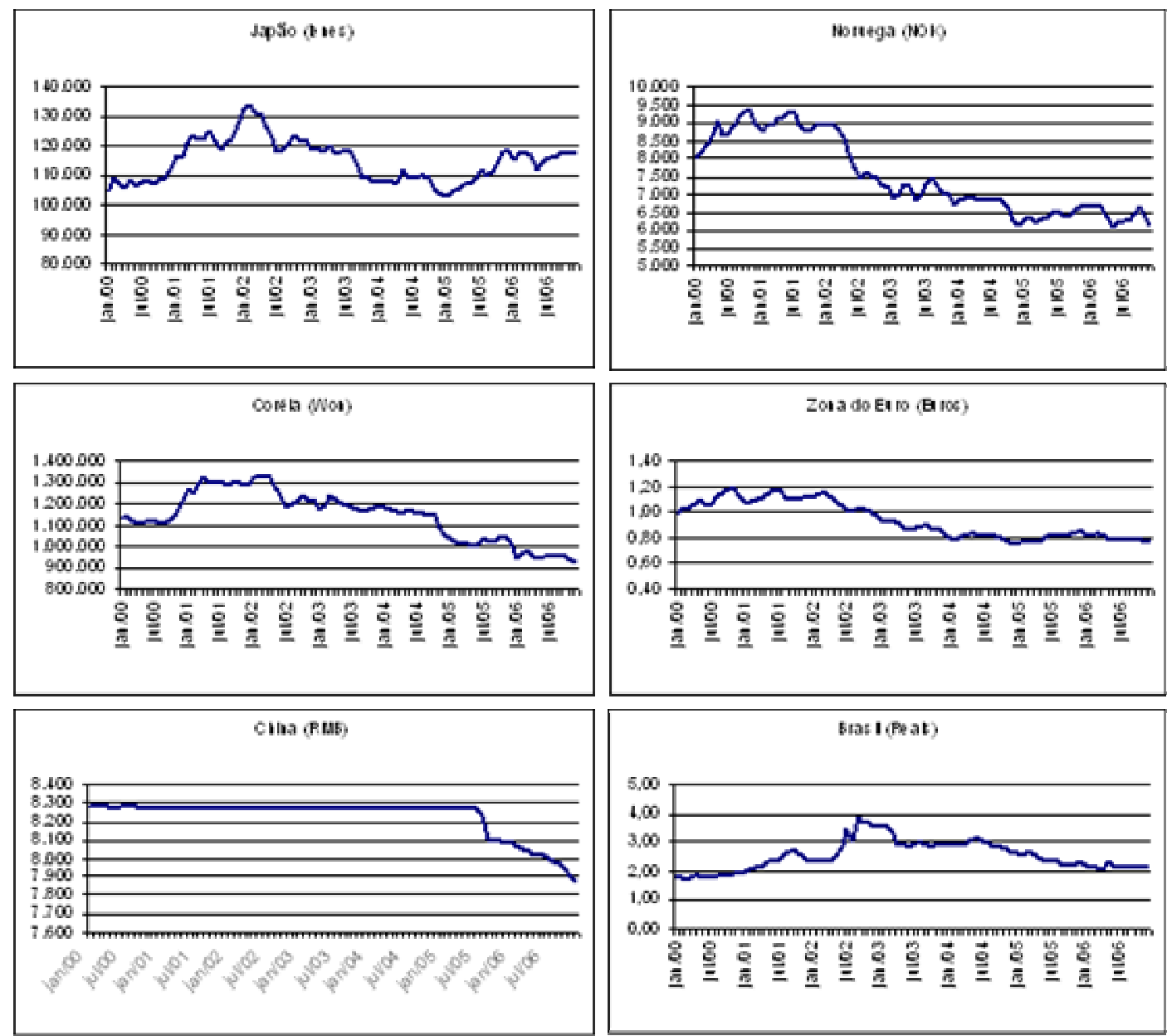

Gráfico 8 - Variação cambial em relação ao US\$ por país selecionado (jan/00 a dez/06). Fonte: Elaborado pelo autor

estatísticos indicam que, no período analisado o $\mathrm{R} \$$ apreciou menos que proporcionalmente em relação às moedas dos países considerados. Esse efeito, ao captar o risco esperado da variação do preço relativo das moedas, deve ser embutido na apuração da taxa $r_{D}^{K}$, o que é feito no modelo. 


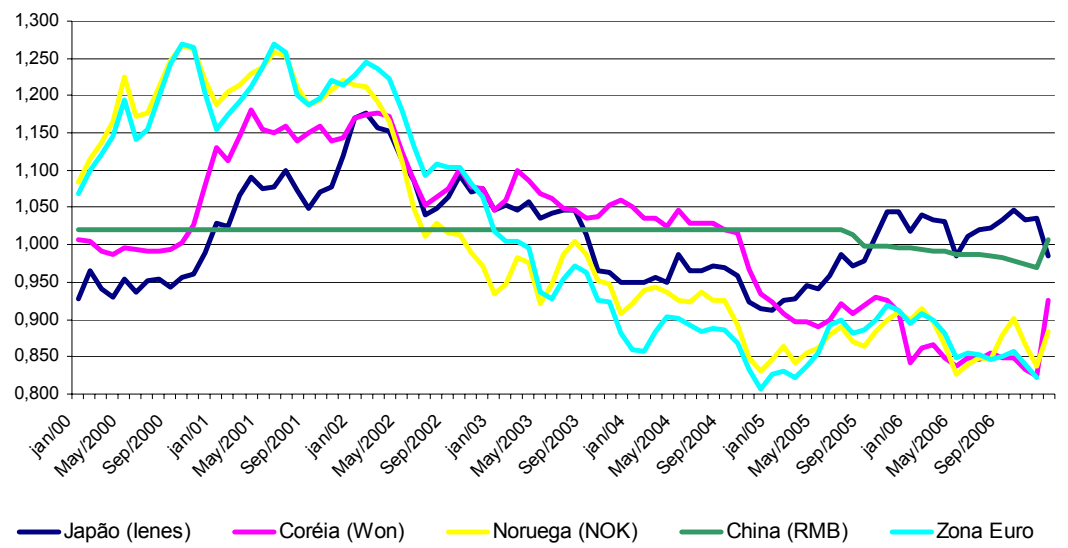

Gráfico 9 - Variação cambial em relação ao R\$ por país selecionado (jan/00 a dez/06). Fonte: Elaborado pelo autor

\subsubsection{Apuração da Estrutura de Capital - $\widehat{E} \mathbf{e} \widehat{D}$}

Conforme a hipótese H3, apresentada na seção 5.4, a aplicação do modelo partiu do pressuposto que o projeto será financiado por apenas duas fontes de capital: aporte de recursos da empresa e da fonte de financiamento cujas remunerações são $r_{E}$ e $r_{D}^{K}$, respectivamente ${ }^{130}$. Isso evita uma série de dificuldades na estimação da estrutura de capital tal como apontadas por Copeland, Koller e Murrin (2002) e Damodaran (2004).

Assim, como o objeto de investigação é a estrutura de financiamento local, se parte do princípio que uma parcela $D^{K}=\theta^{K} P$ dos recursos destinados a financiar o empreendimento é provida pelo aporte de recursos por meio de financiamento. A outra parcela $E=\left(1-\theta^{K} P\right)$ é provida integralmente pelos lucros retidos da empresa de armação. No caso, o valor da participação de capital próprio é função do valor financiado respeitado os padrões de cada estrutura de financiamento.

Nas simulações a variação de $\theta^{K}$ vai de 0,5 até o limite financiado pelo respectivo país. No caso do Brasil, por exemplo, como o BNDES financia até $90 \%$ do valor do projeto, temos $0,5 \leq \theta^{B} \leq 0,9$. Nesse saco, assumindo que o valor do projeto de construção seja US\$100 milhões, o valor financiado varia uniformemente no intervalo de US\$ 50 a US\$ 90 milhões, respectivamente. Dessa forma, o índice

${ }^{130} \mathrm{O}$ uso da taxa $r_{E}$ diz respeito a hipótese H0, conforme apresentado na seção 5.6. 
de atratividade foi construído a fim de refletir certa sensibilidade em relação aos diferenciais de participação do financiamento no empreendimento.

\subsubsection{Procedimentos para a Equalização de Prazos - $\widehat{A C}$}

A literatura aponta que, sob o critério de VPL ou VPL de custos, dois fluxos de caixa só podem ser comparados quando referenciarem o mesmo horizonte de prazo. Portanto se fez necessário a adoção de um mecanismo de equalização de prazos acoplado aos dados de entrada da simulação. Isso foi feito por meio do seguinte procedimento.

Em termos dos períodos de carência se assumiu que o este variaria de dois anos (o qual coincide com o prazo de construção assumido em todas as simulações) até o limite de carência definido na estrutura de financiamento. No caso do Brasil este período variaria de 2 a 4 anos, com capitalização trimestral. Por outro lado, se assumiu que o prazo de amortização deveria variar de 8 até o prazo máximo de amortização estabelecido em cada estrutura. No caso do Brasil portanto, este prazo varia de 8 a 20 anos. Em ambos os casos de assume que o formato das distribuições é uniforme.

Como assumido na seção 5.4 , quando ocorrem diferenciais no prazo total do financiamento, $n_{K}+z_{K} \leq n_{B}+z_{B}$, por exemplo, $V P L_{C}$ de cada alternativa não pode ser comparado diretamente. Para que isso seja possível estes devem ser corrigidos por meio de um critério de equalização prazos. Assim, considerando duas alternativas de financiamento mutuamente excludentes, sob este critério os termos $P M T_{t}$ da alternativa de menor prazo total $\left(n_{K}+z_{K}\right)$ devem ser levados a valor futuro por meio do correspondente fator de valor futuro $\left(1+r_{\text {WACC }}\right)^{t}-$ onde $\left(t=1,2, \ldots, n_{K}\right)$. A partir da

soma do valor futuro das prestações até o instante $n_{K}$, se aplica $\left(1+r_{\text {WACC }}\right)^{\left(n_{B}-n_{k}\right)}$. Em seguida, se traz o resultado obtido a valor presente pelo fator de valor atual $1 /\left(1+r_{D}^{K}\right)^{n_{B}+z_{B}}$. Este procedimento, ao garantir a equalização de prazos das diferentes alternativas, possibilita a comparação direta entre os valores presente dos diferentes fluxos de pagamentos, $P M T_{t}^{K}$ tendo como referência o instante 0 . 


\subsubsection{Estimação do Valor das Parcelas do Financiamento - $\widehat{P M T_{t}^{K}}$}

Conforme apresentado na seção 5.2, o valor de cada prestação, ao incorporar amortização e juro $\left(\operatorname{PMT}_{t}^{K}=A^{K}+J_{t}^{K}\right)$, pode ser obtido por meio do Sistema de Amortização Constante (SAC), amplamente empregado nas operações de financiamento setorial e cuja determinação depende dos seguintes componentes: prazo de amortização $\left(n_{K}\right)$, taxa praticada $\left(r_{D}^{K}\right)$ e valor do projeto de construção do navio a ser financiado $(\bar{P})$. Este é formado exogenamente, no processo de negociações entre armador e estaleiro, e a partir da definição das demais condições apresentadas no quadro 5. Por meio dos seis pares de planilhas, as quais relacionam os dados correspondentes do Brasil com o país $K$, o modelo é implementado.

No caso o valor das prestações do país $K$, agrega em colunas diferentes. Estas calculam, respeitando a variação assumida nos elementos que os compõe, o valor da amortização, o valor da amortização sobre o montante de juros apurados durante o período de carência, o juro sobre o principal da dívida e os juros apurados sobre montante de juros acumulados ao longo do período de carência e os correspondentes saldos devedores (ANEXO 9).

O resultado, obtido linha à linha, é o valor das prestações $P M T_{t}^{K}=A^{K}+J_{t}^{K}$. A soma do valor futuro das prestação até o instante $n_{K}$ dessa coluna é ajustada pelo procedimento de equalização de prazos. Desta forma se relaciona com a planilha correspondente que calcula os dados do financiamento local. O resultado é trazido a valor presente pelas respectivas taxas de desconto $\left(r_{\text {WACC }}\right)$ gerando um único índice $I A_{B, K}$ para cada par de planilhas. Os procedimentos para a obtenção de $r_{W A C C}$ são discutidos a seguir. 


\subsubsection{Cálculo Empírico da Taxa de Desconto - $\widehat{r_{\text {WACC }}^{K}}$}

O cálculo da taxa de desconto foi feito por meio do custo médio ponderado do capital (WACC) a partir das taxas obtidas de acordo com os procedimentos explicitados nas seções 5.6 .2 e 5.6.3. Essa metodologia é a mais emprega e adequada no cálculo da taxa de retorno (DAMODARAN, 2004). Por meio dela, a taxa de desconto deve refletir o custo de oportunidade de todas as fontes de capital empregadas no empreendimento. Estas são ponderadas pelas correspondentes participações de capital próprio e de terceiros na simulação, conforme procedimento explicitado na seção 5.6.4.

Como a magnitude da estimativa $r_{\text {WACC }}$ depende da estrutura de capital da empresa, o beta utilizado na simulação foi o beta ajustado. Sua aplicação se destina a equalização de prazos para, a partir daí, calcular os seis índices $I A_{B, K}$. Estes são apurados para Brasil/Japão $\left(I A_{B, J A P}\right)$, Brasil/China $\left(I A_{B, C H I}\right)$, Brasil/Coréia do Sul $\left(I A_{B, C O R}\right)$, Brasil/EUA $\left(I A_{B, E U A}\right)$, Brasil/Alemanha $\left(I_{B, A L E}\right)$ e Brasil/Noruega $\left(I A_{B, N O R}\right)$.

\subsection{Resultados do Modelo Proposto - $\widehat{I A_{B, K}}$}

O procedimento metodológico adotado consistiu em simular a contratação de ativos tendo como base a geração de um fluxo de pagamentos de despesas financeiras associadas ao financiamento de uma embarcação cujo valor de construção assumido foi da ordem de US $\$ 100$ milhões. A partir daí foram criados seis pares de tabelas (ANEXO 10). A partir da aplicação das equações apresentadas na seção 5.4 , essas foram construídas para retornar os valores das séries de amortização e de juros a partir de cada estrutura de financiamento. A geração dos valores em cada par de planilhas deveria respeitar a sistemática de apuração das prestações adotada em cada país conforme os quadros 5 e 25. Nesse processo foram utilizadas informações relacionadas ao percentual financiado, 
período de carência, prazo e periodicidade de amortização, taxa praticadas, etc., de cada país em cada par de planilhas.

Em particular, as taxas de retorno sobre capital próprio e de terceiros que alimentaram o modelo foram apuradas de acordo com metodologias específicas e aplicadas sobre dados financeiros secundários provenientes do BACEN, OCDE, Unctad, etc.. Isso objetivou maior realismo ao modelo uma vez que, conforme o quadro 5 , tais informações são empregadas em operações reais de financiamento ao setor. Assim, no caso do Brasil foi utilizada, além da taxa de referência compreendida no intervalo (2,5\%a.a.; 5,0\%a.a.), a série da taxa TJLP na apuração da taxa de juros a partir da qual se forma o valor dos juros associados a cada prestação no instante t. Para os demais países foram utilizas séries da CIRR ou a Libor, conforme o caso. Na modelagem das taxas foram introduzidas a variação cambial e o risco país, exceto no caso do Brasil. Informações acerca do formato das estatísticas de posição, dispersão e formato das distribuições dessas variáveis foram introduzidas no processo de simulação a fim de imprimir maior realismo nos resultados. Essas foram obtidas por meio do emprego do software Palisade Decision Tools.

Além disso, nas simulações se assumiu que o período de carência, prazos e valor financiado partiriam de limites inferiores, previamente definidos e iguais para todos os países, e que o limite superior de cada uma dessas variáveis deveria corresponder ao valor máximo previsto em cada estrutura de financiamento (quadro 25 e ANEXO 10). Para cada uma dessas variáveis foi atribuída uma dada distribuição, uma vez que não foi possível obter os critérios de fixação adotados nessas operações de financiamento.

Nas tabelas, macros especiais foram incorporadas de modo a garantir que, a cada variação no período de carência ou no prazo fossem, ajustados os valores das parcelas de amortização e juros que conformam o valor de cada prestação (ANEXO 10). O mesmo se deu em relação ao valor financiado. No processo de simulação macros também objetivavam garantir o processo de equiparação do prazo total (carência e amortização) por meio do modelo de atividade cessante (AC) apresentado na seção 5.4 .

Nesse contexto, o modelo desenvolvido objetivou captar o nível de atratividade da estrutura de financiamento local em relação aos padrões vigentes nos demais países construtores apresentados. Nesse ínterim, a sensibilidade do 
índice de atratividade em relação aos parâmetros de cada estrutura de financiamento e aos fatores de risco, a partir do processo de obtenção e introdução das taxas nele aplicadas, poderiam ser verificadas (ANEXO 11). O modelo foi desenvolvido de modo a captar a distribuição de freqüências e as fontes de variação do índice de atratividade proposto.

Os resultados da aplicação do modelo proposto são apresentados nos gráficos apresentados a seguir. Vale apontar que o ANEXO 11 apresenta o sensitivity chart obtido a partir de cada simulação.

Conforme o gráfico 10, a probabilidade de vezes em que $0 \leq I A_{B, C H I} \leq 1$ foi da ordem de $58 \%$. Isso significa que, no processo de simulação, em $5.10^{3}$ a estrutura de financiamento nacional seja é mais atrativa que a chinesa. O intervalo de variação do índice reflete a volatilidade de variação dos prazos das operações, montante de participações, etc. As fontes de variação podem ser visualizadas no ANEXO 11.

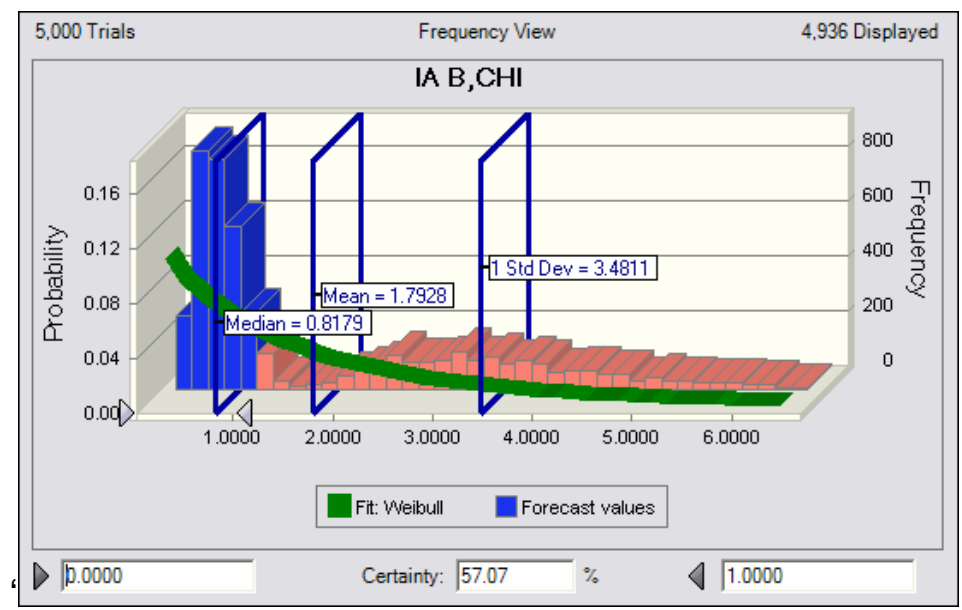

Gráfico 10 - Índice de Atratividade do financiamento naval do Brasil vs. China.

Fonte: Elaborado pelo autor

O resultado refletiu o diferencial de prazos de amortização de cada país que são de 20 e 15 anos, para o Brasil e a China, respectivamente. Como o processo de formação de juros no caso do financiamento nacional é trimestral, o valor presente das prestações nacionais com vencimento mais distante do instante 0 é mais reduzido que o correspondente valor das prestações ajustadas por meio do processo de equalização de prazos $(A C)$ no caso da China. Esses fatores explicam 
o menor valor e a maior parte da variabilidade do índice (ANEXO 11) uma vez que o diferencial de taxas a.a. foi pequeno (10,7\% a.a contra $9,8 \%$ a.a. no caso da China). Não obstante, a amplitude de variação de taxas é maior no caso chinês $(4,5 \%$, $18,3 \%$ ) em razão dos fatores que determinam sua taxa (CIRR, LIBOR, risco país, risco cambial, etc.).

A participação maior no caso do Brasil (90\% contra $80 \%)$ afetou positivamente a variabilidade do índice. Em contraste, o período de carência (com valor máximo de 7 anos no caso chinês) compensou ligeiramente o peso do diferencial de prazos de amortização. De acordo com o modelo, esses são os principais fatores explicam a atratividade do financiamento local em relação ao caso chinês. O risco cambial teve pouca influência. A rigor, a valorização do real contribuiu para a redução desse tipo de risco. Por outro lado, a apreciação do RMD (moeda chinesa), ao reduzir a capacidade de aquisição de RMD por meio do US\$, esterilizou esse efeito. Uma vez que a CIRR chinesa permaneceu estável com leve tendência de queda essa afetou de maneira muito discreta os resultados da simulação. Por fim, a queda no risco país puxou a taxa $\mathrm{rD}$ da china para baixo fazendo com que o índice sofresse ligeira redução.

O gráfico 11 permite inferir que a probabilidade de vezes em que se verificou $0 \leq I A_{B, C O R} \leq 1$, foi da ordem de $45 \%$, bem inferior ao $I A_{B, C H I}$. Neste caso, a variabilidade desse resultado sofreu pouco efeito em termos da variabilidade das participações no financiamento, uma vez que esta é igual nos dois casos. O diferencial de período de carência (4 contra 5 anos no caso coreano) das estruturas de financiamento brasileira também contribuiu pouco para a variabilidade do índice. O diferencial de taxas (10,7 a.a. contra 13,3 a.a.) e sua dispersão maior no caso coreano implicaram em certo grau de variabilidade no índice. No entanto, o diferencial de prazos de amortização (20 contra 12 anos no caso coreano) e a incidência trimestral dos juros, explica o baixo valor e grande parte da variação do índice. Os juros formados sobre o saldo devedor contribuíram para reduzir o valor no índice. Os demais parâmetros implicaram em efeito marginal, embora a CIRR da Coréia tenha sofrido ligeira queda. 


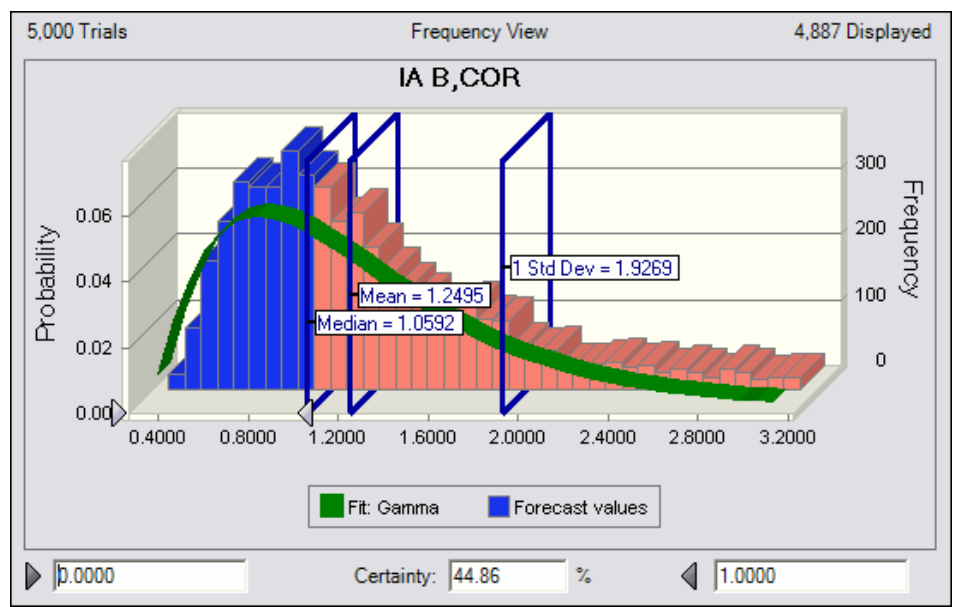

Gráfico 11 - Índice de Atratividade do financiamento naval do Brasil vs. Coréia do Sul. Fonte: Elaborado pelo autor

Os resultados da simulação mostrados no gráfico 12 indicam que $0 \leq I A_{B R A, J A P} \leq 1$ foi da ordem de $67 \%$. O maior prazo de amortização brasileiro foi o fator que mais contribuiu para a variabilidade negativa do índice. Esse efeito foi parcialmente suavizado pela maior participação no financiamento nacional.

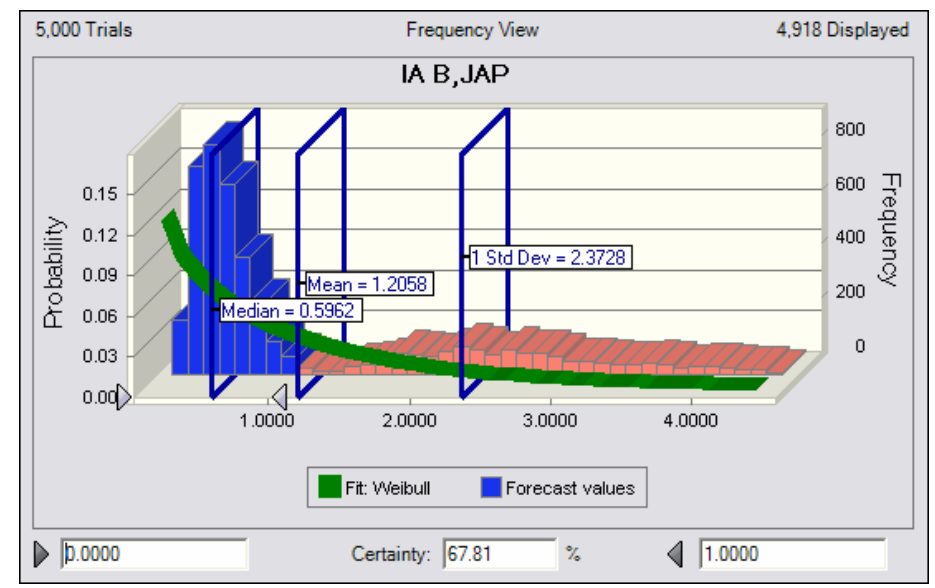

Gráfico 12 - Índice de Atratividade do financiamento naval do Brasil vs. Japão.

Fonte: Elaborado pelo autor.

Conforme o gráfico 13. $0 \leq I A_{B, E U A} \leq 1$ foi da ordem de 35,0 o que refletiu, fundamentalmente, o maior prazo e período de carência aplicado na estrutura de financiamento dos EUA. A ligeiramente maior participação na estrutura de financiamento local $(90 \%$ contra $87,5 \%)$ também contribui para que o índice apresentasse valor modesto. Fatores como a valorização do real e o risco país foram inexpressivos. 


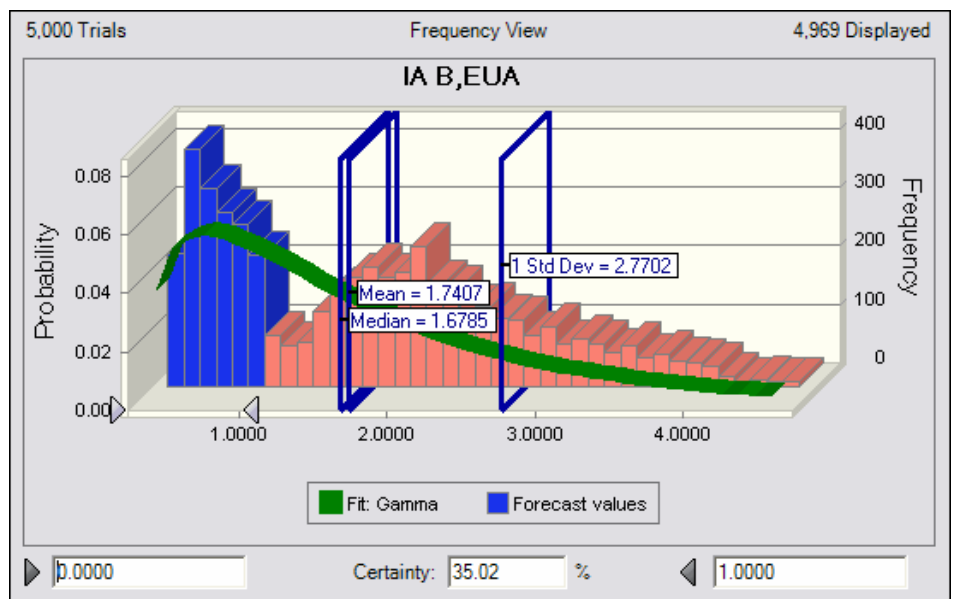

Gráfico 13 - Índice de Atratividade do financiamento naval do Brasil vs. EUA. Fonte: Elaborado pelo autor

O $0 \leq I A_{B, N O R} \leq 1$ foi 72,1 . (gráfico 14). Este valor refletiu a variabilidade provocada pela maior participação no financiamento na estrutura norueguesa, que pode chegar a $100 \%$ do valor do contrato. Esse efeito foi ligeiramente influenciado pelo maior prazo de amortização da estrutura de financiamento nacional.

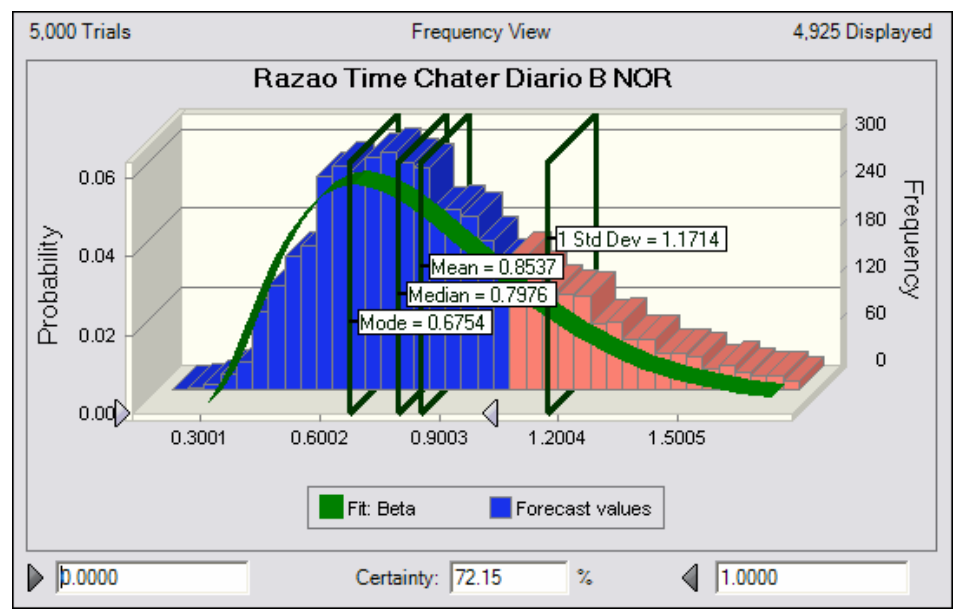

Gráfico 14 - Índice de Atratividade do financiamento naval do Brasil vs. Noruega. Fonte: Elaborado pelo autor

Finalmente (gráfico 11.6), o $0 \leq I A_{B, A L E} \leq 1$ foi 81,2 , refletiu as semelhanças nos prazos de amortização e da magnitude da participação do financiamento. Apesar disso, o menor período de carência (4 contra 0,5 anos na Alemanha) contribuiu fortemente para na variabilidade do índice. 


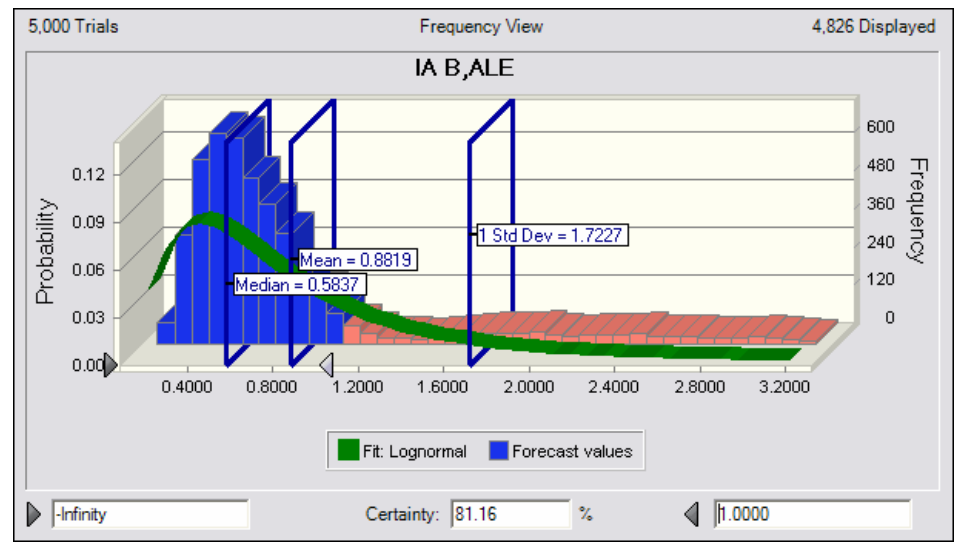

Gráfico 15 - Índice de Atratividade do financiamento naval do Brasil vs. Alemanha. Fonte: Elaborado pelo autor

Em suma, a estrutura de financiamento nacional figura entre as mais atrativas do mundo. A variabilidade verificada nos IA's pode ser atribuída aos diferenciais das estruturas de financiamento. Isso ocorre em razão da convergência verificada entre as taxas de juros praticadas, apreciação das moedas e redução do risco cambial.

\subsection{Conclusões do Capítulo}

O objetivo desse capítulo foi comparar a estrutura de financiamento local com as práticas internacionais. Para tanto foi necessário de desenvolver, verificar e validar um modelo matemático, radicado no sistema SAC (ANEXO 9) na estruturação de planilhas (ANEXO 10), a partir das quais foram realizadas simulações. Essas estiveram fundamentadas em técnicas de avaliação por meio do conceito de Valor Presente Líquido de Custos $\left(V P L_{C}^{K}\right)$. Sua apuração exigia, além do emprego dos parâmetros de cada estrutura de financiamento e do emprego métodos de amortização, que se apurassem as taxas de desconto a serem empregadas no dimensionamento de prestações e sua avaliação.

Os métodos empregados na obtenção da referida taxa se baseou no WACC, cuja determinação foi possível graças ao cálculo de uma proxy do retorno sobre capital próprio $\left(\widehat{r_{E}}\right)$ e de terceiros $\left(\widehat{r_{D}^{K}}\right)$ em tais empreendimentos. Por meio do emprego do modelo de atividade cessante $(\widehat{A C})$, foi definido o índice de atratividade 
$\left(\widehat{I A_{B, K}}\right)$ cujo emprego dependeria da estimação empírica de um conjunto de variáveis. Com efeito, o retorno sobre o capital de terceiros foi calculado a partir de métodos de econométrica de séries temporais. Esta taxa de retorno do setor em US\$ está em torno de 18,3\% a.a.. Esta taxa não constitui a taxa final de desconto, a qual deve ser apurada pelo modelo WACC ajustado pelo nível de alavancagem financeira.

Já as estimativas de taxa de retorno $\left(\widehat{r_{\text {WACC }}^{K}}\right)$ exigida para aferir o custo do capital do empreendimento variaram a depender da estrutura de financiamento. A rigor, estas responderam pela variação das taxas institucionalizadas em cada estrutura de financiamento $i_{k}$, risco pais $r_{P}$ e risco cambial $r_{\varepsilon}$.

Os resultados apresentados, embora preliminares e exigindo ajustes mais meticulosos, permitem inferir que a estrutura de financiamento local figura entre as mais atrativas do mundo.

Por meio do modelo adotado foi possível constatar que dados os juros subsidiados, os prazos das operações (carência e amortização) implicam em efeitos pronunciados na atratividade do financiamento local. O mesmo se verifica em relação à participação do financiamento no empreendimento. O baixo efeito dos fatores de risco (embutidos nas taxas de juros) nos resultados das simulações refletem certos fenômenos econômicos e financeiros relacionados à desvalorização do dólar americano, redução do risco soberano e queda das taxas de juros internacionais e convergência entre estas taxas.

Em todas as simulações executadas se constatou que devido à forte depreciação verificada nas moedas o efeito das variações cambiais contribui muito pouco na magnitude dos índices de atratividade, tal como aqui formulado. Ante a redução do risco país o impacto dessa variável também foi reduzido. O mesmo se deu em relação às taxas de juros de longo prazo - introduzidas nas correspondentes estruturas como meio de captar spread de risco relacionado às operações, conforme as hipóteses assumidas.

Assim, o grau de atratividade da linha de financiamento local depende, além da estrutura de financiamento local em relação às práticas internacionais, da flutuação nos índices que regem a transferência de ativos nos mercados internacionais de capital. Em momentos de crise na economia mundial, certamente 
este diferencial deve se reverter em maior atratividade do financiamento local. Fatores como o nível de reservas e a confiança do investidor, captadas pela taxas de variação no câmbio e pelo risco país, tendem a tornar perenes as vantagens.

Finalmente a variação do ativo de mercado e ativo livre de risco, ao ser capturada pelas taxas empregadas, ponderada pelo grau de alavancagem financeira e pelo ajustamento nos prazos para efeito de comparação das operações, também contribui pouco para a variabilidade dos índices obtidos, a depender da diferenças nos períodos de carência e prazo de amortização previstos em cada estrutura de financiamento. O financiamento local é mais barato e pode viabilizar o dinamismo do setor. Contudo, demonstrado no capítulo 4, a contratação de recursos depende dos processos de avaliação de risco de crédito (credit scoring e credit risk) sofrendo ainda influências de fatores exógenos (barreiras á entrada a importação, exclusividade no uso do FMM, distorções provocadas pela majoração de custos indiretos, burocracia, velocidade nas contratações, etc.).

O adensamento dessas linhas de estudo permitirá desenvolver uma melhor percepção, em bases tecnicamente consistentes, acerca da vantagem relativa da estrutura de financiamento á construção naval brasileira em relação a outros países construtores. 


\section{CONSIDERAÇÕES FINAIS E IDENTIFICAÇÃO DE NOVAS LINHAS DE PESQUISA}

Até o presente, poucos estudos tratam da economia marítima e do shipping finance (compreendido como a área da economia marítima que trata da provisão de financiamento ao setor). Inserido nesse contexto, este trabalho tratou aspectos contábeis e matemáticos relacionados ao financiamento orientado à construção naval sob a ótica das empresas de navegação. Ao fazer isso, procurou discutir a percepção dos agentes quanto a adequação do financiamento setorial brasileiro e em que condições o financiamento provido pelo BNDES é mais atrativo quando comparado às condições de financiamento vigentes em outros países construtores.

Foram abordados os microfundamentos que orientam uma operação de financiamento dirigida ao setor. Dada a intrínseca relação do mercado de construção com os demais mercados que conformam o setor naval, o estudo explorou as interações com o mercado de fretes, mercado de compra e venda de embarcações usadas e mercado de demolição. No tratamento desses assuntos, foi estabelecida uma sistematização sumária do financiamento sob a ótica de diferentes agentes (armadores, estaleiros, agentes financeiros, seguradoras e governo). Nesse ínterim, foram destacadas as principais questões relacionadas ao financiamento orientado à construção de embarcações.

Estabelecida essa revisão, o estudo se orientou na direção de dois enfoques, ambos de natureza estritamente financeira. Esses derivaram de entrevistas realizadas durante a fase exploratória deste estudo (ANEXO 1).

No primeiro enfoque o estudo exploratório indicou que, no Brasil, o papel do financiamento é limitado, fundamentalmente, devido aos riscos associados aos empreendimentos (notadamente risco armador e estaleiro). Estes estariam relacionados à avaliação dos empreendimentos e situação financeira das empresas envolvidas nas propostas.

No segundo enfoque, se constatou que, no Brasil os custos associados às operações de financiamento seriam menores do que os praticados nos demais países. Além disso, em termos absolutos as condições de financiamento figuram entre as mais vantajosas do mundo. 
Para tratar dos temas relacionados ao primeiro enfoque duas estratégias metodológicas complementares, ambas condizentes com o plano metodológico geral do estudo, foram adotadas. A primeira, de natureza quantitativa consistiu na obtenção e análise de indicadores econômico-financeiros das empresas de navegação. A segunda abordagem, de natureza qualitativa, consistiu na realização e análise de entrevistas estruturadas em torno de temas de interesse (formatação de projetos, riscos dos empreendimentos, escolha do estaleiro e pontos fortes e fracos percebidos quanto à estrutura de financiamento local provida pelo BNDES) junto a operadores que atuam no setor (diretores financeiros de empresas de navegação e apoio marítimo (ANEXO 2), membros de associações classistas e da academia).

Para dar conta dos aspectos quantitativos mencionados, foram calculados indicadores econômico-financeiros (IEF) de solvência, atividade, alavancagem e rentabilidade, sugeridos pela literatura e os aplicados pelo do BNDES (estes definidos no âmbito do FINEM). Os IEF foram obtidos a partir de amostras não intencionais de empresas nacionais e estrangeiras dos segmentos de transporte e apoio marítimo (ANEXOS 2, 3 e 4).

Os testes estatísticos não sustentam haver diferenças significativas entre as médias da maior parte dos indicadores econômico-financeiros calculados. A rigor, não se pode rejeitar a hipótese nula para a maior parte dos indicadores (exceto GAT, MB, LB e DCP). Com efeito, a avaliação das Demonstrações Financeiras sugere que as práticas operacionais e financeiras das empresas de navegação se encontram de acordo com padrões internacionais.

Ante a estas constatações, as razões apontadas para o mau funcionamento do mercado de financiamento orientado ao setor devem ser buscadas em outros fatores causais (fatores associados à formação de preços e custos no mercado de construção, regulamentação quanto ao acesso aos recursos do FMM, barreiras á entrada no mercado de construção, dificuldades de importação, etc.).

Quanto aos aspectos qualitativos se verificou não haver grandes críticas em relação aos critérios de avaliação de projetos estabelecidos pelo BNDES. Segundo a maior parte dos entrevistados, elementos exógenos estão no cerne dos problemas do modelo de financiamento e implicam em práticas de sobre-preço e absorção de vantagens providas pela linha de financiamento pelos estaleiros ${ }^{131}$. O que também é

\footnotetext{
${ }^{131}$ A rigor, devido as barreiras à entrada e obrigatoriedade de contratação de estaleiro nacional para
} uso dos recursos do FMM, muitos armadores alegam que o sobre-preço não resulta exclusivamente 
corroborado por membros das entidades classistas consultados. Essa constatação remeteu a análise qualitativa. Com base na análise das entrevistas se, chegou as seguintes conclusões: a avaliação de riscos leva em conta fatores históricos que distorcem as avaliações; as barreiras à entrada por meio de altas taxas de importação de navios e restrição ao uso dos recursos à importação de embarcações (exceto em casos excepcionais) implicam em distorções na formação dos preços no mercado de construção; a prática de sobre-preço se encontra relacionada as barreiras à entrada que induzem a majoração dos custos apropriados pelos estaleiros permitindo a reprodução de ineficiências operacionais; o requinte de leis e morosidade dos trâmites burocráticos provoca incrementos nos custos e riscos associados a novos empreendimentos; em geral, os riscos operacionais associados à construção implicam em incrementos nos custos.

Com base nas informações apresentadas e confronto entre teste e resultados das entrevistas, as proposições 1.1 (as empresas encontram dificuldades na aprovação do financiamento junto ao BNDES devido as suas precárias condições econômico-financeiras) e 1.2 (a análise de propostas se baseia em um amplo conhecimento dos agentes e BNDES acerca da forma de funcionamento do setor naval) não se sustentam, devendo ser rejeitadas.

O tratamento do segundo enfoque (atratividade do financiamento) envolveu a elaboração de um modelo de simulação destinado a avaliar a atratividade da estrutura de financiamento local em relação às práticas de seis países construtores (Japão, Coréia do Sul, China, Alemanha, Noruega e EUA). A formulação do modelo de simulação se fez necessária uma vez que não foi possível obter dados de projetos realizados com objetivo de analisar e comparar o diferencial das estruturas de financiamento em vigor nos diferentes países com a atualmente praticada no Brasil pelo BNDES.

A modelagem empregou técnicas de avaliação de fluxo de caixa. Sua aplicação se baseou em quatro elementos: cálculo do valor das prestações por meio do emprego dos parâmetros das linhas de financiamento de cada país abordado; cálculo da taxa de retorno sobre capital próprio e de terceiros por meio do CAPM e apuração da taxa de desconto do FDC por meio do modelo WACC; emprego do

de diferenciais na estrutura de custos. Por meio da inflação dos custos apropriados (custos de mãode-obra, despesas operacionais etc.), uma parcela dos pagamentos é apropriada sem ônus pelos estaleiros. 
modelo de atividade cessante. Para tanto, foram empregados o conceito de valor presente de custos e técnicas econométricas. Embora calcado em dados que compreendem o período de 2002 a 2006 se constatou que a estrutura de financiamento nacional figura entre as mais atrativas. Desta forma não se pode rejeitar a proposição 2.1 (as condições de financiamento brasileiras são, sob certos limites, competitivas em termos dos parâmetros financeiros adotados)

Ao utilizar dados históricos o modelo permitiu chegar as seguintes conclusões. Uma vez que as taxas de juros internacionais, risco país e risco cambial sofreram substancial redução no período, fazendo com que as taxas de juros empregadas no financiamento convergissem, o modelo indicou que a atratividade do financiamento brasileiro se associa significativamente aos diferenciais verificados nos período de carência, prazo de amortização e participação do financiamento no empreendimento. Caso estas taxas sofram incrementos, a atratividade deve responder pelos diferenciais no retorno exigido pelo capital de terceiros.

Uma vez que uma estrutura de financiamento se refere ao “...processo por meio do qual as condições de pagamento e valor do empréstimo, seu suporte (se é por meio de garantia real, sem garantia, com garantia não real [...] ) e seu preço são combinados para atingir a finalidade à qual se destina o dinheiro que é tomado como empréstimo." (RUTH, 1991, p. 273), novos estudos poderão dar maior ênfase a questão das garantias de financiamento orientadas ao setor.

Os resultados apresentados, embora preliminares e exigindo ajustes mais meticulosos, permitem inferir que a estrutura de financiamento local figura entre as mais atrativas do mundo. A partir do modelo é possível constatar que em razão dos juros subsidiados, os prazos das operações implicam em efeitos pronunciados no custo final do financiamento. O mesmo se verifica em relação à participação do financiamento no empreendimento. $O$ baixo efeito dos fatores de risco (embutidos nas taxas de juros) nos resultados das simulações reflete certos fenômenos econômicos e financeiros relacionados à desvalorização do dólar americano, redução do risco soberano e queda das taxas de juros internacionais. Em todas as simulações executadas se constatou que devido à forte apreciação verificada nas moedas o efeito das variações cambiais contribui muito pouco na magnitude dos índices de atratividade, tal como aqui formulado. Ante a redução do risco país o impacto dessa variável também foi reduzido. O mesmo se deu em relação às taxas de juros de longo prazo - introduzidas nas correspondentes estruturas como meio 
de captar spread de risco relacionado às operações, conforme as hipóteses assumidas.

Assim, a atratividade da linha de financiamento local depende, além da estrutura de financiamento local em relação às práticas internacionais, da flutuação nos índices que regem a transferência de ativos nos mercados internacionais de capital. Em momentos de crise na economia mundial, certamente o diferencial verificado deve se reverter em maior atratividade do financiamento local. Fatores como o nível de reservas e a confiança do investidor, captadas pela taxas de variação no câmbio e pelo risco país, tendem a tornar perenes estas vantagens.

Constata-se que, além do necessário adensamento das abordagens aqui estabelecidas, novas linhas de pesquisa orientadas ao tema devem enfatizar em aspectos associados aos processos da contratação de recursos por meio de modelos destinados a estabelecer a avaliação do perfil de crédito e perfil de risco dos contratos (credit scoring e credit rating). Tais análises estão umbilicalmente relacionadas aos processos de avaliação, fixação e contratação de garantias (collateral). Não restam dúvidas que o estudo e tratamento desses elementos constituem um dos principais desafios ao financiamento setorial. Dois outros campos profícuos de investigação estão relacionados ao estudo dos processos de formação do valor dos contratos e tratamento do aporte de recursos aos projetos.

Nesse ínterim, assume importância fundamental o estudo de modelos e práticas de securitização e correspondentes modelagens associadas à avaliação qualitativa e quantitativa dos riscos envolvidos nas operações. As avaliações devem envolver temas relacionados ao seguro de crédito e seguro de garantia e suas correspondentes abordagens na definição do valor do prêmio e aporte de recursos, caso eventos de risco previstos nos contratos ocorram. A avaliação de mecanismos seguro e resseguro também é de interesse, devendo ser incorporada em futuras investigações. 


\section{REFERÊNCIAS}

ADLAND, R.; JIA, H.; STRANDENES, S. Asset bubbles in shipping? an analysis of recent history in the drybulk market. Disponível em: <http://www.nhh.no/sam/respubl/2006/13.pdf> Acesso em: 26 set. 2006.

ALEX, O. Shipping finance: approach to hellenic market. Athens: [s.n.], 2004. 187 p. Disponível em:

$<$ http://www.maritime.deslab.naval.ntua.gr/documents/extra/diplomatheses/Orfanidis \%20Alexis/ShipFinance.pdf>. Acesso em: 15 out. 2005.

ARAÚJO, J. L. Regulação de monopólios e mercados: questões básicas.

Disponível em: <http://www.ie.ufrj.br/download/index.php>. Acesso em: 22 out. 2003.

ASSIS, L. F. Análise do sistema brasileiro de conferências de frete. 1991. 224 f. Dissertação (Mestrado) - Programa de Engenharia Oceânica, Universidade Federal do Rio de Janeiro, 1991.

BANCO NACIONAL DE DESENVOLVIMENTO ECONÔMICO E SOCIAL. Pesquisa geral no site. Disponível em: <http://www.bndes.gov.br>. Acesso em: 17 nov. 2006.

BARBOZA, T. L. O atual cenário da construção naval civil e militar no mundo, incluindo o subcenário brasileiro. Disponível em:

<http://www.emgepron.mil.br/cenario_construcao_naval.pdf>. Acesso em: 10 nov. 2004.

BELL, J. Doing your research project: a guide for the first-time researchers in education and social science. Buckingham: Open University, 1999.

BLANARU, A.; TELES, E. L. Estudo sobre a avaliação de empresas diante das condições de incerteza das premissas: análise probabilística gerada por simulação de Monte Carlo como auxílio ao processo decisório. Disponível em: <http://www.investsul.com.br/textos_academicos.asp>. Acesso em: 23 nov. 2006.

BONOMA, T. V. Case research in marketing: opportunities, problems, and process. Journal of Marketing Research, Chicago, v. 22, n. 2, p. 199-209, May 1985.

BOTELHO, M. F. Considerações sobre a ICN brasileira, projeto, localização, mercado e alternativas. 1998. 152 f. Dissertação (Mestrado) - Programa de 
Engenharia de Produção, Coordenação dos Programas de Pós Graduação em Engenharia, Universidade Federal do Rio de Janeiro, Rio de Janeiro, 1998.

BRANCH, A. E. Economics of shipping practice and management. $2^{\text {nd }}$ ed. London: Chapman \& Hall, 1988.

BRASIL. Ministério dos Transportes. Portaria 090/2005: aprova os procedimentos e regras para a liberação de recursos financeiros do Fundo da Marinha Mercante durante a execução dos projetos aprovados. Disponível em:

$<$ http://www.transportes.gov.br/BaseJuridica/Detalhe.asp?Codigo=00644>. Acesso em: 29 nov. 2006.

BRESSAN, F. O método do estudo de caso. Administração On Line: Prática, Pesquisa, Ensino. São Paulo, v. 1, n. 1, jan./fev. 2000. Disponível em:

<http://www.fecap.br/adm_online/art11/flavio.htm>. Acesso em 18 nov. 2006.

BROOKS, C. Introductory econometrics for finance. Cambridge: Cambridge University, 2002.

BRYMAN, A. Research methods and organization studie. London: Unwin Hyman, 1989.

BUSSAB, W. O.; MORETTIN, P. E. Estatística básica. 5. ed. São Paulo: Saraiva, 2002.

CAFE MONEY. Pesquisa geral no site. Disponível em: <http://www.cafemoney.com/>. Acesso em: 25 fev. 2007.

CAMINHA, J. C. G. História marítima. Rio de Janeiro: Biblioteca do Exército Editora, 1980. (Coleção General Benício; v. 184).

CAMPANÁRIO, M. A.; SILVA, M. M. Fundamentos de uma nova política industrial. In: FLEURY, M. T. L.; FLEURY, A. (Org.). Política industrial 1. São Paulo:

Publifolha, 2004. p. 13-45.

CATAPAN, E. A. Aspectos relevantes do método fluxo de caixa descontado na avaliação de empresas de energia elétrica em processo de privatização. 2001. 106 f. Dissertação (Mestrado em Engenharia de Produção) - Universidade Federal de Santa Catarina, Florianópolis, 2001. 
CHO, D. S.; PORTER, M. E. Changing global industry leadership: the case of shipbuilding. In: PORTER, M. E. (Ed.). Competition in global industries. Boston: Harvard Business School, 1986. cap. 17, p. 539-567.

COMISSÃO DAS COMUNIDADES EUROPEIAS. Definição do futuro do sector europeu da construção naval e da reparação naval - competitividade através da excelência. Bruxelas: CCE, 2003.

COMISSÃO ECONÔMICA PARA A AMÉRICA LATINA E O CARIBE. Pesquisa geral no site. Disponível em: <http://www.eclac.cl/brasil/>. Acesso em: 16 nov. 2005.

COPELAND, T. E.; KOLLER, T.; MURRIN, J. Avaliação de empresas - valuation: calculando e gerenciando o valor das empresas. Tradução Allan Vidigal Hastings. 3. ed. São Paulo: Makron Books, 2002.

COPELAND, T. E.; WESTON, J. F. Financial theory and corporate policy. $3^{\text {rd }}$ ed. Reading: Addison-Wesley, 1992.

CÔRTES, I. A ICN brasileira - apresentação ao BNDES: cenário nacional. In: SEMINÁRIO INDÚSTRIA NAVAL E TRANSPORTE HIDROVIÁRIO, 2003, Rio de Janeiro. Anais Eletrônicos... Disponível em <http://www.bndes.gov.br/conhecimento/seminario/naval_2a.pdf>. Acesso em: 13 set. 2004.

COUTINHO, L. C. (Coord.). et al. Estudo da competitividade de cadeias integradas no Brasil: impactos das zonas de livre comércio. Campinas: Unicamp, 2003. 18 p. Disponível em: $<$ http://www.eco.unicamp.br/neit/cadeias_integradas/sintese_preliminar.pdf>. Acesso em: 17 set. 2004.

CUNHA, M. S.; ANDRADE, B. L. R. Considerações estratégicas sobre a indústria de construção naval. In: CONGRESSO NACIONAL DE TRANSPORTES MARÍTIMOS, CONSTRUÇÃO NAVAL E OFFSHORE, 21., 2006, Rio de Janeiro. Anais... Rio de Janeiro: SOBENA, 2006. 1 CD-ROM.

DAMODARAN, A. Avaliação de investimentos: ferramentas e técnicas para a determinação do valor de qualquer ativo. Rio de Janeiro: Qualitymark, 2003. 
DAMODARAN, A. Finanças corporativas: teoria e prática. 2. ed. Porto Alegre: Bookman, 2004.

DEMO, P. Pesquisa e construção de conhecimento: metodologia científica no caminho de Habermas. Rio de Janeiro: Tempo Brasileiro, 2000.

DIXIT, A. K.; PINDYCK, R. S. Investment under uncertainty. Princeton: Princeton University, 1994.

DREWRY CONSULTANTS. Shipping finance: a high risk - low return business. London: Drewry, 1996.

ECO, U. Como se faz uma tese. São Paulo: Perspectivas, 1983.

EHRLICH, P. J.; MORAES, E. A. Engenharia econômica: avaliação e seleção de projetos de investimento. 6. ed. São Paulo: Atlas, 2005.

EL CICLO marítimo y las tendencias de la industria en América Latina. Boletín Fal, n. 228, 2005. Disponível em: $<$ http://www.eclac.cl/Transporte/noticias/bolfall/5/22205/FAL-228-WEB.pdf>. Acesso em: 13 out. 2006.

EMPRESA BRASILEIRA DE PLANEJAMENTO DE TRANSPORTES. Política governamental e competitividade da indústria de construção naval. Brasília: GEIPOT, 1999. $169 \mathrm{p}$.

ENDERS, W. Applied econometric time series. $2^{\text {nd }}$ ed. Hoboken: John Wiley, 2004.

ESTRADA, J. The cost of equity in emerging markets: a downside risk approach. Emerging Markets Quarterly, New York, v. 13, n. 1, p. 19-30, 2000.

EVANGELISTA, M. L. S. Estudo comparativo de análise de investimentos em projetos entre o método VPL e o de opções reais: o caso cooperativa de crédito Sicredi Noroeste. 2006. 163 f. (Tese de Doutorado) - Universidade Federal de Santa Catarina, Florianópolis, 2006.

EVANS, J. R.; OLSON, D. L. Introduction to simulation and risk analysis. Upper Saddle River: Prentice Hall, 1998. 
FACHIN, O. Fundamentos de metodologia. 3. ed. São Paulo: Saraiva, 2001.

FADDA, E. A. Construção naval: uma indústria global - as estratégias para a retomada do crescimento. $16 \mathrm{p}$. Disponível em:

$<$ <ttp://www.transportes.gov.br/bit/estudos/constr-naval/industria-global.pdf>. Acesso em: 12 jun. 2006.

FARTHING, B. International shipping: an introduction to the policies, politics, and institutions of the maritime world. London: Lloyd's of London Press, 1993.

FERGUSON, C. E. Microeconomia. Rio de Janeiro: Forense, 1989.

FERRAZ, J. C. et al. Estudo da competitividade de cadeias integradas no Brasil: impactos das zonas de livre comércio - cadeia: indústria naval. Campinas: Unicamp/IE, 2002.

FLORIANO, C. M.; PIRES JUNIOR, L. F. A.; ASSIS, C. M. An analysis of the brazilian ship financing system. Maritime Policy \& Management, London, v. 32, n. 3, p. 209-226, 2005.

FREITAS, P. T. R. ICN brasileira - apresentação ao BNDES: cenário mundial. In: SEMINÁRIO INDÚSTRIA NAVAL E TRANSPORTE HIDROVIÁRIO, 2003, Rio de Janeiro. Anais Eletrônicos... Disponível em <http://www.bndes.gov.br/conhecimento/seminario/naval_1.pdf>. Acesso em: 13 set. 2004.

GIAMBIAGI, F.; ALÉM, A. C. Finanças públicas: teoria e prática no Brasil. 2. ed. Rio de Janeiro: Campus, 2001.

GITMAN, L. J. Principles of managerial finance: brief. $2^{\text {nd }}$ ed. Reading: AddisonWesley, 2000. (The Addison-Wesley Series in Finance).

GOSS, R. O.; MARLOW, P. B. Internationalism, protectionism and interventionism in shipping. In: GWILLIAM, K. M. (Ed.). Current issues in maritime economics. Dordrecht: Kluwer Academic, 1993. p. 45-67. 
GRAMMENOS, T. C. Challenges and prospects in shipping finance. [S.I.]: International Association of Maritime Economists, 2004. 12p. Disponível em: <http://web.deu.edu.tr/smbm/IAME2004-Grammenos.pdf>. Acesso em: 14 set. 2005.

GREENE, W. H. Econometric analysis. New Jersey: Prentice Hall, 2003.

GRIFFITHS, W. E.; HILL, R. C.; JUDGE, G. G. Learning and practicing econometrics. New York: John Wiley, 1993.

GUJARATI, D. N. Econometria básica. 3.ed. São Paulo: Makron, 2000.

GWILLIAM, K. M. (Ed.). Current issues in maritime economics. Dordrecht: Kluwer Academic, 1993.

HELFERT, E. A. Técnicas de análise financeira. 9. ed. Porto Alegre: Bookman, 2000.

IRENE, L.Y. et al. Korean shipbuilding industry: strategies for global competitiveness. 2001.64 f. Dissertação (Mestrado) - Nanyang Business School, Nanyang Technological University, 2001.

JASON, S. F. Mercado internacional de fretes marítimos: a participação do Brasil no período de 1969-1981. 1988. 203 f. Dissertação (Mestrado) - Faculdade de Economia, Administração e Contabilidade, Universidade de São Paulo, 2003.

JOHANSEN, S.; JUSELIUS, K. Maximum likelihood estimation and inference on cointegration - with applications to demand for money. Oxford Bulletin of Economics and Statistics, Oxford, v. 52, n. 3, p. 169-210, 1990.

JOHNSON STOKES \& MASTER. A guide to shipping finance in Hong Kong. Hong Kong: JSM, [200-?]. 22 p. Disponível em:

<http://www.jsm.com.hk/images/upload/Guide\%20to\%20Shipping\%20Finance\%20in \%20Hong\%20Kong\%20(Oct\%202004).pdf>. Acesso em: 14 set. 2005.

KASSAI, J. R. Retorno de investimento: abordagem matemática e contábil do lucro empresarial. 2. ed. São Paulo: Atlas, 2000.

KENDALL, L. C.; BUCKLEY, J. J. The business of shipping. $7^{\text {th }}$ ed. Centreville: Cornell Maritime Press, 2005. 
KERZNER, H. Gestão de projetos: as melhores práticas. Porto Alegre: Bookman, 2002.

KHALID, N. Ship financing in Malaysia: bridging the gap between shipping companies and financial institutions. Kuala Lumpur: Maritime Institute of Malaysia, 2005.

KING, J. New directions in shipbuilding policy. Marine Policy, Surrey, v. 23, n. 3, p. 191-205, 1999.

KRUGMAN, P. R.; OBSTFELD, M. Economia internacional: teoria e política. 5. ed. São Paulo: Makron Books, 2001.

LACERDA, S. M. Oportunidades e desafios da construção naval. Revista do BNDES, Rio de Janeiro, v. 10, n. 20, p. 41-78, dez. 2003.

LAFFONT, J. J.; TIROLE, J. A theory of incentives in procurement and regulation. Cambridge: MIT Press, 1993.

LEE, T. Shipping development in far east Asia: the korean experience. Seoul: [s.n.], 1996.

LEE, T. W. The Korean government policy and development of the shipbuilding and shipping industries. Rio de Janeiro: SOBENA, 1996.

LIMA, E. T.; VELASCO, L. O. M. Construção naval no Brasil: existem perspectivas? Revista BNDES, Rio de Janeiro, n. 10, p. 217-233, dez. 1998.

LIMA, E. T.; VELASCO, L. O. M. Navegação de cabotagem no Brasil. Informe InfraEstrutura, Rio de Janeiro, n. 10, maio 1997.

LINTNER, J. The valuation of risk assets and the selection of risk investments in stock portfólios and capital budgets. Review of Economics and Statistics, Cambridge, v. 47, n. 1, p. 13-37, Feb. 1965. 
MARCONI, M. A.; LAKATOS, E. M. Técnicas de pesquisa: planejamento e execução de pesquisa, amostragens e técnicas de pesquisa e elaboração, análise e interpretação de dados. 3. ed. São Paulo: Atlas, 1985.

MARITIME BUSINESS STRATEGIES. World shipbuilding deliveries. Disponível em: <http://www.coltoncompany.com/shipbldg/statistics/world.htm>. Acesso em: 17 nov. 2004.

MARKOWITZ, H. M. Portfólio selection. Journal of Finance, Oxford, v. 7, n. 1, p. 7791, 1952.

MARX, K. O capital. São Paulo: Difel, 1982.

MAYR, T. P.; MCGRATH, R. H. Tramp shipping: the role of taxation in international resource allocation. Maritime Policy and Management, London, v. 24, n. 3, p. 261283, 1997.

MAYR, T. P.; MCGRATH, R. H. Tramp shipping: the role of taxation in international resource allocation. Maritime Policy and Management, London, v. 24, n. 3, p. 261283, 1997.

MODIGLIANI, F.; MILLER, M. H. The cost of capital, corporation finance, and the theory of investiment. American Economic Review, Nashville, v. 48, n. 3, p. 261297, June 1958.

MOSSIN, J. Equilibrium in a capital asset market. Econometrica, Chicago, v. 34, n. 4, p. 768-783, 1966.

MOTTA, R. R.; CALÔBA, G. M. Análise de investimentos: tomada de decisão em projetos industriais. São Paulo: Atlas, 2002.

MUSGRAVE, R. A.; MUSGRAVE, P. B. Public finance in theory and practice. $5^{\text {th }}$ ed. New York: McGraw Hill, 1989.

NATIONAL SHIPBUILDING RESEARCH PROGRAM. Strategic investment plan. [S.I.]: NSRP, 2002.

NORTH, D. C. Institutions, institutional change and economic performance. Cambridge: Cambridge University, 1990. 
NORTON ROSE. New opportunities for KG finance in shipping. Disponível em:

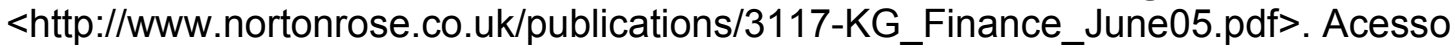
em: 23 jun. 2005.

OLIVA, J. A. B. Políticas de transporte marítimo e construção naval no Brasil: uma abordagem crítica. 2004. 140 f. Dissertação (Mestrado) - Coordenação dos Programas de Pós-Graduação de Engenharia, Universidade Federal do Rio de Janeiro, Rio de Janeiro, 2004.

PAIVA, F. D. Modelos de precificação de ativos financeiros de fator único: um teste empírico dos modelos CAPM e D-CAPM. Caderno de Pesquisas em

Administração, São Paulo, v. 12, n. 2, p. 49-65, 2005.

PARRA FILHO, D.; SANTOS, J. A. Metodologia científica. São Paulo: Futura, 1998.

PASIN, J. A. B. Indústria naval do Brasil: panorama, desafios e perspectivas. Revista do BNDES, Rio de Janeiro, v. 9, n. 18, p. 121-148, dez. 2002.

PIRES JUNIOR, F. C. M. Desenvolvimento da indústria naval. In: SEMINÁRIO INDÚSTRIA NAVAL E TRANSPORTE HIDROVIÁRIO, 2003, Rio de Janeiro. Anais Eletrônicos... Disponível em:

<http://www.bndes.gov.br/conhecimento/seminario/naval_4.pdf>. Acesso em: 20 set. 2004.

PIRES JUNIOR, F. C. M.; ASSIS, L. F.; CIPRIANO, W. Impacto do país de construção no preço do navio de segunda. In: CONGRESSO NACIONAL DE TRANSPORTES MARÍTIMOS, CONSTRUÇÃO NAVAL E OFFSHORE, 21., 2006, Rio de Janeiro. Anais... Rio de Janeiro: SOBENA, 2006. 1 CD-ROM.

PIRES JUNIOR, F. C. M.; ASSIS, L. F.; SERRA, E. G. An analysis of brazilian maritime industry policies. In: ANNUAL CONFERENCE AND MEETING OF THE INTERNATIONAL ASSOCIATION OF MARITIME ECONOMISTS, 2002, Panamá. Proceedings... Victoria: IAME, 2002.

PIRES JUNIOR, F. C. M.; ASSIS, L. F.; SOUZA, C. M. An analysis of the brazilian ship financing system. Maritime Policy and Management, London, v. 32, n. 3, p. 209-226, 2005. 
PIRES JUNIOR, F. C. M.; REZENDE, M. Um modelo alternativo para avaliação de investimento em navios em condições de incerteza. In: CONGRESSO NACIONAL DE TRANSPORTES MARÍTIMOS, CONSTRUÇÃO NAVAL E OFFSHORE, 21., 2006, Rio de Janeiro. Anais... Rio de Janeiro: SOBENA, 2006. 1 CD-ROM.

PROJECT MANAGEMENT INSTITUTE. Um guia do conjunto de conhecimentos em gerenciamento de projetos - guia PMBOK. 3. ed. Newtown Square: PMI, 2004.

PORTER, M. E. Estratégia competitiva: técnicas para a análise de indústrias e da concorrência. Rio de Janeiro: Campos, 1996.

PORTER, M. E. On competition. Boston: Harvard Business School, 1998.

PORTER, M. E. The competitive advantage of nations. New York: The Free Press, 1990.

RIZZO, C. F. Estrutura de mecanismos de garantia para o financiamento de construção de embarcações para a capacitação da indústria nacional. 2003. (Relatório Final TM-03). Disponível em $<$ http://www.prominp.com.br/paginadinamica.asp?grupo=245>. Acesso em: 25 jun de 2006.

RODRIGUES, J. A.; MENDES, G. M. Governança corporativa: estratégia para a geração de valor. Rio de Janeiro: Qualitymark, 2004.

ROSS, S. A. The arbitrage theory of capital asset pricing. Journal of Economic Theory, New York, v. 13, n. 3, p. 341-360, 1976.

ROSS, S. A.; WESTERFIELD, R. W.; JAFFE, J. F. Administração financeira: corporate finance. Tradução Antonio Zoratto Sanvivente. 2. ed. São Paulo: Atlas, 2002.

RUTH, G. E. Empréstimos a pessoas jurídicas. São Paulo: IBCB, 1991.

SCHUMPETER, J. A. A teoria do desenvolvimento econômico. Tradução Maria Silvia Possas. 3. ed. São Paulo: Nova Cultural, 1988.

SERRA, E. G. O desenvolvimento das indústrias de construção naval do Brasil e da Coréia do Sul. 2002. 353 f. Tese (Doutorado) - Coordenação dos Programas 
de Pós Graduação em Engenharia, Universidade Federal do Rio de Janeiro, Rio de Janeiro, 2002.

SHARPE, W. F. Capital asset prices: a theory of market equilibrium under conditions of risk. The Journal of Finance, Oxford, v. 19, n. 3, p. 425-442, 1964.

SHARPE, W. F.; ALEXANDER, G. J.; BAILEY, J. V. Investments. $6^{\text {th }}$ ed. Upper Saddler River: Prentice Hall, 1999.

SIMAS, J. R.; PADILLA, A. A ICN brasileira - apresentação ao BNDES: cenário nacional. In: SEMINÁRIO INDÚSTRIA NAVAL E TRANSPORTE HIDROVIÁRIO, 2003, Rio de Janeiro. Anais Eletrônicos... Disponível em:

<http://www.bndes.gov.br/conhecimento/seminario/naval_2b.pdf >. Acesso em: 20 set. 2004.

SLOGGETT, J. E. Shipping finance: financing ships and mobile offshore installations. London: Fairplay Publications, 1984.

SØDAL, S.; KOEKEBAKKER, S.; ADLAND, R. Value based trading of real assets in shipping under stochastic freight rates. In: ANNUAL CONFERENCE AND MEETING OF THE INTERNATIONAL ASSOCIATION OF MARITIME ECONOMISTS, 2006, Melbourne. Proceedings... Victoria: IAME, 2006.

STEPHENSON, H. Shipping finance. $2^{\text {nd }}$ ed. London: Euromoney Books, 1995.

STIGLITZ, J. E. Economics of the public sector. New York: W.W. Norton, 1986.

STOPFORD, M. Maritime economics. 2. ed. London: Unwin Hyman, 2005.

TOBIAS, A. C. B.; PASIN, R. M. Um resumo das principais metodologias de avaliação de empresas. São Paulo: Cavalcanti \& Associados, [200-].

TOBIN, J. Liquidity preference as a beharviior toward risk. Review of Economic Studies, Oxford, v. 25, n. 66, p. 66-86, 1958.

TSOLAKIS, S. Econometric analysis of bulk shipping markets implications for investment strategies and financial decision-making. 2005. $149 \mathrm{f}$. Tese (Doutorado) - Erasmus University Rotterdam, Rotterdam, 2005. 
UNITED NATIONS CONFERENCE ON TRADE AND DEVELOPMENT. Pesquisa geral no site. Disponível em: <http://www.unctad.org>. Acesso em: 26 jun. 2006.

VELASCO, L. O. M.; LIMA, E. T. Construção naval no Brasil e no mundo. Informe Infra-Estrutura, Rio de Janeiro, n. 14, set. 1997.

VERGARA, S. C. Projetos e relatórios de pesquisa em administração. São Paulo: Atlas, 2004.

VERMULM, R.; ERBER, F. Estudo da competitividade de cadeias integradas no Brasil: impactos das zonas de livre comércio - cadeia: bens de capital - nota técnica final. Campinas: Unicamp/IE, 2002.

VOSS, C.; TSIKRITSIS, N.; FROHLICH, M. Case research in operations management. International Journal of Operation \& Production Management, Bradford, v. 22, n. 2, p. 195-219, 2002.

WEISS, J. M. G. Cadeia de suprimentos e competitividade da indústria de construção naval. In: CONGRESSO NACIONAL DE TRANSPORTES MARÍTIMOS, CONSTRUÇÃO NAVAL E OFFSHORE, 21., 2006, Rio de Janeiro. Anais... Rio de Janeiro: SOBENA, 2006. 1 CD-ROM.

WEISS, J. M. G. Origens do desequilíbrio na indústria brasileira de construção naval. 1990. 163 f. Dissertação (Mestrado) - Escola de Administração de Empresas, Fundação Getulio Vargas, São Paulo, 1990.

WESTON, J. F.; BRIGHAM, E. F. Fundamentos da administração financeira. Tradução Sidney Stancatti. 10. ed. São Paulo: Makron Books, 2000.

WILLIAMSON, O.E. Markets hierarchies. New York: Free Press, 1975.

WOILER, S.; MATHIAS, W. F. Projetos: planejamento, elaboração e análise. São Paulo: Atlas, 1996. 294 p.

YIN, R. K. Estudo de caso: planejamento e métodos. Tradução Daniel Grassi. 3. ed. Porto Alegre: Bookman, 2005. 
ZAN, Y.; JIAN, C. Elements of ship finance. 13 p. Disponível em: $<$ http://www.paper.edu.cn/scholar/download.jsp?file=yangzan-

2\&title=Elements $\% 20$ of\%20ship $\% 20$ finance\#search=\%22\%22Elements $\% 20$ of $\% 20$ sh ip\%20finance\%22\%20Zan\%20Yang\%22>. Acesso em: 17 set. 2004. 


\section{ANEXOS}

\section{ANEXO 1 - QUESTIONÁRIO APLICADO DURANTE A FASE EXPLORATÓRIA DA}

\section{PESQUISA}

Este questionário foi parte integrante da pesquisa exploratória da qual derivou este documento. Esta rodada de entrevistas foi realizada no início do mês de junho de 2006. Os entrevistados foram pesquisadores do Instituto de Pesquisas Tecnológicas do Estado de São Paulo (IPT), técnicos do BNDES, do DMM e do Instituto de Pesquisas Econômicas Aplicada (IPEA). Também foram entrevistados pesquisadores da COPPE/UFRJ, funcionários do SYNDARMA e técnicos do SINAVAL.

1. LITERATURA Que modelo ou prática de financiamento inspiraram a criação e as formas de repasse do FMM? Você conhece modelos ou alguma literatura que ajudaram a orientar a estruturação das linhas de financiamento?

2. CARACTERÍSTICAS Quais as principais características (prazos entre a submissão e aprovação de propostas, critérios empregados em sua avaliação, fluxo de desembolsos, taxas cobradas, prazos de carência e de amortização, exigências e garantias de risco, além da necessidade de incorporar formas eficientes e transparentes de transferência dos recursos do fundo setorial ao setor produtivo nacional, etc.) do modelo de financiamento para a ICN nacional?

3. OPERAÇÃO Na prática como se dá a operação do FMM em termos de submissão e avaliação de projetos? Como os contratos de financiamento procuram articular os interesses das diversas partes envolvidas nos contratos de financiamento? Na prática quem contrata e o que se exige do credor?

4. APERFEIÇOAMENTOS Em sua opinião, o que poderia ser feito para que as formas de financiamento à construção naval no Brasil possam se tornar mais eficientes e eficazes no sentido de desenvolver a ICN?

5. ORÇAMENTAÇÃO Qual o valor orçado e realizado do FMM? Ao que se pode atribuir este fato? Quais as principais restrições que podem ser apontadas quanto a estrutura do FMM?

6. SUGESTÕES Tendo como base sua experiência, como o modelo poderia ser aperfeiçoado? Atualmente há grupos de estudo tratando do tema ou projetos em vias de implementação no sentido de aperfeiçoar o modelo? Quais os principais avanços verificados nos últimos anos?

7. PRÁTICAS INTERNACIONAIS Há diversos modelos de shipping finance no mundo. Como se estruturam e quais as principais características das linhas de financiamento dedicadas a construção naval disponíveis no mercado internacional? Quais principais simetrias e assimetrias entre estes casos? Que modelo seria, em sua opinião, mais aderente a realidade brasileira?

8. GARANTIAS A questão das garantias é apontada como crítica para a consolidação de contratos de financiamento. A exigência de garantias está vinculada diretamente a estruturação do financiamento. Por esta razão, dependendo do tomador e a análise de risco é diferente em cada caso. Como atualmente é tratada a questão das garantias no Brasil?

9. RATING Um fator crítico para a tomada de decisão de financiamento é a existência de um rating dos tomadores. Por meio de quais critérios é feito este rating?

10. CENTRALIZAÇÃO Certos dispositivos normativos (MP 177) pretendem facilitar a obtenção dos financiamentos permitindo que outras instituições financeiras, além do BNDES, possam se habilitar para operar os recursos do fundo (embora a questão das garantias seja um dos principais entraves para obtenção dos empréstimos e não tenha sido objeto da MP). Houve avanços em termos da transferência na operação do fundo?

11. SEGURO DE CRÉDITO Houve avanços na estruturação do seguro de crédito? Há consenso em torno da proposta? 
12. LEASING Por meio de contratos de leasing, o banco aplica recursos financiando um fundo que cede seu(s) navio(s) ao armador. Em caso de problema, retira-se facilmente o bem. Há práticas de leasing no Brasil orientadas para o setor?

13. MERCADO DE CAPITAIS Quais as dificuldades encontradas para as empresas acessarem o mercado de capitais por meio do lançamento de papeis para a captação de recursos? Essa prática já foi implementada no Brasil?

14. COMPETITIVIDADE A despeito das características do arranjo de financiamento da ICN, os principais desafios da ICN não se restringem à retomada das encomendas mas formas de reativar instalações e montar uma eficiente e eficaz capacidade produtiva, para atendê-las. $\mathrm{O}$ Brasil consegue ser competitivo (qual sentido?) na construção de embarcações? Em quais segmentos? Quais os fatores críticos desse diagnóstico?

15. ALTERNATIVAS Uma vez que a especialização é uma alternativa interessante para a sobrevivência da indústria naval local ante a ascensão da produção asiática, que estratégias e alternativas podem ser apontadas como interessantes para a indústria de construção local?

16. DISTORÇÕES Alguns autores apontam que o financiamento por meio de fundos do governo funciona como subsídios que podem tornar o setor naval menos competitivo e dependente de intervenção do governo. Quais mecanismos de incentivos os agentes operadores das linhas de financiamento utilizam e como podem evitar estas distorções?

17. SUGESTÕES Quais as alterações necessárias nas dimensões financeira e institucional para que o Estado possa prover meio de reativar e ou estimular o desenvolvimento da indústria naval presente em seu território e atrair novos investimentos?

18. ENTIDADES CLASSIFICADORAS Qual o papel desempenhado pelas entidades classificadoras?

19. SUGESTÕES Poderia sugerir referências que pudessem viabilizar o aprofundamento das discussões estabelecidas?

20. COMENTÁRIO FINAL Há algum comentário final a ser feito em função dessas discussões?

21. GOSTARIA DE TECER CONSIDERAÇÕES ADICIONAIS? 


\title{
ANEXO 2 - PROTOCOLO E QUESTIONÁRIO APLICADOS NA PESQUISA DE CAMPO
}

\author{
O questionário aplicado durante as entrevistas esteve baseado no protocolo de pesquisa \\ apresentado no ANEXO 5. Este aplica os procedimentos sugeridos por Yin( 2005) e foi estruturado a \\ partir dos seguintes elementos: carta de apresentação, questões da pesquisa (conforme apresentada \\ a seguir), revisão do referencial teórico, evidências consideradas, proposições assumidas, escopo \\ das entrevistas, procedimento de coleta de dados, plano de análise e estrutura dos relatórios.
}

Aqui vale apresentar, a partir do problema da pesquisa e de seus objetivos definidos acima, as questões formuladas:

1. FORMATAÇÃO DO PROJETO E EXPOSIÇÃO A LINHAS DE FINANCIAMENTO: como tem início a formatação de propostas, como ela é modelada em torno de seus componentes e quais técnicas são empregadas em sua avaliação?

2. RISCOS DOS EMPREENDIMENTOS: sob a ótica do financiamento, quais os principais riscos dos empreendimentos e como são abordados?

3. CRITÉRIOS SEGUIDOS NA ESCOLHA ESTALEIRO: preço, qualidade, prazo de entrega, reputação, etc., são apontados como critérios críticos na escolha de um estaleiro. Quais critérios a sua empresa utiliza nesta decisão?

4. COMENTÁRIOS SOBRE O FUNCIONAMENTO DO MODELO: tal como concebido, o modelo de financiamento setorial provoca indução a riscos? Qual sua percepção?

5. DIFICULDADES PARA OBTER FINANCIAMENTO: quais principais empecilhos e dificuldades provocadas pelas distorções apontadas acima? Como são contornadas?

6. RODADAS DE NEGOCIAÇÕES: uma vez que a proposta obteve prioridade como funcionam as rodadas de negociação junto ao agente financeiro? Quais os aspectos críticos e desafios a serem enfrentados?

7. EXECUÇÃO E POLÍTICA DE REPASSE DE RECURSOS: durante a execução do projeto de construção quais os principais problemas enfrentados, como são contornados e quais os efeitos sobre o empreendimento?

8. PONTOS FORTES, PONTOS FRACOS E SUGESTÕES: em sua opinião, quais os pontos fortes e fracos do modelo de financiamento local? Como poderiam ser contornados ou evitados?

Dadas estas questões, a finalidade do presente protocolo que deu suporte às entrevistas foi fornecer meios para que fosse possível identificar e documentar, por meio de questionário previamente elaborado, a percepção de agentes envolvidos na formatação e exposição de projetos de construção de embarcações à linha de financiamento, identificando seus pontos fortes e fracos.

\section{REFERENCIAL TEÓRICO}

Como conhecido, há poucos estudos discutindo o papel e a racionalidade empregado no desenho de linhas de financiamento destinadas a construção naval. A escassa literatura recuperada e sistematizada no projeto de pesquisa, ao apontar a importância do financiamento do financiamento para os negócios ligados a economia marítima e sua estrutura. A literatura indica que a ICN é uma indústria de bens de capital que produz sob encomenda (VERMULM.; ERBER, 2002). Este segmento se caracterizada como uma indústria de montagem intensiva em mão-de-obra onde as economias dinâmicas, resultado da repetição das experiências de projetar e fabricar bens com características semelhantes, são cruciais e cuja principal fonte de tecnologia advém dos ofertantes de navipeças (CHO; PORTER, 1986). A rigor, a "competitiveness in the shipbuilding industry has been defined in terms of price, quality, product innovation, delivery period, timeliness (ability to meet deadlines), flexibility, reputation, financing services, and customer service." (IRENE et. al, 2001, p. 13).

No ambiente de produção sob encomenda, um bom planejamento e controle da produção possuem enorme importância (VERMULM; ERBER, 2002) o que trás severas repercussões sobre o cumprimento de prazos e orçamento previstos no escopo do projeto de construção. Tal é que o "delivery period and timeliness are also important factors because shorter delivery periods and timely delivery can reduce the exposure of shipping companies to investment risks resulting from changes in interest rates, foreign exchange rates, and shipping demand." (IRENE et. al, 2001, p. 14). 
Navios são caros para construir e operar, o que significa que assistência financeira é necessária para estaleiros e armadores (KHALID, 2005; STOPFORD, 2005). Esse peso do financiamento tem se agravado uma vez que hoje a construção de um navio envolve grandes volumes de recursos que só podem ser viabilizados por meio da atuação de instituições financeiras (BARBOZA, 2004; KHALID, 2005).

Os bancos baseiam suas práticas em informações sobre as experiências pretéritas bem como na análise de indicadores econômico-financeiros obtidos a partir dos demonstrativos contábeis das empresas envolvidas nas propostas. ${ }^{132}$ Do tratamento sistemático dessas informações resulta a classificação de credito e perfis de riscos dos empreendimentos - variáveis críticas durante o processo de investigação das atividades ligadas ao setor (KHALID, 2005, ALEX, 2004).

Sob a ótica do agente financeiro as operações de financiamento devem ser entendidas como expectativa de recebimento de determinada quantia de dinheiro por determinado período de tempo fixados em contrato (GITMAN, 2000). A concessão de financiamento envolve cinco critérios que são tradicionalmente utilizados para avaliar riscos: caráter, capacidade, capital, collateral, conglomerado estes constituem os cinco C's preconizados por Weston e Brigham (2000).

Segundo Johnson Stokes \& Master (200-?), estes fatores repercutem no financiamento à construção naval e implicam nas seguintes ações: construir um perfil da obrigação contratual em torno do empreendimento e do caráter do cliente relacionando-os com tipo de empreendimento objeto da proposta; avaliar seus riscos operacionais que se refletem na aderência da execução do projeto com o plano de construção do navio e na precisão das projeções ou estimativas de fluxo de caixa; medir a condição financeira dos atores envolvidos na operação, estas advêm dos indicadores obtidos a partir de demonstrativos contábeis os quais devem ser complementados por outras análises que captem a eficiência dos ativos intangíveis); verificar o nível de disposição em alocar capital próprio no total do investimento (capital); avaliar a segurança que o tomador do financiamento pode oferecer para o banco (caução, penhor, valor mobiliário posto à disposição do credor como garantia paralela de pagamento de dívida).

Em meio a essas diretrizes a "reputation is an important factor considering that planning, production and financing of a new shipbuilding is a complex task. Ship owners usually prefer shipbuilders who have achieved good track record in terms of delivery period, meeting deadlines, and quality" (IRENE et. al, 2001, p. 13).

O risco financeiro constitui a possibilidade de perda financeira; ativos considerados mais arriscados são os que oferecem maiores possibilidades de perdas financeiras Gitman (2000). O mercado relacionado as operações das empresas ligadas ao mundo naval é cíclico (COMISSÃO ECONÔMICA PARA A AMÉRICA LATINA E O CARIBE, 2005). Devido aos riscos que emanam das atividades ligadas ao setor, o financiamento naval envolve sofisticados mecanismos de avaliação e de fixação de garantia de divida dados os riscos envolvidos nas operações (ALEX, 2004; KHALID, 2005).

Em função das características das operações, o financiamento naval envolve sofisticados mecanismos de avaliação e de fixação de garantias sobre as dívidas (ALEX, 2004; KHALID, 2005) os quais são função das altas somas envolvidas, prazos das operações e níveis de riscos (JOHNSON STOKES \& MASTER, 200-?). Uma das formas contornar estes desafios é por meio do estabelecimento de cláusulas que garantam o direito do financiador tomar posse do navio ou de outros ativos da empresa que efetiva o contrato em caso de não cumprimento do contrato (KHALID, 2005).

Em função da experiência passada e considerando que o funcionamento da economia marítima é complexa e que e apresenta flutuações cíclicas, os bancos que operam linhas de financiamento orientadas ao setor são sempre muito cautelosos (KHALID, 2005).

Como apontam Khalid (2005), Alex (2004), Kendall e Buckley (2005), Stopford (2005), Johnson Stokes \& Master (200-?) e Cho e Porter (1986), o financiamento à construção naval deve levar em conta diversos parâmetros, entre eles: aspectos da política setorial do país considerado (política de marinha mercante, política naval, política industrial seletiva, política de comércio exterior, etc.); desenho de políticas especificamente associadas as operações de financiamento as quais estabelecem prazos, taxas de juros, períodos de carência, regras de amortizações, etc., compatíveis com cada operação; confiabilidade em torno da competência técnica e produtiva do construtor

${ }^{132}$ Os indicadores econômico-financeiros serão apresentados discutidos com os entrevistados. 
traduzidas em habilidades na programação da produção e montagem da embarcação; habilidades de negociação das partes envolvida, entre outros fatores; capacidade financeira e nível de risco dos agentes vinculados nas propostas de financiamento; participação mínima de capital por parte das empresas envolvidas; complexidade da documentação e necessidade de recursos humanos treinados e especializados em shipping finance; potencial publicidade adversa e perdas não seguradas relacionada a poluição (óleo, resíduos, etc.) e riscos de outros desastres ambientais (particularmente para navios petrolíferos); flutuação no valor dos ativos das companhias e rigidez dos contratos vis-à-vis o alto nível de flexibilidade de fundos para empréstimos (particularmente durante as períodos recessivos).

\section{EVIDÊNCIAS CONSIDERADAS}

A sistematização de entrevistas realizadas durante a fase exploratória deste estudo indica que, no Brasil, o papel do financiamento é limitado, fundamentalmente, devido as condições econômicas e financeiras das empresas, histórico de descumprimento de prazos de entrega e desvios nos custos dos projetos bem como à forma de tratamento dada aos riscos associados aos empreendimentos. ${ }^{133}$ Estes se relacionam à natureza intrínseca e extrínseca da avaliação dos empreendimentos e situação financeira da empresa pleiteante. Em função disso, muitos contratos deixam de ser efetivados devido a composição de ativos das empresas envolvidas, às dificuldades que os armadores enfrentam de atender as condições exigidas nas operações de financiamento e problemas associados a programação da produção.

Ao que tudo indica, no Brasil os custos associados às operações de financiamento são menores dos que os praticados nos demais países. Além disso, as condições de prazo são mais vantajosas. Essa afirmativa se sustenta na medida em que atualmente, segundo as entrevistas feitas durante a fase exploratória da pesquisa, muitas empresas estrangeiras estão recorrendo aos recursos do FMM, o que parece corroborar essa proposição. Contudo, esta hipótese só pode ser aceita se devidamente testada por meio de técnicas apropriadas de cálculo financeiro e emprego de simulações a fim de verificar as condições de sua validade. Fatores como grau de alavancagem financeira, modelagem de riscos (cambial, país, de crédito, etc.) e over-price podem distorcer resultados.

\section{PROPOSIÇÕES ASSUMIDAS}

A partir da questão 1 foram estabelecidas a seguintes proposições que se encontram agrupadas em torno dos seguintes temas: projeto do produto e do processo; avaliação financeira; desenho institucional:

\section{- avaliação financeira:}

o proposição 1.1: as empresas encontram dificuldades na aprovação do financiamento junto ao BNDES no que se refere aos critérios de avaliação econômico-financeira.

o proposição 1.2: a análise de propostas se baseia em um amplo conhecimento do agente financeiro acerca da forma de funcionamento do setor, isso se reflete em sua avaliação, nas rodadas de negociação e nas exigências estabelecidas para a sua provação.

o proposição 1.3: as garantias exigidas para obtenção do financiamento representam o principal entrave para a aprovação de propostas junto ao BNDES, a maioria das empresas não consegue atender a tais exigências para a efetivação dos contratos.

- projeto do produto e do processo:

o proposição 1.4: os estaleiros nacionais atendem satisfatoriamente ao escopo do produto; contudo, ainda precisam aprimorar os processos de gestão da produção para que atinjam maior qualidade em projetos, evitando desvios nos prazo, custo e orçamento.

- desenho institucional:

\footnotetext{
${ }^{133}$ Ver Anexo 2.
} 
o proposição 1.5: na percepção dos agentes, não há uma definição clara entre a política de marinha mercante e a política de construção naval, o que se reflete na política de financiamento setorial, assim as empresas não possuem uma clara estratégia e política de negociação ao formatar, submeter e negociar novas propostas.

A partir da questão 2 foi estabelecida a seguinte proposição:

- proposição 2.1: as condições de financiamento brasileiras são, sob certos limites, competitivas em termos dos parâmetros financeiros adotados (taxas praticadas, período de carência, prazos de amortização, etc.), seguindo padrões internacionalmente aceitos; nesse sentido, são mais atrativas quando comparadas aos esquemas de financiamento em vigor em outros países.

\section{ESCOPO DAS ENTREVISTAS}

A partir dessas proposições foram elaboradas as seguintes questões:

- Q1. PEDIDO DE FINANCIAMENTO: a empresa submeteu pedido de prioridade para utilização dos recursos do FMM e da conta vinculada para a construção de embarcações? O Sr.(a) participou desse processo?

- Q2. FORMATAÇÃO DO PROJETO E EXPOSIÇÃO A LINHAS DE FINANCIAMENTO: como tem início a formatação de propostas, como ela é modelada em torno de seus componentes e quais técnicas são empregadas em sua avaliação?

- Q3. RISCOS DOS EMPREENDIMENTOS: sob a ótica do financiamento, quais os principais riscos dos empreendimentos e como são abordados?

- Q4. CRITÉRIOS SEGUIDOS NA ESCOLHA ESTALEIRO: preço, qualidade, prazo de entrega, reputação, etc., são apontados como critérios críticos na escolha de um estaleiro. Quais critérios a sua empresa utiliza nesta decisão?

- Q5. COMENTÁRIOS SOBRE O FUNCIONAMENTO DO MODELO: tal como concebido, o modelo de financiamento setorial provoca indução a riscos? Qual sua percepção?

- Q6. DIFICULDADES PARA OBTER FINANCIAMENTO: quais principais empecilhos e dificuldades provocadas pelas distorções apontadas acima? Como são contornadas?

- Q7. RODADAS DE NEGOCIAÇÕES: uma vez que a proposta obteve prioridade, como funcionam as rodadas de negociação junto ao agente financeiro? Quais os aspectos críticos e desafios a serem contornados?

- Q8. EXECUÇÃO E POLÍTICA DE REPASSE DE RECURSOS: durante a execução do projeto de construção quais os principais problemas enfrentados, como são contornados e quais os efeitos sobre o empreendimento?

- Q9. PONTOS FORTES, PONTOS FRACOS E SUGESTÕES: em sua opinião, quais os pontos fortes e fracos do modelo de financiamento local? Como poderiam ser mitigados ou evitados?

\section{PROCEDIMENTO DE COLETA DE DADOS}

Foram realizadas 6 rodadas de entrevistas com diretores financeiros de empresas ligadas ao segmento de transporte marítimo e apoio marítimo. O processo de escolha das empresas ou definição de "casos" foi inicialmente feito com base na obtenção de contatos com informantes-chaves. Posteriormente, os próprios entrevistados e os informantes-chaves passaram a fornecer uma rede de contatos.

A primeira rodada de entrevistas, ainda sob uma perspectiva exploratória, foi realiza entre os dias 06/06 e 09/06 de 2006. O método utilizado a fim de julgar seu conteúdo foi a validade dos constructo (baseada em múltiplas fontes de evidência e seu encadeamento) e validade interna (por meio de construção de explanações) cujo conteúdo foi avaliado por informantes-chaves na segunda rodada de entrevistas. Tais procedimentos são recomendados por Yin (2005).

A segunda rodada foi realizada entre os dias $27 / 11$ e 01/12 de 2006, durante a realização do XXI Congresso Nacional de Transportes Marítimos, Construção naval e Offshore e EXPONAL 2006, 
promovido pela Sociedade Brasileira de Indústria Naval (SOBENA). Estas se basearam na aplicação de questionário estruturado. As informações das entrevistas foram transcritas e analisadas em torno de seus pontos de convergência e divergência e também avaliadas por meio dos procedimentos descritos no parágrafo anterior. Adicionalmente e com base no volume de informações coletadas, foi eleito um método adicional: teste de confiabilidade. Este se baseou no presente protocolo e no desenvolvimento de um banco de dados do estudo, tal qual recomendado por Yin (2005).

A terceira rodada de entrevistas foi realizada durante os dias 27/11 e 01/12 de $2006 \mathrm{em}$ visitas a empresas de entidades ligadas ao mundo naval.

Em meio a elaboração das entrevistas junto aos diretores financeiros das empresas, também foram entrevistados informantes-chaves junto ao Sindicato Nacional das Empresas de Navegação Marítima (SYNDARMA), DMM, (SINAVAL), BNDES, Associação Brasileira das Empresas de Apoio Marítimo (ABEAM), Sindicato Nacional da ICN e Offshore (SINAVAL), técnicos do Instituto de Pesquisas Tecnológicas do Estado de São Paulo (IPT), e acadêmicos da Escola Politécnica da USP (POLI/USP) e da COPPE/UFRJ.

\section{PLANO DE ANÁLISE}

As informações das entrevistas, baseadas em questionário estruturado, foram transcritas e analisadas em torno de seus pontos de convergência e divergência. Dentro do plano de análise, foram realizados relatórios individuais de cada entrevista e relatório de análise cruzada destas.

\section{ESTRUTURA DOS RELATÓRIOS}

A estrutura do relatório das entrevistas segue o padrão proposto por Yin (2005): sumário, objetivos, características gerais do método de estudos de caso, definição de procedimentos, formulação de questões. A consolidação de resultados foi estabelecida por meio de construção e explanações e quadros resumo em torno das questões. Estas informações são apresentados no capítulo 4. 
ANEXO 3 - RELAÇÃO DE EMPRESAS NACIONAIS CONTATADAS PARA ELABORAÇÃO DAS ENTREVISTAS.

\begin{tabular}{|c|c|c|c|c|}
\hline Empresa & Atividades & Endereço & E-mail & Tel \\
\hline Astromarítima Navegação SA & $\begin{array}{l}\text { Apoio marítimo às atividades } \\
\text { de exploração e produção de } \\
\text { petróleo na plataforma continental } \\
\text { brasileira }\end{array}$ & $\begin{array}{l}\text { Rua Lauro Muller, } 116 \text { grupo 1305- } \\
\text { Torre Rio Sul } \\
\text { Botafogo - Rio de Janeiro } \\
\text { CEP : 22.290-160 }\end{array}$ & astro@astromarítima.com.br & $\begin{array}{l}\text { (21) 3820-1250 - tel } \\
\text { (21) 2295-0610 - fax }\end{array}$ \\
\hline Aliança Navegação Ltda. & $\begin{array}{l}\text { Sistema que associa o transporte } \\
\text { terrestre (rodoviário e/ou } \\
\text { ferroviário) e marítimo para coleta } \\
\text { e entrega da carga em local } \\
\text { definido pelo cliente. Transporta } \\
\text { cargas de projeto (turbinas e } \\
\text { máquinas de grandes dimensões) e } \\
\text { cargas rolantes (ônibus, caminhões, } \\
\text { tratores, etc.). }\end{array}$ & $\begin{array}{l}\text { Rua Verbo Divino, } 1547,5^{\circ} / 6^{\circ} \text { e } 8^{\circ} \\
\text { ao } 14^{\circ} \\
\text { Chácara Santo Antônio - SP - SP } \\
\text { CEP: 04719-002 }\end{array}$ & $\begin{array}{l}\text { willy.schaller@são.alianca.com.br } \\
\text { heidi.jensen@sao.hamburgsud.com }\end{array}$ & $\begin{array}{l}\text { (11) 5185-5600 - tel } \\
\text { (11) 5185-5624 - fax }\end{array}$ \\
\hline Argos Navegação S.A & $\begin{array}{l}\text { Cabotagem-Armador de } \\
\text { Cabotagem } \\
\text { Tipo de serviços: Carga geral, } \\
\text { containers, projeto. }\end{array}$ & $\begin{array}{l}\text { Rua Visconde de Inhaúma, } 77 \text { - 7o. } \\
\text { andar - Centro - RJ } \\
\text { CEP: 20091-007 }\end{array}$ & argos@argosnave.com & $\begin{array}{l}\text { (21) 2543-7203 tel } \\
\text { (21) 2253-8778 - fax }\end{array}$ \\
\hline ATL/Space - filial & $\begin{array}{l}\text { Transporte Marítimo-Armadores. } \\
\text { Navios de Carga Geral/Breakbulk }\end{array}$ & $\begin{array}{l}\text { Av. Batel 1230, conj. } 609 \\
\text { Curitiba - PR } \\
\text { CEP: 80420-090 }\end{array}$ & overhagen@spaceship.com.br & $\begin{array}{l}\text { (41) 342-9734 - tel } \\
\text { (41) 342-2984 - fax }\end{array}$ \\
\hline
\end{tabular}




\begin{tabular}{|c|c|c|c|c|}
\hline Atlantis Amazônia Comércio Ltda & $\begin{array}{l}\text { Transporte de derivados de petróleo } \\
\text { na região amazônica, em parceria } \\
\text { com a Companhia Brasileira de } \\
\text { Petróleo IPIRANGA, tendo } \\
\text { viabilizado o abastecimento de } \\
\text { combustível até o Oeste do Mato } \\
\text { Grosso. }\end{array}$ & $\begin{array}{l}\text { Rua Coronel Ferreira de Araújo, } 809 \text { - } \\
\text { Petrópolis } \\
\text { Manaus - Amazonas } \\
\text { Cep: 69.063-000 }\end{array}$ & |paulo@atlantisdaamazonia.com.br & $\begin{array}{l}\text { (92) 631-9451 - tel } \\
\text { (92) 631-9461 - tel } \\
\text { (92) 631-9465 - tel } \\
\text { (92) 631-9397 - fax }\end{array}$ \\
\hline $\begin{array}{l}\text { Barcas S.A Transportes } \\
\text { Marítimos }\end{array}$ & $\begin{array}{l}\text { Transporte de passageiros no modo } \\
\text { aquaviário. }\end{array}$ & $\begin{array}{l}\text { Rua Miguel de Lemos, } 80 \text { - Ponta } \\
\text { D’Areia - Niterói - RJ } \\
\text { CEP: } 24040-260\end{array}$ & sac@barcas-sa.com.br & $\begin{array}{l}\text { (21) } 4004-3113 \text { - tel } \\
\text { (21) 2620-2879 - tel } \\
\text { (21) 2109-1006 - } \\
\text { Contabilidade }\end{array}$ \\
\hline Brasflex Tubos Flexíveis Ltda. & Transporte Marítimo-Armadores & $\begin{array}{l}\text { R.da Glória, } 290-3^{\circ}, 4^{\circ} \text { e } 9^{\circ} \text { and. } \\
\text { Rio de Janeiro - RJ } \\
\text { CEP: 20241-180 }\end{array}$ & fernanda.delfino@br.coflexip.com & (21) 2139-7000 - tel \\
\hline CCL Costa Container Line SPA & Transporte Marítimo-Armadores & $\begin{array}{l}\text { Avenida Rio Branco, } 25 \text { - 5o. andar } \\
\text { P.O. Box } 21007 \\
\text { Rio de Janeiro - RJ } \\
\text { CEP: 20090-903 }\end{array}$ & box@wilsonsons.com.br & $\begin{array}{l}\text { (21) 2516-3294 - tel } \\
\text { (21) } 22064293 \text { - } \\
\text { fax }\end{array}$ \\
\hline CMA CGM do Brasil Ltda. & Transporte Marítimo-Armadores & $\begin{array}{l}\text { Av. Rio Branco, } 12-10^{\circ} \text { and. } \\
\text { Rio de Janeiro - RJ } \\
\text { CEP: 20090-000 }\end{array}$ & elimaria@cma-cgm.com.br & $\begin{array}{l}\text { (21) 2221-3520 - tel } \\
\text { (21) 2507-1829 - fax }\end{array}$ \\
\hline $\begin{array}{l}\text { Companhia Brasileira de Offshore - } \\
\text { C.B.O. }\end{array}$ & Transporte Marítimo-Armadores & $\begin{array}{l}\text { Av. Pasteur, } \mathrm{n}^{\circ} 110 \text { - } 9^{\circ} \text { andar } \\
\text { Botafogo - Rio de Janeiro - RJ } \\
\text { CEP: 22290-240 }\end{array}$ & cbo@cborio.com.br & $\begin{array}{l}\text { (21) 2546-1122 - tel } \\
\text { (21) 2546-1387 - fax }\end{array}$ \\
\hline Companhia de Navegação Norsul & $\begin{array}{l}\text { Transporte de granel seco na região } \\
\text { da costa leste da América do Sul, } \\
\text { atende tanto o comércio de } \\
\text { Cabotagem como o Internacional } \\
\text { (longo curso). }\end{array}$ & $\begin{array}{l}\text { Av. Augusto Severo, 8, } 8^{\circ} \text { andar } \\
\text { Rio de Janeiro - RJ } \\
\text { CEP: CEP: 20021-040 }\end{array}$ & norsul@norsul.com & $\begin{array}{l}\text { (21) 2139-0505 - tel } \\
\text { (21) 2507-1547 - fax }\end{array}$ \\
\hline Companhia Libra de Navegação & $\begin{array}{l}\text { Serviço de transporte marítimo de } \\
\text { cargas em contêineres }\end{array}$ & $\begin{array}{l}\text { Rua São Bento, } 8 \text { - } 8^{\circ} \text { Andar } \\
\text { Centro - Rio de Janeiro - RJ } \\
\text { CEP 20.090-010 }\end{array}$ & librario@libra.com.br & $\begin{array}{l}\text { (21) 2203-5000 - tel } \\
\text { (21) } 22833001 \text { - fax }\end{array}$ \\
\hline
\end{tabular}




\begin{tabular}{|c|c|c|c|c|}
\hline | Companhia Navegação das Lagôas & | Transporte Marítimo-Armadores & $\begin{array}{l}\text { R. Visconde de Inhaúma, } 37 \text { - Grupo } \\
2001 \\
\text { Rio de Janeiro - RJ } \\
\text { CEP: 20091-000 }\end{array}$ & cnl@cnl.com.br & \begin{tabular}{|l} 
(21) 2233-5684 - tel \\
(21) 2233-5684 - fax
\end{tabular} \\
\hline Cosco Brasil Mar S/A & Transporte Marítimo-Armadores & $\begin{array}{l}\text { Av Paulista, } 1337 \text { - 18o. Andar } \\
\text { São Paulo - SP } \\
\text { CEP 01311-200 }\end{array}$ & spo@cosco.com.br & $\begin{array}{l}\text { (11) 3177-2888 - tel } \\
\text { (11) 3177-2877- fax }\end{array}$ \\
\hline $\begin{array}{l}\text { Delba Marítima } \\
\text { Navegação S.A }\end{array}$ & $\begin{array}{l}\text { Operação, agenciamento e } \\
\text { administração de embarcações. } \\
\text { Afretamento de embarcações } \\
\text { de apoio Marítimo e de } \\
\text { embarcações especiais. }\end{array}$ & $\begin{array}{l}\text { Ladeira de Nossa Senhora, } 163 \\
\text { Rio de Janeiro - RJ } \\
\text { CEP: 22.211- } 100\end{array}$ & delba@delbamaritima.com.br & $\begin{array}{l}\text { (21) 3235-9345 - tel } \\
\text { (21) 3235-9384 - fax }\end{array}$ \\
\hline DSND Consub S/A & Transporte Marítimo-Armadores & $\begin{array}{l}\text { R. Engenheiro Fabio Goulart, } 155 \\
\text { Rio de Janeiro - RJ } \\
\text { CEP: } 24050-090\end{array}$ & consub@ax.apc.org & $\begin{array}{l}\text { (21) 2622-9800 - tel } \\
\text { (21) 2622-9191 - fax }\end{array}$ \\
\hline Eisa - Estaleiro Ilha S/A & $\begin{array}{l}\text { Construção naval, reparos navais, } \\
\text { conversões, grandes reformas, } \\
\text { reparos em plataformas e } \\
\text { estruturas submarinas. }\end{array}$ & $\begin{array}{l}\text { Praia do Rosa, } 2 \text { - Ilha do Governador } \\
\text { - RJ } \\
\text { CEP: 21.920-630 }\end{array}$ & eisa@eisa.com.br & $\begin{array}{l}\text { (21) 2468-8002 - tel } \\
\text { (21) 3396-2903 - fax }\end{array}$ \\
\hline Empresa de Navegação Elcano S/A & Transporte Marítimo-Armadores & $\begin{array}{l}\text { Praia de Botafogo, } 440-12^{\circ} \text { and. } \\
\text { Rio de Janeiro - RJ } \\
\text { CEP: } 22250-040\end{array}$ & comercial@elcano-sa.com.br & $\begin{array}{l}\text { (21)2546-9831 - tel } \\
\text { (21) 2586-6002 - fax }\end{array}$ \\
\hline Enavi e Renave Estaleiros & $\begin{array}{l}\text { Estaleiro- ENAVI e RENAVE } \\
\text { fundiram-se em Outubro de 1995, } \\
\text { reunindo facilidades em reparos } \\
\text { navais. Foram comprados } \\
\text { pelos Grupo Reicon (Belém - Pará). }\end{array}$ & $\begin{array}{l}\text { Avenida do Contorno, } 169 \text { - Barreto } \\
\text { Niterói - RJ }\end{array}$ & renave@enavi.com.br & $\begin{array}{l}\text { (21) 2199-8044 - tel } \\
\text { (21) 2624-1662 - fax }\end{array}$ \\
\hline Estaleiro Mauá-Jurong & $\begin{array}{l}\text { Offshore, cosntrução naval e } \\
\text { reparos }\end{array}$ & $\begin{array}{l}\text { Rua Dr. Paulo Frumêncio, } 28 \\
\text { Ponta d' Areia - Niterói - RJ } \\
\text { Cep: 24.040-290 }\end{array}$ & presidencia@mauajurong.com.br & $\begin{array}{l}\text { (21) 2189-9999 - tel } \\
\text { (21) } 27191392 \text { - fax }\end{array}$ \\
\hline
\end{tabular}




\begin{tabular}{|c|c|c|c|c|}
\hline $\begin{array}{l}\text { FLUMAR Transportes de } \\
\text { Químicos e Gases Ltda. }\end{array}$ & $\begin{array}{l}\text { Transporte de produtos químicos, } \\
\text { ácidos e óleos }\end{array}$ & $\begin{array}{l}\text { Rua do Rosário, } 113-6^{\circ} / 7^{\circ} \text { andares } \\
\text { Centro - RJ - CEP. 20041-004 }\end{array}$ & flumar@flumar.com.br & $\begin{array}{l}\text { (21) 2292-3944 - tel } \\
\text { (21) 2242-980 - fax }\end{array}$ \\
\hline Grupo Wilson, Sons & $\begin{array}{l}\text { Rebocagem, Operação Portuária, } \\
\text { Logística Integrada, Agenciamento } \\
\text { Marítimo e Construção Naval. }\end{array}$ & $\begin{array}{l}\text { Avenida Ibirapuera, } 2033 \text { - Conj. } 13 \text { e } \\
14 \text { - Moema - SP } \\
\text { (P.O. Box 523) } \\
\text { CEP:04029-100 }\end{array}$ & agesp@wilsonsons.com.br & $\begin{array}{l}\text { (21) 2126-4222 - tel } \\
\text { RJ }\end{array}$ \\
\hline Maersk Brasil ( Brasmar ) Ltda & $\begin{array}{l}\text { Logística e transporte marítimo de } \\
\text { carga em contêiner }\end{array}$ & $\begin{array}{l}\text { Praia do Flamengo, } 154 \text { 2andar - Rio } \\
\text { de Janeiro-RJ, Brasil CEP:22210906 }\end{array}$ & rionlfin@maersk.com & (11) 2555-2808 - tel \\
\hline $\begin{array}{l}\text { Marítima Petróleo e Engenharia } \\
\text { Ltda. }\end{array}$ & Transporte Marítimo-Armadores & $\begin{array}{l}\text { Av. Almirante Barroso,52 - Grupo } \\
3400 \\
\text { Rio de Janeiro - RJ } \\
\text { CEP: 20031-000 }\end{array}$ & hilda diretoria@maritimapetroleo.com.br & $\begin{array}{l}\text { (21) 2544-4044 - tel } \\
\text { (11) 3835-8822 - tel } \\
\text { SP }\end{array}$ \\
\hline Metalnave Navegação S/A & Transporte Marítimo-Armadores & $\begin{array}{l}\text { Av. Rio Branco, } 37 \text { - Sl. } 912 \\
\text { Rio de Janeiro }\end{array}$ & metalnv@ibm.net & $\begin{array}{l}\text { (21) 2620-1414 - tel } \\
\text { (21) 2620-8017- fax }\end{array}$ \\
\hline Navegação Guarita & $\begin{array}{l}\text { Transporte interno por hidrovia de } \\
\text { cargas, transferências aquaviárias } \\
\text { hidroviárias e marítimas, centrais } \\
\text { de } \\
\text { serviços armazéns e portos e } \\
\text { bunkering. }\end{array}$ & $\begin{array}{l}\text { Rua Florêncio Ygartua, } 131 \text { cj. } 301 \\
\text { Porto Alegre - RS } \\
\text { CEP: 90430-010 }\end{array}$ & & $\begin{array}{l}\text { (51) 3222-1133 - tel } \\
\text { (51) 3222-1340 - fax }\end{array}$ \\
\hline $\begin{array}{l}\text { Navegação Vale do Rio Doce S/A } \\
\text { - Docenave }\end{array}$ & Transporte Marítimo-Armadores & $\begin{array}{l}\text { Av. Graça Aranha, } 26 \text { - Centro - } 9^{\circ} \\
\text { andar } \\
\text { Rio de Janeiro - RJ } \\
\text { CEP: 20005-900 }\end{array}$ & \begin{tabular}{|l|} 
jramos@cvrd.com.br ou \\
prgalvao@cvrd.com.br
\end{tabular} & \begin{tabular}{|l} 
(21) $3814-4556 /$ \\
\\
$3814-4074$ - tel \\
(21) $3814-4179$ - fax
\end{tabular} \\
\hline Neptúnia Companhia de Navegação & Transporte Marítimo-Armadores & $\begin{array}{l}\text { Av. Brasil, } 1823 \\
\text { São Paulo - SP } \\
\text { CEP: 01431-001 }\end{array}$ & neptunia@neptunia.com.br & $\begin{array}{l}\text { (11) 3060-8433 - tel } \\
\text { (11) 3060-8214 - fax }\end{array}$ \\
\hline
\end{tabular}




\begin{tabular}{|c|c|c|c|c|}
\hline Norskan Offshore & | Transporte Marítimo-Armadores & $\begin{array}{l}\text { Rua Lauro Muller,116 / } 1105 \\
\text { Botafogo - RJ } \\
\text { Cep: 22290-160 }\end{array}$ & office@rio.norskan.com.br & $\begin{array}{l}\text { (21) 2103-5700 - tel } \\
\text { (21) 2103-5707 - fax }\end{array}$ \\
\hline Rebrás - Rebocadores do Brasil & Transporte Marítimo-Armadores & $\begin{array}{l}\text { Av. Presidente Vargas, } 309 \\
\text { - 8 andar - Centro } \\
\text { Rio de Janeiro - RJ } \\
\text { CEP: 20040-010 }\end{array}$ & & $\begin{array}{l}\text { (21) 2121-1000 - tel } \\
\text { (21) 2121-1024 - fax }\end{array}$ \\
\hline Sanave Navegação Ltda. & Transporte Marítimo-Armadores & $\begin{array}{l}\text { R. Carlos Seidl, } 993 \\
\text { Rio de Janeiro - RJ } \\
\text { CEP: 20931-001 }\end{array}$ & rio@sada.com.br & $\begin{array}{l}\text { (21) 2580-0279 - tel } \\
\text { (21) 2580-0279 - fax }\end{array}$ \\
\hline Semertal & $\begin{array}{l}\text { Docagem e reparo de embarcações } \\
\text { e } \\
\text { plataformas, manutenção de off- } \\
\text { shore, } \\
\text { movimentação de cargas (até } 350 \\
\text { ton), } \\
\text { construção naval, entre outras. } \\
\end{array}$ & $\begin{array}{l}\text { Rua General Gurjão, parte } 2 \\
\text { Cajú - Rio de Janeiro - RJ } \\
\text { CEP: 20931-900 }\end{array}$ & diretoria@sermetal.net & $\begin{array}{l}\text { (21) 2585-9400 - tel } \\
\text { (21) 2585- } 9429 \text { - fax }\end{array}$ \\
\hline Skannor Offshore LTDA & $\begin{array}{l}\text { Prestação de serviços na } \\
\text { navegação de apoio marítimo. }\end{array}$ & $\begin{array}{l}\text { Rua Lauro Muller, } 116 \text { - sala } 1105 \\
\text { Botafogo, Rio de Janeiro - RJ }\end{array}$ & & \\
\hline Transdourada Transportes Ltda. & $\begin{array}{l}\text { Atua no segmento de transporte } \\
\text { fluvial e rodoviário de derivados de } \\
\text { petróleo e álcoois, na região norte ( } \\
\text { Belém/PA, Atamira/PA, } \\
\text { Manaus/AM). }\end{array}$ & Ananindeua/Pará & transdourada@transdourada.com.br & \\
\hline Transportes Bertolini LTDA & Transporte fluvial de cargas. & $\begin{array}{l}\text { Rua Nova Guataporanga, } 366 \\
\text { Cumbica - Guarulhos - SP }\end{array}$ & tblgru@tbl.com.br & (11) 6482-8000 - tel \\
\hline Trico Serviços Marítimos Ltda. & Transporte Marítimo-Armadores & $\begin{array}{l}\text { Av. Nilo Peçanha, } 50 \text { / } 1613 \\
\text { Rio de Janeiro - RJ } \\
\text { CEP: 20044-900 }\end{array}$ & tricobr@uol.com.br & $\begin{array}{l}\text { (21) 2215-1949 - tel } \\
\text { (21) 2215-8597 - fax }\end{array}$ \\
\hline UP Offshore Apoio Marítimo Ltda. & Transporte Marítimo-Armadores & $\begin{array}{l}\text { Av.Ataufo de Paiva, } 1.235 \text { / } 3^{\circ} \text { Andar } \\
\text { Leblon - Rio de Janeiro - RJ } \\
\text { CEP: 22.440-031 }\end{array}$ & mhelman@upoffshore.com.br & $\begin{array}{l}\text { (21) 2112-4545 - tel } \\
\text { (21) 2112-4557 - fax }\end{array}$ \\
\hline
\end{tabular}




\title{
ANEXO 4 - E-MAIL E CONTATO DE SOLICITAÇÃO DE ENTREVISTAS ENCAMINHADO ÀS EMPRESAS NACIONAIS
}

\author{
Os contatos foram estabelecidos por meio telefônico e eletrônico. Em ambos \\ as abordagem o roteiro abaixo foi utilizado.
}

E-MAI LS ENCAMI NHADOS

A/ C

Ref.: Realização de Pesquisa de Mestrado POLI/ USP

Prezado

Saudações.

Meu nome é Marcello Muniz, sou aluno regular do Programa de Pós-graduação do Departamento de Engenharia Naval e Oceânica da Escola Politécnica da Universidade de São Paulo (POLI/USP).

Atualmente estou realizando pesquisa acadêmica destinada a elaboração de dissertação de mestrado. O objetivo do projeto é discutir a estrutura de financiamento destinada ao setor naval no Brasil.

A rigor, o trabalho tem como objetivos centrais:

(i) comparar a estrutura de financiamento da indústria naval brasileira com as práticas adotadas em outros países;

(ii) discutir como são operados e de que forma os critérios de financiamento adotados no Brasil interferem na aprovação de pedidos contratação orientados à construção de novas embarcações.

Feita esta breve apresentação, gostaria de agendar entrevista para que possa discutir alguns aspectos relacionados a questão do financiamento setorial.

Como estarei no Rio de Janeiro entre os dias XX/YY e ZZ/NN, gostaria agendar entrevistas durante estas datas em local de sua conveniência.

A finalidade da entrevista, desenvolvida sob orientação do Prof. Dr. Marcelo Ramos Martins da POLI/USP, é identificar e documentar, por meio de questionário previamente elaborado, vossa percepção acerca dos pontos fortes e fracos da formatação da linha de financiamento provida pelo BNDES

As questões abrangerão os seguintes temas: (1) desenvolvimento e formatação de projetos; (2) aspectos da estrutura de financiamento local; (3) exposição de novos projetos às linhas de financiamento; (4) execução e controle de projetos sob a ótica financeira; (5) considerações críticas sobre o FMM.

Tenho ciência de que seu tempo é escasso, porém o questionário elaborado irá Ihe tomar pouco tempo.

Assumo inteiro o compromisso de não divulgar a fonte de informações, de lhe enviar cópia dos documentos para vossa revisão e remeter resultado final do trabalho.

Desde já, agradeço pela compreensão e pelo tempo até aqui dispensado.

Sem mais,

Marcello Muniz

Depto de Engenharia Naval POLI/USP

(11) 8175 - 3838 / (11) 3767-4426 / (11) 5611-2434

marcello_muniz@yahoo.com.br; marcello@ipt.br, marcello.silva@poli.usp.br 


\section{ANEXO 5 - RELAÇÃO DE EMPRESAS INTERNACIONAIS ${ }^{134}$}

\begin{tabular}{|c|c|c|c|c|c|c|c|}
\hline Empresa & Sede da empresa & Site & Região de atuação & Segmento de atuação & Frota & UM & $\begin{array}{l}\text { Capacidade de } \\
\text { carga total }\end{array}$ \\
\hline $\begin{array}{l}\text { Alexander \& Baldwin } \\
\text { Inc. }\end{array}$ & Havaí, EUA & www.alexanderbaldwin.com & $\begin{array}{l}\text { Long Beach, Oakland, Seattle, } \\
\text { e outros portos no Hawaii, nas ilhas } \\
\text { de Oahu, Kauai, Maui, e Havaí }\end{array}$ & $\begin{array}{l}\text { Estiva, transporte, bens } \\
\text { imobiliários e produtos } \\
\text { alimentícios }\end{array}$ & $\begin{array}{l}12 \text { contêneires, } 3 \\
\text { reboques- } \\
\text { contêiner, } 1 \text { barco roll- } \\
\text { on/roll-off e } 2 \text { barcos- } \\
\text { contêiner }\end{array}$ & - & - \\
\hline $\begin{array}{l}\text { American } \\
\text { Commercial Lines, } \\
\text { Inc. }\end{array}$ & Indiana, EUA & www.aclines.com & $\begin{array}{l}\text { Chicago, New Orleans, } \\
\text { Jeffersonville, Indiana, Venezuela e } \\
\text { República Dominicana }\end{array}$ & $\begin{array}{l}\text { Transporte marítimo e } \\
\text { prestação de serviços }\end{array}$ & $\begin{array}{l}3174 \text { barcos: barcos } \\
\text { para cargas seca } \\
\text { e líquida, barcos } \\
\text { tanques para cargas } \\
\text { líquidas e } 149 \\
\text { rebocadores }\end{array}$ & - & - \\
\hline $\begin{array}{l}\text { Aries Maritime } \\
\text { Transport Ltd. }\end{array}$ & Atenas, Grécia & www.ariesmaritime.com & Mundial & $\begin{array}{l}\text { Afretamento e transporte de } \\
\text { derivados de petróleo }\end{array}$ & $\begin{array}{l}10 \text { navios-tanque ( } 5 \\
\text { tanques double-hull MR, } \\
4 \text { tanques double-hull } \\
\text { Panamax e } 1 \text { tanque } \\
\text { double-hull Aframax) e } \\
5 \text { contêineres }\end{array}$ & $\begin{array}{l}\text { dwt (navios- } \\
\text { tanque) } \\
\text { TEU } \\
\text { (contêineres) }\end{array}$ & \begin{tabular}{|l}
429,772 \\
9,593
\end{tabular} \\
\hline $\begin{array}{l}\text { Arlington Tankers } \\
\text { Ltd. }\end{array}$ & Hamilton, Bermuda & www.arlingtontankers.com & Mundial & $\begin{array}{l}\text { Transporte de petróleo e } \\
\text { seus derivados }\end{array}$ & $\begin{array}{l}2 \text { navios-tanque V-MAX, } \\
2 \text { navios-tanque } \\
\text { Panamax, } \\
4 \text { navios-tanque } \\
\text { Arlington } \\
\end{array}$ & - & - \\
\hline $\begin{array}{l}\mathrm{B}+\mathrm{H} \text { Ocean Carriers } \\
\text { Ltd. }\end{array}$ & Hamilton, Bermuda & www.bhocean.com & Mundial & $\begin{array}{l}\text { Aquisição, controle da } \\
\text { empresa, operação, vendas } \\
\text { e transporte marítimo }\end{array}$ & $\begin{array}{l}6 \text { navios-tanque MR, } \\
1 \text { navio-tanque } \\
\text { Panamax e } \\
5 \text { navios de transporte } \\
\text { de minérios, ferro e óleo } \\
\end{array}$ & dwt & 788,916 \\
\hline Danaos Corporation & Piraeus, Grécia & www.danaos.com & Mundial & $\begin{array}{l}\text { Controle da empresa e } \\
\text { operação de navios } \\
\text { contêineres e de cargas } \\
\text { secas }\end{array}$ & 27 navios-contêineres & TEU & 116,115 \\
\hline
\end{tabular}

\footnotetext{
${ }^{134}$ Além das empresas apresentadas, foram obtidos dados adicionais das seguintes empresas: Maersk, Evergreen, Hanjin e NYK Line
} 


\begin{tabular}{|c|c|c|c|c|c|c|c|}
\hline Diana Shipping, Inc. & Atenas, Grécia & www.dianashippinginc.com & Mundial & | Transporte marítimo & $\begin{array}{l}13 \text { navios Panamax de } \\
\text { carga seca e } \\
1 \text { navio Capesize de } \\
\text { carga seca }\end{array}$ & dwt & | 1milhão \\
\hline $\begin{array}{l}\text { Double Hull Tankers, } \\
\text { Inc. }\end{array}$ & $\begin{array}{l}\text { St. Helier,llhas } \\
\text { Chanel }\end{array}$ & - & Mundial & \begin{tabular}{|l|} 
Controle da empresa e \\
operação de navios carga
\end{tabular} & $\begin{array}{l}7 \text { tanques com casco } \\
\text { duplo, sendo: } 3 \text { grandes } \\
\text { carregadores de } \\
\text { petróleo bruto e } 4 \\
\text { navios tanque Aframax }\end{array}$ & $d w t$ & $\begin{array}{l}1,113,000 \\
\text { (aproximadamente) }\end{array}$ \\
\hline DryShips, Inc. & Atenas, Grécia & www.dryships.com & Mundial & $\begin{array}{l}\text { Controle da empresa e } \\
\text { operação de navios de } \\
\text { carga seca (granel) }\end{array}$ & $\begin{array}{l}36 \text { graneleiros, sendo: } \\
4 \text { Capesize, } 27 \\
\text { Panamax, } 3 \text { Handymax } \\
\text { e } 2 \text { novos Panamax }\end{array}$ & dwt & 2,9 millões \\
\hline $\begin{array}{l}\text { Eagle Bulk Shipping, } \\
\text { Inc. }\end{array}$ & Nova York, EUA & www.eagleships.com & EUA & $\begin{array}{l}\text { Transporte marítimo } \\
\text { graneleiro }\end{array}$ & $\begin{array}{l}\text { 16 graneleiros, sendo: } \\
12 \text { Supramax e } 4 \\
\text { Handymax }\end{array}$ & dwt & 796,663 \\
\hline $\begin{array}{l}\text { Excel Maritime } \\
\text { Carriers Ltd. }\end{array}$ & Atenas, Grécia & www.excelmaritime.com & Mundial & $\begin{array}{l}\text { Controle da empresa e } \\
\text { operação de navios } \\
\text { graneleiros }\end{array}$ & $\begin{array}{l}17 \text { graneleiros, sendo: } \\
10 \text { Panamax e } 7 \\
\text { Handymax }\end{array}$ & dwt & $1,004,930$ \\
\hline FreeSeas, Inc. & Piraeus, Grécia & www.freeseas.gr & Piraeus, Greece & $\begin{array}{l}\text { Transporte de várias } \\
\text { commodities secas, como: } \\
\text { minérios, ferro, grãos, } \\
\text { bauxita, fosfato e produtos } \\
\text { de ferro }\end{array}$ & 3 navios graneleiros & $d w t$ & 84,798 \\
\hline Frontline, Ltd & Hamilton, Bermuda & www.frontline.bm & $\begin{array}{l}\text { Portos petroleiros do: Golfo Meio } \\
\text { Leste até o Longe Leste, do Norte } \\
\text { da Europa, do Caribe e Louisiana }\end{array}$ & \begin{tabular}{|l|} 
Controle da empresa, \\
compra/venda, afretamento \\
e \\
transporte de petroleiros \\
\end{tabular} & $\begin{array}{l}30 \text { VLCCs, } \\
28 \text { navios-tanque } \\
\text { Suezmax e } 2 \\
\text { contêineres }\end{array}$ & TEU & 1,7 \\
\hline $\begin{array}{l}\text { Genco Shipping \& } \\
\text { Trading Ltd. }\end{array}$ & Nova York, EUA & www.gencoshipping.com & Mundial & $\begin{array}{l}\text { Controle da empresa e } \\
\text { tranporte de cargas a } \\
\text { granel }\end{array}$ & $\begin{array}{l}17 \text { graneleiros, sendo: } \\
5 \text { Panamax, } 7 \\
\text { Handymax e } 5 \\
\text { Handysize }\end{array}$ & dwt & 839 \\
\hline $\begin{array}{l}\text { General Maritime } \\
\text { Corp. }\end{array}$ & Nova York, EUA & www.generalmaritimecorp.com & $\begin{array}{l}\text { Portos no Caribe, nas Américas do } \\
\text { Sul e Central, nos EUA, no oeste } \\
\text { da África, no Mediterrâneo, na } \\
\text { Europa, no Mar do Norte e no Mar } \\
\text { Negro }\end{array}$ & $\begin{array}{l}\text { Transporte de petróleo } \\
\text { bruto }\end{array}$ & 27 navios-tanque & & \\
\hline Golar LNG Ltd. & Hamilton, Bermuda & www.golar.com & Mundial & $\begin{array}{l}\text { Aquisição, controle, vendas } \\
\text { e transporte de gás natural } \\
\text { liquefeito (LNG) }\end{array}$ & 12 navios & & \\
\hline
\end{tabular}




\begin{tabular}{|c|c|c|c|c|c|c|c|}
\hline Grupo TMM, S. A & \begin{tabular}{|l|} 
Cidade do México, \\
México
\end{tabular} & www.tmm.com.mx & México e EUA & $\begin{array}{l}\text { Logística e tranporte } \\
\text { marítimo } \\
\text { para a indústria petrolifera e } \\
\text { seus derivados }\end{array}$ & $\begin{array}{l}36 \text { navios, entre eles: } \\
\text { tanques, petroleiros e } 1 \\
\text { reboque }\end{array}$ & |- & - \\
\hline Horizon Lines, Inc. & $\begin{array}{l}\text { Carolina do Norte, } \\
\text { EUA }\end{array}$ & www.horizonlines.com & $\begin{array}{l}\text { Alasca, Havaí, Porto Rico, EUA, } \\
\text { Guam, Hong Kong e Taiwan }\end{array}$ & $\begin{array}{l}\text { Logística e tranporte } \\
\text { marítimo }\end{array}$ & 16 navios & - & - \\
\hline $\begin{array}{l}\text { Hornbeck Offshore } \\
\text { Services, Inc. }\end{array}$ & Louisiana, EUA & www.hornbeckoffshore.com & $\begin{array}{l}\text { EUA, Golfo do México e demais } \\
\text { países }\end{array}$ & \begin{tabular}{|l|} 
Transporte maritimo de \\
petróleo e seus derivados \\
(OSV)
\end{tabular} & \begin{tabular}{|l|}
12 rebocadores $\mathrm{e}$ \\
18 barcos-tanques
\end{tabular} & - & - \\
\hline $\begin{array}{l}\text { International } \\
\text { Shipholding Corp. }\end{array}$ & Louisiana, EUA & www.intship.com & Mundial & $\begin{array}{l}\text { Opera em cinco segmentos: } \\
\text { Serviços de transporte, } \\
\text { Contratos de afretamento } \\
\text { por cronograma, Contratos } \\
\text { de afretamento, Serviços } \\
\text { férreos e outros }\end{array}$ & - & dwt & \begin{tabular}{|l}
28,000 \\
(fretamento)
\end{tabular} \\
\hline $\begin{array}{l}\text { Jupiter Marine } \\
\text { International } \\
\text { Holdings, Inc. }\end{array}$ & Flórida, EUA & www.jupitermarine.com & $\begin{array}{l}\text { EUA (Costa Leste) e Golfo do } \\
\text { México }\end{array}$ & $\begin{array}{l}\text { Construção, design e venda } \\
\text { de barcos pesqueiros }\end{array}$ & & - & \\
\hline Kirby Corp. & Texas, EUA & www.kmtc.com & Mundial & \begin{tabular}{|l|} 
Transporte marítimo de \\
petróleo e derivados e \\
serviços de motor a diesel
\end{tabular} & $\begin{array}{l}897 \text { barcos-tanque, } 239 \\
\text { rebocadores-barcos, } 4 \\
\text { navios de carga seca, } 4 \\
\text { rebocadores de navios, } \\
1 \text { rebocador }\end{array}$ & - & |- \\
\hline $\begin{array}{l}\text { Knightsbridge } \\
\text { Tankers Ltd. }\end{array}$ & Hamilton, Bermuda & Www.knightbridgetankers.com & $\begin{array}{l}\text { Portos petroleiros de: Golfo Árabe } \\
\text { e Extremo Oriente, Europa do } \\
\text { Norte, Caribe e Louisiana }\end{array}$ & $\begin{array}{l}\text { Transporte marítimo } \\
\text { internacional de petróleo } \\
\text { bruto }\end{array}$ & $\begin{array}{l}5 \text { petroleiros double- } \\
\text { hull, }\end{array}$ & - & 1- \\
\hline $\begin{array}{l}\text { K-Sea Transportation } \\
\text { Partners L.P. }\end{array}$ & Nova Jérsei, EUA & www.k-sea.com & EUA & \begin{tabular}{|l|} 
Transporte marítimo, \\
distribuição e logística de \\
derivados de petróleo \\
refinado
\end{tabular} & $\begin{array}{l}61 \text { barcos-tanque, } 2 \\
\text { tanques e } 41 \\
\text { rebocadores }\end{array}$ & - & \\
\hline
\end{tabular}




\begin{tabular}{|c|c|c|c|c|c|c|c|}
\hline MC Shipping, Inc. & Hamilton, Bermuda & | www.moshipping.com & Mundial & $\begin{array}{l}\text { Atua no investimento, } \\
\text { propriedade e operação de } \\
\text { embarcaçôes de segunda } \\
\text { mão }\end{array}$ & $\begin{array}{l}16 \text { navios, sendo: } 9 \\
\text { cargueiros de gás } \\
\text { liquefeito, } 2 \text { cargueiros } \\
\text { de cabotagem, } 50 \% \text { de } \\
\text { um outro cargueiro de } \\
\text { gás liquefeito e } 25,8 \% \\
\text { de } 4 \text { contêineres. }\end{array}$ & $\begin{array}{l}\text { cbm (navios } \\
\text { de LPG) } \\
\text { TEU } \\
\text { (cargueiros) }\end{array}$ & $\begin{array}{l}367,042 \\
9,312\end{array}$ \\
\hline $\begin{array}{l}\text { Navios Maritime } \\
\text { Holdings, Inc. }\end{array}$ & Piraeus, Grécia & www.navios.com & Mundial & $\begin{array}{l}\text { Serviços de logística e } \\
\text { transporte marítimo de } \\
\text { carga a granel }\end{array}$ & $\begin{array}{l}\text { Graneleiros próprios: } \\
10 \text { Ultra-Handymax e } \\
6 \text { Panamax. } \\
\text { Graneleiros afretados: } \\
16 \text { Panamax } \\
1 \text { Ultra-Handymax }\end{array}$ & $d w t$ & $1,715,590$ \\
\hline $\begin{array}{l}\text { Nordic American } \\
\text { Tanker } \\
\text { Shipping Ltd. }\end{array}$ & Hamilton, Bermuda & www.nat.bm & Mundial & $\begin{array}{l}\text { Proprietária e operadora de } \\
\text { navios-tanque para petróleo } \\
\text { bruto }\end{array}$ & $\begin{array}{l}9 \text { navios-tanque double } \\
\text { hull } \\
\text { Suezmax }\end{array}$ & $\mathrm{mt}$ & 1.864 .488 \\
\hline $\begin{array}{l}\text { Omega Navigation } \\
\text { Enterprises, Inc. }\end{array}$ & Piraeus, Grécia & www.omeganavigation.com & Mundial & $\begin{array}{l}\text { Proprietária e operadora de } \\
\text { navios-tanque e cargueiros }\end{array}$ & $\begin{array}{l}6 \text { navios-tanque double- } \\
\text { hull, } \\
2 \text { cargueiros Hndymax }\end{array}$ & dwt & 471,958 \\
\hline OMI Corp. & Connecticut, EUA & www.omicorp.com & Mundial & $\begin{array}{l}\text { Transporte marítimo de } \\
\text { petróleo cru e refinado, } \\
\text { fretamento, manutenção, } \\
\text { tripulação e seguro }\end{array}$ & $\begin{array}{l}33 \text { navios de transporte } \\
\text { e } \\
13 \text { navios-tanque } \\
\text { Suezmax }\end{array}$ & dwt-MT & 28651181 \\
\hline $\begin{array}{l}\text { Overseas } \\
\text { Shipholding Group, } \\
\text { Inc. }\end{array}$ & Nova York, EUA & www.osg.com & EUA & $\begin{array}{l}\text { Transporte marítimo de } \\
\text { petróleo cru e derivados }\end{array}$ & $\begin{array}{l}107 \text { navios, sendo: } 87 \\
\text { navios de bandeira } \\
\text { estrangeira e } 20 \text { de } \\
\text { bandeira americana }\end{array}$ & dwt & $12,016,962$ \\
\hline $\begin{array}{l}\text { Quintana Maritime } \\
\text { Ltd. }\end{array}$ & Glyfada, Grécia & www.quintanamaritime.com & Grécia e mundial & $\begin{array}{l}\text { Transporte marítimo de } \\
\text { carga } \\
\text { a granel seca e operação } \\
\text { de navios }\end{array}$ & $\begin{array}{l}23 \text { navios, sendo: } 10 \\
\text { Panamax, } 11 \\
\text { Kansarmax e } 2 \\
\text { Capesize }\end{array}$ & dwt & $1,134,008$ \\
\hline Rand Logistics, Inc. & Nova York, EUA & - & $\begin{array}{l}\text { Canadá e EUA (região dos } \\
\text { Grandes } \\
\text { Lagos) }\end{array}$ & $\begin{array}{l}\text { Transporte marítimo de } \\
\text { granéis }\end{array}$ & $\begin{array}{l}4 \text { navios graneleiros no } \\
\text { Canadá e } 3 \text { navios } \\
\text { graneleiros e um } \\
\text { rebocador nos EUA }\end{array}$ & - & - \\
\hline
\end{tabular}




\begin{tabular}{|c|c|c|c|c|c|c|c|}
\hline $\begin{array}{l}\text { SEACOR Holdings, } \\
\text { Inc. }\end{array}$ & Houston, Texas & www.seacorholdings.com & Mundial & $\begin{array}{l}\text { Proprietária, investimento, } \\
\text { marketing e transporte } \\
\text { marítimo, principalmente de } \\
\text { petróleo e gás }\end{array}$ & diversos navios & - & \\
\hline Seaspan Corp. & Hong Kong & www.seaspancorp.com & Mundial & $\begin{array}{l}\text { Proprietária e fretamento de } \\
\text { navios-contêiner }\end{array}$ & 15 navios-contêiner & TEU & 12,721 \\
\hline $\begin{array}{l}\text { Ship Finance } \\
\text { International Ltd. }\end{array}$ & Hamilton, Bermuda & www.shipfinance.org & Mundial & \begin{tabular}{|l|} 
Propietária e controle \\
de petroleiros
\end{tabular} & $\begin{array}{l}28 \text { VLCCs, } 7 \\
\text { navios-contêineres, } 8 \\
\text { cargueiros Suezmax e } \\
14 \text { Suezmax }\end{array}$ & - & \\
\hline StealthGas, Inc. & Atenas, Grécia & www.stealthgas.com & Grécia e mundial & $\begin{array}{l}\text { Transporte marítimo para } \\
\text { gás liquefeito (LGP) }\end{array}$ & $\begin{array}{l}28 \text { navios cargueiros } \\
\text { para LGP }\end{array}$ & $\mathrm{mc}$ & 120,469 \\
\hline Stolt-Nielsen S.A & Londres, Inglaterra & www.stolt-nielsen.com & Inglaterra e mundial & $\begin{array}{l}\text { Transporte marítimo e } \\
\text { frutos } \\
\text { do mar }\end{array}$ & 149 navios-tanque & - & - \\
\hline Trailer Bridge, Inc. & Flórida, EUA & www.trailerbridge.com & EUA e Porto Rico & $\begin{array}{l}\text { Transporte rodoviário e } \\
\text { marítimo }\end{array}$ & $\begin{array}{l}2 \text { barcos roll-on/roll-off } \\
\text { e } 2 \text { navios cargueiros }\end{array}$ & - & \\
\hline TBS International Ltd. & Hamilton, Bermuda & www.tbsship.com & $\begin{array}{l}\text { Brasil, Japão, Chile, EUA, Peru, } \\
\text { Emirados Árabes, Venezuela, } \\
\text { Coréia, e China }\end{array}$ & $\begin{array}{l}\text { Transporte maritimo } \\
\text { através } \\
\text { de navios próprios e } \\
\text { fretados }\end{array}$ & 37 navios & - & \\
\hline $\begin{array}{l}\text { Teekay LNG Partners } \\
\text { L.P. }\end{array}$ & Nassau, Bahamas & www.teekaylng.com & Bahamas, Espanha e mundial & $\begin{array}{l}\text { Proprietária e operadora de } \\
\text { gás natural liquefeito (LNG), } \\
\text { além de transporte maritimo }\end{array}$ & $\begin{array}{l}4 \text { navios cargueiros de } \\
\text { LNG e 8 navios-tanque } \\
\text { Suezmax para petróleo } \\
\text { bruto }\end{array}$ & - & \\
\hline $\begin{array}{l}\text { Teekay Shipping } \\
\text { Corporation }\end{array}$ & Nassau, Bahamas & www.teekay.com & Mundial & $\begin{array}{l}\text { Fornece petróleo cru e } \\
\text { transporte marítimo de } \\
\text { petróleo }\end{array}$ & 145 navios & - & \\
\hline Tidewater, Inc. & Louisiana, EUA & www.tdw.com & $\begin{array}{l}\text { EUA, Golfo do México, Mar do } \\
\text { Norte, } \\
\text { Golfo Pérsico, Mar Cáspio, } \\
\text { Austrália, Brasil, Egito, India, } \\
\text { Indonésia, Malásia, México, } \\
\text { Trinidade, Venezuela, Oeste da } \\
\text { África }\end{array}$ & $\begin{array}{l}\text { Fornece embarcaç̃̃es para } \\
\text { a indústria petroleira e } \\
\text { transporte marítimo }\end{array}$ & 520 navios & & \\
\hline
\end{tabular}




\begin{tabular}{|c|c|c|c|c|c|c|c|}
\hline TOP Tankers, Inc. & Atenas, Grécia & www.toptankers.com & Mundial & $\begin{array}{l}\text { Transporte marítimo de } \\
\text { petróleo cru e derivados }\end{array}$ & $\begin{array}{l}27 \text { navios, sendo: } 14 \\
\text { navios-tanque double- } \\
\text { hull Handymax e } 13 \\
\text { navios-tanque double- } \\
\text { hull Suezmax }\end{array}$ & dwt & | 2,600,000 \\
\hline $\begin{array}{l}\text { Tsakos Energy } \\
\text { Navigation Ltd. }\end{array}$ & Atenas, Grécia & www.tenn.gr & Mundial & $\begin{array}{l}\text { Transporte marítimo de } \\
\text { petróleo cru e derivados }\end{array}$ & $\begin{array}{l}28 \text { navios-tanque, } \\
\text { sendo: } 3 \text { navios } \\
\text { fretados, } 3 \text { VLCC, } 8 \\
\text { Suezmax, } 7 \text { Aframax, } 7 \\
\text { Panamax e } 3 \text { navios } \\
\text { cargueiros Handymax }\end{array}$ & $d w t$ & $5,292,000$ \\
\hline $\begin{array}{l}\text { U.S. Shipping } \\
\text { Partners L.P. }\end{array}$ & Nova Jérsei, EUA & www.usslp.com & EUA & \begin{tabular}{|l|} 
Transporte marítimo de \\
petróleo cru e derivados
\end{tabular} & $\begin{array}{l}10 \text { navios-tanque, } \\
\text { sendo: } 3 \text { barcos } \\
\text { rebocadoras (ITBS), } 1 \\
\text { navio-tanque e } 3 \\
\text { tanques químicos } \\
\text { (parcela) }\end{array}$ & - & \\
\hline
\end{tabular}




\section{ANEXO 6 - DETALHAMENTO DE INFORMAÇÕES PRESENTES NOS DEMONSTRATIVOS CONTÁBEIS DAS EMPRESAS ESTRANGEIRAS}

\begin{tabular}{|c|c|c|c|}
\hline Planilha & Categorias & Subcategorias & Contas \\
\hline \multirow{7}{*}{$\begin{array}{l}\text { Balance } \\
\text { Sheet }\end{array}$} & \multirow[t]{3}{*}{ Ativo } & - & Total Ativo \\
\hline & & Ativo Circulante & $\begin{array}{l}\text { Dinheiro e ativos líquidos } \\
\text { Estoques } \\
\text { Investimentos de curto prazo } \\
\text { Outros ativos circulantes } \\
\text { Recebíveis líquidos } \\
\text { Total do Ativo Circulante }\end{array}$ \\
\hline & & Exigível de Longo Prazo & $\begin{array}{l}\text { Amortização acumulada } \\
\text { Ativo diferido de longo prazo } \\
\text { Ativo imobilizado } \\
\text { Bens intangíveis } \\
\text { Fundo de comércio } \\
\text { Investimento de longo prazo } \\
\text { Outros ativos } \\
\text { Total Exigível de Longo Prazo }\end{array}$ \\
\hline & \multirow[t]{4}{*}{ Passivo } & - & $\begin{array}{l}\text { Passivo (Total Passivo + Result. PLA) } \\
\text { Total Passivo }\end{array}$ \\
\hline & & Exigível de Longo Prazo & $\begin{array}{l}\text { Exigível a longo prazo } \\
\text { Fundo de comércio negativo } \\
\text { Outros exigíveis a longo prazo } \\
\text { Participações minoritárias } \\
\text { Passivo diferido de longo prazo } \\
\text { Total Exigível a Longo Prazo }\end{array}$ \\
\hline & & Passivo Circulante & $\begin{array}{l}\text { Contas a pagar } \\
\text { Obrigações e provisões de curto prazo } \\
\text { Outras obrigações e provisões } \\
\text { Total do Passivo Circulante } \\
\end{array}$ \\
\hline & & $\begin{array}{l}\text { Patrimônio líquido dos } \\
\text { acionistas }\end{array}$ & $\begin{array}{l}\text { Aç̃̃es em tesouraria } \\
\text { Ações ordinárias } \\
\text { Ações preferenciais } \\
\text { Ações preferenciais resgatáveis } \\
\text { Despesas diversas de opções de garantias } \\
\text { Ganhos retidos } \\
\text { Outros patrimônios líquidos dos acionistas } \\
\text { Reserva de capital } \\
\text { Resultado do Patrimônio Liquído dos } \\
\text { acionistas } \\
\text { Total Ativos Líquidos Tangíveis } \\
\text { Total do Patrimônio Líquido dos acionistas }\end{array}$ \\
\hline
\end{tabular}




\begin{tabular}{|c|c|c|c|}
\hline Planilha & Categoria & Subcategoria & Item \\
\hline \multirow[t]{9}{*}{ Cash Flow } & \multirow[t]{9}{*}{ Não se aplica } & Atividades Financeiras & $\begin{array}{l}\text { Dividendos pagos } \\
\text { Empréstimos líquidos } \\
\text { Outras fontes de recursos financeiros } \\
\text { Venda ou compra de títulos }\end{array}$ \\
\hline & & Efeito da variação cambial & - \\
\hline & & $\begin{array}{l}\text { Fluxo de caixa alocado em } \\
\text { investimento }\end{array}$ & - \\
\hline & & Fluxo de caixa operacional & $\begin{array}{l}\text { Depreciação } \\
\text { Receita líquida ajustada } \\
\text { Variação de estoques } \\
\text { Variação em outras atividades operacionais } \\
\text { Variação nas contas à receber } \\
\text { Variação no passivo } \\
\end{array}$ \\
\hline & & $\begin{array}{l}\text { Fluxo de caixa oriundo das } \\
\text { atividades de } \\
\text { financiamento }\end{array}$ & - \\
\hline & & $\begin{array}{l}\text { Fluxo de caixa proveniente } \\
\text { das atividades operacionais }\end{array}$ & - \\
\hline & & Receita Líquida & - \\
\hline & & $\begin{array}{l}\text { Recursos alocados em } \\
\text { investimentos }\end{array}$ & $\begin{array}{l}\text { Dispêndio de capital } \\
\text { Investimentos } \\
\text { Outros fluxos de investimento }\end{array}$ \\
\hline & & $\begin{array}{l}\text { Variação no caixa e } \\
\text { equivalentes }\end{array}$ & - \\
\hline
\end{tabular}




\begin{tabular}{|c|c|c|c|}
\hline Planilha & Categoria & Subcategoria & Item \\
\hline \multirow[t]{9}{*}{$\begin{array}{l}\text { Income } \\
\text { Statment }\end{array}$} & \multirow{9}{*}{ - } & $\begin{array}{l}\text { Ações preferenciais e } \\
\text { outros ajustes }\end{array}$ & - \\
\hline & & Custos Receita Bruta & - \\
\hline & & Despesas Operacionais & $\begin{array}{l}\text { Despesas Operacionais de vendas e } \\
\text { administrativas } \\
\text { Não recorrentes } \\
\text { Outras } \\
\text { Pesquisa e desenvolvimento } \\
\text { Total das Despesas Operacionais } \\
\text { operacionais }\end{array}$ \\
\hline & & Lucro Bruto & - \\
\hline & & Lucro líquido & - \\
\hline & & $\begin{array}{l}\text { Lucro líquido aplicado a } \\
\text { ações ordinárias }\end{array}$ & - \\
\hline & & Receita Bruta & - \\
\hline & & $\begin{array}{l}\text { Receitas de operações } \\
\text { normais }\end{array}$ & $\begin{array}{l}\text { Efeitos de mudanças contábeis } \\
\text { Eventos não recorrentes } \\
\text { Ganhos antes de juros e impostos } \\
\text { Gastos com imposto sobre o lucro } \\
\text { Gastos com juros } \\
\text { Itens extraordinários } \\
\text { Lucro antes do imposto } \\
\text { Lucro líquido de atividades normais } \\
\text { Operações descontinuadas } \\
\text { Outros itens } \\
\text { Participações minoritárias } \\
\text { Total líquido de outras receitas/Despesas } \\
\text { Operacionais }\end{array}$ \\
\hline & & $\begin{array}{l}\text { Resultado ou perda } \\
\text { operacional }\end{array}$ & - \\
\hline
\end{tabular}




\section{ANEXO 7 - RESUMO DA LEGISLAÇÃO QUE REGULAMENTA O REPASSE DE RECURSOS DO FMM}

- Lei 10.893/2004, que dispõe sobre o Adicional ao Frete para a Renovação da Marinha Mercante - AFRMM e o Fundo da Marinha Mercante - FMM, e dá outras providências.

- Portaria MT 90/2005, que aprova os procedimentos e regras para a liberação de recursos financeiros do Fundo da Marinha Mercante, durante a execução dos projetos aprovados.

- Portaria SFA 001/2005, diz respeito ao reconhecimento do crédito dos serviços prestados (ou bens fornecidos).

- Decreto 5.140/2004, trata da subvenção ao prêmio do seguro-garantia modalidade executante construtor para construção de embarcações e dá outras providências.

- Decreto 5.269/2004, dispõe sobre a competência, composição e funcionamento do Conselho Diretor do Fundo da Marinha Mercante CDFMM, e dá outras providências.

- Decreto 5.543/2005, que dispõe sobre o Adicional ao Frete para a Renovação da Marinha Mercante - AFRMM e o Fundo da Marinha Mercante - FMM, e o art. 17 da Lei no 9.432, de 8 de janeiro de 1997, que dispõe sobre a ordenação do transporte aquaviário, e dá outras providências.

- Resolução BACEN 3.262/2005, que dispõe sobre a aplicação dos recursos do Fundo da Marinha Mercante (FMM).

- Roteiro FINEM (Agente BNDES), no qual são especificadas as características básicas da empresa e do empreendimento necessárias à análise do enquadramento da operação nas Políticas Operacionais do BNDES.

- Carta Consulta do BNDES, é o primeiro passo do pedido formal de financiamento no BNDES. A Consulta Prévia deverá ser encaminhada, diretamente ou por intermédio de uma das instituições financeiras credenciadas, ao BNDES. 


\section{ANEXO 8 - SUMÁRIO DAS CARACTERÍSTICAS DAS EMPRESAS NACIONAIS VISITADAS DURANTE PESQUISA DE CAMPO}

- A empresa A atua há mais de duas décadas na prestação de serviços de apoio marítimo às atividades de exploração e produção de petróleo na plataforma continental brasileira. Além disso, oferece serviços de operação, agenciamento e administração de embarcações e afretamento de embarcações através de acordos operacionais com diversas empresas. Opera em viagens de longo curso, cabotagem e apoio marítimo. Dentre a amostra das quatro empresas nacionais, sua participação na receita operacional foi de 14,47\% para o ano de 2005.

- A empresa B é uma empresa de navegação marítima que opera no segmento de transporte de granel em viagens de longo curso, cabotagem e fluvial, no transporte de cargas em geral e na navegação de apoio portuário.Sua participação na receita operacional bruta das quatro em presas foi de 13,97\% em 2005.

- A empresa $C$ atua no segmento de transporte de granéis sólidos, utilizando os tipos de navegação de cabotagem e de longo curso. No ano de 2005 apresentou participação de $25,35 \%$ no total da receita operacional bruta da amostra.

- A empresa $D$ atua no Brasil há mais de quatro décadas, como empresa de navegação, no transporte de cargas a granel, tanto na cabotagem, como no longo curso. Essa empresa foi a que possui maior participação no total da receita operacional bruta no ano de 2005 (46,21\%). 


\section{ANEXO 9 - APÊNDICE MATEMÁTICO E DETALHAMENTO DA MODELAGEM}

Este apêndice auxilia no entendimento dos procedimentos adotados na construção do modelo e provê meios para um melhor entendimento dos resultados apresentados ao longo do estudo os quais foram obtidos por meio da utilização das tabelas * .xls que acompanham o volume impresso. São elas B CHI, B JAP, B COR, B ALE, B EUA e B NOR. A estrutura de cada planilha é detalhada no ANEXO 10.

Vale lembrar que o uso das planilhas depende da verificação das hipóteses assumidas na seção 5.4 e determinação dos procedimentos empíricos apresentados na seção 5.5 desse trabalho. Este ANEXO se encontra dividido em 13 seções.

\subsection{ESTRUTURA DOS ARQUIVOS E TABELAS}

Cada arquivo é composto por duas planilhas as quais são organizadas em 12 tabelas. Estas foram elaboradas a partir da revisão da literatura acerca dos processos de avaliação, procedimentos adotados na elaboração de simulações, parâmetros das estruturas de financiamento apresentados no quadro 5 e variáveis empíricas apresentadas no quadro 21.

\subsection{AMORTIZAÇÃO DO PRINCIPAL E DOS JUROS ACUMULADOS NO PERÍODO DE CARÊNCIA (A)}

O valor da amortização $A_{D}^{K}$ depende do valor financiado. Se supõe que os recursos são aportados ao longo de 2 anos de execução do projeto. Nesse período longo dos quais são acumulados juros acumulados até o final do período de carência. Neste caso, j representa o indexador do valor aportado, o termo a capta a periodicidade e $\left(\alpha z_{K}-j\right)$ ajusta o fator de formação da amortização.

$$
A_{D}^{K}=\frac{\sum_{j=0}^{2 \alpha} P_{j}\left(1+r_{D}\right)^{\alpha z_{K}-j}}{\alpha n_{K}}
$$

O sobrescrito indica que se trata de dados apurados para o pais $K$.

\subsection{AMORTIZAÇÃO DO PRINCIPAL}

A amortização sobre o principal segue o Sistema de Amortização Constante (SAC), amplamente empregado no setor. Sua magnitude depende do valor aportado $\left(\theta_{K}\right)$ e do prazo de amortização ajustado pelo fator de periodicidade (a) de cada estrutura de financiamento. 


$$
A_{D}^{K}=\frac{D_{k}}{\alpha n_{K}}=\frac{\sum_{j} P_{j}}{\alpha n_{K}}
$$

\subsection{AMORTIZAÇÃO DOS JUROS ACUMULADOS DURANTE O PERÍODO DE CARÊNCIA}

O montante de juros formado durante o período de carência deve ser pago ao longo do prazo de amortização - qual é ajustado pelo fator de periodicidade $(\alpha)$.

$$
A_{J}^{K}=\frac{\sum_{j=0}^{2 \alpha} P_{j}\left(1+r_{D}\right)^{\alpha z_{K}-j}-\sum_{j} P_{j}}{\alpha n_{K}}
$$

\subsection{VALOR DOS JUROS NO INSTANTE $t$}

O valor do juro a ser pago em cada instante t é composto por duas parcelas: juros sobre o principal aportado e totalidade dos juros acumulados ao longo do período de carência. Ambos são ajustados pela periodicidade prevista nas estruturas de financiamento.

$$
J_{t}=\frac{r_{D}^{K}}{\alpha n_{K}}\left[\sum_{j=0}^{2 \alpha} P_{j}\left(1+r_{D}\right)^{\alpha z_{K}-j}\left(\alpha n_{K}+\alpha z_{K}-t\right)\right]
$$

\subsection{VALOR DA PRESTAÇÃO NO INSTANTE $t$}

As prestações são determinadas por amortização e juros. No caso, amortizações sobre o principal e juros acumulados ao longo do período de carência.

$$
P M T_{t}^{K}=\frac{1}{\alpha n_{K}}\left[1+r_{D}^{K}\left(\alpha n_{K}+\alpha z_{K}-t\right)\right] \sum_{j=0}^{2 \alpha} P_{j}\left(1+r_{D}^{K}\right)^{\alpha z_{K}-j}
$$

\subsection{SALDO DEVEDOR DO PRINCIPAL EM $\mathbf{t}$}

O saldo devedor sobre o principal é ajustado pelo prazo de carência.

$$
S D_{t}^{A_{K}}=D_{K}-\left(t-\alpha z_{K}+1\right) A_{D_{K}}^{K}
$$




\subsection{SALDO DEVEDOR DOS JUROS ACUMULADOS NO PERÍODO DE CARÉNCIA EM t}

O saldo devedor sobre os juros acumulados ao longo do período de carência são ajustados pelo período de carência.

$$
S D_{t}^{J_{K}}=\left(\sum_{j=0}^{2 \alpha} P_{j}\left(1+r_{K}^{D}\right)^{\alpha z_{K}-j}-\sum_{j} P j\right)-\left(t-\alpha z_{K}+1\right) A_{J}^{K}
$$

\subsection{ATIVIDADE CESSANTE (AC)}

A equalização de prazos constitui um processo necessário na comparação de alternativas. O modelo de atividade cessante $(A C)$ prevê que se deve equalizar diferentes alternativas a valor futuro tendo como base o diferencial entre 0 maior e o menor prazo para, em seguida, trazer o resultado a valor presente pelo prazo maior. Isso pode ser feito sem considerar os fatores de ajustamento de periodicidade, desde que a taxa esteja compatível com o prazo sem ajustamento.

$$
A C=\frac{\left(1+r_{\text {WACC }}\right)^{\left(z_{B}+n_{B}\right)-\left(z_{K}+n_{K}\right)}}{\left(1+r_{\text {WACC }}\right)^{\left(z_{B}+n_{B}\right)}}=\frac{1}{\left(1+r_{\text {WACC }}\right)^{\left(z_{k}+n_{k}\right)}}
$$

para $z_{B}+n_{B} \geq z_{K}+n_{K}$ e vice-versa. No caso a taxa de reconto é $r_{W A C C} q u e$ constitui a taxa de desconto do fluxo de caixa do empreendimento. Esta foi apurada por meio do beta desalavancado com uso do CAPM a partir de técnicas de cointegração.

\subsection{VALOR PRESENTE LÍQUIDO DE CUSTOS (VPLC)}

$\mathrm{O}$ valor presente líquido de custos $\left(\mathrm{VPL}_{\mathrm{C}}\right)$ constitui uma abordagem que permite comparar diretamente custos de despesas associados a projetos de investimento, desde que estejam equalizados no tempo. Daí a necessidade de emprego do modelo de atividade cessante (AC). Como se trata de valor presente de custos ou despesas (como as despesas com prestações no caso desse estudo) um valor menor apresenta maior atratividade. No caso do modelo proposto se deve dimensionar pelo prazo total da operação.

$$
V P L_{C}^{K}=\left\{\begin{array}{cl}
A C \sum_{t=\alpha z_{K}}^{\alpha n_{K}} P M T_{t}^{K}\left(1+r_{W A C C}\right)^{\alpha \overline{n_{K}}-t} & \text { se } \overline{\mathrm{n}_{B}}=\mathrm{z}_{B}+n_{B} \geq \overline{\mathrm{n}_{K}}=z_{K}+n_{K} \\
\sum_{t=0}^{\alpha n_{K}} \frac{P M T_{t}^{K}}{\left(1+r_{\text {WACC }}\right)^{t+\alpha z_{K}}} & \text { se } \overline{n_{B}}=z_{B}+n_{B}<\overline{n_{K}}=z_{K}+n_{K}
\end{array}\right.
$$




\subsection{1 ÍNDICE DE ATRATIVIDADE DO FINANCIAMENTO LOCAL B EM RELAÇÃO AO PAÍS $K\left(I A_{B, K}\right)$}

O índice de atratividade como apresentado, constitui a razão entre o $V P L_{C}^{B}$ da estrutura de financiamento local em relação ao $V P L_{C}^{K}$ do país K. Como quanto menor representa "mais atrativo" este é definido no intervalo $0 \leq I A_{B, K} \leq 1$.

$I A_{B, K}=\left\{\begin{array}{cc}0 \leq \frac{V P L_{C}^{B}}{V P L_{C}^{K}} \leq 1 & \text { se o modelo de financiamento local for mais atrativo que o do país } \mathrm{K} \\ \frac{V P L_{C}^{B}}{V P L_{C}^{K}}>1 & \text { caso contrário }\end{array}\right.$

\section{DADOS DE ENTRADA}

O modelo é alimentado por duas fontes básicas de informações: parâmetros da estrutura de financiamento de cada país, conforme apresentado no quadro 5 do estudo, e dados empíricos relacionados (taxas de juros de referência, fontes de risco, etc. por meio dos quais de compõe as taxas de juros, prazos, etc.) Os procedimentos adotados foram apresentados e discutidos com mais detalhes nas seções 54. e 5.5 do estudo. 


\subsection{DERIVADAS PARCIAIS DOS ELEMENTOS DO MODELO}

\begin{tabular}{|c|c|c|c|c|}
\hline \multicolumn{5}{|c|}{ QUADRO 1A: Interpretação de resultados a partir de dados de $I A_{B, C H I}$ e I $A_{B, E U A}$} \\
\hline \multirow{2}{*}{ VARIÁVEL } & $\begin{array}{c}\text { PRAZO } \\
\text { AMORTIZAÇÃO }\end{array}$ & PARTICIPAÇÃO & TAXA & CARÊNCIA \\
\hline & $\mathbf{n}_{\mathrm{K}}$ & $\boldsymbol{\theta}_{\mathrm{K}}$ & $r_{K}=f\left(i_{K}\right)$ & $\mathbf{z}_{\mathrm{K}}$ \\
\hline A & $\frac{\partial A_{K}}{\partial n_{K}}<0$ & $\frac{\partial A_{K}}{\partial \theta_{K}}>0$ & $\frac{\partial A_{K}}{\partial r_{D}}>0$ & $\frac{\partial A_{K}}{\partial z_{K}}>0$ \\
\hline $\mathbf{J}$ & $\frac{\partial J_{K}}{\partial n_{K}}<0$ & $\frac{\partial J_{K}}{\partial \theta_{K}}>0$ & $\frac{\partial J_{K}}{\partial r_{D}}>0$ & $\frac{\partial J_{K}}{\partial z_{K}}>0$ \\
\hline$I A_{B, K}\left(n_{B}^{*}>n_{K}^{*}\right)$ & $\frac{\partial I A}{\partial n_{K}}>0$ & $\frac{\partial I A}{\partial \theta_{K}}<0$ & $\frac{\partial I A}{\partial r_{K}}>0$ & $\frac{\partial I A}{\partial z_{K}}>0$ \\
\hline $1 A_{B, K}\left(n_{B}{ }^{*}<n_{K}{ }^{*}\right)$ & $\frac{\partial I A}{\partial n_{K}}>0$ & $\frac{\partial I A}{\partial \theta_{K}}>0$ & $\frac{\partial I A}{\partial r_{K}}<0$ & $\frac{\partial I A}{\partial z_{K}}>0$ \\
\hline SINAL IA $A_{B, C H I}$ & $\begin{array}{c}(+) \\
\text { PMT baixo B } \\
\text { Aumenta IA } \\
(\mathbf{2 0} ; \mathbf{1 7 )}\end{array}$ & $\begin{array}{c}(+) \\
\text { PMT auto } \\
\text { Reduz IA } \\
(\mathbf{9 0 \% ; 8 0 \% )}\end{array}$ & $\begin{array}{c}(-) \\
\text { Reduz IA } \\
\text { Menor taxa CHI e } \\
\text { efeito queda } \\
\text { riscos }\end{array}$ & $\begin{array}{c}(-) \\
\text { Reduz IA } \\
(\mathbf{4} ; \mathbf{7})\end{array}$ \\
\hline SINAL IA $A_{B, E U A}$ & $\begin{array}{c}(-) \\
\text { PMT baixo } \\
\text { Aumenta IA } \\
(\mathbf{2 0} ; \mathbf{2 5 )}\end{array}$ & $\begin{array}{c}(+) \\
\text { PMT auto } \\
\text { Reduz IA } \\
\text { (90\%; 87,5\%) }\end{array}$ & $\begin{array}{c}(-) \\
\text { Reduz IA } \\
\text { Menor taxa EUA e } \\
\text { efeito queda } \\
\text { riscos }\end{array}$ & $\begin{array}{c}(-) \\
\text { Reduz IA } \\
(4 ; 5)\end{array}$ \\
\hline
\end{tabular}




\section{ANEXO 10 - CD ROM COM PLANILHAS PARA OBTENÇÃO DO ÍNDICE DE ATRATIVIDADE (IA)}

Todos os arquivos que geraram as simulações por meio de planilhas em Excel podem ser consultados em CD ROM. Esse se encontra disponível junto a Biblioteca do Departamento de Engenharia Naval e Oceânica da Escola Politécnica (POLI/USP).

Esta nota indica a forma de uso e adensa as explicações acerca dos procedimentos adotados na obtenção do índice de atratividade (IAB,K) por meio do uso de planilhas - tal como modelado no capítulo 5 da dissertação. Os procedimentos abrangem os parâmetros apresentados. Alterações nos formatos das distribuições das variáveis alterarão a distribuição do $\mathrm{IAB}, \mathrm{K}$ e podem ser feitas no modelo. A rigor, elementos não modelados, como o valor e aporte de recursos ao longo do período de construção podem ser introduzidos no modelo desde que respeitem a lógica de obtenção do Fluxo de Caixa aqui expressas para geração da simulação.

Cada planilha $\mathrm{B}$ e K (onde $\mathrm{K}$ representa JAP, CHI, COR, ALE, EUA e NOR) contêm por 12 tabelas. A determinação do Índice de Atratividade (IAB, K) depende da obtenção do Valor Presente Líquido de Custos (VPLC) de cada país. Estes são função do valor das prestações (PMTt), taxas de juros (rD e rE) e prazos de carência e amortizações ( $\mathrm{zK}$ e $\mathrm{nK}$ ). A modelagem de cada fator é objeto das tabelas apresentada a seguir. Essas são detalhadas adiante nessa NOTA. Detalhamentos adicionais foram introduzidos por meio de comentários em certas células das planilhas B e K.

A TABELA 1 (PARÂMETROS DO FINANCIAMENTO NO PAÍS $K$ ) contém os parâmetros da estrutura de financiamento de cada país, conforme apresentados no QUADRO 5 da dissertação.

A TABELA 2 (VERIFICAÇÃO DA VALIDADE DAS EQUAÇÕES ADOTADAS E APRESENTADAS NO ANEXO 9) consolida a verificação e validação das fórmulas empregadas na determinação do valor das prestações (PMT) em cada instante t.

A TABELA 3 (CUSTO DE CAPITAL DE TERCEIROS rD) abrange os dados de entrada para obtenção do custo do capital de terceiros $[\mathrm{rD}=\mathrm{f}(\mathrm{iK})]$ por meio do financiamento. O processo de simulação depende dos formatos das distribuições de cada série histórica que conforma a taxa determinação de rK. Estas, a depender do caso, são formadas pelas taxas de referência, spread de risco país e de risco cambial.

A TABELA 4 (CUSTO DE CAPITAL PRÓPRIO rE) contém os dados de entrada para determinação do custo do capital de próprio $(\mathrm{rE})$ do financiamento. O processo de simulação depende dos formatos das distribuições dos elementos que compõe rE. Trata-se do beta alavancado e desalavancado das empresas de navegação (NAV), ativo livre de risco (cotação do US Treasury 10) e prêmio de risco da carteira de títulos das empresas (diferença entre o índice Dow Jones e ativo livre de risco, ou US T 10).

A TABELA 5 (PARTICIPAÇÃO NO PROJETO \%D) discrimina os processos de determinação do valor da participação do financiamento (\% Financiamento) cuja determinação é exógena ao modelo. Este valor pode ser modelado de forma independente pelo usuário. Basta acrescentar mais linhas e formatos das distribuições, conforme o caso. 
A TABELA 6 (TAXA DE DESCONTO DO EMPREENDIMENTO rWACC) lista os procedimento para a determinação da taxa de desconto do empreendimento (rWACC) por meio do Custo Médio Ponderado do Capital. A taxa de desconto depende, entre outros, das taxas $r K=f(i D)$ e $r E$. Portanto sua variabilidade depende da variação dos elementos que compõe essas taxas. Essas implicam em parte da variabilidade de IAB,K.

A TABELA 7 (PRAZO DE AMORTIZAÇÃO $\mathbf{n K}$ ) discute o tratamento adotado na determinação do prazo de amortização (nK) no processo de simulação.

A TABELA 8 (PERÍODO DE CARÊNCIA zK) apresenta o tratamento adotado na determinação do período de carência (zK) no processo de simulação.

A TABELA 9 (VALOR DA EMBARCAÇÃO P E DO CONTRATO \%D) apresenta a determinação do valor do contrato $(P)$. Nas simulações, este varia com a magnitude da participação definida na TABELA 5. Este valor pode ser (re)modelado pelo usuário.

A TABELA 10 (VALOR PRESTAÇÃO) consolida a determinação do valor das prestações (PMTt) sobre o valor financiado $P$, por meio de $r D$ e $n K$.

A TABELA 11 (APORTE DE RECURSOS E JUROS ACUMULADOS NO PERÍODO DE CARÊNCIA) consolida as hipóteses assumidas quanto ao aporte de recursos de financiamento ao projeto $(\mathrm{Pj})$ e o processo de formação de juros ao longo do período de carência (zK).

A TABELA 12 (FLUXO DE CAIXA DE PAGAMENTOS DE OBRIGAÇÕES FINANCEIRAS B ou K) automatiza todos os processos de ajustamento de prazos (carência e amortização) e determinação do valor de prestações que geram o fluxo de caixa. A rigor, a determinação desse fluxo constitui um dos elementos centrais do processo de simulação assumido. Conforme o modelo, a distribuição do Índice de Atratividade $(\mathrm{IAB}, \mathrm{K})$ depende de duas planilhas ( $\mathrm{B}$ e $\mathrm{K}$ ). $\mathrm{O}$ uso dessas e seu aperfeiçoamento dependem de uma consulta de cada uma das tabelas apresentadas abaixo. Podem ser introduzidos ajustes nos prazos de construção, aporte de recursos, entre outras variáveis não modeladas (dados os objetivos da dissertação). Também podem ser assumidas outras hipóteses quanto às distribuições das demais variáveis. Dentro dos intervalos de variação assumidos para certas variáveis, a tabela 12 automatiza a construção do fluxo de prestações (formadas pelos correspondentes juros e amortizações) no processo de simulação. Um detalhamento das explicações foi introduzido por meio de comentários em certas células das planilhas $\mathrm{B}$ e $\mathrm{K}$. 


\section{ANEXO 11 - SENSITIVIY CHART DAS SIMULAÇÕES DOS ÍNDICES DE} ATRATIVIDADE (IA $\left.{ }_{B, K}\right)$ PARA OS PARES DE PAÍSES INVESTIGADOS.

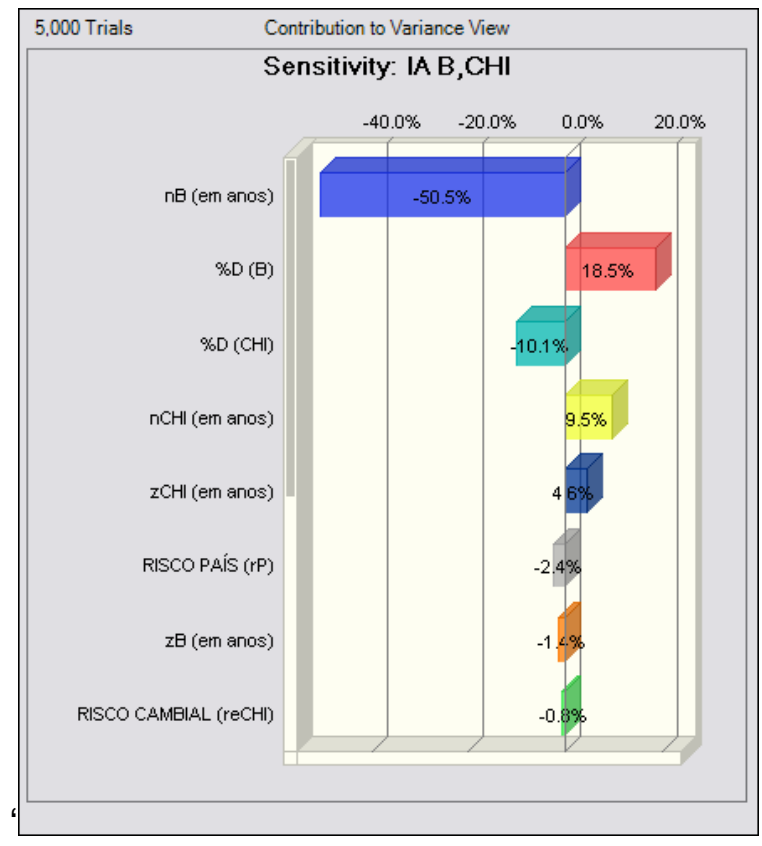

Gráfico A1 - Sensivitity Chart do financiamento naval do Brasil vs. China. Fonte: Elaborado pelo autor.

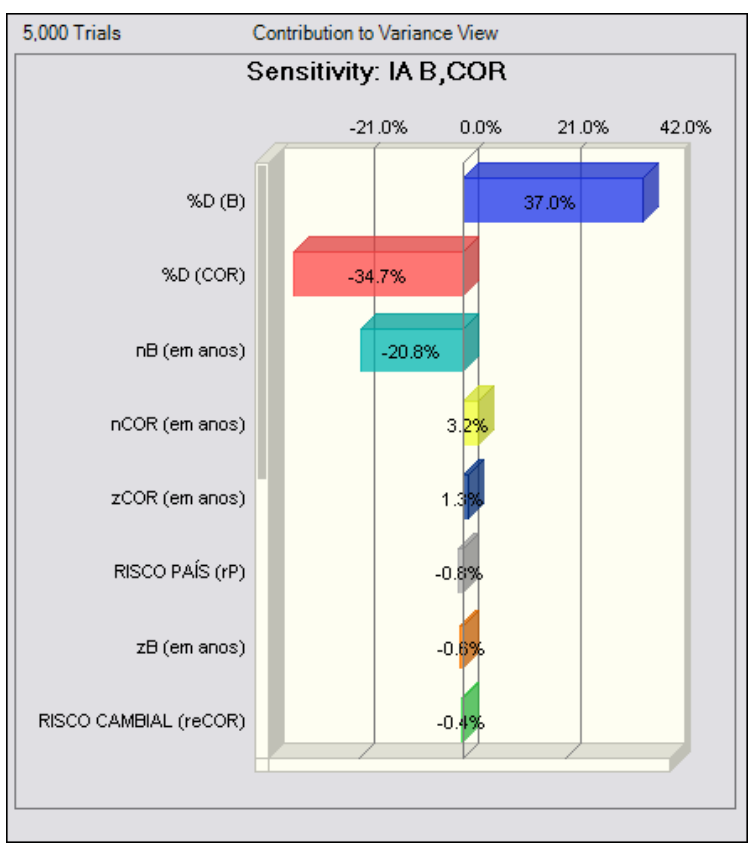

Gráfico A1 - Sensivitity Chart do financiamento naval do Brasil vs. Coréia do Sul.

Fonte: Elaborado pelo autor. 


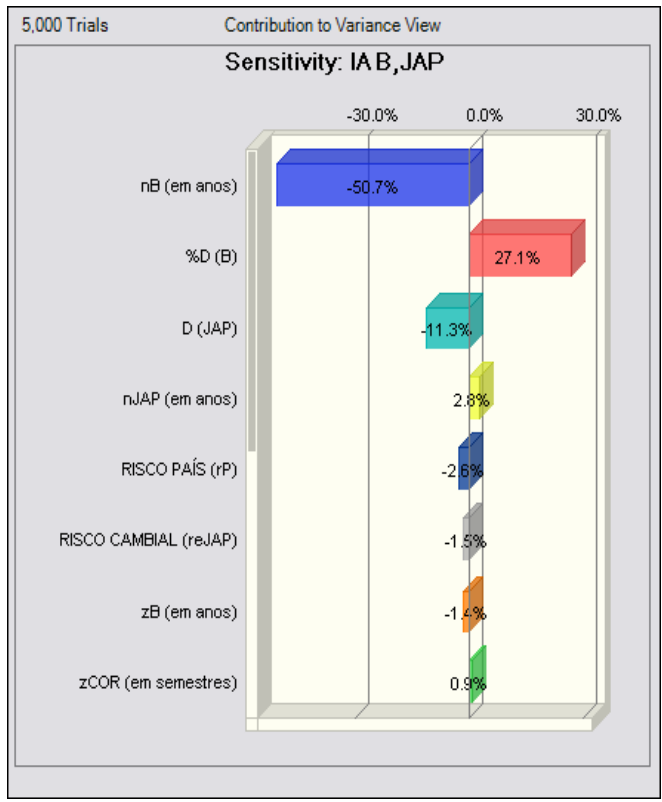

Gráfico A2 - Sensivitity Chart do financiamento naval do Brasil vs. Japão. Fonte: Elaborado pelo autor.

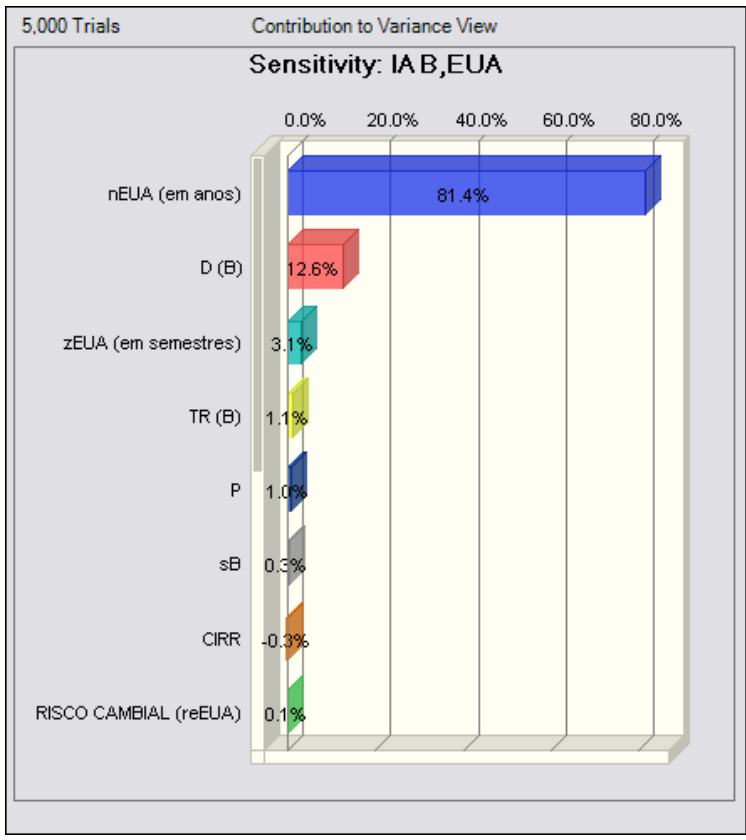

Gráfico A3 - Sensivitity Chart do financiamento naval do Brasil vs. EUA. Fonte: Elaborado pelo autor. 


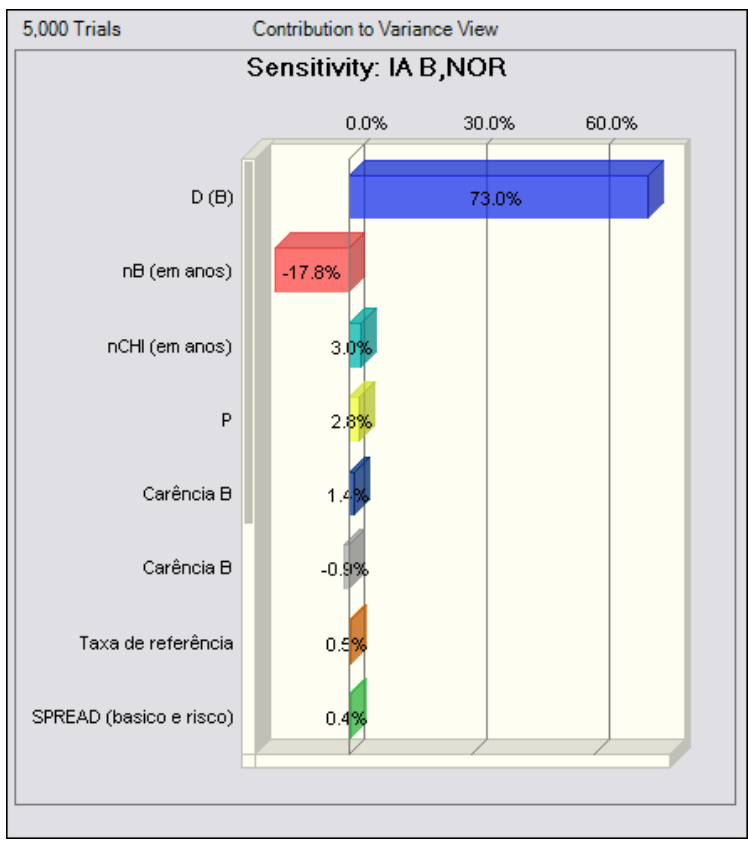

Gráfico A3 - Sensivitity Chart do financiamento naval do Brasil vs. EUA. Fonte: Elaborado pelo autor.

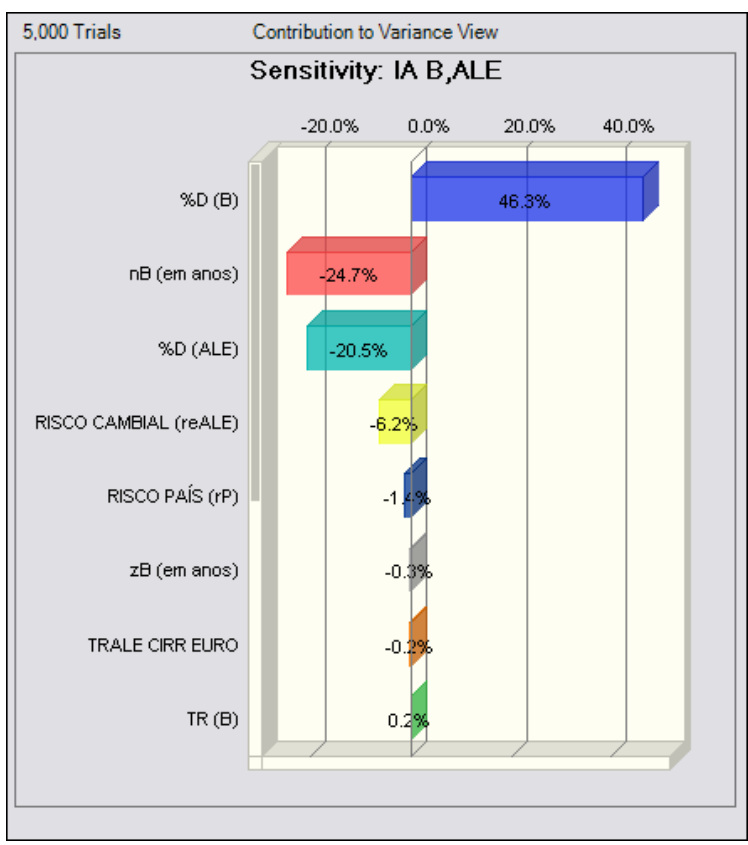

Gráfico A3 - Sensivitity Chart do financiamento naval do Brasil vs. Alemanha. Fonte: Elaborado pelo autor. 